\title{
Aan vorst en vaderland gehecht, doch tevreden zijn zij niet : Limburgse politici în Den Haag 1839-1918
}

Citation for published version (APA):

Lemmens, E. W. G. (2004). Aan vorst en vaderland gehecht, doch tevreden zijn zij niet : Limburgse politici in Den Haag 1839-1918. [Doctoral Thesis, Maastricht University]. Wereldbibliotheek.

https://doi.org/10.26481/dis.20040116el

Document status and date:

Published: 01/01/2004

DOI:

10.26481/dis.20040116el

Document Version:

Publisher's PDF, also known as Version of record

\section{Please check the document version of this publication:}

- A submitted manuscript is the version of the article upon submission and before peer-review. There can be important differences between the submitted version and the official published version of record.

People interested in the research are advised to contact the author for the final version of the publication, or visit the DOI to the publisher's website.

- The final author version and the galley proof are versions of the publication after peer review.

- The final published version features the final layout of the paper including the volume, issue and page numbers.

Link to publication

\footnotetext{
General rights rights.

- You may freely distribute the URL identifying the publication in the public portal. please follow below link for the End User Agreement:

www.umlib.nl/taverne-license

Take down policy

If you believe that this document breaches copyright please contact us at:

repository@maastrichtuniversity.nl

providing details and we will investigate your claim.
}

Copyright and moral rights for the publications made accessible in the public portal are retained by the authors and/or other copyright owners and it is a condition of accessing publications that users recognise and abide by the legal requirements associated with these

- Users may download and print one copy of any publication from the public portal for the purpose of private study or research.

- You may not further distribute the material or use it for any profit-making activity or commercial gain

If the publication is distributed under the terms of Article $25 \mathrm{fa}$ of the Dutch Copyright Act, indicated by the "Taverne" license above, 
Aan vorst en vaderland gehecht, doch tevreden zijn zij niet 



\section{Aan vorst en vaderland gehecht, doch tevreden zijn zij niet}

Limburgse politici in Den Haag 1839-1918

\section{PROEFSCHRIFT}

TER VERKRIJGING VAN DE GRAAD VAN DOCTOR

AAN DE UNIVERSITEIT MAASTRICHT OP GEZAG VAN DE RECTOR MAGNIFICUS, PROF.MR. G.P.M.F. MOLS,

VOLGENS HET BESLUIT VAN HET COLLEGE VAN DECANEN

IN HET OPENBAAR TE VERDEDIGEN

OP VRIJDAG 16 JANUARI 2004 OM 16.00 UUR

DOOR

ERIC WILHELMUS GERARDUS LEMMENS

GEBOREN TE VENRAY 
Promotor: prof. dr. A. Labrie

Co-promotor: dr. J. Talsma (Universiteit van Amsterdam)

Beoordelingscommissie: prof. dr. A. Knotter (voorzitter)

prof. dr. J.Th.J. van den Berg (Universiteit Leiden)

prof.dr. A.M.J.A. Berkvens

prof.dr. J.L.J. Bosmans (Katholieke Universiteit Nijmegen)

prof, dr. J.H.W. Kusters

Het onderzoeksprogramma De Natiestaat

Dit boek maakt deel uit van het onderzoeksprogramma 'De Natiestaat. Politie in Nederland sinds 1815'. Dit programma wordt gefinancierd door de Nederlands Organisatie voor Wetenschappelijk Onderzoek (Nwo), zeven faculteiten Letteren e Geschiedenis en het Instituut voor Nederlandse Geschiedenis (ING). Het startte i 1995 en omvat zeventien projecten: negen proefschriften en acht onderzoeken o postdoctoraal niveau. De coördinatie van het programma is ondergebracht bij he Nederlands Centrum voor Contemporaine Geschiedenis te Groningen.

Het programma 'De Natiestaat' beoogt een impuls te geven aan de geschiedschri, ving over politiek in Nederland in de negentiende en twintigste eeuw. Naast d institutionele geschiedenis van wetgeving en partijvorming gaat de aandacht u naar de ontwikkeling van politieke stijl, cultuur en omgangsvormen.

Omslagontwerp Volken Beck

Q9 2004 Eric Lemmens

en Uitgeverij Wereldbibliotheek bv, Amsterdam

Spuistraat $283 \cdot 1012$ vR Amsterdam

info@wereldbibliotheek.nl

ISBN 9028420312 (proefschrifteditie) 


\section{Inhoud}

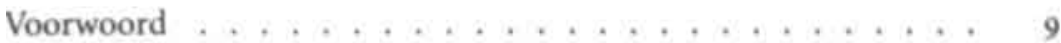

Inleiding $\ldots \ldots \ldots \ldots \ldots \ldots \ldots \ldots \ldots$ n

Het onderzoek . . . . . . . . . . . . 13

Het boek . . . . . . . . . . . . . . 17

1. Tussen Brussel en Den Haag. Limburgse afgevaardigden voor $1840 \quad 21$

Een zuidelijk gewest . . . . . . . . . . . . 22

De Limburgse notabelen . . . . . . . . . . . . 24

Limburgse kamerleden in het Verenigd Koninkrijk . . . 26

De scheiding . . . . . . . . . . . . 33

Naar Brussel . . . . . . . . . . . . . . . . 37

Limburg in het Belgisch parlement . . . . . . 45

Terugkeer in de Staten-Generaal . . . . . . . . . . . . . 52

2. Vertegenwoordigers van het Nederlandse volk. Limburgse afgevaardigden en hun mandaat .......... 61

Kiesrecht in Limburg . . . . . . . . . . . . . . . . . . . 62

Limburgse kiesdistricten . . . . . . . . . . . . . . 67

Beperkt kiesrecht . . . . . . . . . . . . . . . . 68

Volwaardige Nederlanders? . . . . . . . . . 70

'Niet geheel vreemd aan Limburg' . . . . . . . . . . . . 74

District Boxmeer . . . . . . . . . . . . . . . 75

Gekozen, geboren en wonend in Limburg . . . . . . . 78

Limburgers buiten de provincie ......... . . . 94

Naar het Binnenhof . . . . . . . . . . . . . 95

Participatie . . . . . . . . . . . . 97

Parlementaire ervaring en sociale achtergrond . . . . . . 104 
3. In de Nederlandse familie. Limburgse afgevaardigden en de band met Nederland . . . . . . . . . . . . . . . . . . . 119

De Limburgse kwestie(s) . . . . . . . . . . . . . 120

De kwestie geactualiseerd . . . . . . . . . . . 126

'La question du Limbourg' . . . . . . . . . . . . . . 128

Kamerleden en de kwestie . . . . . . . . . . . . . 131

Afgevaardigden van het hertogdom . . . . . . . . . . . 134

'Eene meer Nederlandsche stemming' . . . . . . . . 146

'Als Limburgsch afgevaardigde' . . . . . . . . . . . 156

Een hernieuwde proeve van loyaliteit? . . . . . . . . . 161

Vertegenwoordigers uit 'Limbourg céde' . . . . . . . . . . . 167

'Als Limburger' . . . . . . . . . . . . . . . . . . 173

4. Beginselen en richtingen. Limburgse afgevaardigden en politieke groepsvorming ................. 181

Bondgenoten van Thorbecke . . . . . . . . . . . . 181

Jaren vijftig . . . . . . . . . . . . 185

Thorbecke en Limburg . . . . . . . . . . 189

Tussen Limburg en liberalen . . . . . . . . . . . . . . . . . . 193

'De Limburgsche oppositie' . . . . . . . . . . . 194

Liberalen en katholieken . . . . . . . . . . . . . 208

Lager onderwijs . . . . . . . . . . . . . . . 224

Romeinse kwestie . . . . . . . . . . . . . . . 232

Conservatieven en katholieken . . . . . . . . . . 245

Katholieke afgevaardigden . . . . . . . . . . . 252

Verkiezingen in een katholiek gewest . . . . . . . . 253

Limburgse katholieken en katholieke Limburgers . . . . 266

5. 'In een geheel exceptionelen toestand'. Limburgse afgevaardigden en de belastingen ......... 281

Een fiscale status aparte . . . . . . . . . . . . . . . . 282

'Met meer verschooning behandeld' . . . . . . . . 283

Provinciaal antagonisme . . . . . . . 290

'Effecten koopen kan hij niet' . . . . . . . . . . . . . . . 292

In het parlement . . . . . . . . . . . . . . 294

De middelenwet en het Limburgse ongenoegen . . . . . 300

Tegenover 'Holland' . . . . . . . . . . . 303 
'... en thans moet ik spreken over het gewest mijner inwoning' . 304

Gedachten, woorden en werken ... . . . . . 309

Met last en ruggespraak ........... . . 313

Slot. 'De naam van "Limburgsch vertegenwoordiger"' . . . . . , , 321

Bijlagen . . . . . . . . . . . . . . . . . 329

I. Uitslag van de stemming onder zuidelijke notabelen over de grondwet van 1815 . . . . . . . . . . . . . . . . . . 329

II. Leden van de Tweede Kamer der Staten-Generaal uit Limburg, $1815-1830$. . . . . . . . . . . . . 330

III. Leden van Belgische nationaal-parlementaire organen uit

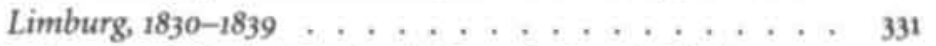

Iv. Leden van de Duitse Nationale Vergadering uit Limburg,

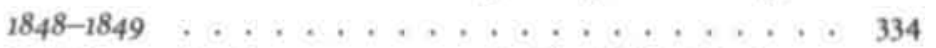

v. Indeling van Limburgse gemeenten in (hoofd)kiesdistricten ten behoeve van de Tweede Kamerverkiezingen, 1848-1918 . 335

vi. Leden van de Staten-Generaal geboren in of afgevaardigd uit Limburg, 1839-1918 . . . . . . . . . . . . . 339

vir. Zittingsperiode van de leden van de Staten-Generaal uit Limburg, $1839-1918$. . . . . . . . . . . . . . . . 342

vIII. Tijdsbalk met de parlementaire zetels ingenomen door leden uit Limburg, 1839-1918 . . . . . . . . . . . 356

IX. Bezettingsgraad van parlementaire zetels, 1839-1918 (elk vijfde zittingsjaar) . . . . . . . . . . 361

x. Wereldlijke en kerkelijke autoriteiten, Limburg, 1815-1918 . . 362

Afbeeldingen ....................... 367

Noten ........................ 371

Geraadpleegde bronnen ................ 423

Archieven .................. . . 423

Periodieken ................. . . . 425

Literatuur en uitgegeven bronnen .......... 426

Register ...................... . 441 
Summary ... . . . . . . . . . . . . . 449

Curriculum vitae ................ 455 


\section{Voorwoord}

Mijn belangstelling voor de geschiedenis van Limburg is vooral gevoed tijdens mijn studiejaren in Nijmegen. Opmerkingen en grappen van huisgenoten maakten duidelijk dat de provincie waar ik was geboren en getogen voor velen binnen Nederland een bijzondere positie innam. Geintrigeerd dook ik in de Limburgse geschiedenis en ondervond dat die zeer de moeite van het bestuderen waard was. Nog altijd herinner ik me het vreugdevolle moment waarop ik te horen kreeg dat het Natiestaatonderzoek naar Limburgse kamerleden door mij mocht worden verricht.

Met veel genoegen kijk ik terug op de voorbije jaren in de Maastrichtse Kapoenstraat. De medewerkers van de Faculteit der Cultuurwetenschappen en het faculteitsgebouw boden een bijzonder plezierige - en in mijn geval zeer ruime - werkomgeving. Mijn promotor Arnold Labrie en co-promotor Jaap Talsma dank ik hartelijk voor hun steun en begeleiding. Zij lieten mij de vrijheid om het onderzoek op eigen wijze gestalte te geven, maar zorgden er met hun tijdige interventies gelukkig ook voor dat het tot voltooiing kwam. Verder dank ik Pieter Caljé die het manuscript voorzag van opbouwende kritiek en Jos Perry voor de nuttige opmerkingen en tips. De vele medewerkers van door mij bezochte archieven en bibliotheken ben ik dankbaar voor alle hulp. Hun enthousiasme en kennis gaf me telkens weer moed om het woud aan informatie te lijf te gaan.

De promovendi-bijeenkomsten die Arnold Labrie bij hem thuis organiseerde, hebben me erg geholpen het onderzoek zijn uiteindelijke vorm en inhoud te geven. Ik dank Sophie Bouwens, Guido Goossens, Amanda Kluveld, Nel Knols, Frederiek Lommen, Manuel Stoffers, Jessica Slijkhuis, Cécile aan de Stegge en Thijs Viertelhauzen heel hartelijk voor hun waardevolle commentaar. Daarnaast noem ik graag mijn collega-Alo's van de faculteit. Ondanks de zeer uiteenlopende onderzoeksonderwerpen zijn onze onderlinge contacten voor mij altijd van grote betekenis geweest en ik bewaar fijne herinneringen aan de gezamenlijke lunches en de regelmatige 'sı-pizza/soep'-avonden. Een woord van dank aan Ruth Benschop, Marco Goud, David Hamers, Ruud Hendriks, Anique Hommels, Stine Jensen, Jessica Mesman, Ruth Mourik, Peter Peters, Jessica Slijkhuis en Cécile aan de Stegge, 
Van mijn collega's in het onderzoeksprogramma De Natiestat heb ik veel geleerd. Dat geldt ook voor mijn collega's en de docenten in et Postdoctorale Opleidingsprogramma Negentiende- en Twintigste-Eewse Geschiedenis en in het Huizinga Instituut. Niet alleen vormden zinuttige klankbordgroepen, zij hielpen daarnaast om vaardigheden te otwikkelen die onontbeerlijk zijn voor een onderzoeker en een schrijverran een dissertatie.

Tot slot gaat een warm woord van dank uit naar mijn naaste fmilieleden. Hun onvoorwaardelijke steun tijdens dit voor hen enigszinmistige onderzoeksproject was, waarschijnlijk zonder dat zij zich daarvarbewust waren, geregeld een belangrijke hulp. Met name Amber bracht d nodige afleiding. Zij zorgde er in ieder geval voor dat haar peetoom naasde voor het onderzoek relevante literatuur nog vele andere boekjes las. 


\section{Inleiding}

In de aanloop naar de laatste Tweede-Kamerverkiezingen van de twintigste eeuw, in mei 1998 , klonk in de media een roep om meer verkiesbare posities voor kandidaten uit Limburg. Prominente Limburgse leden van de drie grootste politieke partijen (PvdA, CDA en vvD) spraken eensgezind hun zorg uit over het geringe aantal provinciegenoten die een plaats zouden weten te verwerven in de bovenste regionen van de diverse kandidatenlijsten en daarmee in de nieuw te kiezen volksvertegenwoordiging.' Bij de verkiezingen van vier jaar later (mei 2002) zette een van de zittende Tweede-Kamerleden, vvD'er Frans Weekers uit Weert, via onder meer het internet een campagne op touw onder het motto 'Stem Limburgs'. Gelet op de peilingen vreesde de afgevaardigde een 'desastreuze' verkiezingsuitslag: 'We lijken namelijk af te gaan op een halvering van het aantal Limburgse Tweede Kamerleden, en dat in een periode dat het er misschien meer dan ooit om gaat om een Limburgse stem te laten horen in Den Haag.'2

Het waren geen nieuwe geluiden uit Limburg. De roep om meer volksvertegenwoordigers uit die provincie klonk ook al in de negentiende eeuw. Zo probeerden Gedeputeerde Staten van Limburg de Tweede Kamer er in 1864 van te overtuigen dat een extra (vijfde) afgevaardigde uit hun provincie dringend gewenst was om zo 'in 's lands vergaderzaal minstens zoveele tolken zijner grieven, zoveele verdedigers zijner belangen te tellen, als waarop het [Limburg] naar regt en billijkheid mag aanspraak maken'. 'Thorbecke, toen minister van Binnenlandse Zaken, veroordeelde dit streven. De Limburgse kamerleden die het betoog van Gs steunden, stelden zich volgens de liberale voorman ten onrechte op als representanten van hun provincie: de Staten-Generaal vertegenwoordigden het gehéle Nederlandse volk en bestonden niet uit behartigers van provinciale deelbelangen. In de Kamer verklaarde hij: 'Zoo de naam van "Limburgsch vertegenwoordiger" hier te pas komt: en die naam, Mijnheer de President, komt hier niet te pas."

Limburgse politici in Den Haag bevonden zich in een spanningsveld tussen provinciaal en nationaal belang. Hun plaats en functioneren in de landelijke politiek staan in dit onderzoek centraal. Daarbij zal met name gekeken worden naar de positie die zij innamen in de processen van nationalisering en ideologisering die de Nederlandse politiek in de negentiende 
eeuw kenmerkten en waarvan de vorming van landelijke politieke partijen het resultaat was. Zochten en kregen de afgevaardigden uit Limburg aansluiting bij deze ontwikkelingen?

Dat hierbij juist de Limburgers interessant zijn, hangt samen met de bijzondere positie die hun provincie, in vergelijking met de overig landsdelen, inneemt in de historische ontwikkeling van de Nederlandse natiestaat (zie met name de hoofdstukken 2 en 4 ). Limburg zou zich na de vredesregeling van 1839 , waarbij het terugkeerde onder Nederlands gean, nog lang een vreemdeling voelen binnen het koninkrijk en door de overige provincies ook als zodanig worden beschouwd, aldus Nuyens in haar proefschrift over de staatkundige geschiedenis van Limburg.s Mede als gevolg daarvan bevonden de Limburgse leden van de Staten-Generaal zichin Den Haag in eenzelfde positie, constateert Prins in zijn tweedelig artilel over de Limburgse volksvertegenwoordigers tussen 1840 en 1880 : 'Temidden van de afgevaardigden uit de overige provinciën moesten zij zich gevoelen als vreemde eenden in de bijt [...].6

In de loop van de negentiende en twintigste eeuw werd de band net $\mathrm{Ne}$ derland hechter: Limburgers werden Nederlanders, hoewel het eer moeizaam integratieproces was. ${ }^{7} \mathrm{Dat}$ her integratieproces aith begin twintigste eeuw (deels) had voltrokken, kan beluisterd worden in het officiële volkslied van Limburg: het uit 1909 stammende Limburg mijn vaderland, beter bekend onder de aanvangszin 'Waar in 't bronsgroen eikenhout', dat nog steeds als het Limburgse volkslied fungeert. In het derde couplet wordt weliswaar in positieve zin melding gemaakt van de 'eigen zeden', de band met het Nederlandse vaderland ligt in de erop volgende strofe hecht verankerd:
Waar aan 't oud Oranjehuis, 't volk blijft houw en trouw; met ons roemrijk Nederland één in vreugd en rouw. ${ }^{8}$

Hoe anders had het een halve eeuw eerder geklonken in het door de priester W. Everts, leraar aan het seminarie te Rolduc, geschreven Limburgsch Volkslied:

Holland roeme op kiel en haven,

Op zijn schuimend pekelveld,

Waar het levend in begraven,

Siddrend in ligt vastgekneld: 
Limburg's zalige landouwen,

Met haar zee van golvend graan,

Zijn mij schooner om te aanschouwen,

Doen mijn boezem ruimer slaan.

Ook in dit lied werd de eigenheid van de Limburgse zeden bezongen, maar nu door ze af te zetten tegen verderfelijke, vreemde zeden:

Weg dan, weg, verpeste zeden,

Walm uit vreemde lustwarand!

In dit onverdorven Eden

Tiert niet ééne onreine plant."

De Limburgse Commissaris des Konings, jhr. P.J.A.M. van der Does de Willebois, toonde zich weinig ingenomen met Everts' tekst. Op een moment dat men zich in Limburg nog steeds niet onverdeeld tevreden voelde binnen het Nederlands staatsverband, meende Van der Does de Willebois zich afstandelijk te moeten opstellen tegenover een dergelijk regionaal patriottisme. ${ }^{10}$ De tekst zou dan ook nimmer een officięle status krijgen. De tekstschrijver wel: op 14 november 1893 nam Everts zitting in de Tweede Kamer der StatenGeneraal. Als een van de Limburgse vertegenwoordigers in Den Haag had hij vooral te maken met de politieke kant van het integratieproces. Deze politieke kant staat in dit boek centraal.

\section{Het onderzoek}

Bij een onderzoek naar de positie van de Limburgse politiek binnen een nationaal-Nederlands verband nemen de Limburgse leden van de StatenGeneraal een prominente plaats in. Indien we de Limburgse politiek hier opvatten als de Limburgse deelname aan de landelijke politiek, behoren zij tot de primaire actoren.

Zoals in hoofdstuk 3 zal blijken, werden de Limburgse volksvertegenwoordigers veelal gerekruteerd uit een sociaal-economische elite, een relatief kleine groep. Of hun opvattingen overeenkwamen met de publieke opinie in Limburg, staat mede daarom zeker niet vast. Overigens lijkt de literatuur soms wel een zekere mate van representativiteit te veronderstellen. Zo konden de Limburgse kamerleden zich in de jaren veertig van de negentiende eeuw niet onttrekken aan de anti-Nederlandse gevoelens die in hun provincie leefden. ${ }^{11}$ Bronnen die een beeld kunnen geven van de 
van belang is aandacht te hebben voor de houding van Nederlandse politici - onder wie hun nieuwe collega-volksvertegenwoordigers - heeft 1839 in dit onderzoek de voorkeur boven 1840 .

Ten slotte wordt ook wel 1867 genoemd, omdat in dat jaar een einde kwam aan het Limburgse lidmaatschap van de Duitse Bond (zie hoofdstuk 4). Naar aanleiding van die gebeurtenis schrijft Huijs bijvoorbeeld: 'Het tijdperk der staatsrechtelijke integratie van Limburg met het Koninkrijk der Nederlanden was begonnen [....$^{13}$ In het verlengde hiervan stelt Op den Camp dat de constructie waarbij Limburg behalve Nederlandse provincie tevens deel was van de Duitse Bond, het ontluiken van een Nederlands nationaal bewustzijn in Limburg altijd belemmerd had. ${ }^{16}$ In dit onderzoek staat de Limburgse deelname aan de nationale politiek centraal en omdat de Limburgers ook in de decennia vóór 1867 participeerden in de landelijke politiek, zal ook de periode 1839-1867 worden bekeken.

Over het moment waarop de politieke integratie van Limburg voltooid was, als zij al ooit tot voltooiing kwam, lopen de meningen eveneens uiteen. Dat blijkt onder meer uit het feit dat sommigen die voltooiing plaatsen in het jaar waarin de politieke integratie volgens anderen juist begon, namelijk in 1867 . Volgens Orbons en Spronck werd Limburg dat jaar, nadat het was ontdaan van zijn banden met de Duitse Bond, 'een volwaardige provincie van Nederland. ${ }^{17}$ Een delegatie uit Provinciale Staten die dat jaar naar Den Haag toog, sprak inderdaad tot de koning: 'Heden, Sire, wij zeggen het met vreugde en met fierheid, heden zijn wij niets anders meer dan Nederlanders [...].', '1

De politieke integratie wordt door Orbons en Spronck gelijkgesteld aan de staatsrechtelijke. In dit onderzoek worden de Limburgse volksvertegenwoordigers als uitgangspunt genomen en niet internationale verdragen of nationale wetten die op Limburg betrekking hadden. En er mag niet op voorhand worden aangenomen dat de beide processen van integratie gelijklopend zijn geweest.

Prins lijkt de voltooiing van de politieke integratie van de provincie te leggen in de jaren tachtig van de negentiende eeuw. De katholieke samenwerking kreeg in die jaren politiek gestalte en de parlementaire zetels, daarvoor nog ingenomen door katholieke Limburgers, werden vanaf die tijd bezet door Limburgse katholieken. 'Limburg is dan een provincie geworden als elke andere, ${ }^{19}$ laat Prins hierop volgen. Alberts gaat in zijn Geschiedenis van de beide Limburgen minder ver. Hij stelt dat de integratie van Limburg in het Nederlandse staatsverband door de katholieke samenwerking in de landelijke politiek een 'snelle voortgang' maakte. ${ }^{20}$ Van een voltooid proces 
van belang is aandacht te hebben voor de houding van Nederlandse politici - onder wie hun nieuwe collega-volksvertegenwoordigers-heeft 1839 in dit onderzoek de voorkeur boven 1840 .

Ten slotte wordt ook wel 1867 genoemd, omdat in dat jaar een einde kwam aan het Limburgse lidmaatschap van de Duitse Bond (zie hoofdstuk 4). Naar aanleiding van die gebeurtenis schrijft Huijs bijvoorbeeld: 'Het tijdperk der staatsrechtelijke integratie van Limburg met het Koninkrijk der Nederlanden was begonnen [... $]^{\prime \prime 1}$ In het verlengde hiervan stelt Op den Camp dat de constructie waarbij Limburg behalve Nederlandse provincie tevens deel was van de Duitse Bond, het ontluiken van een Nederlands nationaal bewustzijn in Limburg altijd belemmerd had. ${ }^{16}$ In dit onderzoek staat de Limburgse deelname aan de nationale politiek centraal en omdat de Limburgers ook in de decennia vóór 1867 participeerden in de landelijke politiek, zal ook de periode 1839-1867 worden bekeken.

Over het moment waarop de politieke integratie van Limburg voltooid was, als zij al ooit tot voltooiing kwam, lopen de meningen eveneens uiteen. Dat blijkt onder meer uit het feit dat sommigen die voltooiing plaatsen in het jaar waarin de politieke integratie volgens anderen juist begon, namelijk in 1867. Volgens Orbons en Spronck werd Limburg dat jaar, nadat het was ontdaan van zijn banden met de Duitse Bond, 'een volwaardige provincie van Nederland. ${ }^{17}$ Een delegatie uit Provinciale Staten die dat jaar naar Den Haag toog, sprak inderdaad tot de koning: 'Heden, Sire, wij zeggen het met vreugde en met fierheid, heden zijn wij niets anders meer dan Nederlanders [...].'.18

De politieke integratie wordt door Orbons en Spronck gelijkgesteld aan de staatsrechtelijke. In dit onderzoek worden de Limburgse volksvertegenwoordigers als uitgangspunt genomen en niet internationale verdragen of nationale wetten die op Limburg betrekking hadden. En er mag niet op voorhand worden aangenomen dat de beide processen van integratie gelijklopend zijn geweest.

Prins lijkt de voltooiing van de politieke integratie van de provincie te leggen in de jaren tachtig van de negentiende eeuw. De katholieke samenwerking kreeg in die jaren politiek gestalte en de parlementaire zetels, daarvoor nog ingenomen door katholieke Limburgers, werden vanaf die tijd bezet door Limburgse katholieken. 'Limburg is dan een provincie geworden als elke andere, ${ }^{19}$ laat Prins hierop volgen. Alberts gaat in zijn Geschiedenis van de beide Limburgen minder ver. Hij stelt dat de integratie van Limburg in het Nederlandse staatsverband door de katholieke samenwerking in de landelijke politiek een 'snelle voortgang' maakte. ${ }^{20}$ Van een voltooid proces 
is bij hem geen sprake. In lijn hiermee schrijft Van den Berg in zin dissertatie over de Tweede-Kamerleden tussen 1849 en 1970 dat veel reginalisme zich in Limburg heeft kunnen voortzetten onder de vlag van he politiek georganiseerde katholicisme. ${ }^{21}$ Een verlenging van de onderzoek periode, waarbij ook tijd wordt bestreken waarin er al sprake was van $e_{1}$ min of meer georganiseerd politiek-katholicisme, lijkt dan ook gerechtvąrdigd.

De keuze voor 1918 als eindpunt van het onderzoek vindt zijn grynd in de aanname dat de politieke integratie van Limburg toen reeds ver g.vorderd was, getuige de benoeming van de eerste Limburger tot minister-President. Bovendien pleit een praktische reden voor 1918 als eindpunt. De oen van kracht geworden grondwet maakte een eind aan het districten voerde een systeem van evenredige vertegenwoordiging in. De bard tussen kiezer en gekozene werd daardoor fundamenteel gewijzigd. Die me $\mathrm{e}_{\text {ing was }}$ ook een van de bekendste Limburgse Tweede-Kamerleden, W.H.Nolens, toegedaan. Tot in 1917 schreef hij regelmatig artikelen in de Venlooshe Courant, later de Nieuwe Venlosche Courant. Dat Nolens daarmee in 1917ophield, vond een voorname grond in de wijziging van het kiesstelsel: hij acitte zich door die herziening niet langer gebonden aan de belofte 'voeling tehouden

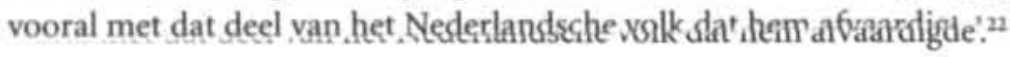

Dit onderzoek maakt deel uit van het landelijk onderzoeksprogramma $D e$ Natiestaat. Politiek in Nederland sinds 1815 . Omdat de politieke strijd in hoge mate een strijd was om 'meetellen' en 'meedoen' in de Nederlandse natie, richt het onderzoeksprogramma zich met name op drie vragen. Wie maakten de eigenlijke natie uit en mochten dus meepraten? Welke onderwerpen behoorden tot het domein van de nationale politiek en konden derhalve onderwerp zijn van politiek debat? Welke vormen kon en mocht de politieke strijd aannemen?

Vertaald naar de Limburgse situatie is de vraag aan de orde welke Limburgers mochten afreizen naar Den Haag en door wie en op grond waarvan dit werd bepaald. Ook kan de vraag gesteld worden welke zaken de Limburgse kamerleden in het parlement aan de orde stelden en op welke wijze zij dat deden. Om de antwoorden perspectief te geven zullen de Limburgse afgevaardigden worden vergeleken met collega-kamerleden. Daarmee kan tevens duidelijk worden of en op welke punten 'de naam van "Limburgsch vertegenwoordiger"' in de praktijk te pas kwam.

De parlementaire activiteiten van de Limburgse kamerleden zullen vooral worden onderzocht en beschreven aan de hand van de Handelingen van 
de Staten-Generaal, aangevuld met gegevens uit de archieven van Eerste en Tweede Kamer. Secundaire literatuur, artikelen uit de pers, persoonlijke correspondentie en notities vormen een andere belangrijke bron van informatie; een bron die bovendien kan helpen de buitenparlementaire activiteiten van de Limburgers in beeld te brengen. Biografische gegevens zijn met name verkregen uit het databestand van het Parlementair Documentatiecentrum (PDC) van de Universiteit Leiden. Daar waar op het punt van de sociale, economische en politieke achtergrond een vergelijking met de overige Nederlandse parlementariërs aan de orde is, zal dankbaar gebruik gemaakt worden van de dissertaties van Van den Berg en Van den Braak, waarin de leden van de Tweede respectievelijk de Eerste Kamer worden onderzocht. ${ }^{2}$

Om eventuele bemoeienissen van de centrale overheid - vooral bij verkiezingen - te kunnen achterhalen, zullen brieven, nota's en rapporten bekeken worden die zijn gewisseld tussen koning(in), ministers en gezagsdragers in Limburg. De strijd die rondom verkiezingen gevoerd werd, zal hoofdzakelijk worden geanalyseerd aan de hand van brochures en in de pers gepubliceerde en aan de kiezers gerichte advertenties en circulaires, aangevuld met informatie uit secundaire literatuur. Bovendien wordt gekeken naar commentaren en aanbevelingen die in kranten verschenen. Deze kranten bieden eveneens zicht op de publieke opinie in Limburg, waarbij ook de activiteiten van het provinciaal bestuur, secundaire literatuur en eerder genoemde correspondentie behulpzaam kunnen zijn.

\section{Het boek}

De politieke integratie van Limburg, zelfs wanneer teruggebracht tot de bijdrage die Limburgse kamerleden leverden aan de Nederlandse politiek, beslaat een omvangrijk terrein. Om dit terrein met overzicht te kunnen bewandelen, zal een aantal aspecten afzonderlijk aan de orde komen.

Het eerste hoofdstuk richt zich hoofdzakelijk op wat eerder het voorspel is genoemd: de periode tot 1840 , het jaar waarin de Limburgse afgevaardigden terugkeerden in de Staten-Generaal. Deze periode valt uiteen in drieën. Het eerste tijdvak is dat van het Verenigd Koninkrijk (1814/1815-1830). Centraal staat daarbij de vraag hoe de Limburgse afgevaardigden zich verhielden tot de noordelijke provincies. De jaren tot 1830 kunnen inzicht geven in de positie die de Limburgers toen innamen in de nationale volksvertegenwoordiging, een positie waarop latere afgevaardigden wellicht voortbouwden. In de periode van het Verenigd Koninkrijk zullen dan ook met name de af- 
gevaardigden worden gevolgd die uit het gedeelte van Limburg afkomstig waren dat na 1839 (wederom) tot Nederland zou gaan behoren. Vervolgens wordt aandacht besteed aan de Belgische periode (1830-1839). Ook hier staan de afgevaardigden uit het latere Nederlands-Limburg centraal: hoe stonden zij tegenover hun nieuwe vaderland (België) en wat was hun houding ten aanzien van de (voortdurend dreigende) terugkeer onder $\mathrm{Ne}$ derlands gezag? Het hoofdstuk sluit af met de discussies die in de StatenGeneraal werden gevoerd over de rentree van Limburgers in hun midden. Deze discussies kunnen licht werpen op de atmosfeer waarin de eerste Limburgse volksvertegenwoordigers terechtkwamen en moesten werken.

Hoofdstuk 2 begint met een schets van het institutionele kader waarbinnen kamerleden opereerden. De aandacht gaat daarbij in het bijzonder uit naar de vereisten die de grondwet en de kieswet stelden aan het lidmaatschap van Eerste en Tweede Kamer. Deze eisen bepaalden voor een belangrijk deel welke Nederlanders - en meer in het bijzonder welke Limburgers - afgevaardigd konden worden naar Den Haag. Vervolgens zal worden onderzocht welke band de afgevaardigden onderhielden met Limburg. Met name hun geboorte- en woonplaats en hun loopbaan zullen daarbij als criteria worden gehanteerd. Ten slotte wordt geprobeerd een antwoord te vinden op de vraag of de Limburgse afgevaardigden zich onderscheidden van hun collega-volksvertegenwoordigers wanneer het gaat om participatie, parlementaire ervaring en sociale achtergrond.

Waar lag voor de Limburgse kamerleden hun vaderland? In hoofdstuk 3 zal worden onderzocht welke houding zij aannamen jegens de Nederlandse natiestaat en welke rol zij speelden in het uiteindelijke behoud van hun provincie voor Nederland. Er zal worden aangesloten bij de momenten waarop de staatsrechtelijke band met Nederland expliciet op de parlementaire agenda verscheen. Dat was het geval in de jaren $1840-1850$, in de jaren zestig en in de periode rondom het einde van de Eerste Wereldoorlog.

Een wezenlijk aandachtspunt bij het onderzoek naar de politieke integratie van Limburg is de aansluiting van Limburgse afgevaardigden bij politieke groeps- en partijvorming op nationaal niveau. In hoofdstuk $4 \mathrm{zal}$ de politieke verhouding van Limburgse kamerleden tot de overige parlementariërs worden bekeken. Met wie gingen zij een bondgenootschap aan? Waren zij hierbij eensgezind of verdeeld? Op een aantal punten zullen de afgevaardigden uit de eveneens overwegend katholieke provincie NoordBrabant als referentiegroep dienen.

Hoofdstuk 5 bevat een casestudie: de houding van de Limburgse kamerleden tegenover (de wetgeving inzake) de Nederlandse belastingen. De 
keuze voor dit onderwerp vindt zijn grond in de vaststelling dat de belastingen in de parlementaire activiteiten van de Limburgers een zeer prominente plaats innamen. De aandacht in dit onderzoek gaat uit naar de vraag of de Limburgers in Den Haag zich op het terrein van de belastingen in opvatting en handelen onderscheidden van hun collega-parlementarièrs en hoe hun doen en laten zich verhield met de opinie in Limburg, met name met de gevoelens die leefden bij vertegenwoordigers van de provinciale politiek.

Afsluitend worden de aspecten die aan de orde zijn gekomen met elkaar in verband gebracht. De Limburgse leden van de Staten-Generaal wordt daarmee een plaats gegeven in de Nederlandse politiek tussen 1839 en 1918 en de vraag kan worden beantwoord of en in welke opzichten 'de naam van "Limburgsch vertegenwoordiger"' toepasselijk was. 

HOOFDSTUK 1

\section{Tussen Brussel en Den Haag Limburgse afgevaardigden voor 1840}

Op 19 oktober 1840 - de derde maandag in oktober - opende Willem n, sinds twaalf dagen Koning der Nederlanden, het nieuwe parlementaire jaar. In zijn rede tot de leden van de Staten-Generaal richtte hij een bijzonder woord tot de Limburgers onder hen:

... het [is] Mij aangenaam, leden uit het Hertogdom Limburg in uw midden te zien. Hierdoor is de band bevestigd, welke de belangen van dat gewest met die der overige deelen des Koningrijks in broederlijke gemeenschap zamenvoegt. ${ }^{1}$

Een welkomsgroet aan de afgevaardigden uit Limburg: na een afwezigheid van bijna tien jaar waren zij terug in de Staten-Generaal.

In 1830 had een koninklijke boodschap van Willem 1 het voorlopig einde ingeluid van de Limburgse afvaardiging in Eerste en Tweede Kamer. 'Wij verlangen,' zo had hij de beide Kamers laten weten, dat 'U Edel Mogenden zich, van nu af, aanmerken, als eeniglijk en alleen vertegenwoordigende de Noordelijke provinciën.'2

In het zuidelijk deel van het koninkrijk waren de opstootjes, eind augustus begonnen in Brussel, uitgegroeid tot een opstand tegen het Nederlands gezag. Het Voorlopig Bewind, dat zich aan de leiding van deze opstand had gesteld, had inmiddels de Belgische onafhankelijkheid uitgeroepen. De afgevaardigden uit het Zuiden waren daarom niet meer welkom in de $\mathrm{Ne}$ derlandse volksvertegenwoordiging, als zij zich zelf al geroepen voelden om daar nog langer te verschijnen.

De koninklijke lastgeving, in de Tweede Kamer met gejuich ontvangen, had belangrijke gevolgen gehad voor de Limburgse parlementariërs. Vanaf de oprichting van het Verenigd Koninkrijk in 1815 hadden zij deel uitgemaakt van het Nederlandse parlement. Nu had hun provincie de zijde gekozen van Belgiê, hetgeen 'normaal kon heten voor een Zuidnederlands gewest.'

Met de Limburgse parlementariërs als uitgangspunt voor dit onderzoek dient de vraag zich aan of de keuze voor België ook voor hen zo vanzelfsprekend was. In dit hoofdstuk zal worden gekeken naar de standpunten die 
deze vertegenwoordigers innamen bij discussies over de wenselijkheid van een staatsrechtelijke band met Noord-Nederland. Behalve bij de Belgische afscheiding in 1830 speelde deze discussie in het bijzonder bij de start van het Verenigd Koninkrijk. Voor de tussenliggende jaren zal de houding van de Limburgse kamerleden worden onderzocht op die momenten waarop er zich in het Nederlandse parlement een duidelijke tegenstelling aftekende tussen de vertegenwoordigers uit de noordelijke en de zuidelijke provincies. Daarbij richten we onze blik hoofdzakelijk op de Tweede Kamer, want in de 'andere kamer, welke den naam van eerste draagt', zoals de grondwet van 1815 de Eerste Kamer zo fraai noemde, kwamen ten tijde van het Verenigd Koninkrijk wezenlijke Noord-Zuid-tegenstellingen niet aan het licht.

\section{Een zuidelijk gewest}

In het vredesverdrag van Parijs, in mei 1814 gesloten na de troonsafstand van Napoleon, werd onder meer vastgelegd dat de noordelijke Nederlanden, voorheen de Republiek, zouden worden verenigd met de voormalige Oostenrijkse Nederlanden, het vroegere prins-bisdom Luik en nog enkele (kleinere) gebieden. Een 'réunion de la Hollande et de la Belgique' die 'intime et complète' zou moeten zijn. ${ }^{5}$ Het nieuwe koninkrijk werd een jaar later op het Congres van Wenen door de grote Europese mogendheden bevestigd.

De creatie van dit Verenigd Koninkrijk markeert tevens het ontstaan van de provincie Limburg: een eenheid was die provincie daarvoor nooit geweest. De historische kaart van Limburg van voor de negentiende eeuw is volgens de historicus Rogier in staat om zelfs de meest ondernemende geschiedvorser tot vertwijfeling te brengen. ${ }^{6}$ De grondwet van 1815 kon bij de territoriale afbakening van de provincie Limburg derhalve niet volstaan met de bepaling dat zij haar oude grenzen zou behouden, zoals dat bij de meeste provincies - dertien van de zeventien - gebeurde. ${ }^{7}$ Limburg werd hoofdzakelijk gevormd door samenvoeging van nagenoeg het gehele voormalige Franse departement van de Neder-Maas met een klein gedeelte van het vroegere departement van de Roer, hetgeen vrijwel overeenkomt met het huidige grondgebied van Nederlands en Belgisch-Limburg samen. ${ }^{8} \mathrm{De}$ provincie kreeg door de grondwetscommissie die in 1815 was ingesteld, oorspronkelijk de naam Maastricht, waarbij Opper-Gelderland als mogelijk alternatief werd genoemd. Op uitdrukkelijk verlangen van de koning werd uiteindelijk gekozen voor Limburg, naar een uit de Middeleeuwen stammend hertogdom. Het grondgebied van dit oude hertogdom lag weliswaar 
voor het overgrote deel buiten de gelijknamige nieuwe provincie, de naam Limburg mocht niet verloren gaan, zo tekende de koning aan."

In het Verenigd Koninkrijk werd Limburg gerekend tot de zuidelijke provincies. In tegenstelling echter tot de andere zuidelijke gewesten was de bestuurlijke band met Noord-Nederland voor Limburg, althans voor delen daarvan, geen noviteit. H.J. Brouwers, Limburgs Tweede-Kamerlid in de jaren zeventig en tachtig van de negentiende eeuw, kon in 1857 dan ook in zijn dissertatie over de staatsrechtelijke positie van zijn provincie schrijven: 'Ik heb in het kort den Staatsregtelijken toestand van Limburg sedert eeuwen herwaarts trachten aan te toonen om te doen zien, dat een groot gedeelte dezer provincie sedert dat de Noordelijke Provincieèn als een onafhankelijke Staat bestonden, aan deze toebehoorde. ${ }^{10}$

Tot 1795 hadden verschillende Limburgse plaatsen, waaronder de vestingstad Venlo, als generaliteitslanden aan de Republiek toebehoord. Het bestuur over Maastricht - een andere vestingstad - werd door de Republiek gedeeld met de prins-bisschop van Luik. Deze generaliteitslanden besloegen wat oppervlakte betreft een groot deel van het huidige (Nederlands) Midden- en Zuid-Limburg. Gemeten in de jaren 1840, woonde meer dan veertig procent van de bevolking van Nederlands-Limburg in gebieden die voor 1795 onder Noord-Nederlandse soevereiniteit hadden gestaan. "In 1795 werden de Nederlandse bezittingen in de latere provincie Limburg bij het verdrag van Den Haag afgestaan aan Frankrijk.

Toen de Prins van Oranje - de latere koning Willem 1-op 2 december 1813 de soevereiniteit over de Verenigde Nederlanden (de vroegere Republiek) aanvaardde, bleek al spoedig dat hij ook de voormalige generaliteitslanden in het latere Limburg weer tot zijn Noord-Nederlandse rijk rekende. De prins, die de titel Soeverein Vorst had aangenomen, gaf opdracht deze gebieden namens hem in bezit te nemen. De terugkeer van het Nederlandse gezag werd er positief begroet: 'De dispositien der oude hollandsche landen zijn niet beter te wenschen. De vreugde is luidrijk over de wederkeer onder 's prinsen souvereiniteit', berichtten de commissarissen die met de opdracht waren belast. ${ }^{12}$ Ook indien de commissarissen hun ervaringen hier wat te positief inkleurden, kan worden gesteld dat de aanwezigheid van de Republiek tot 1795 , zelfs als die niet werd geapprecieerd, de bevolking met het Noorden vertrouwd had gemaakt. ${ }^{13}$ En dit gold zeker voor de politiekbestuurlijke elite.

De vroegere generaliteitslanden werden in 1814 , als van oudsher deel uitmakend van de Nederlanden, ingedeeld bij de provincie Brabant. ${ }^{14}$ En dus benoemde de Soeverein Vorst dat jaar G.A.E. van Aefferden 'wegens de 
stad Venlo' in de Provinciale Staten van Brabant. ${ }^{15}$ Nog voordade noordelijke en de zuidelijke Nederlanden met elkaar waren verenigd, thoorde de latere provincie Limburg dus deels al tot de Nederlandse staat. lit zou later wel eens leiden tot weinig overzichtelijke situaties. Zo was de lederlandse jachtwet van juli 1814 gedurende de gehele periode van het Vrenigd Koninkrijk wel van toepassing op deze eerder ingelijfde gebieden a Limburg, maar niet op het overige gedeelte van de provincie, waar de ade Franse jachtwetgeving bleef gelden. ${ }^{16}$

Dat Limburg ondanks zijn oude banden met Noord-Nederlant werd beschouwd als zuidelijk gewest, vond zijn weerslag onder meer ir de grondwettelijke bepalingen ten aanzien van de Tweede Kamer. De grondwet van 1815 had bij de verdeling van het aantal afgevaardigden over deprovincies het pariteitsbeginsel toegepast: aan de negen noordelijke provinies was een gelijk aantal afgevaardigden (55) toegekend als aan de negen zuielijke, overigens met voorbijgaan aan het grotere bevolkingsaandeel van let Zuiden. De vier Tweede-Kamerleden waar Limburg volgens de grondwt recht op had, dienden daartoe bij de zuideliike helft te wordengeteld. Wa het echter ook voor de Limburgse parlementariërs zelf vanzelfsprekend dat zij werden ingedeeld bij het zuidelijk deel van het koninkrijk?

Een duidelijk antwoord kwam in 1830 van jhr. André Charles Membrède, lid van de Eerste Kamer. Toen de voorzitter van die Kamer in oktober van dat jaar, ten gevolge van de Belgische opstand, slechts de noordelijke leden uitnodigde, protesteerde Membrède bij de koning. Als geboren Maastrichtenaar wenste hij beschouwd te worden als Noord-Nederlander. Hier was, zo liet Willem I antwoorden, inderdaad sprake van een 'oorspronkelijk en aangeboren regt' dat hem niet kon worden ontzegd. ${ }^{17}$ De Eerste Kamer besloot daarop Membrède weer toe te laten tot haar vergaderingen. Door Membrèdes ingrijpen behield Limburg, als enige van de (voormalige) zuidelijke gewesten, een vertegenwoordiging in Den Haag. ${ }^{18}$ Het vertrek van de Limburgers uit de Staten-Generaal werd daardoor uitgesteld tot 23 oktober 1831, de dag waarop Membrède stierf.

\section{De Limburgse notabelen}

De eerste grote tegenstelling tussen de noordelijke en de zuidelijke provincies openbaarde zich reeds bij hun samengaan in 1815 . De ontwerp-grondwet voor het koninkrijk, opgesteld door een commissie onder leiding van jhr. Gijsbert Karel van Hogendorp, werd in augustus van dat jaar ter stemming 
voorgelegd: in het Noorden aan de Staten-Generaal en in het Zuiden, bij ontbreken van een vertegenwoordigend lichaam, aan vergaderingen van notabelen. Deze vergaderingen werden, naar de oude Franse indeling, departementsgewijs bijeengeroepen; op elke tweeduizend inwoners benoemde de koning één notabele. ${ }^{19}$

In het geval van de provincie Limburg deed zich hierbij een bijzonder vraagstuk voor. Doordat delen ervan eerder al waren ingelijfd bij de Noord-Nederlandse provincie Brabant, waren de bewoners van deze gebieden al vertegenwoordigd in de Staten-Generaal, zoals zij ook reeds afgevaardigden hadden in de Brabantse Provinciale Staten. De uitspraak die de Staten-Generaal zouden doen over de nieuwe grondwet, zou dus mede namens hen worden gedaan. In eerste instantie leek de regering daarom ook voornemens om slechts notabelen op te roepen uit de 'Limburgse' gebieden die niet tot Brabant behoorden; uiteindelijk besloot zij echter vermoedelijk om praktische redenen - terug te grijpen op de Franse indeling van het departement van de Neder-Maas en Limburg in te delen in de arrondissementen Hasselt, Maastricht en Roermond. ${ }^{20}$ Ook de delen van deze arondissementen die al waren ingelijfd bij de provincie Brabant, werden op deze manier bij de notabelenvergaderingen betrokken. Zo kon het gebeuren dat een zittend lid van de Staten van Brabant, jhr. J.A.C. van Panhuys uit Maastricht, werd opgeroepen als notabele in het arrondissement Maastricht en dat een andere notabele die zich eerder al in een van de Noord-Nederlandse notabelenvergaderingen had mogen uitspreken over de (Noord-Nederlandse) grondwet van 1814 nu werd gevraagd zijn mening als zuidelijk notabele te geven.

Terwijl de Staten-Generaal de grondwet met algemene stemmen accordeerde, stemde $60,3 \%$ van de zuidelijke notabelen tegen het voorstel. Met behulp van een eigenaardige rekenmethode - bekend als de 'arithmétique hollandaise' - reduceerde Willem $\mathrm{t}$ het aantal zuidelijke tegenstemmers drastisch: de 126 notabelen die hun tegenstem met godsdienstige redenen hadden gemotiveerd, werden geacht vóor te hebben gestemd. Na vervolgens het unanieme votum van de Staten-Generaal te hebben verdisconteerd, stelde hij vast dat zijn koninkrijk met een duidelijke meerderheid zijn zegen had gegeven aan de nieuwe grondwet. De stemming in het Zuiden had echter duidelijk gemaakt dat het nieuwe staatsverband daar niet op veel sympathie hoefde te rekenen.

Het verzet in het zuidelijk deel van het koninkrijk tegen de grondwet was evenwel niet gelijkmatig verdeeld (zie bijlage I). In 11 van de 29 arrondissementen kon de grondwet wel degelijk rekenen op een meerderheid en 
in één arrondissement, Charleroi, was het aantal voor- en tegenstanders gelijk. Indien we de latere provinciale indeling op deze arrondissementen projecteren, blijken drie provincies de nieuwe staatsregeling in meerderheid te hebben gesteund: Luik, Luxemburg en Limburg. ${ }^{21}$ In de twee laatste provincies was de steun voor de staatsregeling te vinden in alle arrondissementen. In elk van de Limburgse arrondissementen - Roermond, Maastricht en Hasselt - bracht meer dan driekwart van de notabelen zijn stem voor de grondwet uit, in Roermond was de steun zelfs algemeen. In contrast met de overige zuidelijke provincies, Luxemburg en in mindere mate Luik uitgezonderd, konden het nieuwe Nederlandse staatsverband en de vereniging met het Noorden in 1815 dus rekenen op een welwillende houding van de Limburgse elite. ${ }^{22}$

\section{Limburgse kamerleden in het Verenigd Koninkrijk}

Het derde hoofdstuk van de nieuwe grondwet behandelde de Staten-Generaal. Om de band tussen Noord en Zuid te onderstrepen, was in artikel 98 bepaald dat de volksvertegenwoordiging afwisselend - om het jaar zou vergaderen in 'eene stad der noordelijke, en in eene der zuidelijke provincien': in de praktijk Den Haag en Brussel. De Tweede Kamer zou no leden tellen, te kiezen door de Provinciale Staten, waarbij aan iedere provincie een vast aantal kamerleden was toegekend. PS van Limburg mochten vier afgevaardigden aanwijzen.

De eerste 110 afgevaardigden werden echter, op grond van additioneel artikel 1 van diezelfde grondwet, benoemd door de koning. Dit artikel gaf de koning het recht, met het oog op een snelle en geregelde inwerkingtreding van de grondwet, om 'voor de eerste reize' alle colleges en ambtenaren te benoemen van wie de verkiezing of benoeming door de grondwet aan andere organen was toegekend. Deze bevoegdheid stelde Willem $\mathrm{I}$ mede in staat om hem minder welgevallige personen voorshands van het lidmaatschap uit te sluiten. Bij de Eerste Kamer hoefde de koning daarvoor geen beroep te doen op de additionele artikelen, want haar leden werden overeenkomstig de grondwet voor het leven door de vorst benoemd.

De koninklijke bemoeienis met de samenstelling van de Tweede Kamer hield echter geenszins op na de benoeming van de eerste afgevaardigden in 1815. Ook in de daaropvolgende jaren, toen de kamerleden door Provinciale Staten werden gekozen, poogde de koning invloed uit te oefenen op de verkiezingen. Hij maakte daarbij gebruik van de gouverneurs in de provincies. ${ }^{23}$ Ook jhr. Charles de Brouckère, die ten tijde van het Verenigd 
Koninkrijk verreweg de meeste jaren gouverneur van Limburg was (van 1815 tot 1828 ), werkte hieraan mee. Zijn bemoeienis bij de kamerverkiezingen mag zelfs 'zeer opvallend' worden genoemd. ${ }^{24}$ Limburg had als gedeeltelijk oud-Staats gebied dan ook de bijzondere belangstelling van de koning. ${ }^{2}$ Maximilien baron de Beeckman, die het Limburgse gouverneursambt bekleedde vanaf 1828 tot het uiteenvallen van het koninkrijk in 1830 , speelde bij de verkiezingen eveneens een actieve rol. De inzet van de beide gouverneurs, die ook zelf bij de verkiezingen steeds meestemden, was er voortdurend op gericht om regeringsgezinde kandidaten te laten afvaardigen naar de Kamer en achter de schermen poogden zij daartoe statenleden over te halen hun stem op bepaalde personen uit te brengen. ${ }^{26}$

Met name De Brouckères pogingen waren niet zonder succes. Tot 1826 lukte het geen van de verklaarde anti-gouvernementelen om in Limburg verkozen te worden tot Tweede-Kamerlid. ${ }^{2}$ In dat jaar was het nota bene De Brouckères zoon, Charles jr., die hieraan een einde maakte. Als lid van de Tweede Kamer ontpopte hij zich al snel als een van de liberale voorlieden, tot ergernis van zijn vader, aan wie deze verkiezing 'als de mislukking van zijn leven' moet zijn voorgekomen. ${ }^{28}$ Een andere teleurstelling voor de gouverneur was de verkiezing, twee jaar later, van Erasme Louis baron de Surlet de Chokier. Dat het De Brouckère sr. voordien was gelukt om de baron tien jaar lang uit de Kamer te houden, werd door hem, zo schreef hij de koning, beschouwd als 'une nouvelle preuve de mon amour et de mon dévouement pour la personne sacrée de Votre Majesté et de mon attachement pour son gouvernement'. ${ }^{29}$ De Surlet de Chokier was in 1815 weliswaar door de koning zelf benoemd tot Tweede-Kamerlid, maar hij werd vervolgens al snel te liberaal bevonden door de regering. In 1818 was hij niet herkozen.

Tijdens de korte periode van De Beeckmans gouverneurschap werd er tweemaal, in 1829 en 1830 , een verkiezing gehouden. In het eerste jaar wilde de gouverneur een herverkiezing van opposant De Brouckère jr. voorkomen. Hij trachtte daartoe zoveel mogelijk statenleden over te halen tot het regeringskamp. Desondanks legde de door hem gesteunde kandidaat, jhr. Arnold Hendrik Michiels van Verduynen, het af tegen het zittende kamerlid De Brouckère. De reguliere verkiezing die voor 1830 op het programma stond, werd gehouden op 7 juli, aan de vooravond van de Belgische opstand. Pieter Willem baron de Liedel de Well, zittend kamerlid, werd met 53 van de 58 stemmen herkozen. ${ }^{30} \mathrm{Hij}$ kon worden beschouwd als 'gouvernementeel' en daarmee als acceptabel voor de gouverneur. Die had het dan ook niet nodig geacht een tegenkandidaat naar voren te schuiven. De geloofsbrieven 
van De Liedel de Well zijn wellicht nog naar de Tweede Kamer gezonden, behandeld werden ze niet meer: ten gevolge van de Belgische opstand werden bij aanvang van het parlementaire jaar $1830-1831$ slechts de geloofsbrieven van de nieuw gekozen noordelijke leden aan het gebruikelijke onderzoek onderworpen.

Tussen 1815 en 1830 , de periode van het Verenigd Koninkrijk, hebben in totaal elf afgevaardigden vanuit Limburg zitting gehad in de Tweede Kamer (zie bijlage $\mathrm{u}$ ). Mede als gevolg van genoemde interventies door de Limburgse gouverneurs kon de Nederlandse regering over het algemeen bij de meeste van deze kamerleden op steun rekenen. Van de vier afgevaardigden uit Limburg die hun lidmaatschap langer dan vier jaar - de duur van een reguliere zittingsperiode - aaneengesloten bekleedden, behoorde er geen één tot de oppositie. G.A.E. van Aefferden wordt door de historicus Prins nog enigszins voorzichtig aangeduid als 'geen oppositieman quand mème', Membrède krijgt het predikaat 'aarts-gouvernementeel.'31 Bij deze laatste richtte, zoals we al zagen, de loyaliteit zich mede op de noordelijke provincies; hii werd door de noordeliike kamerleden niet voor niots 'à demi hollandais' beschouwd. En om die reden was hij weer minder geliefd bij de zuidelijke kamerleden. ${ }^{32}$

Ook de twee andere kamerleden die langer dan vier jaar aaneengesloten in de Kamer zitting hebben gehad, lijken gehecht te zijn geweest aan het Noorden. Bij jhr. Willem Dominique Aloys Kerens de Wolfrath hebben we van doen met een 'uitermate "Hollandsch" gezinden' functionaris. ${ }^{33}$ Guillaume Georges François graaf de Borchgrave d'Altena liet zich kennen als orangist en overtuigd aanhanger van één ondeelbaar koninkrijk van de noordelijke en zuidelijke Nederlanden.

De bijzondere positie die Membrède innam in het spanningsveld tussen Noord en Zuid, werd geillustreerd bij de benoeming van de kamervoorzitter in oktober 1816. Zoals gebruikelijk bij de aanvang van een parlementair jaar, koos de Kamer drie leden die aan de koning zouden worden voorgedragen als kandidaat-voorzitter. Het voorzitterschap rouleerde jaarlijks tussen een zuidelijk en een noordelijk lid en dit keer was het de beurt aan het Zuiden. Het was echter niet Th. Dotrenge, voorheen de kandidaat van de zuidelijken, maar Membrède die, met de stemmen van de noordelijke kamerleden, als eerste kandidaat werd gekozen.

Tegenover deze uitgesproken Nederlandsgezinde kamerleden uit Limburg stonden afgevaardigden als Jean-François Hennequin en de eerder genoemde De Brouckère jr. en De Surlet de Chokier. Zij waren de regering 
veel minder welgezind en zouden later alle drie een duidelijke rol spelen in de opbouw van een onafhankelijk Belgiè. Hennequin, Fransman van geboorte, was in de jaren twintig een van de hoofdpersonen binnen de "anti- "Hollandse" oppositie' in Maastricht." In 1820 diende hij zijn ontslag in als Tweede-Kamerlid; als reden gaf hij taalproblemen op. 'Ne comprenant pas suffissamment la langue hollandaise pour suivre les discussions parlementaires,' vermeldt een necrologie die vlak na zijn overlijden in 1846 werd opgesteld." In maart 1821 werd Hennequin ontslagen als burgemeester van Maastricht en door de regering voor het gerecht gedaagd na een herhaalde weigering gelden vrij te maken voor de plaatselijke schutterij. In de rechtszaak stond de vraag centraal of de stad Maastricht behoorde tot de noordelijke of de zuidelijke Nederlanden. De kwestie kan beschouwd worden als 'een Maastrichts voorspel van de Belgische opstand.'.6

Uit het bovenstaande komt ten aanzien van de personen die vanuit Limburg tussen 1815 en 1830 naar de Tweede Kamer werden afgevaardigd, een beeld naar voren van onderlinge verdeeldheid. Deels kunnen zij gerekend worden tot de oppositie en tot de krachten die de band tussen Noord en Zuid met reserve tegemoet traden. Een ander deel van de afgevaardigden uit Limburg toonde zich loyaal aan de regering en hechtte juist sterk aan de band met de noordelijke provincies.

Met behulp van de parlementaire activiteiten van de kamerleden uit Limburg kan het hiervoor geschetste beeld nader worden getoetst. In zijn artikelen over de parlementaire geschiedenis tussen 1815 en 1830 geeft Prins nauwgezet aan bij welke kwesties Noord en Zuid in de Kamer tegenover elkaar stonden." In een aantal gevallen zijn de individuele stemmen van kamerleden niet te achterhalen door de onvolledigheid van de (zo'n halve eeuw later gereconstrueerde) Handelingen. Dit is bijvoorbeeld het geval in februari 1819 bij het voorstel van Hennequin om de belasting op de scheepvaart op de Maas af te schaffen, 'een twistappel [...] tusschen Noord en Zuid', waarbij de Tweede Kamer in een noordelijke en zuidelijke helft uiteenviel. ${ }^{38}$

Indien we de stemmingen terzijde laten waarbij de individuele stemmen niet zijn te achterhalen en ook de twee stemmingen die met betrekking tot de scheiding aan de orde waren, vooralsnog buiten beschouwing laten - zij komen later aan de orde - blijven er achttien stemmingen over. Deze stemmingen, waarbij noordelijke en zuidelijke afgevaardigden dus in opvallende mate tegenover elkaar kwamen te staan, zijn opgenomen in tabel 1 . 
Tabel 1. Stemmingen in de Tweede Kamer over (wets)voorstellen waarbij cen tegenstelling zichtbaar werd tussen de noordelijke en de zuidelijke afgevaardigden met vermelding van het stemgedrag van de kamerleden uit Limburg, ten tijde van het Verenigd Koninkrijk (1815-1830)

\begin{tabular}{|c|c|c|c|c|}
\hline (Wets)voorstel & $\begin{array}{l}\text { Datum } \\
\text { Stemming }\end{array}$ & $\begin{array}{c}\text { Noonden } \\
\text { voor-tegen }\end{array}$ & $\begin{array}{l}\text { Zuiden' } \\
\text { voor-togen }\end{array}$ & $\underset{\text { noor - togen }}{\text { Limbury }}$ \\
\hline straffen beledigen vreemde mogendheden & $20-2-1818$ & 35-7 & $1-32$ & $0-4$ \\
\hline afschaffen heerlijke recht jacht in bet Noorden & $26-2-1819$ & 9-35 & 43-3 & 3-0 \\
\hline door Frankrijk onafgedane schuldvorderingen & $17-5-1819$ & 5-24 & $36-1$ & $2-0$ \\
\hline woorieggen aan regering van brief Plasschart & 1.12 .1819 & $7-27$ & 43-3 & $2-2$ \\
\hline verkoop domeinen & $24-12-1819$ & $45-4$ & $9-40$ & $3-1$ \\
\hline m.b.t. de tienjaartijkse begroting & $24-12-1819$ & $40-9$ & 3-46 & $1-3$ \\
\hline stelselwet (regeling belastingstelsel) & $30-6-1821$ & $52-1$ & $3-50$ & $2-2$ \\
\hline perionele belasting & $15-5-1822$ & $48-4$ & $6-42$ & $2-2$ \\
\hline routaccijns & $27-6-1822$ & $45-1$ & $2-48$ & $2-2$ \\
\hline accijns op gemaal & $18-7-1822$ & $52-3$ & $2-53$ & $2-2$ \\
\hline accijns op geslacht & $19-7.1822$ & $53-2$ & $4-50$ & $2-2$ \\
\hline accijns op gremaal & $5 \cdot 8-1822$ & $53-2$ & $6-48$ & $3-1$ \\
\hline afschaffing geldigheid Franse munten & $11-1-1825$ & $41-2$ & $6-40$ & $2-2$ \\
\hline intrekking wetgeving beteugeling onrust & 3-12-1828 & $1-53$ & $43-6$ & $2-2$ \\
\hline adres aan koning over verzockschriften & 25-3-1829 & 5-39 & 50-1 & 40 \\
\hline vaststelling middelen voor $1830-1840$ & $19-12-1829$ & $47-7$ & $5-48$ & $0-3$ \\
\hline vaststelling uitgaven voor 1830 & $19-12 \cdot 1829$ & 49-6 & $5-47$ & $0-3$ \\
\hline beteugeling hoon en laster & $21-5-1830$ & $47-4$ & $5-48$ & $1-3$ \\
\hline
\end{tabular}

Bij twaalf van de achttien stemmingen bevonden zich één of meer afgevaardigden uit Limburg bij de zuidelijke minderheid die eenzelfde stem uitbracht als de meerderheid van noordelijke afgevaardigden. (Het betreft de stemmingen genummerd $4,5,6,7,8,9,10,11,12,13,14$ en 18.) Hieruit kan al worden afgeleid dat de Tweede-Kamerleden uit Limburg een vrij opmerkelijke positie innamen bij de tegenstellingen tussen Noord en Zuid: bij verreweg de meeste van de in aanmerking komende stemmingen schaarden afgevaardigden uit Limburg zich immers bij de grote meerderheid van noordelijke kamerleden. Indien we alle achttien uitslagen bij elkaar optellen, blijkt dat van de 878 stemmen die in totaal door zuidelijke afgevaardigden werden uitgebracht, er zich 77 bij de noordelijke meerderheid voegden. De afvaardiging uit Limburg leverde 24 van deze 77 stemmen, hetgeen betekent dat ruim $33 \%$ van de 'dissidente' zuidelijke stemmen uit Limburg afkomstig was. Aangezien de kamerleden uit die provincie een aandeel hadden van $7,3 \%$ in het zuidelijke part van de Tweede Kamer (vier van de 55 afgevaardigden), kunnen we vaststellen dat zij zich relatief vaak aan noordelijke zijde schaarden.

De spanning tussen Noord en Zuid bereikte met name rondom de stemmingen $7 \mathrm{t} / \mathrm{m} \mathrm{12}$, die plaatsvonden tussen juni 1821 en augustus 1822, een 
tot dan toe ongekend hoogtepunt. Aan de orde was om te beginnen het wetsvoorstel dat de grondslagen van het Nederlandse belastingstelsel wilde vastleggen: de stelselwet. Dat de Noord-Zuid-tegenstelling hierbij zo duidelijk naar voren trad, is niet verwonderlijk, daar in de eerste jaren van het koninkrijk de belangen en inzichten van de noordelijke afgevaardigden enerzijds en die van de zuidelijke anderzijds het scherpst contrasteerden op het terrein van de belasting- en tariefpolitiek: 'steeds weer ziet men het Noorden tegenover het Zuiden staan', aldus Prins. ${ }^{39}$ Het contrast laat zich grofweg beschrijven als een voorkeur voor vrijhandel versus een voorkeur voor protectionisme. In 1816 pleitte L.A. Reyphins, afgevaardigd door de provincie West-Vlaanderen, dan ook voor twee afzonderlijke belastingsystemen. ${ }^{* 0}$

In de Tweede Kamer liepen de emoties tijdens de beraadslagingen over de stelselwet hoog op. In hartstochtelijke bewoordingen beklaagden zuidelijke leden zich over de invoering van heffingen zoals de accijnzen op het gemaal (granen) en het geslacht (slachtvee). Het werd 'schimpen en schelden', aldus het bekende kamerlid Van Hogendorp; de noordelijke leden werden zelfs beticht van 'le fratricide de la vieille et loyale Belgique'," Ook het aanwezige publiek roerde zich; de vergaderingen vonden plaats in Brussel en het publiek zal overwegend uit de zuidelijke provincies afkomstig zijn geweest. Door de 'woeste staat' van de tribunes achtte Van Hogendorp het niet raadzaam om nog verder te spreken ten faveure van het wetsontwerp en veel noordelijke leden wilden de tribunes laten ontruimen. ${ }^{42}$

De afgevaardigden uit het Noorden stonden vrijwel lijnrecht tegenover die uit het Zuiden. Getalsmatig hielden de beide groepen elkaar in evenwicht: uit elk rijksdeel waren 53 kamerleden aanwezig. Bezien vanuit de Noord-Zuid-tegenstelling is het stemgedrag van vier kamerleden opmerkelijk: het noordelijke lid A.J.H. le Heu (Noord-Brabant) stemde tegen de wet en drie zuidelijke leden stemden voor. Onder deze laatsten bevonden zich twee van de vier Limburgse afgevaardigden: de Maastrichtenaren Membrède en Kerens de Wolfrath. Door zich te scharen bij de leden uit het Noorden hielpen zij de wet aan een meerderheid, hetgeen hun stemgedrag des te opvallender zal hebben gemaakt.

De nipte goedkeuring van de stelselwet was voor de regering een zorgelijke zaak: diverse wetsvoorstellen die in de nadere uitvoering van de stelselwet voorzagen, moesten nog aan het parlement worden voorgelegd. Het eerste wetsontwerp dat in dit kader werd ingediend, had betrekking op de personele belasting. Ook nu stemden verreweg de meeste noordelijke leden (48 van de 52) voor het wetsvoorstel; bij de zuidelijke leden was het overgrote deel ( 47 van de 53) tegen. Evenals bij de stelselwet steunden Membrède 
en Kerens de Wolfrath (nu samen met vier andere leden uit het 'uiden) de regering en sloten zich aan bij het overgrote deel van de noordeijke leden.

Spoedig na de behandeling van het wetsontwerp op de pesonele belasting volgden voorstellen over de accijns op het zout, op hetzemaal en op het geslacht. Ook bij deze voorstellen was er een tegenstellin; tussen de noordelijke en de zuidelijke helft van de Kamer: een grote meerdrheid van de noordelijke leden stemde telkens voor het voorstel en een rume meerderheid van de zuidelijke leden daartegen. De enige twee afgevaadigden uit het Zuiden die voor de accijnzen op het zout en het gemaal stemien, waren Membrède en Kerens de Wolfrath. Beiden maakten eveneens del uit van de groep van vier zuidelijke leden die de accijns op het geslachtsteunden. Na het wegstemmen van de accijnzen op het zout en het gemaaldiende de regering nog diezelfde maand gewijzigde voorstellen in, waarin an enkele bezwaren tegemoet was gekomen. Van een contrast tussen Nood en Zuid was bij het nieuwe voorstel aangaande het zout weinig meer te meken. Deze tegenstelling vinden we wel weer terug bij de stemming over het ;ewijzigde ontwerp inzake de accijns op het gemaal, hoewel ze nu met zeszuidelijke voorstemmers, enigszins aan scherpte had verloren. Snvallendis wel dat niet minder dan drie van deze zes stemmen afkomstig waren van afgevaardigden uit Limburg. Naast Membrède en Kerens de Wolfrath stemde nu ook Van Aefferden voor het wetsontwerp.

De tegenstelling tussen Noord en Zuid in de Kamer leek vervolgens te luwen, maar nog geen drie jaar later, in 1825 , was het alsof de dagen van de behandeling van het belastingstelsel waren teruggekeerd. ${ }^{43}$ De regering had een wetsvoorstel ingediend dat een eind moest maken aan het gebruik van Franse munten in de zuidelijke provincies van het koninkrijk. In de Kamer juichten vrijwel alle leden uit het Noorden de maatregel toe en de zuidelijke leden keurden hem, als nadelig en onpraktisch, in grote meerderheid af. Zes zuidelijke afgevaardigden stemden voor en twee noordelijke tegen het ontwerp en wederom hadden de Limburgse kamerleden een prominent aandeel in de 'zuidelijke minderheidsgroep': zowel Kerens de Wolfrath als Van Aefferden stemde voor. Membrède, voorheen vaak opvallend met de meeste noordelijke leden meestemmend, had de Tweede Kamer toen reeds verlaten, na zijn benoeming tot gouverneur van Antwerpen.

Ten slotte kijken we naar het stemgedrag van de Limburgse Tweede-

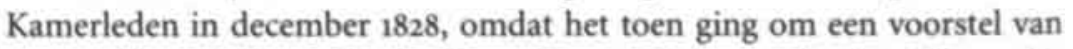
een van hen: De Brouckère jr. Deze afgevaardigde toonde zich tijdens zijn parlementaire loopbaan een warm voorstander van de vrijheid van drukpers en in 1828 diende hij een voorstel in tot intrekking van de wetgeving ter 
beteugeling van onrust en kwaadwilligheid. Zijn voorstel werd verworpen en ook nu stonden de noordelijke afgevaardigden tegenover hun zuidelijke collega's. Van de 44 leden die voor stemden, was er slechts éen afkomstig uit het Noorden; van de 61 tegenstemmers kwamen er zes uit het Zuiden. Twee van deze zes waren afkomstig uit Limburg: De Liedel de Well en graaf de Borchgrave d'Altena. De Surlet de Chokier, een politiek bondgenoot van De Brouckère jr., stemde voor het voorstel.

Dat de afgevaardigden uit de provincie Limburg zich opsplitsten in twee gelijke delen, is niet uitzonderlijk te noemen. Uit tabel 1 kan worden afgeleid dat dit bij de tien Noord-Zuid-stemmingen waarbij zij verdeeld stemden, acht keer het geval was. Van belang is hier de vaststelling dat de Tweede-Kamerleden uit Limburg zich bij de geregeld zichtbaar wordende Noord-Zuid-tegenstelling voortdurend aan beide zijden bevonden. In vergelijking met de afgevaardigden uit de overige zuidelijke provincies mag dit opmerkelijk worden genoemd.

\section{De scheiding}

De liberale juli-omwenteling in Frankrijk, die de hertog van Orléans, LouisPhilippe, op de troon bracht, zorgde in de zomer van 1830 voor onrust in diverse delen van Europa. Ook in de zuidelijke Nederlanden was de situatie gespannen en op 25 augustus braken er relletjes uit in Brussel. Met enige vertraging raakte ook Limburg betrokken bij de gebeurtenissen. In de eerste week van september vonden er ongeregeldheden plaats in steden als Tongeren, Hasselt, Sittard en Roermond, later die maand ook in de hoofdstad Maastricht.

Een groep zuidelijke kamerleden, onder wie De Brouckère jr., kwam begin september in Brussel bijeen om de situatie te bespreken. Zij brachten hun ideeën over aan de kroonprins, die door zijn vader ter beteugeling van de onrust, met zesduizend manschappen naar Brussel was gestuurd. In een door vijftien kamerleden ondertekende verklaring lieten zij weten de Prins van Oranje op de hoogte te hebben gebracht van de 'vurigste wensch' van België, zijnde 'eene algeheele afscheiding tusschen de Zuidelijke en Noordelijke provincien, zonder eenig ander punt van aanraking, dan dat beide onder een en hetzelfde regerend stamhuis zouden staan."4

Willem 1 had inmiddels besloten de Staten-Generaal in een buitengewone zitting bijeen te roepen. Zijn voornaamste doel was tijdwinst, in de hoop dat hij de situatie alsnog onder controle zou kunnen brengen. Alvorens zich op uitnodiging van de koning te verzamelen in Den Haag, kwamen 
de meeste zuidelijke kamerleden bijeen ten huize van Tweece-Kamerlid F.M.J.H. baron de Secus (afgevaardigd door de provincie Hegouwen). $\mathrm{Na}$ een discussie over de wenselijkheid van deelname aan de $\mathrm{k}_{\text {imende be- }}$ raadslagingen in de Staten-Generaal besloten de afgevaardigder af te reizen naar Den Haag.

Hier kregen de Kamers twee 'vraagpunten' voorgelegd. Als erste vraag werd gesteld 'of de ondervinding de noodzakelijkheid heeft angetoond om de nationale instellingen te wijzigen' en als tweede 'of, is dat geval, de betrekkingen tusschen de twee groote afdeelingen van hetKoningrijk gevestigd, tot bevordering van het gemeenschappelijk belang, n vorm of aard zouden behooren te worden veranderd'. Met name deze twede vraag is van belang, omdat zij de kwestie stelde van een mogelijke scheiling tussen Noord en Zuid. ${ }^{45} \mathrm{Na}$ een rumoerige discussie in de Tweede Karier over de wijze van beantwoording werden de twee vragen na elkaar in stemming gebracht. Een meerderheid van de kamerleden - 55 van de $102 \mathrm{~d}_{\mathbf{z}}$ aanwezig waren - sprak zich uit voor een scheiding (zie tabel 2).

Tabel 2. Stemming in de Tweede Kamer over de vraag of een scheaison ....... de noordelijke en de zuidelijke provincies wenselijk was (tweede vraagpunt), 29 september 1830, naar provincie

Noordelijke provincies Zuidelijke provincies

Non
Ja Nee liquet*

$\begin{array}{lrrrlrrr}\text { Noord-Brabant } & 0 & 6 & 0 & \text { Zuid-Brabant } & 7 & 0 & 0 \\ \text { Gelderland } & 3 & 2 & 1 & \text { Limburg } & 2 & 2 & 0 \\ \text { Holland } & 11 & 10 & 0 & \text { Luik } & 4 & 1 & 0 \\ \text { Zeeland } & 1 & 1 & 0 & \text { Oost-Vlaanderen } & 4 & 4 & 0 \\ \text { Utrecht } & 0 & 3 & 0 & \text { West-Vlaanderen } & 7 & 1 & 0 \\ \text { Friesland } & 0 & 5 & 0 & \text { Henegouwen } & 8 & 0 & 0 \\ \text { Overijssel } & 0 & 2 & 1 & \text { Namen } & 1 & 0 & 0 \\ \text { Groningen } & 0 & 3 & 0 & \text { Antwerpen } & 3 & 2 & 0 \\ \text { Drenthe } & 0 & 1 & 0 & \text { Luxemburg } & 4 & 0 & 0 \\ \text { Totaal } & 15 & 33 & 2 & \text { Totaal } & 40 & 10 & 0\end{array}$

* Non liquet $=$ stemonthouding.

Er is een opmerkelijk verschil waar te nemen tussen de leden uit de noordelijke provincies en die uit het Zuiden: bij de eerste groep stemde een ruime meerderheid tegen een scheiding terwijl een grote meerderheid van 
de zuidelijke afgevaardigden juist voor was. De scheidslijn tussen voor-en tegenstanders komt echter niet geheel overeen met die tussen Noord en Zuid in de Kamer. Zo stemden vijftien afgevaardigden uit het Noorden - voor het grootste deel afkomstig uit de provincie Holland - voor een scheiding. Ook vinden we tien van de vijftig zuidelijke leden bij de tegenstanders. Het aantal tegenstanders is bij de zuidelijke provincies relatief het grootst onder de afgevaardigden uit Oost-Vlaanderen en Limburg, gevolgd door die uit de provincie Antwerpen.

De Limburgse Tweede-Kamerleden stemden verdeeld. De Brouckère jr. had eerder al samen met veertien andere kamerleden verklaard voorstander van een scheiding te zijn en hij beantwoordde de vraag nu dan ook met 'ja'. Ook De Surlet de Chokier bracht zijn stem uit voor een scheiding. De twee Limburgse tegenstemmers waren De Liedel de Well en De Borchgrave d'Altena.

Evenals de Tweede Kamer stemde de Eerste Kamer - hier werden de twee vragen gelijktijdig in stemming gebracht - in meerderheid ( 31 tegen 7) voor een scheiding. Van de zeven tegenstemmen kwamen er zes uit de

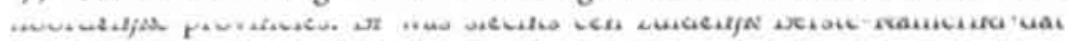
tegen de scheiding stemde: Membrède uit Maastricht. ${ }^{* 6}$ Voor een scheiding stemde de vroegere gouverneur in Limburg, De Brouckère sr.

Limburg sprak in Den Haag dus met twee tongen. Dit geldt ook voor vier andere zuidelijke provincies, te weten Oost-Vlaanderen, Antwerpen, West-Vlaanderen en Luik. Maar in tegenstelling tot Limburg waren de tegenstanders in het geval van de twee laatst genoemde provincies in een duidelijke minderheid. Het aantal Limburgse tegenstemmers was relatief gezien ongeveer gelijk aan de aantallen tegenstemmers uit Oost-Vlaanderen en Antwerpen, maar Limburg was wel weer de enige provincie waarbij het verzet zich uitstrekte over beide Kamers.

Hoe de scheiding eruit zou moeten zien, was op dat moment ook voor de voorstanders nog niet duidelijk. Tweede-Kamerlid De Brouckère was voorstander van een scheiding 'soit partielle, soit totale' en De Surlet de Chokier wilde, zoals veel kamerleden die voor een scheiding hadden gestemd, een zekere band met de noordelijke Nederlanden behouden." $\mathrm{Hij}$ was een van de weinigen die zich meer precies uitlieten over de administratieve organisatie na een scheiding. De Surlet de Chokier wilde onder andere een gezamenlijke dynastie en gemeenschappelijke ministeries van Buitenlandse Zaken en Oorlog.

Het Noord-Brabantse Tweede-Kamerlid J.L.A. Luyben wees tijdens de parlementaire beraadslagingen nog wel op de bijzondere positie van Lim- 
burg, immers gedeeltelijk 'oud Hollandsch': de grens tussen Noord en Zuid zou daar derhalve moeilijk te trekken zijn. ${ }^{48}$ Omdat de provincie in de voorafgaande jaren altijd gerekend was tot de zuidelijke gewesten, leek het echter niet onwaarschijnlijk dat wanneer het koninkrijk in een noordelijk en een zuidelijk deel zou uiteenvallen, Limburg tot het Zuiden zou blijven behoren. In dat licht deed De Liedel de Well een interessant voorstel. In een nota schreef hij:

Quant à la deuxième question, il [De Liedel de Well] observe que si, contre son attente, les Chambres, de commun accord avec le Roi, se décidaient à effectuer des changements dans la forme ou la nature des relations établies par les traités et la Loi fondamentale entre les deux grandes divisions du Royaume et qu' une séparation en fût le résultat, il serait juste de laisser aux provinces le choix de la partie du Royaume à laquelle elles voudraient appartenir.49

De keuze tussen Noord en Zuid behoorde volgens hem dus toe aan de provincies. Toegespitst op zijn eigen provincie zou dit inhouden dat een indeling van Limburg bij het eventueel af te scheiden zuidelijk rijksdeel niet als vanzelfsprekend moest worden beschouwd. Een continuering van de band met Noord-Nederland zou op die manier ook voor Limburg tot de mogelijkheden blijven behoren. ${ }^{50}$ Ook het Tweede-Kamerlid jhr. G.J.M. van Velsen (provincie Antwerpen) wilde dat in geval van een scheiding, waarvan hij overigens een voorstander was, de grensprovincies de mogelijkheid geboden werd aan te geven bij welk deel zij wilden behoren. Later, nadat België zich onafhankelijk had verklaard, lijkt De Liedel de Well zich te hebben laten leiden door de hoop dat de scheiding uiteindelijk niet verder zou gaan dan een zuiver administratieve, met behoud van de Oranjedynastie."51 Hij zou zich, als een van de weinige afgevaardigden in het Belgische Nationaal Congres, verzetten tegen het besluit om de Oranjes uit te sluiten van de Belgische troon.

De Liedel de Wells medestander in de Tweede Kamer, De Borchgrave d'Altena, zou zich in de jaren dertig niet minder actief tonen als het ging om het behoud en later het herstel van de Oranjedynastie. 'Votre Majesté ne nous abandonnerait jamais!' schreef hij koning Willem $\mathrm{I}$ in 1833 vanuit zijn kasteel in Bovelingen (bij Sint-Truiden) ${ }^{32}$ Met een groep gelijkgezinden streefde hij niet alleen een restauratie van de Oranjedynastie na, zij poogden zelfs internationaal steun te verwerven voor 'le rétablissement intégral et désormais indissoluble du Royaume des Pays-Bas.53 Mede met het oog 
daarop verstrekte De Borchgrave d'Altena inlichtingen aan de Nederlandse (militaire) autoriteiten.

De buitengewone zitting van de Staten-Generaal werd op 2 oktober 1830 gesloten. De dag ervoor had Willem I een staatscommissie benoemd die op korte termijn moest onderzoeken hoe de door de beide Kamers uitgesproken wens tot scheiding er in de praktijk zou moeten gaan uitzien. Het rapport van de commissie zou vervolgens, zo was het plan, bij aanvang van de komende (gewone) parlementszitting aan de kamers worden voorgelegd.

De gebeurtenissen in het Zuiden lieten zich echter niet langer sturen door beraadslagingen in en besluiten van de Nederlandse volksvertegenwoordiging. Veel zuidelijke kamerleden, onder wie De Brouckère jr. en De Surlet de Chokier, hadden de officiële sluiting dan ook niet meer afgewacht en waren voortijdig uit Den Haag vertrokken. De Limburgse Tweede-Kamerleden die tegen een scheiding hadden gestemd, De Liedel de Well en De Borchgrave d'Altena, bleven tot de laatste dag de vergaderingen van de Kamer bijwonen.

\section{Naar Brussel}

Terwijl de Staten-Generaal nog beraadslaagden over de wenselijkheid van een scheiding tussen Noord en Zuid, had de Nederlandse regering reeds besloten over te gaan tot militaire actie. Prins Frederik, de tweede zoon van Willem I, kreeg opdracht Brussel aar, te vallen. De aanval, ingezet op 23 september 1830 , werd een fiasco: de Nederlandse troepen raakten in het centrum van de stad omsingeld en moesten zich vier dagen later onder beschutting van de nachtelijke duisternis terugtrekken.

Ondanks de voor Nederland steeds ongunstiger wordende situatie wenste Willem $\mathrm{t}$ nog altijd slechts een puur administratieve scheiding te overwegen, met een gemeenschappelijke dynastie. Van een volledige onafhankelijkheid voor België, zoals op 4 oktober geproclameerd was door het Voorlopig Bewind in Brussel, wilde hij dan ook niets weten.

De ideeèn van Willem 1 over de positie van Limburg werden al vrij snel duidelijk. In een reactie op het eerder genoemde protest van Membrède tegen diens uitsluiting als Eerste-Kamerlid, schreef secretaris van staat J.G. baron de Mey van Streefkerk op 21 oktober:

... zoo zouden, naar's Konings inzien, bij weder-afscheiding van het oude grondgebied der Vereenigde Nederlanden van die landstreken, waarmede zij in 1815 tot één Koningrijk vereenigd zijn, de oude 
ingezetenen der Vereenigde Nederlanden, thans tot Limburg nog behoorende, terugkeeren tot hunnen ouden regtstoestand. ${ }^{54}$

Niet veel later, begin november, werkte Willem I zijn standpunt nader uit, naar aanleiding van het rapport van de staatscommissie die zich had beziggehouden met het opstellen van de voorwaarden voor een administratieve scheiding. De vorst stelde in zijn reactie dat hij in ieder geval het grootste deel van Limburg voor Nederland wenste te behouden. Een meerderheid van de commissie had de provincie nog in haar geheel willen indelen bij België, mede vanwege 'de gehechtheid der inwoners aan het Zuiden'ss De koning voelde echter meer voor het minderheidsstandpunt dat drie commissieleden, A.J.L. Borret, G.G. Clifford en W.B. Donker Curtius van Tienhoven, hadden ingenomen waarbij de voormalige generaliteitslanden in Limburg na een scheiding bij het Noorden zouden worden ingedeeld; deze gebieden hadden immers al voor de vereniging van de noordelijke en zuidelijke Nederlanden in 1815 deel uitgemaakt van de Nederlandse staat. ${ }^{56}$ De koning sloot zich hier niet alleen bij aan, hij ging nog een stap verder: niet slechts de voormalige generaliteitslanden in Limburg dienden aan Nederland toe te komen, de koning wilde de gehele departementen Roermond en Maastricht tot de Nederlandse staat gerekend zien. ${ }^{57}$ Tijdens de jarenlange onderhandelingen die zouden volgen, zou hij zijn aanspraken op (delen van) Limburg nimmer prijsgeven. Het behoud van een deel van de provincie voor Nederland kan daarmee in belangrijke mate op het conto van Willem I worden geschreven.

De opstand in de Belgische provincies groeide al spoedig uit tot een internationaal vraagstuk. Gevolmachtigden van de grote Europese mogendheden - Engeland, Frankrijk, Rusland, Pruisen en Oostenrijk - kwamen op 4 november in Londen bijeen om de kwestie te bespreken. Geen van de mogendheden had belang bij een Europees conflict en voor een gewapend ingrijpen voelden zij niets. Willem $\mathrm{I}$ had eerder, na de mislukte poging van prins Frederik om Brussel te onderwerpen, Engeland, Rusland, Pruisen en Rusland wel verzocht om zo'n militaire interventie. Een van de eerste besluiten van de Londense conferentie was het afkondigen van een wapenstilstand. Anderhalve maand later, op 20 december 1830 , hechtten de vijf landen hun goedkeuring aan de onafhankelijkheid van België, tot grote ontsteltenis van de Nederlandse koning.

De mogendheden trachtten vervolgens een scheidingsregeling op papier te zetten. In het eerste ontwerp, de Bases de séparation van januari 1831, werden 
de gebieden die voor 1790 deel hadden uitgemaakt van de Republiek, toegewezen aan Nederland. Belgie kreeg het overige grondgebied van het Verenigd Koninkrijk, met uitzondering van het groothertogdom Luxemburg dat als apart gebiedsdeel aan het Huis van Oranje-Nassau werd toebedeeld. De voormalige generaliteitslanden in Limburg werden in dit plan dus deel van Nederland, waarbij ruimte gelaten werd om deze gebieden door middel van ruil tot een aaneengesloten geheel te maken.

Willem 1 verklaarde akkoord te kunnen gaan: hij las in de bepalingen vooral dat zijn rechten op de soevereiniteit over de nieuwe staat Belgiè niet zouden worden aangetast. De Belgen reageerden teleurgesteld en wezen de regeling af: zij wilden Luxemburg in hun staat opgenomen zien en daarnaast maakten zij aanspraak op de gehéle provincie Limburg. Aan Nederlandse zijde hoopte men dat de Belgische weigering om de regeling te aanvaarden, zou leiden tot internationale strafmaatregelen die de onafhankelijkheid van de nieuwe staat in gevaar zouden brengen. Deze hoop werd niet vervuld, integendeel: de conferentie kwam de Belgen tegemoet door de toezegging met de Nederlandse koning te zullen onderhandelen over het afstaan van Luxemburg aan België 'moyennant de juste compensation's ${ }^{\text {s }}$

Nederland kon door deze toezegging zijn aanspraken op Limburgs grondgebied versterken, omdat de compensatie waarvan sprake was, gezocht kon worden in Limburg. Vooral Engeland was een voorstander van zo'n territoriale ruil. Frankrijk bedong nog wel dat de compensatie ook uit een geldbedrag zou mogen bestaan, een territoriale schadeloosstelling in Limburg bleef uitdrukkelijk tot de mogelijkheden behoren. Vanuit Nederlands perspectief werd die ruil van grondgebied niet onaantrekkelijk gevonden: de koning 'offerde' het ver weg gelegen en door velen als weinig aanlokkelijk beschouwde Luxemburg op voor een vergroting van het $\mathrm{Ne}$ derlandse grondgebied. ${ }^{59}$ Naast de Nederlandse enclaves en de door middel van ruil verkregen verbindingsgebieden daartussen zouden nu ook andere delen van Limburg deel kunnen gaan uitmaken van Nederland.

Het plan stuitte op een Belgische weigering: nogmaals werd duidelijk gemaakt dat men héél Limburg wenste. De verkiezing van prins Leopold van Saksen-Coburg-Gotha tot eerste Koning der Belgen had de Londense conferentie tot een meer welwillende houding jegens de jonge Europese staat gestemd, hetgeen tot uitdrukking kwam in de nieuwe scheidingsregeling - de Achttien artikelen - die op 26 juni 1831 werd vastgesteld. De vrii vage bepalingen boden België perspectief op gunstige uitkomsten. De Luxemburgse kwestie werd tot een separate zaak verklaard en daarmee losgekoppeld van de territoriale regeling in Limburg. Ook op een ander punt 
was rekening gehouden met de Belgische wensen: Maastricht wed niet zonder meer aan Nederland toegewezen. Indien zou komen vast te saan dat de Republiek daar voor 1790 geen exclusieve soevereiniteit had bezten, zoals de Belgen beweerden, zou over de status van de stad nader moetn worden onderhandeld. De gebieden waarvan wel duidelijk was dat zij ehoorden tot de voormalige generaliteitslanden, kwamen volgens het verdag wel aan Nederland toe, met wederom de mogelijkheid tot onderlinge ru.

De vaagheid van de bepalingen bood Sylvain van de Weyc, die binnen het Voorlopig Bewind was belast met de buitenlandse betekkingen, de mogelijkheid een wel erg eenzijdige interpretatie te geven va het verdrag: Maastricht zou bij Belgiẻ komen en ook Venlo, dat voon79o toch had behoord tot de generaliteitslanden, zou daarin opgaan. HeNationaal Congres gaf, mede op grond van dit gunstig vooruitzicht, zijn at aan de overeenkomst. ${ }^{60}$

Willem 1 greep nu naar militaire middelen. De Tiendaagseveldtocht (2 tot 13 augustus 1831 ) leverde het Nederlandse leger aanvanklijk grote successen op, maar ingrijpen van Frankrijk voorkwam een Belische ne-

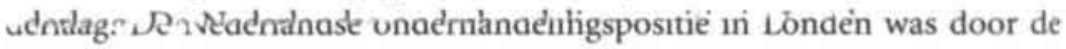
actie echter versterkt en de koning trachtte daarvan gebruik te maken door nu de gehele provincie Limburg voor Nederland op te eisen. Dat ging de conferentie te ver, wel stelde zij in oktober 1831 een nieuwe regeling voor - de Vierentwintig artikelen - die voor Nederland heel wat gunstiger uitpakte dan de eerdere Achttien artikelen, ook wat betreft de aanspraken op Limburg. Dit had met name te maken met de deling van Luxemburg, waarin de verdragstekst voorzag. Het oostelijk deel van Luxemburg kwam als onafhankelijke staat onder het groothertogelijk gezag van Willem I en het westelijk deel zou toevallen aan Belgiě. Ter compensatie van dit verlies aan Luxemburgs grondgebied ontving Willem 1 een deel van Limburg. Het gebied op de oostelijke Maasoever werd hem volgens artikel 4 toebedeeld 'soit en sa qualité de Grand-Duc de Luxembourg, soit pour être réunis à la Hollande.61 Voor het Limburgse grondgebied op de linker Maasoever ten noorden van Wessem kon deze keuze niet worden gemaakt: dat ging in elk geval deel uitmaken van het Koninkrijk der Nederlanden. Maastricht bleef krachtens het traktaat uitdrukkelijk in Nederlandse handen.

Met name door de gunstige territoriale bepalingen werden de Vierentwintig artikelen positief ontvangen door de Nederlandse publieke opinie. ${ }^{62}$ Desondanks weigerde Willem $\mathrm{I}$ - hoofdzakelijk geleid door dynastieke overwegingen - er zijn goedkeuring aan te hechten: ondertekening van de overeenkomst zou immers een formele erkenning inhouden van het verlies van 
zijn soevereiniteit over Belgiè. De openbare mening in Nederland werd succesvol bewerkt en de koning kon rekenen op brede steun. ${ }^{63}$ Regering en parlement in Brussel, bewust van de penibele situatie waarin hun land zich bevond, accepteerden de bepalingen wel.

Een nieuwe militaire actie werd aan Nederlandse zijde overwogen, maar was, gelet op de internationale verhoudingen, niet mogelijk. Een jarenlange status-quo trad in, waarbij Limburg de facto tot België behoorde. Maastricht en het nabijgelegen St. Pieter vormden een uitzondering: gelegen in Belgisch gebied waren zij een Nederlandse enclave.

Dat Maastricht in de jaren na 1830 onder Nederlandse controle bleef, versterkte de voortdurende aanspraken van Willem 1 op Limburgs grondgebied aanzienlijk. ${ }^{-4}$ Omgekeerd kunnen we stellen dat het de Belgische onderhandelingspositie in de Limburgse kwestie verzwakte. Terugkijkend stelde de Belgische minister en oud-onderhandelaar J.B. baron Nothomb dan ook vast: 'La fait de la non-possession de Maastricht par la Belgique a, dès 1830 , dominé les négociations. ${ }^{\text {'s }}$

De Nederlandse koning hechtte bijzonder aan het behoud van Maastricht: de vesting was in zijn ogen van groot belang voor de landsverdediging. ${ }^{66}$ De vestingcommandant ter plaatse, luitenant-generaal B.J.C. Dibbets, die erin slaagde om de stad in Nederlandse handen te houden, werd in november 1835 dan ook beloond met de erfelijke titel van baron.

In Nederland nam ondertussen de druk op de koning toe om zijn volhardingspolitiek los te laten, met name vanwege de hoge kosten die een voortdurend paraat leger met zich meebracht. Onder die druk liet Willem 1 op 4 maart 1838 weten alsnog te zullen instemmen met de Vierentwintig artikelen. In België reageerden velen verschrikt. Er werden plannen ontwikkeld om de af te scheiden delen van Luxemburg en Limburg in ruil voor een financiële genoegdoening te behouden. De grote mogendheden, die de overeenkomst al jaren daarvoor hadden geratificeerd en niet van zins waren om de situatie nog langer slepende te houden, wilden de Vierentwintig artikelen - enkele minder belangrijke punten daargelaten - ongewijzigd doorgevoerd zien: het oostelijk deel van Limburg zou derhalve moeten terugkeren naar Nederland.

De periode $1830-1839$ overziend, kan met betrekking tot Limburg worden vastgesteld dat deze terugkeer al die jaren als een zwaard van Damocles boven de provincie hing. Alle internationale ontwerp-traktaten bevatten een bepaling die delen van Limburg aan Nederland toewees. Daarbij kwamen nog de voortdurende Nederlandse aanspraken op (delen van) Limburg en de snelle aanvaarding door België van de Vierentwintig artikelen. 
Eén uitvloeisel van de vredesregeling verdient hier afzonderlijk aandacht. De nieuwe Nederlandse provincie Limburg zou, met uitzondering van de vestingsteden Maastricht en Venlo, tevens deel worden van de Duitse Bond: een samenwerkingsverband van Duitse staten en staatjes onder leiding van Pruisen en Oostenrijk. De kaart van Europa die in 1815 op het Congres van Wenen was getekend, lag hieraan ten grondslag. Luxemburg was toen weliswaar toegekend aan Willem 1 , het was tevens opgenomen in de Duitse Bond. Nu een deel van Luxemburg aan België moest worden afgestaan, c̈ende ook de Duitse Bond schadeloos te worden gesteld. De Bond had al in 1836, ten tijde van de status-quo, naar voren gebracht een territoriale compensatie in Limburg te begeren. Toen Willem $t$ in maart 1838 bekendmaakte de Vierentwintig artikelen te aanvaarden, liet hij tegelijkertijd meedelen met deze wens te kunnen instemmen. Zo ontstond in 1839 een bijzondere staatsrechtelijke constructie - 'een politiek en juridisch "monstrum" volgens Boogman $^{67}$ - die tot 1867 zou blijven bestaan.

Hoe was gedurende de jaren dertig de publieke stemming in Limbarg? Zoals reeds gemeld, werd de onrust die in augustus r 830 in B̈russel was ontstaan en zich vervolgens uitbreidde over de zuidelijke provincies, pas met enige vertraging in Limburg merkbaar. Dit kan vooral toegeschreven worden aan de aanwezigheid van militairen in de provincie, niet aan het ontbreken van steun voor de Belgische opstand. De omverwerping van het Nederlands gezag kon in Limburg juist vrij algemeen op instemming rekenen. ${ }^{68} \mathrm{Op} 10$ november werd Venlo met medewerking van de plaatselijke bevolking door Belgische troepen ingenomen. Deze gebeurtenis had een belangrijk moreel effect: het hele arrondissement Roermond koos nu de zijde van België.69

Zowel in de steden als op het platteland bleef een aantal 'orangistische kernen' actief. De kleine protestantse minderheid in Limburg verkoos op godsdienstige gronden een vereniging met Nederland boven een opgaan in het katholieke België. Ook economische motieven konden aanleiding zijn tot pro-Nederlandse gevoelens. Het is niet toevallig dat de Kamers van Koophandel en Fabrieken uit Maastricht en Vaals, de twee plaatsen waar de industrie in opkomst was, zich in 1830 tegen een scheiding uitspraken. Het latere Limburgse Eerste-Kamerlid Petrus Regout is uit deze kringen voortgekomen.

Daarnaast kan gewezen worden op andere personen die behoorden tot de (politieke) elite in Limburg en die min of meer openlijk kozen voor Nederland. Enkele invloedrijke families bleven bewust afzijdig van het Belgische bestuur, zoals de familie van het latere Tweede-Kamerlid Arnold 
Hendrik Michiels van Verduynen, die ook zelf in de jaren dertig weigerde een Belgische openbare betrekking te bekleden. Een ander toekomstig kamerlid, A.L.G.H. Bloemarts, verliet bij het begin van de onlusten in $1830-$ hij was toen burgemeester van Weert - zijn stad om Den Haag te waarschuwen voor de gevaarlijke situatie.

Van grote invloed op de publieke stemming in Limburg was de aanvaarding van de Vierentwintig artikelen door het Belgisch parlement in oktober 1831. Veel inwoners van de provincie voelden zich in de steek gelaten en hun aanvankelijk enthousiasme voor België bekoelde door de ontstane onzekerheid over de staatkundige toekomst. Deze gevoelens zullen zijn versterkt door de handelingen van de Belgische overheid die erop wezen dat zij terdege rekening hield met een afstand van oostelijk Limburg aan Nederland. Zo werden er uit het gebied geen miliciens opgeroepen voor het Belgisch leger, voorstellen tot verbetering van de gemeentefinanciën werden niet uitgevoerd en Limburg werd niet betrokken bij de plannen voor de aanleg van een Belgisch spoorwegennet. ${ }^{70}$

De jarenlange status-quo, waarbij Limburg - Maastricht en St. Pieter uitgezonderd - (de facto) Belgisch gebied was, zorgde er echter voor dat de hoop Belgisch te kunnen blijven, althans onder de Limburgse bevolking, toenam. Dit lag anders voor de gezagdragers in Limburg. De goedkeuring van de Vierentwintig artikelen door België had op deze overheidsdienaren, met name op lokaal niveau, een sterkere en meer blijvende invloed dan op de Limburgse bevolking in het algemeen. Lokale en regionale bestuurders bleven zich ervan bewust dat België het verdrag had aanvaard. Het Belgisch bestuur kreeg in het gehele met afstand bedreigde gebied te kampen met weinig coöperatieve gemeentelijke overheden. Een 'vrij belangrijk aantal personen in openbare dienst' lijkt uit verbittering over de Belgische houding een Nederlands bewind te hebben geprefereerd. ${ }^{71} \mathrm{Zij}$ zullen daarbij zeker hun eigen toekomst in het oog hebben gehouden: bij uitvoering van het verdrag zouden zij immers voor hun werk afhankelijk worden van de Nederlandse overheid.

Toen Willem $\mathrm{I}$ in maart 1838 verklaarde akkoord te gaan met de Vierentwintig artikelen en de uitvoering ervan aanstaande leek, kwamen er in Limburg protestacties op gang. In verschillende plaatsen op de rechter Maasoever werd de Belgische vlag uitgestoken en op initiatief van een aantal Limburgse notabelen stuurden diverse gemeenteraden en plaatselijke groepen van vooraanstaande burgers petities naar Brussel om tegen de afscheiding te protesteren: La protestation du Limbourg. ${ }^{72}$ De deelname aan dit petitionnement is echter niet overweldigend te noemen. Diverse 
bestuurscolleges waren nogal pragmatisch ingesteld; zij haddenich al verzoend met de gezagswisseling. ${ }^{73}$ Veel Limburgse notabelen wren tot de conclusie gekomen dat uitvoering van de Vierentwintig artikeln door de internationale druk onvermijdelijk was geworden en bij gebrek an leiding stortte het protest weldra ineen. ${ }^{74}$

Bij de overdracht van de soevereiniteit zouden zich geennoemenswaardige incidenten voordoen. De Limburgers lijken de niewe situatie gelaten te hebben geaccepteerd, hoewel er her en der wel uingen van anti-Nederlandse gevoelens werden gerapporteerd.

Deze kennelijke rust was mede te danken aan de tolerante huding die door de Nederlandse overheid werd aangenomen. ${ }^{75}$ Het Maastrihtse Journal du Limbourg schreef: 'Sa Majesté retrouve ses fidèles sujets aec joie, et dit à ceux qu'une triste erreur abusa: revenez à moi, tout est oblié! ${ }^{\prime 7}$ En dankbare stadsbestuurders van Venlo schreven hun nieuwe komg in zijn proclamatie te hebben gelezen dat 'Uwe Majesteit met koninklke grootmoedigheid al wat hier is voorgevallen niet meer [wil] gedenkn: ${ }^{7}$ In de vredesregeling was dan ook de volgende bepaling opgenomen: 'Inde gewesstas wealka an van regtstreeksche of middelijke deelneming op wat wijze dan ook aan de staatkundige gebeurtenissen, vervolgd of verontrust kunnen worden. ${ }^{37}$

Zowel in politieke kringen als in kringen van handel en nijverheid toonden verscheidene personen zich dus, op diverse gronden, bereid om zich te schikken in een terugkeer onder Nederlands gezag. Dit laat echter onverlet dat de bevolking van het oostelijk deel van Limburg in de jaren dertig in grote meerderheid gestemd was vóor een definitieve opname in het Koninkrijk België. Zij wist zich daarbij prima vertegenwoordigd door de Limburgse afgevaardigden in Brussel.

Uit het Nederlandse parlement waren de Limburgse afgevaardigden na de dood van Membrède verdwenen. Hoewel Maastricht en St. Pieter tussen 1830 en 1840 voortdurend in Nederlandse handen bleven, zond de provincie in die jaren geen afgevaardigden naar Den Haag. Provinciale Staten van Limburg werden na 1830 weliswaar nooit opgeheven - de statenverkiezingen vonden in Maastricht gewoon doorgang - maar de Staten kwamen in de jaren dertig nimmer in vergadering bijeen. De taken van Provinciale Staten werden vanaf 1831 waargenomen door een nieuw orgaan: de provinciale raad. Deze raad, die vier leden telde, verving tevens het college van Gedeputeerde Staten. Met een van de belangrijkste taken van PS: de benoeming van afgevaardigden in de Tweede Kamer, heeft de raad zich niet beziggehouden. 
Limburg in het Belgisch parlement

Van aanvang af hebben er afgevaardigden uit Limburg deelgenomen aan de werkzaamheden van de parlementaire organen van Belgiē. Het eerste vertegenwoordigend lichaam op landelijk niveau was het Nationaal Congres, dat op 18 november 1830 bijeengeroepen werd met de voorname opdracht een grondwet te ontwerpen. Het Congres bestond uit vertegenwoordigers van de negen Belgische provincies en was geconvoceerd 'au Palais des cidevant Êtats-Genéraux, à Bruxelles': de Belgen beschouwden de Nederlandse Staten-Generaal duidelijk als verleden tijd."

Uitdrukkelijk werden de inwoners uit de gehele provincie Limburg opgeroepen om hun afgevaardigden in het Nationaal Congres te kiezen. Zo was bij de voorbereidingen op de verkiezingen niet vergeten om ook voor de stad Maastricht - in Nederlandse handen - een census (het bedrag aan te betalen belasting) te bepalen als voorwaarde voor het actief kiesrecht. De kiezers uit Maastricht werden tevens ingeschreven in de Belgische kiezerslijsten." Van de Nederlandse autoriteiten viel bij de Belgische verkiezingen vanzelfsprekend geen medewerking te verwachten, hetgeen met name problemen opleverde voor de kiezers in het district Maastricht die op de oostelijke Maasoever woonden. Niet alleen konden zij hun stem onmogelijk in de stad zelf uitbrengen, alle plaatsen op de linkeroever waren minder goed bereikbaar, doordat de enige vaste oeververbinding in de provincie - de Sint-Servaasbrug - zich binnen de stadsmuren bevond. Er werd daarom een extra stembureau ingericht te Sittard. Het hoofdstembureau van het district had zijn zetel in Tongeren. Ook later, toen er verkiezingen voor de Belgische Kamer en Senaat plaatsvonden, zou de status van Maastricht als Nederlandse enclave - in Belgische termen was er sprake van een 'occupation par l'ennemi' - een speciale regeling vereisen voor de kiezers in het gelijknamige district. ${ }^{81}$ De bewoners van de oostelijke Maasoever werden verwezen naar Valkenburg, die van de westelijke Maasoever naar Tongeren.

Drie van de vier afgevaardigden die ruim een maand daarvoor nog namens Limburg zitting hadden gehad in de Tweede Kamer, keerden nu terug in het Nationaal Congres. In totaal koos Limburg zeventien van de 200 Congresleden (zie bijlage III). In de Belgische parlementaire geschiedenis tussen 1830 en 1840 zouden zij een prominente rol spelen. Zo werd De Surlet de Chokier gekozen als eerste voorzitter van het Nationaal Congres en enkele maanden later, in afwachting van de eerste Koning der Belgen, benoemd tot regent. De enige tegenkandidaat bij deze benoeming, Félix graaf de 
Mérode, was eveneens uit Limburg afgevaardigd. Twee van de uit rier leden bestaande commissie die namens het Nationaal Congres de Belgische kroon aanbood aan prins Leopold van Saksen-Coburg-Gotha, waren inLimburg gekozen: de zojuist genoemde De Mérode en Charles Destouveles. Louis de Schiervel bekleedde vanaf november 1838 het voorzitterschap van de Belgische Senaat en ten slotte kan nog het ministerschap van Bathélemy Théodore ridder de Theux de Meylandt (1831-1832 en 1834-1840 worden gememoreerd.

$\mathrm{Na}$ het uitschrijven van de verkiezingen voor het Nationaal Congres ontstond met name in Limburg grote verwarring, hetgeen hoodzakelijk is te wijten aan de Prins van Oranje. Willem was door zijn vacer belast met het bestuur van de zuidelijke gebieden die nog onder Necerlandse controle stonden, hoofdzakelijk de vestingsteden Antwerpen, Luxemburg, Maastricht en Venlo. In een poging het Zuiden sympathiek te stemmen maakte de prins op 5 oktober bekend met het oog op de Belgishe wens tot afscheiding een aantal 'verlichte lieden' te zullen raadplegen. ${ }^{82}$ De negen personen die Willem hiervoor uitzocht, waren allen voormalig lid van de

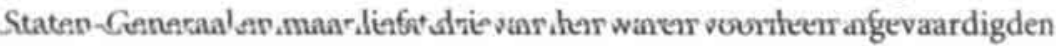
uit Limburg: De Surlet de Chokier, De Brouckère jr. (beiden voormalige leden van de Tweede Kamer) en Ph.J.M. graaf d'Archot Schoonhoven (Eerste Kamer). Een volgende prinselijke proclamatie, gedateerd 16 oktober 1830, kwam neer op een onvoorwaardelijke erkenning van de Belgische onafhankelijkheid. Ook liet de prins zich uit over de verkiezingen van het Nationaal Congres:

\section{BELGES!}

Depuis que je me suis adressé à vous par ma Proclamation du 5 du présent mois, j'ai étudié avec soin votre position, je la comprends et vous reconnais comme nation indépendante; c'est vous dire que dans les Provinces mêmes où j'exerce un grand pouvoir, je ne m'opposerai en rien à vos droits de Citoyens; choisissez librement, et par le MÊME MODE que vos Compatriotes des autres Provinces, des députés pour le congrès national qui se prépare, et allez y débattre les intérêts de la Patrie $[\ldots] .83$

Naar aanleiding van deze proclamatie vroeg commandant Dibbets vanuit Maastricht om instructies van de regering. Leden van het Maastrichtse gemeentebestuur gingen op hun beurt bij Dibbets te rade, die hen, omdat 
hij het zelf ook niet wist, naar de gouverneur verwees. Daarnaast stuurde het gemeentebestuur een deputatie naar Den Haag om daar meer duidelijkheid te krijgen. En ondertussen vergaderde het college van Gs over de kwestie. Gedeputeerde Staten besloten op 21 oktober om de prinselijke proclamatie in het openbaar af te kondigen:

Vermeenen aan de ingezetenen dezer provincie te moeten doen opmerken dat zij, naar luid der evengemelde Proklamatie, vrijelijk kunnen deel nemen aan het kieswerk, waarvan het resultaat het einde der onlusten, aan welke het Vaderland ten prooi is, doet verwachten. ${ }^{.4}$

Wat in Maastricht toen nog niet bekend was, was dat de koning zich had gedistantieerd van de daden van zijn zoon. De kroonprins was onmiddellijk ontheven van zijn functie als opperbestuurder in het Zuiden. De afvaardiging van het Maastrichtse stadsbestuur kreeg te verstaan dat van verkiezingen geen sprake kon zijn.

Pas op 29 oktober werd de situatie in Maastricht duidelijk: Dibbets kreeg nu het opperste gezag in die delen van Limburg die nog in Nederlandse handen waren: Maastricht, St. Pieter en Venlo. En de verkiezingen voor het Nationaal Congres waren, voor zover het in de macht van de Nederlanders lag, van de baan. Kiesgerechtigden uit het grootste deel van Limburg, dat in Belgische handen was, konden daarentegen gewoon deelnemen aan de verkiezingen.

Het Nationaal Congres moest België naast een grondwet ook voorzien van een staatshoofd. Met een ruime meerderheid - daaronder alle Limburgse afgevaardigden - werd op 22 november 1830 gekozen voor een monarchale regeringsvorm. België ging op zoek naar een koning.

Willem 1 koesterde ook na de Belgische onafhankelijkheidsverklaring nog de hoop de troon van België te kunnen bestijgen. Op 23 november vond er een voor hem cruciale stemming plaats in het Nationaal Congres: aan de orde was de vraag of het Huis van Oranje-Nassau diende te worden uitgesloten van de Belgische troon. De atmosfeer in het Congres was voornamelijk anti-Oranje. Er leek zelfs moed vereist om tegen een uitsluiting van het Nederlandse koningshuis te stemmen: de Limburgse afgevaardigde Destouvelles die dit deed, gaf volgens Juste in zijn Histoire du Congrès $\mathrm{Na}$ tional blijk van 'un courage bien rare en bravant les sentiments exaltés du peuple'. ${ }^{25}$ Leden die hun stem tegen de uitsluiting uitbrachten, werden uitgemaakt voor vijanden van het vaderland. 
Destouvelles was overigens niet de enige afgevaardigde uit Limburg die zich tegen een uitsluiting van de Oranjes verklaarde: ook De Liedel de Well, Clément graaf de Renesse-Breidbach en Jean-Baptiste graaf de Marchant d'Ansembourg deden dat. De meeste afgevaardigden uit Limburg dertien man sterk, stemden wel voor uitsluiting (zie bijlage III). Ook het Nationaal Congres in zijn totaliteit stemde de wens van de orangisten met een ruime meerderheid van 161 tegen 28 weg en dus verklaarde De Surlet de Chokier, in zijn hoedanigheid van voorzitter, dat de erfgenamen uit het Huis van Oranje-Nassau 'à perpétuité' waren uitgesloten van de Belgische troon." Vermelde cijfers geven aan dat de Limburgse leden van het Nationaal Congres orangistischer stemden dan gemiddeld het geval was. Waren et onder hen wellicht ook voorstanders van een hereniging met Nederland? Deze vraag nodigt uit een blik te werpen op hun overige doen en laten.

Zoals eerder al is geconstateerd, hing de hereniging van oostelijk Limburg met Nederland als een voortdurende dreiging boven het gebied. Toch is de kwestie politiek gezien op vier momenten in het bijzonder actueel geweest. De eerste maal was in juli 1831 , toen het Nationaal Congres beraadslaagde over de Achttien artikelen. Ten tweede kannen de berandslagingen genoemd worden die in de Belgische Kamer en Senaat gehouden werden over de Vierentwintig artikelen (oktober 1831). Ten derde is er de periode volgend op 4 maart 1838 , de dag waarop de Nederlandse koning kenbaar maakte dat ook hij de Vierentwintig artikelen accepteerde. Ten slotte verscheen de kwestie op de parlementaire agenda in maart 1839, toen Kamer en Senaat moesten besluiten of zij Leopold $\mathrm{r}$ al dan niet toestemming zouden verlenen het verdrag te ondertekenen.

De Achttien artikelen werden door een grote meerderheid in het Nationaal Congres - 126 tegen 70 - weggestemd. Van de zestien leden uit Limburg die een stem uitbrachten, waren er zes vóór en tien tegen (zie bijlage ii1). Hoewel de verhouding tussen voor- en tegenstemmers bij het Limburgse smaldeel in het Nationaal Congres nauwelijks afweek van die in de gehele vergadering, blijft het opmerkelijk dat zoveel Limburgse afgevaardigden voor het verdrag stemden: de gevolgen van de overeenkomst zouden immers naast Luxemburg vooral hun provincie treffen. Dit stemgedrag rechtvaardigt echter niet de conclusie dat ruim een derde van de Limburgse afgevaardigden voorstander was van een afstand van een deel van de provincie aan Nederland.

Een aanwijzing hiervoor is al dat de toespraken van Joseph Jaminé en Félix de Mérode - zij stemden beiden voor het verdrag - zijn opgenomen in een publicatie waarmee het Belgische Comité de Politique Nationale na 
de Eerste Wereldoorlog trachtte aan te geven hoe groot het verzet van de Limburgers was geweest tegen hun terugkeer naar Nederland. De Limburgse steun aan het verdrag moet veeleer worden verklaard uit het gegeven dat de bepalingen vaak zo werden gelezen dat een belangrijk deel van Limburg Belgisch zou blijven. Onder andere het Voorlopig Bewind gaf een dergelijke draai aan het verdrag.

De Limburgse leden die tegen het verdrag pleitten, deden dat veelal op hartstochtelijke wijze. Een van hen was Henri de Brouckère:

Et l'on pourrait penser [...] que moi, qui dois l'honneur de siéger parmi vous à un arrondissement qui renferme cette ville de Venloo et onze des villages qu'on veut nous faire abandonner, je souscrirais à une semblable proposition! Non! messieurs mille fois non [...]. ${ }^{\text {n? }}$

Limburgse afgevaardigden spraken van landverraad en vier Limburgse congresleden dienden, samen met 33 collega's, een protestnota in. Indien het verdrag zou worden aanvaard, beschouwde hij het als zijn plicht zijn mandaat als lid van het Nationaal Congres neer te leggen, zo zei R.P. de Tiecken de Terhove. ${ }^{8 s}$

Een nieuwe regeling, vervat in de Vierentwintig artikelen, werd eind oktober 1831 aanvaard door de Belgische volksvertegenwoordiging, inmiddels bestaande uit Kamer van Volksvertegenwoordigers en Senaat. De Limburgse deling, die in deze verdragstekst veel explicieter werd beschreven dan in de voor verschillende interpretaties vatbare Achttien artikelen, werd daarmee gefiatteerd. 'Quel avenir, Messieurs! La Belgique horriblement multilée!'no Zo riep Henri de Brouckère zijn mede-afgevaardigden in de Kamer toe. In felle bewoordingen bekritiseerde hij het verdrag en hij werd hierin gevolgd door verschillende andere kamerleden uit Limburg. Zij stemden allen tegen het traktaat, met uitzondering van De Theux de Meylandt (afgevaardigd uit het district Hasselt) die, inmiddels minister van Binnenlandse Zaken geworden, het regeringsvoorstel om het verdrag te aanvaarden ondersteunde. In de Senaat was het met name François baron de Loë-Imstenraedt de Mheer (district Maastricht) die trachtte zijn collega's over te halen tegen te stemmen. Maar ook hier konden de vier Limburgse afgevaardigden met hun verzet niet voorkomen dat een meerderheid voor stemde.

Ondanks de aanvaarding door België leek een daadwerkelijke uitvoering van het verdrag voorlopig nog ver weg: de Nederlandse koning weigerde halsstarrig akkoord te gaan. Toen Willem 1 bijna zeven jaar later, in maart 1838, verklaarde alsnog zijn handtekening te willen zetten, kwamen de 
Limburgse afgevaardigden wederom in verzet tegen de voorziene deling van hun provincie. Op voorstel van De Marchant d'Ansembourg (district Maastricht) bood de Senaat de Belgische koning een adres aan waarin tegen de voorgenomen afscheiding werd geprotesteerd. In een uiterste poging de uitvoering van het verdrag tegen te houden zonden de Limburgse leden van zowel Kamer als Senaat De Marchant d'Ansembourg op een diplomatieke missie naar Parijs. Van 14 december tot 17 januari verbleef hij in de Franse hoofdstad om koning Louis-Philippe en het Franse parlement voor zijn zaak - en die van zijn mede-afgevaardigden uit Limburg - te winnen. Zijn reis werd in Limburg met grote interesse gevolgd. ${ }^{90}$ Hoewel het hier, gelet op de internationale situatie, een hopeloze onderneming betrof, illustreert zij de grote weerzin onder de Limburgse afgevaardigden in Brussel om te moeten terugkeren onder Nederlands gezag.

Deze weerzin bleek opnieuw toen in maart 1839 gediscussieerd werd over de ondertekening van de Vierentwintig artikelen. Alle Limburgse kamerleden die gekozen waren in de districten die volgens de overeenkomst grotendeels aan Nederland zouden toevallen, Maastricht en Roermond, hielden redevoeringen waarin zij pleitten tegen het verdrag. Met uitzondering van De Theux de Meylandt stemden alle Limburgse afgevaardigden tegen.

In zijn hoedanigheid van minister van Binnenlandse én Buitenlandse Zaken voerde De Theux de Meylandt de verdediging van de Vierentwintig artikelen. De Kamer had het verdrag in een eerder stadium al goedgekeurd, zei hij in zijn betoog, dat heel wat zakelijker klonk dan de vrij emotionele toespraken van zijn collega-kamerleden uit Limburg. Graaf de RenesseBreidbach, afgevaardigd uit het district Maastricht, barstte in tranen uit, zo berichtte het Algemeen Handelsblad op 19 maart 1839. En denkend aan de bevolking in de af te scheiden delen van Luxemburg en Limburg, stelde Louis Beerenbroek (district Roermond) verbitterd vast:

Le roi Guillaume parviendra difficilement à gagner la confiance de ces populations, mais, je vous le dis hautement, si vous avez le malheur de les renvoyer sous son sceptre, vous n'aurez pas de plus grands ennemis que les habitants du Luxembourg et du Limbourg."1

Van de 100 kamerleden stemden er 58 in met het verdrag.

De tegenstand in de Senaat was minder groot, wellicht ten gevolge van de steeds onwaarschijnlijker wordende mogelijkheid de inwerkingtreding van het verdrag te kunnen tegenhouden. De discussie was aanmerkelijk 
korter dan in de Kamer en het aantal tegenstanders was relatief klein: met 31 van de 47 stemmen werd de ondertekening van het verdrag geaccordeerd. ${ }^{92}$ Drie van de vier Limburgse senatoren namen deel aan het debat. Aan de oproep die De Marchant d'Ansembourg en A.C.D. van Muyssen deden om het traktaat te verwerpen, werd bij de stemming in ieder geval gehoor gegeven door C.F. baron de Stockem Méan de Kermpt, senator namens Hasselt. De vierde afgevaardigde uit Limburg (district Roermond) en tevens senaatsvoorzitter De Schiervel onthield zich van stemming. Aan de ene kant vreesde hij de internationale gevolgen na een Belgische weigering het verdrag te aanvaarden; anderzijds kon hij het niet over zijn hart verkrijgen zijn medewerking te geven aan de afstand van oostelijk Limburg, 'l'abandon enfin de ces commettants auxquels je dois l'honneur d'avoir pris place dans cette enceinte.'s

Als het aan de afgevaardigden uit oostelijk Limburg had gelegen, was het gebied nimmer aan Nederland overgedragen. Daarnaast moet echter worden geconstateerd dat de vele pogingen die zij gedurende al die jaren hebben ondernomen om Belgisch te blijven, uiteindelijk tevergeefs zijn geweest.

Voor de kamerleden en senatoren die in het van België af te scheiden deel van de provincie gekozen waren, had de overeengekomen deling van Limburg onmiskenbaar gevolgen voor hun parlementaire mandaat. Wat waren de directe consequenties? Deze vraag hield in ieder geval henzelf bezig. Evenals hun collega's uit het van Belgiè af te scheiden deel van Luxemburg kwamen zij bijeen om hun positie te bespreken, zo berichtte de Nederlandsche staatscourant, die zelf maar meteen de opvatting poneerde dat de desbetreffende vertegenwoordigers 'nauwelijks meer geacht kunnen worden, een deel der belgische wetgeving uit te maken.'4

Nu zouden er enkele maanden later, in juni 1839, reguliere verkiezingen plaatsvinden en zoals gebruikelijk werden een gedeelte van de Kamer en een gedeelte van de Senaat dan opnieuw gekozen. Omdat het deze keer onder meer de beurt was aan de Limburgse afvaardiging in de Kamer en de Luxemburgse afvaardiging in de Senaat, loste het vraagstuk zich daar vanzelf op. Wel moest het kiesstelsel eerst nog worden aangepast, hetgeen gebeurde bij wet van 3 juni 1839: het verkleinde (Belgisch-)Limburg werd heringedeeld in kiesdistricten en kreeg een minder getal aan kamerleden (van negen naar vijf) en senatoren (van vier naar twee).95

De verkiezingen ondervonden door de procedure rond deze wetswijziging weliswaar een vertraging van ongeveer een maand, bij de opening van het nieuwe parlementaire jaar was het aantal kamerleden uit Limburg 
aangepast aan de nieuwe situatie. De Nederlandsche staatscourant mékte op dat de drie kamerleden 'die in het Nederlandsche gedeelte van Luxmburg te huis behooren' toen nog wel aanwezig waren. ${ }^{96}$ Dat dit ook het geal was met de senatoren die waren afgevaardigd uit het afgescheiden deel va Limburg, viel de Nederlandsche staatscourant blijkbaar niet op. Toch bleen ook zij hun zetel bezetten. Bij de verkiezingen waren de Limburgse seatoren (en de Luxemburgse kamerleden) immers niet aan de beurt geweest Kamer en Senaat waren toen slechts gedeeltelijk opnieuw gekozen. En aagezien de afgevaardigden werden geacht niet slechts het district waarin zij दkozen waren, te vertegenwoordigen, maar de hele Belgische bevolking, nochten zij - ook nu hun kiesdistrict niet meer bestond - zitting blijven louden totdat hun wettelijk mandaat was afgelopen.

Voor de senatoren uit oostelijk Limburg betekende dit dat zij lun zetel pas in 1843 hoefden te ontruimen." Desondanks was De Mrchant d'Ansembourg na de terugkeer van zijn landstreek onder Nederla'ds gezag, nimmer in de Belgische Senaat verschenen, zo verklaarde fj later tegenover de gouverneur van Nederlands-Limburg. Gouverneur iericke van Herwijnen zag hierin voldoende reden om de graaf uit te nodigen voor een soiree, zo schreef hij in een geheim rapport aan koning Willem $\mathrm{II}^{98} \mathrm{De}$ Schiervel, eveneens afgevaardigd uit een district dat grotendeels aan $\mathrm{Ne}$ derland werd afgestaan (Roermond), bleef daarentegen na 1839 wel zitting nemen in de Belgische Senaat; hij bleef zelfs aan als voorzitter. ${ }^{99}$

\section{Terugkeer in de Staten-Generaal}

Naast een uitgesteld vertrek uit de Belgische Senaat lijkt er sprake te zijn geweest van een uitgestelde terugkeer in de Nederlandse Staten-Generaal: terwijl oostelijk Limburg in juni 1839 officieel door koning Willem 1 in bezit genomen was, namen de eerste Limburgse afgevaardigden pas in oktober 1840 zitting in Eerste en Tweede Kamer. Gedurende ruim een jaar deed zich daarmee de paradoxale situatie voor dat Nederlands-Limburg op nationaal niveau uitsluitend vertegenwoordigd was in het Belgisch parlement. ${ }^{100}$ Strikt formeel gezien kan overigens worden gesteld dat de Limburgers in deze periode ook in Nederland vertegenwoordigd waren: de Staten-Generaal vertegenwoordigden volgens de grondwet het gehele Nederlandse volk en daartoe behoorden toen (sinds korte tijd weer) de Limburgers. Zo luidde ook het betoog van Tweede-Kamerlid jhr. H.M.A.J. van Asch van Wijck in juni 1840 tijdens de beraadslagingen in de Tweede Kamer over de terugkeer van oostelijk Limburg onder Nederlands gezag. Vervolgens brak een periode 
aan waarin de Nederlandse provincie vertegenwoordigers had in zowel de Staten-Generaal als de Belgische Senaat. De Belgische senaatsverkiezingen van 1843 maakten een eind aan deze 'tweezijdige mandatering'.

Voordat de eerste Limburgers terugkeerden in de Staten-Generaal, beraadslaagden Tweede en Eerste Kamer over de opname van oostelijk Limburg in het Nederlandse staatsverband. Weliswaar werd het Londense traktaat van april 1839 in Nederland, anders dan in België, niet onderworpen aan een parlementaire goedkeuring, de behandeling van de grondwetsherziening die door de vredesregeling noodzakelijk was geworden, gaf de Staten-Generaal ruimschoots gelegenheid hun gevoelens omtrent de kwestie kenbaar te maken. ${ }^{101}$

Bij de opening van het nieuwe parlementaire jaar op 21 oktober 1839 werden de voorstellen tot wijziging van de grondwet door Willem 1 aangekondigd en in december werden zij - vijf in getal - aangeboden aan de Tweede Kamer. Naast grondwetsartikel 1, waarin de provincies werden opgesomd, moest onder meer artikel 79 aangepast worden: dit artikel bepaalde per provincie het aantal zetels in de Tweede Kamer. Aan de nieuwe provincie Limburg werden in het voorstel drie zetels toegekend.

De Limburgse kwestie raakte bij de indiening van de vijf voorstellen enigszins op de achtergrond door de steeds luider wordende roep - zowel binnen als buiten de Kamer - om een grondwetswijziging die verder ging dan hetgeen door het traktaat noodzakelijk was geworden. De regering besloot hieraan toe te geven, mede om zelf de controle over de herziening te behouden en diende zeven aanvullende voorstellen in. Hoewel de wijzigingen die direct betrekking hadden op de terugkeer van Limburg daardoor minder aandacht kregen, bleven zij zeker niet onbesproken.

Een aantal kamerleden toonde zich uitdrukkelijk niet erg ingenomen met de terugkeer van oostelijk Limburg. Dat Limburg behalve provincie van Nederland ook deel werd van de Duitse Bond, was voor hen veelal een groot bezwaar. In een kamerverslag lezen we:

Eenige leden hadden gaarne gezien, dat dit landschap, met betrekkingen ten opzigte van den Duitschen Bond belast, niet aan Nederland ware toegevoegd geworden; zij vrezen en voorzien hieruit, bij volgende twisten tusschen de naburige Europesche mogendheden, nieuwe en uiterst moeijelijke verwikkelingen. ${ }^{102}$

In de Tweede Kamer werd het bezwaarlijk geacht 'het Rijk weder met een heterogeen bestanddeel te belasten' en men begreep niet dat de regering 
'voor een gering voordeel ons geheel bestaan in de waagschaal sellen zal'; Limburg kon volgens een ander kamerlid voor Nederland nits anders zijn dan 'een wezenlijke bezwaarpost.' ${ }^{103}$ Tijdens de tweede lezig van de voorstellen lieten verschillende leden zich eveneens weinig enthasiast uit over de terugkeer van oostelijk Limburg. Zo zei S.H. Anemaet brovincie Holland):

Ik voor mij zoude liefst het oude huisgezin zien bevestigen, ander vreemd inmengsel of ongelijksoortige bijvoegingen, en alle krchten zien aanwenden, om aan hetzelve duurzaam geluk en voorsped te bezorgen, zonder daaraan te voegen, hetgeen naar aard en ntuur daarvan afgezonderd wil zijn. Het is met één woord, evenals veger, eene gedwongene vereeniging, die, aangevangen onder ongustige voorteekenen, zich te eeniger tijd losrukt ten koste der beide veeend geweest zijnde deelen. ${ }^{104}$

Ook Groen van Prinsterer, eveneens afgevaardigd door de provirie Holland. vreesdedatide ajenaarurliegewuonnen van ner gewest in dẻ toekomst tot problemen zouden leiden, zoals eerder met België gebeurd was. ${ }^{105} \mathrm{Hij}$ doelde ongetwijfeld met name op het katholieke karakter van de nieuwe provincie en in dat licht bezien is het niet verwonderlijk dat positieve geluiden over de aansluiting van Limburg bij Nederland afkomstig waren van onder anderen Noord-Brabantse (katholieke) afgevaardigden. Zowel P. Gouverneur als jhr. P.E.A. de la Court stemde uitdrukkelijk in met de nieuwe aanwinst. ${ }^{106}$ Volgens De la Court waren de belangen van Limburg en Noord-Brabant nauw met elkaar verbonden en hij voorzag belangrijke economische voordelen. Dat Gouverneur zich in het debat mengde, geeft het belang aan dat hij aan de zaak hechtte: hij voerde namelijk zelden het woord in de Kamer. ${ }^{107}$

Verder bleven instemmende reacties grotendeels uit. De Hollandse afgevaardigde jhr. G. Beelaerts van Blokland beoordeelde de opneming van Limburg in het koninkrijk uit het oogpunt van de Nederlandse defensie als 'nuttig', ${ }^{108}$ maar kon als voormalig lid van de regering - hij was tot januari minister van Financie̋n geweest - moeilijk een ander standpunt innemen tegenover een mede namens hemzelf ingediend voorstel. Ook B.W.A.E. baron Sloet tot Oldhuis (provincie Overijssel) en F.A.A.C. baron van Lynden tot Sandenburg (provincie Holland) meenden dat het bezit van Limburg Nederland meer voor- dan nadelen bood. L.C.R. Copes van Cattenburch (provincie Holland) drukte zich nog het meest positief uit door de hoop 
uit te spreken dat Limburg een 'parel aan de Nederlandsche kroon' zou worden. ${ }^{107}$ De meeste kamerleden zwegen over de kwestie.

Ondanks of wellicht dankzij deze zwijgende meerderheid wordt duidelijk dat de terugkeer van Limburg niet met ieders instemming, laat staan tot ieders vreugde plaatsvond: de eerste Limburgse kamerleden kwamen uit een provincie die een deel van hun collega's liever kwijt dan rijk was. Dat (oostelijk) Limburg onderdeel zou gaan uitmaken van het Nederlandse koninkrijk was in april 1839 echter internationaal bezegeld, en daar konden de beraadslagingen in de Staten-Generaal niets meer aan veranderen.

Een zaak waarin de Nederlandse volksvertegenwoordiging wel zeggenschap probeerde te verwerven, betrof de vraag op welk moment de afgevaardigden uit de nieuwe provincie geroepen moesten worden om aan de parlementaire werkzaamheden in Den Haag te komen deelnemen. Tal van Tweede-Kamerleden protesteerden tegen de afwezigheid van de Limburgers bij de parlementaire beraadslagingen over de grondwetsherziening. ${ }^{110}$

Alvorens het parlement zich met dit vraagstuk bezighield, had de ministerraad er zich al over gebogen. Over de grondwettelijke opname van Limburg in het koninkrijk kon volgens de ministers worden beslist zonder de vertegenwoordigers van die provincie te horen. De teruggekeerde gebieden hadden zich immers vrijwillig van Nederland afgescheiden en konden daardoor geen beroep meer doen op de bestaande grondwettelijke bepaling waarin aan (de oude) provincie Limburg het recht werd toegekend afgevaardigden in de Tweede Kamer te kiezen. Een verstandige staatkunde gebood echter wel dat de Limburgers zouden worden betrokken bij verdere grondwetswijzigingen. ${ }^{\mathrm{m}}$

De druk om de grondwet verdergaand te wijzigen nam toe; de Tweede Kamer vond de vijf voorstellen die bij haar aanhangig waren gemaakt, onvoldoende. De ministerraad concludeerde dat er niet langer gewacht kon worden op de Limburgse kamerleden: er diende buiten hun aanwezigheid te worden overgegaan tot een ruimere herziening van de grondwet dan eerst was voorzien. Een opmerkelijk standpunt, want de ministerraad had een Limburgse afwezigheid bij een ruimere herziening eerder nog als staatkundig onverstandig bestempeld. De koning volgde de ommezwaai van zijn ministers.

Welke mening huldigden de leden van de Staten-Generaal, de toekomstige collega's van de Limburgse afgevaardigden? Uit de bewoordingen in de verslagen gekozen, kan worden afgeleid dat een meerderheid in de Tweede Kamer van oordeel was dat de grondwetswijzigingen in aanwezigheid van 
Limburgse vertegenwoordigers dienden te worden behandeld. ${ }^{2}$ De verhoudingen in de Eerste Kamer zijn niet precies te traceren; wemeldt het verslag van de algemene afdeling dat 'eenige leden' er het standpur innamen dat de Limburgers betrokken zouden moeten worden bij de grodwetsher. ziening. ${ }^{113}$

In verschillende afdelingen waarin de Tweede Kamer was verceld, werd opgemerkt dat een spoedige deelname van Limburgse afgevaargden aan de werkzaamheden van het parlement in de toekomst veel einde zou kunnen vermijden:

Hierdoor zal men voorkomen, dat de ingezetenen zich, als ret geraadpleegd zijnde, ook minder verbonden beschouwen om e verpligtingen na te komen, die hun door de Grondwet worden opelegd. Soortgelijke onaangename discussiën hebben vroeger met devertegenwoordigers der zuidelijke gewesten plaats gehad en hebln tot verkeerde gevolgen aanleiding gegeven. ${ }^{114}$

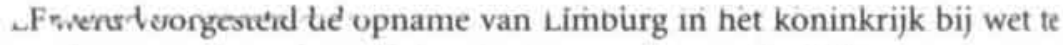
regelen, voorafgaand aan de herziening van de grondwet. ${ }^{115}$

De regering bleef echter bij haar standpunt: zij antwoordde dat het recht van de Limburgers op een vertegenwoordiging 'moeilijk betoogbaar' was. "It Het zou leiden tot een aanmerkelijke vertraging van de grondwetsherziening en daarnaast zou een voorafgaande wettelijke regeling in strijd zijn met de grondwet, omdat in de constitutie nog niets over de vertegenwoordiging van de nieuwe provincie was geregeld.

Onder de tegenstanders van een snelle vertegenwoordiging van Limburg in de Staten-Generaal was de Utrechtse afgevaardigde jhr. H.M.A.J. van Asch van Wijck de belangrijkste woordvoerder. Zijn bijdrage aan de beraadslagingen werd door collega-kamerleden meermaals aangehaald en minister J.G. baron Verstolk van Soelen van Buitenlandse Zaken volstond in zijn reactie met een verwijzing naar het kamerlid. ${ }^{117}$ Van Asch van Wijck ging uitvoerig op de kwestie in en betoogde dat het grondwettelijk gezien onmogelijk was Limburgse afgevaardigden op te roepen. Eerst diende het aantal Limburgse Tweede-Kamerleden te worden vastgesteld en dit kon alleen door de grondwet. Bovendien functioneerden de Provinciale Staten van Limburg nog niet: het enige college dat Tweede-Kamerleden mocht aanwijzen. ${ }^{118}$

Naast bezwaren van praktische aard werd verschillende keren verwezen naar de Limburgse houding bij de Belgische omwenteling. Zo beschouwde 
W.L.F.Ch. ridder van Rappard, afgevaardigde uit Gelderland, de Limburgers als muiters. En: '... heeft dit gedeelte [Limburg met uitzondering van Maastricht en St. Pieter| zich geregtigd gevoeld, om zonder eenige toestemming van Koning of van vertegenwoordiging zich van Nederland af te scheiden, dan kunnen zij zich over eene hereeniging zonder hunne toestemming niet beklagen.'"19

Ook baron Van Lynden tot Sandenburg was van oordeel dat de Limburgers hun grondwettelijk recht op een parlementaire vertegenwoordiging hadden verspeeld omdat zij zich 'moedwillig' hadden 'losgescheurd'. ${ }^{120} \mathrm{On}$ der aanhaling van Hugo de Groot was G. van Leeuwen, eveneens afgevaardigd door $\mathrm{PS}$ van Holland, dezelfde mening toegedaan

Wederom was het een Noord-Brabants kamerlid dat voor Limburg in de bres sprong: volgens L.D. Storm was er geen sprake van dat de Limburgers zich vrijwillig aan Belgische zijde hadden geschaard; hij sprak van 'eenen vijandelijken inval, dien zij niet hebben kunnen beletten'. ${ }^{\prime \prime \prime}$ Hun grondwettelijke rechten waren daarom onaangetast gebleven. Storms woorden bereikten ook Limburg: in de berichtgeving over de parlementaire debatten werd het kamerlid geciteerd door het Journal du Limbourg. ${ }^{122}$

Storm kreeg bijval van de Leidse hoogleraar J.R. Thorbecke. Al voor zijn kamerlidmaatschap had Thorbecke zich beziggehouden met de Limburgse vertegenwoordiging in het Nederlandse parlement, zo blijkt uit zijn briefwisseling. In een schrijven aan Tweede-Kamerlid L.C. Luzac sprak hij in juni 1840 van 'de ongrondwettigheid eener herziening zonder de Limburgers' en enige dagen later toonde hij zich verheugd over een artikel in het Algemeen Handelsblad waarin diezelfde opvatting was verwoord. ${ }^{12}$ Ook in de Kamer uitte hij zijn ongenoegen over de Limburgse afwezigheid. De argumenten die waren aangedragen om deze afwezigheid te rechtvaardigden, sneden geen hout, aldus Thorbecke. Zo had hij tot zijn verontwaardiging 'de tegenwoordige behandeling van Limburg hooren voordragen als eene billijke straf van den opstand en afval, waaraan de Limburgers zich zouden hebben schuldig gemaakt. [...] De provincie zou dus moeten worden gestraft, waar de individus hebben misdaan'. Dit zou noodzaken, zo voegde hij cynisch toe, tot 'een nieuw, tot dusverre onbekend, stelsel van strafwetgeving.' ${ }^{124}$

Ook een ander argument werd resoluut door Thorbecke van de hand gewezen. Zowel Luzac als J. Rau had eerder aangedragen dat de inwoners van de nieuwe provincie, toch al sinds april 1839 op de hoogte van de bepalingen omtrent hun staatkundige toekomst, nimmer blijk hadden gegeven bij de beraadslagingen in de Staten-Generaal betrokken te willen worden: geen 
enkel verzoekschrift daarover had Den Haag bereikt. ${ }^{125}$ Thorbecte was het hier volstrekt niet mee eens: 'Het niet eischen van hunne zijde virmindent onzen pligt niet, hun regt te doen [... ]. ${ }^{126}$

Dat de kwestie de Limburgers geheel onverschillig liet, lijkt overigens onwaarschijnlijk. Het Journal du Limbourg, voorlopig de enige povincialt krant in Nederlands-Limburg, berichtte regelmatig over de parlementaire discussies die werden gevoerd over de afwezigheid van Limburgseafgevaardigden. ${ }^{127}$ Hoewel de krant zich daarbij onthield van eigen conmentaar, haalde zij begin juni 1840 uitgebreid een artikel in het Algemeen Handels blad aan, waarmee het Journal du Limbourg kennelijk kon instemmen. ${ }^{\text {la }}$ In dit artikel, hetzelfde als waarnaar Thorbecke in zijn eerder genoemde brief verwees, veroordeelde het Handelsblad de Limburgse afwezgheid bii de grondwetsherziening als inconstitutioneel.

De talrijke protesten konden niet verhinderen dat de grondwitsherziening zonder de participatie van Limburgse kamerleden werd behandeld. $\mathrm{Na}$ goedkeuring in tweede lezing werd de nieuwe grondwet van het Koninkrijk der Nederlanden op 24 september 1840 in Limburg van kracht verdaard.

Flet aantal Limburgse afgevaardigden in de Tweede Kamer was door de gewijzigde grondwet bepaald op drie. Op 6 oktober 1840 werden zij - Frans Corneli, jhr. Pièrre Kerens en jhr. Arnold Hendrik Michiels van Verduynen - bij Koninklijk Besluit benoemd. Voor de Eerste Kamer ontbrak een grondwettelijke verplichting tot spreiding van de leden over de provincies. Toch werd de nieuwe situatie ook daar bezegeld met de komst van de Noord. Limburgse groot-grondbezitter Pieter Willem baron de Liedel de Well. Zijn benoeming vond eveneens plaats op 6 oktober en behoorde samen met de aanwijzing van de Tweede-Kamerleden tot de laatste daden van Willem 1 als regerend koning.

De volgende dag deed hij afstand van de troon: de recent van kracht geworden grondwetsherziening was voor de koning te ver doorgeschoten en ontnam hem de lust nog langer aan te blijven. De bezwaren die hij koesterde tegen de nieuwe grondwet richtten zich duidelijk niet op de wijzigingen die oostelijk Limburg weer hadden doen opnemen in zijn koninkrijk. Daarmee immers was, in ieder geval deels, voldaan aan een al sinds de Belgische opstand levend koninklijk verlangen.

De 'broederlijke gemeenschap' tussen Limburg en de overige delen van Nederland, waarvan koning Willem n in oktober 1840 sprak, was toen in werkelijkheid ver te zoeken. Een meerderheid van de Limburgers had zich in 1830 aan Belgische zijde geschaard en niet de volkswil, maar een inter- 
nationaal machtswoord was dan ook bepalend geweest voor de terugkeer van oostelijk Limburg onder Nederlands gezag. Deze opinie zien we terug bij de Limburgse afgevaardigden in de Belgische parlementaire organen: zi) ageerden daar fel tegen een afstand door België van (delen van) hun provincie.

Ook in Nederland werd de territoriale aanwinst niet onverdeeld gunstig ontvangen. Er heerste wantrouwen jegens de nieuwe landgenoten. In de Staten-Generaal werd dit wantrouwen door een aantal leden openlijk uitgesproken. Weliswaar wilde een meerderheid in de Tweede Kamer de Limburgers zo spoedig mogelijk vertegenwoordigd zien in haar midden, ook aan deze wens lag meermaals een gebrek aan vertrouwen ten grondslag: de vrees bestond dat de Limburgers zich anders niet gebonden zouden voelen aan de Nederlandse grondwet en dat de situatie van 1830 zich daardoor zou herhalen.

Zowel vanuit Limburgs als Nederlands perspectief lijken er daarmee in de jaren 1839-1840 weinig geschikte uitgangspunten aanwezig voor een succesvolle politieke integratie van de nieuwe provincie. Toch kan, wederom vanuit beide zijden bezien, een aantal elementen aangewezen worden die deze integratie positief tegemoet zouden kunnen treden.

In de eerste plaats speelde koning Willem 1 een belangrijke rol bij de terugkeer van oostelijk Limburg onder Nederlands gezag. Gedurende de gehele in dit hoofdstuk behandelde periode was hij aan het bewind en voortdurend gaf hij er blijk van het behoud van Limburg, of in ieder geval delen ervan, op hoge prijs te stellen.

Daarnaast kan worden gewezen op Thorbecke, in 1840 nog slechts buitengewoon lid van de Tweede Kamer, maar weldra een der leidende figuren in de Nederlandse politiek. In 1840 toonde hij zich een pleitbezorger van de betrokkenheid van de Limburgers bij de Nederlandse politiek en zijn (politieke) belangstelling voor de provincie zou ook in later jaren niet verdwijnen. Naast Thorbecke waren er diverse andere politici die aangaven de terugkeer van oostelijk Limburg en de komst van de nieuwe kamerleden uit dat gebied te begroeten. Hierbij kan in het bijzonder gewezen worden op de (katholieke) kamerleden uit Noord-Brabant.

Ook de politieke situatie in Limburg zelf bood aanknopingspunten voor een meer positieve kijk op de integratie van de provincie in de Nederlandse politiek. Zowel het tijdvak van het Verenigd Koninkrijk als 'de Belgische periode' (1830-1839) toont aan dat de politieke elite in Limburg zich deels loyaal opstelde tegenover de (Noord-)Nederlandse staat. Juist bij de Limburgse afgevaardigden in de Staten-Generaal was dit voortdurend tot 
uitdrukking gekomen. Het contrast met hun opvolgers, de Limbugse leden van de Belgische vertegenwoordigende organen, is evident: inrussel ageerden zij vrijwel zonder uitzondering met kracht tegen een mgelijke terugkeer naar Nederland. Het lijkt er na 1839 voor de Nederlands ginden dan ook vooral op aan te komen het 'juiste' deel van de elite aan te reken bij de verkiezing en benoeming van de Limburgse kamerleden. Daase had het Nederlandse kiesstelsel voorheen zeker mogelijkheden gebode zoals met name de Limburgse gouverneur De Brouckère sr. had aangetord. Dir kiesstelsel was bij de terugkeer van oostelijk Limburg niet fundarented gewijzigd en bood dus nog steeds de mogelijkheid invloed uit te ifenen op de keuze van de Limburgse vertegenwoordigers in de Staten-Geraal.

Deze mogelijkheden tot beïnvloeding en de beperkingen waar $n$ het kiesrecht wettelijk onderhevig was, hebben ongetwijfeld gevolgetzehad voor de representativiteit van de Limburgse kamerleden. En de me van representativiteit raakt op zijn beurt de reikwijdte van de politie integratie. Maar ondanks de overwegend Belgisch gezinde bevolkir is de mogelijkheid om de Limburgse vertegenwoordigers op nationaal nzau te

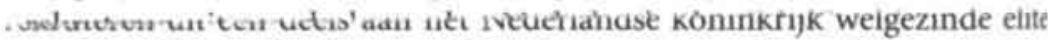
van wezenlijke betekenis. De politieke integratie van de provincie was daardoor immers niet bij aanvang al kansloos, maar kreeg de mogelijkheid om zich via de Limburgse afgevaardigden in Den Haag te ontplooien. 


\section{Vertegenwoordigers van het Nederlandse volk Limburgse afgevaardigden en hun mandaat}

Op 19 oktober 1840 verschenen de jonkheren Arnold Hendrik Michiels van Verduynen en Pièrre Kerens voor koning Willem u. Zij waren de eerste Limburgse leden van de Tweede Kamer die de eed van zuivering en de eed van trouw op de Nederlandse grondwet kwamen afleggen. Frans Corneli, het derde Tweede-Kamerlid uit Limburg, was hierbij niet aanwezig. Hij legde de voorgeschreven eden drie dagen later af in handen van de tijdelijk Tweede-Kamervoorzitter, jhr. M.W. de Jonge van Campensnieuwland, die daartoe was gemachtigd door de koning. Wanneer Eerste-Kamerlid Pieter Willem baron de Liedel de Well de eden aflegde, is niet bekend. ${ }^{1}$

In de grondwet van 1840 troffen de nieuwe kamerleden in artikel 70 een omschrijving aan van hun taak: 'De Staten-Generaal vertegenwoordigen het geheele Nederlandsche volk.' Tot 1918 zouden tientallen afgevaardigden uit Limburg de eed van trouw op de grondwet afleggen. Het hoofdstuk 'Van de Staten-Generaal' bleef al die tijd, ook na de grondwetsherzieningen van 1848 en 1887 , openen met genoemde bepaling. ${ }^{2}$

Terwijl dit grondwetsartikel ongewijzigd bleef, was het kiesstelsel dat de Nederlandse volksvertegenwoordiging gestalte gaf, tussen 1840 en 1918 onderhevig aan grote veranderingen. Dit institutionele kader en met name de uitwerking ervan op (de selectie van) de Limburgse kamerleden, zullen hieronder centraal staan. Een aantal kenmerken van de Limburgse leden van de Staten-Generaal staat immers in rechtstreeks verband met de (grond)wettelijke vereisten die werden gesteld aan het kiesrecht.

Mede aan de hand van het kiesstelsel zal vervolgens worden bekeken wie in het kader van dit onderzoek gerekend kunnen worden tot de Limburgse afgevaardigden in Den Haag. Hierbij zal met name de band betrokken worden die parlementariërs hadden met Limburg door geboorte, woonplaats en beroep. Ten slotte worden de parlementaire participatie en de achtergrond van de Limburgse kamerleden nader onderzocht. Waar mogelijk zal daarbij worden vergeleken met de afgevaardigden uit de overige delen van Nederland. 


\section{Kiesrecht in Limburg}

De procedure van verkiezing of benoeming van de Limburgse Eerste en Tweede-Kamerleden werd in de periode 1840-1918 een aantal male herzien. Voor elk van de Kamers kan daarbij een aantal tijdvakken worden onderscheiden (zie tabel 1).

Tabel 1. Wijze van verkiezing of benoeming van de leden van de Staten-Generaalit Limburg, 1840-1918

\section{Eerste-Kamerleden}

1840-1848:

benoeming door de koning

1849:

benoeming door de koning uit een lijst van (rechtstreeks gekozen) kandidaten

1850-1918:

verkiezing door de leden van

Provinciale Staten van Limburg
Tweede-Kamerleden

1840:

benoeming door de koning

1841-1848:

verkiezing door de leden van

Provinciale Staten van Limburg

1848-1918:

rechtstreekse verkiezing in

de Limburgse kiesdistricten

De eerste Limburgse afgevaardigden in zowel Eerste als Tweede Kamer werden in oktober 1840 benoemd bij Koninklijk Besluit. Bij de Eerste Kame was dit de gebruikelijke procedure. Haar leden zouden tot de grondwets herziening van 1848 voor het leven worden benoemd door de koning. $\mathrm{Hi}$ diende zich daarbij, zo bepaalde artikel 82 van de grondwet, te beperket tot hen die 'door diensten aan den Staat bewezen, door hunne geboorte of gegoedheid onder de aanzienlijksten van den Lande behooren'.

Nader gedefinieerd werd deze bepaling niet, hetgeen de koning een grott vrijheid liet bij de benoemingen. Zo was er bijvoorbeeld niets bepaald ten aanzien van de spreiding van Eerste-Kamerleden over de provincies. En het is ook maar de vraag of de koning, als voorstander van een gecentrliseerde eenheidsstaat, een evenredige verdeling naar provinciale herkoms wenselijk vond. Toch zullen in 1840 alle regionale tongvallen in de Kame te horen zijn geweest behalve het Limburgs. ${ }^{3}$ Dit veranderde op 20 oktober 1840 , toen de Noord-Limburgse grootgrondbezitter Pieter Willem baron de Liedel de Well zijn intrede deed in de Eerste Kamer. Zijn benoeming, nof door Willem I, was gelijktijdig geschied met de aanwijzing van de eerstt Limburgse afgevaardigden voor de Tweede Kamer. Blijkbaar had de koning 
de terugkeer van (oostelijk) Limburg ook in de Eerste Kamer duidelijk tot uiting willen laten komen, hoewel daartoe geen grondwettelijke verplichting bestond.

Door in 1840 tevens de Limburgse leden van de Tweede Kamer te benoemen week de koning af van de reguliere procedure. Tweede-Kamerleden dienden immers volgens de grondwet gekozen te worden door Provinciale Staten. Omdat de Limburgse Staten nog niet volledig in functie waren, maakte Willem I gebruik van additioneel artikel 1 van de grondwet. Hierin was bepaald dat de koning, om de constitutie zo spoedig mogelijk in werking te laten treden, voor een eerste maal personen mocht benoemen van wie het recht tot aanstelling aan andere organen was toegekend.

Dat Willem 1 zich, met voorbijgaan aan de reguliere bepalingen, het recht van benoeming had toegeěigend, was niet onomstreden. Zelfs in het buitenland werd er over bericht. De Allgemeine Preußische Staats-Zeitung schreef op 20 oktober 1840 :

Die Staatscourant hat vor kurzem ohne weitere Erklärung die mittels Königl[ichen] Dekrets erfolgte Ernennung der Mitglieder des Herzogthums Limburg für die zweite Kammer der Generalstaaten veröffentlicht. [...] Gleichwohl wird diese Maßregel in der bevorstehenden Session der Generalstaaten Anlaß zu heftigen Angriffen darbieten, und es wäre nicht unmöglich, daß diese noch von König Wilhelm I. ernannten Mitglieder von der zweiten Kammer nicht als gültig erwählt betrachtet würden.

Geen van de kamerleden plaatste echter een kanttekening bij de manier waarop de nieuwe Limburgse collega's waren benoemd. Buiten de Kamer werd de procedure wel openlijk bekritiseerd: Thorbecke, op dat moment geen parlementslid, was mede-auteur van een artikel in het Algemeen Handelsblad waarin kritische opmerkingen werden geplaatst bij de gevolgde gang van zaken.` Ook een van de benoemden zelf, Kerkradenaar Frans Corneli, trok de rechtmatigheid van het Koninklijk Besluit in twijfel. Dat bleek drie jaar later toen zijn benoeming op reguliere wijze werd bevestigd ten gevolge van zijn (eerste) herverkiezing door Provinciale Staten. Bij een diner, aangeboden door gouverneur jhr. Paul Gericke van Herwijnen, bracht Corneli een toast uit, waarbij hij opmerkte tot dan toe 'krachtens een onwettig mandaat' in de Kamer te hebben gezeten, welke situatie nu door zijn herverkiezing was rechtgezet. Opmerkelijke woorden, want de door Corneli geconstateerde onwettigheid had hem er drie jaar daarvoor 
niet van weerhouden zijn benoeming te aanvaarden. Daarnaast jetuigd de uitspraak van weinig dankbaarheid jegens de koning die Corne in 184 een post had aangeboden die hij had aanvaard en blijkens zijn kanidatum bij de eerstvolgende verkiezingen ook ambieerde. Op de aanwezig tafelge noten maakte Corneli's optreden 'eenen allerongunstigsten indri', aldu de gouverneur, die het voorval onmiddellijk doorbriefde naar DerHaag'

Overigens had de grondwet in het geval van de Tweede Kmer, in tegenstelling tot de Eerste Kamer, voor iedere provincie een vat aante leden voorgeschreven: Limburg kreeg drie (van de 58) afgevaardigen. Hun zittingsduur bedroeg drie jaar; elk jaar trad een derde deel af. Voor imbur betekende dit dat er - afgezien van tussentijdse verkiezingen, bijvorbeek na het overlijden van een afgevaardigde - jaarlijks één Tweede-kmerii diende te worden gekozen.

Wat betreft de Limburgse afvaardiging in de Staten-Generaal dent ver der gewezen te worden op de drie buitengewone leden - A.L.G.I. Blok marts, J.M. Swart en A.J.J.H. Thissen - die in 1848 door Provincia: State van Limburg werden afgevaardigd naar de Tweede Kamer. Bij eergrond

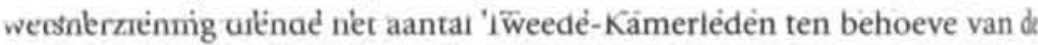
tweede lezing te worden verdubbeld; er werd dan ook wel gesproken var de Dubbele Kamer. In september en oktober 1848 - de zittingsduur van dt Dubbele Kamer - telde de Tweede Kamer dus zes Limburgers.

De nieuwe grondwet die in 1848 totstandkwam, wijzigde het kiesstelsel ingrijpend. Zo zou de Tweede Kamer voortaan rechtstreeks worden gekozen binnen nader te bepalen kiesdistricten. Voor de Limburgse kiezers niet nieuws: voor hen was de terugkeer naar het Nederlandse staatsverband in 1839 vanuit democratisch oogpunt bezien een teruggang geweest. Want terwijl zij de leden van het Nationaal Congres en van de Belgische Kamet en Senaat nog rechtstreeks hadden kunnen kiezen, waren zij in 1839 bij de afgevaardigden voor de Tweede Kamer teruggevallen in een complex sys: teem van indirecte verkiezingen, om van de Eerste Kamer maar te zwiigen De Nederlandse regering kon bij de invoering van de directe verkiezinget daarom ook maar beter lering trekken uit de ervaringen die eerder waren opgedaan in Limburg, 'alwaar men acht jaren regtstreeksche verkiezingen heeft gehad en de bewerkingen kent', aldus het toen net teruggetreden Limburgse Tweede-Kamerlid Louis Beerenbroek in een brief aan ministe Bentinck van Nijenhuis van Buitenlandse Zaken. ${ }^{6}$

De Tweede-Kamerleden kregen in 1848 een mandaat voor vier jaat waarbij om de twee jaar de helft aftrad. In de na 1850 gevormde dubbelk 
districten, dat wil zeggen districten met twee afgevaardigden, zoals Maastricht en Roermond, betekende dit dat de kiezers om de twee jaar éen kamerlid mochten kiezen, behoudens tussentijdse verkiezingen. Er werd sinds 1848 gekozen volgens het absolute meerderheidsstelsel; indien geen van de kandidaten bij de stemming een meerderheid behaalde, volgde een tweede ronde waarin gekozen kon worden tussen de twee kandidaten die in de eerste ronde het hoogst geèindigd waren.?

Tot 1897 was er geen sprake van een geformaliseerde kandidaatstelling: de kiezer kreeg een blanco stembiljet en kon daarop een naam naar keuze vermelden. In de praktijk werd er bij verkiezingen, met name via de pers, wel degelijk gekandideerd voor het kamerlidmaatschap. Dit laat onverlet dat kiesgerechtigden hun stem ook konden uitbrengen op personen die zichzelf niet beschikbaar hadden gesteld.

Op 19 mei 1860 liet zittend Tweede-Kamerlid Martin Strens (district Roermond) via onder meer een advertentie in het weekblad De Volksvriend weten bij de aanstaande verkiezingen niet meer herkiesbaar te zijn. Desondanks verkreeg hij de meeste stemmen (534), en samen met Karel Cornelis (522 stemmen) ging hij door naar de tweede ronde. Wederom plaatste Strens een annonce waarin hij verklaarde niet meer voor het kamerlidmaatschap in aanmerking te willen komen. ${ }^{\circ}$ Opnieuw echter vergaarde hij de meeste stemmen en werd daarmee gekozen. Andermaal plaatste Strens een advertentie: hij schreef dat dit 'groot blijk van vertrouwen' hem verplichtte tot het aannemen van het mandaat, 'hoe ongaarne ook', zo liet hij niet na te vermelden. Erg enthousiast lijkt hij dus niet te zijn geweest. Hij schreef het kamerlidmaatschap dan wel wederom op zich te zullen nemen, 'zonder zich echter hierdoor in het minst te verpligten die taak lang te blijven vervullen'. Overigens meenden sommigen dat Strens komedie had gespeeld en altijd al gewoon herkozen had willen worden. ${ }^{10}$ Ook Thorbecke liet zich in die richting uit."

Vanaf 1897 werd er wel gewerkt met vooraf aan te melden kandidaten. Hun namen werden voortaan op het stembiljet vermeld. Bij een enkelvoudige kandidaatstelling vond er geen stemming meer plaats, hetgeen in Limburg het geval was bij 22 van de 45 verkiezingen die daar in de periode $1897-1918$ gehouden werden. ${ }^{12}$

Opmerkelijk genoeg verlangde de in 1897 van kracht geworden nieuwe kieswet geen bewilligingsverklaring van kandidaten, dat wil zeggen een verklaring waarin zij instemden met hun kandidaatstelling. De wet bepaalde dat iedere stemgerechtigde een kandidaat kon stellen, mits die kandidatuur schriftelijk werd gesteund door veertig stemgerechtigden. De inleve- 
ring van zo'n opgave moest door de indiener persoonlijk gesch:den. 'D candidaat kan daarbij aanwezig zijn,' bepaalde de kieswet. ${ }^{13}$ De aanke zigheid was dus niet vereist. Eveneens ontbrak, zoals gezegd, e eis de de aangemelde kandidaat schriftelijk verklaarde akkoord te gaa met $\dot{\alpha}$ kandidatuur.

Dit kwam in ieder geval aan het licht bij de verkiezingen variuni 196 in het district Gulpen. Het stembiljet aldaar bevatte twee names die ve het zittende Tweede-Kamerlid (Joseph Merckelbach) en van eenuitdage jhr. Louis van der Maesen de Sombreff, die enkele jaren later zting zos nemen in de Eerste Kamer. De kandidaatstelling van Van der Macen bled te zijn geschied buiten diens instemming. Sterker nog: toen hij er ahter wa gekomen dat hij als kandidaat was aangemeld, had hij de burgemester va Gulpen, die de kandidatenlijst moest vaststellen, per telegram latn weter 'Ik stel mij niet beschikbaar voor lidmaatschap ze Kamer.' ${ }^{\prime 4}$ Het otbrak $\alpha$ burgemeester echter aan wettelijke mogelijkheden om de naam va Van de Maesen te schrappen en dus verscheen die naam toch op het sterbiljet. Op 6 en 8 juni plaatste Van der Maesen een advertentie in de Lmburge

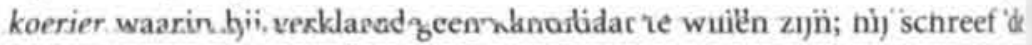
Heeren kiezers dringend te verzoeken bij de stemming op 14 juni a.s. hunns stem niet op hem uittebrengen'. Van der Maesen werd niet gekozen, ma: kreeg toch nog 360 van de 2055 geldig uitgebrachte stemmen.

De grondwet van 1848 voorzag voor de Eerste Kamer in een eenmalige rege ling, vastgelegd in het Voorloopig Kiesreglement. In elk van de kiesdistricter die ten behoeve van de Tweede-Kamerverkiezingen werden gevormd, dien: den de kiesgerechtigden tevens twee kandidaten voor de Eerste Kamer aan te wijzen. Uit de 136 kandidaten die aldus werden gekozen, benoemde d koning er 39 tot lid van de Eerste Kamer. Van de Limburgse kandidaten werden er drie benoemd. Een jaar later vonden er Eerste-Kamerverkiezinges plaats overeenkomstig de nieuwe kieswet; nu kozen Provinciale Staten d. afgevaardigden. Ps bleven ook in de jaren daarna het kiescollege voor d Eerste Kamer, die vooralsnog 39 leden bleef tellen. De leden werden voor negen jaar gekozen en om de drie jaar trad een derde deel af; Provinciak Staten in Maastricht kozen elke drie jaar één Eerste-Kamerlid. Het aantil afgevaardigden zou tot 1918 voor Limburg gelijk blijven, ook nadat de Eersts Kamer in 1887 was uitgebreid tot 58 leden.

De Tweede Kamer groeide eveneens: haar ledental was de eerste viet decennia na 1848 gekoppeld aan de bevolkingsomvang. Op elke 45000 inwoners diende er, zo bepaalde de grondwet, één lid te worden gekozen. in 
1887 werd het aantal Tweede-Kamerleden gefixeerd op honderd. Tot die tijd maakte de voortdurende bevolkingsgroei regelmatig een vermeerdering van het aantal afgevaardigden noodzakelijk. Er moest dan geschoven worden met de bestaande districtsgrenzen en dit leidde vrijwel altijd tot commotie. ${ }^{16}$ Ook in Limburg werden de grenzen een aantal malen herzien.

\section{Limburgse kiesdistricten}

De eerste indeling in kiesdistricten (1848) geschiedde provinciegewijs en was opgedragen aan Gedeputeerde Staten. Er was sprake van enkelvoudige districten - één afgevaardigde per district - en Limburg kreeg vijf kamerleden toegewezen. Gedeputeerde Staten verdeelden de provincie in de districten Maastricht, Heerlen, Sittard, Roermond en Venlo.

Toen de regering een jaar later poogde deze indelingsmethodiek - per provincie en door de colleges van Gs - in een nieuwe kieswet te handhaven, verzette een meerderheid in de Kamer zich tegen deze provinciegewijze indeling. De grondwet had immers uitdrukkelijk bepaald dat 'het Rijk' moest worden verdeeld in kiesdistricten en niet de provincies. De provinciegrenzen werden in de uiteindelijke wet, mede op aanwijzing van minister Thorbecke van Binnenlandse Zaken, buiten beschouwing gelaten. Zo werd het noordelijk deel van Limburg met een aantal Noord-Brabantse gemeenten samengevoegd tot het hoofdkiesdistrict Boxmeer, waarvan tussen 1878 en 1887 ook nog drie Gelderse gemeenten deel uit maakten.

Er werden zoveel mogelijk 'grote' districten gevormd waarbij er per district meer dan één - meestal twee - afgevaardigden zouden worden gekozen. Naast het enkelvoudige district Boxmeer - één afgevaardigde werd Limburg verdeeld over de dubbele districten Maastricht en Roermond, met elk twee vertegenwoordigers. Tot 1887 bleef Limburg ingedeeld in deze drie kiesdistricten. De samenstelling van de districten Maastricht, Roermond en Boxmeer wijzigde in deze periode wel, doordat gemeenten soms overgingen naar een ander district en doordat het district Boxmeer in 1869 werd vergroot tot een dubbel district.

Bij de grondwetsherziening van 1887 werd een stelsel van enkelvoudige districten ingevoerd. ${ }^{17}$ Voor Limburg waren dit Maastricht, Gulpen, Sittard, Roermond, Weert en Venlo. Dit laatste kiesdistrict bestond, evenals voorheen Boxmeer, tevens uit een aantal Noord-Brabantse gemeenten. Deze indeling bleef tot 1918 gehandhaafd. Toen werd de grondwet gewijzigd: de kiesdistricten werden afgeschaft en een stelsel van evenredige vertegenwoordiging werd ingevoerd. Voor de verkiezing van de Eerste Kamer werd dit 
stelsel met ingang van 1923 ingevoerd en toen verdween in die lamer he vaste aantal zetels per provincie. Voor de districtsindeling van Lizburg te 1918 zie bijlage $\mathrm{v}$. Tabel 2 geeft deze indeling schematisch weer.

Tabel 2. Indeling van Limburg in kiesdistricten t.b.v. de Tweede-Kamervekiezinga $1840-1918$

Periode Indeling van Limburg

Aantal afrwaandigh

1840-1848 geen indeling in kiesdistricten uit Lnburg*

1848-1850 indeling in de enkelvoudige hoofdkiesdistricten

3

Maastricht, Heerlen, Sittard, Roermond en Venlo

1850-1869 indeling in de hoofdkiesdistricten Maastricht, Roermond (beide dubbele districten) en Boxmeer (enkelvoudig)

1869-1887 indeling in drie dubbele hoofdkiesdistricten: Maastricht, Roermond en Boxmeer

1887-1918 indeling in de enkelvoudige (hoofd)kiesdistricten Maastricht. Gulpen. Sittard. Roermond. Weert en Venlo** afschaffing districtenstelsel

- Uit Limburg (1840-1848) of uit de districten waarvan Limburgse gemeenten deel uitmaakten (1848-1918).

* Vanaf de kieswet van 1896 werd gesproken van 'kiesdistricten' i.p.v. 'hoofdkiesdistricten.

Zoals gezegd was een (wisselend) aantal Limburgse gemeenten sameng: voegd met een gedeelte van Noord-Brabant en Gelderland, eerst in he district Boxmeer, later in het district Venlo. In dit onderzoek zullen all districten waarvan Limburgse gemeenten deel hebben uitgemaakt, worde meegenomen. Of de daar gekozen kamerleden betiteld kunnen worde als Limburgse afgevaardigden, is een vraag die verderop aan de orde zi komen.

\section{Beperkt kiesrecht}

De grootste beperking die in de periode 1840-1918 aan het kiesrecht w gesteld, vloeide voort uit een tot 1887 ongeschreven regel. Zij was gelegeni wat de liberale staatsrechtgeleerde J.Th. Buys de 'natuurlijke voorwaard noemt: zowel het recht te opteren voor een kamerlidmaatschap- het passi' kiesrecht - als het recht kamerleden te kiezen - het actief kiesrecht - wa voorbehouden aan mannen. ${ }^{18}$ De Nederlandse vrouwen werd het passi' 
kiesrecht toegekend door de grondwetswijziging van 1917; in 1919 kregen zij het actief kiesrecht. De eerste vrouw uit Limburg, G.S.H.M. (Truus) Kok, deed overigens pas in 1959 haar intrede in de Tweede Kamer. ${ }^{19}$

Het actief kiesrecht was tussen 1848 en 1918 gebonden aan een minimumbedrag aan betaalde belasting, bij wet vastgesteld en van plaats tot plaats verschillend. De leeftijdsgrens, in 1848 nog 23 jaar, verschoof in 1896 naar 25. Vanaf dat laatste jaar mochten ook bepaalde huurders, spaarders, werkenden in een vast dienstverband en mannen met bepaalde diploma's of beroepen een stem uitbrengen.

De verkiesbaarheid tot lid van de Tweede Kamer was tot 1887 beperkt tot ingezetenen van Nederland. Bovendien gold er een leeftijdsgrens van dertig jaar en waren bepaalde categorieèn ingezetenen uitgesloten. ${ }^{20}$ Ten slotte was er de vereiste van het Nederlanderschap. Deze nationaliteitseis was in de periode tot 1848 nader gespecificeerd; daarover later meer.

Het aantal mannen dat vanaf 1848 verkozen kon worden in de Eerste Kamer was, in vergelijking met het aantal verkiesbaren voor de Tweede Kamer, veel minder groot. Naast de vereisten waaraan een Tweede-Kamerlid moest voldoen, werd er namelijk een fiscale voorwaarde gesteld. Slechts de hoogst aangeslagenen in de directe rijksbelastingen kwamen voor een lidmaatschap in aanmerking: per 3000 inwoners was één persoon verkiesbaar. ${ }^{21} \mathrm{De}$ grondwetswijziging van 1887 vergrootte het aantal tot één per 1500 inwoners. Daarnaast werd in dat jaar toegevoegd dat voortaan ook zij gekozen konden worden die 'eene of meer hooge en gewigtige openbare betrekkingen, bij de wet aangewezen, bekleeden of bekleed hebben',2 Het aantal verkiesbaren voor de drie Limburgse Eerste-Kamerzetels steeg van 68 in 1851 tot 170 in $1891 .^{23}$

Met betrekking tot het lidmaatschap van de Staten-Generaal noemde de grondwet een aantal incompatibiliteiten en het kwam regelmatig voor dat afgevaardigden terugtraden na het aanvaarden van een met het kamerlidmaatschap onverenigbare functie. Bij de kamerleden uit Limburg deed deze situatie zich voor bij Hubert Brouwers (in 1889 benoemd tot lid van de Raad van State), Ruijs de Beekenbrouck senior en junior (benoemd tot Commissaris der Koningin in Limburg in respectievelijk 1893 en 1918) en Martin de Ras (in 1902 benoemd tot lid van de Algemene Rekenkamer). Het ministersambt viel niet onder de incompatibiliteiten. Toch traden kamerleden meestal terug na een benoeming tot minister. Dat deden ook de Limburgers Martin Strens (in 1861 benoemd tot minister van Zaken der Rooms-Katholieke Eredienst), Gustave Ruijs van Beerenbroek (in 1888 
benoemd tot minister van Justitie) en de broers Robert en Louis Regou (in 1909 benoemd tot respectievelijk minister van Justitie en minister ve Waterstaat).

Het kamerlidmaatschap kwam soms tot een voortijdig einde door he overlijden van een afgevaardigde. Zeventien van de 70 parlementariềrs diz vanuit Limburg naar Den Haag werden gezonden, stierven tijdens hun par lementaire loopbaan (zie bijlage viI). Naast de dood was er nog een aantil andere oorzaken dat kon leiden tot een vroegtijdige beëindiging van he mandaat. Zo werd M.J.G.J. Arnoldts in 1903 van het kamerlidmaatschap vervallen verklaard wegens faillissement. Zittende kamerleden dienden al te treden op het moment dat zij een betaalde overheidsfunctie aanvaardden of daarin werden herbenoemd; zij waren dan wel weer onmiddellijk het kiesbaar. Vooral in districten waar de politieke strijd hevig was, betekende het aannemen van zo'n (her)benoeming een politiek risico: de uitkoms van de te houden stemming was immers onzeker.

Met het oog op de positie van de Limburgers in de Nederlandse politick verdient een van de wettelijke vereisten voor het kamerlidmaatschap en nadere uitwerking: het Nederlanderschap.

\section{Volwaardige Nederlanders?}

Op 12 november 1846 kozen Provinciale Staten van Limburg een van hun leden, J.L.M. Leclercq, president van de arrondissementsrechtbank te Roermond, tot lid van de Tweede Kamer. Zoals elk nieuw gekozen kamerlid zond Leclercq zijn geloofsbrieven naar Den Haag en op 9 februari, na het winterreces, bracht de commissie die belast was met het onderzoek van dezt papieren, verslag uit. Er hadden zich, zo werd de Kamer gemeld, 'moeijelijkheden' voorgedaan. Welke problemen precies waren gerezen, werd de volgende dag duidelijk, toen de commissie, na een nader onderzoek, uitgebreid berichtte van haar bevindingen. Leclercq bleek wettig gekozen en zou normaliter kunnen worden toegelaten tot de Kamer, 'ware het niet dat zich de zwarigheid had opgedaan, of de heer Leclercq wel is een geborat Nederlander, in den zin van art. 7 der Grondwet.' ${ }^{24}$

Drie jaar later - in juli 1850 - werd Karel de Limpens in het distrit Maastricht gekozen tot kamerlid. De commissie die was belast met het onderzoek van zijn geloofsbrieven liet over de Limburger weten: 'Ten zijnen opzigte is alleen twijfelachtig of hij Nederlander is.'25 Deze twijfel zou in 1855 -De Limpens werd toen wederom gekozen-opnieuw openlijk in de Tweede Kamer worden uitgesproken. ${ }^{26}$ 
Dat deze beide Limburgse afgevaardigden niet werden beschouwd als (volwaardige) Nederlanders hield direct verband met de staatkundige geschiedenis van hun provincie. Bij de invulling van de Haagse kamerzetels zou de Limburgse deling van 1839 nog vele jaren van grote betekenis blijven.

Bij Leclercq noemde de kamercommissie het zevende grondwetsartikel als obstakel. Hierin was een aantal vereisten vastgelegd die onder meer betrekking hadden op het lidmaatschap van de Staten-Generaal. Zo was bepaald dat alleen Nederlandse ingezetenen 'geboren binnen het Rijk [...] uit ouders aldaar gevestigd' gekozen mochten worden. De kwestie was nu of Leclercq voldeed aan deze eis. Zijn geboorteplaats, Maaseik, lag op dat moment (1847) in Belgisch-Limburg. Eerder, in de jaren voor de afscheiding van Belgiê, had het stadje wel behoord tot het Koninkrijk der Nederlanden. Welk moment was bepalend? Deze vraag was overigens al jaren daarvoor, tijdens de parlementaire discussies over de grondwetsherziening van 1840 , uitdrukkelijk onder de aandacht gekomen. In een van de voorlopige verslagen van de Tweede Kamer lezen we:

Ten gevolge der afscheiding van de Belgische gewesten is het noodzakelijk om nader te bepalen, in welken zin men de woorden: geboren binnen het Rijk, dient op te nemen. Nederlanders, in Belgiẽ geboren, kan men bezwaarlijk uitsluiten. ${ }^{27}$

De commissie die zich met de geloofsbrieven van Leclercq bezighield, ging echter volledig voorbij aan dit bezwaar en adviseerde de Limburger niet toe te laten tot het Nederlandse parlement. Een grote kamermeerderheid volgde dit advies en weigerde in te stemmen met de komst van Leclercq. Provinciale Staten van Limburg moesten een nieuwe afgevaardigde kiezen.

Bij De Limpens hield de nationaliteitskwestie vooral verband met de wet op het Nederlanderschap, die even daarvoor van kracht was geworden. Volgens deze wet werden personen die zich binnen twee jaar na het vredesverdrag met België (1839), vanuit dat land in Nederland hadden gevestigd, geacht de Nederlandse nationaliteit te bezitten. De Limpens voldeed niet aan die bepaling, omdat hij pas op 25 mei 1842 vanuit Turnhout was verhuisd naar Klimmen.

Eerder al was echter bij Koninklijk Besluit bepaald dat tot twee jaar na ratificatie van het verdrag een verzoek kon worden ingediend bij de koning om het Nederlandse staatsburgerschap te verkrijgen. Een dergelijk verzoek 
had De Limpens gedaan, op 29 mei 1841. Over het precieze momen waaro deze termijn van twee jaar afliep, konden de meningen echter uitenlopen aldus de commissie; zelf hield zij een datum aan waardoor De impen zijn verzoek drie dagen te laat had ingediend. Overigens was de conmisit eigenlijk van oordeel dat de bepalingen van dit Koninklijk Beslut in he geheel niet van toepassing waren, omdat de rechtsgeldigheid erval moes worden betwijfeld.

Eduard Borret (district Maastricht) meende dat de zaak ingewkkelde werd gemaakt dan zij was. Volgens hem kon De Limpens gewoon aasspral maken op het Nederlanderschap. Want toen De Limpens in Herethalsin 1850 gelegen op Belgisch grondgebied - geboren werd, had zijn vder ee overheidsbetrekking in Klimmen en dus binnen de Nederlandse renze van na 1840 . De gehele vergadering van 16 oktober 1850 werdaan $\alpha$ kwestie gewijd. ${ }^{28}$ De belangrijkste vraag was welke regeling nu preies va toepassing was op De Limpens. De commissie die met het onderzek nat zijn geloofsbrieven was belast, adviseerde om de Limburger niet toe e laten Een kleine meerderheid negeerde dit advies -28 tegen 21 stemmen - en D. Limpens kon afreizen naar Den Haag.

Het al dan niet toelaten van Leclercq en De Limpens raakte niet slecht deze individuele afgevaardigden: de uitkomst van de discussies over $d$ volwaardigheid van hun Nederlanderschap had gevolgen voor veel meet leden van de Limburgse elite. Diverse vooraanstaande Limburgers ware geboren in (het latere) België, ook prominenten buiten de politiek. Zo wa de hoogste kerkelijke autoriteit in de provincie, apostolisch vicaris Joanne Augustinus Paredis, ter wereld gekomen in het Belgisch-Limburgse Bret In het geval van Leclercq werden de consequenties voor de inwoners van Limburg tijdens de parlementaire beraadslagingen meermaals aangeroerd Minister De Jonge van Campensnieuwland van Justitie zei:

Hier zal niet slechts worden uitgemaakt of het uit Limburg benoemde lid in de Staten-Generaal kan worden toegelaten, maar er zal uitspraak tevens worden gedaan over de al dan niet bevoegdheid daartoe van zoovele Limburgers welke met hem in hetzelfde geval verkeeren. ${ }^{29}$

En zo werd het ook in Limburg zelf gevoeld: de weigering om Leclercq toett laten 'heeft bij velen, die in dit Hertogdom in eene gelijksoortige stelling ab de Heer Leclercq zijn, eenen onaangenamen indruk gemaakt', schreef gotverneur Van Meeuwen aan minister graaf van Randwijck van Binnenlands Zaken. ${ }^{30}$ Eerder had zijn voorganger Gericke van Herwijnen overigens 2 
iemand met interesse in het kamerlidmaatschap afgeraden zich kandidaat te stellen op grond van het feit dat hij in Belgisch-Limburg was geboren."

Ook in het geval van De Limpens kwam de reikwijdte van de beslissing aan bod. De Maastrichtse afgevaardigde Borret merkte bijvoorbeeld op dat de beslissing van de Kamer 'een antecedent zal stellen', ${ }^{32}$ Hoewel bij De Limpens werd besloten om de gekozene wel tot de Kamer toe te laten, toont de uitgebreide discussie over zijn nationaliteit en het grote aantal kamerleden dat tegen zijn toelating stemde, dat de positie van de Limburgse elite in de Nederlandse politiek nog allerminst zeker was.

De discussies uit 1847 en 1850 over het Nederlanderschap van de Limburgse afgevaardigden plaatsten veelal de 'harde' criteria uit de grondwet van 1840 en uit de wet op het Nederlanderschap (1850) tegenover de meer voluntaristische strekking van het Londense traktaat. Bij dit traktaat was immers 'als beginsel' aangenomen 'dat de ingezetenen het grondgebied volgden voor zoover zij dat begeerden', zo hield de minister De Jonge van Campensnieuwland de Kamer voor. ${ }^{33}$

Het Limburgse kamerlid Corneli verwees uitdrukkelijk naar deze keuzemogelijkheid. Tijdens het kamerdebat van februari 1847 citeerde hij delen van het traktaat. Hij merkte op dat 'volgens het daarin bepaalde, ieder ingezetenen van afgestane gewesten eene keuze kon doen omtrent den Staat, waarin hij zijn domicilie wilde vestigen en daardoor in het genot zou komen van de regten, aan de onderdanen van zoodanig een Staat toekomende." Corneli hanteerde een meer subjectieve definitie van het natieconcept: de natie als een politieke gemeenschap die gebaseerd is op de vrijwillige participatie van burgers. ${ }^{35}$ Andere verdedigers van het verlenen van admissie aan Leclercq lieten zich op gelijke wijze uit.

Ook bij De Limpens werd de vrije nationaliteitskeuze benadrukt. Door het insturen van een verzoek tot verkrijging van het Nederlanderschap had hij zelf een voorkeur uitgesproken. Bovendien, zo werd tijdens een vergadering van Provinciale Staten aangedragen, had De Limpens gedurende de tijd dat hij in Belgiê woonde, geen ambt uitgeoefend. Het latere TweedeKamerlid Edmond van Wintershoven leidde hieruit een 'esprit de retour' af: een hang naar het (Noord-) Nederlandse vaderland. ${ }^{36}$

De argumentatie die ten gunste van Leclercq en De Limpens werd aangevoerd, is opmerkelijk. Terwijl de Limburgse bevolking enkele jaren daarvoor gedwongen had moeten terugkeren onder Nederlands gezag, trachtten haar afgevaardigden toegang te krijgen tot de volksvertegenwoordiging door juist hun vrijwillige keuze voor de Nederlandse natie te benadrukken. 
Nu was deze specifiek Limburgse problematiek van tijdelijke aard: be meer tijd er zou verstrijken vanaf de Belgische periode, hoe onwaarschijp lijker het werd dat zij zich zou voordoen. De kinderen van Leclercq zoude bijvoorbeeld wel in aanmerking komen voor het kamerlidmaatschap, a had koning Willem n hun vader tot troost medegedeeld. ${ }^{37}$ Het Belgisck verleden van de provincie zou echter, met name via de vereiste van he inboorlingschap, nog tot in de twintigste eeuw hebben kunnen doorwe ken, indien deze eis bij de grondwetsherziening van 1848 niet was komet te vervallen. Na 1848 hebben er dan ook vier Limburgers in de Kamen zitting gehad die in Belgisch-Limburg waren geboren, te weten Johan lo dewijk Matthias Leclercq, Charles Antoine baron de Bieberstein Rogah Zawadsky, Karel de Limpens en jhr. Louis Libert de Villers de Pité. Dr Bieberstein en De Villers de Pité zaten nog in 1880 in de Staten-General Door de grondwetsherziening werd aan verschillende leden van de pot tieke elite in Limburg de toegang tot het Binnenhof niet langer ontzegl Een fraaie illustratie daarvan vormde Leclercq zelf. Nadat hij bij de eerst verkiezingen volgend op de grondwetsherziening was gekozen, werd hi zonder problemen tot de Kamer toegelaten.

Uit het bovenstaande blijkt dat het kiesstelsel door middel van he uitsluiten van bepaalde categorieën mede bepaalde wie er vanuit Limbur zitting namen in de Staten-Generaal. Het ging daarbij niet altijd om eet beoogde uitsluiting. Zo hadden de vereisten die tot 1848 werden gestel aan het Nederlanderschap, althans in de ogen van de regering, voor de Limburgers onbedoelde gevolgen. Er zijn echter ook aanwijzingen te vindet die erop duiden dat de overheid juist zocht naar mogelijkheden om via eet welgekozen inrichting van het kiesstelsel invloed uit te oefenen op de selectir van de Limburgse afgevaardigden; hierover meer in het volgende hoofdstuk.

\section{'Niet geheel vreemd aan Limburg'}

Wie van de Eerste- en Tweede-Kamerleden tussen 1840 en 1918 was Limburger? Bij de beantwoording van deze vraag liggen drie criteria voor de hand in Limburg (1) geboren, (2) gekozen of benoemd en (3) woonachtig. Ondet het tweede criterium vallen personen die (a) gekozen werden door Provinciale Staten van Limburg; (b) door de koning werden benoemd namens Ps (Tweede Kamer 1840) en bij gelegenheid van de terugkeer van Limburk onder Nederlands gezag (Eerste Kamer 1840); (c) benoemd werden doot de koning uit de kandidaten voor de Eerste Kamer die in de Limburge districten waren gekozen (1849); of (d) gekozen werden in een van de Lim. 
burgse kiesdistricten. Met behulp van de gegevens van het Parlementair Documentatie Centrum kunnen we de eerste twee criteria toepassen op de personen die tussen 1840 en 1918 werden gekozen of benoemd tot lid van de Staten-Generaal. Het resultaat is een lijst met 66 Tweede- en 18 EersteKamerleden (zie bijlage vi); vier afgevaardigden hadden zowel in de Eerste als in de Tweede Kamer zitting.

\section{District Boxmeer}

Als het gaat om de verhouding tussen woonplaats, geboorteplaats en provincie neemt het kiesdistrict Boxmeer een bijzondere positie in. Dit kiesdistrict was immers slechts gedeeltelijk Limburgs. Deze exceptionele positie geldt minder voor het in 1887 gevormde district Venlo. Weliswaar bestond ook dit uit gemeenten aan beide zijden van de provinciegrens, in tegenstelling tot het district Boxmeer was het district Venlo echter duidelijk overwegend Limburgs wat betreft inwoners en kiezers: slechts een kleine minderheid woonde in de vier Noord-Brabantse gemeenten die tot het district behoorden.

Voor drie afgevaardigden uit het district Boxmeer geldt dat hun loopbaan zich volledig afspeelde in of vanuit Noord-Brabant: J.B.J. Hengst, P. van den Heuvel en H.C.F. Kerstens. Zo waren ze alle drie in die provincie actief in de plaatselijke of provinciale politiek. Deze drie volksvertegenwoordigers werden door tijdgenoten beschouwd als Noord-Brabander, of in dit kader beter gezegd: niet beschouwd als Limburger. Zo telde Thorbecke in 1856 vier Limburgse afgevaardigden en dat deed negen jaar later ook het Venlose Tweede-Kamerlid Pieter de Lom de Berg. ${ }^{38}$ De vertegenwoordiger uit het district Boxmeer (respectievelijk Hengst en Kerstens) werd daarmee uitdrukkelijk buitengesloten. Kerstens werd ook door Tweede-Kamerlid Leopold Haffmans in diens krant, het Venloosch Weekblad, beschouwd als een Noord-Brabantse volksvertegenwoordiger."

Het provinciebestuur in Maastricht nam eveneens duidelijk stelling. Zolang het aantal Noord-Brabantse kiezers in het district Boxmeer het aantal Limburgse overtrof, waren Gedeputeerde en Provinciale Staten van oordeel dat 'de kiesgeregtigden van Limburg steeds in de minderheid blijvende hun verkiezingsregt tot een ijdel vertoon zagen afdalen'. Met een meerderheid aan Noord-Brabantse kiezers zouden de Limburgers er immers nooit in slagen 'eenen vertegenwoordiger harer keuze naar 's lands vergaderzaal af te vaardigen'. ${ }^{20}$ Limburgse kiezers wilden Limburgse kamerleden, meende het provinciebestuur. Nu berichtte het blad De Noord-Brabanter op 16 januari 
1868 inderdaad dat de Noord-Limburgse kiezers in het district Bomee 'verbitterd' waren over hun afgevaardigde Kerstens, 'omdat hij nog noiti de Kamer een woord gesproken heeft ter verdediging van de Limbugschs belangen'.

Toen de districtsindeling in 1869 wederom op de parlementaire aend verscheen, kwam er in Limburg een petitiebeweging op gang die het vark. ment ervan wilde overtuigen dat de provincie, gelet op haar bevolkinggetal. recht had op een vijfde afgevaardigde. Ook hier werd de afgevaardige uit het district Boxmeer dus niet als Limburgs kamerlid meegeteld. Om lt ge tal van vijf volksvertegenwoordigers te bereiken, diende het noordelix ded van Limburg niet langer bij een groot deel van oostelijk Noord-Brabnt tt worden gevoegd. Een van de verzoekschriften was afkomstig van Geleputeerde Staten uit Maastricht en ging vergezeld van een voorstel waarirLim. burg binnen de eigen provinciegrenzen werd opgedeeld en vijf kameieden zou kunnen afvaardigen. Het was een goed georganiseerd petitionnenent Zo wist de burgemeester van Venray zijn gemeenteraad al in een vrog str. dium te melden dat vanuit bijna alle Limburgse gemeenten verzoekschiftet zouden worden ingediend. ${ }^{41}$ Ook uit de deelname aan de petitiebeweging blijkt de goede organisatie. In Venray bijvoorbeeld plaatsten 119 van de 130 kiesgerechtigden een handtekening onder het verzoekschrift.

Datzelfde jaar werd het district Boxmeer vergroot: van een enkelvoudif district werd het een dubbel district. Leopold Haffmans werd dat jaat gekozen als tweede Boxmeerse afgevaardigde naast het zittende TweedeKamerlid Kerstens, zoals gezegd een Noord-Brabander. Omdat in dubbek districten iedere twee jaar verkiezingen werden gehouden, telkens voor een van de beide zetels (dat wil zeggen om-en-om) ging het twee jaar later, in 1871, om de zetel van Kerstens. Het Venloosch Weekblad schreef toen:

Ons district bestaat ter helfte uit Limburgsche, ter helfte uit Noordbrabantsche kiezers. Het spreekt van zelf dat er dus een Limburger en een Noord-Brabander gekozen wordt. En even als in 1869 de katholieke kiezers van Noordbrabant ons de hand hebben gereikt om den katholieken Limburgschen candidaat [Haffmans] te doen zegevieren, zoo moeten wij Limburgers thans wederkerig voor den Noordbrabantschen candidaat onzer richting zorgen. ${ }^{42}$

Er werd dan ook geen Limburger kandidaat gesteld; de strijd ging in 1871 tussen twee Noord-Brabanders: Kerstens en de Eindhovense rechtet Petrus van den Heuvel. Geheel in lijn hiermee was de strijd die twee jart 
eerder had plaatsgevonden om de andere - lees: Limburgse - zetel, gevoerd tussen twee Limburgers: Haffmans en de Blerickse notaris Johannes Clercx. De systematiek van het om beurten kiezen van een Limburger en een Noord-Brabander blijkt te zijn gehanteerd bij de verkiezingen van 1869 , 1871,1873 en 1875 . Enige maanden na de reguliere verkiezingen in het laatstgenoemde jaar nam Van den Heuvel ontslag wegens zijn verkiezing tot lid van Gedeputeerde Staten van Noord-Brabant. Volgens het tot dan toe geldende gebruik - 'billijkerwijze' schreef het Venloosch Weekblad - zou in plaats van Van den Heuvel een provinciegenoot gekozen moeten worden." De kiesvereniging Noord-Brabant die in het district Boxmeer de katholieke kandidaten aanwees (zie hoofdstuk 4), schoof echter de Limburger Hubert Brouwers naar voren. Brouwers werd gekozen en daarmee waren de twee afgevaardigden uit Boxmeer beiden afkomstig uit Limburg. Toen Brouwers in 1882 tussentijds zijn zetel opgaf, kandideerde kiesvereniging NoordBrabant Johannes Clercx. Het Venloosch Weekblad schreef:

Wederom een Limburger, ofschoon het district Boxmeer, ter helfte Noord-Brabantsch, ter helfte Limburgsch, reeds door een Limburger [Haffmans] vertegenwoordigd is. De provincie Noord-Brabant had aanspraak dat de opengevallen plaats door eenen Noord-Brabander vervuld wierd, maar het heeft die niet doen gelden. Dit verdient te meer aanerkenning van Limburgsche zijde daar Noord-Brabant de candidatuur in handen had."

Dat de provincie Noord-Brabant haar 'aanspraak' niet had doen gelden én het gevoelen dat Limburg zijn buurprovincie daarvoor dank verschuldigd was, lijkt te duiden op een verschil in opvatting aan de twee zijden van de provinciegrens. De kiesvereniging Noord-Brabant was het primair te doen om de politieke kleur van de afgevaardigde: zij voerde een strijd tegen de liberaal-katholieken (zie hoofdstuk 4). Ook in Limburg werd die strijd gevoerd, maar daar hechtte men tevens sterk aan de provincie van herkomst van de kandidaat. Dit verschil tussen de twee provincies werd ook door het Venloosch Weekblad opgemerkt. ${ }^{45}$ Inderdaad is er in het Boxmeersch Weekblad Maasbode bij de acht verkiezingen vanaf oktober 1877 , toen alleen nog Limburgers werden genomineerd door kiesvereniging Noord-Brabant, geen enkele kritische noot te vinden. ${ }^{46}$

Terug naar de Tweede-Kamerleden Hengst, Van den Heuvel en Kerstens. Gezien hun levensloop en gelet op het oordeel van tijdgenoten zal, in- 
dien er in het vervolg van dit onderzoek gesproken wordt van Limiurge kamerleden, niet op deze drie afgevaardigden worden gedoeld.

\section{Gekozen, geboren en wonend in Limburg}

In juni 1863 behandelde de Tweede Kamer het verdrag met België over $\alpha$ aftappingen van Maaswater: een heet hangijzer in Limburg. In de tame stonden de twee afgevaardigden uit Maastricht, Edmond van Wintersove en Charles Antoine baron de Bieberstein Rogalla Zawadsky, lijnrecht egenover elkaar. Volgens Van Wintershoven werden de belangen van duiznden Limburgers weer eens opgeofferd door De Bieberstein en diens poitick vrienden in het tweede kabinet-Thorbecke. Hij voegde eraan toe dit he eigenlijk wel te begrijpen was dat De Bieberstein de Limburgse belnget verwaarloosde: de baron was immers geen echte Limburger:

Neen, Mijnheer de Bieberstein is niet geboren aan de oevers un dien stroom [de Maas]; hij heeft er geen groote levensindrukkn ontvangen, de wieg zijner kinderen heeft er niet gestaan. Hij is er eerst in lateren leeftijd gekomen. ${ }^{47}$

Kennelijk gold het inboorlingschap voor Van Wintershoven als een politick bruikbaar criterium.

Bij eerdere verkiezingen had het er inderdaad op geleken dat de Limburgse kiezers hechtten aan kamerleden die in hun eigen provincie waret geboren en getogen. Bij de verkiezingen van 1848 had Maastricht nog de in Noord-Brabant geboren en getogen Eduard Borret afgevaardigd. ${ }^{48}$ Vief jaar later werd Borret niet herkozen, hetgeen wel wordt toegeschreven aan provincialistische motieven bij de kiezers. ${ }^{49}$ De niet-Limburgse afkomst van Borret was al in 1850 , tijdens de toen gevoerde verkiezingscampagne, et item geweest. Het Journal du Limbourg had hem bestreden door erop th wijzen dat hij geen Limburger was. Een ander blad, dat nota bene de naam De Limburger droeg, had hem gesteund door aan te voeren 'dat al is de het Borret geen Limburger van geboorte, hij daarom niettemin aanbevelens waardig blijft'. ${ }^{\circ}$

Dat het de niet-Limburgse afkomst was die Borret zijn herverkiezin in 1852 versperde, lijkt een voorbarige conclusie. Nauwelijks een jaar b ter kozen de kiezers uit hetzelfde district de nog verder buiten Limbur opgegroeide Zwollenaar Johan Rudolf Thorbecke tot hun afgevaardigde Een uitzonderlijke gebeurtenis schreef het Maastrichtse Tweede-Kamerlid 
Van Wintershoven, een politiek bondgenoot en vriend van Thorbecke: de verkiezing van iemand van buiten Limburg was in Maastricht 'bijna onmogelijk: Van Wintershoven had voorafgaand aan de verkiezingen niet willen uitsluiten dat Thorbecke zware concurrentie zou krijgen van een kandidaat die zijn steun dankte aan het feit dat 'hij slechts hier geboren zoude zijn'.' Borret en Thorbecke behoorden, als buiten de provincie geboren, inderdaad tot een minderheid, zo blijkt uit tabel 3 .

Tabel 3. Leden van de Staten-Generaal 1840-1918, gekozen in of benoemd vanuit Limburg, naar geboorteprovincie*

$\begin{array}{lccc}\text { Geboorteplaats } & \text { Eerste Kamer } & \text { Tweede Kamer } & \text { Staten-Generaal * } \\ \text { In Limburg } & 13 & 43 & 54 \\ \text { Buiten Limburg } & 2 & 12 & 13 \\ \text { Totaal } & 15 & 55 & 67 \\ \text { - Exclusief de Noord-Brabantse leden uit het district Boxmeer } \\ \text { (Hengst, Van den Heuvel en Kerstens). } \\ \text { "* De kolom 'Staten-Generaal' is niet gelijk aan de optelsom van de } \\ \text { kolommen 'Eerste Kamer' en 'Tweede Kamer', omdat drie personen } \\ \text { zitting hebben gehad in beide Kamers. }\end{array}$

Een ruime meerderheid van de afgevaardigden werd in Limburg geboren. lets minder dan een vijfde deel - 13 van de 67 - kwam elders ter wereld. Acht van deze dertien waren het grootste deel van hun leven echter wel in Limburg beroepsmatig actief. Het betreft hier Charles Antoine baron de Bieberstein Rogalla Zawadsky (voor de eerste maal gekozen in 1850), Frederik baron de Keverberg de Kessel (1864), Johan Lodewijk Matthias Leclercq (1849), Karel de Limpens (1850), Gerard Johan de Rijk (1849), Carl Ruland (1886), Jan Marius Swart (1848) en jhr. Louis Libert de Villers de Pité (1948). Zij namen er deel aan de lokale of provinciale politiek en werden bij uitsluiting vanuit Limburg afgevaardigd naar Den Haag. Zonder uitzondering stierven zij ook in Limburg. Een band met de provincie was in hun geval dus duidelijk aanwezig.

Die band was er ook bij een negende kamerlid, Jan Lodewijk baron van Scherpenzeel Heusch, in 1849 gekozen in het district Sittard. In de jaren veertig was hij een van de leidende figuren binnen de separatistische beweging in Limburg en hij had zijn politieke lot met dat van de provincie verbonden. Eind jaren veertig was Van Scherpenzeel vanuit Limburg afgevaardigd naar 
de Duitse Nationale Vergadering in Frankfurt am Main (zie hoofdstuk 3 ) en hij werd uitsluitend in Limburg gekozen tot Tweede-Kamerlid. In 1872 stierf hij in het Midden-Limburgse Vlodrop.

Ook buiten Limburg geboren waren Eduard Borret en George Diepen, twee kamerleden met een duidelijke band met Limburg: zij werden bij uitsluiting vanuit die provincie afgevaardigd naar de Staten-Generaal en op her moment van hun verkiezing oefenden zij in Limburg hun beroep uit. Bo. vendien waren zij voorafgaand aan hun parlementaire loopbaan er al enige tijd woonachtig. Meer echter dan de hiervoor genoemde groep van negen kamerleden hadden zij gedurende hun leven familiaire en beroepsmatige banden met andere landsdelen.

Borret woonde bij zijn verkiezing in november 1848 al ten minste zeven jaar in Limburg; hij was op dat moment advocaat-generaal bij het pro. vinciaal gerechtshof in Maastricht. Na ruim tien jaar in Limburg te hebben gewoond, verliet hij de provincie. Borrets familie was politiek en bestuurlijk sterk op Noord-Brabant geconcentreerd. Zijn vader A.J.L. Borret was gouverneur (later Commissaris des Konings) van deze provincie. Een broer, F.H.H. Borret, werd als Tweede-Kamerlid afgevaardigd door de districten Zevenbergen (1850-1868) en Tilburg (1882-1888). Zijn zoon Theodorus (Th.L.M.H. Borret) was afgevaardigde voor Oosterhout en trachtte, toen hij daar niet werd herkozen, via een tussentijdse verkiezing in Zevenbergen in de Tweede Kamer te komen. Toen dit mislukte, greep hij een tussentijdse verkiezing in het Noord-Hollandse district Beverwijk aan om zijn doelhet kamerlidmaatschap - alsnog te bereiken. ${ }^{52}$

Diepen was burgemeester van Roermond en hij woonde voorafgaand aan zijn verkiezing tot Tweede-Kamerlid al zo'n negentien jaar in Limburg. Zeventien jaar bracht hij door in het bij Roermond gelegen Heel, waar zijn schoonmoeder woonde en waar hij eerder was getrouwd. Voor zijn komst naar Heel speelde Diepens carrière zich af in 's-Hertogenbosch, waar hij gedurende dertien jaar leiding gaf aan het familiebedrijf, een lakenhandelszaak. Na vierentwintig jaar in Limburg te hebben gewoond, keerde hij met zijn vrouw terug naar Noord-Brabant: hij verhuisde in 1896 naar Vught, waar hij in 1918 overleed. Zijn zoon Arnold Frans was tussen 1919 en 1942 bisschop van 's-Hertogenbosch. ${ }^{53}$

Twee kamerleden, Johan Rudolf Thorbecke en Martin de Ras, nemen een bijzondere positie in omdat zij op het moment van hun verkiezing in Limburg geen functie bekleedden in die provincie: meer dan de hiervoot vermelde afgevaardigden werden deze twee politici van buiten de provinci 'gehaald'. De Ras was op het moment van zijn verkiezing burgemeestef 
van het Gelderse Pannerden. Bovendien hadden zij eerder al pogingen ondernomen in een niet-Limburgs district te worden gekozen. De Ras was in 1891 kandidaat in het kiesdistrict Elst (Gelderland), maar werd daar toen verslagen. Thorbecke werd eerder gekozen in het district Leiden en was voordien al afgevaardigd als buitengewoon lid van de Tweede Kamer door Provinciale Staten van Holland en als Tweede-Kamerlid door ps van ZuidHolland. Thorbecke is daarmee de enige van de dertien buiten Limburg geboren kamerleden die ook vanuit een ander landsdeel naar Den Haag werd gezonden.

Indien we de geboorteplaatsen van de Tweede-Kamerleden chronologisch bezien (zie tabel 4 ), moet worden geconstateerd dat vanuit Limburg steeds minder Tweede-Kamerleden werden afgevaardigd die buiten de provincie geboren waren. De band van de gekozenen met Limburg werd in dit opzicht in de loop der tijd hechter. Weliswaar vormen de jaren 1890-1899 hierop een uitzondering, keren deden zij deze ontwikkeling niet. Overigens is de periode $1840-1848$ hier buiten beschouwing gelaten, omdat de toen geldende regels met betrekking tot het Nederlanderschap de verhouding tussen de wel en niet in Limburg geborenen sterk zou beinnloeden. Daardoor zijn deze acht jaren moeilijk te vergelijken met de daaropvolgende decennia. ${ }^{54}$

Tabel 4. Geboorteplaats van in Limburg gekozen Tweede-Kamerleden in percentages van het aantal 'manjaren', 1848-1918*

$\begin{array}{lcc}\text { Periode } & \text { Geboren in Limburg } & \text { Geboren buiten Limburg } \\ 1849-1859 & 63 & 37 \\ 1860-1869 & 72 & 28 \\ 1870-1879 & 81 & 19 \\ 1880-1889 & 93 & 7 \\ 1890-1899 & 83 & 17 \\ 1900-1909 & 96 & 4 \\ 1910-1918 & 100 & 0 \\ \text { - Exclusief de Noord-Brabantse leden uit het district Boxmeer } \\ \text { (Hengst, Van den Heuvel en Kerstens). }\end{array}$

Leesvoorbeeld: in de periode $1849-1859$ werden de zetels vanuit de Limburgse kiesdistricten voor $63 \%$ van de tijd ingenomen door een afgevaardigde die in Limburg geboren was. 
Als het gaat om de binding met Limburg kan de woonplaats van afge vaardigden nadere informatie verschaffen. Krachtens de grondwet van 1840 dienden Tweede-Kamerleden woonachtig te zijn in de provincie die hen afvaardigde. In 1848 werd deze eis uit de grondwet geschrapt. Desondanks bleef het ingezetenschap door de kiezers in Limburg 'schier gevorderd' worden, zo lezen we in een brief uit 1849 van gouverneur Van Meeuwen aan minister Thorbecke van Binnenlandse Zaken. ${ }^{55}$ Tabel 5 bevestigt dit slechts vier afgevaardigden die tussen 1848 en 1918 in Limburg werden g* kozen, woonden op het moment van hun eerste verkiezing aldaar niet in die provincie. In tabel 6 worden deze vier parlementariërs nader bekeken.

Kamerleden die in Limburg waren opgegroeid en die voorafgaand aan hun verkiezing buiten de provincie woonden in verband met de uitoefening van hun beroep, keerden doorgaans naar Limburg terug. Strens, in 1853 gekozen in het district Roermond, liet zich dat jaar op de verkiezingsdag, 17 mei, samen met zijn gezin weer inschrijven in het bevolkingsregister van Roermond, na een verblijf van zo'n zes jaar in 's-Hertogenbosch en Den Haag waar hij werkzaam was geweest als procureur-generaal respectieveliik minister van Justitie. 56 Van der Maesen de Sombreff keerde na zijn aftreden als minister van Buitenlandse Zaken vanuit Den Haag, waar hij gedurende zijn ministerschap (1862-1864) had gewoond, met zijn gezin terug naar Houthem. ${ }^{57}$ Spoedig daarna werd hij in het district Maastricht gekozen tot Tweede-Kamerlid. Van Groenendael woonde op het moment van zijn verkiezing nog buiten Limburg (zie tabel 6; hij werkte in Zwolle als griffier van Provinciale Staten van Overijssel). Van Groenendael verlangde echter niets liever dan terug te keren naar de provincie waar hij was opgegroeid. zo lieten zijn aanhangers voorafgaand aan de verkiezingen aan de kiezers weten. ${ }^{58} \mathrm{Hij}$ vestigde zich inderdaad weer in Limburg. Na het griffierschap eerst nog ruim een jaar te hebben gecombineerd met het kamerlidmaatschap liet Van Groenendael zich op 6 oktober 1917, samen met zijn gezin inschrijven in het bevolkingsregister van Sittard. Hij ging zijn werk als afgevaardigde nu combineren met een baan in Limburg en werd leraar staatsinrichting aan de HBs te Rolduc. ${ }^{39}$

De Ras was geboren in Nijmegen, maar hij had wel enkele jaren van zijn jeugd doorgebracht in Maastricht: de stad waar zijn vader als militait gelegerd was geweest en waar in 1892, toen hij werd gekozen, nog altijd familie van hem woonde. Door middel van een advertentie in de Limburger koerier kondigde De Ras na zijn verkiezing aan zich spoedig (weer) in Maastricht te zullen vestigen. ${ }^{\infty}$ Eerder, in 1889 , had hij tevergeefs geprobeerd 
om in het district Roermond gekozen te worden. Ook toen had hij de kiezers eenzelfde verzekering gegeven: na te zijn gekozen zou hij zich vestigen in de bisschopsstad. ${ }^{61}$ De Ras deed zijn belofte gestand en vestigde zich op 28 september 1892 , tweeènhalve maand nadat hij werd gekozen, samen met zijn vrouw in Maastricht. Vier dagen later verhuisden zij naar het nabij gelegen Meerssen. ${ }^{\alpha 2}$

Tabel 5. Leden van de Staten-Generaal 1848-1918, gekozen in Limburg, naar woonplaats ten tijde van hun eerste verkiezing in die provincie*

$\begin{array}{lccc}\text { Woonplaats } & \text { Eerste Kamer } & \text { Tweede Kamer } & \text { Staten-Generaal ** } \\ \text { In Limburg } & 14 & 41 & 53 \\ \text { Buiten Limburg } & 0 & 4 & 4 \\ \text { Totaal } & 14 & 45 & 57\end{array}$

- Exclusief de Noord-Brabantse afgevaardigden uit het district Boxmeer (Hengst, Van den Heuvel en Kerstens).

“ De kolom 'Staten-Generaal' is niet gelijk aan de optelsom van de kolommen 'Eerste Kamer' en 'Tweede Kamer', omdat in de periode 1848-1918 twee personen zitting hebben gehad in beide Kamers.

Tabel 6. Tweede-Kamerleden 1848-1918, gekozen in Limburg, van wie de woonplaats ten tijde van hun eerste verkiezing in Limburg buiten deze provincie lag, in volgorde van het jaar van verkiezing

$\begin{array}{lcccc}\text { Naam } & \begin{array}{c}\text { Jaar eerste } \\ \text { verkiczing }\end{array} & \begin{array}{c}\text { In Limburg } \\ \text { geboren? }\end{array} & \begin{array}{c}\text { Vór cerste } \\ \text { verkiezing in } \\ \text { Limburg gewoond? }\end{array} & \begin{array}{c}\text { Na eerste } \\ \text { verkiezing naar } \\ \text { Limburg verhuisd? }\end{array} \\ \text { Thorbecke } & 1853 & \text { nee } & \text { nee } & \text { nee } \\ \text { De Ras } & 1892 & \text { nee } & \text { ja } & \text { ja } \\ \text { DeStuers } & 1901 & \text { ja } & \text { ja } & \text { nee } \\ \text { Van Groenendaci } & 1916 & \text { ja } & \text { ja } & \text { ja }\end{array}$

Thorbecke is de enige afgevaardigde die nimmer in Limburg heeft gewoond. Alleen hij en Victor de Stuers vestigden zich na hun eerste 'Limburgse verkiezing' niet in Limburg. Hoewel zij een verhuizing naar deze provincie niet lijken te hebben overwogen, wekten zij naar buiten toe wel de indruk er te willen wonen (Thorbecke) of daar nog steeds een thuis te hebben (De Stuers). Thorbecke schreef in de zomer van 1853: 'Volgde ik mijne genegenheid, dan bragt ik mijne familie en woning naar het platte land van Limburg over.'63 
Victor de Stuers, die op het moment van zijn eerste verkiezing to Tweede-Kamerlid al jaren in Den Haag woonde, vroeg bij het schrijven van zijn verkiezingscirculaire raad aan de Roermondse kapelaan P.J.H. Geurts redacteur van de Maas- en Roerbode:

Wat dunkt u van de dagteekening 'Maastricht'. Ik heb daar nog het ouderlijk huis, waar ik jaarlijks heen ga. Vindt gij Maastricht goed. Of is het noodig dat ik schrijve 'den Haag - Maastricht'?

In ieder geval wilde hij dus Maastricht vermeld zien.

Kijkend naar geboorteplaats, woonplaats en beroepsuitoefening, kan worden vastgesteld dat de kamerleden die tussen 1840 en 1918 vanuit Limburg werden afgevaardigd naar Den Haag, een duidelijke band met die provinci onderhielden (de drie Noord-Brabantse leden uit het district Boxmeer zijn daarbij buiten beschouwing gelaten). Thorbecke was de grote uitzondering.

De politicoloog J.Th.J. van den Berg heeft de Tweede-Kamerleden tussen 1849 en 1970 onder meer onderzocht op geboorteplaats. Uit zijn onderzoek blijkt dat de westelijke provincies, als het aantal daar geboren kamerleden wordt vergeleken met het bevolkingsgetal, enigszins zijn oververtegenwoordigd. ${ }^{65}$ Het aandeel van de kamerleden die zijn geboren in het zuiden Zeeland, Noord-Brabant en Limburg - volgt de bevolkingsspreiding vrif nauwkeurig. Alleen in de periode tussen 1879 en 1891 is er sprake van een belangrijke onevenredigheid tussen het aantal in de zuidelijke provincies geboren kamerleden en het bevolkingsgetal. Dit kan in verband gebracht worden met het op gang komen van de katholieke politieke organisatie, waardoor 'enige "Hollanders" in katholieke kring' via de zuidelijke districten toegang kregen tot de Tweede Kamer. ${ }^{\circ 6}$ Alleen in het zuiden bestond voor katholieke kandidaten immers zekerheid op een verkiezing. Zo werd Herman Schaepman, geboren in Twente, in 1880 gekandideerd én gekozen in het district Breda.

Indien we de afgevaardigden uit de Limburgse kiesdistricten in deze periode bezien, moet worden vastgesteld dat geen van deze districten blijkt te fungeren als 'veilig district' voor (katholieke) kandidaten van buiten de provincie. Limburg onderscheidde zich daarmee van het eveneens overwegend katholieke Noord-Brabant: in tegenstelling tot deze laatste provincie vaardigde Limburg tussen 1879 en 1891 slechts 'eigen' kandidaten af natr 
Den Haag. Van de Limburgse Tweede-Kamerleden uit deze periode is alleen Ruland geboren buiten de provincie (in Aken). Voordat hij de Kamer betrad beheerde hij al dertig jaar het familiegrondbezit in Vaals en was hij reeds twintig jaar burgemeester van die plaats. Hij zou die functie ook na het beěindigen van zijn kamerlidmaatschap blijven vervullen. Er kan hier dus niet gesproken worden van een katholiek die van buiten de provincie via eén van haar districten in de Kamer werd gekozen.

Ook volgens de historicus De Jong waren de Limburgse kiesdistricten in vergelijking met de Noord-Brabantse districten veel minder toegankelijk voor kandidaten van buiten de provincie. Zijn onderzoek bestrijkt de periode $1848-1887$ en hij concludeert dat het verschil tussen Limburg en Noord-Brabant toenam naarmate de tijd voortschreed. Na 1880 was nog slechts een minderheid van de afgevaardigden uit Noord-Brabant door woonplaats of geboorte aan die provincie verbonden. ${ }^{67}$ Indien we de Limburgse districten in dezelfde periode bezien, moeten we vaststellen dat die band er bij álle afgevaardigden was.

Wat betreft de Eerste Kamer stelt Van den Braak vast dat tot 1880 geen van de afgevaardigden woonde buiten de provincie van afvaardiging (hoewel dit wettelijk wel mogelijk was). ${ }^{68}$ Met name na 1888 veranderde dit, echter: 'Limburg bleef Limburgers afvaardigen'. ${ }^{69}$ In veel andere provincies kregen ook personen van elders een kans, bijvoorbeeld in Noord-Brabant. Hoewel deze provincie in hoofdzaak eigen inwoners bleef afvaardigen, werd zij soms benut om de verkiezing zeker te stellen van katholieke kandidaten die van buiten kwamen, zoals in 1883 toen Provinciale Staten van Noord-Brabant de Rotterdamse koopman J.G. de Bruijn kozen tot lid van de Eerste Kamer.

Zowel wat betreft de Tweede als de Eerste Kamer bleef Limburg in tegenstelling tot Noord-Brabant dus gesloten voor katholieke politici van buiten de provincie. En dat werd niet overal in katholieke kring gewaardeerd: toen de Jabeekse herenboer Jean Beckers in 1903 werd gekozen in het district Sittard, klaagde de katholieke Noord-Nederlandse pers dat de Limburgers alleen 'lui van de streek' tot hun afgevaardigden kozen. ${ }^{70}$

Indien mogelijk werd het Limburgerschap van kandidaten tijdens verkiezingscampagnes in stelling gebracht. Zoals we zagen, was De Ras - in 1892 in Maastricht gekozen - niet in Limburg geboren. Hij had drie jaar eerder al geprobeerd om via het district Roermond in de Tweede Kamer te komen. Zijn aanhangers presenteerden hem toen opvallend genoeg als 'Limburger van geboorte': kennelijk was het inboorlingschap belangrijk genoeg om het met de waarheid niet al te nauw te nemen. ${ }^{17} \mathrm{Zijn}$ tegenstanders stelden de 
verbondenheid van De Ras met Limburg duidelijk ter discussie door he eigen kandidaat, baron d'Olne, te afficheren als 'een bekend Limburger [..] en geen vreemde'? 72

Ook bij de Maastrichtse kandidaatstelling van De Ras in 1892 zia we zijn aanhangers pogen om twijfel over de verbondenheid van he kandidaat met Limburg weg te nemen. Zo was De Ras volgens de Limburge koerier 'door trouwe banden aan Limburg en diens hoofdstad gehects waarmee hij zich, om zoo te zeggen, geheel één gevoelt. ${ }^{73}$ In een spannenغ strijd versloeg hij - pas in de tweede ronde - zijn tegenstander Constat Schreinemacher, die wel in Limburg was geboren. Hoewel de meerderhed van de kiezers hun 'provincialisten zin' ter zijde had geschoven, zoals de Limburger koerier het wilde, vond de krant het blijkbaar toch raadzaan om enkele dagen voor de verkiezingen het Limburgse karakter van De Ra nog eens te benadrukken: 'Men kan aan hem zien, dat hij van Limburgscke afkomst is: dat cordiale en ongekunstelde is hem eigen. ${ }^{34} \mathrm{Zijn}$ deels nie. Limburgse verleden bleef De Ras achtervolgen. Nog in 1900 werd hij bij de verkiezingen door tegenstanders uitgemaakt voor 'een vreemdeling die Limburg niet kent'. De keuze kon daarom niet moeilijk zijn, want hun eigen kandidaat Jozef Haex was wel 'een volbloed Limburger. ${ }^{75}$ Wederom was de marge waarmee De Ras won, niet groot: hij haalde $57,6 \%$ van het aantal uitgebrachte stemmen.

Ook bij andere verkiezingen werd het Limburgerschap als argument ge bruikt. Nadat de in Noord-Brabant geboren en woonachtige J.B.J. Hengt berouw had gekregen over zijn terugtreden als Tweede-Kamerlid voor het district Boxmeer in 1860, trachtte hij bijna een jaar later, via een tussentijds verkiezing in het district Roermond, opnieuw in de Kamer te komen. ${ }^{76}$ Te vergeefs: hij moest zijn meerdere erkennen in Karel Cornelis, die wel in Limburg was geboren en daar in tegenstelling tot Hengst ook woonde en werkte. Het Roermondse weekblad De Volksvriend legde in zijn steunbetuigingen aan Cornelis sterk de nadruk op het gegeven dat diens tegenstreva van buiten Limburg kwam. Hengst werd aangeduid als 'den vreemdeling' et 'een aan ons Hertogdom vreemd zijnden kandidaat'. De krant riep de kiezers op om 'geoorloofde bewijzen van provincialismus te geven, en derhalve uit uw midden een Limburger boven den Noord-Brabander te kiezen."

Uit de advertentie waarin Hengst aangaf te bewilligen in een kandidaturt voor het district Roermond, kan worden opgemaakt dat hij de band met Limburg ook zelf zag als een punt dat in de afweging van kiezers een rol speelde. Hij benadrukte in de tekst van zijn verkiezingsadvertentie namelijk sterk dat hij helemaal niet vreemd was aan de provincie, na 'gedurende tien 
jaar het Noordelijk gedeelte van Limburg vertegenwoordigd te hebben'. Hengst doelde hierbij op zijn afvaardiging vanuit het deels Limburgse district Boxmeer in de periode 1850-1860. Wellicht om zijn gehechtheid aan Limburg nog meer tot uiting te doen komen, voorzag Hengst - woonachtig in Boxmeer - de advertentietekst van de dagtekening 'Maastricht, den 19 Maart 1861?

De band met Limburg werd ook begin twintigste eeuw in stelling gebracht. Bij de verkiezingen van 1901 in het district Weert ging de strijd tussen een kandidaat die in Limburg geboren en getogen was, Victor de Stuers, en een kandidaat die buiten de provincie ter wereld was gekomen: B.J. Hulshof, burgemeester van Bergen op Zoom. De Stuers was niet alleen in Maastricht, waar hij was geboren en opgegroeid, maar ook elders in Limburg een bekende figuur. Zo bood het in 1893 in Roermond opgerichte genootschap Limburg, dat zich onder meer met geschiedbeoefening bezighield, De Stuers datzelfde jaar nog het erelidmaatschap aan, dat hij overigens weigerde. ${ }^{79}$

De Stuers' kandidatuur in 1901 werd onder anderen gesteund door het zittende Tweede-Kamerlid voor Weert, Jan Truijen, die zelf geen kandidaat meer was. In een brief liet Truijen aan Hulshof weten dat die als niet-Limburger weinig kans maakte. Nolens schreef aan hoofdredacteur P.J.H. Geurts van de Maas- en Roerbode - deze krantvoerde campagne voor De Stuers - dat De Stuers steun verdiende omdat hij onder meer 'niet geheel vreemd aan Limburg, zelf Limburger maar tevens Noord-Nederlander' was. ${ }^{* 0}$ De Maas- en Roerbode sprak in één zin over De Stuers als een 'geboren Limburger' en over Hulshof als een 'vreemdeling'. ${ }^{\text {.1 }}$ Ook Tweede-Kamerlid Bolsius (district Roermond) had hoofdredacteur Geurts schriftelijk laten weten De Stuers te steunen, daarbij Hulshof ter zijde schuivend als 'dezen onbeduidenden vreemdeling. ${ }^{22}$ In de argumenten pro en contra de kandidaten speelde Limburgs chauvinisme een rol, stelt P.A.M. Geurts vast in een artikel over deze verkiezing. ${ }^{33}$ De Stuers werd gekozen met een duidelijke meerderheid van 2270 stemmen tegen 1032 voor Hulshof.

Er zijn twee gevallen bekend waarbij burgemeesters hebben getracht het lidmaatschap van de Tweede Kamer te verwerven, terwijl zij afkomstig waren van buiten Limburg en in verband met hun functie pas kortstondig in die provincie werkzaam en woonachtig waren. Hoewel zij door hun ambt behoorden tot de lokale notabelen, faalden beiden in hun streven te worden afgevaardigd naar Den Haag en hun binding met Limburg speelde in de verkiezingscampagnes een prominente rol. In 1913 kandideerde burgemeester Gijzels van Sittard zich voor een Tweede-Kamerzetel in het gelijknamige 
kiesdistrict. Drie jaar later was de Weertse burgemeester Kolkman kandidaat in het district Weert. Beiden waren tot aan hun burgemeestersbenoeming buiten Limburg woonachtig geweest. ${ }^{84} \mathrm{Hun}$ kandidatuur werd fel bestreden. 'Limburg moet worden vertegenwoordigd in de Kamer door Limburgers', werd de kiezers in 1913 voorgehouden tijdens een bijeenkomst te Sittard. 'Bedenkt wel, dat gij als Limburger, ook een Limburger als afgevaardigde hebt te kiezen', aldus de raad die in 1916 aan de kiezers van Weert werd meegegeven. Burgemeester Gijzels werd 'een uit Holland overgewaaiden ambtenaat' genoemd en Kolkman werd beschreven als 'iemand, die voor enkele jaren hier ronddwaalt' en zich later weer elders zou vestigen. ${ }^{55}$ De tegenstandet van Gijzels, zittend kamerlid Jean Beckers, gaf zelfs een eigen krantje uit onder de veelzeggende naam De Limburger. Orgaan ter bevordering van de candidatuur Jean Beckers. ${ }^{6}$

Ook de sociaal-democraten hechtten in Limburg aan een duidelijke band tussen hun kandidaten en de provincie. $\mathrm{Zij}$ slaagden er weliswaar niet in om een van de Limburgse parlementszetels in te nemen, maar vanaf 1897 stelde de sDAP kandidaten bij Tweede-Kamerverkiezingen, hoofdzakelijk in het district Maastricht (zie hoofdstuk 4). De sDAP-kandidaten in dit distric waren zonder uitzondering Limburgers: Willem Vliegen in 1897 , Servass Baart in 1901 en jhr. Willem Casper de Jonge in 1909 en 1913. De bekendste onder hen, de in Gulpen geboren Vliegen, haalde bij verkiezingen geregeld ook stemmen in andere delen van de provincie. De liberalen in Limburg, dir vanaf de jaren tachtig evenmin in staat waren zetels te bemachtigen, schoven ook vaak bekende provinciegenoten naar voren. Zo was jhr. L. Michiels van Kessenich in 1888 de liberale kandidaat in de districten Venlo, Roermond én Maastricht.

Kamerleden konden hun binding met Limburg op diverse manieren tot uitdrukking brengen, bijvoorbeeld door een lidmaatschap van het begin jaren zestig opgerichte Oudheidkundig Genootschap in het Hertogdom Limburg. In de eerste tien jaar van zijn bestaan is een meerderheid van de destijds zittende Limburgse kamerleden hiervan lid geweest. ${ }^{87}$ De voorzitter van het genootschap, A. Schaepkens, sprak tijdens een ledenvergadering op 3 januari 1864 een beginselverklaring uit: 'Messieurs, le Limbourg se réveille et relève fièrement la tête $[\ldots]]^{\text {ss }}$ Het manifest stoelde mede op 'gewesteliik nationalisme. ${ }^{89}$ Het genootschap zou onder meer de Publications uitgevel en later ook De Maasgouw, dat voor een breder publiek bedoeld was.

Niet alleen waren het vrijwel zonder uitzondering Limburgers die werder afgevaardigd naar Den Haag, bij nadere beschouwing blijkt, dat er zels 
hoogst zelden personen werden gekozen die in een ander Limburgs kiesdistrict woonachtig waren. Aan de hand van een aantal verkiezingen kan duidelijk gemaakt worden dat kamerleden bij voorkeur opteerden voor een parlementair mandaat van het district waarin zij woonden. Meer nog dan de eigen provincie lijkt het eigen district richtinggevend. 'Uwe waardigheid verbiedt $\mathrm{U}$ stemgeregtigden, een vertegenwoordiger te kiezen buiten het district,' schreef De Volksvriend op 6 april 1861.

Toen Leopold Haffmans' woonplaats Venlo in 1869 ten gevolge van de nieuwe districtsindeling overging van het district Roermond naar Boxmeer, stelde hij (tot dan toe afgevaardigd door Roermond) zich bij de eerstvolgende verkiezingen kandidaat in zijn nieuwe 'woondistrict' Boxmeer. De Volksvriend schreef dat Haffmans voortaan 'vreemd aan het district Roermond' was en zich daar daarom niet meer beschikbaar stelde. ${ }^{\oplus}$

$\mathrm{Na}$ de dood in 1881 van Jan Hendrik Arnoldts, kamerlid uit het district Roermond, stelde Hubert Brouwers zich hier kandidaat. Tot dan toe was Brouwers afgevaardigd door het district Boxmeer, waar men van NoordBrabantse zijde geen problemen had met een Limburgse vertegenwoordiger. Brouwers' woonplaats Roermond, waar hij burgemeester was, lag tot dan toe dus buiten het district dat hem had afgevaardigd en wel in het district van collega-afgevaardigde Arnoldts. Diens dood deed Brouwers onmiddellijk besluiten ontslag te nemen als afgevaardigde voor Boxmeer en zich kandidaat te stellen in het district waarin hij woonachtig was. De Maasen Roerbode vond het op 7 januari 1882 een vanzelfsprekendheid dat Brouwers 'zoodra de gelegenheid daartoe zich aanbood' door het kiesdistrict Roermond naar 's lands vergaderzaal werd afgevaardigd. Overigens was Brouwers, geheel met de hiervoor geschetste lijn, in de jaren zestig nog kandidaat-Tweede-Kamerlid geweest in het district Maastricht. In die jaren woonde en werkte hij namelijk in dat district: hij was kantonrechter in Gulpen.

Brouwers vormde met zijn Boxmeerse mandaat (1877-1881) een uitzondering op de gewoonte dat afgevaardigden behalve Limburger ook inwoner waren van het eigen kiesdistrict. Het was uitzonderlijk dat een afgevaardigde uit een ander deel van de provincie afkomstig was. Naast Brouwers kunnen we hier Hubert Pijls en Gustave Ruijs van Beerenbroek noemen: beiden woonden in Zuid-Limburg en werden gekozen in Midden-Limburg (het district Roermond). Verder kan worden gewezen op Victor de Stuers die weliswaar zelfs buiten Limburg woonde op het moment dat hij in Weert gekozen werd, maar door zijn verleden sterk verbonden was met ZuidLimburg en uitdrukkeliik niet met het Midden-Limburgse Weert (hij was 
een geboren en getogen Maastrichtenaar). Ook Charles Ruijs de Beerenbrouck woonde niet in het district van zijn verkiezing (Gulpen), maar in Maastricht.

Pijls, Gustave Ruijs van Beerenbroek, De Stuers en Charles Ruijs d Beerenbrouck opteerden dus voor een zetel die werd ingevuld vanuit en ander deel van Limburg dan waarmee zij door woonplaats of verleden primair verbonden waren. Dat was uitzonderlijk en rondom hun verkiezing zijn er dan ook aanwijzingen te vinden die erop duiden dat hun verbondenheid met een ander deel van de provincie zeker niet als een pre wert beschouwd.

De Maastrichtse wethouder Pijls werd in 1869 gekozen in het distric Roermond. Zijn kandidatuur werd bestreden door het Venloosch Weekblad Op 5 juni, in het laatste nummer voor de verkiezingen, luidde de kop vat het openingsartikel: 'Welke aanspraak heeft de heer Pijls, om in Roermond gekozen te worden?' De krant vond deze vraag opportuun:

Waarom stellen wij deze vraag? Omdat de heer Pijls niet in het district Roermond thuis behoort. Hij komt daar als vreemdeling de gastvrijheid inroepen. En daar moeten redenen voor bestaan. In den regel kiest een district mannen die daar wonen, slechts bij uitzondering neemt men iemand die vreemd is.

Het gegeven dat Pijls van buiten het district afkomstig was, al was hij dan we een Limburger, werkte tegen hem, zo moest ook De Volksvriend vaststellen Het hem welgezinde liberale Roermondse weekblad probeerde het bezwat weg te nemen door te benadrukken dat 'door de versnelde middelen van vervoer' - de in 1865 gereedgekomen spoorweg Maastricht-Roermond - de infrastructuur dusdanig goed was, dat kiezer en gekozene zich gemakkelii met elkaar in verbinding konden stellen." Pijls won, maar het was getl gemakkelijke overwinning: in de eerste ronde schaarde de grootste groef kiezers zich achter zijn voornaamste concurrent, de wel in het distric woonachtige Jan Hendrik Arnoldts, Pas in de tweede ronde haalde Pijls de meeste stemmen.

Gustave Ruijs van Beerenbroek werd in 1892 gekozen in het distrid Roermond. Hij had daar overigens vele jaren van zijn leven doorgebracht maar op het moment van de verkiezingen woonde en werkte hij er al zo't vijftien jaar niet meer. In 1877 was hij naar Maastricht vertrokken waar hi werkzaam was bij de rechterlijke macht. Tussen 1880 en 1888 was hij naar $\alpha$ Tweede Kamer afgevaardigd vanuit het kiesdistrict Maastricht. De katho- 
lieke kiesvereniging die hem in 1892 in Roermond kandideerde, achtte het kennelijk van belang om geen enkel misverstand te laten bestaan over de binding die Ruijs ondanks zijn jarenlang verblijf in Maastricht nog steeds had met Midden-Limburg. Zij stelde hem aan de kiezers voor als 'Roermondenaar van geboorte, te Roermond opgevoed, als Substituut Officier van Justitie te Roermond eene reeks van jaren doorgebracht hebbende, met de toestanden van ons district volkomen bekend', 92

In een vergadering van de katholieke kiesvereniging gaf Ruijs van Beerenbroek aan dat indien hijzelf had mogen bepalen voor welk kiesdistrict hij naar Den Haag zou gaan, zijn keuze zonder twijfel op Roermond zou vallen, want daar had hij naar eigen zeggen de beste jaren van zijn leven doorgebracht.93 Een enigszins pijnlijke uitspraak voor de kiezers uit ZuidLimburg die hem eerder tot zes keer toe vanuit het district Maastricht naar het parlement hadden afgevaardigd.

De Stuers had gezien zijn verleden duidelijk minder binding met het district dat hem afvaardigde (Weert) dan Ruijs van Beerenbroek had met het district Roermond. Terwijl Ruijs in Roermond was geboren en opgegroeid, had De Stuers zijn jeugd in het geheel niet doorgebracht in of rondom Weert. In het voordeel van De Stuers werkte echter dat zijn tegenstander Hulshof geen Limburger was en daardoor nog minder dan hij verbonden kon worden met het district Weert. De Stuers achtte het wijs om in de plaatselijke kranten aan de kiezers te beloven zich na zijn verkiezing 'voortdurend in betrekking te stellen met het district.'. In 1908 doneerde hij een bedrag van 500 gulden aan de Sint-Martinuskerk in Weert ten behoeve van een van haar grote vensterramen. ${ }^{95}$

Charles Ruijs de Beerenbrouck was bij zijn verkiezing in 1905 in het district Gulpen niet onomstreden. Dat hij in Maastricht woonde, speelde hierbij een duidelijke rol. Zijn opponent, het statenlid J.H. Princkers, was wel afkomstig uit het district en diens aanhangers wezen nadrukkelijk op dit onderscheid tussen de twee kandidaten.\%

Niet slechts de band met de provincie, maar vooral ook de relatie met de meer onmiddellijke leefomgeving was kennelijk van belang. Dit zou overigens ook later nog het geval zijn bij een bekende Limburgse politicus als Sjeng Tans, Tweede-Kamerlid namens de PvdA van 1954 tot 1970 . Tans voelde zich volgens zijn biografe Klijn in de eerste plaats Maastrichtenaar, vervolgens Limburger en dan pas Nederlander."

Dat voor kiezers vooral de eigen streek richtinggevend was, sluit aan bij de vaststelling dat de gemiddelde Limburger zich in de negentiende eeuw primair met zijn eigen woongemeenschap identificeerde. De provincie 
kenmerkte zich door een sterk ontwikkeld lokalisme. De structuur va de samenleving - een agrarische provincie, relatief dunbevolkt met tee gemiddeld laag welvaartspeil - en de staatkundige verbrokkeling tot 179 waren belangrijke oorzaken.

Het Limburgse - en dus bovenlokale - zelfbewustzijn groeide in \& negentiende eeuw. Rond 1880 valt een verbreding van de belangstelling voor de eigen (Limburgse) historie en cultuur waar te nemen. ${ }^{98}$ In dit kade kan gewezen worden op een bekendmaking in de Maas- en Roerbode ops juni 1888. De krant berichtte toen over de oprichting van een 'Limburgsck Vereeniging' te Amsterdam. Deze vereniging had een tweeledig doel: he bevorderen van 'gezellig verkeer' onder de in Amsterdam woonachtip Limburgers en informatieverschaffing aan provinciegenoten die een bezod brachten aan de hoofdstad. Van een 'uitgesproken regionaal zelfbewustziit was in Limburg pas in het begin van de twintigste eeuw sprake, ten gevol van de grote sociaal-economische veranderingen.9 ${ }^{9}$

Bij de ontwikkeling van een Limburgse identiteit speelde de katholick geestelijkheid een voorname rol. In de negentiende eeuw werd aan $\alpha$ seminaries het kader gevormd dat de belangrijkste drager en promotit zou worden van het provinciaal zelfbewustzijn. ${ }^{100}$ De grenzen van het i 1840 gevormde apostolisch vicariaat Limburg en van het latere bisdon Roermond, liepen precies gelijk met die van de provincie Limburg. $\mathrm{H} 6$ gezag van de hoogste kerkelijke autoriteit in Roermond strekte zich du uit over geheel Limburg en ook uitsluitend over die provincie. Limbun was de enige Nederlandse provincie waarbij dit het geval was. De eenhes die Limburg in 1839 staatkundig ging vormen, werd versterkt doordat bo gewest ook op kerkelijk gebied tot een eenheid werd gemodelleerd.

Hier komt nog bij dat Joannes Augustinus Paredis, die het vicariat en bisdom bijna een halve eeuw leidde, een Limburgs exclusivisme cult veerde. ${ }^{101}$ Tijdgenoot G.P. Wilmer, bisschop van Haarlem, schilderde if collega Paredis af als een provincialist. ${ }^{102}$ Paredis was de Noord-Brabants geestelijken die in zijn ambtsgebied werkzaam waren, liever kwijt dan rip en hij stelde dan ook bij voorkeur Limburgse priesters aan. In contacten me katholieken uit de overige landsdelen zag hij meer nadelen dan voordelen." De aan het Luikse seminarie gevormde kerkleider bouwde hiermee voort to een houding die de katholieken uit de zuidelijke provincies al ten tijde $\mathrm{rt}$ het Verenigd Koninkrijk (1815-1830) aannamen: zij zagen de katholiekt in het Noorden meer als 'onbekende en andersgeaarde lieden' dan als $\mathrm{F}$ loofsgenoten met dezelfde belangen; omgekeerd gold overigens hetzelfde." Paredis stippelde de rode lijn uit die tot het midden van de twintigste ew 
door het beleid van alle Limburgse bisschoppen zou lopen: Limburg is anders dan de rest van Nederland en dient afgeschermd te worden. ${ }^{105}$

Terwiil het provinciaal zelfbewustzijn in de loop van de negentiende ceuw groeide, zagen veel Limburgers hun provincie vaak (nog) niet als een homogeen geheel. Zij maakten veelal onderscheid tussen de diverse regio's. Er heerste een rivaliteit tussen Noord- en Zuid-Limburg. ${ }^{106}$ In de Sittardse pers werden Zuid- en Noord-Limburgers aan het eind van de negentiende ceuw tegen elkaar afgezet. ${ }^{107}$ Uit een eerdere periode (1855) stamt een brief van Commissaris des Konings Van Meeuwen. Hij schreef minister Van Reenen van Binnenlandse Zaken dat er sprake was van enige 'naijver' tussen de kiesdistricten Maastricht en Roermond. De Limburgers zelf maakten een duidelijk verschil tussen zuiderlingen en inwoners uit het midden van de provincie, zo gaf de Commissaris des Konings aan. Het rijkere zuiden telde, ten gevolge van het censuskiesrecht, een aanmerkelijk groter aantal kiezers. Indien er door de nieuwe districtsindeling Zuid-Limburgse gemeenten zouden worden gevoegd bij Midden-Limburgse, zouden de kiezers uit het zuiden dientengevolge 'eenen zeer groote invloed' krijgen bij het aanwijzen van de daar te kiezen afgevaardigde(n). Dit zou leiden tot grote onvrede in Midden-Limburg. ${ }^{108}$ Van Meeuwens opvolger als Commissaris des Konings, Van der Does de Willebois, maakte in zijn jaarverslag over 1857 melding van een verschil in 'landaard' tussen bewoners van Zuid-Limburg en de rest van de provincie. ${ }^{109}$

Binnen Limburg ervoer men verschillen en daarbij paste het streven om bij de verdeling van parlementaire mandaten een evenwichtige geografische spreiding over de provincie in acht te nemen. We zien dit streven reeds naar voren komen bij de eerste verkiezing van een Limburgs TweedeKamerlid door Provinciale Staten in 1841. De zittende afgevaardigde, de Maastrichtenaar Kerens, stelde zich niet herkiesbaar en de algemene wens was dat ook zijn opvolger uit de Limburgse hoofdstad zou komen, zo schreef gouverneur Gericke van Herwijnen aan de minister van Binnenlandse Zaken. De Roermondse jonkheer Petit die vervolgens werd gekozen, had verklaard alleen beschikbaar te zijn indien 'een bekwaam mededinger uit Maastricht' niet voorhanden was. ${ }^{110}$

Een zeker evenwicht in de geografische spreiding over de provincie werd ook nagestreefd bij de verdeling van de zetels aan de overzijde van het Binnenhof. Indien we de Limburgse Eerste-Kamerleden vanaf 1850 met behulp van hun levensloop onderscheiden naar Noord-, Midden- en ZuidLimburg, dan valt op dat een van de drie zetels telkens overging op een afgevaardigde die was verbonden met het midden of noorden van de pro- 
vincie. Tussen 1850 en 1902 werd de zetel ingenomen door een kamerlid ti Midden-Limburg (achtereenvolgens L.F.H. Beerenbroek, L.H.A. Magne en F.J.P.M. Coenen) en vanaf 1902 door een Noord-Limburgse afgevas digde (J.S.H. Brouwers en O.F.M. Haffmans). Op de overige twee zete namen zonder uitzondering Zuid-Limburgers plaats. Provinciale State door wie de Eerste-Kamerleden met ingang van 1850 werden gekozen end zelf vanaf 1848 districtsgewijs waren samengesteld, maakten dus duideli verschil tussen een Zuid-Limburger en een inwoner uit het noorden e midden van de provincie.

Van het zuidelijk overwicht in de Eerste Kamer, te verdedigen met de gr tere bevolkingsomvang van het zuiden, was in het eerste decennium na 18 , overigens nog geen sprake. In die periode werden de Eerste-Kamerledenb noemd bij Koninklijk Besluit en wellicht stelden de Nederlandse koningt meer rentrouwerv in Nband- as Middan-Limhurgers. Willew s hennems in 1840 de Noord-Limburger Pieter Willem baron de Liedel de Well it de Eerste Kamer; tot 1849 zou hij daarin de enige Limburger zijn. In de laatste jaar benoemde Willem $n$ drie Limburgers tot Eerste-Kamerlid: Pt: rus Regout (Zuid-), Gerard Johan de Rijk (Noord-) en Louis Beerenbrod (Midden-Limburg).

\section{Limburgers buiten de provincie}

Er waren tussen 1839 en 1918 ook kamerleden die in Limburg waren geborat maar elders in Nederland werden gekozen. Het gaat hier om negen affo vaardigden. Met vermelding van het jaar van hun eerste verkiezing buite Limburg waren dit J.G.S. Bevers (1888), A. Kool (1879), L.P.M.H. baron M. chiels van Verduynen (1888), E.R.H. Regout (1905), L.H.W. Regout (1915) G.W. Sannes (1913), Th.G.G. Valette (1893), W.H. Vliegen (1909) en A.J. Vo de Wael (1848). Voor de meeste van hen lijkt het gegeven dat zij in provincie werden geboren het voornaamste element te zijn geweest dat he met Limburg verbond.

Indien we kijken naar hun beroepsuitoefening, wordt duidelijk dat de band met de provincie bij drie van deze kamerleden intenser was: Low (L.H.W.) Regout, in 1913 door Provinciale Staten van Noord-Brabant kozen tot lid van de Eerste Kamer, zijn broer Robert (E.R.H.) Regout, 1909 gekozen tot Tweede-Kamerlid in het Noord-Brabantse kiesdistrict Hd mond, en Willem Vliegen, tussen 1909 en 1915 Tweede-Kamerlid name een van de Amsterdamse kiesdistricten en vervolgens tot Eerste-Kameti gekozen door PS van Noord-Holland. Deze drie afgevaardigden onderhit 
den geruime tijd na hun geboorte nog steeds een duidelijke band met Limburg. Zo startten ze alledrie hun beroepscarrière in die provincie: Louis Regout begon zijn loopbaan binnen het familiebedrijf, de Sfinxfabriek in Maastricht; Robert Regout was na zijn studie in dezelfde stad werkzaam als advocaat en Willem Vliegen startte zijn carrière als letterzetter in Gulpen. De Regouts maakten bovendien deel uit van een van de bekendere Limburgse families.

Voor Louis Regout en Willem Vliegen geldt bovendien dat zij niet alleen buiten Limburg, maar ook in die provincie politiek actief waren. Vliegen maakte zich in de jaren tot 1897 in en om Maastricht sterk voor de socialistische zaak en het was met grote tegenzin dat hij dat jaar verhuisde naar Rot-

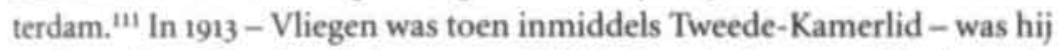
wederom kandidaat in Limburg en wel bij de Tweede-Kamerverkiezingen in het kiesdistrict Gulpen. Louis Regout was voordat hij vanuit Noord-Brabant werd gekozen in de Eerste Kamer, al vijf jaar in die Kamer afgevaardigd geweest door de Staten van Limburg (1904-1909). Bovendien was hij voor 1904 lid geweest van Provinciale en Gedeputeerde Staten van Limburg.

Robert Regout woonde in Roermond op het moment van zijn verkiezing in Helmond. Zijn kandidatuur was daar onomstreden en hij werd benoemd bij enkelvoudige kandidaatstelling. Door de functies die hij bekleedde, genoot hij ook in katholieke kringen buiten Limburg grote bekendheid en de politieke samenwerking tussen de Nederlandse katholieken maakte het de Limburger Regout mogelijk om via Noord-Brabant in de Kamer te komen. ${ }^{112}$ Met de beide Regouts en met Vliegen zien we dat Limburgers zich vanaf het einde van de negentiende eeuw via de samenwerkingsverbanden van katholieken en sociaal-democraten gingen mengen in het nationaalpolitieke bestel van Nederland. Overigens bleef Robert Regout zich ook tijdens zijn kamerlidmaatschap vanuit Helmond bij tijd en wijle presenteren als Limburger. Toen in 1909 in Heerlen een vergadering van kiezers plaatsvond ten gunste van de kandidatuur van Charles Ruijs de Beerenbrouck sprak hij de aanwezigen toe 'als Limburger met hart en ziel.'1,

\section{Naar het Binnenhof}

Op zondag 16 juli 1848 schreef het toen juist teruggetreden Tweede-Kamerlid Beerenbroek aan minister Bentinck van Nijenhuis van Buitenlandse Zaken over zijn opvolger: 'Heden heeft de Heer Geradts de reis naar de residentie aangenomen $[\ldots]]^{\prime \prime \prime 4}$ Dat was een hele onderneming, want per snelste verbinding deden Limburgse afgevaardigden er eind jaren veertig zo'n 
vierentwintig uur over om in Den Haag te arriveren. ${ }^{115}$ Gedurende $d$ herfst- en wintermaanden was het zelfs haast onmogelijk om 's lands ve gaderzaal vanuit Limburg te bereiken, aldus een klacht die we aantreffenin kamerstukken uit $1843 .{ }^{116}$

De aanleg van spoorwegen betekende voor kamerleden een belangrijk verbetering in de bereikbaarheid van Den Haag. Met de komst van et railverbinding tussen Maastricht en Venlo in 1865 en tussen Venlo en Eindhoven een jaar later, werd de vergaderplaats van de Staten-Generaal vanuil Limburg per trein bereikbaar. Vanuit Maastricht deed een afgevaardigd er in 1866 overigens nog altijd zo'n acht uur en drie kwartier over om vil het spoor in Den Haag te komen. De bouw van een spoorbrug over he Hollands Diep verkortte de reistijd aanmerkelijk (voorheen moesten trein. reizigers per stoomboot naar Rotterdam worden overgezet om daar hu treinreis te vervolgen). In $188 \mathrm{o}$ kwam een afgevaardigde uit Maastricht $z$. venenhalf uur later aan in Den Haag, in 1900 was de reistijd teruggebradt tot vijfenhalf uur, mede door een vermindering van het aantal halteplaatsen tussen Maastricht en Venlo. De laatste afgevaardigden die in dit onderzod centraal staan, deden er (in 1917) vanuit Maastricht ongeveer vier uur to twintig minuten over alvorens in Den Haag aan te komen. ${ }^{117}$

Kamerleden konden rekenen op een goede serviceverlening. In $1898 \mathrm{nam}$ Tweede-Kamerlid Martin de Ras (district Maastricht) deel aan een dint ter gelegenheid van de opening van de spoorlijn Sittard-Heerlen. Toen hif aangaf de tafel vroegtijdig te moeten verlaten om de laatste aansluiting op ${ }^{\alpha}$ stoptrein naar zijn woonplaats Meerssen te kunnen halen, zei de aanweriq directeur-generaal van de Nederlandsche Staatsspoorwegen: 'Blijf gerus bij ons, mijnheer de Ras, ik zal de avondsneltrein wel in Geulle [nabi Meerssen] doen stoppen.' De opdracht werd, aldus het verslag van een wa de aanwezigen, naar Utrecht getelegrafeerd, en: 'De heer de Ras werd dris uur later alleen en extra thuisgebracht in Limburgs kleinste stations-ns door de grand-expresse Bazel-Maastricht-Amsterdam.'118

Voor de eenwording van Nederland, en zeker ook voor het betrekken n' Limburg bij dit proces, waren goede verbindingen van groot belang. Dr werd ook toentertijd al erkend. In 1843 werd in de Tweede Kamer gesproke over het beschikbaar stellen van rijksgelden voor de aanleg van een verharth weg - een 'steenweg' - die Limburg zou verbinden met Nijmegen. D. provincie zou daarmee aangesloten worden op het netwerk van verhath (Noord-)Nederlandse wegen. Dat de communicatie met het overig ts van Nederland in die tijd soms noodgedwongen over vreemd grondgchin (Belgiẻ en Pruisen) moest plaatsvinden, beschouwde de regering als to 
zaak die niet mocht blijven voortduren. Zij schreef de Tweede Kamer: 'De onderdeelen des Rijks moeten een geheel uitmaken, en geen gewest mag zich voortdurend in een zoo geïsoleerden staat bevinden [...]."'19

De Kamer stemde hiermee in en sprak van een 'staatkundig belang.' ${ }^{120}$ In de krant De Limburger werden wegen die Limburgse plaatsen verbonden met steden en dorpen in overig Nederland veelbetekenend 'Gemeenschapswegen' genoemd. ${ }^{121}$ In een gedicht ter gelegenheid van de ingebruikstelling van de spoorlijn Sittard-Heerlen lezen we:

\section{Men reikt $\mathrm{U}$ [Heerlen] nu de broederhand}

Van Neerlands heerlijk Noordzeestrand [...].

En studenten uit Rolduc zongen de eerste treinreizigers op dit traject toe:

\section{Ren, vuurdraak, langs Germanje's zoomen}

Snoer Limburgs grens aan Hollands strand. ${ }^{122}$

Tussen 1840 en 1918 maakten tientallen Limburgse afgevaardigden geregeld de reis naar Den Haag. Op het Binnenhof maakten zij kennis met de volksvertegenwoordigers uit de overige delen van het koninkrijk. Vielen zij in vergelijking met die collega-kamerleden op door hun houding of door hun achtergrond?

\section{Participatie}

Gelet op de literatuur lijken we bij een onderzoek naar de parlementaire activiteiten van Limburgse kamerleden te maken te krijgen met een contradictio in terminis. Zo constateert Van den Braak in zijn proefschrift over de Eerste Kamer dat de Limburgse afgevaardigden uit de periode 1849-1888 'een buitengewoon passieve houding' aan de dag legden. ${ }^{123}$ Eenzelfde constatering treffen we aan in het gedenkboek ter gelegenheid van het 175-jarig bestaan van de Eerste Kamer in 1990: er wordt gesproken van een 'enigszins afwijkende positie' die de Limburgse leden in de eerste jaren na 1849, 'maar ook nog ver daarna' innamen: 'veel absenteǐsme en, voor zover aanwezig, weinig belangstelling.' ${ }^{124}$

Met betrekking tot de Limburgse leden van de Tweede Kamer spreekt parlementair-historicus Van Welderen Rengers in zijn Schets eener parlementaire geschiedenis van een 'stelselmatige afwezigheid der Limburgsche heeren bij sommige onderwerpen niet onmiddellijk die provincie betref- 
fende.' ${ }^{125}$ Zelfs Prins, die in zijn tweedelige publicatie over de Limburgsepe lementsleden tussen 1840 en 1880 een duidelijk meer welwillende houdir jegens hen aanneemt dan Van Welderen Rengers, merkt bij de Limburg afgevaardigden een 'ietwat afzijdige houding' op. ${ }^{126}$ Bij Orbons en Spronc komen de Limburgse leden van de Tweede Kamer er niet veel beter af: 'mokten, zwegen of stemden tegen'. ${ }^{127}$ Een groep Noord-Limburgse kierz stelde aan het einde van de negentiende eeuw in de Venloosche Courantve 'Limburg heeft de naam, dat het afgevaardigden naar Den Haag zendt, $d$ niet berekend zijn voor hun taak.'128

Van diverse individuele Limburgse kamerleden is inderdaad bekend hun aandeel in de parlementaire werkzaamheden gering was. Een van he jhr. Louis Libert de Villers de Pité, dankt zijn vermelding in de parlementz: annalen zelfs vrijwel uitsluitend aan het gegeven dat hij tijdens zijn me. dan dertig jaar durende lidmaatschap van de Staten-Generaál nimmer ke woord voerde in de plenaire vergadering. De Limpens (afgevaardigd if Maastricht in de jaren vijftig) staat bekend als 'de zwijger', aldus Schreude in een artikel over de verkiezingen van $1855 .{ }^{129}$ Parlementair journalist BW herinnerde zich over Kerens de Wylré (Tweede-Kamerlid van 1873 tot 1880 dat diens maiden-speech tevens zijn zwanenzang was geweest en bestoni uit één enkele korte zin. ${ }^{130}$ Tillema vermeldt in zijn boek over De Stuersdi deze afgevaardigde uit het begin van de twintigste eeuw 'nogal eens' afwers was en dat hij, indien hij wel aanwezig was, soms lange tijd het stilzwijgat kon bewaren. ${ }^{131}$ Jan Jacob Lambrechts, die een halve eeuw eerder zitting hax in de Tweede Kamer, wordt in De Tijd 'de steeds afwezige afgevaardigde ut Limburg' genoemd. ${ }^{132}$

De geringe deelname aan de parlementaire werkzaamheden was cal onderwerp dat ook geregeld in Limburg zelf opdook. Voorafgaand aan ${ }^{\prime}$ Tweede-Kamerverkiezingen van 1855 schreef De Limburger over de zittenks afgevaardigde uit Maastricht: 'De antecedenten van De Limpens zijn trow wens in Limburg zeer goed bekend. Het publiek weet wat hij in Den Hall gepresteerd heeft: afwezig en ziek zijn en nooit het woord voeren. ${ }^{133}$

Bij de verkiezingen die in 1871 plaatsvonden, meldde het Venloost Weekblad, de krant van Tweede-Kamerlid Haffmans, over diens collę Kerstens: 'Afgesloofd heeft hij zich nooit en er is zeker geen lid der Kans die de zaak zoo ligt nam als hij.' ${ }^{14}$ Eerder had De Noord-Brabanter Kerste al beschuldigd van inactiviteit: 'Nog nimmer heeft hij eenig teeken w leven gegeven.' ${ }^{135}$ In 1864 verweet Charles Antoine baron de Bieberstein ? mede-afgevaardigde uit Maastricht, Van Wintershoven, dat die afwezig w geweest bij de behandeling in de afdelingen van een voor hun provino 
belangrijk onderwerp. ${ }^{136}$ Lavater jr. - een pseudoniem van de liberaal Van Raalte - schreef in 1879 over Jan Hendrik Arnoldts dat deze afgevaardigde zich in de regel tevredenstelde 'met den rol van figurant'. ${ }^{137}$

Nu gaat het hier om verwijten van politieke tegenstanders. Bij sommige kamerleden kwam de vaststelling dat zij niet bijzonder veelvuldig deelnamen aan de parlementaire werkzaamheden echter uit minder verdachte hoek. Na de dood van Arnoldts in december 1881 prees De Katholieke Illustratie dit Tweede-Kamerlid uitvoerig en stelde en passant vast:

Bescheiden was zijne taak in het Nederlandsche Parlement [...]. Ofschoon niet met redenaarstalenten toegerust, nam de heer Arnoldts nu en dan het woord om zijne goed- of afkeurende stem over het een of ander wetsontwerp te motiveren $[\ldots] .^{130}$

$\mathrm{Na}$ het overlijden van J.S.H. Brouwers sprak de voorzitter van de Eerste Kamer, J.E.N. baron Schimmelpenninck van der Oye, een kort in memoriam uit. Hij zei onder meer: 'De heer Brouwers vroeg niet dikwijls het woord, maar als hij het deed, getuigde zijn spreken van een zorgvuldige voorbereiding.' 139

In een roemrijk portret van voormalig Tweede-Kamerlid Bolsius, ter gelegenheid van diens zestigste verjaardag, vermeldde het Limburgse maandblad De Nedermaas met betrekking tot zijn parlementaire werk: 'in de Kamer sprak hij niet vaak en nooit om te spreken.' 140

Er waren echter ook Limburgse kamerleden die juist bekend staan en stonden om hun intensieve deelname aan de parlementaire debatten. EersteKamerlid L.H.W. Regout staat te boek als 'een redenaar van formaat.' ${ }^{141} \mathrm{Na}$ zijn overlijden in 1915 memoreerde Eerste-Kamervoorzitter J.J.G. baron van Voorst tot Voorst hem als 'een gemakkelijk spreker' met een 'zeer werkzaam aandeel' in de bezigheden van de Kamer. ${ }^{162}$ In een necrologie van Ch.A. baron de Bieberstein lezen we: 'il avait le don d'attirer l'attention de ses collegues et du pays par des discours, peu élaborés il est vrai, mais empreints d'un cachet de franchise et de bonne foi.'.43

Leopold Haffmans zei ooit over zichzelf: 'Men acht hem wijs, die den vinger op den mond leit. Verstond ik ook die kunst! Maar wat op 's harten grond leit, Dat welt mij naar de keel.'14 Dit was weliswaar een oordeel over zichzelf, maar de parlementaire activiteiten van Haffmans overziende, kan zelfkennis hem op dit punt niet ontzegd worden. Hij en Ch.A. baron de Bieberstein waren bij uitstek afgevaardigden die zich in hun vele toespraken geregeld lieten leiden door emotie. Van zowel Haffmans als De Bieberstein 
zijn in de Handelingen redevoeringen te vinden waarbij de kamervoorzitte zich genoodzaakt zag de spreker te verzoeken zich te matigen in de gebruikt uitdrukkingen. ${ }^{145}$ De Bieberstein was volgens parlementair-journalist Blok een 'zuidelijk heethoofd.'146 En Haffmans' redevoeringen blonken volgen het weekblad De Amsterdammer niet uit door 'blijken van fijne besche ving'. ${ }^{147}$ Haffmans zelf erkende in de Kamer dat 'irenisch' spreken zijn 'gent' niet was. ${ }^{148}$

Omdat er ook meer spraakzame kamerleden uit Limburg werden afge vaardigd, is het onjuist alle kamerleden uit die provincie te etiketteren al inactief. Er moet echter worden vastgesteld dat er in de latere parlementairhistorische literatuur en in de periode zelf veelal de nadruk wordt en went gelegd op juist die Limburgers die minder vaak aanwezig waren of die van hun aanwezigheid minder deden blijken.

Nu kunnen afgevaardigden voor hun geringe mate van participatie vanzelfsprekend goede gronden hebben gehad. De Stuers' gezondheid noodzaakte hem 'vaker dan hem lief was' om verstek te laten gaan. ${ }^{149}$ Gustav Ruijs van Beerenbroek brak in de winter van 1885-1886 zijn rechterbeen bi een val op het ijs. Hij was daardoor enige tijd niet aanwezig in de Kamet Eind maart 1886 kwam hij overigens ondanks zijn tijdelijke handicap tod naar de vergaderzaal; het Venloosch Weekblad schreef in zijn verslag: 'gedtrende de pauze komt de heer Ruys op krukken aangesukkeld'. ${ }^{150}$ Ruijs kwan die dag naar de Tweede Kamer omdat er een belangrijke stemming (over de subsidiëring van het bijzonder onderwijs) op de agenda stond. ${ }^{151}$

Meer dan voor de afgevaardigden uit westelijk Nederland zal de geogrfische afstand tot Den Haag voor hun Limburgse collega's een belemmering hebben gevormd bij het bezoeken van vergaderingen. Indien parlement tariërs bijvoorbeeld wegens bezigheden elders of wegens familieomstandigheden tussentijds huiswaarts moesten keren, werd de duur van hw afwezigheid mede beïnvloed door de benodigde reistijd. Toen op 29 decem ber 1869 in de Eerste Kamer het voorstel aan de orde was de vergadering verdagen, zodat de leden in de gelegenheid zouden zijn de periode rond de jaarwisseling thuis in familiekring door te brengen, bracht de Limburge afgevaardigde Michiels van Kessenich naar voren dat het voor verschillend" leden moeilijk zou zijn om in het winterseizoen op en neer naar huis te rozen. Samen met onder anderen de overige Limburgers in de Eerste Kame - Beerenbroek en De Villers de Pité - stemde hij tegen het voorstel. ${ }^{\text {Isi }}$ Bi dit alles speelden ook vertragingen een rol die onderweg konden worder opgelopen. Zo was Tweede-Kamerlid Nolens op maandag 22 december $19 \mathrm{c}$ niet tijdig aanwezig wegens 'trein-verlating.' 153 
Als het gaat om de geringe deelname aan de beraadslagingen, lijkt bij een aantal afgevaardigden uit Limburg mee te hebben gespeeld dat zij het Nederlands - na de afscheiding van België de enige parlementaire voertal - onvoldoende beheersten. Van de meest opvallende parlementaire zwijger uit Limburg, De Villers de Pité, is bekend dat hij buiten de Kamer uitsluitend Frans sprak. ${ }^{154}$ Dat was ook de reden dat deze jonkheer zịn provincie graag naar Belgiē zag terugkeren, zo schreef gouverneur Gericke van Herwijnen in een geheim rapport aan de koning. De Villers de Pite, 'de Hollandsche taal niet kennende', verwachtte volgens de gouverneur in Belgié een voornamere rol te kunnen spelen dan in Nederland. ${ }^{13 s}$ Zuid-Limburg zond soms volksvertegenwoordigers naar Den Haag die het Nederlands wel verstonden, maar het niet durfden spreken. ${ }^{156}$ In de jaren zestig verontschuldigde De Keverberg de Kessel zich voor een pijnlijke verspreking tijdens een parlementair debat door erop te wijzen dat hij tot ver in zijn jeugd de Nederlandse taal in het geheel niet machtig was geweest. ${ }^{157}$ In een komedie, die in 1872 met veel succes werd opgevoerd in Roermond en Maastricht, sprak het personage dat de baron lijkt te persifleren, halfFrans. ${ }^{158} \mathrm{Nog}$ in de jaren tachtig was de beheersing van het Nederlands een item: een van de kandidaten bij de Tweede-Kamerverkiezingen van 1880 in het district Maastricht kreeg van zijn tegenstanders het verwijt niet in staat te zijn de belangen van zijn achterban in Den Haag te verdedigen, omdat hij 'nagenoeg onbekend' was met het Nederlands. ${ }^{139}$ Overigens was deze kandidaat, F. baron de Pelser-Berensberg, op dat moment wel al lid van Provinciale Staten van Limburg. Tot Tweede-Kamerlid zou hij het niet brengen.

Dominee J. Craandijk schreef in de jaren zeventig en tachtig verhalen over zijn reizen door Nederland. Toen hij in dit kader Limburg aandeed, noteerde hij: 'het kan u ligt gebeuren dat uw Hollandsch evenmin wordt verstaan, als gij een letter begrijpt van de taal, die gij hoort.' In de omgeving van Valkenburg werd veel Frans gesproken, zo constateerde hij. ${ }^{160}$ In oostelijk Zuid-Limburg was het Duits in de negentiende eeuw de eerste taal na het plaatselijk dialect. Pas in de twintigste eeuw werd het Duits er door het Nederlands verdrongen als schrijf-en leestaal. ${ }^{161}$ Als we afgaan op Lavater in zijn Politieke photografien, dan sprak het Sittardse Tweede-Kamerlid Arnoldts in de Kamer een mengeling van Nederlands en Duits: 'Iek schtem also deze wetschvortragt af', zo laat hij de afgevaardigde een fictieve stemverklaring beëindigen. ${ }^{162}$ In 1887 schreef het toonaangevende tijdschrift $\mathrm{De}$ Gids over de provincie Limburg: 
In zeden, gewoonten, taal wijkt zij van al de anderen af. Wat wij van haar taal te hooren krijgen uit den mond der mannen, die de provincie in ons wetgevend lichaam heeten te vertegenwoordigen; wat wij van haar zeden en gewoonten nog onlangs vernamen uit de arbeidsenquête, draagt er nu juist niet toe bij om ons, andere kinderen uit het groote [Nederlandse] gezin, tot dit ééne, in onze oogen wonderlijk kind bijzonder aangetrokken te gevoelen. ${ }^{163}$

Dat de Limburgse afgevaardigden zich inmiddels zonder uitzondering bekenden tot het politiek katholicisme (zie hoofdstuk 4), zal het liberal georiënteerde blad overigens waarschijnlijk bij voorbaat al minder positié hebben doen staan tegenover deze volksvertegenwoordigers. Het zal eindjren tachtig niet zozeer een kwestie van taal, maar vooral van tongval gewest zijn. Kamerleden die de landstaal zo slecht meester waren als De Villers de Pité, zien we in de laatste decennia van de negentiende eeuw namelijk nit meer verschijnen in Den Haag.

Het genoten onderwijs zal hieraan zeker een bijdrage hebben gelevent Terwijl verschillende Limburgse kamerleden uit de jaren veertig en viffig gestudeerd hadden aan een universiteit in (het latere) België, hadden d meeste afgevaardigden uit het laatste kwart van de negentiende eeuw ent opleiding genoten aan een (Noord-) Nederlandse instelling voor academisch of hoger beroepsonderwijs. Dat de beheersing van het Nederlands rond de eeuwwisseling geen echt probleem meer was, vindt zijn bevestiging in $d k$ spot die een Maastrichtse carnavalsgids eind negentiende eeuw dreef mat de Limburgse afgevaardigden in Den Haag: 'Wis geer dat eus Limburgs kamerlede op d'n doer hun Limburgse stumme kwietrake vaan 't hoeghollends spreke wat zie doen?' (Wist u dat onze Limburgse kamerleden op de duur hun Limburgse stemmen kwijtraken van het Hoog-Hollands spreke dat zij doen? $)^{104}$

Indien we de aanwezigheid van kamerleden als element van participt. tie apart nemen, kunnen we aan de hand van de presentielijsten uit $\alpha$ Handelingen nagaan of de Limburgse afgevaardigden afweken van de 8 middelde Nederlandse volksvertegenwoordiger. De periode $1840-1918$ tell 87 parlementaire zittingsjaren, waarvan er achttien voor deze studie onderzocht, te beginnen met het eerste jaar $(1840-1841)$ en vervolgens iede vijfde zittingsjaar. ${ }^{165}$ De gegevens zijn verzameld in bijlage $1 \mathrm{x}$.

Overigens werd presentie in ieder geval door sommigen beschouwd w een voornaam facet van het kamerlidmaatschap. Aanhangers van $\mathrm{Ch} . \mathrm{C} d z$ Bieberstein moesten in 1901 toegeven dat hun afgevaardigde in de Kamks 
niet op de voorgrond trad als het ging om het spreken, zij lieten daar echter direct op volgen: 'Hij was altijd aamwezig, een eerste en voornaamste vereischte voor een goed Kamerlid.'106 Afgevaardigde Beckers, door tegenstanders 'Jan de Zwijger' genoemd, rekende de Sittardse kiezers in 1913 voor dat hij bij twee derde van de vergaderingen aanwezig was geweest. Tegelijkertijd stelde hij dat het eerder een kunst was om te zwijgen in de Kamer dan om er te spreken. ${ }^{167}$

Bijlage ix laat zien dat de gemiddelde bezettingsgraad van de Limburgse zetels in de Tweede Kamer in veertien van de achttien onderzochte zittingsjaren onder het gemiddelde van de Kamer lag; slechts in vier parlementaire jaren behaalden de afgevaardigden uit Limburg gemiddeld een hogere score. Voor de Eerste Kamer geldt dat de gemiddelde bezettingsgraad van de Limburgse zetels zich in elf van de achttien onderzochte jaren onder het gemiddelde bevond. Hoewel hiermee bevestigd lijkt te worden dat een parlementslid uit de zuidelijkste provincie vaker dan zijn doorsnee collega verstek liet gaan, is een nuancering op haar plaats. Met uitzondering van twee zittingsjaren bij de Tweede Kamer en vier zittingsjaren bij de Eerste Kamer was er immers altijd wel minimaal één kamerlid cit Limburg dat vaker aanwezig was dan de gemiddelde Nederlandse volksvertegenwoordiger in de desbetreffende Kamer.

De Limburgse afgevaardigden vertonen onderling grote verschillen. Een aantal van hen is in alle peiljaren waarin zij zijn meegenomen, vaker aanwezig dan het gemiddelde Nederlandse kamerlid. Kijken we naar de afgevaardigden waarvan de parlementaire loopbaan zich uitstrekte over minimaal drie peiljaren, dan zijn er drie Limburgers die bij alle metingen hoger scoorden dan hun doorsnee collega: Charles Antoine baron de Bieberstein en Willem Nolens (elk vijf peiljaren) en Charles Ruijs de Beerenbrouck (drie peiljaren). Edmond van Wintershoven was daarentegen opvallend vaak afwezig: in de drie parlementaire jaren waarin zijn presentie is bekeken, lag de bezettingsgraad van zijn zetel telkens meer dan tien procent onder het kamergemiddelde.

Het is aannemelijk dat er een verband bestaat tussen aanwezigheid en het bekleden van een (hoge) parlementaire functie. Nolens behoorde vanaf het begin van de twintigste eeuw tot de leidinggevenden binnen de Nederlandse politiek en in het bijzonder binnen het katholieke samenwerkingsverband; sinds 1910 was hij voorzitter van de katholieke kamerclub. Nolens was in alle peiljaren relatief vaak present. Leopold Haffmans was in zes van de zeven peiljaren minder aanwezig dan het gemiddelde; alleen in het jaar waarin hij voorzitter was van de katholieke kamerclub (1893-1894), was 
hij vaker present dan het doorsnee Tweede-Kamerlid. En Charles Antoine baron de Bieberstein was in de laatste twee maanden van zijn leven wegen: zijn slechter wordende gezondheid nimmer aanwezig, behalve in de wed waarin hij het tijdelijk voorzitterschap van de Tweede Kamer op zich mockt nemen. ${ }^{168}$

Twee Limburgse kamerleden lijken een bijzondere gedrevenheid voor het parlementaire werk aan de dag te hebben gelegd: zij tekenden in de onderzochte jaren opvallend vaak als eerste de presentielijsten. Jhr. Frans Michiels van Kessenich was bij 20 van de 76 vergaderingen die hij bezoctr de eerste intekenaar. Pijls meldde zich nog vaker als eerste: bij 34 van de 104 vergaderingen die hij bijwoonde. Indien we hier het aantal keren bi optellen dat Pijls als tweede tekende - dit was zestien maal het geval - biijt hij in bijna de helft van de vergaderingen die hij bezocht, tot de eerste twat intekenaars behoord te hebben.

\section{Parlementaire ervaring en sociale achtergrond}

$\mathrm{Bij}$ het meten van parlementaire ervaring van afgevaardigden dient zid een specifiek Limburgs vraagstuk aan: wat te doen met de ervaring die í opgedaan in de parlementaire organen van België? Drie Limburgse kamerleden, Pieter Willem baron de Liedel de Well, Louis Beerenbroek en Frats Corneli, hadden zitting in de vertegenwoordigende lichamen van dat land gedurende de periode dat het grootste deel van Limburg deel van Belgi. had uitgemaakt. ${ }^{169}$ Omdat de parlementaire gebruiken en machtsmiddela in Nederland duidelijk verschilden van die in België, worden de Belgisck jaren hier niet meegeteld.

Wat betreft de Eerste Kamer stelt Van den Braak in zijn onderzoek vs dat als het gaat om de duur van het lidmaatschap, Limburgse leden in de periode $1849-1888$ de kroon spanden. Terwijl een afgevaardigde in $\begin{gathered}\text { s } \\ \text { s }\end{gathered}$ periode gemiddeld tien à twaalf jaar lid bleef van de Kamer, bedroeg he lidmaatschap van $j$ hr. Frans Michiels van Kessenich tweeëntwintig jaar, vit jhr. Louis Libert de Villers de Pité dertig jaar en van Louis Beerenbroek zels vierendertig jaar. ${ }^{170}$

In de jaren tussen 1888 en 1918 was de doorstroming bij het Limburg deel van de Eerste Kamer eveneens relatief beperkt. Wat dit betreft is Lim burg een van de stabielere provincies. ${ }^{171}$ Afgevaardigden uit deze provino bleven inderdaad vaak lange tijd lid van de Kamer: L.H.A. Magnée overlas na achttien jaar, W.H. Pijls trad na negentien jaar terug om gezondheis redenen en H.G.L. Regout trad terug (ten gunste van zijn zoon Louis) st 
drięntwintig jaar. De drie afgevaardigden die in 1918 namens Limburg zitting hadden, bleven nog jaren Eerste-Kamerlid: jhr. L.H.L.J. van der Maesen de Sombreff en A.H.J.H. Michiels van Kessenich zouden tot hun dood lid blijven - zij waren toen respectievelijk zeventien en drieēntwintig jaar kamerlid; O.F.M. Haffmans zou in 1932 afscheid nemen na eenendertig jaar lidmaatschap. Alleen begin twintigste eeuw was de roulatie onder de Limburgers in de Eerste Kamer vrij hoog: F.J.P.M. Coenen, in 1902 toegetreden tot de Kamer, overleed nog geen vijf maanden later; zijn opvolger I.S.H. Brouwers stierf na vijf jaar en L.H.W. Regout, in 1904 gekozen tot Eerste-Kamerlid, trad in 1909 terug ten gevolge van zijn benoeming tot minister van Waterstaat.

De Tweede Kamer laat een ander beeld zien: de gemiddelde ervaring van de Limburgse afgevaardigden week op de peilmomenten die Van den Berg in zijn onderzoek hanteert, niet opvallend af van de ervaring die een gemiddeld Tweede-Kamerlid had. Op vier tijdstippen/periodes week de doorsnee Limburgse afgevaardigde enigszins (dat wil zeggen meer dan twee jaar) af van het gemiddelde in de Tweede Kamer: begin jaren zeventig (in de peiljaren 1871 en 1873), in 1883, in de daaropvolgende peiljaren (1887, 1888, 1891 en 1894), en in de periode 1897-1909 (peiljaren: 1897, 1901, 1905 en 1909).

Begin jaren zeventig had een Tweede-Kamerlid uit Limburg gemiddeld minder ervaring dan zijn collega. Er kunnen daarvoor twee oorzaken worden aangewezen. In de eerste plaats kwam er in 1869, na de verdubbeling van het district Boxmeer, een extra Limburger in de Tweede Kamer: een afgevaardigde die op dat moment aan het begin stond van zijn parlementaire carrière en nog geen enkele ervaring had. In de tweede plaats kenmerkte deze periode zich in Limburg door een felle strijd tussen liberaal- en conservatiefkatholieken (zie hoofdstuk 4). Twee zittende liberaal-katholieken, Karel Cornelis en Paul van der Maesen de Sombreff, werden bij verkiezingen verslagen en vervangen door nieuwkomers.

Aanvang jaren tachtig was de roulatiesnelheid bij het Limburgse deel van de Tweede Kamer eveneens relatief hoog. Dit is vooral te wijten aan de vele sterfgevallen onder de afgevaardigden. In een periode van tweeënhalf jaar overleden maar liefst vier Limburgse kamerleden. Het Venloosch Weekblad verzuchtte op 1 juli 1882 :

De provincie Limburg-het moet gezegd zijn-heeft het tegenwoordig zwaar te verantwoorden. Om niet van andere rampen te gewagen, de vertegenwoordigers ontvallen haar keer op keer. In weinige jaren tijds 
zagen wij drie afgevaardigden uit ons midden scheiden, de heeren De Bieberstein, Kerens [de Wylré] en Arnoldts. En thans staan wij aan het graf van den vierde [Nijst].

Het herstel in ervaringsjaren zette hierna spoedig in en vanaf midden jaren tachtig (peiljaren $1887,1888,1891$ en 1894 ) lag de doorsnee ervaring van de Limburgse parlementariërs zelfs duidelijk hoger dan die van de Kamer in haar geheel. Dit kan met name op het conto geschreven worden van twet kamerleden: Jerome Lambrechts en Leopold Haffmans. Hun beider dool in 1896, na respectievelijk ruim twintig en bijna dertig jaar lidmaatschap, leidde tot een grote terugval in ervaring binnen de groep van Limburge afgevaardigden.

Wat betreft hun leeftijd, laten de afgevaardigden uit Limburg onderlin duidelijke verschillen zien. Dit geldt met name voor de Tweede-Kamerleder Van Wintershoven kon bij zijn komst naar het Binnenhof jong genoemd worden: hij was dertig jaar oud, de minimumleeftijd voor een lid van de Staten-Generaal. ${ }^{172} \mathrm{Er}$ waren overigens meer Tweede-Kamerleden uit Limburg die hun parlementaire carrière startten toen zij begin dertig waren Bolsius en Charles Ruijs de Beerenbrouck in respectievelijk 1900 en 190509 eenendertigjarige leeftijd, Borret in 1849 als tweeẻndertigjarige en Jeromk Lambrechts in 1873 als drieëndertigjarige.

Tegelijk met Lambrechts deed echter tevens de bejaarde jonkheer Keren de Wylré zijn intrede in de Tweede Kamer; hij was toen achtenzestig. Ook Charles Antoine baron de Bieberstein behoorde van aanvang af tot $d k$ oudere afgevaardigden: toen hij de Kamer voor het eerst betrad, was hi tweeënzestig en hij bleef daar tot zijn dood op vierentachtigjarige leeftijd Met dat aantal levensjaren is de 'oude kolonel', zoals De Tijd hem noemde zelfs blijven behoren tot de recordhouders in de Tweede Kamer. ${ }^{173}$ De baron verhulde zijn leeftijd niet, hij koketteerde zelfs met zijn ouderdom. $\mathrm{N}$ twintig jaar voor zijn dood zag De Bieberstein in een brief aan Thorbeds zijn levenseinde naderen. ${ }^{174}$ En hoewel hij na zijn overlijden werd herinnerd als 'een krachtige en beweeglijke gestalte, ${ }^{175}$ benadrukte De Bieberstein zd' graag de starheid van zijn oude gewrichten.

Mijnheer de Voorzitter! Ik sta langzaam en met huivering op, want ik voel mijne jaren klimmen [...].

Mijnheer de Voorzitter, niettegenstaande mijne hooge jaren en het 
bukken mij bezwaarlijk wordt, kan ik toch niet nalaten, wanneer men an Limburg den handschoen toewerpt, denzelven op te rapen.

Mijnheer de Voorzitter, ik ben langzaam opgestaan, want iedere dag is er een [...].

Zo leidde hij drie van zijn redes in. ${ }^{176}$ Toen De Bieberstein in december 1878 het woord nam onmiddellijk nadat zijn vijfenveertigjarige provinciegenoot Brouwers gesproken had, begon hij met: 'Op het jongste lid van Limburg volgt nu de veteraan. ${ }^{\text {' } 77}$

De Bieberstein was op dat moment al een aantal jaren het oudste TweedeKamerlid. Dit had, naar goed parlementair gebruik, een eervolle bijkomstigheid. Bij aanvang van elk parlementair jaar diende er opnieuw een voorzitter te worden benoemd. De procedure was dat de Tweede Kamer een voordracht (met drie genomineerden) deed aan de koning die vervolgens gewoontegetrouw de eerst vermelde persoon benoemde. Tot het moment waarop bekend werd wie door de koning als (nieuwe) kamervoorzitter was aangewezen, werd het voorzitterschap uitgeoefend door de oudste afgevaardigde. De Bieberstein heeft op deze manier vanaf het zittingsjaar 1873-1874 zeven maal de voorzittershamer mogen hanteren. Hij richtte zich bij gelegenheid van zijn tijdelijk voorzitterschap altijd met enkele wijze woorden tot de Kamer. De laatste keer, in september 188o, deed hij een hartstochtelijke oproep tot eendracht en hij verhaalde van de Nederlandse onafhankelijkheidsstrijd in 1813 en 1814 :

Vergeeft Mijne Heeren, aan uwen nestor, aan den ouden strijder van die dagen, die er grootsch op is u die tijden nog te kunnen herinneren, deze kleine ontboezeming. ${ }^{178}$

Het werd hem vergeven: de toespraken waarmee De Bieberstein als oudste kamerlid zijn tijdelijk voorzitterschap pleegde te beëindigen, werden volgens De Tijd van 3 november 1880 altijd aanhoord met 'een soort van vriendschappelijke hilariteit'.

Indien we kijken naar levensovertuiging, dan vormden de kamerleden die tussen 1839 en 1918 vanuit Limburg werden afgevaardigd naar Den Haag, in hoge mate een homogeen 'gezelschap': met uitzondering van twee kamerleden waren zij allen katholiek. Thorbecke, afgevaardigd door het district Maastricht in de jaren $1853-1856$, was luthers. Eerder, in 1848 , 
had de protestantse advocaat Swart (uit Maastricht) als buitengewoon lic gedurende een maand zitting gehad in de Tweede Kamer.

Nu zal de wijze waarop katholieke afgevaardigden hun geloof beleden en beleefden, de plaats die religie innam in hun leven, ongetwijfeld uiten hebben gelopen. Van Strens wordt wel vermeld dat hij een niet-praktiserend katholiek was. ${ }^{179}$ In het leven van de priester-kamerleden Nolens en Evert zal het kerkelijk leven juist een prominente plaats hebben ingenomen. $D_{\text {r }}$ rol die levensbeschouwing innam bij de selectie van kamerleden, veranderde in de loop van de tijd: in de latere decennia werd het katholicism. een voorwaarde voor kandidaten om verkozen te worden. Alleen personen die zich (vooraf) committeerden aan de politieke samenwerking van de Nederlandse katholieken, werden toen naar Den Haag gezonden. De sterker wordende politiek-katholieke identiteit van de Limburgse kamerleden weerspiegelde zich in de afvaardiging in de jaren negentig van twee katholieke priesters: Willem Everts (1893, district Roermond) en Willem Nolens (1896, district Venlo). Vooral de intrede van Everts baarde opzien. Hij be nadrukte zijn hoge priesterlijke waardigheid - hij was pauselijk kamerher - door te verschijnen in een zijden paarse mantel, tot grote hilariteit binnen en buiten de Kamer. Onder de titel 'Joyeuse Entreé van Roermond's Afgevaardigde of een vreemde Kamerling in onze Kamer' dichtte het satirisct weekblad Uilenspiegel:

o! President der Kamer,

Leg uwen hamer neer,

Ontvang eerbiedig buigend

Des Pausen Kamerheer.

Het blad liet de kans niet voorbijgaan om lucht te geven aan zijn antipapisme:

('t Is waar wel, Christus zelf eens

Had Kamerheer noch knecht...

Maar... tempora mutantur!

Naar de oude spreuk nog zegt). ${ }^{180}$

Van de personen die tussen 1840 en 1918 vanuit Limburg werden afge vaardigd naar de Staten-Generaal, was een ruime meerderheid academisch geschoold. Voor zover het de Tweede Kamer betreft, kunnen we de gegeves relateren aan de data uit het onderzoek van Van den Berg. Deze constatert 
dat de academici in de periode $1849-1888$ overheersten met 80 tot $85 \%$ van het antal afgevaardigden. ${ }^{121}$ Limburg sloot hierop nauw aan (met $85 \%$ academisch opgeleide Tweede-Kamerleden). In het daaropvolgende tijdvak (1888-1918) daalde het aandeel van de universitair geschoolden in de Kamer. Dit gold voor het Limburgse part in versterkte mate: $56 \%$ van de Tweede-Kamerleden uit Limburg had in deze latere jaren een academische opleiding genoten. De kiesrechtuitbreiding was aan deze (landelijke) tendens debet. Dat het percentage academische afgevaardigden uit Limburg tussen 1888 en 1918 lager lag dan het gemiddelde in de Tweede Kamer, sluit aan bij de constatering dat het aantal universitair opgeleiden binnen emancipatorische partijen - in Limburg de katholieke 'partij' - lager was dan bij de liberalen. ${ }^{102}$

Een meerderheid van de Tweede-Kamerleden uit Limburg van wie de opleiding bekend is, was jurist. Dit gold eveneens voor hun collega's uit de andere landsdelen. Academisch geschoolde afgevaardigden met een andere universitaire opleiding dan rechten traden vanuit Limburg alleen vanaf het einde van de negentiende eeuw toe tot de Tweede Kamer: in 1889 werd de Maastrichtse huisarts J.H.J. Schreinemacher gekozen en in 1913 de werktuigbouwkundige M.Ch.E. Bongaerts, die tot dan toe werkzaam was geweest bij Rijkswaterstaat. Ook hiermee past de provincie in het landelijk beeld: tot 1888 was een overgrote meerderheid onder de TweedeKamerleden-academici jurist, daarna nam het aandeel van afgevaardigden met een andere universitaire opleiding toe. ${ }^{183}$

Kijkend naar opleiding en beroep, kan worden vastgesteld dat de diversiteit onder de Limburgse Tweede-Kamerleden na 1887 toenam. Dit lijkt in sommige gevallen in verband te staan met de kieswetuitbreiding van dat jaar. Zo zien we twee afgevaardigden met uitgesproken agrarische antecedenten verschijnen in de Tweede Kamer: Jan Truijen (district Weert, 1894-1901) en lean Beckers (district Sittard, 1903-1918). Beckers had de boerderij - met bijbehorende branderij - van zijn ouders overgenomen. Hij was actief in diverse agrarische organisaties in Limburg en in de Kamer sprak hij vooral over landbouwaangelegenheden. ${ }^{184} \mathrm{De}$ landbouw was in het kiesdistrict van Beckers een belangrijke economische peiler en zijn primaire gerichtheid op agrarische aangelegenheden werd gewaardeerd door de kiezers: Beckers werd telkens (vier maal) herkozen. ${ }^{185}$

Truijen stond bekend als 'boerenkoning'. 106 Volgens collega-kamerlid Bolsius was Truijen een ervaren agrariër, 'wiens levenslust de frissche lucht ademde van het veld waarin hij was opgegroeid'. ${ }^{187}$ Tot zijn vierentwintigste werkte Truijen op de boerderij van zijn ouders, maar ook daarna bleef hij 
actief in de agrarische sector, onder meer als voorzitter van de Limburge Landbouwbond en van de Zuid-Nederlandse Zuivelbond. Ook in de economie van het district Weert was de agrarische sector prominent aanweri en na het terugtreden van de 'boerenkoning' in 1901 ging het er dan ook in de eerste plaats om welke kandidaat de belangen van de landbouw het bes zou kunnen behartigen. ${ }^{188}$ De aanhangers van Hulshof - een van de twee kandidaten - stelden de volgende vraag om duidelijk te maken dat hun togenstander - 'kunstkenner' De Stuers - niet geschikt was als afgevaardigde

Kiezers van 't district Weert, hebt ge liever een representant, die u zeggen kan, dat uwe kerk of kerktoren niet in gothieken stijl is, of hebt ge liever een representant, die kennis heeft van rogge, haver, weiden, koeien en kalveren, boter en melk enz.? ${ }^{189}$

De Stuers had echter bji voorbaat al een voorsprong go Hulshof. omdat hi de steun genoot van Truijen. Dat het kiesrecht zich rond de eeuwwisseling tot bredere lagen van de bevolking had uitgestrekt, moge blijken uit de wijze raad van Truijen om tijdens de verkiezingscampagne die De Stuer in 1901 voerde, te zwijgen over de landbouwhogeschool te Wageningen. Dit was een delicaat onderwerp, want slechts een beperkte boerenelite trok profijt van deze onderwijsinstelling. ${ }^{190} \mathrm{Het}$ belang van de landbouw in Weet en omgeving vinden we ook terug in de activiteiten van Eerste-Kamerlid L.H.A. Magnée. Deze afgevaardigde was gedurende vele jaren namens het kiesdistrict Weert lid geweest van Provinciale Staten van Limburg. Hij was onder-voorzitter van de Maatschappij van Landbouw in Limburg en toonde zich volgens het overzichtswerk Onze afgevaardigden uit 1897 'steeds een voorstander van de landbouwbelangen'. ${ }^{191}$

In juli 1918 trad Henri Hermans toe tot de Tweede Kamer; hij was gekozen in het district Gulpen. Hermans had 'slechts' lager onderwijs enevenals zijn collega-kamerlid Vliegen - een opleiding tot typograaf genoten. Hij greep zijn vak aan om zichzelf verder te ontwikkelen en begaf zid op het journalistieke pad. ${ }^{192}$ Onder de bescherming van Charles Ruijs de Beerenbrouck werd Hermans actief in de katholieke sociale beweging in Limburg. De Nedermaas schreef:

Er zijn sociale werkers in soorten. Sommigen beginnen hunne loopbaan, steunend op den naam van hun familie [...]; anderen ontleenden een deel van hun carrière aan het bezit van fortuin $[\ldots]$. Weer anderen vonden aan ' $t$ begin van hun werk steun in hunne pries- 
terlijke waardigheid. [...] De zwaarste weg echter werd voorzeker afgelegd door hen, die geen fortuin tot hunne beschikking hadden, noch voortkwamen uit de hoogste standen, maar alles danken aan hun eigen door God gezegende wilskracht. Tot dezen behoort Henri Hermans. ${ }^{193}$

De komst naar het Binnenhof van deze laatste Limburger onder het districtenstelsel is illustratief voor de maatschappelijke verbreding van de groep waaruit kamerleden werden gerekruteerd.

Tabel 7. Leden van de Staten-Generaal gekozen/benoemd in/uit Limburg en behorend tot de Nederlandse adel, 1840-1918

\section{Naam}

1 Ch.A. baron de Bieberstein Rogalla Zawadsky

2 Ch.C.M.H. baron de Bieberstein Rogalla Zawadsky

3 Thr. P.A.S. Kerens

4 ihr, G.E.F.X.M. Kerens de Wylré

5 F.H.C.E. baron de Keverberg de Kessel

PW. baron de Liedel de Well

7 ihr. L.H.L.I. van der Maesen de Sombreff

8 ihr. P.Th. van der Maesen de Sombreff

9 J.B.C.E.M. graaf de Marchant d'Ansembourg (in 1915 werd de familienaam gewijzigd in de Marchant et d'Ansembourg)

10 jhr. A.H.J.H. Michiels van Kessenich

11 Thr. F.B.H. Michiels van Kessenich

12 jhr. A.H.Th. Michiels van Verduynen (tot 13-6-1842) A.H.Th. baron Michiels van Verduynen (m.i.v. 13-6-1842)

13 L.E.H.W. baron d'Olne

14 jhr. P.M.J.F. Petit

15 jhr. Ch.J.M. Ruijs de Beerenbrouck (tot 1895 was de familienaam Ruijs van Beerenbroek)

16 jhr. G.L.M.H. Ruijs van Becrenbroek (in 1895 werd de familienaam gewijzigd in Ruijs de Beerenbrouck)

17 1.L.Th.A.L. baron van Scherpenzeel Heusch

18 ihr. V.E. de Stuers

19 har. L.L.W.M.J. de Villers de Pité

20 C.M.H. baron de Weichs de Wenne

- Nam na verkiezing geen zitting

Tx. Tweede Kamer

ix Eerste Kamer

\section{Kamer en zittingsperiode}

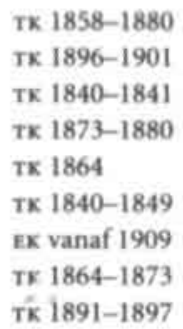

EK vanaf 1899

EX 1859-1881

TX 1840-1846

TK 1889-1891

TK 1841-1844

Tx 1905-1918

TK 1880-1888

TK 1892-1893

TK $1849^{*}$

TK 1901-1916

TK 1849-1850

EK 1850-1880

TK 1847-1849 
Twintig van de 67 kamerleden die tussen 1839 en 1918 vanuit Limburg werdet afgevaardigd naar de Staten-Generaal, kenmerkten zich door een adellii distinctief. ${ }^{194}$ Zeven droegen de titel baron en één was graaf, in Nederlande hoogste adellijke titel na die van prins. Twaalf afgevaardigden voerden het predikaat jonkheer. Alle Nederlandse (mannelijke) edelen die niet zijn begiftigd met een adellijke titel, zijn tot het voeren van dit predikaat gerechtigd.

In de periode $1849-1923$ was $29 \%$ van de Eerste-Kamerleden van adel." Limburg haalde met vier van de veertien afgevaardigden een zelfde percentage. Voor een goede vergelijking zou het echter beter zijn om niet he aantal adellijke leden, maar hun zittingsduur als uitgangspunt te nemen. De Limburgers De Villers de Pité en F.B.H. Michiels van Kessenich spanden immers de kroon als het ging om de duur van het kamerlidmaatschap Terwijl Limburg tussen 1849 en 1888 met deze twee afgevaardigden op etn 'adellijk percentage' van 25 uitkomt, indien dus gekeken wordt naar het aantal kamerleden van adel (twee van de acht), hadden De Villers de Pitt en Michiels van Kessenich met respectievelijk dertig en tweeëntwintig zittingsjaren een aandeel van $41 \%$ in de 117 'manjaren' die tussen 1849 en 1888 vanuit Limburg werden ingevuld. ${ }^{196}$

In de periode $1888-1918$ is het percentage adellijke manjaren voor Limburg lager, namelijk 31. Toch kan niet worden gesproken van een duidelijke ontwikkeling naar minder adellijke Eerste-Kamerleden. Gedurende de eerste elf jaar van de periode 1888-1918 zond de provincie namelijk geen enkels adellijke afgevaardigde naar Den Haag terwijl in de laatste negen jaar twet van de drie leden van adel waren. Wat betreft het adellijk aandeel in de parlementaire afvaardiging was het beeld voor zover het Limburg aangat wisselend. Voor de totale Eerste Kamer is er tussen 1888 en 1918 een duidelijk dalende lijn in het aantal adellijke leden vast te stellen. ${ }^{197}$

Van den Berg heeft de Tweede-Kamerleden uit de periode 1849-1917 onderzocht op twintig peilmomenten. Tussen 1849 en 1887 lag het percentag adellijke afgevaardigden telkens rond de 25 . In de peiljaren uit het tijdvak 1888-1917 lag dit aandeel tussen de 13 en de $22 \%$. Limburg scoorde in eb van deze periodes een gemiddelde van $24 \%$. Ervan uitgaande dat er zid in deze jaren tussen deze peilmomenten geen grote afwijkingen hebbet voorgedaan met de grensjaren waarin hij de metingen heeft verricht, kunnet we vaststellen dat Limburg wat de inbreng van de adel betreft niet meeded met de landelijke tendens van gemiddeld minder adel in de latere jaren.

Indien we de afvaardiging vanuit Limburg in de Eerste en Tweed Kamer samen bekijken, kunnen we vaststellen dat de adel tussen 18400 1918 voortdurend vertegenwoordigd was. Alleen tussen april 1888 toen jtit. 
Gustave Ruijs van Beerenbroek ontslag nam, en juli 1889 toen baron d'Olne toetrad tot het parlement, kende de Limburgse afvaardiging in Den Haag geen edelman. Deze adelloze periode van veertien maanden was des te meer uitzonderlijk, omdat er gedurende het grootste deel van de periode 1840-1918 ten minste twee adellijke afgevaardigden uit Limburg waren.

Tabel 8. Familierelaties tussen adellijke Limburgse kamerleden, 1840-1918

\begin{tabular}{|c|c|c|c|c|}
\hline $\begin{array}{l}\text { How: } \\
\text { Glajear }\end{array}$ & Bruid & $\begin{array}{l}\text { Relarie bruad } \\
\text { met bamerlid }\end{array}$ & Bruidegom & $\begin{array}{l}\text { Relanie bruidogom } \\
\text { met bamerlid }\end{array}$ \\
\hline 182 & $\begin{array}{l}\text { ikv. IF.P. Michiels } \\
\text { van Verduynen }\end{array}$ & $\begin{array}{l}\text { dochter van (jhr) } \\
\text { A.H.Th. (baron) } \\
\text { Michiels van } \\
\text { Verduynen }\end{array}$ & $\begin{array}{l}\text { Thr. F.B.H. Michiels } \\
\text { van Kensenich }\end{array}$ & self kamerlid \\
\hline InS2 & $\begin{array}{l}\text { kve. H.M.C.H. Michiels } \\
\text { van Kensenich }\end{array}$ & $\begin{array}{l}\text { dochter van jhr. } \\
\text { FH.H. Michiets van } \\
\text { Kessenich }\end{array}$ & $\begin{array}{l}\text { P.G.F.H. baron de } \\
\text { Bieberstein Rogalla } \\
\text { Zawadsky }\end{array}$ & $\begin{array}{l}\text { zoon van Ch. A. baron } \\
\text { de Bieberitein Regalla } \\
\text { Zwwadsky }\end{array}$ \\
\hline 1853 & $\begin{array}{l}\text { E.W.H.C. barones de } \\
\text { Bieberstein Rogalla } \\
\text { Zawadsky }\end{array}$ & $\begin{array}{l}\text { dochter van Ch.A. } \\
\text { baron de Bieberstein } \\
\text { Rogalla Zawadsky. }\end{array}$ & $\begin{array}{l}\text { Thr. L.E van der } \\
\text { Maesen de Sombreff } \\
\text { vader van jhr. L.H.L.I. } \\
\text { van der Maesen } \\
\text { de Sombreff }\end{array}$ & $\begin{array}{l}\text { broer van jhr. P.Th. } \\
\text { van der Maesen } \\
\text { de Sombreff }\end{array}$ \\
\hline 1857 & $\begin{array}{l}\text { ikvr. IM.L de Villen } \\
\text { de Pite }\end{array}$ & $\begin{array}{l}\text { dochter van jhr. } \\
\text { L.LW.M.I. de Villen } \\
\text { de Pité }\end{array}$ & $\begin{array}{l}\text { F.H.C.E. baron de } \\
\text { Keverberg de Kessel }\end{array}$ & zelf kamerlid \\
\hline IAS8 & $\begin{array}{l}\text { M.Th.V. barones van } \\
\text { Scherpenzed Heusch }\end{array}$ & $\begin{array}{l}\text { dochter van } \\
\text { J.L.Th.A.L baron } \\
\text { van Scherpenzed } \\
\text { Heusch }\end{array}$ & $\begin{array}{l}\text { F.M.H. baron de } \\
\text { Weichs de Wenne }\end{array}$ & $\begin{array}{l}\text { broer van C.M.H. } \\
\text { baron de Weichs } \\
\text { de Wenne }\end{array}$ \\
\hline 1661 & $\begin{array}{l}\text { fkvt. R.M S.H. Michiels } \\
\text { van Kessenich }\end{array}$ & $\begin{array}{l}\text { dochter van jhe. FB.H. } \\
\text { Michicls van Kessenich }\end{array}$ & $\begin{array}{l}\text { E.H.\}. baron de } \\
\text { Bieberstein Rogalla } \\
\text { Zwwadsky }\end{array}$ & $\begin{array}{l}\text { zoon van Ch.A. } \\
\text { baron de Bieberstein } \\
\text { Rogalla Zawadaky }\end{array}$ \\
\hline 1890 & $\begin{array}{l}\text { M.I.Th.I.H barones } \\
\text { de Weichs de Wenne }\end{array}$ & $\begin{array}{l}\text { dochter van C.M.H. } \\
\text { baron de Weichs } \\
\text { de Wenne }\end{array}$ & IF H.W. baron d'Olne & zelf kamerlid \\
\hline
\end{tabular}

Zuid-Limburg onderscheidde zich op dit punt duidelijk van Noord-en Midden-Limburg. Terwijl de Zuid-Limburgse Tweede-Kamerzetels voor ruim veertig procent van de tijd werden ingenomen door afgevaardigden van adel, ligt dat percentage bij de zetels uit het noorden en midden van de provincie onder de tien. De Eerste Kamer laat eenzelfde beeld zien. Eerder is angegeven dat de drie Limburgse zetels geografisch kunnen worden geduid: er waren twee zetels voor het zuiden en één voor het noorden en midden van de provincie. Voor de zuidelijke afvaardiging gold dat zij tussen 1848 en 1918 voor meer dan de helft van de tijd bestond uit edelen. De 
zetel voor Noord- en Midden-Limburg werd in diezelfde periode nimmet ingenomen door een afgevaardigde van adel.

De Limburgse adel was onderling verbonden door familierelaties. Dezt familiebanden zien we terug bij de Limburgse afgevaardigden (zie tabel 8). Bij vijftien van de twintig adellijke kamerleden uit Limburg is sprake van onderlinge relaties: door een huwelijk dat zij zelf aangingen met de dochter van een andere afgevaardigde (driemaal het geval), doordat een familielidin de eerste graad (een zoon, dochter of vader) trouwde of was getrouwd met een zoon of dochter van een ander kamerlid (driemaal), of via een huwelij van een dochter met een broer van een andere afgevaardigde (tweemaal),

Binnen de totale groep van Limburgse kamerleden - zowel adel abs niet-adel - is meermaals sprake van bloedverwantschap (zie tabel 9). Zo afgevaardigden uit de periode $1840-1918$ hadden een vader die eveneens lid was geweest van de Staten-Generaal. Voor twee kamerleden gold dat hun grootvader in het parlement zitting had gehad. Daarnaast was de grootvader van J.B.C.E.M. graaf de Marchant d'Ansembourg lid geweest van de Belgische Senaat in de periode dat Limburg deel van België was. Twet afgevaardigden hadden een oom die hun was voorgegaan als (Nederlands) kamerlid; twee andere kamerleden waren elkaars broer.

Drie Limburgse afgevaardigden hadden een schoonvader die eveneens kamerlid was (geweest). Een van hen, baron de Keverberg de Kessel, had gedurende enige maanden zelfs gelijktijdig met zijn schoonvader, De Vilers de Pité, zitting in de Staten-Generaal, zij het elk in een andere Kamer. Deze familierelaties maakten de Limburgse afgevaardigden overigens niet uniek: ook kamerleden uit de rest van Nederland hadden niet zelden (schoon)vaders, grootvaders en broers met parlementaire ervaring. ${ }^{199}$

Een uitgesproken parlementaire stamboom treffen we aan bij de familie Regout. Tussen 1849 en 1918 werd een van de drie Limburgse EersteKamerzetels voor meer dan de helft van de tijd bezet door een lid van dif Maastrichtse geslacht. Petrus Regout was afgevaardigd in de jaren $1849^{-}$ 1859; zijn zoon H.G.L. (Louis) Regout nam tussen 1881 en 1904 een zetel in Deze zetel ging in 1904 direct over van vader op zoon, L.H.W. Regout, evereens met de roepnaam Louis. Een jaar later nam een broer van deze Louls Robert Regout, zitting in de Tweede Kamer namens het district Helmond Overigens werd de statenzetel die Louis jr. tot zijn vertrek naar Den Haa innam, in 1904 overgenomen door weer een andere broer, Eugène Regout Ook hier kan weer worden vermeld dat een 'parlementair geslacht' als du van de Regouts meer voorkwam in Nederland, zie bijvoorbeeld de familio Van Asch van Wijck, Schimmelpenninck en Van Nispen. ${ }^{199}$ 
Tabel 9. Bloedverwantschap tussen Limburgse kamerleden, 1840-1918

\begin{tabular}{|c|c|c|}
\hline Kancrid I & $\begin{array}{l}\text { Relatie met } \\
\text { kamerlid } 2\end{array}$ & Kamerlid 2 \\
\hline 1.H. Amoldts & vader van & M.J.G.J. Arnoldts \\
\hline 11. Lambrechts & vader van & H.F. Lambrechts \\
\hline F.B.H. Michiels van Kessenich & vader van & A.H.J.H. Michiels van Kessenich \\
\hline G.L.M.H. Ruijs de Beerenbrouck & vader van & Ch.J.M. Ruijs de Beerenbrouck \\
\hline P.D. Regout* & vader van & H.G.L Regout \\
\hline H.G.L Regout & vader van & L.H.W. Regout \\
\hline P.D. Regout & grootvader van & L.H.W. Regout \\
\hline $\begin{array}{l}\text { Ch.A. baron de Bieberstein } \\
\text { Rogalla Zawadsky }\end{array}$ & grootvader van & $\begin{array}{l}\text { Ch.C.M.H. baron de Bieberstein } \\
\text { Rogalla Zawadsky }\end{array}$ \\
\hline $\begin{array}{l}\text { P.Th. van der Maesen } \\
\text { de Sombreff }\end{array}$ & oom van & $\begin{array}{l}\text { L.H.L.J. van der Maesen } \\
\text { de Sombreff }\end{array}$ \\
\hline $\begin{array}{l}\text { A.H.Th. baron Michiels van } \\
\text { Verduynen"* }\end{array}$ & oom van & F.B.H. Michiels van Kessenich \\
\hline H.J. Brouwers & broer van & J.S.H. Brouwers \\
\hline \multicolumn{3}{|c|}{$\begin{array}{l}\text {-P.D. Regout was ook de vader van E.R.H. Regout, Tweede-Kamerlid voor het district } \\
\text { Helmond (1905-1910). }\end{array}$} \\
\hline
\end{tabular}

In de negentiende eeuw en in het begin van de twintigste eeuw was een opvolging door een familielid niet ongebruikelijk. Diverse afgevaardigden uit Limburg volgden hun vader of broer op in bestuurlijke functies. Arnold Hendrik Michiels van Verduynen volgde in 1821 zijn broer op als districtscommissaris van Roermond. Jan Truijen werd in de jaren zeventig wethouder in Weert, als opvolger van zijn overleden vader. ${ }^{200}$ Toen J.B.J. Hengst in 1890 op eigen verzoek ontslag kreeg als burgemeester van Boxmeer, werd in zijn plaats een van zijn zonen benoemd. En in 1918 volgde Charles Ruijs de Beerenbrouck zijn vader op als Commissaris der Koningin in Limburg.

Dat het evenmin ongewoon werd geacht om een opengevallen kamerzetel te laten innemen door een familielid, blijkt uit de steun die kandidaten ontvingen bij pogingen om een familiaire opvolging te bewerkstelligen. Er is reeds gewezen op Louis Regout die in 1904 zijn vader opvolgde als EersteKamerlid; hij werd gekozen met 41 van de 42 stemmen. Als het gaat om de Tweede-Kamerzetels, werd er in ieder geval tweemaal getracht om een opengevallen parlementaire zetel door een bloedverwant te laten bezetten. $\mathrm{Na}$ de dood van het Maastrichtse Tweede-Kamerlid J.H.J. Schreinemacher in 1892 stelde zijn zoon Constant zich kandidaat. Een groot deel van het electoraat steunde hem: in de eerste ronde vergaarde hij de meeste stem- 
men, maar niet de absolute meerderheid, en in de tweede ronde verloor hi van Martin de Ras. In het noorden van Limburg schaarde een deel van d aanhang van Leopold Haffmans zich na diens dood in 1896 onmiddelin achter zijn jongste broer Emile. ${ }^{201}$ In een advertentie beloofde deze aand kiezers dezelfde politieke lijn te zullen volgen als wijlen zijn broer. ${ }^{2 m}$ Venloosche Courant, die zich bij de verkiezingen aan de zijde van Emilests genstander Nolens schaarde, plaatste een artikel waarin op voorhand werd aangenomen dat de invloed van de familie Haffmans Emile een groot aanti stemmen zou opleveren. Er werd echter eveneens gesteld dat toch mos worden toegegeven dat het parlementair mandaat niet erfelijk was. ${ }^{203} \mathrm{D}$. kennelijke vrees dat de familie Haffmans erin zou slagen de opvolging intern te regelen, zal mede haar grond gevonden hebben in een gebeurteni van zeven jaar eerder. Toen Leopold Haffmans in 1889 was teruggetreder als lid van Provinciale Staten van Limburg - na meer dan dertig jaar lidt zijn geweest van dit college -, was Emile ook al als beoogd opvolger nar voren geschoven en destijds met succes.

De regels met betrekking tot het Nederlanderschap vormden gedurende de eerste acht jaren na de terugkeer van de Limburgers in de StatenGeneraal een belangrijke belemmering voor de politieke participatie van de Limburgse elite. De opheffing van dit obstakel in 1848 was voor de provincie dan ook van grote betekenis: de achtergrond van de kamerleder die vervolgens gingen deelnemen aan het politieke leven in Nederland, toont aan dat een deel van de maatschappelijke bovenlaag in Limburg niet lange werd uitgesloten van vertegenwoordigende functies op nationaal nivew Meer dan vóór 1848 werd de Limburgse elite daarmee, via de beide Kamer van de Staten-Generaal, betrokken bij de Nederlandse politiek.

Een katalysator voor de integratie van Limburg in het politieke en stat: kundige bestel van Nederland vormde de nationaal-politieke groepsvor ming die vanaf het einde van de negentiende eeuw gestalte kreeg: in Limburg geboren en getogen afgevaardigden betraden sindsdien via andert landsdelen het parlement.

Terwijl het Nederlandse staatsbestel zich steeds meer openstelde voor Limburgse ambtsdragers, droeg de provincie zelf aan het einde van $\alpha$ periode 1840-1918, wat betreft haar afgevaardigden, zeker géén opena karakter. Van een toenemende integratie was hier geen sprake. De band die de kamerleden onderhielden met Limburg bleef onverminderd stet. personen van buiten de provincie werden in de tachtig onderzochte jart nauwelijks gekozen. Dat de vertegenwoordiging van het noordelijk deel vet 
Limburg - behorend tot het kiesdistrict Boxmeer - enige tijd door een Noord-Brabander geschiedde, was onder meer het provinciebestuur dan ook een doorn in het oog. Limburg lijkt in de loop der jaren eerder meer gesloten te zijn geworden: steeds minder afgevaardigden uit Limburg waren buiten deze provincie geboren en de verkiezing van een bij uitstek nationale figuur zoals Thorbecke, een kamerlid dat bovendien geen familiaire of beroepsmatige binding had met Limburg, zou na de jaren vijftig nooit meer voorkomen.

Dat het Limburgerschap van belang was, blijkt uit de verkiezingscampagnes. Indien een kandidaat van buiten de provincie kwam, werd zijn niet-Limburgse afkomst tegen hem ingebracht. Gezien de wijze waarop niet-Limburgse kandidaten of hun aanhang hier doorgaans op reageerden, kan worden afgeleid dat ook zij die afkomst als een handicap beschouwden. Nader onderzoek leert dat bij de keuze van volksvertegenwoordigers vooral de eigen streek als referentiekader diende. In de praktijk beperkten de kiezers zich bij de keuze van Tweede-Kamerleden vooral tot bewoners van het eigen kiesdistrict. Zelden kwamen de gekozenen van elders, dus ook zelden uit een ander deel van Limburg. In het verlengde hiervan namen Provinciale Staten bij de invulling van de drie Eerste-Kamerzetels een geografische spreiding over de provincie in acht.

Met betrekking tot opleiding en beroep weken de afgevaardigden uit Limburg niet opvallend af van het totaalbeeld dat eerder onderzoek heeft geschetst van de beide Kamers der Staten-Generaal. Als het gaat om de adel, kan worden opgemerkt dat haar aandeel in met name de Zuid-Limburgse afvaardiging naar Den Haag in de latere decennia relatief groter was.

In hun parlementaire werk lieten de Limburgse kamerleden grote verschillen zien, zowel als het ging om aanwezigheid als om de deelname aan beraadslagingen. Generaliserende uitspraken kunnen op dit punt daarom niet worden gedaan. Bij de participatie kon de taalbarrière aanvankelijk een rol spelen. In de laatste decennia van de negentiende eeuw vormde de kennis van het Nederlands echter geen of in ieder geval een minder grote belemmering. Wat dat betreft was het Limburgse smaldeel in de loop van de tijd meer thuis geraakt in het Nederlandse parlement. 



\section{In de Nederlandse familie Limburgse afgevaardigden en de band met Nederland}

In 1864 blikte Tweede-Kamerlid Pieter de Lom de Berg, afgevaardigd uit het district Roermond, terug op de jaren dertig, de periode waarin zijn provincie 'ten gevolge van politieke gebeurtenissen, gedurende negen jaren van het moederland wordt afgescheiden.' Door al dan niet bewust te spreken van 'moederland' lijkt hij de verhouding tussen Limburg en het overige deel van Nederland in koloniale termen te bezien. Dat De Lom de Berg zich niet bediende van de aanduiding 'vaderland' is wellicht te begrijpen via de stelling van de historicus Rogier dà dit begrip voor de meeste Limburgers, nog vele jaren na hun terugkeer onder Nederlands gezag, 'even reëel geweest moet zijn als voor een vondeling het begrip "ouders" [...]'?

Ook in de rest van Nederland werd regelmatig opgemerkt dat de relatie tussen de zuidelijkste provincie en het Nederlandse vaderland een bijzonder karakter had. Zo vergeleek het toonaangevende tijdschrift De Gids Limburg in 1887 met de overige tien provincies:

In een gezin van elf kinderen loopt er allicht één onder, dat wat uit den aard slaat. Zonder dat het hem aan verstandelijke vermogens hapert, weet de knaap de ontwikkeling der anderen niet geheel bij te houden. Hij wil, en doet en denkt in den regel anders dan de andere kinderen $[\ldots]$. Al is hij niet slechter dan de tien overigen, zeker is het, dat die tien hem meestal laten loopen, zoo ze hem niet uitlachen of erger. Zulk een eigenaardig kind is in de Nederlandsche familie de provincie Limburg. ${ }^{3}$

In dit hoofdstuk zullen de Limburgse kamerleden worden onderzocht op de houding die zij aannamen tegenover het land dat in 1839 verdragsrechtelijk hun vaderland werd. Daarbij zal - in chronologische volgorde - worden aangesloten bij die momenten waarop de staatkundige band van Limburg met Nederland expliciet op de politieke (en tevens op de internationale) agenda verscheen. Deze politieke actualiteit bleek mede uit het verschijnen 
van brochures over het onderwerp. Zo werd in 1848 De Limburgsche kwotie gepubliceerd en in 1919 La question du Limbourg. Het vraagstuk dat in dea geschriften werd opgeworpen, verschilde weliswaar op een aantal punten maar de oplossing was dezelfde: Limburg moest worden afgescheiden vat Nederland.

\section{De Limburgse kwestie(s)}

De Nederlandse grondwet van 1840 liet er geen twijfel over bestaan: $\alpha$ nieuwe provincie Limburg nam binnen het koninkrijk een aparte positi in. Het eerste artikel luidde als volgt:

Het Koningrijk der Nederlanden bestaat uit de volgende provincien: Noord-Braband, Gelderland, Zuid-Holland, Noord-Holland, Zeeland, Utrecht, Vriesland, Overijssel, Groningen en Drenthe, mitsgaders het Hertogdom Limburg, behoudens de betrekkingen van dat Hertogdom, met uitzondering der vestingen Maastricht en Venlo en van derzelver kringen, tot het Duitsche Verbond. ${ }^{4}$

Als enige Nederlandse provincie werd Limburg nader geduid: het was een hertogdom dat bovendien was opgenomen in de Duitse Bond. Althans grotendeels, want de vestingsteden Maastricht en Venlo (en hun omgeving waren daarvan uitgesloten. ${ }^{5}$ In de redactie van het grondwetsartikel val verder op dat in de opsomming van landsdelen het naar afsluiting neigend. 'en' al voor de tiende provincie (Drenthe) is geplaatst. De positie van dif verbindingswoord bracht een gewenste distantie aan tussen Limburg en $d$ overige Nederlandse gewesten, zo oordeelde in 1848 de Duitse rijksminister van Binnenlandse Zaken, A. Ritter von Schmerling. ${ }^{6}$

De in de grondwet beschreven staatkundige constructie waarbij Lim: burg deel was zowel van het Koninkrijk der Nederlanden als - grotendeds - van de Duitse Bond, dateerde van 1839 en zou blijven bestaan tot 1869 Deze constellatie was een uitvloeisel van de vredesregeling uit 1839 tussth Nederland, Belgiě en de grote Europese mogendheden. Overeenkomstigdie verdragen had Willem $\mathrm{I}$ in zijn hoedanigheid van groot-hertog van Luxem: burg het westelijke (Waalse) deel van het groothertogdom afgestaan an België. Ter compensatie verkreeg hij delen van Limburg (zie hoofdstuk1.)

Omdat Luxemburg sinds 1815 deel uitmaakte van de Duitse Bond, vet langde ook de Duitse Bondsvergadering gecompenseerd te worden: ook moest immers een deel van haar territorium afstaan aan Belgiē. ${ }^{7}$ Deze schr 
deloosstelling werd eveneens gevonden in Limburg: de nieuw te vormen Nederlandse provincie zou, met het resterende gedeelte van het groothertogdom Luxemburg, deel uitmaken van de Duitse Bond, echter met uitzondering van de steden Venlo en Maastricht die van oudsher staatkundige banden onderhielden met de noordelijke Nederlanden. De provincie werd een hertogdom en 'für ewige Zeiten' onder het erfelijk gezag van het Nederlandse vorstenhuis geplaatst. ${ }^{8}$ De Nederlandse koning ging de titel Hertog van Limburg voeren.

Dat Limburg onderdeel was van twee staatkundige verbanden had onder meer tot gevolg dat in de provincie zowel de Nederlandse wetgeving als die van de Duitse Bond gold. Overeenkomstig internationale overeenkomsten verloren Nederlandse wetten in Limburg (met uitzondering van Maastricht en Venlo) hun rechtskracht indien zij in strijd waren met de wetgeving van de Duitse Bond.' Ook de Nederlandse grondwet stelde zich uitdrukkelijk secundair op. ${ }^{10}$ In de praktijk werd in Limburg echter meestal de Nederlandse wetgeving gevolgd, ook als zij botste met de wetten en besluiten van de Duitse Bond."

Gezien het onderwerp van dit boek treffen we een opmerkelijk voorbeeld van strijdigheid tussen Duitse en Nederlandse regelgeving aan als we het Bundesbeschlu $\beta$ van 28 juni 1832 in beschouwing nemen. ${ }^{12}$ De wetgevende bevoegdheden die een volksvertegenwoordiging (met jurisdictie over een tot de Duitse Bond behorend gebied) mocht hebben, met name als het ging om het budgetrecht, waren door de artikelen van dit besluit gelimiteerd. De macht van de Staten-Generaal overtrof - ook in 1840 al - de vastgestelde grenzen. Op dit punt waren de bepalingen uit de Nederlandse grondwet dus in strijd met het Duitse Bondsrecht. Aangezien de wetgeving van de Duitse Bond boven de Nederlandse constitutie stond, hadden de Limburgers in de jaren 1840-1848 derhalve strikt genomen geen afgevaardigden naar de Staten-Generaal in Den Haag mogen zenden. ${ }^{13}$

In de jaren veertig was de vraag of Limburg deel moest blijven uitmaken van het Nederlandse koninkrijk regelmatig aan de orde. ${ }^{14}$ De kwestie was met name actueel in de jaren 1843-1844 en 1848-1849, twee perioden waarin er in de provincie sprake was van een sterke opleving van separatistische activiteiten.

De ontwerp-belastingwet van minister F.A. van Hall uit het voorjaar van 1844 (zie hoofdstuk 5) wakkerde de gevoelens van onvrede in Limburg aan, hetgeen door afscheidingsgezinden werd benut om hun streven kracht bij te zetten. Dit streven vond zijn ncerslag in een meersporenbeleid: de separatisten streefden naar een hereniging met Belgiē, en indien dit niet haalbaar 
was, wensten zij een onafhankelijk hertogdom - analoog aan de positi van Luxemburg - of de aansluiting van Limburg bij de Duitse Zollverein? Doordat de in het wetsvoorstel van Van Hall voorziene vermogensbelar ting uiteindelijk niet werd ingevoerd - een eraan gekoppelde lening has voldoende geld opgebracht -, mislukte de Limburgse afscheidingspoging Diverse separatistische voormannen bleven echter streven naar een afsche ding van Nederland en in 1848 kregen zij een tweede kans om hun ideaal verwezenlijken.

Grote delen van Europa waren dat jaar in de ban van revolutionairebs wegingen. Ook Duitsland bleef niet onberoerd. Ten gevolge van de politite onrust in het voorjaar van 1848 kreeg het in liberale kring levende verlanga naar Duitse eenheid een belangrijke impuls. Door bij die wens aan te hake trachtten de Limburgse aanhangers van een scheiding met Nederland he doel dichterbij te brengen. Hun provincie maakte immers deel uit van Duitse Bond en zou daarom volgens hen moeten opgaan in het nieuwt vormen Duitse rijk.

Het streven naar Duitse eenheid werd voortvarend aangepakt. Zo werl er besloten tot het bijeenroepen van een 'constituirende deutsche Nationalversammlung' waarin vertegenwoordigers van alle Duitse Bondsstate zouden samenkomen om te beslissen over de toekomst van de Duitsentie. Limburg kreeg twee afgevaardigden. Om de Duitse decreten inzake de verkiezing van de leden van de Nationalversammlung tot uitvoer te bren gen, werd voor Limburg bij Koninklijk Besluit een nieuw ambt in het leven geroepen: de Hertogelijk Limburgs commissaris voor de Duitsche Bondst ken (zie ook bijlage $\mathrm{x}$ ). Het Limburgse Tweede-Kamerlid Louis Beerenbrod werd op deze post benoemd.

De aankondiging dat er in het hertogdom verkiezingen zouden worden gehouden voor het Duitse parlement, maakte daar diepe indruk. Vele meenden dat een volledige afscheiding van Nederland aanstaande was en op diverse plaatsen werd de zwart-rood-gele Duitse vlag uitgestoken. ${ }^{16} \mathrm{Op}$ th mei 1848 werden de kiesmannen gekozen die op hun beurt, vier dagen late voor elk van de twee Limburgse kiesdistricten - Roermond en Maastrichtde bekende separatistenleider Jan Lodewijk baron van Scherpenzeel Heust grootgrondbezitter te Baarlo, aanwezen als afgevaardigde. De inwoners vat de steden Maastricht en Venlo en hun strategische kringen mochten nic deelnemen aan de verkiezingen, daar hun woongebied geen deel uitmaakts van de Duitse Bond. Van Scherpenzeel Heusch opteerde voor Roermod en bij de herstemming in het district Maastricht - de kiesmannen $1 \mathrm{z}$ dit district kwamen bijeen te Valkenburg - werd op 27 mei Alexande 
Schoenmaeckers benoemd. Deze grondbezitter uit Amby stond eveneens Van Scherpenzeel Heusch bekend als aanhanger van een afscheiding van Nederland.

De Duitse Nationale Vergadering kwam op 18 mei 1848 voor het eerst bijeen in de Paulskirche in Frankfurt am Main. Naar aanleiding van een schrijven van Van Scherpenzeel Heusch boog het parlement zich spoedig over de positie van Limburg. De baron sprak in zijn brief van 'das anomale Verhältniß [...] zwei Herren anzugehören: einmal deutsches Bundesland, dann niederländische Provinz zu sein, und gleichzeitig Abgeordnete zur hiesigen Nationalversammlung und zu den Generalstaaten im Haag schicken zu müssen." Aan deze tweeslachtigheid diende zo snel mogelijk een einde te komen door Limburg los te maken van Nederland. Van Scherpenzeel Heusch vroeg de Nationale Vergadering daarom ondubbelzinnig te verklaren dat Limburg bij Duitsland hoorde.

Op 19 juli 1848 behandelde het parlement dit vraagstuk naar aanleiding van een rapport dat de commissie voor volkenrechtelijke aangelegenheden had opgesteld. Hierin werd onder meer gesteld: 'Jetzt dürfte die Zeit gekommen sein, wo $[\ldots]$ in Uebereinstimmung mit den deutschen Brüdern in Limburg eine nicht Bloß nominelle, sondern auch reelle Vereinigung mit Deutschland hergestellt werden kann und muß,'s $\mathrm{Op}$ voorstel van de commissie besloot de Nationale Vergadering te verklaren dat Limburg 'ein deutsches Bundesland' was en dat de onderwerping van het gewest aan de Nederlandse grondwet als onwettig moest worden beschouwd. Op geen ander moment in de periode 1848-1849 waren de pro-Duitse gevoelens in Limburg zo sterk als na dit parlementsbesluit. ${ }^{19}$

Enkele maanden verstreken. De Duitse rijksregering ondernam echter nauwelijks actie tegen de bestaande banden van Limburg met Nederland. Onder meer op aandringen van Van Scherpenzeel Heusch verklaarde de Nationale Vergadering daarom op 25 november 1848 te volharden in haar besluit van 19 juli. Van onderhandelingen met Nederland kon geen sprake zijn, want de Duitse status van Limburg stond vast.

Veel gevolgen had ook dit parlementsbesluit niet en een halfjaar later, op 14 mei 1849, berichtte parlementsvoorzitter J.L.T. Reh dat er een 'Austrittsanzeige' was binnengekomen van Van Scherpenzeel Heusch, die had geschreven mede te handelen voor zijn collega Schoenmaeckers. Hun ontslagname was, zo werd het parlement medegedeeld, "in Form eines Protestes übergeben worden'? ${ }^{20}$ Tot zijn grote teleurstelling, zo liet Van Scherpenzeel Heusch zijn collega-afgevaardigden weten, was aan de parlementsbesluiten van 19 juli en 25 november geen enkel gevolg gegeven. Verbitterd keerde hij 
zich daarom af van Duitsland. Van Scherpenzeel Heusch en Schoenmaecken hadden, "indem sie nur das Wohl des Landes, das sie zu vertreten die Ehreh. ben, berücksichtigen, die traurige Pflicht, gegen die fernere Vereinigungdo Herzogthums Limburg mit Deutschland zu protestieren.' ${ }^{21}$ De beide Lim burgse afgevaardigden restte niets anders dan hun mandaat neer te leggen

De vergadering besteedde nauwelijks aandacht aan de Limburgse pro teststem en ging over tot orde van de dag. ${ }^{22}$ Met het vertrek van Van Sche. penzeel Heusch en Schoenmaeckers uit Frankfurt verdween de Limburge kwestie van de Duitse parlementaire agenda: het hertogdom zou niet met ter sprake komen.

Het Nederlands gezag was in de jaren veertig in Limburg weinig populit en de anti-Nederlandse gevoelens waren er bijzonder hevig. De Limburgen voelden zich binnen het Nederlandse staatsverband veelal 'min of meer wh vreemden', zowel op godsdienstig, cultureel als economisch gebied. ${ }^{3} \mathrm{D}$. afscheidingsbeweging kon dan ook rekenen op brede steun.

Op het platteland, waar de (economische) grieven tegen het Nederlands bewind het grootst waren, vond de separatistische beweging haar belang rijkste aanhang, met name onder de (groot)grondbezitters. De Limburge adel nam binnen de beweging een leidende positie in. Industriëlen en groothandelaars, vooral te vinden in en om de steden, waren op economiscts gronden juist veelal tegen een scheiding van Nederland: zij wilden de NoortNederlandse afzetmarkt behouden en vreesden aan het eind van de jara veertig voor een aansluiting bij de Zollverein. Zowel een incorporatie in $\mathrm{di}$ tolverbond alsook een aansluiting bij België zou hen confronteren met ft: lere concurrentie. In de steden ondervonden de separatisten overigens wd weer steun bij de lagere sociale klassen. ${ }^{24} \mathrm{De}$ ambtenarij - veelzeggend ${ }^{4}$ nordniederländische Beamtenschaft' genoemd ${ }^{25}$ - was merendeels teget:stander van secessie. Waarschijnlijk speelden carrièremogelijkheden hierbi een rol. Bovendien waren deze ambtenaren relatief vaak protestant; if behoorden daarmee tot een groep waarbinnen een hoge mate van aanhat kelijkheid bestond jegens het eveneens grotendeels protestantse Noorden. Hoe was de stemming in het Noorden? Boogman schrijft over de poblieke opinie eind jaren veertig:

It does not look as if many Dutchmen would have been too unhappy if that remote strip of land, half Belgian and Roman Catholic, had in fact been incorporated into the new German empire, which was to have been formed at that time. ${ }^{26}$ 
In lijn hiermee constateerde minister J.M. de Kempenaer van Binnenlandse Zaken: 'Er zijn velen in den lande, die Limburg wel kwijt zouden willen zin." Deze houding hield mede verband met 'de Hollandse contractiementaliteit': de protestantse Nederlander zou zich bij voorkeur hebben teruggetrokken op 'eigen grond'. ${ }^{2 s}$ In de eerder aangehaalde woorden van Tweede-Kamerlid S.H. Anemaet uit 1840 : 'Ik voor mij zoude liefst het oude huisgezin zien bevestigen [...]. ${ }^{29}$ En Limburg maakte van dat gezin geen deel uit. In 1848 verscheen van de hand van J.H.G. Boissevain, redacteur van de Arnhemsche Courant, de brochure De Limburgsche kwestie. De schrijver wilde Limburg - 'een uitwas van ons land, dat onze beste sappen verteert' zo snel mogelijk kwijt, vooral om problemen met Pruisen te voorkomen. ${ }^{30}$ Zijn mening werd gedeeld door velen in Nederland en vond haar weerklank in het grootste deel van de Nederlandse pers."

In de ministerraad was de stemming bij een aantal leden al niet veel anders. Minister D. Donker Curtius van Justitie vond Limburg in september $\$ \$ 48$ eigenlijk maar 'een ellendig strookje land' en zijn collega van Financiên, P.P. van Bosse, was er aanvankelijk zelfs op uit om de provincie in te wisselen tegen gunstige overeenkomsten op het gebied van handel en Rijnvaart. De ruil van een deel van het koninkrijk - inclusief bewoners - tegen economische voordelen was volgens de minister zeer goed te verdedigen, want, zo zei hij tijdens een ministerraadsvergadering: 'Ons bestaan gelijkt veetzins eene groote kruidenierswinkel. ${ }^{32}$ Daartegenover stonden de ministers L.A. Lightenveld (Rooms-Katholieke Eredienst, later Buitenlandse Zaken) en J.M. de Kempenaer die zich van meet af aan verzetten tegen een secessie van Limburg.

Wat vond de koning? Onzekerheid en onvastheid kenmerkten het beleid van Willem $11 .{ }^{33}$ Ook als het ging om de positie van Limburg was zijn houding niet altijd even duidelijk. Dit hield mede verband met het feit dat een afscheiding van Nederland geen afscheiding van Oranje hoefde te betekenen. Een onafhankelijk hertogdom met het behoud van de Oranjedynastie - eenzelfde positie als waarin Luxemburg verkeerde - behoorde zeker in de eerste helft van de jaren veertig tot de aangehangen alternatieven. De koning werd door de Limburgers ook beschouwd als 'minder "Hollands"' dan zijn ministers. ${ }^{44}$ Dit blijkt uit een kwestie die speelde in juni 1841 , toen Willem n Limburg bezocht. Een aantal Zuid-Limburgse gemeenten weigerde een Nederlandse vlag aan te schaffen. De burgemeesters uit het kanton Meerssen lieten de gouverneur weten weliswaar te zullen vlaggen, echter 'slechts Limburgs en Oranje.'35 Willem n zou zich tijdens zijn regering in Limburg mogen verheugen in een zekere mate van populariteit..6 
Hij onderhield een goede verstandhouding met vooraanstaande persone in de provincie zoals de apostolisch vicaris (en latere bisschop) Paredise de industrieel Petrus Regout. ${ }^{37}$ De koning zette zich in voor het herstel te de bisschoppelijke zetel in Roermond en kocht in 1841, niet lang na tiो inhuldiging, een buitenverblijf nabij Maastricht, kasteel Vaeshartelt., $\mathrm{D}_{\mathrm{t}}$ kan worden gezien als een blijk van toenadering tot de nieuwe provinciet haar bewoners. ${ }^{39}$

Op beslissende momenten, dat wil zeggen tijdens de twee separatistisd golven (1843-1844 en 1848-1849) liet Willem II aan de politieke elite i Limburg weten dat een afscheiding van Nederland niet aan de orde was. 2 . kreeg de gouverneur in Limburg, jhr. Paul Gericke van Herwijnen, in ja 1843 de opdracht om aan leden van Provinciale Staten mede te delen dater petitie waarin werd verzocht om afscheiding van de provincie, de konity zou mishagen. ${ }^{* 0}$ Aan de raad van de stad Maastricht werd in de zome van 1848 door minister De Kempenaer van Binnenlandse Zaken, namenst. koning, de boodschap overgebracht dat de koninklijke 'belangstellingin-et bezorgdheid voor - het behoud van die provincie [Limburg]' onverminde. aanwezig zou blijven."

De houding van de Nederlandse regering kan over het algemeen nit bijzonder daadkrachtig genoemd worden: indien mogelijk wilde zij lim burg behouden, maar niet tegen elke prijs. ${ }^{42} \mathrm{Bij}$ een groot deel van $d$ Limburgse bevolking leek er al helemaal geen sterke aandrang aanwerigon de staatkundige banden met Nederland te continueren. Toen de poginge om te komen tot een Duitse staatkundige eenheid echter mislukten, vel de Limburgse afscheidingsbeweging de meeste wind uit de zeilen genome

\section{De kwestie geactualiseerd}

$\mathrm{Na}$ de jaren veertig berustten de meeste Limburgers in hun Nederlands nationaliteit. ${ }^{43}$ Limburg bleef echter deel uitmaken van de Duitse Bond:et constructie die in de provincie het ontluiken van een Nederlands nationti bewustzijn belemmerde. ${ }^{4}$ Dat het Traktaat van Londen van 11 mei Limburg ontsloeg van alle banden met de Duitse statengemeenschap, wort daarmee een belangrijk markeringspunt voor de integratie van Limburgi het Nederlandse koninkrijk. Na bijna dertig jaar kwam er een einde aat d staatkundige status aparte. 'Limburg is bevrijd van alle banden wardor het schijnen zou vreemd te zijn van onze nationaliteit,' verklaarde minist Heemskerk van Binnenlandse Zaken in de Eerste Kamer; 'elke exceptione toestand in een woord is verdwenen [...]?:45 
De toenadering tot Nederland die door de verbreking van de relatie met Duitsland een kans kreeg, werd meteen krachtig gestimuleerd door de in brede kring aanwezige vrees voor de expansiedrang van Pruisen. Met name gedurende de Frans-Duitse Oorlog (1870-1871) was men in Limburg beducht voor inlijving bij het nieuwe Duitsland. De publieke opinie in de provincie toonde zich daarom pro-Nederlands en de provinciale pers gaf regelmatig uiting aan de wens bij Nederland te blijven. ${ }^{\text {th }}$ Commissaris des Konings Van der Does de Willebois meldde in zijn jaarverslag over 1870 dat het conflict tussen Frankrijk en Duitsland de ontwikkeling van een Nederlands-nationale identiteit in Limburg bevorderde. ${ }^{47} \mathrm{De}$ angst om bij Duitsland te worden ingelijfd werkte 'voor het opiniërende deel van de Limburgse bevolking als katalysator voor de ontwikkeling van Nederlandsnationale sentimenten' ${ }^{\text {s. }}$ Vanuit Limburgs perspectief bezien speelde Willem $\mathrm{m}$ in die jaren overigens een weinig gelukkige rol. De koning was, evenals zijn vrouw Sophie, sterk anti-Pruisisch en stak deze gezindheid niet onder stoelen of banken, daarmee ten opzichte van Pruisen met vuur spelend."

Voor de hechting van Limburg aan Nederland was op het internationale vlak nog een andere omstandigheid van belang die veelal over het hoofd wordt gezien: na de definitieve erkenning van de Belgische staat in 1839 leek het gevaar voor zijn onafhankelijkheid nooit zo reěel als in de jaren zestig. Veel Europese staatslieden en diplomaten verkeerden in de veronderstelling dat het nog jonge koninkrijk binnen afzienbare tijd ten prooi zou vallen aan Frans annexionisme, ${ }^{50}$ Ongetwijfeld werd Belgiè dzarmee voor veel Limburgers minder aantrekkelijk als alternatief vaderland.

Bij de Nederlandse regering groeide in ieder geval het vertrouwen in de aanhankelijkheid van de Limburgers jegens Nederland. Illustratief zijn de koninklijke besluiten van september 1867 om de wet op de schutterijen ook in Limburg van kracht te verklaren. ${ }^{51}$ Deze wet was sedert 1839 voor deze provincie buiten werking geweest uit vrees dat men er 'de wapenen naar den verkeerden kant zoude wenden', aldus minister Heemskerk. Maar nu was 'alle zweem van mistrouwen' verdwenen. ${ }^{52}$

Na de gebeurtenissen van 1848 was de verhouding van Limburg tot de Duitse Bond politiek gezien met name in 1863-1864 actueel geworden. In januari 1864 schreef Nederlandsche gedachten dat 'de Limburgsche quaestie thans meer dan ooit aan de orde' is. ${ }^{53}$ In de later dat jaar verschenen brochure Ter toelichting van de Limburgsche kwestie verkondigde de schrijver, jhr. A.P.C. van Karnebeek, dat het streven naar Duitse eenheid de aandacht die in 
Nederland aan de Limburgse kwestie werd gewijd wel moest 'scherpen' De internationale gebeurtenissen rondom het hertogdom Sleeswijk gane daar alle aanleiding toe.

De Denen hadden Sleeswijk in 1863 volledig willen integreren in hunke. ninkrijk, zeer tegen de zin van de Duitse Bond. De Bond begon een militia campagne tegen Denemarken, uitgevoerd door Pruisen en Oostenrijk een aantal opzichten plaatste deze oorlog Limburg in de nationale politide belangstelling. Het gevaar leek reëel dat de provincie in de toekomst, doe haar dubbelzijdige staatkundige positie, aanleiding zou geven tot een soon gelijk conflict met de Duitse Bond of met Pruisen. Bovendien dreigde he neutrale Nederland via de Duitse Bond ongewild bij allerlei internation conflicten betrokken te raken. Ten derde bood de oorlog met Denemarta een uitgelezen kans om internationaal te pleiten voor het verbreken ve de banden tussen Limburg en de Duitse Bond. Het Limburgse Twet Kamerlid Charles Antoine baron de Bieberstein Rogalla Zawadsky meent eind 1863 dat een dergelijk pleidooi in de bestaande 'buitengewone omstas digheden' in Europa wel eens succesvoller zou kunnen zijn dan in 'gewos tijden'.35 Hij kreeg gelijk. Limburg trad, met internationale instemming w de Duitse Bond.

\section{'La question du Limbourg'}

De buitenlandse politiek van België kenmerkte zich tot 1870 door een sto ven naar herwinning van de gebieden die in 1839 verloren waren, waaronder Nederlands-Limburg. ${ }^{56}$ Doorgaans werd dit doel heimelijk beleden, hook een Belgische minister in 1853 volgens een toen in Limburg circulerend rucht openlijk zou hebben gezegd: 'roept ons maar, op den eersten wenkzi. wij bij u.' ${ }^{37} \mathrm{Na} 1870$ raakte dit Belgisch irredentisme op de achtergrond, 00 na afloop van de Eerste Wereldoorlog opnieuw in alle hevigheid verwous te worden. Nederlands-Limburg was in de ogen van veel Belgen 'Limboul cédé, het afgestane Limburg, en zij wilden het terug..$^{58}$

Al tijdens de oorlog werd deze wens geventileerd. In september 1914, is maand na de Duitse inval in België, had de Politieke Directie van het Bcli sche ministerie van Buitenlandse Zaken een uitvoerig territoriaal eisenps gramma geformuleerd; van Nederland verlangde men de provincie Limban en Zeeuws-Vlaanderen. Ook de Belgische generale staf oordeelde ento maanden later dat inlijving van Nederlands-Limburg gewenst was." De $B \mathrm{BC}$ gische regering was verdeeld over de kwestie, die vooralsnog binnenskanc bleef. In het voorjaar van 1915 startte de Belgische krant Le Vingtième Sid 
echter een annexionistische campagne en een jaar later verschenen de eerste innexionistische brochures: de kwestie was in de openbaarheid gekomen,

Tijdens de oorlogsjaren was van Belgische propaganda-activiteiten in Limburg nauwelijks sprake; ze kwamen na het sluiten van de wapenstilstand in november 1918 van de grond. Bijzonder actief hierbij was het Comité de Politique Nationale. In een van zijn uitgaven, La protestation du Limbourg uit 1919, stelde het comité de staatkundige relatie tussen Limburg en Nederland ter discussie met de stelling: 'C'est malgré lui que le Limbourg est devenu hollandais. ${ }^{*}$ De eerder genoemde brochure La question du Limbourg werd eveneens door het comité uitgebracht.

Nast het ontplooien van activiteiten in Nederlands-Limburg ging de Belgische regering de annexatiewensen bepleiten bij haar geallieerde bondgenoten. Die stonden niet onsympathiek tegenover het door oorlogsgeweld zwaar getroffen Belgiè. Daar kwam nog bij dat het neutrale Nederland veel krediet had verloren door in 1918 toestemming te verlenen aan Duitse troepen om zich over Nederlands - nota bene Limburgs - grondgebied uit Belgiè terug te trekken en bovendien door asiel te verlenen aan Wilhelm I, de teruggetreden Duitse keizer.

In Nederland reageerde de publieke opinie sterk afwijzend op de Belgische aanspraken, hetgeen zijn neerslag vond in de pers. De Nederlandse regering voerde een krachtig beleid dat erop gericht was elk verlies van grondgebied te voorkomen. Ook de Limburgse bevolking was in meerderheid tegen de Belgische annexatieplannen. ${ }^{61}$ Het liberale Tweede-Kamerlid W.H. de Beaufort had naar aanleiding van deze plannen al tijdens de oorlog geconstateerd dat 'de Limburgers tegenwoordig ook wel liever Nederlanders zullen blijven.' ${ }^{62}$ De Eerste Wereldoorlog had veel Limburgers de voordelen doen ervaren van hun Nederlandse staatsburgerschap: die nationaliteit had hen buiten de oorlog gehouden. ${ }^{63}$ Bovendien hadden de gesloten staatsgrenzen gedurende de oorlogsjaren de oriëntatie van de Limburgers op het Noorden bevorderd. ${ }^{\circ}$

De belangrijkste Limburgse pleitbezorgers voor de Belgische zaak waren Zuid-Limburgse industriëlen. Zij geloofden, mede op grond van beloften door de Belgische regering, dat een overgang naar Belgiě op economisch gebied voordelen zou brengen. ${ }^{55}$ Daarmee kan tevens worden vastgesteld dat het separatisme in de jaren na de Eerste Wereldoorlog hoofdzakelijk een Zuid-Limburgse aangelegenheid is geweest; in het noorden en midden van de provincie was er nauwelijks steun voor de afscheidingsgedachte. ${ }^{.6}$

Bovenal geldt dat de Limburgse elite in grote meerderheid geen misverstand wenste te laten bestaan over haar loyaliteit jegens de Nederlandse 
staat. ${ }^{67}$ Die elite droeg er dan ook zorg voor dat de anti-annexionistise campagne in Limburg voortvarend werd aangepakt. Dit geldt ook voor verse lokale politici. Zo nam de gemeenteraad van Venlo op 18 decemberis bij acclamatie een motie aan waarin geprotesteerd werd tegen de Belgive aanspraken en die verklaarde dat Venlo een Nederlandse gemeente wenstet blijven. De burgemeester van Venray las tijdens een vergadering van dęF. meenteraad een verklaring voor 'namens den Raad, en de geheele Gemeen om uiting te geven aan de verontwaardiging over 'de pogingen om ta schennende hand, een stuk van Nederland $[\ldots]$ te willen losscheuren $[. . .$,

In heel Limburg werden anti-annexionistische comités opgericht, alsod het Provinciaal comité Limburg bij Nederland. Het anti-annexionismeti. de openlijke steun van de rooms-katholieke Kerk in Limburg en katholid standsorganisaties, de Limburgsche Landbouwbond, de R.K. Werkliede vereeniging, de R.K. Middenstandsbond en de R.K. Werkgeversbond, p bliceerden in december 1918 een gezamenlijk manifest om de Limburg bevolking op te roepen te protesteren tegen de Belgische verlangens."

Het Provinciaal comité Limburg bij Nederland besloot aanvang 19: een volkspetitionnement te organiseren. Maar liefst $42 \%$ van de toth Limburgse bevolking tekende; het is echter niet duidelijk of en in wek mate deelname aan het petitionnement werd gestimuleerd door potentele ondertekenaars onder druk te zetten. ${ }^{70}$ Het resultaat werd in Den Hay aangeboden aan koningin Wilhelmina. De vorstin zong bij deze gelegenhai - naar zij zich herinnerde uit volle borst - het volkslied van Limburg Ww in 't bronsgroen eikenhout mee. Dat deed zij eveneens met het Zeewn Vlaamse equivalent, Waar eens het gekrijsch der meeuwen, want zij hader gelijkluidend petitionnement aangeboden gekregen door een delegatie Zeeuws-Vlaanderen. ${ }^{71}$ Op 6 februari 1919 werd in Den Haag onder auspio en van de Nederlandse regering een nationale manifestatie gehouden gericht was tegen de Belgische aanspraken op grondgebied van Limburge Zeeland. Een van de sprekers was F.I.J. Janssen, voorzitter van het Proviná: comité Limburg bij Nederland.

Over de houding van de Limburgse bevolking kon de Nederland regering tevreden zijn. De koningin zei in de troonrede van septembr 1919:

In innige gemeenschap met Mijn gansche volk gaan Mijne gedachten uit naar Limburg en Zeeuwsch-Vlaanderen, in wier trouw en aanhankelijkheid de hechtheid en de kracht onzer nationale eenheid ondubbelzinnig tot uitdrukking kwamen. ${ }^{72}$ 
'Limburgers zijn zeer goede Nederlanders,' noteerde Wilhemina later in Emzaam maar niet alleen. $\mathrm{Zij}$ meende dat de wens van de bevolking zelf de doorslag had gegeven bij de confererende mogendheden in Parijs. ${ }^{33}$ Ook volgens de historicus Wagemans heeft de sterke afwijzing door de Limburgse bevolking ertoe bijgedragen dat het Belgische annexionisme mislukte. ${ }^{74}$

De Belgische eisen vonden bij de onderhandelaars in Parijs inderdaad weinig bijval. Ze besloten dat gebiedsafstand door Nederland niet aan de orde was. De onderhandelingen over de resterende vraagstukken bijoorbeeld op het gebied van militaire en economische samenwerking - sleepten zich voort. Pas in april 1925 sloten Belgiê en Nederland een verdrag dat vervolgens echter werd verworpen door de Eerste Kamer. Het Belgisch annexionisme was toen inmiddels doodgebloed. ${ }^{75}$ Limburg was vor Nederland behouden gebleven.

\section{Kamerleden en de kwestie}

Afkomstig uit een 'internationaal-rechtelijke amphibie', moesten de eerste Limburgse afgevaardigden zich in Den Haag wel voelen als 'vreemde eenden in de bijt?. Indien we bij hen en bij de latere kamerleden uit de provincie willen vaststellen welke opvattingen zij huldigden over de staatkundige positie van Limburg, is er een aantal aandachtspunten.

In de eerste plaats dient te worden meegewogen dat de nationale volksvertegenwoordiging mogelijk niet de meest geëigende plaats was om separatistische standpunten te verkondigen. Geprononceerde opvattingen over cen afscheiding van Limburg getuigden van een mate van terughoudendheid jegens de Nederlandse staat, die zich waarschijnlijk niet altijd liet verenigen met het parlementair woordgebruik. " Te meer daar de afgevaardigden door een eed van trouw gebonden waren aan de grondwet van diezelfde staat, zoals het Noord-Limburgse kamerlid Clemens baron de Weichs de Wenne in augustus 1848 ook zelf opmerkte. ${ }^{78}$ En door zich aan de grondwet te committeren kon een afscheidingsgezinde afgevaardigde nooit meer zijn dan een 'hinkende separatist', schreef Beerenbroek, oud-kamerlid en tegenstander van secessie, datzelfde jaar. ${ }^{79}$ Een van de meest prominente voorstanders van afscheiding in de jaren veertig, baron van Scherpenzeel Heusch, gaf dan ook aan dat het tot uitvoer brengen van de Nederlandse grondwet reden was om na zijn verkiezing tot Tweede-Kamerlid geen zitting te nemen in de Staten-Generaal. ${ }^{80}$ Ook in de twintigste eeuw werd de grondwet opgeworpen als obstakel voor het uiten van 'onvaderlandslievende gevoelens'. Tweede-Kamerlid Henri van Groenendael die van derge- 
lijke gevoelens werd beschuldigd, kreeg van Willem Nolens te horen tijdte een rede op 15 augustus 1919 in Roermond tot de R.K. Kiezersbond vor Limburg 'dat voor hem in de, op de Grondwet van het Koninkrijk de Nederlanden beëedigde volksvertegenwoordiging geen plaats meer is,"

Een rem op het blijk geven van uitgesproken ideeën kan er mede tox leiden dat parlementaire redevoeringen voor meer dan één uitleg vatboz zijn (en waren). Illustratief is de rede die Corneli op 28 maart 1848 in is Tweede Kamer hield. Terwijl het kamerlid daarbij volgens Boogman lic blijken voor afscheiding te zijn, wijzen Corneli's woorden volgens Prim juist niet op 'een bepaalde voorkeur voor het bestendigen van den band met Nederland'.82 Voor het interpreteren van parlementaire handelingene meer in het algemeen voor het plaatsen van de Limburgse kamerleden la het derhalve raadzaam zijn om ook hun activiteiten buiten het parlemen in ogenschouw te nemen.

Daarbij stuiten we wel op het gegeven dat de onzekere staatkundie toekomst van Limburg diverse publieke figuren in de provincie deed be sluiten tot een flexibele opstelling, een duidelijke en openlijke voorkew achterwege latend. Dit geldt met name voor de jaren veertig. Zo tracht het Maastrichtse stadsbestuur toen de kool en de geit te sparen en volgk de in die stad uitgegeven krant Journal du Limbourg een zigzagkoers ui opportunisme ${ }^{83}$ Het latere kamerlid Willem Hubert Pijls onderhield in diezelfde periode weliswaar een correspondentie met separatistenvoorman Van Scherpenzeel Heusch, maar deed dat vertrouwelijk. Toen hij de bs ron persoonlijk wilde spreken, vroeg hij om een ontmoeting buiten $d k$ landsgrenzen, in Keulen of Aken. ${ }^{84}$

Hoewel de houding van de Limburgse elite in de twintigste eeuw overhe algemeen als duidelijker en eenduidiger kan worden getypeerd, treffen $u$ tegelijk ook een voorbeeld aan van een flexibele opstelling en wel bij de ZuidLimburgse industriëlen die behoorden tot de belangrijkste pleitbezorgen van het Belgische annexionisme. $\mathrm{Zij}$ hielden zich echter op de achtergrond de deur naar Nederland openhoudend voor het geval de Belgische plannet niet verwezenlijkt zouden worden. ${ }^{85}$

Eenzelfde houding zien we bij sommige Limburgse afgevaardigden in Den Haag, bijvoorbeeld bij de zojuist genoemde baron de Weichs de Wenne Tweede-Kamerlid van 1847 tot 1849 . Op 11 april 1848 was hij aanwezig bi een door Van Scherpenzeel Heusch georganiseerde afscheidingsmeeting iv het Midden-Limburgse Neer. De baron haastte zich evenwel om gouvt neur Van Meeuwen te melden dat hij 'als bij surprize in die meeting wa ingesleept'.86 Nu zouden we de verstandelijke vermogens van De Weichs de 
Wenne wel eng onderschatten indien we zouden aannemen dat hij vooraf niet op de hoogte was van de strekking van een door Van Scherpenzeel Heusch georganiseerde bijeenkomst. De baron wilde zich kennelijk zo min mogelijk compromitteren. ${ }^{87}$ Later dat jaar ging hij op reis naar de Pruisische provincie Westfalen, juist toen de Tweede-Kamerverkiezingen voor de deur stonden: blijkbaar wilde hij ook nu niet openlijk kiezen. ${ }^{* 6}$ Daar komt nog bij dat het kamerlid zichzelf bij deze verkiezingen niet opnieuw had gekandideerd, om op die manier 'in dit gewest bij alle partijen of bij elken uitslag bruikbaar te blijven', aldus gouverneur Van Meeuwen ${ }^{*}$

Een ander voorbeeld treffen we ruim zeventig jaar later aan. In $1918 \mathrm{kwa}-$ men separatistische uitspraken van Tweede-Kamerlid Van Groenendael in de openbaarheid. Daarmee geconfronteerd nam de afgevaardigde echter afstand van zijn woorden door te verklaren dat hij er alleen 'schertsenderwijs' over had gesproken, 'zoals wij dat in Limburg wel eens meer doen'; het was bedoeld als 'een grapje:' Toen hem vervolgens zwaar werd aangerekend dat hiij over de afscheidingskwestie had gesproken met de Franse gezant te Brussel, kwalificeerde hij dat gesprek als een onschuldig 'huiselijk praatje',"

Soms werd echter ten onrechte verondersteld dat bepaalde handelingen gericht waren op het openhouden van alle opties. Zo sprak het Journal du Limbourg in 1848 zijn twijfel uit over de 'rondborstigheid' van het Limburgse kamerlid Beerenbroek: 'Eenige maanden geleden gaf hij zijne demissie als lid der Tweede Kamer, juist op het oogenblik, dat het er op aankwam voor of tegen de scheiding (van Limburg van Nederland) te stemmen. ${ }^{192}$ De houding van Beerenbroek wordt hier - al dan niet bewust - verkeerd beoordeeld. Hij nam immers ontslag ten gevolge van zijn benoeming tot hertogelijk commissaris. Hij onttrok zich daarmee niet aan publieke handelingen die verband hielden met de actuele Limburgse kwestie, zoals De Weichs de Wenne. Integendeel, hij speelde daarbij juist een actieve rol.

Het voorzichtige taalgebruik dat werd betracht door kamerleden én hun eventueel flexibele opstelling kunnen een mogelijk streven naar afscheiding onder de Limburgse afgevaardigden versluieren. Daar staat tegenover dat er soms separatistische neigingen werden verondersteld, terwijl het twijfelachtig is of die er ook daadwerkelijk waren.

Van Pieter Willem baron de Liedel de Well (Eerste-Kamerlid 1840-1849) is bijvoorbeeld bekend dat hij geneigd was zijn tegenstanders al snel te brandmerken als separatisten. Dat overkwam ook burgemeester Karel Elders van het Noord-Limburgse Bergen, de gemeente waarin het kasteel van de baron gelegen was. De aversie die De Liedel de Well koesterde jegens de burgemeester lijkt zijn voornaamste grond echter niet te hebben gevonden 
in een verschil van opvatting over de staatkundige toekomst van Limbur maar in een zich al jarenlang voortslepend conflict over het eigendomve een weg. ${ }^{93}$ Met enige voorzichtigheid dienen we daarom kennis te neme van de (politieke) kwalificaties die, met name door tijdgenoten, aan pe. sonen werden toegekend. Dit geldt zeker ook voor de typeringen die ve Limburgse kamerleden werden gegeven.

Zo richtte de antipathie die gouverneur Gericke van Herwijnen in he algemeen koesterde jegens personen met een zekere populariteit in Lim. burg, zich in het bijzonder tegen Arnold Hendrik Michiels van Verduynen.' Van dit Tweede-Kamerlid ging des te meer dreiging uit, omdat Gerickevat Herwijnen vreesde dat hij het gouverneursambt ambieerde. Niet allen typeerde de gouverneur Michiels van Verduynen en zijn familie in w geheim rapport aan Willem II als 'uitermate heerschzuchtig', maar teven als heimelijke voorstanders van een afscheiding van Limburg. ${ }^{95}$ Achter ten 'berispelijk artikel' in het Journal du Limbourg - een artikel met een separtistische strekking - vermoedde de gouverneur in 1842 dan ook prompt $k$ hand van het Tweede-Kamerlid. ${ }^{96}$ Gelet op de persoonlijke gevoelens va Gericke van Herwijnen lijkt het raadzaam om zijn beschuldigingen aan he adres van Michiels van Verduynen niet zonder meer over te nemen.

Ook van de beschuldigingen aan het adres van Tweede-Kamerlid Van Groenendael in 1918-1919 dienen we wellicht met enig voorbehoud kennis te nemen. Aan het in de openbaarheid brengen van de separatistisctr uitspraken van het kamerlid lag immers mede een zakelijk conflict ter grondslag. Van Groenendaels woorden waren door zijn tegenstanders' if achterbakse wijze' in de publiciteit gebracht. ${ }^{97}$

Verslagen, rapporten en brieven die in de jaren veertig door Nederlands overheidsorganen werden geschreven, dienen om nog een andere reden me enige voorzichtigheid te worden gelezen. Ten gevolge van de afscheiding kwestie was het Nederlands gezag toen vaak bijzonder op zijn hoede vout verstoringen van de openbare orde. Het is zeker niet uit te sluiten dat th $_{\text {t }}$ ambtenarij wel erg snel aannam dat achter opstootjes separatistische motic ven schuilgingen: 'In elke kermisruzie zag zij een uiting van separatisme."

\section{Afgevaardigden van het Hertogdom}

In de jaren veertig van de negentiende eeuw werden er vanuit Limburgeth entwintig afgevaardigden gezonden naar de Staten-Generaal in Den Hasf $\mathrm{Zij}$ zijn vermeld in de tabellen 1 en 2 . Van de genoemde parlementariêrs $z$ in het navolgende worden bekeken hoe zij stonden tegenover de staatku' 
dige band met Nederland. Hierbij zal de volgorde worden aangehouden van hun (eerste) verkiezing.

Tahd t. Leden van de Tweede Kamer gekozen/benoemd in/uit Limburg, 1840-1849. in volgorde van (eerste) verkiezing/benoeming

Naam

I jhr. P.A.S. Kerens

2 J.J.F.M.H. Corneli

3 (jhr.) A.H.Th. baron Michiels van Verduynen

4 jhr. P.M.J.F. Petit

5 M.P.H. Strens

6 J.L.M. Leclercq

7 L.F.H. Beerenbroek

8 C.M.H. baron de Weichs de Wenne

9 H.H. Geradts

10 A.L.G.H. Bloemarts

II J.M. Swart

12 A.J.J.H. Thissen

13 E.J.H. Borret

14 J.L.Th.A.L. baron van Scherpenzeel Heusch

15 P.L. de Lom de Berg

16 jhr. L.L.W.M.J. de Villers de Pité

17 J.J. Lambrechts
Periode

$1840-1841$
$1840-1849$
$1840-1846$
$1841-1844$
$1844-1847$
$1847^{*} /$ vanaf 1849
$1847-1848$
$1847-1849$
$1848-1849$
1848 Bui
$1848 B u i$
$1848 B u i$
vanaf 1849
$1849^{*}$
vanaf 1849
vanaf 1849
vanaf 1849

Bui gekozen tot buitengewoon lid

- Nam na verkiezing geen zitting

Bij de Zuid-Limburgse jonkheer Pièrre Kerens - 'een energiek en uitgesproken Nederlandsch gezind man' - werd het handelen gekenmerkt door trouw aan de Nederlandse staat. ${ }^{9} \mathrm{Na}$ de Belgische opstand was hij aangebleven als gedeputeerde in Maastricht en tot 1839 was Kerens zelfs een van de meest prominente vertegenwoordigers van het Nederlandse gezag in Limburg, omdat hij het grootste deel van die periode optrad als waarnemer van de buitengewoon commissaris, Gericke van Herwijnen, die meestal in Den Haag verbleef. Door zijn lidmaatschap van La Grande Société de Maestricht, van oudsher een trefpunt van Oranjegezinden, behoorde hij tot de Maastrichtenaren die ook wel het predikaat 'Hollander' toebedeeld kregen, betgeen overigens bepaald niet complimenteus bedoeld was. ${ }^{100}$ Voor zijn trouwe diensten werd Kerens in juni 1841 beloond met de benoeming tot staatsraad in buitengewone dienst. 
Een geheel andere opstelling treffen we aan bij Tweede-Kamerlid has Corneli: de Kerkradenaar wordt gerekend tot de Zuid-Limburgse kicita van de afscheidingsbeweging. In 1843 was hij betrokken bij een poging ie Provinciale Staten ertoe te bewegen een petitie naar de koning te zende waarin werd verzocht om de afscheiding van het hertogdom. ${ }^{101}$ In deatlis tijd hielp Corneli bij de oprichting van een nieuw, Franstalig dagblad, nid hij eerst nog had geprobeerd het Journal du Limbourg op te kopen. Das poging was echter tevergeefs geweest, waarschijnlijk mede omdat gouveneur Gericke van Herwijnen erin was geslaagd de krant met een finanik injectie te verleiden om niet te vervallen in een structurele oppositic tega de regering. ${ }^{102} \mathrm{Na}$ een drietal proefbladen verscheen op 1 januari $184 \mathrm{~d}$ Gazette du Duché de Limbourg, die tot en met het laatste nummer op 29jej 1845 een spreekbuis zou zijn van de afscheidingsbeweging. ${ }^{109}$ Corneli $n$ ook door middel van familiebanden gerelateerd aan de separatistischeb. weging. Zijn zwagers Alexander Schoenmaeckers en Ch.J.A. baron de Roe steunden Van Scherpenzeel Heusch, de eerste als collega-afgevaardighi Frankfurt. Nadat Schoenmaeckers in juli 1849 ontslag had genomen als van de Duitse Nationale Vergadering, sprak hij tegenover de Nederlande gezant te Frankfurt, jhr. F.H.W. von Scherff, de verwachting uit dat ż schoonbroer Corneli hem zou opvolgen. ${ }^{104}$ Door het uiteenvallen van Nationale Vergadering is van opvolging geen sprake geweest.

Als het ging om de wens tot secessie, nam Tweede-Kamerlid jhr. And Hendrik Michiels van Verduynen (vanaf 1842 baron) een bijzondere positi in. De familie Michiels, waartoe behalve de tak Michiels van Verduynenool de tak Michiels van Kessenich behoorde, was traditoneel sterk orangistist Deze verbondenheid met de Oranjes werd in het familiewapen gesymbol seerd door een oranjeappel op het hartschild. ${ }^{105} \mathrm{Het}$ handelen van Midid van Verduynen weerspiegelde zijn trouw aan het Nederlandse koninghbs Nadat Limburg in 1830 tegen de wil van Willem 1 (de facto) onderder was geworden van Belgiè, was Michiels van Verduynen ontslagen als dis trictscommissaris van Roermond. Vervolgens weigerde hij elke functi: het Belgisch openbaar bestuur. Hij trad pas weer in overheidsdienst nat oostelijk Limburg was teruggekeerd onder het gezag van de Nederlandsclo ning; hij werd toen in zijn oude betrekking hersteld. Michiels van Verdupne zag zichzelf daarom als een 'slagtoffer [...] der Belgische gebeurtenissa."

Omdat orangisme en separatisme elkaar niet hoefden uit te slute maakte de aanhankelijkheid jegens het Huis van Oranje Michiels van 15 duynen niet automatisch voorstander van het opnemen van Limburg it het Koninkrijk der Nederlanden. Het is dan ook niet verwonderlifk 
hii aanvankelijk voorstander was van de in het voorjaar van 1843 gestarte actie waarbij men de koning wilde verzoeken om een afzonderlijke status voor Limburg: de voorgestelde petitie voorzag namelijk uitdrukkelijk in het behoud van de Oranjedynastie voor het hertogdom. Dat Michiels van Verduynen desondanks besloot om deze actie niet te steunen, hing echter eveneens samen met zijn trouw aan Oranje. Gouverneur Gericke van Herwijnen had in een brief aan de koning voorgesteld dat aan Michiels van Verduynen, 'welke zich thans nog in 's-Gravenhage bevindt, door het ministerie met allen ernst en nadruk wierd aanbevolen, om zijnen invloed an te wenden, ten einde het aanbieden van een voorstel tot scheiding in de anstaande Statenvergadering tegen te gaan'. 10 ?

De koning had dit advies ter harte genomen en minister Schimmelpenninck van der Oye van Binnenlandse Zaken opgedragen contact op te nemen met de Limburgse baron. Een scheiding was 'in de gegeven omstandigheden ondenkbaar', aldus Willem It. ${ }^{108}$ En voor een overtuigd orangist als Michiels van Verduynen waren 's konings wensen bevelen. In de afscheidingskwestie prevaleerde dit orangisme: die aanhankelijkheidsgevoelens voorkwamen dat Michiels van Verduynen zich op belangrijke keuzemomenten aan de kant van de separatistische beweging schaarde. Hij was daarmee niet zozeer een voorstander van de band met Nederland, maar van de band met Oranje. Na het ingrijpen van Willem $\mathrm{II}$ impliceerde aanhankelijkheid jegens het vorstenhuis echter tevens trouw aan het Nederlandse koninkrijk.

P.M.J.F. Petit is moeilijker peilbaar inzake zijn opvattingen over de staatkundige positie van Limburg. Over de precieze standpunten van de Roermondse jonkheer is weinig bekend, hetgeen overigens mede aan hemzelf te danken is: aan de parlementaire beraadslagingen in Den Haag heeft hij, gedurende zijn driejarig kamerlidmaatschap, geen enkele bijdrage geleverd. Tijdens de eerste separatistische golf bleek Petit echter aansluiting te hebben gevonden bij de afscheidingsbeweging en toen Provinciale Staten in juli 18544 een Tweede-Kamerlid moesten kiezen, werd de kandidatuur van Petit dan ook gesteund door de separatistische Gazette du Duché de Limbourg. ${ }^{109}$ De gouverneur wilde bij deze verkiezingen alleen een anti-separatist afgevardigd zien en steunde om die reden Petit niet.

De gouverneur steunde diens tegenkandidaat, Martin Strens, wiens carnète nog tijdens de jaren veertig een bovenprovinciale wending zou krijgen: in augustus 1846 werd hij benoemd tot procureur-generaal in NoordBrabant, een duidelijk blijk van vertrouwen van de zijde van de Nederlandse regering. In 1852 zou Strens als eerste Limburger het ministerambt bekleden; hij werd minister van Justitie. 
J.L.M. Leclercq werd in 1843 door gouverneur Gericke van Herwijnetil betrouwbaar beoordeeld. ${ }^{110}$ In 1847 weigerde Leclercq zijn medewerkingue een poging van afscheidingsgezinden om te petitioneren tegen zijn eqf uitsluiting van het kamerlidmaatschap. Een jaar later, in november il stond Leclercq bij de Tweede-Kamerverkiezingen te boek als kandidativen de anti-separatisten.

Nadat Leclercq de toegang tot de Kamer was ontzegd, werd Louis Betere broek in zijn plaats gekozen. Ook hij was tegen de doelstellingen vand separatistische beweging gekant." Limburger'112 was eerder weliswaar lid geweest van de Belgische Kane van Volksvertegenwoordigers en hij had zich in die hoedanigheid vent tegen een terugkeer van oostelijk Limburg aan Nederland, tevens hadi toen voorspeld dat België na die teruggave geen erger vijanden zou hethe dan de Limburgers (en de Luxemburgers; zie hoofdstuk 1). Beerentund zelf heeft in ieder geval gepoogd bij te dragen aan het uitkomen vande profetie. Met name als Hertogelijk Limburgs commissaris voor de Di sche Bondszaken was hij er voortdurend op bedacht de Nederlandse wi te dienen. Hij ontving er zelfs een koninklijke onderscheiding voor: in $\alpha^{*}$ cember 1848 werd hij benoemd tot ridder in de Orde van de Nederlands Leeuw, omdat hij 'de woelingen der separatistische partij steeds met tie bestreden' had. ${ }^{113}$ Zijn benoeming tot hertogelijk commissaris was ovei gens al een blijk geweest van groot koninklijk vertrouwen in Beerenbrodi gezindheid en enkele jaren daarvoor - nadat Beerenbroek met Gerideve Herwijnen had samengewerkt om een voorgestelde petitie van Provincil Staten af te zwakken - had de gouverneur al laten weten dat hij, als het fil om het afscheidingsvraagstuk, in Beerenbroek een bondgenoot zag."

Dit was niet het geval met Clemens baron de Weichs de Wenne. De afgevaardigde werd zelfs gerekend tot de leiders van de afscheidingsbost ging in het noorden van Limburg. ${ }^{115}$ Evenals Corneli was hij betrokkenti de poging in 1843 een separatistische petitie te zenden aan de koning ath de oprichting van de afscheidingsgezinde Gazette du Duché de Limbour

Toen Beerenbroek zich na zijn benoeming tot hertogelijk commissi terugtrok als lid van de Tweede Kamer, werd hij opgevolgd door Henth Herman Geradts. Beerenbroek was bijzonder verheugd 'dat Limburg dxe zulk één man vertegenwoordigd wordt'.116 Geradts beschouwde het dan ố als 'eenen heiligen pligt' het separatisme te bestrijden. ${ }^{177}$ Dit was getedi lijn met de familietraditie, want Geradts behoorde tot de weinige toonst gevende families in Limburg die zich bij het grondvesten van de Belgid staat afzijdig hadden gehouden. ${ }^{118}$ 
Twee maanden na de verkiezing van Geradts voegden Provinciale Staten in Mastricht met het oog op de grondwetsherziening drie extra Limburgse afgevaardigden - de buitengewone leden - aan de Tweede Kamer toe: A.L.G.H. Bloemarts, J.M. Swart en A.J.J.H. Thissen. De gouverneur twijfelde et niet aan dat zij alle drie behoorden 'tot die Partij welke zich tegen de afscheiding van het Hertogdom Limburg heeft verklaard." 19 Een van hen, Thissen, presenteerde het trio ook in Den Haag als tegenstanders van secessie. 1.00

Dat Bloemarts vanuit Nederlands perspectief bezien als betrouwbaar moest worden beschouwd, was eerder al duidelijk geworden. Bij de Belgische opstand van 1830 was hij afgetreden als gemeentesecretaris in Weert. In de jaren dertig hield hij zich verre van petitionnementen waarin verzocht werd Belgisch te mogen blijven en onmiddellijk na de terugkeer van het Nederlands gezag diende hij een verzoek in om weer in overheidsdienst te mogen treden. Zijn wens burgemeester te worden van zijn stad Weert werd gehonoreerd. ${ }^{12}$ Ook in de volgende jaren bleek zijn Nederlandse gezindheid. In juli 1843 was hij tot tevredenheid van de gouverneur gekozen tot voorzitter van een van de vier afdelingen van de Staten en in deze sleutelpositic was hij betrokken bij de succesvolle poging de zojuist bij Beerenbroek genoemde petitie, opgesteld door de afscheidingsgezinde De Villers de Pité, van haar scherpe kanten te ontdoen. ${ }^{122}$ Deze anti-separatistische instelling treffen we ook aan bij een ander prominent lid van de familie Bloemarts en wel bij zijn neef A.J.H.J. Bloemarts, oud-burgemeester van Venlo. ${ }^{123}$

Swart was lid van de eerder genoemde orangistische La Grande Société de Maestricht. Na de terugkeer van Limburg onder Nederlands gezag in 1839 werd hij benoemd tot auditeur-militair, een belangrijke post als het ging om de handhaving van het Nederlands gezag. Waarnemend gouverneur Kerens had dan ook geoordeeld dat Swart 'ten aanzien zijner staatkundige denken handelswijze, een onbeperkt vertrouwen verdient.' ${ }^{124}$

In hun parlementaire bezigheden zouden de buitengewone afgevaardigden Bloemarts, Swart en Thissen het vertrouwen van Nederlandse zijde, dat in hen was uitgesproken door de gouverneur, niet schaden. Tijdens hun kortstondige kamerlidmaatschap - de Dubbele Kamer vergaderde van 18 september tot 14 oktober 1848 - hielden zij alle drie redevoeringen waarin het streven van de afscheidingsbeweging werd bestreden. ${ }^{125}$ De drie buitengewone leden waren de laatste die door Provinciale Staten in de Tweede Kamer werden gekozen. Vanaf de verkiezingen in november 1848 werden de afgevaardigden direct gekozen; geen van de zittende volksvertegenwoordigers keerde terug in de Tweede Kamer. 
Onder de nieuwgekozenen valt, in het licht van de afscheidingskwest vooral de naam van Van Scherpenzeel Heusch in het oog. Hij was rondisq de meest prominente leider van de separatistische beweging en had bon: dien gelijktijdig zitting in de Nationale Vergadering te Frankfurt. Een park mentair dubbelmandaat dat uniek mag heten en tevens illustratief is vook staatkundige positie waarin Limburg zich bevond. In de Tweede Kamerna hij nimmer verschijnen; zijn zetel bleef er meer dan drie maanden lange bezet. Gedurende deze tijd nam de baron wel deel aan de parlementaine. tiviteiten in Frankfurt, daarmee nog eens zijn voorkeur voor het zo snelm gelijk verbreken van de staatkundige band met Nederland onderstrepend

Van Scherpenzeel Heusch was bij de verkiezingen van november is kandidaat gesteld in elk van de vijf Limburgse kiesdistricten en daans was de inzet bij de verkiezingen duidelijk: het was een keuze voori tegen afscheiding. Uiteindelijk - na de tweede stemmingsronde - vm hij in de districten Sittard en Heerlen. In Roermond, Maastricht en Veal zegevierden de anti-separatisten Leclercq, Borret en De Lom de Berg."

Borret was in Noord-Brabant geboren en zijn familie was vooral ine vanuit die provincie politiek en bestuurlijk actief. Zijn vader, A.J.L. Bont (1782-1858), oud-gouverneur van Noord-Brabant, was in de jaren 1839-144 samen met Gericke van Herwijnen als commissaris voor de wederinbezits ming van Limburg belast geweest met de vestiging van het Nederlandse zag in deze provincie. Limburg afscheiden van het overig deel van Nedertur en dus mede van Noord-Brabant kon Borrets instemming geenszins ve dragen. Ook uit politieke overtuiging was hij daartegen: als 'ultra-katholid sympathiseerde Borret allerminst met de afscheidingsbeweging. ${ }^{12}$

Evenals Borret stond De Lom de Berg bij de Tweede-Kamerverkieringr kandidaat voor de anti-separatisten. Daarom werd zijn kandidatur steund door de Nederlandse overheid (zie hieronder). In zijn eerste redki de Kamer gaf hij tot tweemaal toe de verzekering dat de Limburgers ists anders wensten dan met Nederland verbonden te blijven. ${ }^{128}$

Tot de medestanders van Van Scherpenzeel Heusch kunnen we d? Villers de Pité rekenen. Evenals Corneli behoorde hij tot de leiders w de separatistische beweging in het zuidelijk deel van de provincie ${ }^{35}$ de reeds genoemde poging in $1843 \mathrm{om}$ Provinciale Staten te bewegen af verzoek tot afscheiding aan de koning te richten, vervulde De Villes Pité een voortrekkersrol. Hij was toen lid van de Staten en diende in hoedanigheid het voorstel voor de petitie in.

Achter de schermen - tijdens 'particuliere gesprekken' - had de gs verneur de provinciale volksvertegenwoordigers in opdracht van minis 
Schimmelpenninck van der Oye van Binnenlandse Zaken duidelijk gemaakt dat het vragen om secessie 'den Koning zelve min aangenaam zoude wezen.' ${ }^{\prime *}$ De meeste statenleden hadden toegezegd een ontwerp-adres waarin sprake zou zijn van afscheiding niet te zullen steunen. De Villers de Pité zag rich daardoor genoodzaakt het door hem in te dienen voorstel af te zwakken: van afscheiding was niet langer sprake. De toelichting op het ontwerp was echter naar het oordeel van de gouverneur nog steeds in een 'hevigen en overdreven toon' gesteld. Zij bevatte in ieder geval een ware lofzang op Belgiè, het 'pays avec lequel nous avions une conformité parfaite de moeurs, đ'habitudes et d'intéréts.' ${ }^{131}$

Om op de hoogte te kunnen blijven van de activiteiten van de verdachte jonkheer zorgde de gouverneur ervoor dat hij vriendschappelijke betrekkingen bleef onderhouden met De Villers de Pité; 'althans naar den uiterlijken shijn', $z 0$ schreef Gericke van Herwijnen aan Willem $11 .{ }^{132}$ Wellicht vernam de gouverneur op die manier van de plannen waarbij ook De Villers de Pité betrokken was, om in Maastricht een nieuw Franstalig dagblad uit te geven, hetgeen resulteerde in de oprichting van de Gazette du Duché de Limbourg. Inzake de afscheidingskwestie bleef De Villers de Pité lange tijd een eenling in de Kamer, de zetel van Van Scherpenzeel Heusch bleef immers onbezet. Toen deze laatste uiteindelijk, in mei 1849 , afzag van het kamerlidmaatschap, moest het district Sittard een nieuwe afgevaardigde kiezen. Het werd Jan Jacob Lambrechts, een bondgenoot van Van Scherpenzeel Heusch. Lambrechts trad in de jaren veertig minder op de voorgrond dan de eerder genoemde separatistische afgevaardigden, met name omdat hij tot zijn kamerlidmaatschap vooral op lokaal niveau actief was geweest: hij was schepen (wethouder) van het Zuid-Limburgse Grevenbicht. Toch stond hij in 1848 bij gouverneur Van Meeuwen bekend als een van de 'separatistische raddraaijers.' ${ }^{3}$ In november van dat jaar betrad hij het provinciale podium door deel te nemen aan een activiteit die werd georganiseerd door de afscheidingsbeweging en die tot doel had Van Scherpenzeel Heusch te promoten bij de komende Tweede-Kamerverkiezingen.

Om het beeld te completeren volgen nu de leden van de Eerste Kamer. Hier werd Limburg van oktober 1840 tot februari 1849 vertegenwoordigd door Pieter Willem baron de Liedel de Well. In 1830 had hij zich - als Tweede-Kamerlid - uitgesproken tegen een afscheiding van de zuidelijke provincies. Vervolgens had hij zich, als een van de weinige afgevaardigden in het Nationaal Congres in Brussel, verzet tegen het besluit om de Oranjes uit te sluiten van de Belgische troon, met het kennelijke doel om een scheiding te beperken tot een administratieve (zie hoofdstuk 1). Daarmee 
had hij gehandeld in overeenstemming met de wens van Willem It diens opvolger, die beiden nog lange tijd hun zinnen bleven zetten de troon van het nieuwe koninkrijk België. Deze trouw aan Nederland a de Oranjedynastie werd in juni 1841 beloond toen Willem $n$ ter gelegenhei van zijn inhuldiging een tocht maakte door Limburg. Hij vereerde $\mathrm{B}$ Liedel de Well met een bezoek en nuttigde een dejeuner in diens kaster Gedurende de separatistische acties rond 1843 en 1848 onderhield de bana nauwe contacten met regeringskringen in Den Haag. ${ }^{14}$ In mei van ${ }^{14}$ laatste jaar was hij, na een audiëntie bij de koning, betrokken bij een plun van Willem $n$ om 'gegoede ingezetenen' van Limburg een verzoekstri te laten richten tot de Duitse Bond waarin tegen een scheiding tussen he provincie en (overig) Nederland zou worden geprotesteerd. ${ }^{135}$

Tabel 2. Leden van de Eerste Kamer, benoemd uit Limburg, 1840-1849, in wolgri van benoeming

Naam Periode

1 P.W. baron de Liedel de Well 1840-1849

2 L.F.H. Beerenbroek vanaf 1849

3 P.D. Regout vanaf 1849

4 G.J. de Rijk vanaf 1849

In 1848 liet De Liedel de Well zich kennen als een 'pro-Nederlandse dot man'136 en tijdens de eerste separatistische golf treffen we zijn naam ii aan bij acties om te komen tot een zelfstandig hertogdom. Deze houin vinden we terug bij zijn zoon, die in dezelfde tijd weigerde (financide medewerking te verlenen aan de oprichting van een separatistisch daght in Limburg. ${ }^{137}$

Bij de anti-separatistische houding van het Eerste-Kamerlid zullen zi conservatieve opvattingen zeker meegespeeld hebben. De afscheidingit weging stelde zich namelijk in de jaren $1843-1844$ naast zelfstandigheid wow het hertogdom ook een meer liberale invulling van zijn staatsbestel tot dec een gruwel voor De Liedel de Well. Ook de liberale tendensen in Frantir zullen hem ongetwijfeld hebben tegengestaan. Tijdens de grondwetshers ning van 1848 liet hij dan ook aantekenen tegen de voorgestelde wijpiginf van hoofdstuk 3 ('Van de Staten-Generaal') te zijn. ${ }^{138}$

De Limburgse afgevaardigden die in februari 1849 hun intrede dots in de Eerste Kamer, Louis Beerenbroek, Petrus Regout en Gerard Johan b Rijk, kunnen worden aangeduid als 'drie anti-separatisten.' ${ }^{199}$ Ook wolg" 
gouverneur Van Meeuwen was het nieuwe Limburgse drietal in de Eerste Kamer tegenstander van een afscheiding. ${ }^{140}$

Beerenbrock is hiervoor bij de Tweede-Kamerleden reeds aan de orde geweest. Van Regout kan worden vermeld dat hij in 1834 al een keuze vóór Nederland had gemaakt: in dat jaar had hij zijn economische activiteiten in het toen door Belgisch gebied omgeven Maastricht verder uitgebreid, erop speculerend dat de stad Nederlands zou blijven. ${ }^{141} \mathrm{Hij}$ richtte zijn aandacht op Noord-Nederland, zijn beste afzetgebied. ${ }^{162}$ Dat economische belangen en staatkundige vertaling kregen, was geenszins opmerkelijk. Zoals we al ragen werd Regouts opvatting in kringen van industrie en handel veelal gedeeld. Zo ook door zijn collega-kamerlid De Rijk, een steenfabrikant en koopman in Tegelen. Volgens De Rijk waren de Limburgers aan het Nederlanderschap gehecht. ${ }^{16}$

Tabel 3. Leden van de Staten-Generaal gekozen/benoemd in/uit Limburg, 1840-1850, ingedeeld naar hun opvatting over secessie

Eerste Kamer

Overwegend afscheidingsgezind

Primair onangistisch

Tweede Kamer

Overwegend afscheidingsgezind

1. J.J.F.M.H. Corneli

2. J.J. Lambrechts

3. jhr. P.M.J.F. Petit

4. J.L.Th.A.L. baron van Scherpenzeel Heusch

5. jhr. L.L.W.M.J. de Villers de Pite

6. C.M.H. baron de Weichs de Wenne

Primair orangistisch

1. (jhr.) A.H.Th. (baron) Michiels van Verduynen

Overwegend Nederlandsgezind

Overwegend Nederlandsgezind

1. L.F.H. Beerenbroek

2. P.W. baron de Liedel de Well

3. P.D. Regout

4. G.l. de Rijk
1. L.F.H. Beerenbroek

2. A.L.G.H. Bloemarts

3. E.J.H. Borret

4. H.H. Geradts

5. J.L.M. Leclercq

6. P.L. de Lom de Berg

7. jhr. P.A.S. Kerens

8. M.P.H. Strens

9. J.M. Swart

10. A.J.J.H. Thissen 
De informatie over de houding van de Limburgse kamerleden ten ae zien van de band tussen hun provincie en (de rest van) Nederland is same gevat in tabel 3. Hieruit blijkt de adel in belangrijke mate vertegenwondigd te zijn geweest onder de afscheidingsgezinde kamerleden (vier van zes), terwijl zij onder de Nederlandsgezinde afgevaardigden een minds. heid vormde (twee van de dertien). Met betrekking tot de zeven adellis afgevaardigden uit de periode $1840-1850 \mathrm{kan}$ nog worden opgemerkt de de drie edelen die zich níet aan separatistische zijde schaarden, wat bene hun adellijke status veel meer dan de afscheidingsgezinden verbonden ie ren met de Nederlandse koning. Kerens en Michiels van Verduynen hadda hun verheffing in de adelstand te danken aan Willem 1 en de laatste kreeg zijn achtenzestigste verjaardag van Willem II de titel baron. In 1822 was an de toen reeds adellijke De Liedel de Well de titel baron verleend. Bovendin was het zijn enige zoon Guillaume vanaf 1848 vergund om reeds bij het len van zijn vader de baronstitel te voeren. De vier afscheidingsgezinde edder daarentegen behoorden allen tot adellijke geslachten van voor de sticting van het Koninkrijk der Nederlanden en geen van hen kreeg een adelli titel van een Oranjevorst. Toen De Weichs de Wenne en Van Scherpenat Heusch in de Nederlandse adel werden opgenomen was er namelijk ger sprake van een nieuwe titel. De baronstitel voor De Liedel de Well st. lie daarentegen wel als nieuw beschouwd worden: die titel werd hem toow kend door middel van verlening; er was geen sprake van homologatie vu de door hem eerder gevoerde Franse titel baron de l'Empire.

De grondeigenaren waren sterk vertegenwoordigd bij de separatister vier van de zes kamerleden, Corneli, Lambrechts, De Villers de Pité en $D$. Weichs de Wenne, behoorden tot die categorie. Bij de Nederlandsgeindes kan alleen De Liedel de Well tot de grootgrondbezitters worden gerkeni Omdat we het hier over de economische achtergrond van de kamerlade hebben, zij voor de volledigheid nogmaals opgemerkt dat de twee afgerzdigden die hun brood voornamelijk verdienden met handel en nijvethei Regout en De Rijk, zich bij de tegenstanders van afscheiding schaarde Overheidsfunctionarissen bevonden zich uitsluitend aan de zijde val is anti-separatisten, waar zij zelfs in zeer groten getale waren te vinden: nç van de dertien, te weten Beerenbroek, Bloemarts, Borret, Geradts, Lederi De Lom de Berg, Strens, Swart en Thissen. De enige protestant ondet Limburgse kamerleden, Swart, schaarde zich eveneens aan de kant vand anti-separatisten.

De afscheidingskwestie bracht geen scheidslijn aan tussen de afgert digden uit het noordelijk en die uit het zuidelijk deel van de provináe 
was echter wel een andere geografische factor in het spel: de zeven kamerIeden die woonachtig waren in Maastricht en Venlo en hun respectievelijke 'kringen', behoorden zonder uitzondering tot het Nederlandsgezinde deel van de afgevaardigden. Het betreft Borret, Geradts, Kerens, Swart en Regout in Maastricht; De Lom de Berg in Venlo; De Rijk in Tegelen (kring Venlo).

Indien we de sociaal-economische en geografische achtergrond van de Limburgse kamerleden uit de jaren veertig bezien en verbinden met hun opvattingen over secessie, kan worden vastgesteld dat het beeld in hoge mate overeenstemt met de eerder beschreven en deels nog te beschrijven achtergrond van de twee 'partijen' in Limburg: adel en platteland (grondberitters) voornamelijk bij de afscheidingsbeweging; handel en industrie, protestantse inwoners van de provincie alsmede bewoners van Venlo en Mastricht in hoofdzaak bij de tegenstanders van secessie.

Gelet op de stemming in de provincie mag haar afvaardiging in Den Haag opmerkelijk worden genoemd: in de Tweede Kamer was een duidelijke meerderheid tegenstander van afscheiding; in het andere deel van de volksvertegenwoordiging, de Eerste Kamer, namen zelfs uitsluitend Nederlandsgezinde vertegenwoordigers plaats. Tijdens de twee perioden waarin de separatistische beweging zich het meest roerde, 1843-1844 en 1848-1849, werden zelfs meestal Nederlandsgezinde kamerleden afgevaardigd. In 1844 werd de pro-Nederlandse Strens afgevaardigd en in juli en septembęr 1848 werden alle vacante plaatsen ingevuld door anti-separatisten. In de Tweede Kamer die volgend op de verkiezingen van november 1848 bij elkaar kwam, bezetten de separatisten slechts twee van de vijf zetels. De anti-separatistische krant L'Aviso de la Meuse presenteerde deze uitslag dan ook als een cadeau voor Willem $n$, die vijf dagen na de verkiezingen zijn zesenvijftigste verjaardag vierde: 'Ce résultat, Sire, est une des plus belles fleurs que Limbourg puisse vous offrir.'14

Hoewel de Limburgse volksvertegenwoordigers inzake het afscheidingsvragstuk weinig representatief genoemd mogen worden, lukte het hun om gekozen te worden. Dit was in Nederland overigens niet echt opmerketijkc in de eerste helft van de negentiende eeuw bestond er geen duidelijk verband tussen de openbare mening en de samenstelling van de Tweede Kamer. ${ }^{\text {is }}$ Wat betreft de situatie in Limburg is een verklaring hierbij voor en belangrijk deel te vinden in het kiesstelsel. 


\section{'Eene meer Nederlandsche stemming'}

Wie de provincie Limburg in de eerste jaren na haar terugkeer in 1839 a gaan vertegenwoordigen in Den Haag, werd grotendeels bepaald door Nederlandse koning. Dit gold vanzelfsprekend voor de Eerste Kamer wie leden tot de grondwetsherziening van 1848 werden benoemd bij Koninkil Besluit. Daarnaast werd er, zoals al gemeld in hoofdstuk 2, bij de aanwijizin van de eerste Limburgse Tweede-Kamerleden een bijzondere procedur gevolgd: de koning had zich in 1840 ook bij hen het recht van benoening toegeëigend, met voorbijgaan aan de reguliere bepalingen. Daardoor tui hij een uitgelezen mogelijkheid om de anti-Nederlandse sentimenten in Limburg vooralsnog niet of slechts in gematigde vorm te laten doorklinken in Den Haag.

Dat de overheid zich bewust was van deze mogelijkheid, blijkt uit $k$. adviezen waarop Willem $\mathrm{t}$ zich bij deze benoemingen baseerde. In een toe lichting op een van deze adviezen lezen we dat gekozen is voor bedaurd weldenkende mannen $[\ldots]$ teneinde het getal der woelgeesten niet te ve: grooten'. ${ }^{16}$ Het lijkt erop dat de exceptionele wijze van benoemen al in oktober 1839 door de raad van ministers werd gerelateerd aan het verkrijgan van gewenste Tweede-Kamerleden. In een rapport aan de koning had de raad geschreven dat het 'niet te vreezen schijnt dat men van de leden wi Limburg, alsdan door U[we] M[ajesteit] krachtens art. 1 der additionck artikelen der grondwet voor de eerste maal te benoemen, groote moeiti heden te wachten heeft'. 14 ?

In dit licht bezien mag de benoeming van Corneli opmerkelijk worda genoemd. Als lid van de Belgische Kamer van Volksvertegenwoordigershy hij zich immers nog fel verzet tegen een terugkeer van oostelijk Limbur onder Nederlands gezag (zie hoofdstuk 1). Willem 1 kon waarschijniti moeilijk geheel voorbijgaan aan de weinig warme gevoelens die onder ${ }^{2}$ Limburgers heersten als het ging om hun nieuwe vaderland. Bovendian was Gericke van Herwijnen, die Corneli bij de koning voordroeg, ente overtuigd dat het kandidaat-kamerlid zich ditmaal niet zou laten meeslepe door oppositionele krachten. ${ }^{148}$

Na de koninklijke benoemingen in oktober 1840 moest bij de aanwijing van de volgende Limburgse Tweede-Kamerleden de reguliere procedust worden gevolgd. De invloed van de vorst zou ook daarin doorwerken, mats omdat hij additioneel artikel 1 van de grondwet tevens had aangegrepen at verreweg de meeste leden van Provinciale Staten in Limburg te benoeme met voorbijgaan - wederom - van de kiezers. ${ }^{149}$ En aan Provinciale Stute 
kwam vanaf 1841 het recht toe om de Limburgse afgevaardigden in de Tweede Kamer te kiezen.

Het Nederlandse stelsel tot verkiezing van Tweede-Kamerleden, zoals dat verankerd lag in de grondwetten van 1840 en 1848 , bevorderde separatistische uitkomsten niet. Het stond in verscheidene opzichten een succes voor de afscheidingsbeweging juist in de weg. Bij de verkiezing van Geradts tot Tweede-Kamerlid (juli 1848) kan een direct verband worden gelegd tussen het kiesstelsel en het gegeven dat de stemming ten gunste van de antiseparatisten uitviel. ${ }^{130}$

In én opzicht was het kiesstelsel tot aan de grondwetsherziening van 1848 echter gunstig voor de afscheidingsgezinden: via de ridderschap - een provinciaal orgaan waarin edelen waren verenigd - had de Limburgse adel een relatief groot aandeel - een derde - in de bezetting van de statenzetels. De wetsvoorstellen tot herziening van het kiesstelsel die in juni 1847 aan de Tweede Kamer werden aangeboden, beoogden onder meer een wijziging in de samenstelling van de Provinciale Staten van Limburg: het aantal zetels voor de adel zou worden teruggebracht. Gouverneur Van Meeuwen had daar eerder bij Willem II op aangedrongen, 'daar toen op afscheiding van Limburg werd aangedrongen, de adel niet achterlijk is gebleven, en onder denzelven de grootste separatisten $[\ldots]$ werden aangetroffen.' ${ }^{151}$ Het terugdringen van de invloed van de Limburgse edelen zou een positieve uitkomst hebben op de vaderlandslievendheid van de leden van Provinciale Staten en daarmee op de Nederlandse gezindheid van de Limburgse afgevaardigden in Den Haag.

Tot wijziging van de verhouding tussen de drie standen in de Limburgse Staten is het niet meer gekomen: weldra raakte de herziening van het kiesrecht door de debatten over een grondwetswijziging in een stroomversnelling. De invloed van de adel werd daardoor, ongetwijfeld tot tevredenheid van de gouverneur, nog meer teruggedrongen, want in het nieuwe kiesstelsel werden Provinciale Staten niet langer standsgewijze samengesteld.

Ondanks de invloed die de adel in het kiesstelsel van 1840 kon uitoefenen op de Limburgse afvaardiging naar de Tweede Kamer, werkte dit stelsel in het nadeel van de afscheidingsbeweging. Dat gold ook voor het kiesstelsel ran na de grondwetsherziening in 1848 . Behalve onder de adel vond de separatistische beweging, zoals gezegd, haar aanhang hoofdzakelijk onder de bewoners van het platteland (boeren en grootgrondbezitters) en de lagere sociale strata in de steden. ${ }^{152}$ Onder deze groepen was het kiesrecht veel minder verspreid dan onder de tegenstanders van secessie. Het kiesstelsel 
kende grote invloed toe aan de gezeten burgerij, waartoe de groothandele en de fabrikanten behoorden, alsmede aan de ambtenarij.

Dit was het gevolg van de hoge census en het - zeker tot aan be nieuwe kiesstelsel van 1848 - bestaande relatieve overwicht van de stede op het platteland. Hoewel het Limburgse platteland in 1839 ruim drie ke zoveel inwoners telde als de steden, kregen beide standen evenvecl zeb (dertien) toegekend in de Staten. ${ }^{153}$ De stedelijke afvaardiging in PS werd-i overeenstemming met de bevolkingscijfers - samengesteld door Maastrid (zes statenleden), Venlo, Weert en Roermond (elk twee) en Sittard (eenl. Volgens gegevens uit 1841 was maar liefst de helft van de kiesgerechtigh inwoners van Maastricht van protestantsen huize en daarmee vrijwel zonde uitzondering tegen een scheiding van Nederland. ${ }^{155}$ In de Maastrichis afvaardiging naar Provinciale Staten namen protestanten een onevenrody grote plaats in, oordeelde gouverneur Gericke van Herwijnen in septembe 1841. Hij hoopte dat de stad eindelijk eens een katholiek zou afvaardiga naar Provinciale Staten, zodat er een 'betere evenredigheid' zou ontstan.?

Dat met name de steden Maastricht en Venlo, vanuit Nederlands pa spectief, werden geacht een gunstige invloed uit te oefenen op de same stelling van de Limburgse afvaardiging in de Tweede Kamer, vinden $\mathrm{k}$ terug in overheidscorrespondentie uit 1854. In januari van dat jaar ontring Commissaris des Konings Van Meeuwen een vertrouwelijke circulairew minister Van Reenen van Binnenlandse Zaken. Met het oog op de komek herziening van de kiesdistricten wilde de minister weten of er wijziginge gewenst werden in de samenstelling van deze districten. ${ }^{157} \mathrm{Nu}$ bood d districtsindeling gelegenheid tot kieswetgeografie ofwel politieke aardritip kunde: de districtsgrenzen konden zo gelegd worden dat zij een politid gewenste uitkomst zouden bevorderen. Het antwoord uit Maastricht op het ministeriële schrijven bevatte hierop een specifiek Limburgse variant.

Indien, aldus Van Meeuwen, zou worden gekozen voor een indelingw de provincie in enkelvoudige kiesdistricten, zou enige sturing in de $\mathrm{N}$ derlandse gezindheid van de afgevaardigden mogelijk zijn. De kiezers Maastricht vormden in het reeds bestaande dubbele district een mindehto ten opzichte van de kiezers uit het omliggende platteland. Een enkelvouf district Maastricht zou aan die situatie een einde maken en dat zou, 20 wor zag de Commissaris des Konings, een Nederlandsgezinde keuze bevorders omdat 'de stad Maastricht veel minder voor de afscheiding van Nederts dan de landelijke gemeenten van het arrondissement genegen is'.

Op eenzelfde wijze zou de keuze in Noord-Limburg kunnen wonte beïnvloed. Daar zou Venlo en omgeving, in plaats van te worden ingedere 
in het bestaande dubbele district Roermond, een eigen enkelvoudig district kunnen gaan vormen. Over zo'n enkelvoudig district Venlo merkt Van Meeuwen op dat het 'meer Nederlandsch gezind dan dat van Roermond zoude zijn, wegens het grooten en drukken verkeer met de Nederlandsche gewesten'.134

Overigens werd het stelsel van enkelvoudige districten niet doorgevoerd in de jaren vijftig: er werd besloten vast te houden aan het beginsel van de dubbele districten. De brief van Van Meeuwen geeft desondanks aan dat de centrale overheid - de Commissaris des Konings kan daar staatsrechtelijk toc worden gerekend - bewust bezig was met de vraag hoe de keuze van Tweede-Kamerleden in Limburg via het kiesstelsel kon worden beïnvloed.

Detegenkracht die de afscheidingsbeweging ondervond van de census en van de kiezers in de steden, met name Maastricht en Venlo, wordt duidelijk als we de uitslagen bekijken van de diverse verkiezingen voor vertegenwoordigende organen op nationaal niveau die in Limburg plaatsvonden. In mei 1848 werden de twee Limburgse afgevaardigden gekozen voor de Nationalversammlung te Frankfurt; in juli, september en november vonden in de provincie verkiezingen plaats voor de Tweede Kamer. ${ }^{159}$ Terwijl de separatisten bij de verkiezingen in mei een groot succes boekten, waren de uitslagen biij de drie kamerverkiezingen veel minder gunstig voor hen. Indien we het kiesstelsel dat werd gehanteerd bij de verkiezingen voor de Duitse Nationale Vergadering vergelijken met de (twee) stelsels die ten grondslag lagen aan de Tweede-Kamerverkiezingen, dan springen twee verschillen in het oog: bij de verkiezingen voor Frankfurt was er geen sprake van een census er gold algemeen mannenkiesrecht (vanaf 23 jaar) - én de bewoners van Maastricht en Venlo mochten niet meestemmen (zie bijlage rv). Daardoor was de achterban van de separatisten in mei veel sterker vertegenwoordigd onder het electoraat dan bij de diverse kamerverkiezingen. Beerenbroek en De Liedel de Well weten de grote winst voor de separatisten in mei uitdrukkelijk aan het ontbreken van een census en eerstgenoemde sprak dan ook de hoop uit dat er nimmer meer van een 'suffrage universel' sprake zou hoeven zijn. ${ }^{100}$

Bii deze vergelijking stuiten we op de kritiek die onder anderen de historicus Geurts heeft op de gebruikelijke interpretatie van de uitkomst van de mei-verkiezingen: hij noemt het aflezen van de populariteit van het separatisme uit die uitslag 'een hachelijke zaak'. ${ }^{161}$ De getrapte verkiezingen, de lage opkomst $(49,75 \%)$ en onzekerheid over de ware motieven die ten grondslag lagen aan de keuzes, plaatsen kanttekeningen bij de overwinning van Van Scherpenzeel Heusch, ${ }^{162}$ Zo was de mogelijke afscheiding van 
Limburg bij de aanwijzing van de kiesmannen uit de gemeente Arcen en Velden zelfs niet echt ter sprake gekomen. ${ }^{163}$ De uitslag van de verkieringa hoeft derhalve weinig te zeggen over de aanhang van het separation onder de stemgerechtigden en daarmee onder de bevolkingsgroepen $\hat{z}$ in 1848 niet of in mindere mate (indirect) zouden mogen deelnemen aan Tweede-Kamerverkiezingen. Pro-separatistisch stemgedrag wilde imne geenszins zeggen dat men zich ten volle bewust was van de consequenitis van zijn keuze; velen lieten zich waarschijnlijk niet leiden door staatkundip motieven maar door onvrede over de drukkende belastingen. ${ }^{164}$

Hoewel de twijfel over de ware motieven van separatistisch stemgath in mei gerechtvaardigd is, is de vraag of daardoor een vergelijking to sen de verkiezingen voor de Nationale Vergadering en die voor de Tweet. Kamer onmogelijk wordt. De onvrede over het fiscale stelsel was bijou beeld in november bij de rechtstreekse kamerverkiezingen geenszins luwd (zie hoofdstuk 5), maar vertaalde zich toen kennelijk minder in m separatistische uitslag. Om deze uitkomst gaat het hier meer dan om 2 achterliggende motieven. Als we bedenken dat in mei 16559 personendebnamen aan de verkiezingen, terwijl Limburg in november ongeveer $y w$ stemgerechtigden telde, zal ondanks de lage opkomst bij eerstgenoemk verkiezingen duidelijk zijn dat velen die in mei mochten stemmen, bij Tweede-Kamerverkiezingen waren uitgesloten. Het lijkt daarmee aannems lijk dat de census invloed uitoefende op de uitslag.

De relatie tussen census en uitslag kan nader worden onderzocht doorbi de mei-verkiezingen niet te kijken naar de stemgerechtigden, maar nart 308 kiesmannen, hiermee het bezwaar dat die verkiezingen indirect ware terzijde stellend. ${ }^{165}$ Van deze kiesmannen is de beroepsmatige achtergrod bekend. ${ }^{166}$ Onmiskenbaar vormden zij in sociaal-economisch opricht to minder elitair gezelschap dan de kiezers in juli en augustus (de leden wa Provinciale Staten) en de kiezers in november.

Door de kiesmannen als uitgangspunt van vergelijking te nemente tevens tegemoet worden gekomen aan het bezwaar dat de kiezers hun stel wellicht niet uitbrachten op grond van hun opvatting over het afscheiding vraagstuk. De kiesmannen stonden immers wel voor een duidelijke keur zij konden hun stem direct uitbrengen op Van Scherpenzeel Heusch die il streven naar afscheiding openlijk en veelvuldig naar voren had gebrat. En deze kiesmannen 'waren geen onwetende boeren wie men iets op de mouw kon spelden'. ${ }^{162} \mathrm{Zij}$ mogen zeker geacht worden de consequentic 18 hun keuze te hebben doorzien; massaal stemden zij voor de afscheiding beweging. 
Ten slotte kan er ten bewijze van de 'meer Nederlandsche stemming' in Venlo en Maastricht gewezen worden op de uitslagen bij de TweedeKamerverkiezingen in november. De tegenstanders van afscheiding vergarden toen hun grootste aanhang in de twee kiesdistricten waarin die steden gelegen waren.

Het kiesstelsel mocht dan niet echt in het voordeel werken van de separatisten, de verkiezing van Van Scherpenzeel Heusch, De Villers de Pité, Lambrechts en eerder van Corneli en De Weichs de Wenne geeft aan dat Nederlandsgezinde keuzes niet gegarandeerd waren. De Nederlandse overheid oordeelde daarom dat een actieve opstelling harerzijds gewenst was, w blijkt bijvoorbeeld uit een brief die minister De Kempenaer van Binnenlandse Zaken enkele maanden voor de Tweede-Kamerverkiezingen van november 1848 schreef aan gouverneur Van Meeuwen: 'De Regering meent [...] dat er iets zal moeten worden gedaan, om de uitkomsten der ophanden zijnde verkiezingen, zoo gewenscht mogelijk te doen uitvallen [...] '.16s

In Den Haag werd gezocht naar middelen om de uitslag binnen de wettelijke kaders, althans zonder aanpassing daarvan, te sturen. Dat was in Nederland niet ongebruikelijk: gedurende de gehele eerste helft van de negentiende eeuw trachtten koning en ministers voortdurend om TweedeKamerverkiezingen te beïnvloeden. ${ }^{169}$ In hoofdstuk 1 is de actieve rol belicht die de Limburgse gouverneurs hierbij speelden in het tijdval. 1815-1830. Maar ook na de terugkeer van de provincie onder Nederlands gezag in 1839 kregen haar gouverneurs een taak bij het bevorderen van de door Den Haag gewenste uitslag.

De eerste reguliere verkiezing van een Tweede-Kamerlid vond in Limburg plaats in oktober 1841 . Het betrof de vacature die was ontstaan na het (periodiek) aftreden van Kerens. Gouverneur Gericke van Herwijnen volgde mogelijke kandidaatstellingen en de verkiezing zelf op de voet, en met hem minister Schimmelpenninck van der Oye van Binnenlandse Zaken die had verzocht om vertrouwelijk te worden geïnformeerd over 'al de bijzonderheden' rondom de stemming. ${ }^{170}$ De gouverneur polste potentiële kandidaten en ontraadde in ieder geval een van hen om zich beschikbaar te stellen. ${ }^{171}$ Met de uitkomst was Gericke van Herwijnen tevreden, berichtte hij aan zowel de koning als de minister van Binnenlandse Zaken: het etrste door verkiezing aangewezen Limburgse Tweede-Kamerlid, jhr. Petit, was een 'weldenkend' man, 'ofschoon enigzins stijfhoofdig'. ${ }^{172}$ Bovenal zou de nieuwe afgevaardigde 'denkelijk in zijne parlementaire verrigtingen de hooge regering niet veel moeijelijkheden berokkenen'. ${ }^{173}$ In het bijzonder 
achtte de gouverneur de kans klein dat Petit de regering zou lastig ralh met redevoeringen'. ${ }^{174}$ Het kamerlid heeft tijdens parlementaire beradis gingen inderdaad nimmer het woord gevoerd.

Toen Petit drie jaar later aangaf in te zijn voor een verlenging van zi mandaat, ondervond hij aanvankelijk dan ook geen enkele tegenwerkin van de gouverneur: die was het namelijk om het even, mits de keuzemu niet zou vallen op een aanhanger van de afscheidingsbeweging. Toenve volgens bleek dat Petits kandidatuur werd gesteund door het separatistivds dagblad Gazette du Duché de Limbourg, veranderde de gouverneur dan os onmiddellijk van strategie. Hij zette zijn gezag nu in voor Strens, 'die he dan ook won', aldus Cramer in zijn dissertatie, daarmee de invloed vand gouverneur benadrukkend. ${ }^{175}$

Nauwelijks had Strens zitting genomen in de Tweede Kamer of hijwei voorgedragen als lid van de Hoge Raad. Strens schreef de Kamer nitti aanmerking te willen komen voor deze hoge justitiële post; een reden we zijn weigering gaf hij niet. ${ }^{176} \mathrm{Zijn}$ motief blijkt uit een andere, niet-openbe brief: de Kamer verlaten zou indruisen tegen de uitdrukkelijke wens va de koning. 'Zijne Majesteits verlangen is, dat gij in de Kamer blijft' had ${ }^{2}$ minister van Binnenlandse Zaken hem medegedeeld. ${ }^{177}$ Een opmerkelite wens, stelt de historicus Witlox, want als verklaard voorstander van em grondwetsherziening had de liberaal Strens zich juist tegenover Willem I geplaatst. Nu stond in de Limburgse politiek van die dagen echter nit de grondwetsherziening in liberale zin centraal, maar de kwestie van $\downarrow$ staatsrechtelijke positie van het gewest. Politieke keuzes, zoals de verkiezin van afgevaardigden naar 's lands vergaderzaal, dienen dan ook niet zover te worden bezien in het perspectief van een mogelijke grondwetswijigin maar veeleer in het licht van de afscheidingskwestie. Aldoende kan ois het koninklijk verlangen worden verklaard. Een vertrek van Strens wi de Kamer zou een nieuwe verkiezing noodzakelijk hebben gemaakt. Dr kans dat dan een voorstander van afscheiding zou worden gekozen w zeker niet denkbeeldig: Strens had immers maar nipt gewonnen van deve separatisme verdachte Petit (18 tegen 16 stemmen).

Gericke van Herwijnen zag het duidelijk als zijn opdracht om de afiut diging van opposanten naar Den Haag te voorkomen. In 1842 schreefhije koning:

Veronderstellende dat het Uwe Majesteit niet onaangenaam zal zin dat de Heer Michiels van Verduynen weder als lid van de staten: generaal worde gekozen, zal ik mijnen invloed daarhene rigten th 
trachten te bewerken dat tot die verkiezing reeds op den dag der opening [van de statenvergadering] wordt overgegaan. ${ }^{178}$

De gouverneur had succes: Michiels van Verduynen werd gekozen. Dat de regering haar hoogste vertegenwoordiger in de provincie inderdaad een bepalende rol toekende bij de verkiezing van de Limburgse afgevaardigden, blijkt nog eens duidelijk uit een brief van november 1846 . Minister Van Randwijck van Binnenlandse Zaken liet daarin, voorafgaand aan de verkietingen, de gouverneur weten erop te vertrouwen dat 'door U Hoog Edel Gestrenge's beleid [...] goede keuzen worden gedaan'. ${ }^{179}$

Soms specificeerde de regering haar wens. Zo werd bij diezelfde verkieingen een negatief oordeel uitgesproken over H.J.J.L. ridder de Stuers. ${ }^{1.00}$ Hocwel de minister geen reden gaf voor deze afwijzing, lijkt het aannemelijk dat aan de loyaliteit van De Stuers getwijfeld werd. Enkele decennia darvoor had hij nog als generaal gevochten aan de zijde van Napoleon en hij had daarmee tegenover de toenmalige Prins van Oranje, nu koning Willem II, gestaan. In de eerstvolgende statenvergadering na de verkiezing van 1846 legde De Stuers 'eene zoort van staatkundige geloofsbelijdenis' af, waarin hij zich beklaagde over de 'kwellingen en vexaties' waaraan het Nederlands gezag de Limburgers - het 'uitgemergelde Volk' - blootstelde. ${ }^{\text {in }}$ En bij de verkiezing in juli 1848 was De Stuers voor zijn stemmen vooral afhankelijk van 'de partij der oude separatisten', noteerde de gouverneur. ${ }^{16}$

De regering probeerde in de jaren veertig een actieve rol te spelen bij de aanwijzing van de Limburgse Tweede-Kamerleden. De eerste afgevaardigden werden in 1840 door haarzelf benoemd en vervolgens werd getracht invloed uit te oefenen, met name via de gouverneur in Maastricht. Daarbij maakte het beperkte aantal kiezers - de 39 statenleden - de zaak overzichtelijk. ${ }^{133} \mathrm{De}$ herziening van het kiesrecht in 1848 bracht hierin verandering: in november van dit jaar werden de Tweede-Kamerleden voor het eerst rechtstreeks gekozen.

Een opmerkelijk aspect bij deze verkiezingen was dat de regering afzag van bemoeienis. Georganiseerde overheidsbemoeienis kwam na 1848 natwelijks voor. ${ }^{134}$ De provincie Limburg vormde bij de eerste rechtsreekse verkiezingen echter een uitzondering op dit beleid van non-interventie. ${ }^{1 \text { s5 }}$ De verklaring moet gezocht worden in de politieke omstandigheden van die jaren. Met name in tijden dat het er politiek om spande was de regering geneigd om verkiezingen te beïnvloeden. ${ }^{186}$ In Limburg was de politieke 
situatie juist in de jaren 1848-1849 bijzonder gespannen: het was de period waarin de separatistische beweging zich krachtig roerde.

Oud-kamerlid Beerenbroek waarschuwde minister Bentinck van $\mathrm{K}$ enhuis van Buitenlandse Zaken in oktober 1848 voor de politieke gente die er kleefden aan rechtstreekse verkiezingen in zijn provincie: zone leiding kunnen populaire verkiezingen moeijelijk goed gaan.' Die vahi zingen mocht men niet overlaten aan 'agitateurs en misbruikmakers ve vertrouwen' ${ }^{187}$ Mede door deze brief van Beerenbroek zagen ministersi Donker Curtius (Justitie), De Kempenaer (Binnenlandse Zaken) en S. bom van Heemstra (Zaken van de Hervormde en andere erediensten, behis? die der Rooms-Katholieke) zich geplaatst voor een dilemma: terwillzij uz de verkiezingen haren vrijen loop zouden wenschen te laten', vroegdelin burgse situatie nu juist om 'gepaste instructien'. ${ }^{188}$ Een juiste woordken bood uitkomst. Een brief van de minister van Binnenlandse Zaken aan gouverneur in Limburg is als volgt geregistreerd in het repertorium oph ingekomen en uitgegane stukken:

Over de verkiezingen voor de Ile Kamer en over de beste wijz. waarop, naar het oordeel der Regering (zonder op de verkiezingen regtstreeks invloed te willen uitoefenen,) de werking tot verkerde einden, door tegenwerking ten goede zal kunnen worden tegengegaan. $^{189}$

Van beïnvloeding van regeringszijde was dus geen sprake, Den Haag wodk zich alleen gedwongen om beïnvloeding door anderen tegen te wethe Gouverneur Van Meeuwen kreeg daarom opdracht zich actief op te stelle voorkomen moest worden dat de separatisten bij de verkiezingen zoute winnen. Het gewijzigde kiesstelsel vroeg echter om andere interventiem delen en minister De Kempenaer had er een aantal in gedachten. Zo zode alle stemgerechtige ambtenaren in Limburg moeten worden aangespors om aan de verkiezingen deel te nemen en bovendien moesten zij vionde en bekenden 'die het met de algemeene zaak wel voor hebben' bew⿰氵 hetzelfde te doen. Vanzelfsprekend zou alleen gestemd mogen worden of tegenstanders van een afscheiding. ${ }^{190}$

In Noord- en Midden-Limburg werden bepaalde kandidaten extra t dersteund: in genoemd repertorium zijn brieven gerubriceerd ondet aanduiding: 'Over de middelen tot het doen slagen der candidatures нн Leclercq en Bontamps.' ${ }^{\prime 191}$ De twee genoemde personen waren kandís in respectievelijk het district Roermond en het district Venlo; zij zoudeb 
regering 'als afgevaardigden welkom zijn', schreef minister De Kempenaer. ${ }^{192}$ Ook in Zuid-Limburg bemoeide de regering zich actief met de kandidaten. He zittende kamerlid Corneli kreeg een negatief stemadvies uit Den Haag en de gouverneur, die tevergeefs had getracht Karel de Limpens over te halen zich kandidaat te stellen, ging op zoek naar een andere geschikte antiseparatistische kandidaat voor de tweede verkiezingsronde in Heerlen. ${ }^{193}$ Bii de herstemming in het district Sittard trachtte hertogelijk commissais Beerenbroek, zo schreef hij, de tegenkandidaat van Van Scherpenzeel Heusch, Willem Delahaye, 'er door te halen'. ${ }^{194}$ Delahaye haalde het niet, maar het verschil met Van Scherpenzeel Heusch was niet bijzonder groot: 20 tegenover $2499^{195}$

Om een gunstige uitslag van de verkiezingen te bewerkstelligen wilde de minister ook de druk op de burgemeesters opvoeren. Hij stelde voor 'aan alle Ambtenaren, vooral aan de Burgemeesters, de opmerking te maken, dat hunne gedragingen, ten dezen opzichte, nauwlettend zullen worden gadegeslagen, en in gedachtenis gehouden, om in aanmerking te worden genomen, bij latere benoemingen of bevorderingen.' ${ }^{196}$

Deze politicke chantage werd nog versterkt doordat erbij zou moeten worden gemeld dat de voordracht van burgemeesters die voor 1 januari 1849 herbenoemd dienden te worden, zou worden uitgesteld tot na de verkiezingen. Uit de Staatscourant wordt in ieder geval duidelijk dat de besluiten tot (her)benoeming van de burgemeesters in de Limburgse gemeenten ná de verkiezingen van 30 november 1848 zijn ondertekend door de koning. ${ }^{197}$

Tot in detail werd de procedure bij de stemming onderzocht op mogelijkheden tot beïnvloeding. Zo werd voorgesteld de stembriefjes die aan de kiezers moesten worden toegezonden, zo laat mogelijk te versturen. Op die manier zou zo veel mogelijk kunnen worden voorkomen dat 'de tegenpartij [de afscheidingsbeweging] de huizen der eenvoudige kiezers indringt' om daar de briefjes alvast in te vullen. ${ }^{198} \mathrm{Na}$ de eerste verkiezingsronde op 30 november 1848 blikte Beerenbroek tevreden terug op alle bemoeienissen van overheidszijde met betrekking tot de Tweede-Kamerverkiezingen: 'Onze pogingen om de separatisten [...] te weren zijn niet tevergeefs aangewend $[\ldots]$...

De procedure die in 1848 werd gevolgd bij de aanwijzing van de EersteKamerleden, bood een meer openlijke gelegenheid tot beïnvloeding. Deze afgevaardigden werden immers door Willem $n$ benoemd. Weliswaar diende hij zich daarbij te beperken tot de kandidaten die rechtstreeks binnen de districten waren gekozen, de mogelijkheid om minder welgevallige figuren buiten de Kamer te houden, was ruimschoots aanwezig. Wat betreft de Lim- 
burgers koos de koning dan ook voor drie 'de Nederlandse zaak' toegodes vertegenwoordigers. Separatistische kandidaten waren door de regeringin deze benoemingen 'voorbijgegaan', noteerde gouverneur Van Meewwea

\section{'Als Limburgsch afgevaardigde'}

Welke invloed hebben de Limburgse afgevaardigden in de hoedanithe van kamerlid uitgeoefend op de gang van zaken? Is de provincie ded ia Nederland gebleven dankzij of ondanks de Limburgers in Den Haag?

Voorop moet worden gesteld dat van zelfbeschikking, uit te offect via volksvertegenwoordigers, geen sprake was. Dat hadden de Limburgn eerder al, in de jaren dertig, kunnen ervaren. Over de staatkundige tockon van Limburg werd buiten de provincie beslist en in belangrijke mate a buiten Nederland. Niet voor niets heeft Van Scherpenzeel Heusch th zwaartepunt van zijn parlementaire activiteiten in Frankfurt am Maine niet in Den Haag gelegd. De rol van de Limburgse leden van de State Generaal kan daarom niet anders dan beperkt en indirect geweest zijn.

Zo konden kamerleden, door deel te nemen aan activiteiten van heri separatisten, hetzij Nederlandsgezinden, de desbetreffende stroming en zekere status geven en daarmee versterken. Gouverneur Van Meewn klaagde in april 1848 dat een afscheidingsmeeting van Van Scherpenu Heusch door de aanwezigheid van de Tweede-Kamerleden De Weichs a Wenne en Corneli 'een te solemneel character' had gekregen. ${ }^{201}$

Ook het tegenovergestelde kon gelden: indien kamerleden hun mok werking weigerden, boette een activiteit aan kracht in. In één geval wow kwam een Limburgse afgevaardigde zelfs dat de afscheidingsbeweging i ting kon geven aan haar gevoelens. Het betreft hier J.L.M. Leclercq, inis/ voor de eerste maal gekozen tot lid van de Tweede Kamer, maar toen is toegelaten (zie hoofdstuk 2). De weigering om Leclercq admissie te velace had in Limburg een bijzonder onaangename indruk gemaakt en gour neur Van Meeuwen had aanwijzigingen dat de onvrede onder de provinoil politici zo groot was dat er in de spoedig volgende statenvergadering et poging zou worden ondernomen een adres over de kwestie te doen wity naar Den Haag.

Nu was Willem n bijzonder bevreesd voor adressen vanuit de provinit vertegenwoordigingen. Eerdere ervaringen met de klachten uit de zuido gewesten in de jaren van het Verenigd Koninkrijk waren hieraan dot Die klachten hadden uiteindelijk de Belgische afscheiding ingeleid. In geval van Leclercq lijkt een vergelijking met de situatie van voor is 
niet ver gerocht, want het waren met name de separatistische kringen in Limburg die trachtten de kwestie te gebruiken. Voor hen was dit staaltje van buitensluiting koren op de molen, wist ook de gouverneur. De door hem gewaarschuwde minister van Binnenlandse Zaken gaf hem dan ook instructic zijn invloed aan te wenden om verzending van een verzoekschrift it voorkomen.

Veel hoefde de gouverneur niet te doen om dit doel te bereiken; hij kreeg hulp van nota bene Leclercq zelf. Die had namelijk alle medewerking aan het doen uitgaan van een adres geweigerd. Het ontbreken van juist zijn handtekening zou het protest enorm ontkrachten. Er werd dan ook van afgerien om een ontwerp-adres aan Provinciale Staten voor te leggen. De koning, door Van Meeuwen in een geheim rapport op de hoogte gebracht, was 20 te spreken over Leclercqs handelwijze dat hij de gouverneur liet opdragen Leclercq 'Z[ijner] M[ajesteits] bijzonderen tevredenheid te doen kennen'

De koning schakelde vaker Limburgse kamerleden in. De parlementaire werkaamheden vereisten een geregelde aanwezigheid in Den Haag, waardoor contacten met ministers en het hof werden vergemakkelijkt. Eerder is al gemeld dat Eerste-Kamerlid De Liedel de Well in regelmatige verbinding stond met regeringskringen en dat hij in mei 1848 op last van de koning poogde een anti-separatistische petitie te initiëren. Ook is al melding gemaakt van het koninklijk bevel om Tweede-Kamerlid Michiels van Verduynen duidelijk te maken dat diens medewerking aan een petitionnement niet op prijs werd gesteld.

De aanwezigheid van Limburgers in Den Haag was verder van belang omdat hun handelen invloed uitoefende op de stemming ten opzichte van Limburg in landelijke politieke kringen, bij het bredere publiek en ook in Frankfurt. Daarbij hadden de Limburgse kamerleden die wilden ijveren voor het behoud van een staatkundige band met Nederland een hindernis te nemen die inherent was aan hun verschijnen in 's lands vergaderzaal: de grote terughoudendheid in de Nederlandse politiek tegenover Limburg was voor een niet-gering deel terug te voeren op de afkeer van de invloed van het katholieke volksdeel in de Staten-Generaal. ${ }^{203}$ Nu konden de weinig hartelijke gevoelens die het gevolg waren van deze vooringenomenheid door de Limburgse afgevaardigden verder worden versterkt of worden verzwakt. Zowasde ministerraad voorafgaand aan de Tweede-Kamerverkiezingen van november 1848 van oordeel dat de komst van separatistische afgevaardigden naar Den Haag 'bij de stemming van sommigen hier te lande aangaande Limburg tot bedenkelijke gevolgen zou kunnen leiden'? 
Alleen al het gegeven dat bij de verkiezing in juli van dat jaar in depe soon van Geradts een overtuigd tegenstander van de afscheidingsbenem naar Den Haag was afgevaardigd, kan dan ook beschouwd worden alke belangrijke steun in de rug voor de regering en zal stellig ook in Franks indruk hebben gemaakt. ${ }^{205}$ Juist op een uiterst kritiek moment voorth behoud van Limburg - als gevolg van het besluit van 19 juli door de lie onale Vergadering - verscheen nu namens de provincie een uitgesprote anti-separatist in de Kamer. Geradts zelf wist de verkiezingsuitslag hane aan te wenden ten nutte van de Nederlandse zaak. Tegenover zijn niken collega's in Den Haag verklaarde hij:

Ja, Edel Mogende Heeren, het hertogdom verlangt dat behoud [ran de band met Nederland]. Tot bewijs daarvan strekke mijne tegenwoordigheid in deze Vergadering: ware het anders, ik zou de eer niet hebben gehad te midden van U Edel Mogenden plaats te nemen.*

Indien we de parlementaire handelingen van de Limburgse kamerledeni de jaren veertig bekijken, blijkt De Weichs de Wenne de enige die in De Haag openlijk, zij het uiterst voorzichtig, durfde te vragen om afscheid indien de regering geen voldoening kon geven aan de 'regtmatige lawe ten van Limburg' diende zij de koning 'eene afzonderlijke administrail in overweging te geven, aldus de afgevaardigde tijdens de zitting ran! augustus $1848 .{ }^{207}$ Overigens had Corneli in maart van dat jaar gesteld de 'de [Nederlandse] administratieve instellingen [...] met onze [Limburge gewoonten niet overeenstemmen $[\ldots]^{208}$ Eerder, ten tijde van de eerstes paratistische golf, had hij in de Kamer reeds gesproken over de verhouding tussen zijn provincie en (de rest van) Nederland. Hij had Limburg toen schreven als 'eenen afzonderlijken, met bijzondere regten en verplichtings en in verscheidenene opzigten zelfstandigen Staat. ${ }^{209}$

Zowel De Weichs de Wenne als Corneli bevond zich an separatisitich zijde. De overige drie kamerleden die daartoe zijn gerekend - Petit. $D$ Villers de Pité en Lambrechts - lieten zich in de hier onderzochte periox nimmer uit over de band met Nederland. Terecht constateert Beumersits ook dat de Limburgse leden van de Tweede Kamer zich nauwelijks 'in nax of mindere mate separatistisch uitten'.210

Veel talrijker klonken verklaringen van aanhankelijkheid jegens Node land. In de jaren veertig hebben acht Limburgse kamerleden zich uitgedet ten gunste van de staatsrechtelijke band met Nederland. ${ }^{21}$ Voor de dick lijkheid zij hier opgemerkt dat die verklaringen geenszins impliceerden bै 
er geen klachten waren over het Nederlands bewind. Eerste-Kamerlid De Rijk zei het in 1849 aldus: 'De inwoners van Limburg zijn Nederlanders aan Vorst en Vaderland gehecht, doch tevreden zijn zij niet [...].'212

De pro-Nederlandse parlementaire redevoeringen waren niet zonder betokenis, vooral niet voor de regering in Den Haag. In de herfst van 1848 liet zij in Frankfurt een brochure verspreiden getiteld Drei Reden Limburgischer Abgeordneten zur Zweiten Kammer der Niederländischen Generalstaaten über die Verhältrisse des Herzogthums Limburg. De bundel bevatte de pleidooien die Geradts, Thissen en Swart in de Kamer hadden gehouden tegen een mogelijke afscheiding. ${ }^{213}$ De leden van de Nationale Vergadering, de Duitse riksministers, de buitenlandse gezanten en de gevolmachtigden ontvingen een exemplaar van de brochure. De Nederlandse gezant in Frankfurt, Von Scherff, die op verzoek van minister Bentinck van Nijenhuis van Buitenlandse Zaken zorg had gedragen voor de verspreiding van de brochure, verwachtte daarvan 'un bon effect'. ${ }^{214}$

Twee Limburgse leden van de Staten-Generaal verdienen hier bijzondere andacht, omdat zij hun parlementaire mandaat uitdrukkelijk en zelfs bij uitsluiting hebben aangewend om hun opvatting over een afscheiding van Limburg kracht bij te zetten: Geradts en Van Scherpenzeel Heusch.

Dat de laatste geen zitting nam in de Kamer belette hem niet het verkregen mandaat te benutten voor de separatistische zaak. Juist door te weigeren als afgevaardigde af te reizen naar Den Haag, trachtte hij de afscheidingsbeweging een dienst te bewijzen. De Tijd schreef over een gerucht dat Van Scherpenzeel Heusch zijn plaats in het parlement niet wilde innemen om op die manier 'de regering in verlegenheid te brengen en de provincie Limburg gedeeitelijk onvertegenwoordigd te laten'.215

Op 15 februari 1849 schreef Van Scherpenzeel Heusch aan de Tweede Kamer dat hij 'als Limburgsch afgevaardigde', alvorens zitting te kunnen nemen in de Kamer, 'een categorisch antwoord' verwachtte op een aantal vragen betreffende de staatkundige positie van het hertogdom. ${ }^{216} \mathrm{Zo}$ wilde hij weten of de Nederlandse wetgever accepteerde dat de Duitse grondwet met instemming van Van Scherpenzeel Heusch door de Nationale Vergadering opgesteld - ook in Limburg van kracht zou zijn. Het was een herhaling van de tactiek die hij in mei 1848 had gevolgd in Frankfurt en waarmee hij er toen voor had gezorgd dat de Limburgse kwestie prominent op de (Duitse) politieke agenda verscheen. ${ }^{27} \mathrm{Nu}$ wilde hij bij het Nederlandse parlement hetzelfde bewerkstelligen.

Maar wat in Frankfurt was geslaagd, mislukte in Den Haag. De commissie van verzoekschriften van de Tweede Kamer boog zich over de missive 
van Van Scherpenzeel Heusch en bracht vervolgens verslag uit: 'Uwe $C_{0}$ missie is van oordeel, dat het wel boven allen twijfel verheven zal zijn, deze Kamer uit geenerlei hoofde kan geacht worden geroepen te zipt het geven van eenig antwoord op de vragen, die de adressant heeft goeds vonden haar ter beantwoording voor te stellen [...]'? ${ }^{218}$ De Kamer beloe overeenkomstig dit advies over te gaan tot de orde van de dag en daarme de brief onbeantwoord terzijde te schuiven. Zo werd voorkomen dat eten debat zou ontstaan over de Limburgse kwestie, zoals eerder in Frankfer was gebeurd.

Op 18 augustus 1848 sprak de Maastrichtenaar Geradts in de Tweed Kamer. Hoewel deze rede zijn enige verbale bijdrage is aan de parleme taire handelingen, zal zij alleen al gezien haar lengte - Geradts moet mee dan een uur hebben gesproken - niet onopgemerkt zijn gebleven. Borai was de toespraak vanuit Nederlands perspectief bij uitstek geschikt we propagandistische doeleinden. Daarvan was ook de tegenpartij zich keme lijk bewust, want Van Scherpenzeel Heusch voelde zich geroepen om in $D$ Limburger in felle bewoordingen op de redevoering te reageren. ${ }^{219}$

Geradts zelf heeft met zijn toespraak ook uitdrukkelijk het doel gehs om de band met Nederland te verstevigen. Uit de kabinetsnotulen blijkte hij minister Donker Curtius van Justitie van tevoren polste met de vam of het niet wenselijk zou zijn dat hij, als nieuwgekozen Limburgse affe vaardigde, bij de discussie over de grondwetsherziening 'de nuttigheid de vereniging van Limburg met Nederland' zou benadrukken. ${ }^{220}$ De toespral heeft de Nederlandse zaak in Limburg ongetwijfeld goede diensten ben: zen. ${ }^{221}$ Het nut van de rede werd ook door de Nederlandse overheid erkent de toespraak maakte deel uit van de eerder vermelde, in Frankfurt uity brachte brochure; daarnaast werd zij verspreid via Nederlandse krantene in Limburg gaf gouverneur Van Meeuwen opdracht Geradts' woorden : drukken en uit te geven.

De toespraak is met name bijzonder omdat hierin werd betoogd de een afscheiding van Limburg niet alleen onwenselijk was voor de provinc zelf, maar in economisch en militair opzicht ook voor Nederland utes nadelig zou zijn. Bovendien was secessie financieel onaantrekkelijk voort Nederlandse staat, omdat Limburg de schatkist jaarlijks meer opbracht zij kostte: een argument dat het in Nederland altijd goed heeft gedan.

Ook gaf Geradts zijn provincie via haar hoofdstad een plaats in c geschiedenis van de Nederlandse natie: Maastricht was 'eeuwen lang Net lands eerste zuidelijke wachtster geweest', een 'voorregt' waarvoor de se zich volgens het kamerlid vele opofferingen en heldendaden had getroos. 
Volgens de afscheidingsgezinde afgevaardigde Corneli ontbrak het nu juist an die historische band. Hij had enkele jaren daarvoor in de Kamer verkondigd dat Limburg bij Nederland was gevoegd 'zonder dat de historische roem van Nederlandsche voorvaderen gemeenschappelijk vaderlandsch gevol kan opwekken'.23 De provincie had volgens Corneli historisch gezien veel meer gemeen met Belgiẽ. In maart 1839 had hij in de Kamer van Volksvertegenwoordigers te Brussel verklaard dat België het land was 'avec laquelle nous sommes unis depuis la glorieuse bataille de Woeringen; avec laquelle nous avons vécu sous Marie-Thérèse, dont nous avons partagé les jours de bonheur et malheur.'224

Dat Geradts en Corneli wezen op de gemeenschappelijke geschiedenis van hun provincie met hetzij Nederland, hetzij Belgiè, was en is een niet ongebruikelijk element in een poging tot natievorming. Dat een van hen of dat zij beiden de historie daarbij (enigszins) geweld aandeden, is al zeker niet ongewoon. ${ }^{23}$

Een hernieuwde proeve van loyaliteit?

$\mathrm{Na}$ in de jaren vijfig op de achtergrond te zijn geraakt, werd de Limburgse kwestie in de jaren zestig weer actueel, met name door de gebeurtenissen rondom het hertogdom Sleeswijk. Deze paragraaf richt zich op de periode die begrensd wordt door de kwestie Sleeswijk (1863) en door de ontbinding van de Duitse Bond (1867).

Provinciale Staten van Limburg reageerden verheugd op het verbreken van de banden met Duitsland. Tijdens de zomervergadering van 1867 besoten zij bij acclamatie een commissie van vijf statenleden af te vaardigen naar Den Haag om daar hun dank over te brengen aan de koning. Na een grootse ontvangst in de residentie, waarbij onder anderen alle ministers, de vice-voorzitter van de Raad van State en de beide kamervoorzitters aanwezig waren, volgde een diner ten paleize. Delegatievoorzitter A.J.J.H. Thissen, oud-lid van de Eerste Kamer, nam het woord en sprak tot Willem nI:

Heden, Sire, wij zeggen het met vreugde en met fierheid, heden zijn wij niets anders meer dan Nederlanders, die ons gelukkig achten onder de wijze regering Uwer Majesteit en de onbelemmerde werking van vrije instellingen, een eenig gemeenschappelijk vaderland met onze broeders in alle provinciën des rijks te bezitten en met hen allen te kunnen wedijveren in liefde voor dat vaderland, in trouw en verknochtheid aan het doorluchtige Huis van Oranje-Nassau. ${ }^{226}$ 
van Van Scherpenzeel Heusch en bracht vervolgens verslag uit: 'Uwe $C_{0}$ missie is van oordeel, dat het wel boven allen twijfel verheven zal zijn, de deze Kamer uit geenerlei hoofde kan geacht worden geroepen te zijn to het geven van eenig antwoord op de vragen, die de adressant heeff goede vonden haar ter beantwoording voor te stellen [...]'? ${ }^{218}$ De Kamer besion overeenkomstig dit advies over te gaan tot de orde van de dag en daame de brief onbeantwoord terzijde te schuiven. Zo werd voorkomen daterea debat zou ontstaan over de Limburgse kwestie, zoals eerder in Frankfu was gebeurd.

Op 18 augustus 1848 sprak de Maastrichtenaar Geradts in de Tweed Kamer. Hoewel deze rede zijn enige verbale bijdrage is aan de parleme taire handelingen, zal zij alleen al gezien haar lengte - Geradts moet me dan een uur hebben gesproken - niet onopgemerkt zijn gebleven. Boveni was de toespraak vanuit Nederlands perspectief bij uitstek geschikt wo propagandistische doeleinden. Daarvan was ook de tegenpartij zich kents lijk bewust, want Van Scherpenzeel Heusch voelde zich geroepen om in $\mathrm{x}$ Limburger in felle bewoordingen op de redevoering te reageren. ${ }^{219}$

Geradts zelf heeft met zijn toespraak ook uitdrukkelijk het doel gehi om de band met Nederland te verstevigen. Uit de kabinetsnotulen blijkt hij minister Donker Curtius van Justitie van tevoren polste met de val of het niet wenselijk zou zijn dat hij, als nieuwgekozen Limburgse aff vaardigde, bij de discussie over de grondwetsherziening 'de nuttigheid de vereniging van Limburg met Nederland' zou benadrukken. ${ }^{220}$ De toesprai heeft de Nederlandse zaak in Limburg ongetwijfeld goede diensten bent zen. ${ }^{221}$ Het nut van de rede werd ook door de Nederlandse overheid erkent de toespraak maakte deel uit van de eerder vermelde, in Frankfurt uity brachte brochure; daarnaast werd zij verspreid via Nederlandse krantena in Limburg gaf gouverneur Van Meeuwen opdracht Geradts' woorden: drukken en uit te geven.

De toespraak is met name bijzonder omdat hierin werd betoogd de een afscheiding van Limburg niet alleen onwenselijk was voor de provinu zelf, maar in economisch en militair opzicht ook voor Nederland utts nadelig zou zijn. Bovendien was secessie financieel onaantrekkelijk woor h Nederlandse staat, omdat Limburg de schatkist jaarlijks meer opbracht zij kostte: een argument dat het in Nederland altijd goed heeft gedaan.

Ook gaf Geradts zijn provincie via haar hoofdstad een plaats in k geschiedenis van de Nederlandse natie: Maastricht was 'eeuwen lang Not lands eerste zuidelijke wachtster geweest', een 'voorregt' waarvoor de $\$$ zich volgens het kamerlid vele opofferingen en heldendaden had getroses" 
Volgens de afscheidingsgezinde afgevaardigde Corneli ontbrak het nu juist an die historische band. Hij had enkele jaren daarvoor in de Kamer verkondigd dat Limburg bij Nederland was gevoegd 'zonder dat de historische roem van Nederlandsche voorvaderen gemeenschappelijk vaderlandsch gewel kan opwekken': ${ }^{w}$ De provincie had volgens Corneli historisch gezien ved meer gemeen met België. In maart 1839 had hij in de Kamer van Volksvertegenwoordigers te Brussel verklaard dat Belgiě het land was 'avec laquelle nous sommes unis depuis la glorieuse bataille de Woeringen; avec laquelle nous avons vécu sous Marie-Thérèse, dont nous avons partagé les jours de bonheur et malheur'.24

Dat Geradts en Corneli wezen op de gemeenschappelijke geschiedenis van hun provincie met hetzij Nederland, hetzij Belgiè, was en is een niet ongebruikelijk element in een poging tot natievorming. Dat een van hen of dat $x$ ij beiden de historie daarbij (enigszins) geweld aandeden, is al zeker niet ongewoon. ${ }^{22}$

\section{Een hernieuwde proeve van loyaliteit?}

$\mathrm{Na}$ in de jaren vijfig op de achtergrond te zijn geraakt, werd de Limburgse kwestic in de jaren zestig weer actueel, met name door de gebeurtenissen rondom het hertogdom Sleeswijk. Deze paragraaf richt zich op de periode die begrensd wordt door de kwestie Sleeswijk (1863) en door de ontbinding van de Duitse Bond (1867).

Provinciale Staten van Limburg reageerden verheugd op het verbreken van de banden met Duitsland. Tijdens de zomervergadering van 1867 besloten zij bij acclamatie een commissie van vijf statenleden af te vaardigen naar Den Haag om daar hun dank over te brengen aan de koning. $\mathrm{Na}$ een grootse ontvangst in de residentie, waarbij onder anderen alle ministers, de vice-voorzitter van de Raad van State en de beide kamervoorzitters aanwezig waren, volgde een diner ten paleize. Delegatievoorzitter A.J.J.H. Thissen, oud-lid van de Eerste Kamer, nam het woord en sprak tot Willem m:

Heden, Sire, wij zeggen het met vreugde en met fierheid, heden zijn wij niets anders meer dan Nederlanders, die ons gelukkig achten onder de wijze regering Uwer Majesteit en de onbelemmerde werking van vrije instellingen, een eenig gemeenschappelijk vaderland met onze broeders in alle provinciën des rijks te bezitten en met hen allen te kunnen wedijveren in liefde voor dat vaderland, in trouw en verknochtheid aan het doorluchtige Huis van Oranje-Nassau. ${ }^{220}$ 
ook de Limburgse afgevaardigden zich op in de twee kampen. De liberal. katholieken Van der Maesen de Sombreff en De Bieberstein stonden an de ene en de conservatief-katholiek Haffmans aan de andere kant; De Lon de Berg nam een minder duidelijke positie in (meer over de indeling in politieke stromingen in hoofdstuk 4).

Tegen de achtergrond van deze nationaal-politieke scheidslijnen laat de houding van de Limburgse Tweede-Kamerleden aan duidelijkheid niets tt wensen over. ${ }^{25}$ Deze houding geeft geen verschil weer in het onverdeckld positieve oordeel over het verbreken van de banden met Duitsland, max duidt op een verschil in nationaal-politieke loyaliteiten. Het (stem)gedrag van de liberaal-katholieke kamerleden uit Limburg wilde dus geenszins de in hun provincie alom aanwezige tevredenheid over het beëindigen van de relatie met Duitsland ter discussie stellen. Hun parlementaire handelingen waren dan ook niet bedoeld als weerlegging van de plechtige dankzegging door Provinciale Staten, hoezeer hun tegenstrever Haffmans ook trachtte zijn collega-afgevaardigden te overtuigen dat dit wel degelijk het geval was

Ik zou mijne geheele provincie en de Provinciale Staten van Limburg, die met acclamatie een dankadres aan den Koning voteerden, een slag in het aangezigt geven, indien ik mij durfde vermeten mij tegen dezen Minister van Buitenlandsche Zaken te verklaren. lk zou de dankbaarheid verloochenen, die ieder Limburger bezielt over hetgeen voor die provincie gedaan is $[\ldots],{ }^{236}$

De verkiezingscampagne die in de winter van 1867-1868 in Limburg werd gevoerd, bevestigt dat de liberaal-katholieken niet het beëindigen van de betrekkingen met Duitsland ter discussie stelden; zij trachtten de kiezers alleen duidelijk te maken dat die - op zich positieve - uitkomst van de internationale verwikkelingen níet te danken was aan Van Zuylen van Nijevelt. ${ }^{26}$

Het losmaken van Limburg uit de Duitse Bond was eerder ondanks dan dankzij de minister tot stand gekomen, oordeelde Van der Maesen de Sombreff. Als oud-minister van Buitenlandse Zaken in het tweede kabinetThorbecke (1862-1866) was hij de meest prominente liberaal-katholiek onder de Limburgse afgevaardigden in Den Haag en hij speelde dan ookeen voorname rol in het verzet tegen zijn conservatieve opvolger Van Zuylen van Nijevelt. Daarbij trok hij samen op met Thorbecke. ${ }^{238}$ Hun kritiek richtte zich er vooral op dat de minister had nagelaten om al in 1866 (officieel) te verklaren dat de Nederlandse regering Limburg niet langet beschouwde als lid van de Duitse Bond; die Bond was toen immers ten 
gevolge van de oorlog tussen de twee belangrijkste Bondsleden, Pruisen n Oostenrijk, feitelijk ontbonden. Van Zuylen van Nijevelt wilde echter vorzichtig opereren om op die manier Pruisen noch Oostenrijk voor het hoofd te stoten: geen eenzijdige en wellicht voorbarige stappen door de Nederlandse regering, maar een internationaal verdrag zou de positie an Limburg moeten veiligstellen. Dat gebeurde in mei 1868 door het Traktast van Londen. Nederland had zich, door ondertekening van dit verdrag, tevens mede-garant gesteld voor de Luxemburgse neutraliteit en deze collectieve garantie dreigde Nederland mee te sleuren in toekomstige internationale conflicten, zo luidde de kritiek van onder anderen Thorbecke en Van der Maesen de Sombreff.

Het ging bij de Limburgse afgevaardigden dus niet om de vraag of iij al dan niet de band met Duitsland wilden verbreken, maar om de raag hoe zij stonden tegenover de politieke signatuur van het zittende labinet. Daarmee gold voor hen wat ook op de overige afgevaardigden van toepassing was: de Luxemburgs-Limburgse kwestie werd aangegrepen als wapen in de nationaal-politieke strijd.

Dit bleek ook bij de verkiezingen van januari 1868 . Voorafgaand aan deze verkiezingen overlegde Commissaris des Konings Van der Does de Willebois met Leopold Haffmans en Jan Hendrik Arnoldts, twee Limburgse kandidaten die de conservatieve regering welgezind waren. Dit overleg vond plaats met medeweten van minister J. Heemskerk Azn. van Binnenlandse Zaken. Ook liet Van der Does de Willebois aan de pastoors in Maastricht weten dat de verkiezingsuitslag zou worden beschouwd als een proeve van loyaliteit aan Oranje en Nederland. ${ }^{29}$ Een hernieuwde proeve van de Limburgse loyaliteit tegenover het Nederlandse vaderland?

Het stemgedrag werd in 1868 ook buiten Limburg in verband gebracht met het doen blijken van aanhankelijkheid jegens Oranje: aanhangers van het conservatieve kabinet hadden, evenals twee jaar eerder, de verkiezingsstrijd het thema 'voor of tegen de koning' meegegeven. ${ }^{240}$ In dat kader dient hier ook de waarschuwing van de Commissaris des Konings te worden geplatst: een stem op de liberaal-katholieken betekende een stem tegen Oranje. De liberalen werden er immers van beschuldigd de koninklijke macht te willen inperken.

Van der Does de Willebois had aangegeven dat de Limburgse kiezers bij de stemming, naast hun aanhankelijkheid jegens Oranje, ook hun loyaliteit tegenover Nederland zouden kunnen tonen. Ook dit was niet uitzonderlijk. $Z_{0}$ had de koning eerder, in oktober 1866 , in een proclamatie die in alle Nederlandse gemeenten was aangeplakt, de belangen van 'ons dierbaar 
Vaderland' verbonden met het aanblijven van het conservatieve kabinet. $x$ In het licht van de politieke strijd tussen liberalen en conservatieven dienen we ook de opmerking van Van der Does de Willebois te plaatsen. ${ }^{20} \mathrm{It}$ meer daar de Commissaris des Konings in de Limburgse kwestie getn aanleiding kan hebben gevonden voor zijn interventie: een stem op de liberaal-katholieken was immers zeker geen stem tegen de staatsrechtelijke band met Nederland. De verbreking van de relatie met de Duitse Bonden het daarmee op ondubbelzinnige wijze gaan behoren tot Nederland, was immers ook hun streven geweest.

De terminologie was dus weliswaar gelijk aan die uit de jaren veertiger werd gesproken van de loyaliteit jegens het (Nederlandse) vaderlandmaar de context was een geheel andere. Tussen 1840 en 1850 makten de Limburgse kamerleden een keuze tussen nationaliteiten of soevereinen, in 1868 betrof het een partijpolitieke keuze.

Ook de verdeling van Limburg in kiesdistricten kan in de jaren zestig meer dan daarvoor in een nationaal-politiek verband worden geplaats. Evenals begin jaren vijftig treffen we eind jaren zestig een plan aan om door middel van een aanpassing van de kiesdistricten de samenstelling van het Limburgse deel van de Tweede Kamer te beïnvloeden. In 1868-1869, toen de reguliere aanpassing van de districtsgrenzen op de politieke agenda stond, werd besibter om eer extra argevaardigde te laten kiezen in ZuidoostNederland, omdat de bevolking hier een grote groei had doorgemaakt.

Het liberale kabinet-Van Bosse-Fock, opvolger van het conservatieve kabinet-Van Zuylen van Nijevelt-Heemskerk, werd er door De Tijd van beschuldigd bij de nieuwe districtsindeling slechts één streven te hebben: het enige Limburgse kamerlid dat niet tot de liberaal-katholieken behoorde, de conservatief-katholiek Haffmans, uit de Kamer te krijgen. ${ }^{24}$ De parlementaire beraadslagingen die volgden, lieten een scherpe tegenstelling zien tussen de liberaal-katholieken en de conservatief-katholieken. Zoals eerder geconstateerd, spleet deze politieke strijd de Limburgse TweedeKamerleden (zie verder hoofdstuk 4).

Bij het beïnvloeden van de keuze van een Limburgse afgevaardigde ging het niet langer om zijn Nederlandse gezindheid, maar om zijn nationaalpolitieke oriëntatie. De invloed die de Commissaris des Konings trachtte uit te oefenen en de kieswetgeografie die met de provincie werd bedreven. droegen niet meer een eigenaardig Limburgs karakter, maar kregen een invulling die ook in andere landsdelen niet ongebruikelijk was. 


\section{Vertegenwoordigers uit 'Limbourg céde'}

londom het einde van de Eerste Wereldoorlog was de staatkundige positie an Limburg opnieuw aan de orde, ditmaal naar aanleiding van de Belgische anspraken op Limburgs grondgebied. Hiermee betreden we voornamelijk iet tijdvak direct volgend op de onderzoeksperiode die in dit boek centraal tast en die eindigt met de sluiting van het parlementaire jaar 1917-1918 op 4 xptember van het laatstgenoemde jaar. Want hoewel Belgiê zijn wensen $10 \mathrm{~g}$ tijdens de Eerste Wereldoorlog kenbaar maakte, was de kwestie politiek prien het meest actueel in de maanden tussen november 1918 en de herfst an 1919.

Waar lag het vaderland van de Limburgse volksvertegenwoordigers die war Den Haag waren afgevaardigd in het zittingsjaar 1917-1918? Om deze rag te kunnen beantwoorden, zullen we met name moeten kijken naar lun houding tijdens het hoogtepunt van de Limburgse kwestie: een moment varop zij mogelijk geen kamerlid meer waren. Overigens behielden zeven un de negen Limburgse leden van de Staten-Generaal die op 14 september vis zitting hadden, ook in het erop volgende parlementaire jaar, dus na de weede-Kamerverkiezingen volgens het nieuwe kiesstelsel, hun zetel. Dit pld voor alle Limburgse leden van de Eerste Kamer: deze kamer zou pas in 1923 volgens het nieuwe kiesstelsel worden samengesteld.

Tabel 6. Leden van de Tweede Kamer gekozen in Limburg, parlementair jaar 19171918 , in volgorde van eerste verkiezing

$\begin{array}{llc} & \text { Naam } & \text { Periode } \\ 1 & \text { W.H. Nolens } & \text { vanaf } 1896+ \\ 2 & \text { F.L.J. Janssen } & \text { vanaf } 1902 \\ 3 & \text { J.H.J. Beckers } & \text { vanaf } 1903 \\ 4 & \text { jhr. Ch.J.M. Ruijs de Beerenbrouck* } & 1905-1918 \\ 5 & \text { M.Ch.E. Bongaerts } & \text { vanaf } 1913+ \\ 6 & \text { H.A.G. van Groenendael } & \text { vanaf } 1916+ \\ 7 & \text { H.G.M. Hermans* } & \text { vanaf } 1918+\end{array}$

* Hermans nam in juli 1918 de zetel van Ruijs de Beerenbrouck in.

+ Behield een zetel in de Tweede Kamer na 14 september 1918. 
Tabel 7. Leden van de Eerste Kamer gekozen in Limburg, parlementair jaar 1917-19: in volgorde van eerste verkiezing

\section{Naam}

1 jhr. A.H.J.H. Michiels van Kessenich

2 O.F.M. Haffmans

3 jhr. L.H.L.J. van der Maesen de Sombreff

\section{Periode}

vanaf $1899+$ vanaf $1909+$ vanaf $1909+$

+ Behield een zetel in de Eerste Kamer na 14 september 1918.

In 1948 memoreerde Henri Hermans - hij had de Kamer inmiddels verlaten - de houding van Limburgse kamerleden jegens het Belgisch annexionisme. Hij deed dit in zijn bijdrage 'Limburg in de parlementaire geschiedenis' aan het provinciaal gedenkboek dat onder de titel Limburg onder de gouden Oranjezon werd samengesteld ter gelegenheid van het vijftigjarig regeringjubileum van koningin Wilhelmina. Hermans wijst op de vele protesten die in de provincie werden uitgesproken tegen de Belgische voornemens, waarbij 'vertegenwoordigers van Limburg in Eerste en Tweede Kamer zich aansloten'. ${ }^{24}$ Door het lidwoord te vermijden - er staat niet 'de' vertegenwoordigers - kon hij het in dit provinciaal huldeblijk uiterst pijnlijke gedra van Tweede-Kamerlid Henri van Groenendael buiten beschouwing laten. De opvattingen en activiteiten van deze afgevaardigde zorgden namelijk voor een dissonant in het Nederlandsgestemde kamerkoor. ${ }^{245}$ De overige negen afgevaardigden die in de tabellen zijn genoemd, laten zich doot uitspraken en handelingen typeren als pro-Nederlands.

Het is opmerkelijk dat de Limburgse kwestie het meest actueel werd op het moment dat Limburgers behoorden tot de meest prominente figuren in de Nederlandse politiek: jhr. Charles Ruijs de Beerenbrouck leidde met ingang van september 1918 het kabinet, waarin Limburg met nog een andere van de elf ministers, te weten A.A.H.W. König (Waterstaat), goed 'vertegenwoordigd' was. En Willem Nolens leidde al sinds jaren de katholieke kamerclub, op dat moment de grootste parlementaire fractie. Ruijs en Nolens waren inmiddels stevig geworteld in het Nederlandse politieke beste en laatstgenoemde verklaarde dan ook dat hij zijn parlementaire zetel niet graag naar Brussel verplaatst zou zien worden. ${ }^{246}$

Dat Nolens zich met Nederland verbonden voelde, bracht hij ook tot uitdrukking in zijn persoonlijk wapen. Op de bovenste helft van het wapen. schild had Nolens aan de ene kant de tiara en de gekruiste sleutels van de paus geplaatst en aan de andere kant de leeuw uit het Nederlandse rijkswapen (dit is tevens de leeuw uit het wapen van het Huis van Oranje-Nassau). 
As passende spreuk koos hij Utrique fidelis: Aan beiden trouw. ${ }^{267}$ VaderIndsliefde en aanhankelijkheid jegens de katholieke Kerk waren de twee gondbeginselen van Nolens. ${ }^{24 s}$

Nolens voelde zich Nederlander en hij vocht ervoor Limburg werkelijk del van Nederland te laten zijn. ${ }^{209}$ Over de Belgische verlangens tot inlijving va de provincie of delen daarvan, liet hij zich 'optimaal onvriendelijk' uit. ${ }^{250}$ Inderdaad droeg de anti-annexionistische rede die Nolens op 12 december 198 in de Tweede Kamer hield een ferm en bevlogen karakter, zeker voor in doen, want Nolens stond niet bekend als een bijzonder begenadigd spreker. Zelf verontschuldigde hij zich bij aanvang van zijn toespraak voor de veklaring die hij zou gaan afleggen: 'in normale tijden' zouden de woorden net gepast zijn, maar de omstandigheden noodzaakten hem ze toch in de mond te nemen. Aanhangers van een inlijving bij België kwalificeerde hij al 'politieke woelwaters, dwarsdrijvers, stokers en fortuinzoekers'. Op hen pste geen andere naam dan 'landverrader'. Hij eindigde met de kreet: 'Raak nit aan het grondgebied van den Staat!'2si

In Limburg zelf maakte Nolens zijn opvatting eveneens duidelijk. Tijdens eer bijeenkomst van de R.K. Kiezersbond voor Limburg in Roermond op 15 atgustus 1919 protesteerde hij tegen de Belgische aanspraken op Limburg en venordeelde hii het gedrag van collega-parlementariër Van Groenendael. Op zijn voorstel stuurde de bond telegrammen aan koningin Wilhelmina, koning Albert van België en aan de internationale commissie die zich in Parijs met de Limburgse kwestie bezighield. Limburg wilde bij Nederland blijven, was de boodschap.

Ook in later jaren zou Nolens die boodschap blijven uitdragen. Nadat een Belgisch vliegtuigje in 1927 boven Maastricht strooibiljetten met een annexionistische boodschap had afgeworpen, maakte Nolens tijdens een feestdiner ter gelegenheid van het vijfentwintigjarig jubileum van de Staatsmijnen duidelijk dat de Limburgers Nederlanders zouden blijven. ${ }^{252}$

Dat de sociale organisaties in Limburg in het geweer kwamen tegen de Belgische eisen, was mede op aandrang van Nolens. Ook Charles Ruijs de Beerenbrouck had daarop aangedrongen. ${ }^{253}$ Laatstgenoemde kwam uit een orangistische en Nederlandsgezinde familie. Zijn grootvader, naar wie hij was vernoemd - jhr. Ch.E.M. Ruijs van Beerenbroek - stond ten tijde van de Belgische opstand bekend als voorstander van het Huis van Oranje: van enige betrekking in Belgische dienst wilde hij niets weten en in 1848 zette hij zich in om de separatistische beweging in Limburg tegen te werken. ${ }^{24}$ Zijn vader Gustave, een zoon dus van Ch.E.M. Ruijs, was eveneens verknocht aan Oranje en wilde Limburg en de Limburgers zo goed mogelijk 
integreren in Nederland. ${ }^{255} \mathrm{Hij}$ was al evenzeer als zijn zoon verankerd in het Nederlandse politieke bestel: behalve Tweede-Kamerlid was hij miniter van Justitie geweest, Commissaris van de Koningin in Limburg en lid van de voogdijraad over de minderjarige Wilhelmina. In januari 1919 werd Gustave op aandringen van onder anderen zijn zoon naar Brussel gezonden om daar de Belgische koning te bezoeken en de Nederlandse zaak te bepleiten.

Zijn zoon Charles stond in die tijd aan het hoofd van het kabinet en was als zodanig nauw betrokken bij al hetgeen de regering ondernam om de Belgische verlangens tegen te werken. Vaak was hij de regeringswoord. voerder inzake de Limburgse kwestie. In december 1918 zei hij in de Tweede Kamer: '... de Regeering is er van overtuigd, dat in alle deelen des lands zonder onderscheid de wil bestaat de integriteit van den vaderlandschen bodem te handhaven'. 256

Acties die tot doel hadden duidelijk te maken dat Limburg onderded wilde blijven van Nederland, konden op de instemming van Ruijs de Beerenbrouck rekenen en hij steunde ze dikwijls met zijn aanwezigheid. Zo woonde hij anti-annexionistische bijeenkomsten in Den Haag en Maastricht bij en nam hij - met de overige ministers van zijn kabinet - zitting in het comite van aanbeveling voor de nationale manifestatie die op 6 februari 1919 in 's-Gravenhage werd gehouden. Ook in Limburg zelf liet hij zich uit over de band van zijn provincie met Nederland. Zo schreef hij in 1923: "'Limburg één met Nederland" zij voor iederen Limburger richtsnoer in handel en wandel!'257 Tevens stelde hij: 'Het eenige uitheemsche dat in ons gewest de aandacht trekt, is de onovertroffen natuur. Maar overigens - godsdienstzin, taal, verbondenheid aan het Oranjehuis, het is "Nederland" tot de bodem."."3 Dat Limburg zelfs in taal - een vaak bij uitstek gekoesterd onderscheidings. teken-zo sterk met Nederland werd verbonden, mag opmerkelijk genoemd worden. Toch was dat in de anti-annexionistische campagne niet ongebruikelijk: tijdens de nationale manifestatie in Den Haag in februari 1919 had de voorzitter van de Tweede Kamer, D. Fock, hetzelfde gedaan. ${ }^{259}$

Naast Nolens en Ruijs de Beerenbrouck speelde ook François Janssen een belangrijke rol in de pro-Nederlandse campagne. Tijdens de Eerste Wereldoorlog was hij een volksvertegenwoordiger pur sang: Janssen was gelijktijdig lid van de Maastrichtse gemeenteraad, van Provinciale Staten van Limburg en van de Tweede Kamer. In september 1918 eindigde ziip kamerlidmaatschap; op lokaal en provinciaal niveau bleef hij echter actief. In zowel gemeenteraad als Staten hield Janssen vanaf het najaar van 1918 verschillende pleidooien tegen het losmaken van (een deel van) Limburg 
ut het Nederlandse staatsverband en het was op zijn initiatief dat elk van dac vertegenwoordigende organen zich tegen het Belgische annexionisme utsprak.

De actieve rol van Janssen werd blijkbaar ook in die jaren zelf opgemerkt. Tien een van zijn collega's in augustus 1919 in de Maastrichtse gemeenteraad voeg om ook nog bij de internationale conferentie in Parijs te protesteren tęen de Belgische aanspraken op Nederlands gebied, reageerde Janssen dor te zeggen: 'Het doet hem [Janssen] enorm veel genoegen, dat op deze kvestie thans ook eens door iemand anders dan door de spreker de aandacht iszevestigd, al zal ook thans wel weer worden gezegd, dat dit op instigatie van rechter Jans[s]en is geschied [...].261

Janssen nam vervolgens het heft weer snel in eigen handen door uitvoerig of de zaak in te gaan en door aan te geven dat hij al had gezorgd voor een Fnnse tekst. Eerder had hij er buiten de vergadering al over gesproken $\mathrm{m}$ t de Nederlandsgezinde burgemeester L.B.J. van Oppen. Bovenal trad Jassen naar buiten als voorzitter van het Provinciaal comité Limburg bij Nderland. In die hoedanigheid sprak hij tijdens manifestaties binnen en buten de provincie en schreef hij in bladen als De katholieke illustratie. ${ }^{202}$

De overige kamerleden - hier met uitzondering van Van Groenendael - raden minder op de voorgrond. Toch liet elk van hen van zich horen in het protest tegen de Belgische aanspraken. Zo maakte Jean Beckers, na de kamerontbinding van 1918 niet meer teruggekeerd in de Staten-Generaal, zijn opvatting duidelijk op provinciaal niveau. In de hoedanigheid van statenlid diende hij op 10 december 1918, samen met onder anderen Janssen, de eerder genoemde motie in waarin Provinciale Staten protesteerden tegen het Belgisch annexionisme. Henri Hermans en Max Bongaerts namen zitting in anti-annexionistische comités: Hermans was actief binnen het Provinciaal comité Limburg bij Nederland en Bongaerts was secretaris en penningmeester van het uitvoerend comité van de nationale manifestatie die op 6 februari 1919 in Den Haag gehouden werd. Lid van dit comité was onder anderen Alice de Stuers, dochter van het voormalig Tweede-Kamerlid.

Wat betreft de opvattingen van de drie Eerste-Kamerleden kan worden gewezen op de gezamenlijke verklaring die zij in december 1918 in de Kamer aflegden. Hierin werd met klem geprotesteerd 'tegen deze pogingen tot aanranding van onze nationaliteit'. De trouw van de Limburgers aan 'ons Vorstenhuis en aan Nederland' was onverbreekbaar. ${ }^{263}$ Overigens stamde de woordvoerder bij deze gezamenlijke verklaring, jhr. Alphonse Michiels van Kessenich, uit een traditioneel sterk orangistische familie. Zijn familiewapen had als devies Alles door en voor den koning en bevatte evenals het wapen 
van Michiels van Verduynen een oranjeappel (onder de jonkheerskroon), $*$ Op deze manier had H.J. baron Michiels van Kessenich (1870-1825), de grootvader van het Eerste-Kamerlid - tevens vader van het Eerste-Kamerlid uit de jaren zestig - uiting willen geven aan de verbondenheid van zijn familie met het Huis van Oranje.

Er was één dissident onder de Limburgse volksvertegenwoordigers: Henri van Groenendael, in de periode 1916-1918 afgevaardigd door het kiesdistrict Weert. Aan hem werd in 1918 de volgende uitspraak toegeschreven: ${ }^{4}$... ik ben avant-tout Limburger, als deputé ga ik minstens zoo graag naar Brussel als naar Den Haag.' Bij diezelfde gelegenheid zou hij hebben verklaard de Belgische aanspraken te steunen en voorstander te zijn van een volksstem. ming in Limburg over de staatkundige toekomst van de provincie. Hij deed deze uitspraken in een gesprek met enkele zakenpartners, die de inhoud later naar buiten brachten, mede omdat zij met Van Groenendael in een conflict verwikkeld waren. ${ }^{265}$ In Limburg werd de kwestie breed uitgemeten in de pers, met name in de Nederlandsgezinde Limburger koerier.

De aantijgingen tegen Van Groenendael werden kennelijk zeer serieus genomen. In de avond van 9 december 1918 werd er huiszoeking verricht bij het kamerlid. Van Groenendael zag zich daardoor genoodzaakt zijn vertrek naar Den Haag uit te stellen. De Tweede-Kamervergadering van 10 december kon hij dientengevolge niet bijwonen. Overigens meldde hij de Kamer dat er 'natuurlijk' geen belastend materiaal was gevonden. ${ }^{266}$

Ook de Kamer zelf nam de zaak hoog op. Tweede-Kamerlid H.P. Marchant wilde duidelijkheid: wat was er waar van de krantenberichten over de uitspraken van Van Groenendael? De laatste bekende wel eens privé over een afscheiding van Limburg te hebben gesproken, maar dat was niet serieus bedoeld: 'Ja, ik heb wel eens in een particulier gesprek zoo schertsenderwip over de zaak gesproken [...] Maar eenige andere uitlating is er van mii niet gekomen.' Er was volgens Van Groenendael voor Limburg 'geen enkele reden $[\ldots]$ om zich thans tegen Holland te keeren en zijn afscheiding te vragen.' ${ }^{267}$

Het Limburgse kamerlid lijkt de mogelijkheid tot een nationaliteitswisseling niet geheel te willen uitsluiten: van een 'Limburg bij Nederland, nu en voor altijd' waarvoor bijvoorbeeld François Janssen zich uitsprak, wa bij Van Groenendael immers geen sprake. ${ }^{268}$ Tweede-Kamerlid C. van der Voort van Zijp wilde dan ook dat Van Groenendael zich nogmaals zou komen verantwoorden in het parlement, maar nu door middel van een 'onomwonden verklaring. ${ }^{209}$ 
Wederom sprak Van Groenendael de Kamer toe en vervolgens verdween kekwestie uit de politieke actualiteit. Totdat in de zomer van 1919 uitlekte dat Ian Groenendael in Brussel een gesprek had gevoerd met een buitenlandse - naar later zou blijken de Franse - gezant. In dit onderhoud had Van Groenendael aangedrongen op het houden van een referendum in Limburg. De Franse diplomaat had de inhoud van het gesprek vervolgens - tot rerrassing van Van Groenendael - doorgebriefd aan de Nederlandse gezant. De pers kreeg er lucht van, er werd een kamervraag over gesteld en Van Groenendael kwam opnieuw in de beklaagdenbank terecht.

Het houden van een volksraadpleging in Limburg werd namelijk aanphangen in Belgische annexionistische kringen en het idee werd met ame gepropageerd door het Comité de Politique Nationale. Aannemelikk is dat Van Groenendael veldwerk verrichtte voor dit comité. ${ }^{200}$ In ieder jeval maakte zijn verdediging in de Kamer en in de katholieke kamerdub een weinig overtuigende indruk: hij was altijd al voorstander geweest un het principe van het plebisciet. Onder de gegeven omstandigheden lon Van Groenendaels pleidooi voor een volksstemming moeilijk anders vorden uitgelegd dan als een pro-Belgische daad, merkte Nolens op tijiens een vergadering van de katholieke kamerclub, ${ }^{271}$ En om die reden tesloot de kamerclub op 1 oktober 1919 om Van Groenendael te royeren. ${ }^{n 2}$ Hij bleef echter als onafhankelijk lid zitting houden in de Tweede Kamer.

Overigens moet worden vastgesteld dat Van Groenendael nimmer in de Tweede Kamer pleitte voor een afscheiding van Limburg. ${ }^{273}$ Verder dan de wens om 'wat meer zelfstandigheid dan tot dusverre' ging hij in zijn functie van nationaal volksvertegenwoordiger niet. ${ }^{274}$

\section{'Als Limburger'}

In de Tweede Kamer was het met name Nolens die elke vorm van annexionisme scherp veroordeelde. ${ }^{275}$ Zoals we zagen kwam hij in het parlement, maar ook daarbuiten, tegenover Van Groenendael te staan. Ook in hun hoedanigheid van Limburgers stonden zij tegenover elkaar. Tijdens een vergadering van de katholieke kamerclub merkte Nolens op: 'Te ergelijker is dat gedrag van den heer Van Groenendael waar hij door Limburg is afgevaardigd [... ]., ${ }^{276}$ Tweede-Kamerlid C. van der Voort van Zijp vergeleek zijn twee Limburgse collega's uitdrukkelijk met elkaar. 'Zoo weldadig' als de woorden van Nolens hadden geklonken, 'zoo teleurstellend' was de toespraak van Van Groenendael geweest. ${ }^{2 \pi}$ 
Doordat de kwestie in de eerste plaats Limburg raakte, werden de afgevaardigden uit die provincie uitgenodigd zich in de Kamer uit te spreken als Limburger' (Nolens) en 'als Limburger van geboorte' (Michiels van Kessenich). ${ }^{278} \mathrm{Zij}$ spraken van 'wij [...] in Limburg' (Van Groenendael) en 'wij Limburgers' (Michiels van Kessenich) om de gevoelens in hun provincie weer te geven. ${ }^{279}$

Paradoxaal genoeg was 'de nationale zaak' in Nederland gediend met een provinciale opstelling van zijn Limburgse adepten: woorden van protest klonken des te krachtiger wanneer zij afkomstig waren van volksvertegenwoordigers uit het betwiste gebied. Niet voor niets werden de teksten van de pro-Nederlandse parlementaire redes van Nolens en Michiels van Kessenich in de anti-annexionistische brochure La protestation du Limbourg hollandais voorafgegaan door hun introductie als 'député du Limbourg.'”

Daarmee werd evenwel een zekere spanning gecreëerd met de Neder. landse grondwet die, waar het de Tweede Kamer betrof, uitdrukkelijk geen provinciale afvaardigingen kende. Nolens leidde zijn parlementaire redevoering van 12 december 1918 dan ook in met: 'Zooals ieder pleeg ik hier te spreken als Nederlander. De Kamer vergunne mij thans een oogenblik het woord te voeren als Limburger.'281 Het werd hem vergund: zijn toespraak werd gevolgd door 'Levendige teekenen van instemming' en zijn woorden werden hartelijk begroet door de regering bij monde van provinciegenoot Ruijs de Beerenbrouck. ${ }^{282}$

Aan de overzijde van het Binnenhof lag de situatie enigszins anders. De Eerste Kamer was - tot 1923 - wel provinciegewijs samengesteld en haar leden konden dan ook met recht zeggen door een bepaalde provincie te zijn afgevaardigd. Dit betekende echter niet dat de leden geacht werden op te treden als vertegenwoordigers voor hun eigen provincie. Desondanks formeerden de drie Limburgse afgevaardigden zich tot een soort provinciale fractie door bij monde van Michiels van Kessenich een gezamenlijke verklaring afte leggen. Ook hun woorden stonden ten dienste van de territoriale integriteit van het koninkrijk en werden - ook in dit deel van het parlement - luid toegejuicht. De Handelingen spreken van 'Teekenen van groote instemming."

De provinciale positie die de Limburgse afgevaardigden innamen, is terug te vinden bij de afgevaardigden uit de provincie Zeeland, deels eveneens opgeêist door België. Zo nam A.J.F. Fokker in december 1918 in de Eerste Kamer het woord 'Als Zeeuw sprekende namens de Zeeuwen en ook namens mijn medelid voor Zeeland'. ${ }^{24}$ De kwestie maakte afgevaardigden die afkomstig waren uit Limburg of Zeeland tot herkenbare Limburgse of Zeeuwse afgevaardigden. 
In nog een ander opzicht bevorderden Limburgse kamerleden het proviciale karakter van hun activiteiten: de royementsprocedure bij Van Groenidael lijkt namelijk eerst en vooral een zuiver Limburgse aangelegenheid tejin geweest. Nog voor de katholieke kamerclub zich over Van Groenedaels gedrag had kunnen buigen - de Kamer was op dat moment met res - werd het oordeel in Limburg zelf al geveld. Tijdens de eerder genemde bijeenkomst van de R.K. Kiezersbond voor Limburg in Roermond of 15 augustus 1919 verklaarde Nolens dat er naar zijn mening voor Van Genendael geen plaats meer was in het Nederlandse parlement en zeker nì meer in de katholieke kamerclub. ${ }^{2 s s}$ Een applaus van de aanwezigen brachtigde dit oordeel. ${ }^{206}$

Daarmee leken de twee vergaderingen die de katholieke kamerclub vervens wijdde aan de kwestie, enigszins voor de vorm te worden gehouden: doeslissing leek immers al in Roermond te zijn gevallen. Dat was ook de bioeling van Nolens. Voorafgaand aan de bijeenkomst in Roermond had himinister jhr. H.A. van Karnebeek van Buitenlandse Zaken meegedeeld $\mathrm{d}$ Van Groenendael tijdens die bijeenkomst - in de woorden van de ministe- 'de nek zal gebroken worden'. ${ }^{287}$ Ook Van Groenendael zelf ervoer de gerejudicieerdestrekking van de Roermondse vergadering: met verwijzing nar de rede die Nolens daar had gehouden, beschuldigde hij Nolens van vooringenomenheid. Onder diens voorzitterschap zou een eerlijke behandeling van de zaak door de katholieke kamerclub niet mogelijk zijn, meende Van Groenendael. ${ }^{288}$

Een verdere aanwijzing voor het pro-formakarakter van de vergaderingen van de katholieke kamerclub treffen we aan in het notulenschrift van die kamerclub. Bij de eerste van de twee vergaderingen over-de kwestie, gehouden op 9 september 1919, was Van Groenendael zelf niet aanwezig. Niet uitgesloten moest worden dat hij de uitnodiging te laat had ontvangen. Hij kreeg daarom, zo werd besloten, nog ten hoogste veertien dagen de tijd om zich te komen rechtvaardigen. Toch bevindt zich in het schrift een inlegvel met daarop een verklaring van het bestuur van de kamerclub - een concept voor een persverklaring? - waarin wordt gesteld dat de club 'in zijn vergadering van de ge dezer' besloten had Van Groenendael te royeren. ${ }^{289}$

Nolens was de eerste vergadering overigens begonnen met te citeren uit zijn Roermondse redevoering en hij herhaalde tijdens de tweede vergadering, op 1 oktober 1919, zijn standpunt dat Van Groenendael uit de katholieke kamerclub diende te worden gezet, daarmee zijn volle gewicht in de schaal leggend. ${ }^{200}$ Het was uiteindelijk op zijn voorstel dat de katholieke kamerclub besloot Van Groenendael te royeren. ${ }^{291}$ De uitgeslotene zelf sprak twee 
weken later in de Kamer van het 'vonnis' van Nolens. ${ }^{292}$ Het was inderdaad Nolens geweest die de leiding had bij het royeren van Van Groenendael: de ene Limburger zette de andere uit de katholieke kamerfractie.

Sterker nog, Van Groenendael werd - zij het indirect - uit de landspo. litiek gebannen. Nolens was weliswaar van oordeel dat er voor Van Groenendael geen plaats meer was in de Nederlandse volksvertegenwoordiging, het was echter niet mogelijk om hem het parlementaire mandaat te ontnemen. Wel stond vast dat er voor Van Groenendael bij de eerstvolgende verkiezingen geen plaats meer zou zijn op de katholieke kandidatenlijs, zoals de bijeenkomst van de R.K. Kiezersbond voor Limburg al duidelijk had gemaakt. Indien hij zijn kamerzetel wilde behouden, zou hij moeten proberen via een eigen lijst te worden gekozen, een poging die, gelet op de sterke positie van de katholieke 'partij' in Limburg, welhaast tot mislukken gedoemd zou zijn. Toch trachtte Van Groenendael bij de verkiezingen van 1922 buiten de katholieke lijst om herkozen te worden. Het werd inderdaad een mislukking: hij behaalde 1636 stemmen en voor een zetel had hij $a$ 21972 nodig gehad. ${ }^{293}$

Naast Nolens speelde een andere Limburgse afgevaardigde een belang. rijke rol in de actie tegen Van Groenendael. Tweede-Kamerlid Bongaerts stelde op 8 juli 1919 namelijk een schriftelijke vraag aan minister Van Karnebeek van Buitenlandse Zaken. Zou de regering de 'ernstige geruchten' niet willen onderzoeken die de ronde deden en volgens welke 'een lid der Nederlandsche Tweede Kamer' in Brussel propaganda zou hebben gemaakt voor het houden van een volksstemming in Limburg?

De vraag van Bongaerts zou in de royementsprocedure een uiterst belangrijke plaats innemen: zij droeg in het 'uitgelokte' antwoord het bewijsstuk aan op grond waarvan Nolens Van Groenendael, verdacht van 'onvaderlandslievende gevoelens', schuldig achtte. ${ }^{24}$ Minister Van Karnebeek antwoordde namelijk dat 'de inhoud der $[\ldots]$ vertrouwelijke rapporten hem niet veroorlooft de geruchten omtrent bedoelde propaganda als uit de lucht gegrepen te beschouwen'? 295

'In gewone taal wil dat zeggen: die geruchten zijn juist bevonden,' verduidelijkte Nolens tijdens de bijeenkomst van de R.K. Kiezersbond voor Limburg in Roermond. ${ }^{296} \mathrm{Om}$ het bewijs nog overtuigender te maken ging hij op nader onderzoek uit, waarschijnlijk bij de minister zelf. De leden van de katholieke kamerclub kregen van hem een gepreciseerd 'concreet feit' voorgelegd: Van Groenendael had op 20 juni 1919 in Brussel een buitenlandse gezant bezocht en daarbij zijn wens naar voren gebracht dat in Limburg een volksstemming gehouden zou worden. ${ }^{297}$ 
Van Groenendael schroomde niet de staatkundige positie van Limburg tot inzet te maken bij de Tweede-Kamerverkiezingen van 1922. Tijdens de campagne die aan die verkiezingen voorafging, keerde Van Groenendael vich duidelijk af van Nederland. Hij stelde dat Limburg 'ethnologisch, historisch, geografisch en economisch tot de Zuidelijke, niet tot de Noordelijke Nederlanden behoort'. Bovendien gaf hij aan zich te kandideren omdat de katholieke voormannen de Limburgers geen kans gaven zich voor Belgiê uit te spreken. ${ }^{28}$ Zijn oordeel is juist: de opvatting van de katholieke voormannen, en in het bijzonder van de Limburgers onder hen, liet aan duidelijkheid niets te wensen over. Voor Limburgse afgevaardigden die hun vaderland ergens anders dan op Nederlandse bodem wensten te situeren, was geen plaats in Den Haag.

Het is overigens goed om op te merken dat de betoonde trouw en aanhankelijkheid jegens het Nederlandse vaderland - ook hier weer niet betekent dat de Limburgse parlementariërs van oordeel waren dat hun provincie altijd rechtvaardig werd behandeld binnen dat vaderland. Zo schreef Nolens in de Nieuwe Venlosche Courant, reagerend op kritiek die Het Handelsblad in 1909 uitte op de eigenaardige houding van Limburg:

'Limburg is niet Nederland', Ja, dat weten wij hier in Limburg maar al te goed. En als we het uit ons-zelven niet wisten; We worden er dagelijks aan herinnerd vooral doordat wat niet geschiedt. ${ }^{299}$

Daarmee stond Nolens niet alleen, want in anti-annexionistische kringen bleef het idee van discriminatie van Limburg hardnekkig aanwezig. ${ }^{300}$

Een aantal van de kamerleden die in 1918 nog door de Limburgse districten waren afgevaardigd, zou een bijzonder prominente rol spelen in de Limburgse kwestie. In de literatuur worden voor hen typeringen gebruikt als 'de anti-annexionistische voorman' (Nolens) en 'een sleutelfiguur' (Janssen), . $^{301}$ Over het gewicht van hun tegenstander Van Groenendael lopen de meningen uiteen. De Waele noemt hem 'een controversiële figuur zonder veel invloed in Limburg', een 'tweederangsfiguur.'. ${ }^{302}$ Wagemans stelt dat door Van Groenendael te royeren juist 'de angel' uit het pro-Belgische kamp werd gehaald. ${ }^{\text {.03 }}$

Zeker is in ieder geval dat een overgrote meerderheid van de politieke elite in Limburg in de jaren rond 1918 openlijk haar Nederlandse gezindheid beleed. Voor een Limburger bij wie aan de trouw jegens Nederland 
getwijfeld moest worden, was naar het oordeel van deze groep geen plaats in het Nederlandse parlement.

In de parlementaire geschiedenis van Nederland neemt Limburg een bij. zondere positie in: bij geen van de overige landsdelen stond de Neder. landse status zozeer ter discussie als bij deze provincie. Weliswaar werd ook Zeeuws-Vlaanderen in 1918-1919 serieus betwist, maar die 'dreiging' was eenmalig. In het geval van de provincie Limburg waren er eerder al jaren geweest waarin er vanuit het buitenland aanspraak werd gemaakt op haar grondgebied. Bovendien maakte Limburg pas sinds 1867 onvoorwaardelijk deel uit van het Koninkrijk der Nederlanden. Tot drie keer toe kwam 'de Limburgse kwestie' in het parlement uitgebreid aan de orde en telkenmale presenteerden kamerleden uit Limburg zich uitdrukkelijk als 'Limburgs afgevaardigde'. Zij voelden zich daartoe geroepen, juist ook indien zij wensten dat hun provincie deel zou blijven uitmaken van Nederland.

Tijdens de momenten waarop de relatie tussen Limburg en (de rest van) Nederland op de parlementaire agenda verscheen, vinden we de roep om secessie niet of nauwelijks terug in de redevoeringen van de Limburgse afgevaardigden in de Staten-Generaal. Alleen op 16 augustus 1848 vroeg een Limburgs kamerlid, Clemens baron de Weichs de Wenne, de regering om een afscheiding van zijn provincie in welwillende overweging te nemen. Uit deze constatering mag niet worden afgeleid dat de separatistische gevoelens zich tot dit ene kamerlid hebben beperkt. In de jaren veertig werden diverse Limburgers naar Den Haag afgevaardigd die zich buiten het parlement lieten kennen als aanhanger van een afscheiding en in de jaren rondom 1918 had een uitgesproken Belgisch gezinde afgevaardigde, Henri van Groenendael, zitting in de Tweede Kamer.

Dat zij hun parlementaire mandaat niet benutten om nadrukkelijker de afscheiding van Limburg te bepleiten, had diverse gronden. Gebondenheid aan de Nederlandse grondwet via een eed van trouw en onzekerheid over de staatkundige toekomst van de provincie maakten hen voorzichtig. Bovendien werd over de staatkundige positie van Limburg niet beslist door de Nederlandse Staten-Generaal, maar werden besluiten daarover doorgaans elders genomen, hoofdzakelijk rondom internationale conferentietafels.

In tegenstelling tot de separatistisch gezinde afgevaardigden uit Limburg lieten hun Nederlandsgezinde provinciegenoten duidelijk van zich horen in de vergaderzalen van Eerste en Tweede Kamer: talrijk zijn de verklaringen van aanhankelijkheid jegens de Nederlandse koning(in) en het bijbehorend vaderland. De betekenis van deze parlementaire woorden lag vooral in de 
invloed die zij hadden op de stemming in de volksvertegenwoordiging en op de opinie in binnen- en buitenland. Zij werden door de Nederlandse regering dan ook aangewend voor propagandistische doeleinden.

Aanhankelijkheid jegens Oranje stond bij éen afgevaardigde, TweedeKamerlid Arnold Hendrik baron Michiels van Verduynen, uitdrukkelijk niet vanzelfsprekend gelijk aan aanhankelijkheid tegenover Nederland. En voor vel Limburgse parlementariërs - én voor veel inwoners van de provincie - gold dat aanhankelijkheid jegens Nederland niet verward moet worden met tevredenheid over het Nederlandse bewind.

Niet alleen overtroffen de pro-Nederlandse redevoeringen in aantal de redes met een separatistische strekking, ook het getal van kamerleden die voor het behoud van de band met (overig) Nederland waren, was vele malen groter dan dat van de afgevaardigden die een afscheiding prefereerden. Dit kwam in de jaren zestig en in de periode 1915-1920 overeen met de publieke opinie in Limburg. Gelet op de anti-Nederlandse sentimenten in de province in de jaren veertig, mag de overwegend Nederlandsgezinde afvaardiging in de Staten-Generaal gedurende dezelfde tijd opmerkelijk genoemd worden. Het kiesstelsel speelde hierbij een belangrijke rol: het kiesrecht was met name beperkt voor die groepen waarbinnen de afscheidingsbeweging haar grootste aanhang had. Bovendien schroomden de koning en zijn ministers niet om zich te mengen in de verkiezingen, met name via hun vertegenwoordigers in Limburg, om op die wijze Limburgers naar Den Haag te laten afvaardigen die de regering en het Nederlandse vaderland welgevallig waren.

De nationale gezindheid van de Limburgse kamerleden was rond 1918 niet langer een onderwerp van grote zorg voor de regering. De Limburgers waren niet alleen in meerderheid afkerig van een nationaliteitswisseling, belangrijker was dat de eveneens Nederlandsgezinde Limburgse elite er voortaan zelf voor zorgde dat separatisten geen kans kregen om in de Haagse vergaderzalen te verschijnen. 



\section{Beginselen en richtingen \\ Limburgse afgevaardigden en politieke groepsvorming}

Detussentijdse verkiezing van een Tweede-Kamerlid in het district Roermind op dinsdag 1 maart 1864 zou een markeringsmoment worden in de poitieke geschiedenis van Limburg, zo voorspelde het Venloosch Weekblad enide dagen daarvoor:

De dag van Dingsdag zal belangrijk zijn voor Limburg. Het is de eerste reis (zooveel wij ons herinneren) dat de kiezers geroepen worden, om tusschen twee politieke rigtingen te kiezen. Vroeger was het steeds eene kwestie van personen, die volkomen dezelfde beginselen beleden. $[. .$.$] thans is het anders. { }^{1}$

Bitieke beginselen en richtingen zullen in dit hoofdstuk centraal staan. De Limburgse kamerleden zullen aan de hand van hun gedrag en opvattingen worden gepositioneerd binnen de nationaal-politieke verhoudingen. Hun band met leidinggevende figuren uit de landelijke politiek en met de overige katholieke afgevaardigden vormen daarbij belangrijke aandachtspunten.

Het hoofdstuk is chronologisch van opbouw. Begonnen werdt met de periode tot de vroege jaren zestig, toen met name de politieke verhouding tot Thorbecke richtinggevend was. Vervolgens komt het proces van ideologisering op gang. Welke positie namen de Limburgers daarbij in? Ten slotte gaat onze aandacht naar hun houding ten aanzien van de katholieke samenwerking die door dit proces tot stand kwam en die in de Tweede Kamer gestalte kreeg in de katholieke kamerclub.

\section{Bondgenoten van Thorbecke}

Tussen 1831 en 1839 was in Limburg - Maastricht uitgezonderd - de liberale Belgische constitutie van kracht. Toen de provincie terugkeerde onder Nederlands gezag en er dientengevolge de Nederlandse grondwet opnieuw verbindend werd verklaard, werden de Limburgers volgens het katholieke 
blad De Godsdienstvriend 'beroofd' van een aantal vrijheden. ${ }^{2}$ En hoewel het Limburgse Tweede-Kamerlid jhr. Arnold Hendrik Michiels van Verduynen zelf altijd een tegenstander was geweest van de opname van zijn provincie in het Belgische staatsverband, moest hij in de Kamer toegeven dat 'de van België voortgekomen wetten, betreffende zaken van Landsbestuur, met onzijdigheid getoetst, meest alle de voorkeur genoten boven de in 1830 bestaande Nederlandse wetten en verordeningen.' ${ }^{3}$ Deze oude Nederlandse wetgeving zou nu weer in Limburg worden ingevoerd. In een nota, die Michiels van Verduynen eerder bij de kamerstukken had laten voegen, schreef hij te betreuren dat onder meer de vrijheid van onderwijs en van vereniging, gedurende de Belgische jaren nog gegarandeerd, nu in zijn provincie zouden worden afgeschaft.

De politiek-bestuurlijke elite van Limburg bleef in de jaren na 1839 ver. bonden met België, door contacten die men bleef onderhouden en door het eigen verleden: niet zelden hadden Limburgse politici in de jaren dertig functies bekleed in het Belgische openbaar bestuur. Diverse Limburgers hadden een prominente rol gespeeld in de opbouw van de Belgische staat (zie hoofdstuk 1). In België werd de politiek in deze tijd beheerst door het unionisme: de samenwerking tussen katholieken en liberalen. In BelgischLimburg bleef de invloed van de liberalen nog tot het midden van de jaren zestig vrij sterk. ${ }^{2} \mathrm{D}$ Tojid oordeclde op $2 s$ januari $x s \sigma s$ dac de uitwerking dit het liberalisme nog steeds had op Nederlands-Limburgse politici, in verband stond met 'hetgeen Limburg van den belgischen toestand eenigermate heeft overgenomen'.

De Limburgse kamerleden uit de jaren veertig staan bekend als overwegend liberaalgezind en dat geldt ook voor de Limburgse burgerij.' In Maastricht lieten liberalen via de sociëteit Momus duidelijk van zich horen.' Het Journal du Limbourg, bij de terugkeer van Limburg onder Nederlands gezag de enige provinciale krant, was van een uitgesproken liberale signatuur, een blad met een 'belgisch-liberale inslag." $\mathrm{Bij}$ de eerste rechtstreekse verkiezingen voor de Tweede Kamer in 1848 lijkt de liberale gezindheid van kandidaten inderdaad van belang te zijn geweest. Zo werd Beerenbroek, kandidaat in het district Roermond, door het Journal du Limbourg getoetst en liberaal genoeg bevonden en presenteerde De Lom de Berg zichzelf in het district Venlo als 'opregt vrijzinnig', waarop hij wel liet volgen: 'maar altijd gematigd'? Hierbij moet wel worden bedacht dat het predikaat Iiberaal' op dat moment aan een sterke inflatie onderhevig was, omdat in Nederland bijna alle kandidaten die aan de verkiezingen deelnamen, zich ermee tooiden. ${ }^{10}$ 
Toch hadden de Limburgse afgevaardigden in Den Haag enkele jaren darvoor al duidelijk gemaakt liberaalgezind te zijn. In 1844 had het voorstel om de grondwet in liberale zin te herzien, gedaan door de Negenman${ }_{n} e^{4}$ onder leiding van Thorbecke, kunnen rekenen op de steun van de die Limburgse Tweede-Kamerleden. Een van hen, Martin Strens, maakte del uit van de Negenmannen. Hier tekende zich een duidelijk verschil af twisen de Limburgse afgevaardigden en hun Noord-Brabantse geloofsgeneten in de Tweede Kamer. Terwijl Strens, Corneli en Michiels van Verdivnen zich uitspraken ten faveure van een grondwetsherziening, gaven ze van de zeven Noord-Brabantse leden aan daartegen te zijn. Michiels val Verduynen was op 30 mei 1845 weliswaar wegens ziekte verhinderd om del te nemen aan de stemming over het voorstel van de Negenmannen, eeder dat parlementaire jaar had hij in de Tweede Kamer al aangegevel het wenselijk te vinden om een grondwetsherziening met klem 'zeer eefbiedig aan de vaderlijke bezorgdheid van Zijne Majesteit aan te beveler.'

De mede door de Limburgse Tweede-Kamerleden voorgestane grondwesherziening zou pas een aantal jaren later, in 1848 , tot stand komen. Toen wod ook de koning bereid gevonden zijn goedkeuring te hechten aan de cosstitutionele wijzigingen, na de veelbesproken nacht waarin Willem u naar eigen zeggen was veranderd van conservatief in liberaal. In Limburg juichte de pers de grondwetsherziening toe, met name de in maart 1848 opgerichte liberale krant De Limburger voerde krachtig campagne..$^{12}$ De desbetreffende voorstellen konden tijdens de parlementaire procedure rekenen op de eensgezinde steun van de drie Limburgse Tweede-Kamerleden, Corneli, Geradts en De Weichs de Wenne, alsmede van de drie buitengewone leden Bloemarts, Swart en Thissen die in september 1848 door Provinciale Staten gekozen waren om in de tweede lezing te gaan deelnemen aan de beraadslagingen en stemmingen.

Tijdens de behandeling van de grondwetsherziening werden de Nederlandse parlementariërs diverse keren herinnerd aan de goede ervaringen die de Limburgers hadden gehad met de vrijzinnige beginselen van de Belgische constitutie. Swart zei in oktober 1848: 'Limburgs ingezetenen verlangen in het bezit te worden hersteld van die staatkundige regten, welke zij gedurende omtrent negen jaren hebben genoten, en welke hun door de thans aangebodenen wets-ontwerpen kunnen worden verzekerd [...]." ${ }^{\text {s }}$

Eerste-Kamerlid De Liedel de Well toonde zich conservatiever van aard. Hij wilde aangetekend zien tegen de voorgestelde wijzigingen met betrekking tot de Staten-Generaal te zijn. ${ }^{14} \mathrm{Nu}$ had De Liedel de Well zijn mandaat 
dan ook niet te danken aan de grotendeels liberaalgezinde politieke elite in zijn provincie: hij was in 1840 - voor het leven - benoemd door de koning

Dat de wens om de staat een meer liberale grondslag te geven in Lim. burg kon rekenen op brede steun, blijkt tevens uit het (aanvankelijke) succes van de afscheidingsbeweging eind jaren veertig. Het Duitse eenheidsstre. ven, waar de Limburgse separatisten zich bij aansloten, kende een sterke stroming die een meer liberale staatsordening wenste. Gouverneur Van Meeuwen wees de regering er in april 1848 op dat een liberale grondwet er veel toe zou kunnen bijdragen om de Limburgers aan Nederland te binden. ${ }^{15}$ Het afscheidingsgezinde Tweede-Kamerlid Corneli had met betrek. king tot de situatie van voor de grondwetsherziening al eerder vastgesteld dat 'de administratieve instellingen [van Nederland] met onze gewoonten niet overeenstemmen.' ${ }^{16}$ En toen Van Scherpenzeel Heusch, leider van de afscheidingsbeweging in Limburg, zich teleurgesteld afkeerde van Duits. land en zich moest neerleggen bij de incorporatie van zijn gewest in het Nederlandse staatsverband, werd zijn pijn naar eigen zeggen verzacht doordat Nederland inmiddels een meer liberale grondwet had aangenomen." In Maastricht schreef een van de lokale leiders van de separatistische beweging, het latere Tweede-Kamerlid Van Wintershoven, in maart 1848 samen met andere stadgenoten een brief aan Thorbecke om hem geluk te wensen met zijn benoeming in de commissie die was belast met het doen van voorstellen voor de grondwetsherziening. De briefschrijvers gaven aan te hechten aan liberale programmapunten zoals een constitutionele regering, ministeriële verantwoordelijkheid, vrijheid van godsdienst, onderwijs en drukpers, gelijkheid van allen voor de wet en directe verkiezingen. ${ }^{18}$ Ook een ander toekomstig lid van de Tweede Kamer, Victor Nijst, behoorde tot de ondertekenaars, die allen advocaat én oud-leerling van Thorbecke waren.

De grote initiator van de grondwetsherziening, Thorbecke, kon de uitwerking ervan in (organieke) wetten zelf ter hand nemen: in november 1849 trad hij aan als hoofd van een liberaal kabinet. Deze regeringswisseling werd in Limburg met vreugde begroet. Het voormalige Tweede-Kamerlid Strens schreef aan Thorbecke:

... met groot genoegen vernam ik die blijde tijding om dat ik overtuigd ben dat wij thans den zoo lang verlangden echt constitutionnelen weg zullen intreden, welke mij, altijd en ook ten gevolge eener ondervinding van negen jaren, die ik van 1830 tot 1839 in mijne geboorteplaats Roermond doorbragt, de beste is toegeschenen om het welbegrepen geluk van vorst en volk te bevorderen. ${ }^{19}$ 
In dit kabinet zou voor het eerst een Limburger zitting nemen: Strens trad in juli 1852 toe als minister van Justitie..20 Tevens was hij daarmee de eerste katholick die een departement van binnenlands bestuur onder zijn hoede krecg. ${ }^{2}$ Dat de eerste katholieke bewindsman op een belangrijk departement een Limburger was, is opmerkelijk. Bij het benoemen van katholieken gaf de Nederlandse overheid nogal eens de voorkeur aan Noord-Brabanders boven Limburgers. Zo werden in Limburg zelf vaak Noord-Brabanders benoemd 'om de "onbetrouwbare" Limburgers in toom te houden'. ${ }^{22}$ In 1849 wees een inwoner van Limburg in De Tijd op de achterstelling bij benoemingen in staatsambten die 'alle katholieken en vooral de Limburgers' tot dan toe ten deel was gevallen. ${ }^{3}$

Jaren vijftig

De Limburgse districten (inclusief Boxmeer) vaardigden tussen 1850 en 1864 elf personen af naar de Tweede Kamer. In een periode waarin politieke partijen niet bestonden, is het toekennen van politieke labels aan TweedeKamerleden bijzonder moeilijk. ${ }^{24}$ In de eerste decennia na het van kracht worden van de kieswet van 1850 waren sociale relaties vaak belangrijker dan politieke verbintenissen. ${ }^{25}$ Desondanks staan tien van de elf Limburgse afgevaardigden in de historiografie doorgaans te boek als liberaalgezind. ${ }^{26}$

Eduard Borret, tussen 1849 en 1852 Tweede-Kamerlid namens het district Maastricht, wordt vaak als enige uitzondering genoemd. Hij wordt wel angeduid als 'conservatief', 'clericaal', 'ultra-katholiek' en 'overtuigd antiThorbeckiaan'.27 Deze kwalificaties hebben overigens deels betrekking op ujp latere politieke loopbaan: Borret zou als minister van Justitie optreden in het conservatieve kabinet-Van Zuylen van Nijevelt-Heemskerk (18661868).

Borret bewaarde als afgevaardigde voor Maastricht een duidelijke afstand tot het liberale kabinet-Thorbecke. Zo speelde hij in december 1849 en prominente rol bij het in de Kamer onder de aandacht brengen van de achterstelling die katholieken ten beurt viel bij het vergeven van staatsambten. ${ }^{28}$ Ook met betrekking tot de door Thorbecke ingediende ontwerpamenwet lijkt Borret een oppositionele rol te hebben gespeeld. Volgens De Tijd van 3 juni 1852 was het bij de verkiezingen van dat jaar met name an belang dat de kiezers zich ervan verzekerden dat de kandidaat waarop zij hun stem zouden uitbrengen, tegen de ingediende armenwet was. Voor de verkiezingen in Maastricht beval het blad van harte Borret aan. Voor Roermond werd - veelbetekenend - geen aanbeveling gegeven. ${ }^{29}$ 
Borret werd niet herkozen, ofschoon hij zich dus wel weer beschikbar had gesteld. In zijn plaats werd Van Wintershoven, een politieke bondgenoot van Thorbecke, afgevaardigd. De motieven die de kiezers hadden om zich niet langer door Borret te laten vertegenwoordigen, zijn onmogelijk precis te achterhalen. Duidelijk is echter wel dat tegenstanders van Borret tegen hem inbrachten dat hij niet liberaal genoeg was: in het Journal du Limboung, dat campagne voerde tegen Borret, werd de liberale gezindheid van het kamerlid in twijfel getrokken. ${ }^{30}$ Dat het gebrek aan een liberale gezindheid gebruikt werd als diskwalificatie, wil niet zeggen dat dit het doorslaggevende criterium was voor de kiezers; er werd bijvoorbeeld eveneens tegen Borrt ingebracht dat hij geen geboren Limburger was (zie hoofdstuk 2). Toch was een liberale houding kennelijk wel een element waarvan werd verwacht dat het voor kiezers van gewicht zou zijn.

Er zijn meer opvattingen van Borret bekend die erop duiden dat hij zich niet verbonden voelde met Thorbecke en zijn liberalen. Zo was hij in 1853 tegen de verkiezing van Thorbecke in het district Maastricht. ${ }^{31}$ En hoewel hii als trouw katholiek onmogelijk kon goedkeuren dat het kabinet-Thorbecke ten val werd gebracht omwille van het herstel van de kerkelijke hiërarchie in Nederland, gaf hij aan geen reden te zien waarom de katholieken zich tegen diens opvolger Van Hall zouden moeten verklaren. ${ }^{32}$ Daarmee weck hij af van de toen zittende Limburgse kamerleden die, zoals we nog zullen

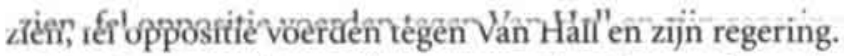

Dat Borret eerder tot de tegenstanders dan tot de medestanders van het kabinet-Thorbecke moet worden gerekend, blijkt verder uit zijn benoeming in juli 1853 tot lid van de Raad van State. De ministerraad had eerder dat jaar onder leiding van Thorbecke de thorbeckiaan N. Olivier benoemd willen zien; Borret was wel ter sprake geweest maar werd niet liberaal genoeg bevonden. De halsstarrige Willem III, een tegenstander van het kabinetThorbecke, weigerde echter Olivier te benoemen. De koning wilde Borret aanstellen. Deze kreeg het ambt spoedig toebedeeld, maar wel pas na de val van het kabinet-Thorbecke en onder verantwoordelijkheid van het kabinetVan Hall. ${ }^{33}$

Met uitzondering van de verkiezingen van 1852, waarbij Borret werd verslagen, lijken politiek-inhoudelijke verschillen in Limburg geen voorname rol te hebben gespeeld bij de keuze van een afgevaardigde. Ook niet bij de verkiezingen van 1860 , die door De Tijd uitdrukkelijk in het teken werden geplaatst van de strijd tegen het (tweede) kabinet-Van Hall. Het blad riep de katholieke kiezers op om te stemmen op de liberale oppositie. Voor het district Roermond werd het zittende kamerlid Strens aanbevolen. ${ }^{4}$ Strens 
wn ternauwernood van zijn opponent Cornelis: het verschil bedroeg in de etste ronde slechts twaalf stemmen ( 534 tegen 522) en geen van de kandidate had daarin de benodigde absolute meerderheid behaald. Er was daarom eq fweede stemming nodig geweest. ${ }^{35}$ Het was echter niet zo dat er in het durict Roermond een strijd had plaatsgevonden tussen een liberaal opposielid en een aanhanger van Van Hall. Zo liet De Tijd zich lovend uit over zoed Strens als Cornelis: de eerste was 'een verdienstelijk man', de tweede 'on knap jong mensch, die veel belooft'. Bij zijn keuze voor Strens liet DTijd zich leiden door vertrouwdheid en ervaring, politiek-inhoudelijke orwegingen treffen we in het blad niet aan. 'De heer Cornelis zal later gegenheid vinden om eene plaats in de Kamer te verkriigen', aldus De Tijd 0525 juni 1860.

Het eerste kabinet-Thorbecke (1849-1853) kreeg in Limburg een positite beoordeling. Ongetwijfeld werd het herstel van de bisschoppelijke hirarchie in 1853 met vreugde begroet. Twee jaar eerder hadden alle Limbigse Tweede-Kamerleden nog hun handtekening gezet onder een daartoe aa de paus gericht verzoek. ${ }^{36}$ Maar het was waarschijnlijk toch in de eerstoplaats het fiscale beleid van het kabinet-Thorbecke dat op instemming ko rekenen. Zo werd het prestige van het kabinet in Limburg aanzienlijk veterkt doordat de accijnsheffing in Limburg gewijzigd werd. ${ }^{37}$ Bovendin stelde de regering voor een rentebelasting in te voeren: een voorstel dat, zoals we in hoofdstuk 5 zullen zien, in de negentiende eeuw decennialang hoog op het verlanglijstje van de Limburgse politici stond. De door Thorbecke ingediende regeling van het armbestuur stuitte weliswaar op fel verzet van katholieke zijde - dit voorstel bevoordeelde de overheidsarmenzorg ten koste van de kerkelijke -, zij lijkt in Limburg op heel wat minder weerstand te hebben hoeven rekenen. Een van de katholieke voormannen, de Noord-Brabander J.B. van Son, beklaagde zich bij J. Zwijsen, de apostolisch vicaris van 's-Hertogenbosch, over 'de exotieke begrippen' die in Limburg op dit punt heersten. ${ }^{38} \mathrm{Het}$ wetsontwerp zal de positieve beoordeling van het kabinet-Thorbecke daar dan ook wel nauwelijks hebben beinvloed.

$\mathrm{Na}$ de val van dit kabinet en het aantreden van het ministerie-Van Hall bleef de Limburgse steun aan de liberalen van Thorbecke gehandhaafd. Voor thorbeckianen was dit nieuwe kabinet er een van de tegenovergestelde richting en het werd door hen dan ook met kracht bestreden. ${ }^{39}$ Aan deze oppositie namen de Limburgse afgevaardigden 'levendig' deel. ${ }^{40} \mathrm{Het}$ voorstel van onder anderen Thorbecke om het tonnengeld en de accijns op het slachtvee af te schaffen, kon rekenen op de steun van de Limburgse afge- 
vaardigden. Het door Van Hall ingediende wetsontwerp tot regeling van het toezicht op de kerkgenootschappen veroorzaakte in Limburg een geweldigt agitatie.

Alle Limburgse kamerleden - ook de afgevaardigde uit Maastricht, Thorbecke - namen deel aan het debat en brachten vervolgens hun stem tegen het wetsontwerp uit." zich eveneens tegen het voorstel. ${ }^{42}$ De parlementaire redevoeringen die de Tweede- en Eerste-Kamerleden uit Limburg hielden over deze kwestie, werden gebundeld en uitgegeven door een Roermondse uitgever. ${ }^{43}$ Overigens volgden niet alle liberale kamerleden Thorbecke bij deze stemmingen; dat deden wel alle katholieke kamerleden.

De Limburgse afgevaardigden gingen niet altijd met Thorbecke mee. Verderop zal de wet op het lager onderwijs uit 1857 aan bod komen. Alle Limburgse kamerleden stemden tegen het befaamde artikel 22, Thorbecke stemde juist vóór. Over het algemeen kon Thorbecke echter op de steun van de Limburgers rekenen. Met de noodzakelijke voorzichtigheid en met uitzondering van Borret kunnen we de Limburgse afgevaardigden tot begin jaren zestig typeren als thorbeckianen.

Toen Van Wintershoven in 1855 besloot zich om gezondheidsredenen terug te trekken uit de landelijke politiek, drong Thorbecke er bij hem op aan om Limburg voor de liberalen te behouden:

Wil dan $[\ldots]$ in allen geval zorgen, dat gij op eene uwer waardige wijze word $[t]$ vervangen. $[\ldots]$ Gij weet hoezeer wij een trouwen bondgenoot behoeven, en van hoeveel belang het is, dat Limburg geene heterogene keuze doe. ${ }^{4}$

Blijkbaar rekende Thorbecke de Tweede-Kamerleden uit die provincie op dat moment allen tot zijn politieke medestanders: de provincie had in zijn ogen een homogene afvaardiging. Dit gold ook voor de Limburgse TweedeKamerleden van vijf jaar later. In het archief van Thorbecke bevindt zich een gedrukte lijst met de kamerleden uit het parlementaire jaar 1860-1861 die is voorzien van aantekeningen over de politieke gezindheid van divers afgevaardigden. De Limburgse Tweede-Kamerleden - De Bieberstein, Van Wintershoven (die zijn rentree had gemaakt in de landelijke politiek), De Lom de Berg en Strens - kregen allemaal het predikaat 'liberaal'. Opmet kelijk is het onderscheid met de zes afgevaardigden uit Noord-Brabant dic op deze lijst voorkomen: aan hen werden namelijk niet alleen liberale neigingen toegekend, maar uitdrukkelijk ook katholieke: zij staan te boek als 
Tiberal-rooms', 'rooms-liberaal' en 'rooms'. ${ }^{45}$ Kennelijk speelde het katholicisme in de toenmalige waarneming bij de vier Limburgers een minder

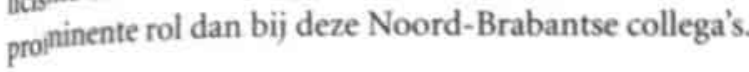

\section{Tho becke en Limburg}

In 168 schreef Thorbecke aan jhr. Paul van der Maesen de Sombreff, met wie hii beviend was en die juist in Maastricht herkozen was als TweedeKanerlid: 'De Limburgers zijn brave lui en bewijzen opnieuw dat ik hun niet ten onregte steeds groote sympathie toedroeg. ${ }^{46}$

jet was niet de eerste keer dat Thorbecke getuigde van zijn belangstelling voor de provincie Limburg en voor haar volksvertegenwoordigers. Reeds voor hun komst naar de Staten-Generaal in 1840 hadden de Limburgse kamerleden in Thorbecke een warm pleitbezorger gevonden: hij veroordeelde hun buitensluiting bij de toen aan de orde zijnde grondwetsherziening (zie hoof dstuk 1).

Bij de Tweede-Kamerverkiezingen van 1853, gehouden na het ontslag van zij kabinet, werd Thorbecke kandidaat gesteld in Maastricht. De zittende afgetaardigde De Limpens gaf aan niet herkozen te willen worden, om zo plaas te kunnen maken voor Thorbecke. Het liberale Journal du Limbourg pleitte er zelfs voor om de liberale voorman in geheel Limburg - dus ook in de districten Roermond en Boxmeer - te laten kiezen. ${ }^{47}$ Thorbecke nam de kandidatuur aan voor Maastricht, wat overigens niet verhinderde dat het district Roermond hem ruim $10 \%$ van de stemmen toebedeelde. ${ }^{4 s}$ Voorafgaand aan de verkiezingen schreef Thorbecke aan Van Wintershoven: 'Gij weet dat ik Limburg zeer lief heb. De gezindheid der Limburgers mijwaarts, hunne eenparige gehechtheid, treft mij hartelijk; zij vergoedt menige miskenning. 99 Thorbecke werd gekozen in zowel Maastricht als Breda, maar nam zitting voor de Limburgse hoofdstad.

Deze verkiezing was vooral ook een keuze voor Thorbecke als persoon. Van Wintershoven, zelf eveneens gekozen in Maastricht, benadrukte dat het de gehechtheid van de kiezers aan Thorbecke persoonlijk was, die had geleid tot zijn verkiezing. Deze aanhankelijkheid was bijzonder groot, schreef hij aan Thorbecke, want een verkiezing van een niet-Limburger was in Maastricht welhaast onmogelijk. ${ }^{30}$

Met betrekking tot de waardering voor Thorbecke kan hier ook gewezen worden op het Roermondse resultaat van de landelijke inzamelingsactic die na de dood van de liberale staatsman in 1872 werd gehouden ten behoeve van de totstandkoming van een huldeblijk (het zou uiteindelijk een standbeeld 
worden). De opbrengst van de 133 plaatselijke inzamelingscomités ken worden gebruikt als populariteitsmeter, stelt Matthey in zijn onderzok naar de oprichtingsgeschiedenis van het Thorbeckebeeld in Amsterdam. Hij wijst op de opmerkelijke 'Thorbeckefilie' in Roermond: hier tekende een op de tien huisgezinnen in, hetgeen landelijk gezien een uitzonderlijke score was. ${ }^{51}$

Terug naar de jaren vijftig. In juni 1856 werd Thorbecke in Maastricht herkozen met 803 van de 823 uitgebrachte stemmen. ${ }^{52}$ Ditmaal opteerdehij niet voor het meest zuidelijke district van Nederland, maar voor Deventer, waar hij eveneens gekozen was. In een manifest richtte hij zich tot de kiezens van het district Maastricht:

... gij zult in mijne optreding voor een ander district geen afscheid van Limburg willen zien; gij zult $\mathrm{u}$ overtuigd willen houden, dat ik, schoon voor Deventer zitting nemende, met hetzelfde hart, als tot dus ver, uwe belangen, in overeenstemming met het algemeen belang, blijf voorstaan; gij zult bij de vier vertegenwoordigers, die Limburg naar de Kamer afvaardigt, mij als vijfden willen tellen, die in liefde voor uw Land en ijver voor de ontwikkeling uwer welvaart door geen hunner zal worden overtroffen. ${ }^{53}$

Opmerkelijk is dat Thorbecke schreef zich te zien als een afgevaardigde van geheel Limburg, niet slechts van het district waar hij tweemaal gekozen was. Wederom benadrukte hij zijn gehechtheid aan de provincie en haar inwoners. Dat deed hij ook meermaals in het parlement. Hier verklaarde hij bijvoorbeeld in 1864 tegenover de Limburgse afgevaardigden dat hij hun toch wel niet hoefde zeggen 'hoe zeer ik Limburg liefheb's4

Wellicht namen de Limburgse kamerleden de aanhankelijkheidsverklaringen van Thorbecke jegens hun provincie soms iets te serieus. In de zomet van 1853 schreef Thorbecke aan, naar wordt aangenomen, het juist terug. getreden Tweede-Kamerlid De Limpens: 'Volgde ik mijne genegenheid, dan bragt ik mijne familie en woning naar het platte land van Limburg over.'ss Eerste-Kamerlid Petrus Regout, die blijkbaar van deze uitsprask op de hoogte was gebracht, schreef daarop aan Thorbecke dat hij wel een geschikte lokatie kende: het kasteel van Eijsden. ${ }^{56}$ Op een dergelijke voortvarendheid had Thorbecke blijkbaar niet gerekend: hij had naar eigen zeggen nog 'met niemand nader over eene verhuizing gesproken' en liet Regout weten af te zien van vestiging in Limburg, onder beleefde dankzegging voor diens suggestie. ${ }^{57}$ 
In de jaren vijftig ondernam Thorbecke een aantal reizen naar Limburg. In het voorjaar van 1851 bracht hij een bezoek als minister van Binnenlandse Zaken. Ook in de zomers van 1855 en 1856 reisde - Tweede-Kamerlid Thorbecke naar (en door) de provincie. Zijn verblijf in Limburg nam telkens ongeveer een week in beslag en uit de brieven aan zijn vrouw blijkt dat hii persoonlijke contacten onderhield met verreweg de meeste Limburgse kamerleden uit de jaren vijftig." Zo overnachtte hij bij De Lom de Berg, Strens en De Limpens, ging hij op bezoek bij Borret en Van Wintershoven en dineerde hij, behalve bij de drie eerstgenoemde gastheren, bij Regout en bij De Rijk. Bij een van de diners zat ook baron de Bieberstein aan, met wie hij tevens afzonderlijke gesprekken voerde. 'Men eet en drinkt hier, gelijk in de romans van Walter Scott, onophoudelijk,' schreef Thorbecke zin echtgenote. ${ }^{59}$

Een bijzonder goede vriendschapsband onderhield Thorbecke met zijn oud-leerling Van Wintershoven. In juli 1861 behoorde Van Wintershoven samen met zijn vrouw tot het selecte gezelschap van politici die waren uitgenodigd voor Thorbeckes zilveren huwelijksfeest. ${ }^{\infty}$ Politiek gezien had met name Strens een goede band met Thorbecke: in de jaren veertig behoorden zij beiden tot de Negenmannen, in 1852-1853 was Strens minister in het kabinet-Thorbecke en in een brief aan de liberale afgevaardigde J.J.P. baron van Zuylen van Nijevelt noemde Thorbecke Strens naar aanleiding van de toen aanstaande verkiezing van de voorzitter van de Tweede Kamer 'onze meest geschikte candidaat'.61

Gedurende Thorbeckes jaren als Tweede-Kamerlid (1853-1862) besteedde hij regelmatig aandacht aan Limburg. Een aanwijzing hiervoor treffen we aan in zijn brieven uit die periode: geen provincie wordt hierin zo vaak genoemd als Limburg. ${ }^{62}$ Thorbecke was overigens ook erelid van de Société Historique et d'Archéologie dans le Duché de Limbourg. ${ }^{.5}$

Indien we de Limburgse afgevaardigden buiten beschouwing laten, hield geen van de Tweede-Kamerleden zich tussen 1853 en 1862 zo prominent bezig met Limburgse onderwerpen als Thorbecke, ook gedurende de jaren warin hij afgevaardigd was uit Deventer. In dit opzicht hield hij zich aan de belofte in het eerder geciteerde manifest aan de Maastrichtse kiezers. Ook later, toen hij minister was, liet hij er zich op voorstaan de Limburgse belangen te dienen: 'wanneer ik zeg dat ik Limburg liefheb, dan beroep ik mij op hetgeen ik van deze plaats gedaan heb'.4

Uit de omvangrijke parlementaire activiteiten die Thorbecke in de jaren 1853-1862 ontplooide, blijkt zijn belangstelling voor onderwerpen die in Limburg zelf van groot belang werden geacht. Met name richtte hij zich op 
de slechte bevaarbaarheid van de Maas en de Zuid-Willemsvaart. Er werd door de Belgen zoveel water aan de rivier onttrokken dat zij in de zomer. maanden nauwelijks bevaarbaar was. In maart 1856 interpelleerde hij de minister van Binnenlandse Zaken over dit onderwerp. ${ }^{65}$ Drie jaar later was Thorbecke samen met twee andere kamerleden, onder wie Strens, initiator van een parlementaire enquête naar de toestand van genoemde vaarwe. gen. ${ }^{66}$ Het was een populair thema voor de Limburgse klaagzang, schreef Commissaris des Konings Van der Does de Willebois. ${ }^{67}$ Uit Limburg werden talrijke verzoekschriften over dit onderwerp naar Den Haag gestuurd." Wellicht mede daardoor was het ook een onderwerp dat de Limburgse af. gevaardigden na aan het hart lag. Aan het debat over de wenselijkheid van een parlementaire enquête naar de kwestie leverden zij allen een bijdrage en hun aandeel in de omvang van die beraadslagingen was bijzonder groot." In de Eerste Kamer diende Regout over dit onderwerp de eerste politicke motie uit de parlementaire geschiedenis in, dat wil zeggen een motie die geen betrekking had op de regeling der werkzaamheden. Regout drong et in deze motie bij de regering op aan om de belangen van Nederland bij de uitvoering van het traktaat met België over de aftapping van Maaswater met kracht te blijven handhaven. ${ }^{70}$

Diyerse keren sprak Thorbecke oyer aspecten die betrekkige hadden,op de band tussen Limburg en de Duitse Bond. Zo interpelleerde hij in maart 1855 minister H.F.Ch. baron Forstner van Dambenoy van Oorlog over de mogelijke verplaatsing van het Limburgse contigent in het bondsleger naar het buitenland. ${ }^{71}$ Een aantal jaren later was een wetsvoorstel aan de orde dat. met het oog op de gespannen internationale situatie, voorzag in het paraat houden van de Limburgse lichtingen ten behoeve van het bondscontingent. Tot vijf keer toe leverde Thorbecke een bijdrage aan het debat over het wetsontwerp. Overigens namen ook alle Tweede-Kamerleden uit Limburg deel aan het debat. Samen met hen stemde Thorbecke als een van de weinige afgevaardigden tegen het wetsontwerp: buiten de Limburgers spraken slechts vier kamerleden - onder hen dus Thorbecke - zich tegen het voorstel uit. Er was hier geen sprake van een samenwerking tussen de Limburgers tn de liberalen maar tussen de Limburgers en Thorbecke. Dat werd nog eens bevestigd door de stemming in de Eerste Kamer. Hier stemden alleen de drie Limburgers en jhr. L.J.B. van Sasse van Ysselt tegen het wetsvoorstel: laatstgenoemde woonde in het deels Limburgse kiesdistrict Boxmeer.

Terugblikkend constateerde De Maasbode op 1 juli 1879: 'Thorbecke was een tijdlang de grote man in Limburg [...].' Het Venloosch Weekblad had op 31 maart 1866 al geschreven: 'De Heer Thorbecke was onze man [...]' 
Deechte band tussen Thorbecke en de provincie én tussen Thorbecke en de mburgse afgevaardigden kan overigens niet geheel los gezien worden vanen wederzijdse belangenafweging. Via de liberale voorman verwierven de mburgse verlangens een prominente(re) plaats in de politieke arena. Thibecke op zijn beurt kon doorgaans rekenen op de steun en de stemmen varie Limburgse afgevaardigden. De getalsmatige steun van de katholieke afgaardigden uit het Zuiden - daaronder Limburg - was in de jaren vijftig en stig van grote betekenis voor de liberalen. ${ }^{n}$

Na sgen jaren in de Tweede Kamer kwam Thorbecke in 1862 opnieuw aan het oofd te staan van een kabinet. Het aantreden van dit kabinet schiep zeki bij de Limburgers hoge verwachtingen. ${ }^{73}$ Het Venloosch Weekblad schef op 18 april 1863: 'Zoolang Limburg met Nederland is vereenigd, is vrzeker nimmer het optreden van een nieuw Kabinet met zooveel vrede en sympathie in dit gewest begroet, als de optreding van het Minterie Thorbecke.' In het archief van Thorbecke treffen we een brief aanın Charles Antoine baron de Bieberstein Rogalla Zawadsky, waarin het Twele-Kamerlid Nederland gelukwenst met de benoeming van de liberale voonan tot minister. Ook De Biebersteins oudste zoon Paul zond een ufficatie: hij sprak de hoop uit dat Thorbecke lang aan het bewind zou blijven. ${ }^{74}$ Daarmee wist hij zich ongetwijfeld tolk van vele Limburgers. Voor menigeen zou het echter uitdraaien op een grote teleurstelling.

\section{Tussen Limburg en liberalen}

Parlementair journalist Blok blikte in 1901 terug op enkele opmerkelijke gebeurtenissen uit zijn lange loopbaan. In Veertig jaar op de tribune beschreef hij onder meer een voorval in de Tweede Kamer in juni 1863:

Eenmaal rustte op den heer van Reenen [de kamervoorzitter] de taak om door tactvol optreden een duel te verhinderen tusschen den ouden heer de Bieberstein Rogalla Zawadsky en den Limburgschen afgevaardigde Van Wintershoven - beiden zuidelijke heethoofden. ${ }^{75}$

Tot kort daarvoor waren de twee Maastrichtse afgevaardigden nog gezamenlijk opgetrokken in de landelijke politiek. 'De heer de Bieberstein weet met hoeveel sympathie ik hem hier heb zien komen,' herinnerde ook Van Wintershoven zich. ${ }^{76}$ Nu stonden zij lijnrecht tegenover elkaar. 


\section{'De Limburgsche oppositie'}

Aan de orde was die dag het verdrag met België over de aftapping van Maaswater. Dit was in Limburg een heikele kwestie. Van Wintershoven was een fel tegenstander van het verdrag dat door het kabinet werd voorgesteld. 'Ik laat mij door al die pressie van politieke berekeningen niet verleiden, welk Ministerie ook aan het bewind is, om tegen mijne overtuiging te handelen. [...] het regt, het belang van Limburg laat ik door geen Ministerit verkorten. ${ }^{\text {.77 }}$

Van Wintershoven distantieerde zich duidelijk van het zittende kabinet. Tot kort daarvoor had hij dat nog voor welhaast onmogelijk gehouden. In een Open brief aan de Heeren kiezers van het district Maastricht schreef hij in maart 1864: 'Gelooft [...] niet, dat ik op dit oogenblik nog in het minste eene opoffering doe met het tegenwoordige Ministerie te bestrijden, een jaar geleden zou mij dit zijn bitter gevallen, toen had ik nog illusien, maar nu niet meer $[\ldots]]^{78}$

Het tweede kabinet-Thorbecke was met hartelijke instemming van Van Wintershoven totstandgekomen, maar nu had hij als kamerlid al sinds maanden met 'bijna onoverkomelijke bezwaren' te kampen. ${ }^{79} \mathrm{Er}$ had zich volgens de afgevaardigde een breuk voorgedaan tussen hem en het tweede kabinet-Thorbecke. ${ }^{\text {s0 }}$ In zijn Open brief schreef hij: 'Met weemoed ondervinde $i k$, hoe eene loijale voorbereiding tot en ondersteuning van het Ministerie Thorbecke door Limburgs afgevaardigden, zoo jammerlijke resultaten heeft opgeleverd, als de wetten die ons bedreigen'si

De wetten (hier dus regeringsvoorstellen) waar Van Wintershoven naar verwees, betroffen naast het voorstel tot goedkeuring van het hiervoor genoemde verdrag met België over de aftappingen van Maaswater verschil. lende belastingwetten, met name het wetsontwerp tot verhoging van de grondbelasting in Limburg en dat tot verhoging van de bieraccijns (zie hoofdstuk 5).

Van Wintershoven stond niet alleen in zijn verzet tegen de plannen van het tweede kabinet-Thorbecke. In Maastricht vond hij een bondgenoot in voormalig Eerste-Kamerlid Petrus Regout. Deze industrieel was bijzonder actief in het verzet tegen het Maastraktaat, waarbij zijn eigen economische belangen zeker gewicht in de schaal zullen hebben gelegd. ${ }^{82}$ Regout financierde vanaf 1864 de uitgave van een krant met de veelzeggende naam L'ami des intérêts Limbourgeois (in 1866 gewijzigd in L'ami du Limbourg). Zijn trouwe vriend Jos Russel was de uitgever. Ook in Noord-Limburg werd gestart met de uitgave van een oppositioneel blad: in februari 1863 zag het 
Venosch Weekblad hier het levenslicht. Een van de directe aanleidingen voode oprichting van deze krant was het wetsontwerp om de grondbelastingin Limburg te verhogen. ${ }^{\text {s3 }}$ Hoofdredacteur van het Venloosch Weekblad waset statenlid Leopold Haffmans, die in 1866 in de Tweede Kamer werd gekzen.

i 1864 vonden er in Limburg drie verkiezingen plaats voor een TweedeKarerzetel. In maart werd in Roermond een tussentijdse verkiezing gehoudern drie maanden later (in juni) vonden de reguliere kamerverkiezingen plass. De Roermondse verkiezing van maart werd door de uitdager van het zitnde kamerlid Karel Cornelis, Frederik baron de Keverberg de Kessel, gehel in het teken geplaatst van de dreigende verhoging van de grondbelasting Hij voerde campagne met de leus 'Weg met het ontwerp, weg met de mirster van financiën', daarmee doelend op het wetsvoorstel dat deze belastigverhoging beoogde. ${ }^{54}$ Het Venloosch Weekblad steunde De Keverberg. Dieou zich in tegenstelling tot Cornelis tenminste te weer stellen tegen de dreende verhoging van de fiscale lasten. De krant hield de kiezers op 27 febaari voor: 'Wanneer gij den vriend van den Minister van Finantien, den Her Cornelis, kiest, dan sterkt Gij dezen Minister in zijne plannen tegen Limurg, dan slaat Gij de oppositie den bodem in'.

Je Keverberg won de verkiezing. Cornelis was volgens het Venloosch Weekblad van 5 maart het terechte slachtoffer geworden van 'eene politieke demonstratie'. De zetels van de overige Limburgse Tweede-Kamerleden die hadden nagelaten de minister van Financiën, G.H. Betz, een blijk van wantrouwen te geven door tegen diens begroting te stemmen - De Lom de Berg en De Bieberstein - 'kraakten', aldus de krant.

Bij de juni-verkiezingen van 1864 ging het om twee zetels: één in het district Maastricht en één in het district Roermond. De oppositionele krachten in Limburg, verenigd in hun verzet tegen het kabinet-Thorbecke, manifesteerden zich nu als een provinciebrede beweging: er was een gemeenschappelijke kandidaat in elk van de twee districten: De Keverberg de Kessel in Roermond en Van Wintershoven in Maastricht. Deze kandidaten werden dan ook beiden aangeprezen in het Zuid-Limburgse L'ami des intérêts Limbourgeois en in het Noord-Limburgse Venloosch Weekblad. ${ }^{\text {s5 }}$

De oppositie die in de jaren zestig in Limburg ontstond tegen het kabinet-Thorbecke, had de provinciale belangen als gemene deler. Haar kandidaten werden in 1864 door het Venloosch Weekblad gepresenteerd als 'Kandidaten der Limburgsche politiek'; L'ami des intérêts Limbourgeois schreef dat hun verkiezing een triomf zou zijn 'der Limburgsche partij'. En terugblikkend sprak Haffmans in 1866 van het driejarig bestaan van 'De 
Limburgsche oppositie'.87 Deze oppositie verweet het kabinet-Thorbecks geen acht te slaan op het welzijn van Limburg: de regering had het volgens Van Wintershoven zelfs 'tegen Limburg gemunt'. ${ }^{88}$ Het Venloosch Weekblad sprak van de 'anti-Limburgsche politiek' van het kabinet. ${ }^{89}$ Het is in dit kader niet vreemd dat zowel Van Wintershoven als De Keverberg de Kessel van Thorbecke het verwijt kregen zich in hun parlementair optreden te laten leiden door provincialisme."

Dat provinciaal particularisme de basis vormde van het verzet tegen het kabinet, blijkt verder uit de isolationistische tendens die bij Van Wintershoven zichtbaar werd. Hij leek zijn separatistische ideeën uit de jaren veertig weer op te pakken, een tendens die Commissaris des Konings Van der Does de Willebois overigens bij meer leden van de Limburgse oppositie war. nam. ${ }^{91}$ In zijn brochures sprak Van Wintershoven in 1864 voortdurend over Limburg in termen als 'onze geännexeerde landstreek' en 'wingewest' en de samenvoeging van zijn provincie met Nederland noemde hij 'nadeelig". Om de kloof tussen Limburg en (overig) Nederland te benadrukken, gaf hij het bedrag dat de provincie extra aan belasting zou moeten gaan betalen door de maatregelen van het kabinet-Thorbecke, mede aan in Belgische

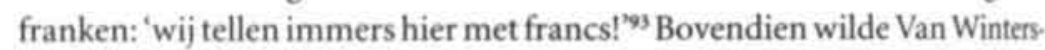
hoven zich in 1864 volledig terugtrekken uit de landelijke politiek: hij stelde zich aanvankelijk niet meer herkiesbaar voor de Tweede-Kamerverkiezingen van juni. ${ }^{94}$ Van diverse zijden werd er echter druk op hem uitgeoefend en uiteindelijk was hij toch weer kandidaat. ${ }^{95}$

De Limburgse oppositie steunde in de eerste helft van de jaren zestig niet op een politiek-ideologisch, in casu anti-liberaal fundament. Haar twee vertegenwoordigers die tussen 1863 en 1866 zitting hadden in de Tweede Kamer, Van Wintershoven en De Keverberg de Kessel, keerden zich in het geheel niet af van het liberalisme. Van Wintershoven, die zich in zijn Open brief distantieerde van het tweede kabinet-Thorbecke, stelde in dezelfde brochure dat de Limburgse kiezers 'zeer zeker' wensten dat hun afgevaardigden 'de liberale regerings politiek [zouden] blijven volgen'. In zijn verdere politieke loopbaan, die zich niet meer op landelijk niveau zou afspelen, bleef Van Wintershoven gematigd liberaal. ${ }^{97}$ De Keverberg de Kessel verklaarde in mei 1864 in een manifest aan de kiezers:

Voor het overige is $\mathrm{U}$ mijn politieke rigting bekend. De liberale beginselen van het tegenwoordige ministerie zijn ook de mijne. Ik heb dit reeds bij verschillende gelegenheden rondborstig en duidelijk verklaard. ${ }^{98}$ 
Gen openlijk beleden breuk dus met het liberalisme, maar ook het thorbeckianisme werd niet vaarwel gezegd. Het Venloosch Weekblad, de krant var Haffmans, verklaarde na de winst van De Keverberg de Kessel bij de tusentijdse verkiezing in maart 1864: 'De Limburgers willen niet voor god breken met het Ministerie Thorbecke. Zij wenschen integendeel dat de rede hersteld worde; maar - op voor ons aannemelijke voorwaarden! ${ }^{m}$ Voł̧ens het weekblad was er geen sprake van een definitieve breuk en de kratt duidde haar tegenstanders in Limburg dan ook niet aan als 'liberalen' of 'horbeckianen', maar als 'ministerie̋len'. De redactie van het Venloosch Wokblad verklaarde zelfs zich te rekenen tot de medestanders van Thorbece. De krant meldde echter wel het kabinet kritisch te zullen volgen, voeal waar het de Limburgse belangen betrof: 'Zoodoende zullen wij, naar one meening, ons beter leerlingen van den grooten staatsman toonen, dan doc onvoorwaardelijk goedkeuren en stilzwijgen. ${ }^{100}$

let politieke etiket dat volgens het Venloosch Weekblad bij deze opstelling hoefe, was dat van 'onafhankelijk Thorbeckiaan'. ${ }^{101}$ Het lijkt erop dat de gehchtheid aan Thorbecke nog dusdanig groot was dat het zeker ook elecoraal gezien ongewenst was om hem te zeer af te vallen. ${ }^{102}$ In dit licht kan worden opgemerkt dat De Keverberg door het Venloosch Weekblad zee duidelijk niet tegenover Thorbecke werd gepositioneerd: de krant schreef er niet aan te twijfelen 'of de Heer Thorbecke neemt volkomen vrede met den Heer de Keverberg. ${ }^{103}$ Zoals slecht beleid van een vorst wel vaker zijn raadgevers werd (en wordt) verweten, om zodoende de vorst zelf buiten schot te houden, zo lijkt de kritiek op het beleid van Thorbecke hem hier niet persoonlijk te worden aangerekend. Althans niet door Haffmans.

Van Wintershoven stelde Thorbecke wel degelijk aansprakelijk voor de naar zijn mening uiterst nadelige wetgeving die Limburg bedreigde. In zijn Tweede open brief schreef hij: 'Ik stelde den Voorzitter van den Ministerraad verantwoordelijk; in een homogeen Ministerie is de heer Thorbecke tegen over Limburg zeer zeker verantwoordelijk voor de wetten [...]. ${ }^{104}$ Wellicht leidde de jarenlange vriendschap met Thorbecke tot gevoelens van persoonlijke verbittering jegens de liberale voorman.

De oppositie richtte haar pijlen vooral op provinciegenoten die ondanks de regeringsplannen achter het kabinet-Thorbecke bleven staan. Deze ministerièlen, zoals ze eerder zijn genoemd, volgden 'blindelings' de regering, schreven L'ami des intérêts Limbourgeois en het Venloosch Weekblad. ${ }^{105} \mathrm{Zij}$ waren daarom, zo luidde het verwijt, niet in staat om in alle onafhankelijkheid de belangen van Limburg te verdedigen. 
Wie waren deze ministeriëlen? We kunnen hen deels identificeren door te kijken tegen wie Van Wintershoven en De Keverberg de Kessel bij de verkiezingen van 1864 opponeerden. Dat waren resepectievelijk jhr. Paul van der Maesen de Sombreff en de eerder genoemde Cornelis. Zij werden niet alleen door hun tegenstanders aangeduid als 'ministerieel', dat gebeurde ook in eigen kring. Het liberale Roermondse weekblad De Volksvriend, dat Cornelis steunde, sprak de hoop uit dat het district Roermond 'een ministeriëel gezinden kandidaat' naar Den Haag zou afvaardigen en dat dat 'in het wezenlijk belang van Limburg' Cornelis zou zijn. ${ }^{106}$ Ook de aanduiding 'Limburgse oppositie' werd niet alleen in eigen kring gebruikt. Zo vinden we haar terug in een brief uit 1864 van burgemeester Beerenbrok van Roermond (tevens Eerste-Kamerlid) aan Thorbecke. ${ }^{107}$ Van der Maesen sprak in datzelfde jaar in een circulaire aan de kiezers - op 28 mei afgedrukt in de Maas- en Roerbode - van 'die stelselmatig-vijandelijke oppositie'.

Van der Maesen de Sombreff was een van de meest prominente aanhangers van het kabinet-Thorbecke: tot kort daarvoor had hij er als minister van Buitenlandse Zaken nog deel van uitgemaakt. ${ }^{108} \mathrm{Hij}$ ging deze verbon. denheid in dezelfde circulaire zeker niet uit weg. Zijn kandidatuur werd gesteund door Le courrier de la Meuse. Deze krant stond onder controle van de invloedrijke Maastrichtse politicus Willem Hubert Pijls, en was in een voortdurende strijd gewikkeld met het door Petrus Regout gesteunde L'ami des intérêts Limbourgeois.

Na de verkiezing van Van der Maesen in juni 1864 deden spoedig geruchten de ronde dat er brieven in omloop waren, geschreven door Thorbecke en door minister Betz van Financiën. Deze brieven zouden zijn gericht aan Van der Maesen en Pijls en daarin zou zijn beloofd dat het kabinet de voorgenomen verhoging van de grondbelasting zou laten rusten indien de verkiezingen in Limburg gunstig zouden uitvallen voor de liberalen. Deze brieven zouden zijn getoond aan kiezers. De oppositie rook haar kans. In Provinciale Staten werd de kwestie aan de orde gesteld door Van Winters. hoven, die bij de Tweede-Kamerverkiezingen was verslagen door Van der Maesen, en de oppositionele bladen, het Venloosch Weekblad en L'ami des intérêts Limbourgeois, maakten veel ophef. Pijls ontkende dat hij een schrijven had ontvangen. Op 18 november 1865 publiceerden beide kranten echter wel een brief van Betz aan zijn oud-collega Van der Maesen. Hierin stond onder meer:

Met $\mathrm{U}$ hoop ik, dat $[\ldots]$ de liberale beginselen in Limburg zullen zegevieren. [... En toen wij $\mathrm{U}$ zoo noode zagen vertrekken, heb 
$\mathrm{kU}$, dank ook aan de loyale houding van uwe afgevaardigden in de xeide kamers, de toezegging gedaan, dat ik de grondbelasting zou laten usten, als de houding van Limburg het mij niet onmogelijk maakt. ${ }^{109}$

Val der Maesen de Sombreff gaf in de Kamer toe dat hij aan 'sommige kieers' had meegedeeld dat minister Betz van Financiën het plan had om de erhoging van de grondbelasting in Limburg te laten varen. ${ }^{110}$ Thorbecke wed door de kwestie, die bekendstaat als de Limburgse brievenkwestie, entig in verlegenheid gebracht. Ze wordt beschouwd als een van de weinige potieke schandalen uit de Nederlandse geschiedenis. "' Betz moest aftreden en an der Maesen de Sombreff werd door de zweem van oneerlijkheid die rorlom zijn verkiezing was komen te hangen, genoodzaakt zich aan een niewe stemming te onderwerpen. Met succes: de kiezers vaardigden hem weerom af. Er werd wel gesproken van een 'pijls-snelle' herverkiezing, warmee werd verwezen naar de hulp die Van der Maesen had ontvangen varzijn politieke vriend Pijls. ${ }^{112}$

le Bieberstein werd evenals Van der Maesen - aan wie hij geparenteerd wa:-gerekend tot 'de coterie' rond Pijls." ${ }^{113}$ Van Wintershoven had De Bieerstein, zoals gezegd, verweten de Limburgse belangen op te offeren aanzijn loyaliteit jegens het zittende kabinet. En dat deed ook het Venloosch Weekblad. ${ }^{114}$

Naast de reeds genoemde Tweede-Kamerleden had in de eerste helft van de jaren zestig De Lom de Berg (district Roermond) zitting. Evenmin als De Bieberstein hoefde hij zich in 1864 te onderwerpen aan het oordeel van de kiezers en er was derhalve voor hem geen noodzaak om in circulaires en brochures een keus te maken in de strijd tussen ministeriëlen en oppositie. Toch gaf hij zichzelf een plaats door zich tot tweemaal toe openlijk - in de Kamer - te distantiëren van de oppositiebeweging in zijn eigen kiesdistrict. Hij deed dat in december 1863 en januari 1866. Bij de eerste gelegenheid verwierp hij de wijze waarop het Venloosch Weekblad oppositie voerde en de tweede maal viel hij Haffmans persoonlijk af. ${ }^{115}$

Bij de parlementaire behandeling van de begroting van Financiën in december 1863 gaven De Bieberstein, Cornelis en De Lom de Berg aan loyaal te zijn en te blijven aan het kabinet-Thorbecke. De minister van dat departement was de eerst-verantwoordelijke voor het regeringsvoorstel om de grondbelasting in Limburg te verhogen. De oppositie in Limburg verwachtte - of liever eiste - daarom van de Limburgse afgevaardigden dat zij tegen die begroting zouden stemmen. Dat gebeurde echter niet. Van Wintershoven was afwezig - hij zou waarschijnlijk wel tegen hebben 
gestemd - en de drie ministeriëlen keurden de begroting van Financięn goed. Zij gaven daarbij wel zonder uitzondering aan zich in een uiterst moeilijk parket te bevinden; De Lom de Berg sprak van 'een hatelijken tweestrijd'.16 Hun loyaliteit aan het kabinet liet zich moeilijk rijmen met het omvangrijke verzet dat in Limburg was ontstaan tegen de lastenverzwaring. Desondanks besloten zij het kabinet geen blijk van wantrouwen te geven door tegen de begroting van Financiën te stemmen. En daar was moed voor nodig, zo gaf Cornelis te verstaan.

In tabel 1 is de positiebepaling van de Limburgse Tweede-Kamerleden tegenover het kabinet-Thorbecke samengevat. De tabel bevat een overzicht van afgevaardigden die behoorden tot de oppositie (de opposanten) en van de kamerleden die gerekend kunnen worden tot de aanhangers van het kabinet (de ministeriëlen).

Tabel 1. De houding van Limburgse Tweede-Kamerleden t.o.v. het tweede kabinetThorbecke, 1862-1866

Opposanten

I.H.L. Haffmans

E.H.C.E baron De Keverberg de Kessef (Roermond 1864)

P.D. Regout

P.F.E. van Wintershoven

(Maastricht 1862-1864)
Ministerielen

Ch.A. baron de Bieberstein Rogalla Zawadsky

(Maastricht 1862-1866)

K.L.J. Cornelis

(Roermond 1862-1864, 1864-1866)

P.L. de Lom de Berg

(Roermond 1862-1866)

jhr. P.Th. van der Maesen de Sombreff

(Maastricht 1864-1866)

W.H. Pijls

De namen van kamerleden uit een eerdere of latere periode wier buitenparlementaire activiteiten ten tijde van het tweede kabinet-Thorbecke duiden op en positiebepaling t.o.v, dit kabinet, zijn cursief weergegeven. Tussen haakjes zijn het district vermeld en de jaren waarin de afgevaardigde gedurende de periode van bet kabinet-Thorbecke zitting had in de Kamer.

De tegenstellingen tussen de Limburgse politici werden gevoed door slechte persoonlijke verhoudingen. Zo was de relatie tussen Regout en Pijls al enige tijd uitgesproken rancuneus. Laatstgenoemde gebruikte zijn machtige positie binnen het Maastrichtse stadsbestuur om Regout waar mogelijk dwars te zitten bij diens plannen op bijvoorbeeld economisch gebied. De 
griven die Regout koesterde tegen het gemeentebestuur, beschreef hij in 1862 in de brochure Een woord over eenige Maastrichtse belangen, die anleiding gaf tot diverse gerechtelijke procedures. ${ }^{117}$ Dat Regout in 1859 niet herkozen werd als lid van de Eerste Kamer, wordt wel toegeschreven aan de invloed van Pijls. ${ }^{118}$ De 'Regout-groepering' wist op haar beurt in ${ }_{1867}$ te bewerkstelligen dat Pijls niet werd herbenoemd tot burgemeester van Maastricht. ${ }^{119}$

De relatie tussen Pijls en Van Wintershoven was eveneens slecht. Bij de Tweede-Kamerverkiezingen van 1860 had Pijls de ambitie gehad om actiff te worden in de landelijke politiek: hij wilde dat Van Wintershoven zich niet meer beschikbaar zou stellen voor het kamerlidmaatschap en ten gurste van hem zou terugtreden. Van Wintershoven weigerde en haalde zich daadoor Pijls' ongenade op de hals. ${ }^{120}$ Deze weinig hartelijke gevoelens warn wederzijds, want toen Pijls in 1872 opnieuw werd benoemd tot bursemeester van Maastricht, nam Van Wintershoven ontslag als lid van de Mastrichtse gemeenteraad. ${ }^{121}$

Hot reageerden de ministerie̋le afgevaardigden uit Limburg op de oppositie vanit hun provincie? Er was een belangrijk verschil tussen de wijze waarop zij ce oppositie tegemoet traden bij de Roermondse verkiezing van maart . $\mathrm{H}_{4}$ en de houding die zij aannamen bij de verkiezingen van juni. In maart voerde Cornelis nog nauwelijks campagne; hij had de kracht van de oppositiebeweging duidelijk onderschat, zo gaf hij later ook zelf toe. ${ }^{122}$ Voorafgaand aan de verkiezingen van juni traden hij en Van der Maesen hun opponenten veel actiever tegemoet. Het Venloosch Weekblad, dat hun kandidatuur bestreed, merkte het verschil met de verkiezing in maart op: 'eindelijk' presenteerde Cornelis zijn ideeën aan de kiezers, schreef de krant op 11 juni.

Met de uitdrukkelijke belofte dat de Limburgse belangen bij hen in zekere hand zouden zijn, trachtten Cornelis en Van der Maesen hét argument om op hun tegenstanders te stemmen, te ondermijnen. $\mathrm{Zij}$ gingen bovendien in de tegenaanval door erop te wijzen dat zij juist door hun band met het kabinet in de gelegenheid waren om het beleid ten gunste van Limburg te beinvloeden. Beiden beweerden in een circulaire aan de kiezers dat het (mede) aan hun interventie te danken was dat de minister van Financiën zijn in Limburg zo gevreesde fiscale ideeën (nog) niet ten uitvoer had gebracht. ${ }^{123}$ En Van der Maesen gebruikte, zoals al opgemerkt, een brief van zijn politieke bondgenoot Betz om duidelijk te maken dat een stem op hem een stem tegen verdere lastenverzwaring zou zijn. 
In de Kamer ging De Bieberstein in de tegenaanval door er bij de behandeling van het voorstel tot verhoging van de grondbelasting tot twee keer toe - subtiel - op te wijzen dat de Limburgse belangen bij opposant Van Wintershoven in het geheel niet veilig waren. Van Wintershoven was namelijk bij de behandeling van het voorstel in de afdelingen helemaal niet aanwezig geweest. ${ }^{124}$ Ook nam De Bieberstein het kabinet in bescherming door aan te geven dat de in de ogen van vele Limburgers veel te strengt uitvoering van de fiscale wetgeving voortvloeide uit beleid dat was ingezet door het vórige kabinet en daarom het kabinet-Thorbecke niet - althans niet in de eerste plaats - verweten kon worden. ${ }^{125}$

De felle oppositie liet de ministeriëlen niet altijd emotioneel onberoerd. De Bieberstein voelde zich 'lusteloos en zwaar moedend', berichtte hij Thorbecke in november 1865; een gevoel van neerslachtigheid dat de baron niet los wilde zien van de politieke situatie in Limburg. Hij hoopte, zo schreefhii Thorbecke, op gunstiger tijden. ${ }^{126} \mathrm{Pijls}$, begin jaren zestig lid van Provinciale Staten, maakte tijdens een vergadering van dit college duidelijk dat hij in een moeilijke positie verkeerde. 'Hij schildert welsprekend de verscheuringen van zijn hart, dat tusschen het ministerie en Limburg geslingerd wordt,' meldde het anti-ministeriële Venloosch Weekblad op 28 mei waarschijnlijk niet zonder leedvermaak.

De activiteiten van de oppositie beïnvloedden ook het parlementair op. treden van de Limburgse aanhangers van het ministerie-Thorbecke. Dit bleek bijvoorbeeld bij de behandeling in 1864 van het wetsontwerp dat de indeling in kiesdistricten regelde. De toen bestaande indeling van Limburg in de dubbele districten Maastricht en Roermond en het enkelvoudige district Boxmeer werd daarin gehandhaafd. Daarmee zouden de Limburgse kiezers in Boxmeer ten opzichte van de Noord-Brabantse kiezers in de minderheid blijven. Gedeputeerde Staten in Maastricht trachtten de Tweede Kamer ervan te overtuigen dat deze situatie ongewenst was. Zij schreven dat Limburg er meer dan enig ander landsdeel recht op had 'om in 's lands vergaderzaal minstens zoveele tolken zijner grieven, zoveele verdedigers $z$ ijner belangen te tellen, als waarop het naar regt en billijkheid mag aanspraak maken'. ${ }^{127}$ Gedeputeerde Staten baseerden deze stelling op de uitzonderlijk ongunstige situatie waarin Limburg zich volgens het college bevond, met name door de dreigende verhoging van de fiscale lasten. Een wijziging in de voorgestelde districtsgrenzen zou de wens van $\mathrm{gs}$ in vervulling doen komen. De door de regering voorgestelde districtsindeling was een onderwerp waarop de oppositie in Limburg haar pijlen richtte, getuige de berichtgeving in het Venloosch Weekblad. Zo wees het blad op 26 maart 1864 in een 
artel over de districtsindeling eerst op de opstelling van 'de ministeriëlen' ('oze tegenstanders') bij de grondbelasting en de bieraccijns om vervolget te schrijven: 'Laat ons thans nagaan, hoe zij zich gedragen hebben bij dewestie der kiesdistricten.'

iij de beraadslagingen in de Tweede Kamer voerde zowel De Keverberg alse Bieberstein het woord. Beiden zochten in hun rede aansluiting bij hererzoekschrift van GS: zij wilden een extra Limburger in de Kamer en spken zich daarom uit tegen het regeringsvoorstel. Hun toespraken lokten eefelle reactie uit van de thorbeckiaan W.H. Dullert: de twee Limburgers haden zich volgens hem op een 'uitsluitend provinciaal standpunt' gesteld en andelden daarmee in strijd met de grondwet. Ook Thorbecke was van ooteel dat de beide redevoeringen op gespannen voet stonden met de constitie. De Staten-Generaal vertegenwoordigden het gehele Nederlandse vol spreken over een extra vertegenwoordiger voor één enkel landsdeel wauit den boze. ${ }^{128}$ Overigens kleedde Thorbecke dit verwijt aan het adres varijn politieke bondgenoot De Bieberstein uiterst vriendelijk in door her 'den dapperen kolonel' te noemen. Een groter compliment was voor Deieberstein - een soldaat in hart en nieren - nauwelijks denkbaar. ${ }^{129}$

loewel de Limburgse baronnen beiden verweten werd te veel oog te heten voor provinciale deelbelangen, droeg het betoog van De Keverberg me dan dat van De Bieberstein een provincialistisch karakter. Dat blijkt bijvoorbeeld uit de wijze waarop zij reageerden op de beschuldiging provincial particularisme te bedrijven. Beiden verklaarden zich onschuldig, echter met een niet-onbelangrijke nuance: terwijl De Bieberstein meende te hebben getoond 'geen provincialisme aan te kleven', ging De Keverberg minder ver door te verklaren een tegenstander te zijn van 'overdreven provincialisme.'130 Bovendien verklaarde De Bieberstein uitdrukkelijk te beseffen dat hij in de Kamer niet alleen Limburg vertegenwoordigde. Het Venloosch Weekblad schreef: 'de Heer de Bieberstein [heeft] nog eens verzekerd [...] dat hij het geheele Nederlandsche volk vertegenwoordigt', om daar cynisch aan toe te voegen: 'daar komen wij ver meê.'.131

De Bieberstein voelde de hete adem van de oppositie in zijn nek. Tijdens het debat maakte hij duidelijk dat hij wel acht móst slaan op de klachten die vanuit Limburg werden geuit: die klachten veronachtzamen kon een afgevaardigde uit die provincie namelijk zijn zetel kosten. Hij verwees daarbij uitdrukkelijk naar Cornelis die twee weken daarvoor een verkiezingsnederlaag had geleden tegen De Keverberg. ${ }^{132}$

De Bieberstein hield dus rekening met de oppositie. Hij trachtte te balanceren tussen de verlangens die vanuit Limburg werden geuit en zijn 
loyaliteit aan het zittende kabinet: hij stemde in met het regeringsontwerp onder voorwaarde dat er de volgende keer wél acht geslagen zou worden op de Limburgse wensen. De Keverberg stemde tegen. Volgens het Venloosch Weekblad had hij zich tijdens het debat doen kennen als 'een dapper verdediger van Limburgs regten. ${ }^{13}$

De partijen stonden in 1864 scherp tegenover elkaar en schrokken er niet voor terug om zware beschuldigingen te richten aan het adres van de tegenstander. In juni 1864 schreef Van Wintershoven, na zijn verkiezingsnederlaag tegen Van der Maesen de Sombreff, in de brochure De heer Hubert Pyls: 'In het belang van de waarheid, moet ik mij onthouden het eindresultaat van de verkiezing in het District Maastricht wat de cijfers betreft te bevestigen.' Hij meldde de Maastrichtse kiezers dat de stembussen, voordat zij geopend waren, een hele nacht onder handbereik hadden gestaan van 'de hevigste kiesintriganten'. En dat was volgens hem des te meer te betreuren omdat de bussen waren voorzien van gemakkelijk los te maken bodèms. Van Wintershoven bracht in dit kader een hem bekend gezegde onder de aandacht: 'dans les élections tous les moyens sont bons. ${ }^{134}$ Enig bewijs droeg hij overigens niet aan en het is tekenend dat hij, ondanks de toch zware beschuldiging, berustte in de uitslag en zich niet beklaagde bij de Tweede Kamer.

Bij de eerstvolgende verkiezingen, in juni 1866, bleek de oppositie uit elkaar gevallen te zijn. Van een provinciebrede beweging was niet langer sprake. Het Venloosch Weekblad negeerde de verkiezing in het district Maastricht en steunde daar geen enkele kandidaat. De krant gaf slechts een aanbeveling voor het district Roermond in de persoon van haar eigen hoofdredacteur Haffmans. Die kandidatuur werd bestreden door L'ami du Limbourg, de krant die twee jaar daarvoor nog een bondgenoot van Haffmans was geweest. 'Il ne représente que soi-même,' oordeelde ze op 12 mei 1866 over haar voormalige medestrijder uit Noord-Limburg.

In Maastricht was er in juni helemaal geen sprake meer van strijd: zittend kamerlid De Bieberstein werd zonder noemenswaardige tegenstand gekozen met 1021 van de 1039 geldige stemmen $(98,3 \%) .{ }^{15}$ De Bieberstein werd gesteund door L'ami du Limbourg en dat is opmerkelijk, want de baron behoorde immers tot de groep rond Pijls en Van der Maesen de Sombreff. Inderdaad stuitte haar steun voor De Bieberstein, zo had de krant zelf ondervonden, op onbegrip. ${ }^{136}$ Twee jaar daarvoor was Van de Maesen bii de verkiezingen nog fel bestreden door Van Wintershoven en L'ami du Limbourg, en diezelfde Van Wintershoven had eerder in het parlement een 
anval elanceerd op De Bieberstein. De beide edellieden werd verweten de Limurgse belangen op te offeren aan hun loyaliteit jegens het kabinetThorbeke. In juni 1866 was De Bieberstein blijkbaar wel een verantwoorde keuze. ami du Limbourg voerde twee redenen aan voor deze (schijnbare) wendin. In de eerste plaats werd De Bieberstein wel degelijk in staat geacht de belagen van Limburg - 'une province isolée et distincte' - te behartigen. Ten twede was het alternatief volgens de krant Pijls zelf, en er was L'ami du Limourg alles aan gelegen dat te voorkomen. ${ }^{137}$ De persoonlijke vete tussen tgout en Pijls zal ook hier wel weer om de hoek zijn komen kijken.

Bij c breuk tussen de Zuid-Limburgse tak van de oppositiebeweging (met Reout en Van Wintershoven als prominente vertegenwoordigers) en de Nooi-Limburgse afdeling (met Haffmans als belangrijkste woordvoerdet) spdde een rol dat het in 1866 ontbrak aan concrete wetsvoorstellen die provincbreed weerstand opriepen. Bij de verkiezingen in juni 1864 waren die er ng wel geweest; toen had met name de dreigende verhoging van de grondbelasting veel Limburgers weten te verenigen. Er was echter ook een verschil van inzicht als het ging om de positionering van de Limburgse oppositie in de landelijke politiek.

Haffmans had al enkele maanden na de verkiezingen van juni 1864 in het Venloosch Weekblad uiteengezet dat er in het Nederlandse parlement 'eene katholieke fractie' moest worden gevormd die zou waken over de katholieke belangen. In lijn met wat eerder is geconstateerd, betekende dit geen breuk met het liberalisme: 'Wij zeggen fractie, omdat wij veronderstellen, dat zij in den regel tot de liberale partij zal behooren en dus een onderdeel van deze zal uitmaken'. ${ }^{138}$ Er was behoefte aan 'aanéénsluiting' met de katholieke afgevaardigden uit bijvoorbeeld Noord-Brabant, de 'natuurlijke bondgenoten' van de Limburgse kamerleden, zo lezen we in een volgend nummer van de krant. ${ }^{199}$ Haffmans had hierbij een voorbeeld aan de politieke ontwikkelingen in het, zeker voor hem als Venlonaar nabije Rijnland, een provincie van Pruisen. $\mathrm{Al}$ in november 1852 hadden katholieke afgevaardigden in de Pruisische Tweede Kamer (vanaf 1855 Huis van Afgevaardigden) zich in een katholieke fractie verenigd; de meeste van hen kwamen uit het Rijnland. $\mathrm{Na}$ een terugval en met het oog op de mogelijk aanstaande Duitse eenheid werden er in het Rijnland vanaf 1864 conferenties gehouden met het doel de katholieke fractie nieuw leven in te blazen of zelfs te komen tot de oprichting van een katholieke partij. ${ }^{100}$

In de bekendmaking van Haffmans' kandidatuur voor de verkiezingen van juni 1866 schreef het Venloosch Weekblad op 28 april tot tweemaal toe over 'ons als Limburgers en katholieken'. Het katholieke element werd 
daarmee duidelijk naar voren geschoven, echter zonder dat het provinciale aspect ondersneeuwde. Volgens de krant ging het bij de verkiezingen namelijk nog steeds om een strijd tegen de ministeriëlen en voor de Limburgse belangen. 'De candidaat der Limburgsche politiek is dit maal Mr. Leopold Haffmans', aldus het Venloosch Weekblad in hetzelfde nummer. De campagne die Haffmans in zijn blad voerde, bleef dan ook voor een groot deel op de verdediging van de Limburgse belangen gebaseerd. ${ }^{141}$ De Lom de Berg, met wie Haffmans de strijd aanbond, werd door het Venloosch Weekblad op één lijn geplaatst met Cornelis. En dat was de ministeriêle kandidaat tegen wie de krant in 1864 had gestreden en door wiens afvaardiging ' $U$ de grondbelasting op den hals [hebt] gehaald', waarschuwde ze de kiezers. ${ }^{16}$

Dat een stem op De Lom de Berg een stem tegen de belangen van Limburg zou zijn, werd echter bestreden door L'ami du Limbourg: de kiezer was in dat opzicht juist aan het goede adres bij de zittende afgevaardigde uit Roermond: 'Il n'a jamais posé volontairement un acte anti Limbourgeois'.

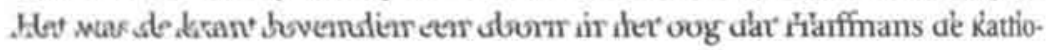
lieke belangen en samenwerking zo duidelijk op de voorgrond plaatste:

... nous sommes dégoûtés en voyant $\mathrm{M}$ [onsieur] Léopold Haffmans, la veille d'élection, prendre l'air d'un catholique dévoué! [...] nous ne favoriserons jamais l'alliance entre les influences catholiques et les hommes de la trempe de M[onsieur] L. Haffmans. ${ }^{143}$

Zuid-Limburg was door zijn geografische ligging traditioneel minder op Noord-Brabant (en Nijmegen) gericht dan het noorden van Limburg. Samenwerking met de Noord-Brabantse katholieken en afgevaardigden uit het eveneens katholieke district Nijmegen was daarom minder vanzelfsprekend. Bovendien was de katholieke geestelijkheid in het zuidelijk deel van Limburg juist verbonden met de grootste tegenstander van Regout en L'ami du Limbourg: Pijls. ${ }^{144}$ Het idee van het katholicisme als basis voor politieke samenwerking zal Regout en zijn krant daarom niet erg hebben aangesproken. L'ami du Limbourg was er weliswaar voorstander van om de katholieke belangen te laten meewegen in de politiek, over de relatie met de overige katholieken in Nederland liepen de ideeèn van de krant en die van Haffmans (vooralsnog) uiteen.

De wijze waarop L'ami du Limbourg over Haffmans schreef, maakt duidelijk dat de verhoudingen inmiddels verre van optimaal waren. Volgens het Venloosch Weekblad was er sprake van een 'persoonlijke aanranding' van Haffmans. ${ }^{145}$ Ook de relatie tussen Haffmans en Van Wintershoven 
raakte indeze jaren verstoord, evenals de verhouding tussen Haffmans en Lom de Ferg. ${ }^{146}$ De ijver waarmee Haffmans de zetel van De Lom de Berg trachtte cer te nemen, zal daarin zeker een inspiratiebron gevonden hebben. Zoas we zagen had De Lom de Berg zich al in december 1863 van Haffman:gedistantieerd door de wijze waarop het Venloosch Weekblad zijn berichtgering placht in te kleden, in de Kamer te veroordelen. Hij had de krant var Haffmans bij die gelegenheid denigrerend 'een sedert kort te Venlo verchijnend weekblaadje' genoemd, hetgeen hem op een sneer was komen testaan door datzelfde blad. ${ }^{147}$ Ook is al verwezen naar de aanval van De Lem de Berg op Haffmans uit december 1865: Haffmans werd daarbij verween zijn ambtsplichten als kantonrechter te verwaarlozen. ${ }^{148} \mathrm{Het}$ Venloosch Weekblad reageerde wederom verontwaardigd. ${ }^{149} \mathrm{Zijn}$ hoofdredeacteur tond dan ook te trappelen van ongeduld om De Lom de Berg te mogenvervangen, want opmerkelijk vroeg maakte hij zijn kandidatuur bekend. Ie krant zelf schreef: 'Wij proclameren onzen candidaat zoo vroegtijdig, opdat onze ministeriëlen zich niet te beklagen hebben, dat wij hen verrassen en overrompelen.' 150

In het najaar van 1866 was er sprake van een voorzichtige hervatting van de eerder bestaande relatie tussen de Zuid-Limburgse oppossanten en hun vroegere bondgenoot in het noorden, Haffmans. Op 27 oktober keurde L'ami du Limbourg een verkiezing van Haffmans in ieder geval niet langer af: indien hij Cornelis zou vervangen, zou dat door de krant van Regout beschouwd worden als 'une victoire pour notre cause'. De relatie was echter nog altijd niet helemaal hersteld, want L'ami du Limbourg gaf wel te kennen liever te zien dat Cornelis zou worden vervangen door De Keverberg de Kessel.

Met betrekking tot de oppositiebeweging die in de eerste helft van de jaren zestig in Limburg ontstond, kan worden geconcludeerd dat haar succes op landelijk niveau, gemeten naar de omvang van haar parlementaire vertegenwoordiging, van korte duur is geweest. In maart 1864 werd De Keverberg gekozen, drie maanden later moest hij de Kamer alweer verlaten. Hij en Van Wintershoven werden toen vervangen door Cornelis en Van der Maesen de Sombreff. 'De Limburgers willen ministeriële afgevaardigden hebben,' stelde het Venloosch Weekblad op 18 juni teleurgesteld vast. Bij de Tweede-Kamerverkiezingen van juni 1866 was er van een eenduidige oppositiebeweging niet langer sprake. Haffmans die zich desondanks opwierp als representant van de Limburgse oppositie, deed een vergeefse poging naar Den Haay te worden afgevaardigd. 


\section{Liberalen en katholieken}

Tijdens de regeringsperiode van het conservatieve kabinet-Van Zuylen van Nijevelt-Heemskerk (1866-1868) tekende zich een duidelijke verscherping af in de Nederlandse politieke verhoudingen. Er werd een scheidslijn zichtbaar tussen de voor- en tegenstanders van de regering. Deze tweedeling kwam met name tot uiting bij vier stemmingen in de Tweede Kamer: de meeste afgevaardigden stemden daarbij consequent voor dan wel tegen het kabinet. Als een rode draad door deze stemmingen loopt de machtsstrijd tussen kroon en volksvertegenwoordiging. ${ }^{151}$

In 1866 trad minister P. Mijer van Kolonièn, een van de voormannen van het kabinet, af om vervolgens te worden benoemd tot gouverneurgeneraal van Nederlands-Indiě. Een meerderheid in de Tweede Kamer was ontstemd over dit ontslag, omdat het kabinet in belangrijke mate Mijers stempel droeg. L.W.C. Keuchenius diende een motie van afkeuring in die de steun kreeg van de liberalen. Van conservatieve zijde werd betoogu' dat de benoeming van de hoogste bestuurder in Indië behoorde tot de prerogatieven van de koning. In deze visie was het uitspreken van een veroordeling niet op zijn plaats. Met 39 tegen 23 stemmen werd de motie aangenomen en de regering reageerde met het ontbinden van de Kamer. Een jaar later ontstond andermaal een conflict tussen regering en parlement, nu over de Luxemburgse kwestie. Willem $\mathrm{m}$, die tevens groot-hertog van Luxemburg was, voelde veel voor het voorstel van keizer Napoleon m om het groothertogdom tegen een financiële schadevergoeding aan hem over te doen. De Pruisische regering protesteerde en verklaarde dat de zaakhet afstaan van een Duits sprekende bevolking aan Frankrijk - voor haar een casis belli was. Een meerderheid in de Tweede Kamer oordeelde dat de regering internationaal bijzonder onhandig had geopereerd met alle gevaren van dien voor Nederland. De begroting van Buitenlandse Zaken werd daarom verworpen en het kabinet bood zijn ontslag aan, hetgeen de koning weigerde te aanvaarden. Een kamerontbinding volgde.

De nieuw gekozen Kamer legde zich hier niet bij neer: een meerderheid stemde voor een motie van P. Blussé van Oud-Alblas waarin de ontbinding niet in het landsbelang werd genoemd. Het kabinet negeerde deze uitspraak, maar toen de Tweede Kamer daarop voor de tweede keer de begroting van Buitenlandse Zaken verwierp, boden de ministers hun ontslag aan, dat ditmaal wel werd geaccepteerd. Het parlementair stelsel werd hierdoor versterkt: voortaan diende een kabinet niet slechts het vertrouwen van de kroon, maar ook dat van de volksvertegenwoordiging te hebben. 
Liberalen en conservatieven stonden bij de vier politieke stemmingen tegenover elkaar en de katholieke afgevaardigden splitsten zich op in conservatief-katholieken en liberaal-katholieken. ${ }^{152}$ Het stemgedrag van de Limburgse kamerleden is vermeld in tabel 2.

Tabel 2. Stemgedrag van de Limburgse Tweede-Kamerleden bij de politieke stemmingen uit de jaren 1866-1868

Naam

$\begin{array}{lllll}\text { District } & 1 & 2 & 3 & 4\end{array}$

Ch.A. baron de Bieberstein Rogalla Zawadsky K.L.J. Cornelis

I.H.L. Haffmans

P.L. de Lom de Berg

jhr. P.Th. van der Maesen de Sombreff

$\begin{array}{lllll}\text { Maastricht } & \text { L } & \text { L } & \text { L } & \text { L } \\ \text { Roermond } & \text { L } & - & \text { L } & \text { L } \\ \text { Roermond } & - & \text { C } & \text { C } & \text { C } \\ \text { Roermond } & \text { C } & \text { L } & - & - \\ \text { Maastricht } & \text { L } & \text { L } & \text { L } & \text { L }\end{array}$

1 Motie-Keuchenius (27 september 1866)

2 Begroting Buitenlandse Zaken (26 november 1867)

3 Motie Blussé van Oud-Alblas (23 maart 1868)

4 Begroting Buitenlandse Zaken (28 april 1868)

L Stemt liberaal (d.w.z. tegen het kabinet)

C Stemt conservatief (d.w.z. voor het kabinet)

- Heeft op moment van stemming geen zitting in de Kamer

We zien dat er een scheidslijn getrokken kan worden tussen enerzijds Haffmans die zich aan conservatieve zijde situeerde en anderzijds De Bieberstein, Cornelis en Van der Maesen die zich bij de liberalen schaarden. De Lom de Berg is moeilijker te plaatsen: bij de motie-Keuchenius steunde hij het conservatieve kabinet (door tegen te stemmen) en ruim een jaar later verwierp hij de begroting van Buitenlandse Zaken die afkomstig was van datzelfde kabinet. De verklaring ligt in de geringe betekenis die politieke verschillen op dat moment hadden in een homogeen katholiek district als Roermond: de polarisering van de politieke verhoudingen was daar nog maar juist op gang gekomen. ${ }^{153}$

Het eerder geschetste beeld van de Limburgse politieke situatie sluit hierop aan: het ging tot aan het aantreden van het kabinet-Van Zuylen van Nijevelt-Heemskerk om provinciale kwesties. Nog op 2 juni 1866 schreef Haffmans in zijn Venloosch Weekblad dat hij geen vijand was van het een dag ervoor teruggetreden liberale kabinet-Thorbecke; het was hem om niets anders te doen geweest dan 'verhoogde belastingen af te weeren'.154 Vanaf de aanvang $7 a n$ het nieuwe parlementaire jaar, enkele maanden later, moesten 
ook de Limburgse kamerleden en zij die een landelijke politieke loopbaan ambieerden (zoals Haffmans) zich gaan verhouden tot de bovenprovinciale politieke tegenstelling die actueel werd en die liberalen en conservatieven nadrukkelijk tegenover elkaar plaatste.

Tabel 3. Politieke kleur van kandidaten bij Tweede-Kamerverkiezingen in Limburg, oktober 1866-juni 1879

Liberaal Conservatief

District Maastricht

Oktober 1866\#

Januari $1868 \#$

Juni 1869

Juni 1871

Juni 1873

Juni 1875

Juni 1877

Juni 1879

District Roermond

$\begin{array}{lll}\text { Oktober 1866\# } & \text { Cornelis } & \begin{array}{l}\text { Haffmans } \\ \text { De Lom de Berg } \\ \text { Januari 1868\# }\end{array} \\ \text { Juni 1869 } & \begin{array}{l}\text { Cornelis } \\ \text { De Lom de Berg } \\ \text { Pijls }\end{array} & \begin{array}{l}\text { Arnoldts } \\ \text { Arnoldts }\end{array} \\ \text { April } 1871^{*} & \text { Cornelis } & \text { Arnoldts } \\ \text { Juni } 1871 & - & \text { Arnoldts } \\ \text { Juni } 1873 & \text { Cornelis } & \text { Lambrechts } \\ \text { Juni } 1875 & - & \text { Arnoldts } \\ \text { Juni } 1877 & - & \text { Lambrechts } \\ \text { Juni } 1879 & - & \text { Arnoldts }\end{array}$

$\begin{array}{ll}\begin{array}{ll}\text { Van der Maesen } \\ \text { De Bieberstein }\end{array} & \text { Brouwers } \\ \text { Van der Maesen } & \text { Brouwers } \\ \text { (De Bieberstein) } & \text { (Wenmaekers) } \\ \text { Van der Maesen } & - \\ \text { De Bieberstein } & - \\ \text { Van der Maesen } & \text { Kerens de Wylré } \\ \text { De Bieberstein } & - \\ \text { Van der Maesen } & \text { Kerens de Wylré } \\ \text { - } & \text { De Bieberstein }\end{array}$




\section{Liberaal Conservatief}

\section{District Boxmeer}

$\begin{array}{lll}\text { Oktober } 1866 & \text { Kerstens } & - \\ \text { Januari } 1868 & \text { Kerstens } & \text { Van der Does } \\ \text { Mei } 1869^{*} & \text { Kerstens } & - \\ \text { Juni } 1869 & \text { Clercx } & \text { Haffmans } \\ \text { Juni } 1871 & \text { Kerstens } & \text { Van den Heuvel } \\ \text { Juni } 1873 & - & \text { Haffmans } \\ \text { Juni } 1875 & - & \text { Van den Heuvel } \\ \text { Juni } 1877 & - & \text { Haffmans } \\ \text { Oktober } 1877^{*} & - & \text { Brouwers } \\ \text { Juni } 1879 & - & \text { Brouwers }\end{array}$

cursief: Naam van degene die de verkiezing won

tussen haakjes: Naam van degene wiens politieke kleur niet (bijzonder) duidelijk was

- Kandidaat ontbrak of behaalde minder dan een kwart van het aantal stemmen

\# Verkiezingen na een kamerontbinding; in dubbele districten zoals Maastricht en Roermond waren de beide zetels gelijktijdig vacant

- Tussentijdse verkiezing

De strijd tussen liberaal-katholieken en conservatief-katholieken, die vanaf de tweede helft van de jaren zestig werd gevoerd, werd uiteindelijk beslist in het voordeel van de laatsten. ${ }^{135}$ Hierbij wordt vaak aangetekend dat het liberaal-katholicisme het langst heeft standgehouden onder de Limburgse volksvertegenwoordigers. In het navolgende zal de strijd tussen liberaalkatholieken en conservatief-katholieken bekeken worden aan de hand van de uitslagen van Tweede-Kamerverkiezingen in Limburg. In tabel 3 zijn de namen genoemd van de voornaamste kandidaten die meededen aan de verkiezingen tussen 1866 en 1879 . Hun politieke kleur is daarbij bepaald met behulp van met name de stemadviezen die gegeven werden in De Tijd en De Maasbode, twee katholieke bladen die zich tegen het liberalisme keerden.

Bij de verkiezingen van oktober 1866 liet De Tijd anvankelijk in het midden hoe haar stemadvies luidde. Na de koninklijke proclamatie van 10 oktober, waarin Willem m zich achter het kabinet-Van Zuylen van NijeveltHeemskerk schaarde, koos de krant de zijde van de conservatieven. ${ }^{156}$ Zo 
gaf De Tijd na de verkiezingen aan het níet te betreuren dat Cornelis was verslagen, daarmee voor Roermond alsnog een duidelijke voorkeur uitsprekend. ${ }^{157}$ Over de zittende kamerleden Cornelis, Van der Maesen en De Bieberstein oordeelde Jos Russel, de uitgever van L'ami du Limbourg: 'Natuurlijk kunnen dus de genoemde afgevaardigden niet langer onze vertegenwoordigers blijven, willen wij mede werken, om den Koning in de mogelijkheid te stellen, onze constitutionele regeringsvorm te handhaven [... [.'sin

Indien we de verkiezingen van oktober 1866 en die van januari 1868 bekijken, stuiten we wederom op de enigszins ambigue positie van De Lom de Berg. Terwijl hij in oktober 1866 nog steun ontving uit conservatieve hoek, werd hij in 1868 samen met Cornelis gekandideerd door de liberale kiesvereniging De Grondwet in Weert (onderdeel van het district Roermond). De uitslag van zijn verkiezing tot liberaal kandidaat lijkt overigens aan te geven dat er ook toen nogal wat twijfels waren. Terwijl Cornelis werd aangewezen met algemene stemmen, kreeg De Lom de Berg slechts een krappe meerderheid van de liberale kiezers binnen de kiesverening achter zich (4A5 van de 79 stemmen). ${ }^{159}$

Bij de verkiezingen van 1868 ageerde De Tijd duidelijk tegen het liberaalkatholicisme, een fenomeen dat, zo schreef ze op 18 januari, achterhaald was en dat met name in Limburg voet aan de grond had gekregen door Belgische invloeden. De Tijd deed een klemmend beroep op de Limburgse kiezers om mee te helpen een kamermeerderheid te vormen die de liberale partij niet voortdurend ten dienste zou staan. Alleen Haffmans had tot dan toe deze gedragslijn gevolgd en was aanbevelenswaardig; Van der Maesen, De Lom de Berg en Kerstens dienden zeker niet herkozen te worden, aldus het oordeel van de krant. Opmerkelijk is het stemadvies dat De Tijd gaf met betrekking tot De Bieberstein. Ofschoon ook deze afgevaardigde an de zijde van de liberalen werd gesitueerd, achtte De Tijd het niet uitgesloten dat hij tot inkeer zou komen. Het liberalisme zat bij De Bieberstein in de ogen van het blad minder diep. In het district Maastricht diende Van der Maesen zeker vervangen te worden door Brouwers, maar het blad wenste geen voorkeur uit te spreken als het ging om de keuze tussen De Bieberstein en Wenmaekers. ${ }^{160}$

Hiermee week De Tijd af van het Venloosch Weekblad. De krant van Haffmans plaatste De Bieberstein wel degelijk op één lijn met De Lom de Berg en Van der Maesen: 'Men verwacht van ons, Limburgers, dat wij $[\ldots]$ de heeren van der Maesen, de Bieberstein en de Lom de Berg, door andere afgevaardigden zullen vervangen.'161 Tijdens de Maastrichtse verkiezingscampagne presenteerden De Bieberstein en Van der Maesen zich 
overigens tok zelf als eenheid. Zo gaven zij een gezamenlijke circulaire uit. Brouwers an Wenmaekers traden eveneens op als koppel en positioneerden zich tegenover het duo Van der Maesen en De Bieberstein. Het kamp van Brouwers an Wenmaekers schuwde overigens een onwaarheid niet als het erom ginghen als eenheid neer te zetten: in de pers werd gemeld dat zij beiden weden ondersteund door De Tijd. ${ }^{162}$ Zoals we zagen, wilde De Tijd echter gees keuze maken tussen De Bieberstein en Wenmaekers. Terwijl er op distictsniveau twee duidelijke kampen tegenover elkaar stonden, werden deverhoudingen buiten de provincie soms (door De Tijd) anders beoordeek.

Roermend zond in 1868 zowel een conservatief-katholiek (Haffmans) als een libraal-katholiek (Cornelis) naar Den Haag. Deze uitslag maakt duidelijk dat de nationaal-politieke tegenstellingen voor de kiezers niet van doorslaggevend belang waren bij de keuze van hun vertegenwoordigers. Het Venlorsch Weekblad schreef al voor de verkiezingen dat de politici partji,mssten kiezen - zij stonden immer 'voor het vuur' -, maar dat de politieke strijd de kiezers veelal onverschillig liet, omdat zij 'op verderen afstand' geplaatst waren. ${ }^{163}$ Indien de landelijke tegenstellingen voor de kiezers bepalend zouden zijn geweest, dan zouden de beide afgevaardigden uit Roermond eenzelfde politieke kleur moeten hebben gehad. Dat was niet het geval en politiek gezien betekende de Roermondse uitslag, in de woorden van De Tijd: 'met de linkerhand vernietigen, wat met de regter is gedaan.' ${ }^{164}$ De krant had eerder die maand geschreven over een typisch Limburgs euvel:

Wij voelen volstrekt geen lust om ons eenigermate in partijschappen te steken die elkander daar, helaas! minder om publiek, dan om persoonlijk belang bevechten. Met diep leedwezen noemen wij dit de kwaal van de zoo schoone en opregt katholieke provincie Limburg, dat schier elke kwestie er zich oplost in een zuiver persoonlijken strijd, waarbij de zaak der groote landsbelangen, zelfs die der godsdienst, bij velen, God dank niet bij allen, maar al te dikwerf wordt beoordeeld naar de eischen der onderlinge persoonlijke twisten, die daar hoog en tot bittere vijandschap opgevoerd worden. ${ }^{165}$

Toch bleef $\mathrm{De}$ Tijd ook in de jaren na 1868 doorgaan met het aan- en afraden van Limburgse kandidaten op grond van die 'grote landsbelangen' en meer in het bijzonder op grond van de houding die deze kandidaten aannamen ten opzichte van het liberalisme. 
Vanaf 1870 kunnen we voor deze houding, althans wat betreft het Lim. burgs-Noord-Brabantse kiesdistrict Boxmeer, kijken welke kandidaat naar voren werd geschoven door de dat jaar opgerichte kiesvereniging Noord. Brabant. De kandidaten van deze kiesvereniging moesten overeenkomstig haar beginselverklaring 'tegenstanders zijn van het moderne liberalismus', 'i In juni 1871 nomineerde zij het eerste kandidaat-kamerlid voor Boxmeet. Dat was een Brabander, Petrus van den Heuvel, maar ook toen het later om 'de Limburgse zetel' van het district ging, stelde de kiesvereniging een kandidaat. ${ }^{167}$ De Limburgers die door het district werden afgevaardigd Haffmans, Brouwers en Clercx - waren allen door haar genomineerd.

Bij de verkiezingen van juni 1869 bemachtigde Maastrichtenaar Pijls volgens De Tijd het hoofd van de liberaal-katholieken in Limburg - de toen vacante Roermondse kamerzetel. ${ }^{168}$ De andere zetel van het district werd op dat moment ingenomen door Cornelis. Daarmee was Roermond geheel in liberaal-katholieke hand. Tot maart 1871. Toen wist de conservatiefkatholiek Arnoldts, met steun van Haffmans, bij een tussentijdse verkiezing Cornelis te verslaan.

De liberaal-katholieken kregen datzelfde jaar meer klappen. Bij de reguliere verkiezingen van juni werden Kerstens en N.R.H. Guljé (district Breda) verslagen. De Maasbode constateerde met vreugde dat daarmee geheel Noord-Brabant van liberalen was 'gezuiverd'. ${ }^{169} \mathrm{De}$ Tijd was eveneens verheugd en meende bovendien te kunnen waarnemen dat de provincie Limburg 'langzamerhand' volgde. Zelfs Pijls, volgens het blad 'de officiele woordvoerder' van de liberaal-katholieken, zou die ontwikkeling niet kunnen tegenhouden. ${ }^{170}$ In het district Boxmeer werden nu beide zetels bezet door een conservatief-katholiek (Haffmans en Van den Heuvel) en in Roermond één van de twee (Arnoldts).

Binnen het politieke spectrum zoals dat werd gehanteerd door De Tijd en De Maasbode, nam De Bieberstein bij de verkiezingen van 1871 wederom een bijzondere positie in. Het kamerlid behoorde volgens De Tijd tot dan toe weliswaar tot 'de liberale partij', maar had nu in een brief aan de kiezers een politiek programma ontvouwd dat volgens het blad 'in den grond der zaak niet liberaal is'. In zijn circulaire had De Bieberstein zich onder meer uitgesproken tegen een scheiding van Kerk en staat, vóór de rechten van de paus als wereldlijk heerser en vóór een wijziging van de schoolwet. ${ }^{171}$ Een aanbeveling wilde $\mathrm{De}$ Tijd hem echter niet meegeven: eerst moest worden afgewacht of en hoe het kamerlid zijn programma in de praktijk zou brengen. De Maasbode nam eenzelfde houding aan en schreef 'niet geheel ontevreden, maar onvoldaan' te zijn. Het blad vond De 
Bieberstein wel duidelijk minder liberaal dan Cornelis en Van der Maesen. ${ }^{172}$ Dit bleek ook uit de reactie van De Maasbode toen het gerucht de ronde deed dat in Maastricht de kandidatuur 'eens volbloeds liberaals' dreigde: op dat moment wilde de krant de verkiezing van De Bieberstein niet langer 'ontraden',om erger te voorkomen. De Maasbode sprak de hoop uit dat De Bieberstein zich na zijn verkiezing zou aansluiten bij de ultramontanen in de Kamer. ${ }^{73}$ Er diende zich overigens geen serieuze tegenkandidaat aan het geructt was onjuist gebleken - en De Bieberstein werd gekozen met ruim negentig procent van de stemmen.

Na 1871 waren De Bieberstein, Van der Maesen en Pijls de enige drie katholieker in de Tweede Kamer die hun plaatsen links in de vergaderzaal hadden, tussen de overige liberalen. ${ }^{174}$ De scheiding met hun geloofsgenoten aan de reciterzijde, onder wie Haffmans en Arnoldts, was daardoor apert vichtbaar. Naar aanleiding van een rede van de liberaal Van Houten, waarin deze zich n weinig vriendelijke woorden had uitgelaten over de katholieke Kerk, merkte de aan de rechterkant gezeten katholieke afgevaardigde C.LA. hleydenryck (district Nijmegen) op:

Mij dunkt, aan de heeren afgevaardigden uit Maastricht en Roermond, zeer nabij den heer van Houten gezeten, en welke tot de linker zijde behooren, moet die uitval zeer vreemd en minder aangenaam in de ooren hebben geklonken. ${ }^{175}$

In 1873 werd Van der Maesen de Sombreff verslagen en vervangen door Kerens de Wylré. De Roermondse zetel die tot dan toe was bezet door Pijls, ging over in handen van Lambrechts, die de liberaal-katholieke kandidaat Cornelis ver achter zich liet (Pijls zelf was geen kandidaat meer). De Tijd jubelde:

De liberalen hebben in Limburg een geduchte nederlaag ondergaan [...]. Wij wenschen onzen limburgschen landgenooten met dien glansrijken uitslag van harte geluk! [...] Limburg heeft zich en voor goed losgemaakt van den liberalen dwang, en voert onzen vertegenwoordigers in de Kamer een zeer te waarderen versterking toe. ${ }^{176}$

Vanaf 1873 was De Bieberstein de enige katholiek in de Tweede Kamer die zich niet aan de ultramontanen had gelieerd. Daarom prijkte zijn naam twee jaar later nog steeds niet in de aanbevelingslijst van De Tijd. Er was ook geen andere aanbeveling voor het district Maastricht, want wederom meldde zich 
geen tegenkandidaat voor De Bieberstein. De Maasbode wilde zich in 1875 evenmin achter De Bieberstein scharen, want zijn 'liberale neigingen doen ons te veel voor de toekomst vreezen'. Het blad hield de moed er echter in en voorspelde met betrekking tot de opmars van de ultramontanen: 'Maastricht zal weldra volgen.' ${ }^{177}$ Het Venloosch Weekblad oordeelde bijzonder hard over De Bieberstein: het was zaak om 'het liberaal-katholicisme in de Kamer met wortel en tak uit te roeien'. De krant van Haffmans sprak van een 'zuiveringsproces' dat ten einde toe moest worden doorgevoerd. ${ }^{17}{ }^{17} \mathrm{De}$ Bieberstein moest daarom uit de volksvertegenwoordiging verdwijnen.

De zekere verkiezing van De Bieberstein in 1875 doet opnieuw de vraag rijzen hoe belangrijk nationaal-politieke scheidslijnen waren voor het electoraat. Terwijl het kamerlid door De Tijd, De Maasbode en het Venloosch Weekblad werd beschouwd als (te) liberaal, was er in Maastricht in het geheel geen sprake van verzet tegen zijn verkiezing. Het lijkt erop dat het netwerk van De Bieberstein dusdanig groot was dat een tegenstander bij voorbaat al kansloos was, zelfs al was hij van onbetwist conservatief-katholieke sig. natuur. De Biebersteins omvangrijke steun bij verkiezingen kan nameliik onmogelijk volledig gebaseerd zijn geweest op een nationaal-politieke voorkeur: in hetzelfde kiesdistrict won de conservatief-katholiek Kerens de Wylre ervoor en erna (1871 en 1877) met ruime cijfers van zijn liberaal-katholieke opponent Van der Maesen de Sombreff.

Dat De Bieberstein actief was bij het opbouwen en onderhouden van een sociaal netwerk, wordt duidelijk uit bewaard gebleven correspondentie. Deze brieven maken duidelijk dat de baron mensen bij Thorbecke aanbeval voor een baan. Bijvoorbeeld in 1871, toen het ging om de post van chef in het Maastrichtse armengesticht en hospitaal Calvarie Berg. De secretaris van deze instelling, tevens een politieke bondgenoot van De Bieberstein, zond hem een brief waarin een bepaalde persoon voor de functie werd aanbevolen. 'Uwe vriend Thorbecke', zo schreef hij, kon deze benoeming bevorderen en hij vroeg De Biebersteins bemiddeling. Uitdrukkelijk werd het Tweede-Kamerlid erop gewezen dat de benoeming van de aangedragen kandidaat een gunstige uitwerking zou kunnen hebben op de verkiezingen van een maand later waarbij de baron kandidaat was: 'Het zou vóóral niet slecht zijn wanneer dit vóór de aanstaande verkiezingen kan geschieden opdat men ondervinde dat wij nog wat in te brengen hebben en de ene dienst de andere waard is.' De Bieberstein geleidde het verzoek door naar Thorbecke met een hartelijke aanbeveling zijnerzijds. ${ }^{179}$ Dat de baron nict te beroerd was om mensen bij Thorbecke aan te bevelen, daarvan geeft zijn correspondentie vaker blijk. ${ }^{180}$ 
Geructien over vriendjespolitiek deden meermaals de ronde. Voor De Biebersteiłs politieke tegenstanders in Limburg stond vast dat diverse relaties van tem hun fraaie betrekking te danken hadden aan het TweedeKamerlid..$^{n t}$ En volgens sommigen pleitte De Bieberstein er in 1874 wel erg nadrukkelj $\mathrm{k}$ voor om de opdracht tot levering van nieuwe geweren aan de Nederlandse infanterie te gunnen aan de Maastrichtse wapenfabrikant Stevens. ${ }^{182}$

Dat de (veronderstelde) nationaal-politieke scheidslijnen op districtsniveau zekerniet altijd van betekenis waren, werd nog eens duidelijk in 1876 , toen regiołale belangen deze landelijk-politieke scheidslijnen doorkruisten. Op de parlementaire agenda verscheen dat jaar een regeringsvoorstel om het keirerlijk decreet van Napoleon betreffende de kerkelijke bezittingen, uitgevaardigd in 1809, in te trekken. Deze intrekking zou met name Limburg rken. Het gebied waaruit die provincie bestond, was eerder dan de overige delen van Nederland ingelijfd bij Frankrijk en dientengevolge waren in Limburg - ook na 1839 - enkele Franse wetten van kracht die elders in Nederland (met uitzondering van Zeeuws=Vlaanderen) niet golden. Dit was onder meer het geval met genoemd keizerlijk decreet. In dit decreet was bepaald dat parochies compensatie moesten blijven krijgen van de burgerlijke overheid voor tijdens de Franse revolutie in beslag genomen kerkelijke bezittingen en inkomsten. Als de inkomsten van een kerkgemeenschap te gering waren, diende de burgerlijke gemeente bijvoorbeeld bij te springen. Dit leidde vaak tot een aanzienlijke geldstroom vanuit de kas van het burgerlijk gezag naar die van de Kerk. Ook resulteerde het decreet in een zekere mate van verwevenheid tussen wereldlijk en kerkelijk gezag. Zo kende de regeling voorschriften met betrekking tot de samenstelling van een kerkbestuur: hierin had ook de plaatselijke burgerlijke overheid een vertegenwoordiger (bijvoorbeeld in de persoon van de burgemeester). Op de provinciale en landelijke overheid rustten eveneens (financiële) plichten ten aanzien van de katholieke Kerk in Limburg. Met het oog op de noodzakelijke integratie van de provincie in het Nederlandse statsbestel noemde Commissaris des Konings Van der Does de Willebois het onwenselijk dat op zo'n belangrijk punt in Limburg een afwijkende regeling van kracht was. Vele malen drong hij er dan ook bij de regering op aan om het keizerlijk decreet in te trekken. ${ }^{183}$ Zijn opvolger, jhr. E. de Kuyper, schreef aan Den Haag dat hij bij zijn aantreden in 1874 met verbazing kennis had genomen van de financiële betrekkingen die als gevolg van het decreet in zijn nieuwe provincie bestonden tussen de burgerlijke en kerkelijke overheid. ${ }^{\text {s4 }}$ De regering gaf gehoor aan de oproep van haar 
vertegenwoordigers in Limburg en diende bij het parlement een wetsvoorstel in dat onder meer de intrekking beval van het keizerlijk decreet uit 1809.

$\mathrm{Nu}$ het om specifiek Limburgse belangen ging, trokken de kamerieden uit Limburg één lijn, dwars door (vermeende) politieke verbanden heen: in de Tweede Kamer verklaarden enerzijds De Bieberstein en anderzijds Haffmans, Arnoldts, Lambrechts en Kerens de Wylré zich tegen het voorstel. Toen artikel 1 , waarin was bepaald dat het decreet werd ingetrokken, desondanks werd aangenomen, diende De Bieberstein zelfs samen met Arnoldts een amendement in waarbij het bedrag dat zou worden uitgekeerd ter compensatie voor de intrekking van het decreet, aanzienlijk werd verhoogd. Arnoldts verklaarde in een toelichting op het amendement: 'Afgevaardigd uit het hertogdom, alléén door deze intrekking benadeeld, vermeenen wij de bijzondere belangen van ons gewest te mogen bevorderen.'185

Zes Limburgse afgevaardigden namen - in de beide Kamers - deel aan de beraadslagingen; alleen de immer zwijgzame Kerens de Wylré en De Villers de Pité spraken niet. Daarmee gaven de Limburgse kamerleden een parlementaire stem aan het verzet dat in hun provincie tegen het regeringsvoornemen bestond; vanuit Limburg werden er vijfenzeventig verzoekschriften naar de Staten-Generaal gestuurd, waaronder adressen van Provinciale en Gedeputeerde Staten. De Limburgse afgevaardigden waren dus eensgezind in hun oppositie tegen het regeringsvoorstel. De overige katholieke leden in de beide Kamers stemden verdeeld. In de Eerste Kamer stemden zelfs alleen de drie Limburgse leden en J.B.J. Hengst, oud-TweedeKamerlid uit het district Boxmeer, tegen het wetsontwerp.

Terug naar de verkiezingen. In 1879 opteerde De Bieberstein opnieuw voor het kamerlidmaatschap en wederom werd hij zonder tegenkandidaat gekozen. Er was echter wel iets wezenlijks veranderd in zijn positie in de landelijke politiek. Enkele maanden voor de verkiezingen had hij in de Tweede Kamer zijn vaste plaats tussen de liberalen - ter linkerzijde, tweede rij, eerste bank - verlaten. Hij was overgestoken naar de rechterzijde en had plaatsgenomen tussen de overige katholieke afgevaardigden. De Bieberstein had zich daarmee onmiskenbaar geprofileerd als ultramontaan en voor het eerst troffen de kiezers zijn naam dan ook aan bij de aangeprezen kandidaten in De Tijd en De Maasbode. ${ }^{187}$

Lavater schreef in 1879 in zijn Politieke photografien dat De Bieberstein naar zijn geloofsgenoten was 'overgeloopen' om aldus zijn herverkiezing veilig te stellen. ${ }^{18 s}$ Als het ging om herkozen te worden, was De Bieberstein 
zeker een utgesproken expert: geen andere Limburger wist zich in de periode 1860-1810 zo lang en electoraal zo onbedreigd te handhaven als hij. Dat De Biebersein op sommige momenten niet precies kon worden ingepast in de politicke verhoudingen, zoals die door De Tijd en De Maasbode, maar ook door het Venloosch Weekblad werden geschetst, en op andere momenten werd geplatst tegenover de andere afgevaardigden uit Limburg en in het bijzonder tegenover zijn collega-afgevaardigde uit Maastricht, was electoraal gezien kennelijk van weinig belang. Voor de kiezers was het geschetste onderscheid tussen liberaal-katholieken en conservatief-katholieken niet doorslaggerend.

Aan het einde van de jaren zeventig voelde De Bieberstein echter toch de behoefte om zich duidelijker dan voorheen politiek te liëren aan de georganiseerde katholieken. Kennelijk achtte hij dat voortaan ook vanuit electoraal oogpunt wenselijk. Maastricht lijkt daarmee aansluiting te hebben gevonden bij de rest van Nederland waar de kiezers in de jaren zeventig en tachtig door ideologische overeenkomsten gebonden werden en waar dientengevolge het belang van programma's toenam en dat van standspolitiek afnam. ${ }^{189}$

Indien we de tegenstelling uit de jaren na 1866 (liberaal-katholieken versus conservatief-katholieken) vergelijken met de tegenstelling uit het begin van de jaren zestig (opposanten versus ministeriëlen), dan zien we een grote persoonlijke continuïteit. Ministeriëlen zoals De Bieberstein, Van der Maesen, Cornelis en Pijls schaarden zich (aanvankelijk) in overwegende mate aan de zijde van de liberalen en opposant Haffmans behoorde duidelijk tot de conservatief-katholieken. Regouts L'ami du Limbourg was eerst een orgaan van de Limburgse oppositiebeweging en bevond zich rond 1870 in conservatief-katholieke hoek. ${ }^{190}$

Persoonlijke verhoudingen bleven de tegenstellingen voeden. Dit kwam af en toe openlijk naar voren, zoals in mei 1872 bij de parlementaire behandeling van het wetsvoorstel dat de verkoop bekrachtigde van een perceel vestinggrond aan Petrus Regout. Het Maastrichtse gemeentebestuur - met Pijls als invloedrijk wethouder - verzette zich daartegen. Nu was Pijls op dat moment tevens Tweede-Kamerlid en in een emotievol betoog pleitte hij ook in 's lands vergaderzaal tegen het wetsontwerp. De minister van Financiën, P. Blussé van Oud-Alblas, sprak veroordelend dat een dergelijke 'opgewondenheid' elders - lees: in Maastricht - wellicht gewaardeerd werd, maar in de Tweede Kamer niet te pas kwam. ${ }^{191}$ De enige sprekers bij het wetsvoorstel waren Pijls en Van der Maesen de Sombreff; zij waren ook de enige tegen- 
stemmers. De derde Maastrichtenaar in de Kamer, De Bieberstein, stemde voor de verkoop aan Regout, hetgeen erop duidt dat op districtsniveau een scherpere tegenstelling bestond tussen Van der Maesen en Pijls enerzijds en Regout anderzijds dan tussen laatstgenoemde en De Bieberstein. Dit zou mede kunnen verklaren waarom de baron in Maastricht veel minder weerstand ondervond dan zijn politieke bondgenoten Van der Maesen en Pijls. Zo schreef Regouts vriend Russel voor de verkiezingen van 1866 in een brochure: 'Wat aangaat den Heer van der Maesen, nog veel minder aan dezen dan aan den Heer de Bieberstein zouden wij ons vertrouwen kunnen schenken.' Weliswaar werd ook De Bieberstein onkundig geacht, maar het was niet uitgesloten dat hij, mits juist geleid, 'in goeden zin' zou kunnen stemmen. ${ }^{192}$

De continuitteit tussen de Limburgse oppositie en de conservatief-katholieken enerzijds en tussen de ministeriëlen en de liberaal-katholieken anderzijds is ook terug te vinden in hun houding ten opzichte van de $\mathrm{Ne}$ derlandse staat en natie. Verhage stelt vast dat de liberaal-katholieken zich meer nationaal en de conservatief-katholieken zich meer provinciaal profileerden. indeling in kiesdistricten blijkt eveneens dat de liberaal-katholieken zich minder provincialistisch opstelden dan de conservatief-katholieken. ${ }^{194}$ Dit laat onverlet dat ook de liberaal-katholieken zich op een aantal momenten in provincialistische zin uitlieten, ook al om zich te weer te kunnen stellen tegen de beschuldiging dat zij de belangen van hun provincie verwaarloosden.

Aan de basis - dat wil zeggen in de Limburgse kiesdistricten - kwamen de tegenstellingen naar voren in de fel gevoerde verkiezingscampagnes, met name in de beschuldigingen die over en weer werden geuit. Na de verkiezingen van oktober 1866 werd bij de Kamer geprotesteerd tegen de benoeming van de liberaal-katholieken Van der Maesen de Sombreff en De Bieberstein. ${ }^{195}$ De voornaamste beschuldiging was dat hun beider politieke bondgenoot, burgemeester Pijls - in hoedanigheid van hoofd van het stembureau in Maastricht - een foutieve uitslag had geproclameerd door zich maar liefst honderd stemmen te vertellen ten nadele van de Gulpense kantonrechter Brouwers, de tegenstrever van de liberaal-katholieken. Daarmee zou niet Van der Maesen de Sombreff ( 921 stemmen) maar Brouwersmet 992 in plaats van de toegekende 892 stemmen - gekozen zijn. Een zeer ernstig verwijt, vond ook de kamercommissie tot onderzoek van de geloofsbrieven. De stembiljetten werden uit Maastricht opgevraagd en in Den Haag 
nageteld. Dat er politieke motieven schuilgingen achter het bezwaar tegen de toelating van Van der Maesen de Sombreff is zeer aannemelijk. Diens verkiezing verd bij de Kamer namelijk betwist door Jos Russel, medestander van Petrus Regout. En het behoeft dan ook geen verwondering dat de tekst van het bezwaarschrift op 1 december 1866 integraal werd opgenomen in L'ami duLimbourg.

Bij de hertelling in Den Haag bleek overigens van de veronderstelde foutieve vaststelling van de uitslag geen sprake te zijn. Aan Brouwers waren, zo bleek bij hetelling, in eerste instantie zelfs vijf stemmen te veel toegekend. Dit werd Rassel, wiens beweringen door de kamercommissie werden gekwalificeerc als 'onjuist en bezijden de waarheid', zwaar aangerekend. Heel wat tijd moet de commissie kwijt zijn geweest met het hertellen van alle biljetten en zij liet niet na 'in het openbaar haar strengste afkeuring uit te spreken ove de handelswijs van den adressant. ${ }^{196}$

Ruim ee] jaar later, in januari 1868 , kwamen er protesten uit het kiesdistrict Roemond. Haffmans was hier reeds na de eerste ronde gekozen verklaard, net ruim veertig stemmen voorsprong op de nummer twee, Cornelis. Als voornaamste bezwaar werd nu aangevoerd dat de stembiljetten met daarop 'Leopold Haffmans' of 'L. Haffmans' zonder verdere aanduiding waren toegekend aan het aftredend Tweede-Kamerlid uit Venlo, terwijl er in het kiesdistrict - en wel in de gemeente Lottum - een man met dezelfde naam woonde. ${ }^{197}$ De commissie die de kwestie onderzocht, meende evenwel dat mocht worden aangenomen dat de Venlose L(eopold) Haffmans werd bedoeld, omdat alleen die zich uitdrukkelijk kandidaat had gesteld. De Kamer nam dit oordeel over.

Bij diezelfde verkiezingen was de strijd om de andere zetel van het district Roermond bijzonder spannend. Nu werd Cornelis wel gekozen verklard, na een nipte overwinning in de tweede ronde. De liberaal-katholiek behaalde slechts drie stemmen meer dan zijn tegenstander Arnoldts: $\mathbf{8 4 4}$ tegen 841 . Ook nu probeerden kiezers uit dit district de Tweede Kamer ervan te overtuigen dat er onregelmatigheden hadden plaatsgevonden. $\mathrm{Zij}$ somden er drie op: één persoon zou hebben deelgenomen aan de stemming, terwijl hij elders in de provincie was gesignaleerd en daarmee nimmer tijdig in het stemlokaal aanwezig kon zijn geweest om zelf zijn stem uit te brengen, zoals vereist was; één stembriefje was ten onrechte toegekend aan Cornelis, want onduidelijk ingevuld; en twee personen hadden een stembiljet ingeleverd terwijl zij niet vermeld waren op de oorspronkelijke kiezerslijst. Vier ongeldige stemmen dus: genoeg om de overwinning van Cornelis te doen omslaan in winst voor Arnoldts. De commissie tot onderzoek van de 
geloofsbrieven achtte de bewijsvoering echter onvoldoende en adviseerde Cornelis toe te laten tot het parlement. De Kamer besliste, na enige discussie, conform dit advies.

Er heerste groot wantrouwen tussen de kampen. Zo werden Maastrichtse kiesgerechtigden die in 1868 hun stem wilden uitbrengen op de conservatief. katholieke kandidaten, in een advertentie gewaarschuwd geen acht te slaan op brieven die zij vlak voor de verkiezingen zouden ontvangen en die in den regel' vol stonden met leugens en laster. 'Geeft ook Uwe stembiljetten niet uit handen; ALZOo voorzichtig!' 198

Stembiljetten werden voorafgaand aan de verkiezingen aan de kiezers toegestuurd en konden op de dag van de stemming in het stembureau worden ingeleverd. In dit licht moet de klacht gezien worden die ruim anderhalf jaar later bij de Tweede Kamer binnenkwam en die er melding van makte dat kiezers uit Venray onderweg naar het stemlokaal door 'sommige lieden' gedwongen waren een herberg binnen te gaan 'ten einde de gelegenheid te hebben hunne stembriefjes in te zien en te veranderen'." Ook nu concludeerde de commissie tot onderzoek van de geloofsbrieven

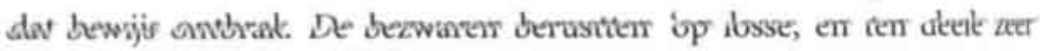
onbestemde beweringen'. 200

In 1872 werd te Roermond een toneelstuk in het dialect opgevoerd onder de titel De leste schlaag of vrije verkiezingen in Limburg. De liberaalgezinde schrijver van deze komedie, Emile Seipkens, wilde zijn provinciegenoten attent maken op de kwalijke praktijken en manipulaties bij de verkiezingen in het district Roermond. Met name de Tweede-Kamerleden Haffmans en Arnoldts moesten het in het toneelstuk ontgelden. ${ }^{201}$

Tekenend voor de gepolariseerde verhoudingen was dat benoemingen in niet-politieke overheidsambten werden gepolitiseerd en daarmee in een bedenkelijk daglicht werden geplaatst. Dit was bijvoorbeeld het geval bijde herbenoeming van Haffmans tot kantonrechter te Venlo, in 1866. Dat deze herbenoeming juist vlak voor de Tweede-Kamerverkiezingen geschiedde. had volgens diverse parlementariërs een politieke grond. Kantonrechters werden telkens benoemd voor een periode van vijf jaar en normaliter werden degenen die in een bepaald jaar aftredend waren en die door de regering in hun functie zouden worden bevestigd, gelijktijdig herbenoend. Een individueel besluit tot herbenoeming, zoals in het geval van Haffmans. was hoogst ongebruikelijk. Zou de minister van Justitie hebben gewacht met de herbenoeming tot ná de kamerverkiezingen, dan zou Haffmans zich spoedig wederom in een risicovolle verkiezingsstrijd hebben moeten storten. Want op het moment dat een zittend kamerlid werd herbenoemd 
in een bezoldigde overheidsfunctie zoals die van kantonrechter, werd zijn kamerzetel vacant (hij was wel weer herkiesbaar). Om dat te voorkomen, 20 meenden velen, had de conservatief-katholieke bewindsman, Eduard Borret, tot de uitzonderlijke maatregel besloten. ${ }^{202}$

Haffmans op zijn beurt plaatste in 1871 vraagtekens bij de benoeming van zijn politieke tegenstander, de liberaal-katholiek Cornelis, tot officier van justitie in Roermond. Deze functie was door het derde kabinet-Thorbecke an Cornels toebedeeld als beloning voor diens volgzame houding, veronderstelde Haffmans. ${ }^{203}$ Het benoemingenbeleid van dit liberale kabinet werd helemaal in een politieke context geplaatst toen Haffmans datzelfde jar niet wetd herbenoemd tot kantonrechter in Venlo, maar in plaats daarvan werd oatslagen. ${ }^{204}$ Hijzelf was de functie graag blijven vervullen. 'In den raad miner politieke vijanden was het echter anders besloten.' Aldus Haffmans in het Venloosch Weekblad. ${ }^{205}$

De kwestie haalde ook buiten Limburg uitgebreid de pers, vooral door toedoen van Haffmans zelf die minister J.A. Jolles van Justitie interpelleerde over de dienstbeëindiging. Hij wilde van de minister weten of er andere dan politize redenen bestonden voor zijn ontslag. Want velen betwijfelden volgens Haffmans 'of de kantonregter te Venlo [hijzelf dus] wel zou zijn ontslagen, indien hij tot de politieke vrienden van de Regering behoord had, indien hij bij voorbeeld de heer Cornelis geweest ware. ${ }^{206}$ De minister ontkende dat er politieke motieven in het spel waren en hij verzuchtte dat dit soort interpellaties, naar hij hoopte, 'in het algemeen belang en ook in het belang van den nationalen tijd $[\ldots]$ tot de zeldzaamheden zullen behooren.'207

Onderzoek heeft aangetoond dat de minister van Justitie Haffmans niet ontsloeg uit politieke overwegingen. ${ }^{208}$ Integendeel, de bewindsman wilde het kamerlid juist als kantonrechter handhaven mede om te voorkomen dat er gesuggereerd zou worden dat de minister zich had laten leiden door politieke motieven. Het was hier koning Willem III die de herbenoeming blokkeerde, op grond van rapporten waarin vraagtekens werden geplaatst bij het functioneren van de Venlose kantonrechter. Dit koninklijk optreden was in 1871 echter niet publiekelijk bekend. Daardoor was het welhaast onvermijdelijk dat het ontslag werd gepolitiseerd: in de politieke strijd van die jaren werden immers ook kwesties zoals overheidsbenoemingen meegenomen.

De Bieberstein werd door zijn tegenstanders in Limburg openlijk beschuldigd van nepotisme. Voor hen stond vast dat zijn zonen, zijn schoonzoon en ook andere relaties hun betrekkingen te danken hadden aan het 
Tweede-Kamerlid. In het archief van Thorbecke bevindt zich een brief van De Biebersteins oudste zoon, Paul, die Thorbecke schriftelijk dankt voor zijn benoeming tot schoolopziener in een Limburgs schooldistrict. ${ }^{209}$ Thor. becke moet als minister van Binnenlandse Zaken, met onderwijs in zijn portefeuille, zeker invloed gehad hebben op die benoeming. Of Pauls vader zich met de invulling van de vacature heeft beziggehouden, wordt nergens vermeld; wel had hij zijn beide zonen eerder bij Thorbecke vriendelijk geìntroduceerd als 'dappere kampvechters.'210

Bij de verwijdering tussen katholieken en liberalen worden in de literatuur veelal twee kwesties centraal gesteld: de onderwijskwestie en de zogeheten Romeinse kwestie. Welke gevolgen deze vraagstukken hebben gehad voor de politieke positie van de Limburgse afgevaardigden in de landelijke politick, zal nu aan de orde komen.

\section{Lager onderwijs}

De wet op het lager onderwijs van 1857 gaf uitvoering aan de in de grondwet van 1848 vastgelegde vrijheid van onderwijs: niet langer hoefde er voor de oprichting van een bijzondere lagere school toestemming te worden gevraagd aan het burgerlijk gezag. Het bijzonder onderwijs bleef echtet verstoken van overheidssteun en was daarom afhankelijk van particuliert financiering. De openbare scholen waren bestemd voor alle gezindten en werden wel financieel mogelijk gemaakt door de overheid. De schoolwetKappeyne uit 1878 handhaafde dit onderscheid in financiering tussen openbaar en bijzonder onderwijs. Doordat deze wet de eisen waaraan scholen moesten voldoen, flink aanscherpte, werden bijzondere scholen geconfronteerd met een aanzienlijke lastenverzwaring. Het bijzonder lager onderwijs kreeg daardoor een extra hoge hindernis te nemen. In toenemende mate vormde de ongelijkheid in financiering van het openbaar en het bijzonder onderwijs een steen des aanstoots voor katholieken en protestanten. Het politieke dispuut met de voorstanders van openbaar onderwijs, die vooral in liberale kring gezocht moesten worden, ontwikkelde zich tot de schootof onderwijskwestie. ${ }^{211}$

In augustus 1868 kwamen de Nederlandse bisschoppen met een onderwijsmandement. Het episcopaat eiste hierin onderwijs dat 'in alle oprigten katholiek en godsdienstig' zou zijn. ${ }^{212}$ De openbare school werd afgewezen. In de Tweede Kamer vond het bisschoppelijk mandement direct weerklank en wel bij de bespreking van de troonrede waarmee in september 1868 het 
nieuwe parementaire jaar was geopend. In zijn toespraak had Willem III weliswaar rieuwe wetgeving met betrekking tot het hoger onderwijs in het vooruitzict gesteld, over het lager onderwijs had hij gezwegen. Nu was het gebruikelijk dat de beide Kamers - afzonderlijk - debatteerden over de troonrede en dat zij er elk in een adres van antwoord op reageerden. In het adres van antwoord van de Tweede Kamer wilde de anti-revolutionair I.W. Gefkes de teleurstelling kenbaar maken over het ontbreken van een passage over het lager onderwijs en hij diende daartoe een voorstel tot wijziging van het ontwerp-adres in. Een ander amendement was afkomstig van W. baron van Goltstein: deze afgevaardigde drukte zich iets minder fel uit, maar ook in zijn voorstel werd de hoop uitgesproken dat de regering tegemoet zou komen aan de bezwaren die tegen het bestaande stelsel van lager onderwijs bestonden. ${ }^{213}$ De beide amendementen werden verworpen.

Ruim en jaar later was een motie aan de orde, ingediend door de antirevolutionar $\mathrm{O}$. baron van Wassenaer van Catwijck, waarin de onvrede met de bestaance en in de wetgeving vastgelegde verhouding tussen openbaar en bijzonder onderwijs opnieuw tot uitdrukking werd gebracht. Ook nu stemde eenmeerderheid tegen en de wet werd niet gewijzigd. Zoals gezegd werd ook bij de herziening van de schoolwet in 1878 niet tegemoet gekomen aan de wensen van de voorstanders van bijzonder onderwijs. Het zou tot 1917 duren voordat er een einde kwam aan de schoolstrijd.

Tabel 4 toont het stemgedrag van de Limburgse leden van Eerste en Tweede Kamer bij de voorstellen met betrekking tot het (bijzonder) lager onderwijs die hiervoor kort zijn vermeld.

De stemming over de onderwijswet uit 1857 geeft, als het om de Limburgse afgevaardigden gaat, geen eenduidig beeld te zien. Van de vier parlementariërs die deelnamen aan de stemming, spraken drie zich voor de wet uit en één, Van Wintershoven, daartegen. De Limburgse TweedeKamerleden stemden wel unaniem tegen artikel 22 waarin werd gesteld dat het openbaar lager onderwijs dienstbaar moest zijn aan de opleiding tot 'alle Christelijke en maatschappelijke deugden'. In katholieke kring werd namelijk gevreesd voor een protestantse invulling van het woord 'christelijk.'214 Ook Van Wintershoven - de enige Limburger die bij de beraadslagingen over dit artikel het woord voerde - had bezwaar tegen het vermelden van het begrip, gezien het 'misbruik' dat daarvan gemaakt werd en zou kunnen worden. 213

In de stemming over artikel 22 wordt soms een begin gezien van de verwijdering tussen de Limburgers en de liberalen. ${ }^{216}$ De vraag is echter of dat zo is. Het wetsontwerp was niet door de liberalen ingediend en 
Tabel 4. Stemgedrag van de Limburgse kamerleden inzake het bijzonder lage onderwijs, 1857-1878 (de Eerste-Kamerleden zijn cursief weergegeven)

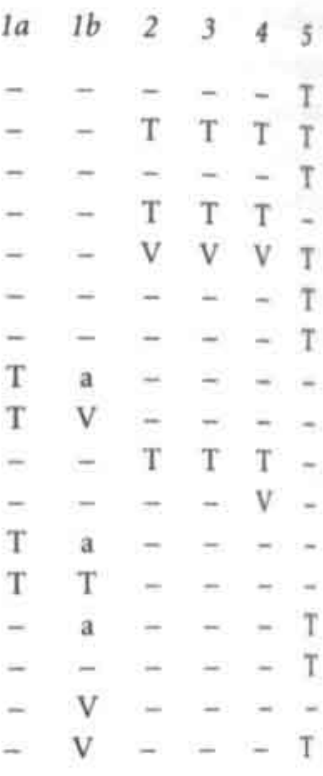

1a Artikel 22 van de wet tot regeling van het lager onderwijs (Tweede Kamer 11 juli 1857)

1b Wet tot regeling van het lager onderwijs (Tweede Kamer 20 juli 1857; Eerste Kamer 12 augustus 1857)

2 Amendement-Gefken (Tweede Kamer 1 oktober 1868)

3 Amendement-Van Goltstein (Tweede Kamer 1 oktober 1868)

4 Motie-Van Wassenaer van Catwijck (Tweede Kamer 15 december 1869)

5 Wetsontwerp herziening wet tot regeling van het lager onderwijs (schoolwet-Kappeyne) (Tweede Kamer 18 juli 1878; Eerste Kamer 7 augustus 1878)

$T$ Stemt tegen

V Stemt voor

a Is afwezig

- Heeft op moment van stemming geen zitting in de Kamer

bovendien lijkt het onderwerp van onvoldoende gewicht te zijn geweest om een wig te kunnen drijven tussen de liberale voorstanders en de Limburgess Drie van de vier afgevaardigden uit Limburg gaven hun stem immers wel 
an het wetscntwerp in zijn geheel. In het algemeen wordt bovendien gesteld dat de kathoieken zich nog niet erg druk maakten om de schoolkwestie. De katholiek leden van de Tweede Kamer stemden verdeeld: zes waren voor en zes egen; in de Eerste Kamer stemden alle katholieken voor het wetsontwerp ${ }^{217}$

Voor Limburg in het bijzonder gold dat de bezwaren die tegen de openbare lagere school bestonden voor een belangrijk deel werden ondervangen doordat ookde onderwijzers die daar in het openbaar onderwijs actief waren, veelal bcrg stonden voor het uitdragen van de katholieke beginselen. ${ }^{218}$ De cerste gonverneur in Limburg, Gericke van Herwijnen, had al in 1841 te horen gekregen dat de openbare scholen in zijn provincie 'in feite katholiek' waren. ${ }^{29} \mathrm{Zij}$ opvolger ten tijde van de behandeling van de onderwijswet uit 1857 , Van der Does de Willebois, constateerde met leedwezen dat het onderwijs in met name de grotere gemeenten in Limburg vrijwel geheel in handen was van kloosterorden, via de door hen geleide en buiten de overheid om gefinancierde bijzondere scholen. Zelfs de zorg voor het onderwijs op openbarescholen was in de provincie door sommige gemeentebesturen in handen van kloosterlingen gelegd. ${ }^{220}$ Gelet op de bij de Tweede Kamer ingekomen verzoekschriften lijkt het lager onderwijs in 1857 inderdaad geen belangrijk item te zijn geweest in Limburg: vanuit dit gewest werd over het wetsontwerp geen enkel adres gestuurd; uit Noord-Brabant arriveerden er bijna veertig. ${ }^{221}$ Het onderscheid tussen 'katholieke openbare scholen' en 'katholieke bijzondere scholen' was voor de Limburgse bevolking volstrekt onbelangrijk. ${ }^{22}$ In de naburige Belgische provincie Limburg verliep de schoolstrijd ook al minder fel, 'op zijn Limburgs', aldus Ubachs in zijn Handboek voor de geschiedenis van Limburg. ${ }^{23}$

Bij de drie stemmingen die over de onderwijskwestie plaatsvonden tijdens de regeerperiode van het liberale kabinet-Van Bosse-Fock (18681871 ), openbaarde zich een tegenstelling tussen liberaal en conservatiefkatholieken. Bij de amendementen ingediend door Gefken en Van Goltstein en bij de motie-Van Wassenaer van Catwijck zien we De Bieberstein, Cornelis en Van der Maesen aan de ene kant staan en Haffmans aan de andere. We mogen hierin echter niet een tegenstelling zien tussen vooren tegenstanders van bijzonder onderwijs. Zo verklaarde Van der Maesen bij de discussie over de beide amendementen juist een aanhanger te zijn van een wijziging van de wet op het lager onderwijs. Dat hij toch tegen de voorstellen stemde, vraagt om een verklaring en Van der Maesen gaf ook zelf aan de noodzaak tot een toelichting in te zien. De beide amendementen zouden volgens hem niet bijdragen tot het bevorderen van het bijzonder 
onderwijs: het waren voorstellen met een primair partijpolitieke strekking - met 'eene vijandige strekking tegen deze Regering' in de woorden var Van der Maesen - en dat was voor hem een voorname reden om tegen te stemmen. ${ }^{224}$

Eenzelfde bezwaar voerde Van der Maesen ruim een jaar later aan tegen de motie-Van Wassenaer van Catwijck. Hij vond de strekking van deze motic overeenkomen met de amendementen van Gefken en van Van Goltstein, 20 verklaarde hij in de Kamer: er werd geen enkele oplossing in aangedragenen het doel ervan leek vooral oppositie voeren tegen het zittende kabinet-hij sprak in dit kader van 'partijdrift' - en ook nu verklaarde hij uitdrukkelijk wijzigingen in de schoolwet 'noodig en nuttig' te vinden.225

Pijls, in die tijd als liberaal-katholiek fel bestreden, schaarde zich bij de stemming over de motie-Van Wassenaer van Catwijck opmerkelijk genoeg aan de zijde van zijn tegenstander Haffmans. Twee dagen eerder had hij in de Kamer duidelijk gemaakt het tijd te vinden voor een herziening van de onderwijswet van 1857 , zodat de bijzondere school niet langer zou worden belemmerd in haar ontwikkeling. ${ }^{226}$ Ruim een jaar later verklaarde Pijls niet alleen altijd al een voorstander te zijn geweest van bijzonder onderwish maar dit standpunt al eerder te hebben ingenomen dan Haffmans, dic daarover ooit 'andere gedachten' had gehad. Pijls verwees naar de tijd war. in Haffmans onder de onderwijswet van 1857 schoolopziener was geweest en zich daardoor volgens hem aan de keuze van openbaar boven bijzonder onderwijs had geconformeerd. ${ }^{227}$ Bovendien verklaarde Pijls tijdens een debat: 'Ten aanzien van de onderwijs-quaestie behoor ik zeer zeker niet tot de liberale partij [...].'228

In de Tweede Kamer lijkt er op het terrein van het onderwijs geen sprake te zijn geweest van een duidelijk verschil in opvatting: niet alleen conservatief-katholieke afgevaardigden zoals Haffmans, Arnoldts en Lambrechts verklaarden voorstander te zijn van bijzonder onderwijs, dat deden ook de liberaal-katholieken Pijls, Van der Maesen en Cornelis. Johanno Clercx, in 1869 de liberale tegenkandidaat van Haffmans in het distrit Boxmeer, liet zich in de pers gelijkluidend uit. ${ }^{229}$ Dat de meningen niet vet uiteen lagen, ligt ook besloten in parlementaire redes van Pijls en Haffmans. De eerste zei in mei 1871: 'Wij [Haffmans en hijzelf] zijn als zoodanit en in betrekking tot dit onderwerp [het lager onderwijs] niet van elkart verwijderd.'230 Haffmans had een maand eerder gezegd: 'Ik zie toch aan de overzijde [bij de liberalen] tot mijn leedwezen mannen gezeten, die dagelijks op de meest plegtige wijze betuigen, dat zij in de onderwijs-quaetix aan onze zijde staan.'231 
Als we dstemming over het wetsontwerp uit 1878 bezien, dan moet worden vastgeseld dat de afgevaardigden uit Limburg zich zonder uitzondering uitsprakenegen de bevoorrechting van het openbaar lager onderwijs. Dat deed dus ok De Bieberstein, terwijl hij toen nog steeds werd beschouwd as (te) libesal.

Niet sleats conservatief-katholieke kandidaten, ook hun liberaal-katholieke oppoenten lieten voorafgaand aan verkiezingen meermalen weten het bijzonder aderwijs te zullen bevorderen. Zo wist De Noord-Brabanter op jo januari 368 te melden dat men er op grond van een 'politieke geloofsbelijdenis' ie Van der Maesen en De Bieberstein tijdens een bijeenkomst van kiezerhadden afgelegd, van mocht uitgaan dat deze afgevaardigden zich in het nderwijsvraagstuk als 'conservatief' zouden opstellen. Het blad bedoelde hrmee dat, indien het bijzonder lager onderwijs aan de orde zou komen, beien zich aan de zijde zouden scharen van de conservatieven. Die hadden naelijk, om katholieke steun te verwerven, voorafgaand aan de verkiezing verklaard de onderwijskwestie te zullen aanpakken.

Bij de vrkiezingen van juni 1871 gaf De Bieberstein een circulaire uit, gericht aar de kiezers van het kiesdistrict Maastricht. Hij schreef onder meer: "Inzake onderwijs zal ik medewerken om de bestaande bezwaren op te heffen. ${ }^{232}$ Dat liet weinig ruimte tot twijfel, aldus het commentaar van De Maasbode op 8 juni: 'Eindelijk zal de heer B. medewerken tot wijziging der schoolwet.

In het parlementair optreden bestond er echter wel een verschil tussen de liberaal georiênteerde kamerleden en de conservatief-katholieken, hier in de persoon van Haffmans. Van der Maesen, De Bieberstein en Cornelis weigerden bij genoemde stemmingen eind jaren zestig - hoewel voorstander van bijzonder onderwijs - hun binding met het zittende liberale kabinet op te geven. Dit geldt ook voor Pijls. Bij de beraadslagingen over de begroting van onderwijs in mei 1871 zei hij dat het juist op de weg van de liberalen lag om de vrijheid van onderwijs ook financieel te waarborgen. Sterker nog: zonder liberalen was een oplossing van de onderwijskwestie volgens hem niet mogelijk. Pijls vestigde zijn hoop vooral op Thorbecke - sinds enkele maanden weer aan het hoofd van een kabinet - die met zijn 'niet te evenaren betoogen' een goed resultaat in de onderwijskwestie zou kunnen bewerkstelligen. ${ }^{233}$

Die hoop was tevergeefs: de wet werd ook onder herhaaldelijk liberaal bewind niet bijgesteld. En dat gaf de conservatief-katholieken in Limburg munitie. Zo trachtte Haffmans meermaals om de liberaal-katholieken klem te zetten met behulp van de onderwijskwestie. Het Venloosch Weekblad stelde op 22 mei 1869 Pijls voor aan de kiezers en bracht tegen hem in stelling 
dat hij behoorde 'tot eene partij in wier vaandel staat: geen wijgiging de schoolwet'. Het verwijt trof ook Van der Maesen de Sombreff, De Bieberstén en Cornelis. Het blad verzuchtte: "Waren er toch geen katholieke liberalerin de Kamer, de liberalen konden het verzet tegen de wijziging der schoohe niet volhouden.'

Ook Haffmans zette het onderwijsmandement in als wapen: het schri, ven van het episcopaat was voor alle katholieken 'zonder onderscheid een norma agendi, verklaarde hij in december 1869 in de Kamer. ${ }^{24}$ Andehalf jaar later wierp hij Pijls voor de voeten:

De heer Pyls trede dan uit de gelederen der liberale partij; hij kome tot ons, de zoogenaamde clericalen of ultramontanen; wij zullen den verloren zoon met open armen ontvangen. Uwe beginselen zijn onse beginselen, en het voegt $u$ niet langer eene partij te stijven, in wiet vaandel bovenaan geschreven staat: handhaving der schoolwet. Z00 lang de heer Pyls dit doet, zal hij zelf een hinderpaal zijn tegen de vervulling zijner eigen wenschen. ${ }^{235}$

Insdaactrint viacritern ué tegenstandérs van ae uberaal-kathoheken eveneens de onderwijskwestie in stelling: Van der Maesen en De Bieberstein werd in $\mathbf{1 8 6 8}$ verweten onduidelijk te zijn als het ging om hun standpunt terzake. Hun tegenkandidaten Brouwers en Wenmaekers trachtten zich met onder meer de onderwijskwestie te profileren: zij waren 'met hart en ziel voor het "godsdienstig onderwijs" gestemd."236

Indien we de verkiezingsuitslagen bezien, lijkt de onderwijskwestie ech. ter geen grote invloed te hebben gehad op de positie van de liberalkatholieken in Limburg. Bij de verkiezingen van 1869 - dus één jaar na het onderwijsmandement - werd in zowel Roermond als Maastricht een liberale kandidaat gekozen. Van der Maesen had in Maastricht zelfs geen tegenkandidaat en Pijls won de Roermondse zetel ten koste van Arnoldts. Hier doet zich een opmerkelijk verschil voor met Noord-Brabant, waar na het bisschoppelijk mandement geen enkele kandidaat meer naar Den Haag werd afgevaardigd die zich niet tegen het liberalisme had verklaard. ${ }^{20}$

De liberaal-katholiek Pijls werd in 1869 nota bene gekozen met steun van het hoogste kerkelijk gezag in de provincie: bisschop Paredis. Deze liet zich weinig gelegen liggen aan de landelijke politieke scheidslijnen en streefic vooral politieke rust in zijn diocees na. Hoewel ook Paredis' handtekening onder het onderwijsmandement stond, nam hij binnen het episcopaat een bijzondere positie in als het ging om het in de praktijk brengen van het 
mandennt. De bisschop van Haarlem, G.P. Wilmer, verdacht zijn collega te Roerrnd ervan het gezamenlijk standpunt alleen in theorie te ondershrijver" In ieder geval kregen de conservatief-katholieken in Limburg - andersan in overige bisdommen - geen steun van het kerkelijk gezag. En die sun was voor een machtswisseling te hunner gunste onontbeerliik, omd alleen de bisschoppen stemgedrag als uiting van geloofstrouw konden anmerken. 239

Overìns had L'ami du Limbourg al op 12 mei 1866 tot zijn spijt moeten vastsllen dat Pijls zich voortdurend zeker wist van de steun van de geestelijkeid. En hij was niet de enige liberaal-katholiek die goede betrekkingen ollerhield met kerkelijke gezagdragers. Zo had Van der Maesen de Sombreffen uitstekende relatie met P.D. van Laer, de pastoor-deken in het Masichtse stadsdeel Wyck. Van Laer vond dat het zicht op zijn SintMartinusłrk werd belemmerd door de Wycker kruittoren uit de dertiende eeuw, volpns sommigen het fraaiste monument van Wyck. Terwijl de vraag of de tore moest worden afgebroken door het conservatieve kabinet-Van Zuylen va Nijevelt-Heemskerk op de lange baan geschoven was, besloot het libera kabinet-Van Bosse-Fock spoedig na zijn aantreden tot sloop over te gaan. In het najaar van 1868 verdween de kruittoren uit het Maastrichtse stadsbeeld. De deken was hierover bijzonder verheugd en hij dankte Van der Maesen de Sombreff voor al zijn inspanningen. ${ }^{240}$ Overigens had Van der Maesen de Sombreff alle belang bij de hulp die hij de pastoor-deken van Wijck had geboden. De Maastrichtse historicus Edmond Jaspar stelt met verontwaardiging vast over 'deen erreme Pollefortore' (die arme kruittoren), 'dat er et slachoffer gewees is vaan politiek gekoonkel en dat heer versjacheld is tegen 'ne zetel in de Twiede Kamer! Zoe wied kin et in de polletiek goon?' (Dat hij het slachtoffer geweest is van politiek gekonkel en dat hij versjacherd is voor een zetel in de Tweede Kamer! Zo ver kan het in de politiek gaan! $)^{241}$ Het ging hier om een liberale zetel welteverstaan, met hulp van de geestelijkheid, terwijl het onderwijsmandement inmiddels al was afgekondigd.

Dat de strijd voor de bijzondere lagere school in de jaren zestig en zeventig in Limburg - ook voor Paredis - nog steeds geen halszaak was, hield verband met de feitelijke situatie op de scholen in die provincie. De bestaande openbare scholen in de religieus vrijwel homogene provincie waren in de praktijk geheel en al katholiek. Dit gold eveneens voor de inzake het lager onderwijs bevoegde gezagdragers: de gemeentebesturen. ${ }^{262}$ Tweede-Kamerlid Comelis sprak in december 1868 dan ook van een 'milde toepassing' van de onderwijswet in streken waar uitsluitend kinderen van eenzelfde gezind- 
Tabel 5. Stemgedrag van de Limburgse kamerleden inzake de Romeinse kwestic, 1861-1872 (de Eerste-Kamerleden zijn cursief weergegeven)

$\begin{array}{lccccc} & 1 & 2 & 3 & 4 & 5 \\ \text { J.A. Arnoldts } & - & - & - & \mathrm{T} & - \\ \text { Ch.A. baron de Bieberstein Rogalla Zawadsky } & \mathrm{T} & \mathrm{T} & \mathrm{T} & \mathrm{T} & - \\ \text { K.L.J. Cornelis } & \mathrm{V} & \mathrm{T} & \mathrm{V} & - & - \\ \text { J.H.L. Haffmans } & - & \mathrm{T} & \mathrm{T} & \mathrm{T} & - \\ \text { P.L. de Lom de Berg } & \mathrm{T} & - & - & - & - \\ \text { jhr. P.Th. van der Maesen de Sombreff } & - & \mathrm{T} & \mathrm{V} & \mathrm{T} & - \\ \text { W.H. Pijls } & - & \mathrm{T} & \mathrm{T} & \mathrm{T} & - \\ \text { P.F.E. van Wintershoven } & \mathrm{a} & - & - & - & - \\ \text { L.F.H. Beerenbroek } & - & - & - & - & \mathrm{T} \\ \text { jhr. F.B.H. Michiels van Kessenich } & - & - & - & - & \mathrm{T} \\ \text { jhr. L.L.W.M.J. de Villers de Pite } & - & - & - & - & \mathrm{T}\end{array}$

1 Amendement-Van Eck (Tweede Kamer 24 september 1861)

2 Motie-Fransen van de Putte (Tweede Kamer 19 december 1870)

3 Motie-Cremers (Tweede Kamer 19 december 1870)

4 Amendement-Dumbar (Tweede Kamer 17 november 1871)

5 Begroting Buitenlandre Zakes (Eorrte Kamer 28 decemmer is72)

T Stemt tegen

V Stemt voor

a Is afwezig

- Heeft op moment van stemming geen zitting in de Kamer

Tweede-Kamerlid voor het district Roermond en vanaf maart 1861 minister voor de Zaken van de Rooms-Katholieke Eredienst. ${ }^{255}$ Volgend op de erkenning van Italië door diverse Europese mogendheden ging in juli ook de Nederlandse regering daartoe over, echter zonder daarvan melding te maken in de troonrede die koning Willem m op 9 september 1861 uitsprak. Op die manier hoopte de regering een parlementair debat over deze precaire kwestie te kunnen vermijden. Zoals reeds opgemerkt was het namelijk gebruikelijk dat de Eerste en Tweede Kamer debatteerden over de troonrede en dat zij er elk in een adres van antwoord op reageerden. Ondanks de bedoelingen van de regering werd in de beide kamers gepoogd om in het adres toch blijk te geven van adhesie met de erkenning van het nieuwe koninkrijk.

Het ontwerp-adres van antwoord waarover de Eerste Kamer zich boog, bevatte, overeenkomstig de wens van de regering, geen opmerking over de 
erkenning van het koninkrijk Italië. Eerste-Kamerlid Jan Fransen van de Putte wilde hier verandering in brengen. Hij stelde voor een positieve beoordeling uit te spreken over het aangaan van diplomatieke betrekkingen, wegens het grote belang voor de handel: een argument waarvoor Nederlanders zich altijd wel gevoelig tonen. ${ }^{256}$ Fransen van de Putte trok zijn voorstel even later echter in en tot een stemming kwam het derhalve niet.

In het ontwerp-adres van antwoord dat aan de Tweede Kamer werd voorgelegd, was wel al een verwijzing opgenomen naar de erkenning van het koninkrijk Italië, maar zonder hier een oordeel over te vellen. ${ }^{257} \mathrm{De}$ liberaal Daniël van Eck wilde voorkomen dat men in de gekozen neutrale formulering 'eene soort van protest tegen de erkenning' zou kunnen lezen en hij diende daarom een wijzigingsvoorstel in. ${ }^{258}$ Dit amendement werd met 52 tegen 7 stemmen verworpen. Onder de voorstemmers bevond zich opmerkelijk genoeg Karel Cornelis, de afgevaardigde uit Roermond, die zijn stem overigens niet mondeling toelichtte. Later zou hij verklaren per abuis voor te hebben gestemd. De overige twee Limburgse kamerleden - Van Wintershoven was afwezig wegens ziekte - maakten duidelijk dat er geen sprake kon zijn van een positieve beoordeling van de Italiaanse eenwording onder leiding van Victor Emanuel II, die immers een bedreiging vormde voor de Kerkelijke Staat.

Hoewel de volledige annexatie van de Kerkelijke Staat pas zo'n tien jaar later haar beslag zou krijgen, kwam het voortbestaan van de Nederlandse diplomatieke missie bij de paus tussen 1861 en 1872 al geregeld in het parlement aan de orde, met name bij de jaarlijkse begrotingsbehandeling van het departement van Buitenlandse Zaken. Zo verklaarde de anti-revolutionair Guillaume Groen van Prinsterer zich al in de eerste helft van de jaren zestig voorstander van de opheffing van het Nederlands gezantschap. Hij werd in november 1862 van repliek gediend door de toenmalige minister van Buitenlandse Zaken, de Limburger Van der Maesen de Sombreff, die weldra ook als kamerlid met de kwestie te maken zou krijgen. ${ }^{259}$

Bij de begrotingsbehandeling in november en december 1864 verklaarde Gerard Dumbar: 'Ik kan mij volstrekt niet voorstellen hoe bij een vorst, die als wereldlijk vorst niet veel invloed meer heeft, nog een diplomatiek agent kan noodig zijn.' ${ }^{260} \mathrm{Zijn}$ collega, de anti-revolutionaire afgevaardigde Willem baron van Lynden, bracht een affaire onder de aandacht die zich had voorgedaan te Rome. Een joodse jongen was er aan de ouderlijke macht onttrokken en, zo ging het verhaal, door de katholieke Kerk gedwongen zich van het geloof van zijn ouders af te keren. Uit verontwaardiging over hetgeen in Rome zou zijn voorgevallen, wilde Schelto baron van Heemstra 
een amendement indienen dat de opheffing beoogde van het Nederlands gezantschap bij de paus. Later trok Van Heemstra zijn wijzigingsvoorstel in, omdat hij geen twistappel 'van zoo teederen aard' in de vergadering wenste te werpen, daar overigens wel aan toevoegend dat hij slechts 'voor het oogenblik' berustte in het behoud van de Nederlandse missie te Rome.

De Bieberstein deed van zich spreken door tijdens het debat tot vier keer toe het woord te voeren. De baron reageerde fel, omdat hij veronderstelde dat anti-papisme de grond was voor het aan de orde stellen van de kwestie. Waarom werd er anders niet in de bres gesprongen voor de joden elders in Europa of voor de katholieken die in sommige landen toch ook werden vervolgd? Van zijn joodse collega Michel Henry Godefroi had De Bieberstein een parlementaire interventie ten gunste van 'dien jeugdige Israetliet, die te Rome tot Christen zou zijn gemaakt' kunnen billijken, hoewel het Limburgse kamerlid dan wel graag zijn stelling door Godefroi bevestigd zou willen zien. Die stelling luidde: 'Wat in Rome gebeurt, gebeurt ook in Amsterdam. [...] In de hospitalen en gasthuizen aldaar worden jongen Israélieten ook tot het Protestantisme overgehaald.'262

De Biebersteins bijdrage aan het parlementaire debat bij deze kwestie tekent zijin betrokkenheid bij de positie van de puus. Dit bleek ook eerr antal jaren later, in 1870 , toen een adresbeweging werd opgezet onder Nederlandse katholieken om er bij Willem III op aan te dringen dat de inbezitneming van de Kerkelijke Staat door het koninkrijk Italië niet zou worden erkenden dat er stappen zouden worden ondernomen tot herstel van de wereldlijke soevereiniteit van de paus. In het comité van vooraanstaande katholieken dat zich voor het welslagen van de beweging inspande, zat onder anderen baron de Bieberstein. ${ }^{263}$

Over dit petitionnement interpelleerde de liberaal-katholiek H.C.F. Kerstens, afgevaardigde uit Boxmeer, op 19 december 1870 J.J. van Mulken, minister van Oorlog en tijdelijk belast met het beheer van het departement van Buitenlandse Zaken. Kerstens, die verklaarde ook zelf zijn handtekening te hebben gezet, diende een motie in waarin hij van de regering vorderde dat zij zou voldoen aan de wens van de katholieke petitionarissen. ${ }^{26}$ Of deze motie de katholieke zaak daadwerkelijk zou dienen, was echter zeet de vraag: een verwerping ervan - hetgeen gelet op de bestaande politieke verhoudingen waarschijnlijk was - zou immers uitgelegd (kunnen) worden als een parlementaire oproep aan de regering om het petitionnement naast zich neer te leggen. Van diverse zijden werd er bij Kerstens op aangedrongen zijn motie in te trekken, een verzoek waaraan hij uiteindelijk voldeed, vooral ook omdat er inmiddels een tweede motie was ingediend door I.D. Fransen 
vn de Putte. Deze motie sprak uit dat het juist géén taak van de Nederlandse regering was om iets te ondernemen tot herstel van de wereldlijke soevereinieit van de paus. Ook deze motie maakte weinig kans en daarmee dacht Kerstens - indirect - alsnog zijn doel te kunnen bereiken. Er werd echter nog een andere motie ingediend, door E.J.J.B. Cremers, die eenvoudigweg har goedkeuring uitsprak over de houding van de regering. ${ }^{265}$

Van belang is hier de vaststelling dat zowel de motie van Fransen van de Putte als die van Cremers strijdig was met het katholieke petitionnement, dar immers bij de koning aandrong op het ondernemen van stappen tot herstè van de pauselijke soevereiniteit over de Kerkelijke Staat. Het is daarom nit verbazingwekkend dat De Bieberstein als mede-organisator van het petitionnement tegen de beide moties stemde. Dat deden ook Pijls en Haffmans. Ook bij de laatste was zijn verzet tegen de beide moties voorspelbaar: Hafmans' krant had de adresbeweging eerder al van harte ondersteund. ${ }^{266}$

Van der Maesen de Sombreff en Cornelis stemden tegen de motie van Fransen van de Putte, maar voor de motie van Cremers. Zij plaatsten zich daarmee tegenover het petitionnement, zoals Van der Maesen zelf ook opmerkte tijdens zijn rede in de Kamer. De Nederlandse neutraliteitspolitiek litr een interventie in dit internationale conflict echter niet toe, aldus de formeel waarschijnlijk juiste redenering door de oud-minister van Buitenlandse Zaken. ${ }^{267}$

In mei 1871 - het restant van de Kerkelijke Staat was inmiddels door Italiê geannexeerd - bracht Dumbar in de Tweede Kamer wederom de onwenselijkheid van het voortbestaan van het Nederlands gezantschap bij de paus ter sprake. Diverse afgevaardigden vielen hem bij. ${ }^{268}$ Dumbar onthield zich nog van het indienen van een voorstel tot opheffing, maar een halfjaar later, in november, deed hij dat wel: hij stelde voor om de uitgaven voor het gezantschap uit de begroting van Buitenlandse Zaken te schrappen. Dit amendement op de begroting werd met 39 tegen 33 stemmen aangenomen.

In de Tweede Kamer voerden alle Limburgse volksvertegenwoordigers het woord, met uitzondering van Arnoldts, die twee weken later alsnog zijn mening over de kwestie in een parlementaire redevoering kenbaar maakte. Zonder uitzondering verklaarden zij zich een fel tegenstander te zijn van het beëindigen van de Nederlandse diplomatieke missie bij de paus. De Bieberstein, Van der Maesen, Pijls, Haffmans en later Michiels van Kessenich in de Eerste Kamer deden allen een beroep op de (Nederlandse) verdraagzaamheid. 'Mijne Heeren, ik bid u, wij zijn nu eenmaal te zamen in één Staat, laten wij ons leven niet lastig en onaangenaam maken. [...] bespaar ons dat harteleed,' zei Haffmans in een zeldzame bui van nederigheid. ${ }^{209}$ 
De Bieberstein zorgde met zijn pleidooi voor de nodige opschudding. Door naar eigen zeggen aan het debat deel te nemen als oud-soldaat en drager van een pauselijke ridderorde, had hij zich wel erg nauw en hartstochtelijk verbonden met de zaak van zijn kerkvorst, oordeelden diverse voorstanders van de handhaving van het gezantschap. De bijdrage van de Limburgse baron had, zo vreesden zij, hun gezamenlijk streven geen goed gedaan. 'Neen, wij zijn hier geen ridders, geen soldaten van den Paus, wij zijn Nederlanders', aldus een van hen. ${ }^{270}$

De Limburgse Tweede-Kamerleden gingen in hun parlementaire protest tegen de opheffing van het Nederlands gezantschap overigens verdet dan sommige andere katholieke afgevaardigden: na aanneming van het amendement-Dumbar stemden zij alle vijf tegen de gehele begroting van Buitenlandse Zaken. ${ }^{271}$ Kennelijk had het verdwijnen van het Nederlands gezantschap de Limburgers onder de katholieke parlementariërs bijzonder diep geraakt.

In de Eerste Kamer constateerde Michiels van Kessenich tot zijn leedwezen dat het gezantschap bij de paus uit de begroting van Buitenlandse Zaken was verdwenen en hij verklaarde daarom tegen die begroting te zullen stemmen. De oqnheffing van het gezantschap was vilgens ham aelf ir strijd met de Nederlandse grondwet. ${ }^{272}$ Zoals tabel 5 vermeldt, stemden ook de twee overige Eerste-Kamerleden uit Limburg tegen de begroting. Zij behoorden tot een minderheid: met 23 tegen 12 stemmen werd de begroting goedgekeurd.

Daarmee was het pleit beslecht en per 1 mei 1872 werd de Nederlandse gezant bij de Heilige Stoel, L.G.I.F. graaf du Chastel de la Howarderie, ontheven uit zijn functie. ${ }^{273}$ Niet alleen de zittende Limburgse volksvertegenwoordigers hadden zich daartegen verzet, ook voormalig Eerste-Kamerlid Regout had nog een poging ondernomen om het gezantschap te redden door de koning aan te bieden jaarlijks drieduizend gulden bij te dragen in de kosten van de diplomatieke missie. ${ }^{274}$ Dit was een substantiële bijdrage, want de kosten van het gezantschap bedroegen volgens de oorspronkelijke begroting achtduizend gulden.

Het verdwijnen van de diplomatieke vertegenwoordiging betekende geenszins dat de Romeinse kwestie voor de Limburgse afgevaardigden had afgedaan. Op 19 maart 1877 interpelleerde Haffmans minister Van der Does de Willebois van Buitenlandse Zaken. 'Ik waag de Vergadering met eene schijnbare nietigheid bezig te houden', aldus de interpellant. ${ }^{273} \mathrm{Hij}$ vroeg aandacht voor het weghalen van het pauselijk wapenschild van een huis aan de Herengracht te Amsterdam, waar het consulaat-generaal van de 
Kekeliikke Staat was gevestigd geweest. Weliswaar erkende Haffmans dat de dar residerende consul-generaal sinds de verovering van de Kerkelijke Staat dor Italië buiten functie was, maar het wapenschild hinderde volgens hem nimand en de verwijdering ervan was bijzonder grievend voor de Nederlandse katholieken: 'Ja, Mijne Heeren, het is juist deze nietigheid, die de zaak vorr ons Katholieken zoo bitter maakt, dat wij ze niet verzwelgen kunnen envehoefte gevoelen ons hart in den boezem der Volksvertegenwoordigers uitte storten. ${ }^{276}$

En zijn hart uitstorten deed Haffmans! In een eerste reactie karakteriseede Van der Does de Willebois het betoog van het Limburgse kamerlid als hartstogtelijk'. Later in het debat sprak de minister van 'beleedigingen vanden geachten afgevaardigde uit Boxmeer.' ${ }^{277}$ Overigens zal de vurigheid warmee Haffmans sprak niet echt als een verrassing gekomen zijn voor de bewindsman: de beide heren kenden elkaar goed. Van der Does de Willeboiwas voorafgaand aan zijn ministerschap achttien jaar Commissaris des Korings in Limburg geweest en al die tijd had hij Haffmans meegemaakt als satenlid.

Viet iedereen nam Haffmans en zijn interpellatie serieus: 'zelden hoorde ik' ir deze Kamer zoo veel lagchen', stelde collega-kamerlid jhr. C.J.C.H. van Nispen van Sevenaer vast. Hij vond de kwestie zelf overigens allerminst om te lachen, maar 'eene allezins ernstige'. ${ }^{278}$ Paradoxaal genoeg tekent de vrolijkheid tijdens het debat de weinig vriendelijke sfeer. Schaepman daarentegen prees Haffmans later omdat hij met zijn interpellatie 'aan het beledigd gevoeld der katholieke Nederlanders voldoening gaf'.279

Hoezeer Limburgse afgevaardigden zich betrokken voelden bij de positie van de paus, blijkt verder uit het feit dat de enige bijdrage die de Mastrichtse afgevaardigde Kerens de Wylré gedurende zijn zevenjarig kamerlidmaatschap leverde aan de parlementaire beraadslagingen, aan deze kwestie gerelateerd was. In 1874 pleitte hij voor het aanstellen van een $\mathrm{Ne}$ derlandse gezant bij de rebellerende Spaanse troonpretendent don Carlos, leider van de pausgezinde opstandelingen in Spanje..$^{280}$

Een andere Limburgse afgevaardigde, De Bieberstein, nam in april 1878 het woord bij een wetsontwerp tot naturalisatie. Een dergelijk voorstel was meestal een hamerstuk, nu betrof het echter een voormalige zoeaaf. Veel jongemannen die naar Rome waren getrokken, hadden bij thuiskomst ontdekt dat zij hun Nederlanderschap hadden verloren, omdat zij zonder toestemming van de koning in vreemde krijgsdienst waren getreden. Overigens was gebleken dat Willem $\mathrm{m}$ desgevraagd zeer wel genegen was die toestemming te verlenen, want de krijgshaftige instelling van deze katholieke onderdanen 
kon hij zeer waarderen. ${ }^{281}$ Die waardering voor de zoeaven werd gedeeld door De Bieberstein: 'Zij waren voorbeelden van orde, discipline, trouwen dapperheid [ ... . . ${ }^{282}$ Wellicht werd de parlementaire interventie door de baron mede gepleegd met het oog op het thuisfront, want eenenzestig zoeaven waren afkomstig uit Maastricht, zijn woonplaats. ${ }^{283} \mathrm{Zijn}$ rede kreeg in ieder geval ruim aandacht in Le courrier de la Meuse, ${ }^{284}$

Het is aannemelijk dat electorale redenen een rol hebben gespeeld bij de opstelling die de Limburgse kamerleden kozen in de Romeinse kwestie. We zagen reeds dat de publieke opinie in Limburg bijzonder pausgezind was. En hoewel de Heilige Stoel zich bepaald geen aanhanger toonde van een democratische staatsordening, wees zij uitdrukkelijk op de invloed die katholieke kiezers konden uitoefenen. ${ }^{285}$ Politici wilden hun kans op verkiezing vergroten met een pauselijke onderscheiding. ${ }^{286}$ Zoals we al zagen, lijkt in ieder geval De Bieberstein de hem door de paus toegekende Orde van de Heilige Sylvester te hebben aangegrepen om zich te profileren: in het debat over het amendement-Dumbar sprak hij, zo meldde hij bij aanvang van zijn redevoering, mede als 'drager eener Pauselijke ridderorde.'s

Electorale motieven werden ook toegeschreven aan de interpellatie van Kerstens: openfijk verweet men hem met zijn pariementaire actie geen ander doel te hebben dan zijn wankele zetel te redden. ${ }^{288} \mathrm{Zo}$ beschuldigde de Limburgse correspondent van De Tijd de liberaal-katholieken - onder hen Kerstens - van een 'verkiezingsmanoeuvre'. ${ }^{289}$ Het mag zeker opvallend genoemd worden dat Kerstens, doorgaans niet op de parlementaire voorgrond tredend, zich vlak voor de verkiezingen in de schijnwerpers plaatste door te grijpen naar het interpellatierecht. ${ }^{290}$

In ieder geval voelden Limburgse kamerleden geregeld de noodzaak zich ten opzichte van hun kiezers te verantwoorden over hun houding ten aanzien van de Romeinse kwestie. Bijvoorbeeld bij de reguliere TweedeKamerverkiezingen die ruim een halfjaar na de inname van Rome plaatsvonden. De Bieberstein was aftredend. Hij stelde zich herkiesbaar, warbii hij eraan hechtte om in een circulaire aan de kiezers duidelijk te stellen wat zijn (onveranderde) houding was ten aanzien van de positie van de paus als wereldlijk heerser: 'Door het uitbrengen mijner stem heb ik meermalen het bewijs geleverd [...] dat ik het gevoelen ben toegedaan dat de Opperherder der Katholijke Kerk in zijne regten hersteld moet worden. ${ }^{291}$

Enkele maanden eerder was bij een tussentijdse verkiezing Jan Hendrik Arnoldts gekozen. Tweede-Kamerlid jhr. J.W.H. Rutgers van Rozenburg sprak zijn zorg uit over deze verkiezing in Roermond, 'van waar men ons een collega gezonden heeft, wiens mandaat, zoo niet imperatief toch apert 
schijnt te zijn om hier te reageren tegen het stelsel van scheiding van Kerk en Staat, en tegen het stelsel van non-interventie in de zaken van vreemde volken.'22 Dit stelsel van non-interventie weerhield de Nederlandse regering ervan actie te ondernemen in de Romeinse kwestie. En zo moest Arnoldts meteen aan de slag in de Kamer om zijn komst naar Den Haag te verdedigen. Hij had helemaal geen lastbrief meegenomen naar het parlement, aldus de nieuwe afgevaardigde; hij had alleen zijn beginselen in een circulaire aan de kiezers kenbaar gemaakt en aan die beginselen zou hij trouw blijven. ${ }^{293}$

Waar mogelijk werd in Limburg getracht om politieke tegenstanders bij verkiezingen in een kwaad daglicht te plaatsen door hun houding ten opzichte van de wereldlijke macht van de paus aan de kaak te stellen. Voorafgaand aan de verkiezingen van januari 1868 stelde L'ami du Limbourg - de krant die met steun van Petrus Regout werd uitgegeven - de verschillende kandidaten voor. De liberaal-katholieken De Bieberstein en Van der Maesen de Sombreff moesten het ontgelden. Van de laatste werd onder meer gezegd: "Het is de man, die als minister het koningrijk Italië erkende, en aan Limburg deschande deed, dat iemand, die zich Limburger en Catholiek noemt, den roof van het erfgoed van den H. Petrus bekrachtigde. ${ }^{294}$ Het koninkrijk Italië was overigens al door de Nederlandse regering erkend voordat Van der Maesen minister van Buitenlandse Zaken werd. Als bewindsman was hij slechts verantwoordelijk geweest voor de continuering van de diplomatieke betrekkingen met die staat.

Dat de Romeinse kwestie een belangrijk punt was bij de electorale selectie van Limburgse Tweede-Kamerleden blijkt des te meer uit de pogingen van kandidaten om het geschetste negatieve beeld over hun houding terzake te corrigeren. Een illustratie vormen de twee ingezonden brieven die de Maasen Roerbode op 11 juni 1864 plaatste in haar laatste uitgave voor de reguliere verkiezingen van dat jaar. Eén brief was geschreven door De Keverberg de Kessel en de ander door Cornelis. Beiden waren dat jaar kandidaat voor de Roermondse zetel en beiden hadden iets recht te zetten met betrekking tot het beeld dat de tegenpartij had gegeven van hun standpunten in de Romeinse kwestie.

De Keverberg de Kessel schreef zijn brief naar aanleiding van de opschudding die was ontstaan na een korte redevoering die hij op 14 mei 1864 in de Kamer gehouden had. Hij had toen bij de regering aangedrongen op cen daadkrachtiger internationaal optreden om zodoende Limburg los te maken uit de Duitse Bond. Als voorbeeld van een dergelijk voortvarend optreden had hij zijn collega-parlementariërs de politiek van de Italiaanse politicus graaf Camillo B. di Cavour voorgehouden, door De Keverberg bij 
die gelegenheid een 'vermaard staatsman' genoemd. ${ }^{295}$ Gezien de bedreiging die het beleid van Cavour vormde voor de Kerkelijke Staat, werden de uitspraken van De Keverberg in katholieke kringen met verbijstering ontvangen: 'een katholiek volksvertegenwoordiger onwaardig', een 'kaakslag' volgens respectievelijk De Tijd en de De Noord-Brabanter. ${ }^{296}$

Voorafgaand aan zijn ingezonden brief, had de afgevaardigde in een ma. nifest aan de kiezers van het district Roermond al geprobeerd zijn uitsprazk recht te zetten. In de Maas- en Roerbode van 28 mei 1864 liet hij weten 'de roovers-politiek van Cavour' te verfoeien, 'gelijk ieder opregte katholiek ze verfoeit'. Hij had alleen willen wijzen op de diplomatieke voortvarendheid van Cavour in Noord-Italië (en dus niet met betrekking tot de Kerkelijke Staat). Hierop was een brief bij de Maas- en Roerbode binnengekomen waarin 'een katholiek kiezer' op 4 juni stelde dat ondanks deze mededeling van het kamerlid overeind bleef staan dat Cavour als voorbeeld bijzonder slecht gekozen was in de ogen van 'de brave katholieke Limburgers'. Een nadere reactie van De Keverberg was volgens de briefschrijver daarom gewenst. Die verscheen in het daaropvolgende nummer van het weekblad: $D_{e}$ Keverberg benadrukte in zijn ingezonden brief zijn gehechtheid aan de pavs door te spreken over 'de treurige staat van zaken in Italie' en 'de vervolging van de Heilige Kerk' aldaar. ${ }^{297}$

De parlementaire rede van De Keverberg was een incident waarovet men veel misbaar bleef maken, zo stelde het Venloosch Weekblad, dat De Keverberg gekozen wilde zien, op 4 juni tot zijn ergernis vast. Ophef maakte bijvoorbeeld De Volksvriend, die campagne voerde voor Cornelis. Op n juni, vlak voor de verkiezingen bracht de liberale Roermondse krant krant nog eens in herinnering dat De Keverberg de daden van Cavour 'voor gansch de Natie' geprezen had. Het excuus van de afgevaardigde schoof De Volksviend als ongeloofwaardig terzijde.

Het Venloosch Weekblad had inmiddels de tegenaanval ingezet. Onder de kop 'De Heer de Keverberg vergeleken met den Heer Cornelis' zette de krant van Haffmans de houding van de beide kandidaten inzake de Romeinse kwestie naast elkaar, met als uitkomst dat niet De Keverberg mast juist Cornelis een ernstig verwijt gemaakt moest worden. Want terwiil de eerste slechts 'zonder kwade bedoelingen' gesproken had over Cavour, had de laatste zijn goedkeuring gehecht aan 'de beroving van den Heilige Stod' door voor het amendement-Van Eck te stemmen. ${ }^{298}$

Cornelis op zijn beurt reageerde met de hiervoor gememoreerde ingezonden brief in de Maas- en Roerbode van 11 juni. Hij verklaarde hierin per ongeluk voor het amendement te hebben gestemd in de veronderstel- 
ling dat de desbetreffende stemming niet ging over dat wijzigingsvoorstel, mar over het oorspronkelijke gedeelte uit het ontwerp-adres van antwoord warin (zonder waardeoordeel) naar de erkenning van het koninkrijk Italië was verwezen. Hij was nog maar kort kamerlid en daardoor niet geheel op de hoogte van de te volgen procedures. Van deze vergissing makten ujn politieke tegenstanders nu 'te kwader trouw' gebruik om hem bij de kezers in een slecht daglicht te plaatsen, klaagde Cornelis. Hij benadrukte de politiek van het koninkrijk Italië te veroordelen.

Dat het electoraal gezien gewenst was geen misverstanden te laten bestaan over de houding ten opzichte van de wereldlijke macht van de paus, blijkt verder uit de verantwoording aan de kiezers die negen jaar later, in 1873 namens Van der Maesen de Sombreff werd afgelegd. Bij de TweedeKamerverkiezingen van dat jaar stelde hij zich wederom kandidaat. In de Limburger courier verscheen vlak voor die verkiezingen een defensieve reactie op de aanvallen waaraan de afgevaardigde, zo constateerde de krant, bloot stond. Het meest uitgebreid werd stilgestaan bij de beschuldiging dat Van der Maesen de katholieke belangen slecht zou hebben behartigd door voor de motie-Cremers te stemmen. Ter verdediging werd de redevoering die Van der Maesen hield tijdens het kamerdebat waarbij deze motie aan de orde was, integraal afgedrukt, waarna de Limburger courier de retorische vraag stelde: 'Ware het dan eerlijk van den afgevaardigde, dat hij zoude eischen van het Ministerie hetgeen hij wist, dat onmogelijk en gevaarlijk was? ${ }^{29}$ Eerlijk was het misschien niet geweest, maar verstandig - althans vanuit electoraal gezichtspunt - waarschijnlijk wel! De opstelling van Van der Maesen bij de motie-Cremers getuigde dan ook van politieke moed. ${ }^{300}$

De katholieke afgevaardigde Heydenryck wees op de moeilijke positie die Van der Maesen en De Bieberstein innamen: als katholieken tussen de liberalen die vrijwel eensgezind voor opheffing van het gezantschap bij de paus waren, konden zij niet anders dan zich van hun politieke bondgenoten distantiëren. ${ }^{301}$

De Romeinse kwestie lijkt de liberaal-katholieken in Limburg inderdaad in een lastig parket te hebben gebracht. Zo moest zelfs Le courrier de la Meuse, een liberaal georiënteerd blad, tot zijn ontsteltenis vaststellen dat de Nederlandse liberalen in hun onverdraagzaamheid nog verder gingen dan hun politieke broeders in België. Limburg was diep gegriefd door de opheffing van de Nederlandse missie bij de paus, zo berichtte de krant. ${ }^{.02} \mathrm{Het}$ lag inderdaad voor de hand om de liberalen te zien als een grote bedreiging voor de wereldlijke macht van de paus. Er stemden bijvoorbeeld slechts twee liberalen tegen het amendement-Dumbar, dat leidde tot de opheffing 
van het Nederlandse gezantschap bij de paus. De Noord-Brabanter sprak dan ook van het 'liberale November-schandaal'; het Venloosch Weekblad schreef over 'deze liberale excecutie.' ${ }^{303}$ Hier kwam nog bij dat de Italiaanse vijanden van de paus zich presenteerden als liberalen en dat zij in liberale kringen in Nederland konden rekenen op levendige sympathie, ${ }^{304}$ Overigens had Thorbecke zich al jaren eerder in een brief afgevraagd in hoeverre de Romeinse kwestie van invloed zou zijn op de verhouding tussen katholieken en liberalen in Nederland. ${ }^{305}$

Beduidend meer dan de positie van het bijzonder lager onderwijs vormde de aantasting van het pauselijk gezag een onderwerp dat de publieke opinie in Limburg in beroering bracht. Toen de onderwijskwestie in de landelijke politiek actueel werd, stond de Romeinse kwestie al jaren op de politieke agenda: de positie van de paus was in Limburg in 1864 al een verkiezingsitem. En terwijl het bisschoppelijk onderwijsmandement níet leidde tot de verwijdering van de Limburgse liberaal-katholieke volksvertegenwoordigers uit de Kamer, zien we hen wél verdwijnen na de annexatie van de Kerkelijke Staat door Italië. Het Venloosch Weekblad had naar eigen zeggen lang gestreden tegen het liberaal-katholicisme in de Tweede Kamer, 'maar de missie [bij de paus] heeft het gedood".96\%

De twee liberaal-katholieken die zich niet onvoorwaardelijk achter het katholieke petitionnement van 1871 schaarden, Van der Maesen en Cornelis, werden bij de eerstvolgende verkiezingen niet meer herkozen. We zagen eerder al dat Van der Maesen zich, voorafgaand aan die verkiezingen, vooral verdedigde tegen de aantijging dat hij de positie van de paus zou hebben ondermijnd. En terwijl Pijls ten aanzien van de onderwijskwestie nog hoopte te kunnen rekenen op liberale ondersteuning, was hij ved negatiever als het ging om de rol van liberalen in de Romeinse kwestie. Toen het amendement-Dumbar aan de orde was, merkte hij op:

Een zonderling verschijnsel is het, dat achttien jaren geleden door diezelfde rigting, die nu het amendement voorstaat, de Katholijken tegen intolerante aanvallen verdedigd en beschermd werden. Het is te betreuren, dat thans juist van die zijde eene noodelooze krenking van de belangen der Katholijken wordt voorgesteld [....$^{307}$

Achttien jaar eerder, in 1853 , was onder verantwoordelijkheid van het liberak kabinet-Thorbecke 1 de kerkelijke hiërarchie in Nederland hersteld.

Dat de Romeinse kwestie bij de verwijdering tussen de liberalen en de Limburgse katholieken meer gewicht in de schaal legde dan het vraagstuk 
van het tijzonder lager onderwijs, hield verband met de houding van de bisschop van Roermond. Terwijl Paredis zich terughoudend opstelde in de politicke strijd om het bijzonder lager onderwijs, toonde hij zich juist zeer betrokken bij de Romeinse kwestie. Aan Pius IX was hij persoonlijk verknocht. ${ }^{\text {.98 }}$

\section{Conservatieven en katholieken}

De verwijdering die plaatsvond tussen de Limburgse katholieken in de Tweede Kamer en de liberalen, leidde ertoe dat liberaal-katholieken werden vervangen door conservatief-katholieken of dat zij een politieke metamorfose ondergingen, zoals De Bieberstein. Impliceert de term conservatiefkatholiek behalve een verwijdering van de liberalen ook een verbintenis met de conservatieven in de Nederlandse politiek?

Hoewel het identificeren van conservatieven in de politiek niet zonder probiemen is, bood het tweede kabinet-Thorbecke de conservatieve krachten in Nederland in elk geval een uitgelezen mogelijkheid zich te profileren. ${ }^{909}$ Jan Heemskerk Azn. was hierbij een centrale figuur en het Dagblad van Zuidholland en 's Gravenhage een belangrijke, landelijke spreekbuis. De krant stond vanaf 1864 onder leiding van Iz.J. Lion, in de jaren zestig één van de voorvechters van een conservatieve politiek.

Al bij de verkiezingen van juni 1864 zag het Dagblad van Zuidholland en 's Gravenhage een bondgenoot in de Limburgse oppositie. De krant sprak op 7 juni de hoop uit dat De Keverberg de Kessel en Van. Wintershoven zouden worden herkozen. Nu was er inderdaad sprake van een zekere overeenstemming tussen de Limburgse oppositiebeweging waarvan deze twee kamerleden vertegenwoordigers waren, en de conservatieven in de Nederlandse politiek: voor zowel de Limburgers als voor de conservatieven was het tweede kabinet-Thorbecke hét mikpunt van kritiek. Maar hoewel het conservatieve idee van lokaal zelfbestuur de Limburgse oppositie waarschijnlijk wel zal hebben aangesproken, was de kritiek op het kabinet-Thorbecke inhoudelijk gezien vooral verschillend van aard: terwijl het de conservatieven ging om zaken als de koloniale politiek en het onderwijs, ${ }^{310}$ domineerden in Limburg primair provinciale kwesties, zoals de dreigende verhoging van de grondbelasting. Eerder is al geconstateerd dat de Limburgse oppositie zich in de eerste helft van de jaren zestig niet kenmerkte door een anti-liberaal vertoog; hier zou kunnen worden gepreciseerd dat zij niet conservatief-ideologisch van aard was. 
De polarisering in de landelijke politiek ten tijde van het conservatiere kabinet-Van Zuylen van Nijevelt-Heemskerk bond de voormalige Limburgse opposanten aan de conservatieven. Op 23 oktober 1866 beval het Dagblad van Zuidholland en 's Gravenhage voor het district Maastricht Brouwers aan en voor Roermond Haffmans en De Lom de Berg. Deze keer baseerde de krant haar steun niet alleen op het gegeven dat genoemde kandidaten zich keerden tegen een door de liberalen voorgestaan beleid, maar tevens op de overtuiging dat zij zich aan conservatieve zijde zouden scharen. De Lom de Berg had als zittend kamerlid immers tegen de motie. Keuchenius gestemd en van alle genoemde kandidaten werd verwacht dat zij het doel van de koninklijke proclamatie van 10 oktober zouden nastreven; in de ogen van het Dagblad van Zuidholland en 's Gravenhage was dat doel een 'bestendiging van rigting', dat wil zeggen het aan het bewind houden van het conservatieve kabinet. Voor het district Boxmeer, waar de zittende liberaal-katholieke afgevaardigde Kerstens geen noemenswaardige tegenstander had, werd niemand aanbevolen.

Ook in Limburg zelf verbond de voormalige oppositie zich met de conservatieven. Evenals in het Dagblad van Zuidholland en 's Gravenhage kreeg de proclamatie van de koning in het Venloosch Weekblad en in Lami du Limbourg uitgebreid aandacht. ${ }^{31}$ Daarmee positioneerden beide bladen zich duidelijk aan conservatieve zijde; de meeste liberale en gematigde bladen besteedden namelijk weinig aandacht aan de koninklijke woorden, die zij beschouwden als een bedenkelijke verkiezingsstunt. ${ }^{312}$ In een brief aan de kiezers rekende Haffmans ook zichzelf tot de afgevaardigden die behalve door het volk ook door de koning werden gewenst. ${ }^{313}$

Van de in oktober 1866 door het Dagblad van Zuidholland en 's Gravenhage gewenste Limburgse kandidaten was Haffmans de enige die een kamerzetel wist te bemachtigen. Met zijn intrede in het parlement kreeg de enkele jaren daarvoor in Limburg ontstane oppositiebeweging in Den Haag een conservatieve kleuring. Bij de politieke stemmingen stond Haffmans, zoals we zagen, consequent achter het conservatieve kabinet. Hii situeerde zich ook tijdens de parlementaire beraadslagingen aan de kant van de conservatieven. In zijn eerste toespraak tot de Kamer, op 23 februari 1867 , verbond Haffmans zich uitdrukkelijk met het kabinet-Van Zuylen van Nijevelt-Heemskerk, door hemzelf bestempeld als 'conservatief.'.14

In het Venloosch Weekblad verkondigde Haffmans een duidelijk conservatieve visie, bijvoorbeeld op het gebied van de koloniale politiek, een van de voornaamste conservatieve thema's. Hij was, geheel in lijn met de conservatieve opvatting, tegen de afschaffing van het cultuurstelsel op lava." 
En toein oktober 1872 gestemd werd over het voorstel van de liberale minister $v_{2}$ Financiën Van Bosse om het protectionistische beleid ten aanzien van Neerlands-Indië los te laten - het betrof hier de afschaffing van de bevoorchte positie die Nederland had boven andere landen in de handel metndië -, stemden de beide conservatief-katholieke afgevaardigden Haffmas en Arnoldts tegen; de liberaal-katholieke kamerleden Pijls, De Biebersin en Van der Maesen stemden voor.

Hafflans predikte ook typisch conservatieve standpunten op staatsrechteli gebied, wanneer het ging om de verhouding tussen volksvertegenwordiging en kroon. Bij de eerste begrotingsbehandeling uit zijn parlemttaire loopbaan riep hij - bij de begroting van het departement van Oorlog de Kamer op om de prerogatieven van de koning te eerbiedigen, zeker wir het het leger betrof. Zelfs indien de kwestie - de bewapening 'strikt gtomen (wanneer men de professoren consulteert)' tot de medezeggenschavan het parlement behoorde, diende niet de volksvertegenwoordiging, aar de koning te besluiten. ${ }^{316}$ De woorden van Haffmans zullen zeker ople hartelijke instemming hebben kunnen rekenen van Willem II, die voot met betrekking tot het leger bijzonder op zijn bevoegdheden was gesteld. Het is de vraag of de koning kennis heeft genomen van Haffmans' rede, want doorgaans had hij weinig belangstelling voor wat er in het parlement voorviel. A.W.P. Weitzel, tijdens het koningschap van Willem In tweemaal minister van Oorlog, schrijft in zijn dagboek dat de koning 'volstrekt geen notie' nam van hetgeen er in het parlement gebeurde. ${ }^{312}$

Een nadere beschouwing over de staatsrechtelijke verhoudingen in $\mathrm{Ne}$ derland gaf Haffmans in april 1868 . Hij toonde zich bij deze gelegenheid een tegenstander van het parlementair stelsel:

Maar moeten wij niet vooruit streven ter bekoming van dat parlementarisme? Ik geloof het niet. [...] Het zuiver parlementarisme zou niet tot heil van Nederland strekken. [...] Wanneer het ooit zoover kon komen (hetgeen de hemel verhoede) dat het Nederlandsche volk kiezen moest tusschen Oranje en de Kamer, dan zou de keuze niet twijfelachtig zijn..$^{318}$

Hier wordt een duidelijke tegenstelling zichtbaar tussen een conservatief denkende Haffmans en een liberaal georiënteerde De Bieberstein. De baron verklaarde namelijk in hetzelfde kamerdebat juist een tegenstander te zijn van het kabinet-Van Zuylen van Nijevelt-Heemskerk. Hij vreesde van die regering 'niets anders [...] dan reactie, gepaard gaande met eene soort van 
verdachtmaking tegen de constitutionele partij in den lande'. En aan die partij wilde De Bieberstein loyaal zijn:

Ja Mijne Heeren, het is aan die groote constitutionele partij in Nederland, en dus aan die liberale mannen, dat de Katholijken hunne politieke regten en vrijheden verschuldigd zijn en te danken hebben.

[... Hiervoor, Mijne Heeren, zal ik die partij ook steeds dankbaar zijn. 319

Onder eerdere conservatieve kabinetten was Nederland ook al nooit geluk. kig geweest, zo voegde hij eraan toe. De Bieberstein was dermate fel in het neerzetten van zijn positie dat hij tot drie keer toe werd onderbroken doot de kamervoorzitter.

Voorafgaand aan de verkiezingen van januari 1868 oordeelde het Dag. blad van Zuidholland en 's Gravenhage dat van de Limburgse afgevaardigden alleen Haffmans mocht blijven zitten. ${ }^{320}$ Wat betreft het district Maastricht werden De Bieberstein en Van der Maesen de Sombreff - 'de Thorbeckevergoders' - veroordeeld wegens hun 'deloyale oppositie' jegens het zittende conservatieve kabinet; voor dat district werden Brouwers en Wenmaekers aanbevolen. Wat betreft het district Roermond moest De Lom de Berg uit de Kamer verdwijnen, omdat hij had bijgedragen aan de val van het kabinet (hij had tegen de begroting van Buitenlandse Zaken gestemd). De Lom de Berg zou moeten plaatsmaken voor Haffmans' bondgenoot J.H. Arnoldts. Arnoldts en Haffmans werden ook in het Venloosch Weekblad gepresenteerd als 'Candidaten der regeering'. ${ }^{321}$ In Boxmeer wilde het Dagblad van Zuidholland en 's Gravenhage Kerstens laten vervangen door jhr. J.M.B.J. van der Does de Willebois. De krant prees Brouwers, Wenmaekers, Haffmans, Arnoldts en Van der Does de Willebois aan als kandidaten met conservatieve standpunten op belangrijke thema's als defensie en de koloniale politiek.

Deze aanbevelingen illustreren de coalitie tussen de Limburgse tegenstanders van het liberalisme en de conservatieven in de landelijke politick. Deze alliantie kreeg bij de eerstvolgende verkiezingen, van juni 1869, een nog prominentere vorm. In december 1868 waren de conservatieven als politieke organisatie naar buiten getreden door de oprichting van de $\mathrm{A}$ gemeene Kiesvereeniging, geen politieke partij in de moderne zin van bet woord, maar wel een organisatie die op nationaal niveau opereerde. Het doel was mannen te doen kiezen die trouw zouden zijn aan de conservaticie beginselen. ${ }^{32} \mathrm{Bij}$ de verkiezingen van juni 1869 konden Haffmans (distritt Boxmeer) en Arnoldts (Roermond) rekenen op steun van de Algemeens 
Kiesvereeniging. Voor Maastricht, waar De Bieberstein zonder tegenkandidaat was, werd niemand door haar aanbevolen. ${ }^{323}$

De verkiezingen van 1869 liepen voor de Algemeene Kiesvereeniging uit op een grote nederlaag en zij zou dit verlies niet meer te boven komen. ${ }^{324}$ Heemskerk zou er niet in slagen de conservatieven te organiseren en hij moest al spoedig erkennen dat de vorming van een conservatieve partij op niets uitliep. ${ }^{325}$ Halverwege de jaren zeventig, na de verkiezingen van 1875, werden er nog slechts acht, na die van 1877 nog maar zes TweedeKamerzetds door conservatieven bezet.

Omdat de Limburgse politici die ten tijde van het tweede kabinet-Thorbecke hadden bejoord tot de oppositie, zich in 1866 lieerden aan de conservatieven in de Nederlandse politiek, is de term conservatief-katholiek op zijn plaats. Terwil de iberaal-katholieken uit Limburg niet zelden de aanduiding 'liberal' in de mond namen als het ging om hun eigen positiebepaling, namen hun politicke tegenstanders in de provincie, voor zover bekend, nimmer het begrip 'corservatief' of 'conservatief-katholiek' in de mond ter etikettering van zichzelf.

In de jaren zestig en zeventig was Haffmans de voornaamste Limburgse conservatief-katholiek in de landelijke politiek. Zo was hij aanvankelijk, in de jaren 1866-1871, de enige niet-liberaal-georiënteerde Limburger in de Tweede Kamer en hij voerde er, ook in de jaren daaropvolgend, geregeld het woord. Bovendien had hij zijn eigen krant, het Venloosch Weekblad, waarmee hij zijn ideeên verspreidde. Commissaris des Konings Van der Does de Willebois meende bij Haffmans dan ook te maken te hebben met 'de groote man [...] der in het gewest heerschende partij', zo schreef hij in 1872 aan minister J.A. Jolles van Justitie. ${ }^{326}$ Tot welke partij mogen we Haffmans precies rekenen?

Zoals hierboven vermeld, verbond hij zich met de conservatieven op grond van gemeenschappelijke opvattingen, bijvoorbeeld inzake het koloniaal beleid en de staatsrechtelijke verhoudingen. Haffmans beschouwde zich echter niet als deel van een conservatieve partij of groepering. In een ârculaire aan de kiezers in oktober 1866 schreef hij: 'Wij Limburgers mogen ons niet onvoorwaardelijk aan eene der beide partijen in Nederland sansluiten'. ${ }^{327}$ L'ami du Limbourg was het hiermee eens en wilde in januant 1868 afgevaardigden 'ne tentant à aucun parti politique du parlement Néerlandais', 323

Vlak voordat Haffmans in april 1866 zijn kandidatuur voor de Tweede Ramer bekend maakte, werden zijn ideeën over de positionering van de 
Limburgse afgevaardigden in het Nederlandse politieke spectrum gepresenteerd door het Venloosch Weekblad. Op 31 maart opende de krant met een schets van de geschiedenis van de Nederlandse katholieken. $\mathrm{Na}$ het stadium van vervolging en onderdrukking was 'het tijdperk der dulding' gevolgd, waarna de katholieken - met hulp van Thorbecke en de liberalen - waren aanbeland in de periode van emancipatie. Nu was er weer een nieuwe episode aangebroken, aldus het blad: 'het tijdperk der waarachtige emancipatie' ofwel 'het tijdperk der zelfstandigheid'. De katholieken dienden politiek 'zelfstandig te zijn en samenstandig' en daarom 'eene katholieke fractie' te vormen. ${ }^{329}$

Het was niet voor het eerst dat Haffmans dit idee naar voren bracht. Hiervoor is reeds gewezen op de opinie van het Venloosch Weekblad in september 1864 . Het verschil was dat de katholieke fractie in het plan van 1864 deel uitmaakte van de liberale partij en zich nu diende te ontwikkelen náást de twee bestaande 'groote politieke partijen' in Nederland, de liberale en de conservatieve partij, zo legde het Venloosch Weekblad later uit. ${ }^{30}$

Ook aanvang jaren zeventig strekten de politieke ontwikkelingen in Pruisen en Duitsland Haffmans tot voorbeeld. In 1870 hadden katholieken in Pruisen een politiek programma uitgevaardigd en na de verkiezingen in juni van dat jaar verenigden vijftig leden van het Huis van Afgevaardig. den in Berlijn zich tot de katholieke Zentrumfraktion. Toen een jaar later het Duitse keizerrijk werd gegrondvest, vormden katholieke parlementariers ook in de Rijksdag een fractie, eveneens onder de naam Zentrum. De rijksdagverkiezingen van maart 1871 waren in het Rijnland een groot succes geweest voor het Zentrum en de partij zou er lange tijd de grootste blijven. ${ }^{331}$ Ook voor Nederland had Haffmans een dergelijk katholiek samenwerkingsverband voor ogen. Op 30 maart 1872 schreef het Venloosch Weekblad:

Wat hebben onze katholieke afgevaardigden te doen? Een voorbeeld nemen aan de katholieken van Duitschland. [...] In Nederland, even als in Duitsland, moet een centrumpartij geformeerd worden.

Het programma van de Nederlandse centrumpartij zou dezelfde uitgangs. punten kunnen krijgen als haar Duitse zusterorganisatie: strenge handhaving van het positief en historisch recht, vrijheid van godsdienst voor alle gezindten en het federatief beginsel (later veelal aangeduid met het begrip subsidiariteit). Evenals in Duitsland zou de partij kunnen openstaan voof andersgezinden, hoewel de katholieken de kern zouden uitmaken. 
Haffmans nam volop deel aan de discussies over de politieke positionering die in katholieke kringen gevoerd werden. Zijn krant sloot zich van harte aan bij De Maasbode die in maart 1872 had opgeroepen tot politieke groepsvorming en op 27 juli van dat jaar reageerde hij in het Venloosch Weekblad op een artikel van collega-kamerlid Heydenryck dat eerder die maand was verschenen in het katholieke blad De Wachter. ${ }^{332}$ Deze conservatiefkatholiek schreef over de katholieke samenwerking in de Tweede Kamer en het bijbehorende politiek programma. Haffmans ondersteunde in zijn weekblad de noodzaak tot het formuleren van een programma en benadrukte - in navolging van Heydenryck - dat de katholieken al sedert lang een eigen programma hadden, zij het dat dat nog niet op papier stond. 'Wij verzoeken codificatie, niets anders.'

Tot zolang vormden de Nederlandse katholieken een 'partij die in haar wording is', had het Venloosch Weekblad een jaar eerder al geschreven. ${ }^{333}$ Hoewel een hecht en structureel samenwerkingsverband in de Tweede Kamer ontbrak, kon er volgens Haffmans al wel een soort van katholieke fractie worden onderscheiden: het Venloosch Weekblad schreef in 1868 over 'de katholieke partij' in de Kamer en in 1871 over 'de hoek der Ultramontanen'.34 In het parlement sprak Haffmans van 'ons, de zoogenaamde clericalen of ultramontanen'. ${ }^{35}$ Een andere Limburgse conservatief-katholiek, Lambrechts, verklaarde voorafgaand aan de verkiezingen in 1873 dat hij zich bij winst zou scharen 'in de gelederen der Katholieke afgevaardigden'. ${ }^{36}$ De aanduiding 'katholiek' werd veelal zonder nadere specificering als politiek predikaat gevoerd door hen die in het voorgaande conservatief-katholiek zijn genoemd.

Haffmans wilde niet opgaan in een conservatieve partij. Toen Pijls hem tijdens een parlementair debat in mei 1871 wilde positioneren in de conservatieve partij, zei Haffmans zich niet te willen rekenen tot 'de conservative partij' maar tot de 'ultramontanen'. En, zo zei hij: 'Dat is een groot verschil.' ${ }^{33}$ 'De distantie die Haffmans bleef bewaren tot de conservatieven, zal vor zover het de jaren zeventig betreft, deels hebben samengehangen met de neergang waarin het conservatisme toen als politieke beweging verzeild was geraakt. Die ontwikkeling nodigde niet bijzonder uit tot een zeer hechte verbintenis. 'De conservatieve partij is machteloos,' schreef het Venloosch Weckblad op 30 maart 1872, niet alleen door haar minderheidspositie, maar ook 'door gebrek aan vaste beginselen'.

Een samenvoeging van katholieken en conservatieven lag niet voor de hand, een bondgenootschap wel. In tegenstelling tot hun ideologische vorgangers in de jaren vijftig, trachten de conservatieven in de jaren zestig 
en zeventig ook katholieken aan zich te binden. Het waren volgens Haffmans 'beschaafde en welopgevoede lieden. ${ }^{2} 38$ Als het bijvoorbeeld ging om de Romeinse kwestie, toonden de conservatieven duidelijk meer oog voor de katholieke verlangens dan de liberalen. Dat bleek uit de specificatie waarvan het Venloosch Weekblad de uitslag van de stemming over het amendementDumbar voorzag. Terwijl slechts twee liberalen - een kleine minderheid dus - tegen het wijzigingsvoorstel hadden gestemd, hadden de conservatieven het amendement juist in grote meerderheid afgewezen. 'Courrier! Wie zijn nu de vrienden der katholieken?' Dit was de retorische vraag die het liberale Maastrichtse blad vanuit Venlo kreeg voorgelegd. ${ }^{339}$

Een bondgenootschap met de conservatieven bood de katholieken voordelen, een opgaan in die conservatieven was echter een stap te ver; daarvoor bleven de specifiek katholieke belangen te verschillend. Zo hadden de meeste conservatieven zich op het politiek heikele punt van het gezantschap bij de paus weliswaar 'veel fatsoenlijker' gedragen dan de liberalen, het Venloosch Weekblad gaf toe dat dit niet altijd was gebeurd met hetzelfde doel als de katholieken in deze kwestie hadden, namelijk de wereldlijke macht van de paus herstellen. ${ }^{340}$ Het zal de (Limburgse) katholieken bovendien niet zijn ontgaan dat de toenadering die de politieke leiding van de conservatieven zocht tot de katholieken bij de conservatieve achterban veelal zeer slecht viel, gevoelens waarvan de liberalen dankbaar gebruik maakten. ${ }^{341}$

Terwijl Haffmans zijn best deed de katholieke samenwerking te bevorderen, probeerden zijn aan de liberalen gelieerde tegenstanders in Limburg de pogingen tot katholieke groepsvorming te verhinderen. Zo adviseerde Pijls in 1868 aan Thorbecke om in het te vormen kabinet niet één, maar twee katholieke ministers op te nemen, om daarmee te voorkomen dat de katholieken in de Kamer een afzonderlijke fractie zouden vormen. Thorbecke volgde dit advies. ${ }^{3 / 2}$ Het kon niet verhelpen dat de politieke samenwerking tussen de Nederlandse katholieken steeds meer - zij het niet zonder haperingen - gestalte kreeg.

\section{Katholieke afgevaardigden}

De Tweede-Kamerleden ter linkerzijde in de vergaderzaal konden, na De Biebersteins oversteek, tot 1918 geen enkele afgevaardigde uit Limburg meer in hun midden begroeten. De Biebersteins opvolger, Gustave Ruijs van Beerenbroek, behoorde 'geheel tot de groote katholieke fractie.'33 Van een hechte eigen kamerfractie was weliswaar in 1880 nog steeds geen sprake. de nieuwe afgevaardigde uit Maastricht nam in ieder geval van anvang 
af plaats tussen de overige katholieken in de Kamer. En alle Limburgers die met en na Ruijs van Beerenbroek in de Tweede Kamer zitting hadden, vonden daar hun plek.

\section{Verkiezingen in een katholiek gewest}

Dat de Limburgse Tweede-Kamerleden vanaf 1879 zonder uitzondering (kunnen) worden voorzien van het politieke predikaat 'katholiek', wil niet zeggen dat de liberalen zich in het geheel niet meer roerden bij verkiezingen. Zo werd nog in 1885 in Maastricht een nieuwe liberale kiesvereniging opgericht onder voorzitterschap van F.H.J. baron de Bieberstein Rogalla Zawadsky, zoon van het voormalige Tweede-Kamerlid. Bij de oprichting schreven zich vijftig personen in als lid. ${ }^{344} \mathrm{Bij}$ de verkiezingen van een jaar later - het ging hierbij in Maastricht om de beide kamerzetels - behaalden de twee liberale kandidaten, de juist genoemde De Bieberstein en J.H. Menten, respectievelijk $350(17 \%)$ en $287(14 \%)$ van de 2093 geldige stemmen. In Roermond behaalde jhr. L. Michiels van Kessenich, de enige liberale kandidaat, $529(25 \%)$ van de 2147 geldig uitgebrachte stemmen. ${ }^{35}$ Bij de verkiezingen van 1891 (Roermond) en 1892 (Maastricht) stemde respectievelijk 35 en $24 \%$ van de kiezers op de liberale kandidaat, respectievelijk L. Geradts en G. Tripels. ${ }^{346}$

Geen onbeduidende aantallen, maar binnen het vigerend kiesstelsel een meerderheidssysteem binnen districten - geen cijfers waarmee de liberale kandidaten een reële kans maakten. Waarschijnlijk schoven de liberalen daarom ook niet altijd kandidaten naar voren voor de Limburgse kamerzetels. Zo besloot de liberale kiesvereniging De Grondwet in $\mathbf{1 8 8 2}$ in het district Roermond geen kandidaat voor te dragen voor de dat jaar te houden verkiezing. ${ }^{347}$ Overigens werden, bij het ontbreken van een liberale kandidaat, blanco stembriefjes ook wel toegeschreven aan liberale kiezers. ${ }^{34 s}$

Bezien we de verkiezingsuitslagen vanaf het moment waarop werd gewerkt met officieel geregistreerde kandidaten (1897), dan valt op dat de liberalen geen enkele maal een kandidaat stelden in de districten Venlo, Weert, Roermond en Sittard en dat er in Gulpen slechts éénmaal, in 1913, een liberale kandidaat deelnam: A.P.E.A. Wijnans, kandidaat voor de Unie Liberalen kreeg er $2,1 \%$ van het aantal uitgebrachte stemmen. ${ }^{349}$ De liberalen beperkten zich vanaf het einde van de negentiende eeuw wat Limburg betreft dus feitelijk tot Maastricht, hoewel zij ook hier bij de achtereenvolgende verkiezingen van 1901, 1902 en 1905 geen kandidaat hadden. 
De enige keer dat een liberale kandidaat na 1879 in Limburg een opmerkelijk goed resultaat boekte, was bij de tussentijdse verkiezing in het district Maastricht in maart 1900: de liberaal Jozef Haex behaalde toen $40,9 \%$ van het aantal uitgebrachte stemmen. Zijn katholieke tegenstrever, het zittende kamerlid De Ras, scoorde een percentage van 55,6. Hoewel het verschil nog altijd zo'n $15 \%$ bedroeg, lagen de beide scores in vergelijking met de andere verkiezingen uit die periode uitzonderlijk dicht bij elkaar. In hoofdstuk 2 is in dit kader al gewezen op de rol die de minder Limburgse achtergrond van De Ras speelde.

Alleen door een overstap naar de katholieken is het liberalen na 1879 in Limburg gelukt een kamerzetel te bemachtigen. Dit geldt voor de Blerickse notaris Johannes Clercx, in $\mathbf{1 8 8 2}$ tot Tweede-Kamerlid gekozen in het district Boxmeer. Tien jaar daarvoor had hij als redacteur van de Venloo. sche Courant nog campagne gevoerd voor de liberaal-katholieken Van der Maesen de Sombreff en Cornelis en tegen Haffmans. In 1869 was Cleta zelfs de liberaal-katholieke opponent geweest van Haffmans bij de kamerverkiezingen in het district Boxmeer. Zijin kandidatuur. was teen gesterund door Kerstens, de liberaal-katholiek die de andere kamerzetel van dat district bezette. Een aantal jaren later, bij de verkiezingen in 1875 , werd Clerc wederom gekandideerd, nu door de liberale kiesvereniging De Grondwet in Roermond. Hij zou het hebben moeten opnemen tegen het zittende kamerlid, de conservatief-katholiek Arnoldts, ware het niet dat Clercx ditmaal uiteindelijk bedankte voor de eer. ${ }^{350} \mathrm{Hij}$ begon zich af te keren van het liberalisme. ${ }^{351}$ Een jaar later deed hij tot verbazing van velen, aldus het Venloosch Weekblad, mee aan de verkiezingen voor Provinciale Staten als katholiek kandidaat. ${ }^{352} \mathrm{Bij}$ de Tweede-Kamerverkiezingen van 1882 in het district Boxmeer was Clercx kandidaat voor de katholieke kiesvereniging Noord-Brabant. ${ }^{353}$ Het Venloosch Weekblad schreef: 'de tijden zijn veranderd en de heer Clercx met hen.' Bij Clercx was 'geen spoor meer van den ouden liberalen zuurdeesem te vinden' en ook de krant van Haffmans kon daarom instemmen met diens kandidatuur. ${ }^{354}$

Pijls verruilde de liberalen eveneens voor de katholieken. Bij de gemeenteraadsverkiezingen van 1881 was hij een van de kandidaten voor de katholieke kiesvereniging, samen met de latere Tweede-Kamerleden W.G. Straetmans en G. Ruijs van Beerenbroek. ${ }^{355}$ Zijn ommezwaai was overigens al van eerdere datum en toen hij zich in juli 1880 kandideerde voor een tetel in de Eerste Kamer, sprak het Venloosch Weekblad zich dan ook niet uit tegen de verkiezing van Pijls. ${ }^{356}$ Opmerkelijk, gelet op de felle campagne die het blad eerder, in 1869 , tegen de kandidatuur van Pijls voor de 
Tweede Kamer had gevoerd. De Limburger koerier stelde later terugkijkend zelfs dat Haffmans Pijls geholpen had om in de Eerste Kamer verkozen te worden. ${ }^{357}$

Dat het katholiek-liberalisme in de jaren tachtig in Limburg grotendeels ad afgedaan, blijkt eens te meer uit de Maastrichtse verkiezingen van 880. De aanhangers van een van de katholieke kandidaten, Emile Roberti, rachtten hun opponent, de eveneens katholieke Victor Nijst, in diskrediet e brengen door te suggereren dat hij gesteund werd door de liberalen. In en advertentie in de Limburger courier van 31 januari van dat jaar werd Nijst oor zijn tegenstanders zonder omwegen een 'liberaal-katholiek' genoemd. ennelijk werd een bondgenootschap met de liberalen beschouwd als een elangrijk electoraal nadeel. Ook de nadrukkelijke ontkenningen door het imp van Nijst wijzen daarop. De kandidaat zelf liet in de pers weten dat hij an overtuiging en beginselen nimmer zou opofferen om steun te krijgen in 'liberale zijde' en zijn aanhangers benadrukten in een advertentie 'dat 'Heer Nyst niet is de candidaat der liberalen, zooals men het heeft willen Gen geloven'. ${ }^{358}$

Het bewijs voor het liberalisme van Nijst dat werd aangedragen, was overigens bijzonder mager. Er werd verwezen naar berichtgeving in Belgische kranten, die volgens de aanhangers van $\mathrm{Nijst}$ van informatie waren voorzien door zijn tegenstanders. Verder werd Nijst verweten in 1875 medeondertekenaar te zijn geweest van een gerechtelijk vonnis waarbij de Miaastrichtse deken F.X. Rutten veroordeeld was wegens het houden van een processie. ${ }^{159}$ Dat we de verdenking van liberalisme niet erg serieus moeten nemen, blijkt wel uit het feit dat Nijst nog geen anderhalf jaar later, bij de reguliere Tweede-Kamerverkiezingen, werd gekandideerd door de katholieke kiesvereniging, dezelfde kiesvereniging dus die zijn kandidatuur in 1880 nog had bestreden.

Aan het eind van de negentiende eeuw dienden zich in Limburg nieuwe opponenten aan voor de katholieke kandidaten: de sociaal-democraten. In de uitslagenlijsten van 1891 zien we de naam van W.H. Vliegen verschijnen. De sociaal-democraat Vliegen, een geboren en getogen Zuid-Limburger, haalde 70 van de 1073 stemmen in het district Maastricht en een klein aantal (drie) in het district Sittard. In 1894 werd de Sociaal-Democratische Arbeiderspartij (SDAP) opgericht; Vliegen was een van haar grondvesters. Bij de eerstvolgende verkiezingen in 1897 , deed de SDAP mee in Maastricht met Vliegen als kandidaat. ${ }^{360} \mathrm{Hij}$ behaalde $11,6 \%$ van het aantal stemmen. De sociaal-democratische score in Maastricht nam bij de volgende 
reguliere verkiezingen (1901) toe tot bijna $24 \%$ en bleef bij de verkiezin. gen van 1905, 1909 en 1913 schommelen tussen ongeveer een vijfde en een kwart. ${ }^{361}$

In twee andere Limburgse kiesdistricten mengde de SDAP zich eveneens in de verkiezingsstrijd. In Gulpen deed ze vanaf 1905 mee aan de verkiezingen, in Venlo vanaf 1909. Zij bleef in deze districten telkenmale ruim onder de tien procent, met uitzondering van de verkiezingen van 1909 in Gulpen toen zij 10,9\% scoorde. In de overige Limburgse kiesdistricten - Roermond, Sittard en Weert - stelde zich nimmer een sociaal-democraat kandidaat.

De sociaal-democraten speelden in Limburg - in de periode voor 1918 en met uitzondering van Maastricht - geen of slechts een marginale rol. ${ }^{\text {se }}$ In en om de Limburgse hoofdstad was hun kiezersaanhang wezenlijk groter dan elders in de provincie. Toch vormden zij ook daar geen acute bedreiging voor de katholieke kandidaten. Wat voor de liberalen gold, gold ook voor de sociaal-democraten: hun kamerfractie zou, voor wat betreft haar omvang, niet profiteren van de Limburgse stemmen. Dit zou pas gebeuren ad de invoering van het steisei' van evenrealige vertegenwoordiging (zonder districten). ${ }^{363}$

Wanneer het ging om de politieke organisatie van de katholieken, kon Limburg volgens het Venloosch Weekblad in 1877 een voorbeeld nemen aan 'zusterprovincie' Noord-Brabant. Daar was al sinds 1870 de katholieke kiesvereniging Noord-Brabant actief, met vertakkingen over de hele provincie. In Limburg daarentegen bestond 'geen beraad, geen gemeen overleg'. 'Het gevolg daarvan is dat alles in het honderd loopt.'.364 In het district Boxmeer stelde de vereniging Noord-Brabant, zoals we zagen, bii Tweede-Kamerverkiezingen de katholieke kandidaten. In de twee overige Limburgse kiesdistricten ontstonden pas later katholieke kiesverenigingen: in Roermond was bij de reguliere verkiezingen van juni 1879 voor het eerst een katholieke kiesvereniging actief, in Maastricht een halfjaar later. bij de tussentijdse verkiezing van februari 1880. Na de herziening van de kiesdistricten in 1887 - Limburg ging toen van drie dubbele naar zes enkelvoudige districten - verminderde de organisatiegraad in de provincie: in de nieuwgevormde districten Gulpen en Venlo werd geen eigen katholieke kiesvereniging opgericht; in de overige vier districten was dat wel het geval.

Het optreden van de katholieke kiesverenigingen was in Limburg niet altijd even succesvol. Het betrof hier vooral een Zuid-Limburgse kwash. stelde de Maas- en Roerbode op 6 februari 1886 vast: terwijl de katholieke kiesvereniging in Roermond 'algemeenen bijval' ondervond, werd die in 
Mastricht voortdurend krachtig en in het geheim tegengewerkt. In en om de Limburgse hoofdstad had men volgens de krant meer oog voor personen dan voor beginselen.

Nu was de katholieke kiesvereniging in Maastricht inderdaad bijzonder ongelukkig van start gegaan. Bij de eerste verkiezing waarbij zij actief was, werd haar kandidaat, Emile Roberti, verslagen door een opponent die zich eveneens presenteerde als katholiek kandidaat: Victor Nijst. De katholieke kiesvereniging werd door Nijst en zijn aanhangers afgeschilderd als een geheim genootschap dat ten onrechte 'het monopolie der Catholiciteit voor zich en hare candidaten in aanspraak neemt'. Roberti zou zijn kandidatuur mede te danken hebben aan familierelaties. ${ }^{365}$

Het beeld dat werd geschetst door de Maas-en Roerbode en dat hierboven werd aangehaald, zal zeker verband hebben gehouden met de verkiezingsstrijd die op dat moment, februari 1886, in Maastricht werd gevoerd. De kandidaat van de katholieke kiesvereniging, Carl Ruland, werd bestreden door loannes Kleuters, notaris in Meerssen en lid van Provinciale Staten. Kleuters was blijkens een advertentie in de Limburger courier van 9 februari kandidaat gesteld door 'vele katholieke kiezers'. Hij behaalde bijna dertig procent van de stemmen. Ruland kreeg zestig procent, hetgeen weinig was in vergelijking met het gemiddeld percentage voor kandidaten van katholieke kiesverenigingen in Limburg in de jaren tachtig.

Twee jaar later, bij de tussentijdse verkiezing van mi 1888 , was er kennelijk in Maastricht zelfs helemaal geen katholieke kiesvereniging actief. Et waren twee katholieke kandidaten, Jan Schreinemacher en Edouard de Beaumont, en geen van beiden werd, zo blijkt uit hun advertenties, aanbevolen door een kiesvereniging. ${ }^{366} \mathrm{Ze}$ ontliepen elkaar niet veel met respectievelijk 55,8 en 41,3 procent van de stemmen. Bij de tussentijdse verkiezing in 1892 was er weliswaar weer een katholieke kiesvereniging actief in Maastricht, maar die was door een bestuurlijke crisis 'gedesorganiseerd', zo lezen we in De Tijd van 5 juli van dat jaar. Er waren daardoor twee katholieke kandidaten naar voren geschoven: $C$. Schreinemacher, zoon van het kort daarvoor overleden kamerlid Jan Schreinemacher, en Martin de Ras. In de eerste ronde behaalde geen van hen een absolute meerderheid; bij de herstemming won De Ras.

De verkiezingen in het district Sittard in 1913 verliepen ook al weinig harmonieus. Eerst moest bisschop J.H. Drehmans van Roermond eraan te pas komen om een conflict te beslechten dat in het dorp Waubach was ontstaan doordat er twee kiesverenigingen opereerden die allebei het predikaat 'katholiek' voerden. De bisschop besliste dat dat recht slechts één van 
beide, de kiesvereniging St. Petrus en Paulus, toekwam. ${ }^{367}$ Vervolgens koos deze voor het zittende Tweede-Kamerlid Beckers, terwijl de centrale katho. lieke kiesvereniging in het district - een 'eigengemaakte Ruzie-organisatie' volgens Beckers $^{36 \mathrm{~s}}$ - de Sittardse burgemeester A.H. Gijzels als kandidaat naar voren had geschoven. Op 12 juni deed de Limburger koerier verslag van een drukbezochte, langdurige en rumoerige vergadering van kiezers in een lokaal etablissement, waarbij de beide kandidaten en aanhangers uit de twee kampen het woord voerden. De 'officiële' katholieke kandidaat, Gijzels, zou het bij de verkiezingen afleggen tegen Beckers, die met ruime cijfers won.

Hoewel de Maas- en Roerbode meende dat het tegenwerken van de katholieke kiesvereniging met name een zuidelijke aangelegenheid was, had ook de katholieke kiesvereniging in Roermond de regie niet altijd strak in handen. Dit bleek bijvoorbeeld al bij de verkiezingen die in 1884 plaatsvonden na de kamerontbinding (de beide Roermondse zetels waren derhalve in het geding). Tot verontwaardiging van de krant hadden de twee kandidaten van de katholieke kiesvereniging in Roermond een mededinger gevonden in C.M. van der Heijden. Deze verklaarde zich onvoorwaardelijk op te stellen achter het programma van kiesvereniging Noord-Brabant. ${ }^{\text {se }}$ Volgens de Maas- en Roerbode was er sprake van 'intrigues van eenige drijvers achter de schermen.' ${ }^{370}$

Vijf jaar later, in 1889, hekelde Martin de Ras het besluitvormingsproces binnen de katholieke kiesvereniging van Roermond. Hij had naar eigen zeggen geen eerlijke kans gehad: de uitkomst van de vergadering had bij voorbaat al vastgestaan: 'alle maatregelen waren genomen, om één candidaat - den candidaat van den voorzitter - te doen zegevieren. ${ }^{31}$ Door zichzelf naast deze 'officiële' katholieke kandidaat, baron d'Olne, naar voren te schuiven, gooide De Ras in de eerste ronde bijna roet in het eten van de katholieke kiesvereniging: d'Olne won met slechts $50,7 \%$ van de uitgebrachte stemmen.

Bij de verkiezingen van 1913 was er wederom sprake van interne verdeeldheid bij de katholieke kiesvereniging in het district Roermond. De grootste gemeentelijke afdeling van deze kiesvereniging (die van de stad Roermond) concludeerde na onderzoek dat er onregelmatigheden hadden plaatsgevonden bij de (voor)verkiezing van de katholieke kandidaat door de leden van de vereniging. De Roermondse afdeling weigerde om die reden zich nog langer achter deze kandidaat te scharen. Daarmee was de katholieke kiezer geheel vrij om te bepalen wie van de twee katholieke kandidaten zijn stem zou krijgen, aldus de Maas- en Roerbode. ${ }^{372}$ 
Of er nu een katholieke kiesvereniging operationeel was of niet, een meervoudige katholieke kandidaatstelling kwam meermaals voor. Dat er geen duidelijk verband bestond tussen het al dan niet bestaan van een katholieke kiesvereniging enerzijds en de aanwezigheid van een of meer katholieke kandidaten anderzijds, blijkt te meer uit de situatie in Venlo. $\mathrm{Na}$ het ontstaan van dit kiesdistrict in 1887 bestond er ruim twee decennia lang geen katholieke kiesvereniging. Pas in 1909 verscheen er een oproep in de Nieuwe Venlosche Courant om steun te verlenen aan de oprichting van een katholieke kiesvereniging in het district. ${ }^{373}$ Bij de eerstvolgende TweedeKamerverkiezingen (1913) was er inderdaad een katholieke kiesvereniging actief. Maar ondanks het ontbreken ervan in de daarvoor liggende periode nam er aan de verkiezingen van 1897, 1901, 1905 en 1909 slechts één enkele katholieke kandidaat deel: Nolens.

De overheersing van het politiek-katholicisme in Limburg betekende dus niet dat er geen strijd plaatsvond over wie de kamerzetel mocht innemen. Een 'katholieke stembusstrijd' - een strijd dus waarbij katholieke kandidaten elkaar de kamerzetel betwistten - kon bijzonder fel zijn.

Over de zojuist genoemde Maastrichtse verkiezingscampagne van 1892 tussen de katholieken Schreinemacher en De Ras meldt het Limburgsch Nieuwsblad dat er zelden gestreden was met 'zooveel heftigheid'. ${ }^{374}$ De verkiezingsstrijd die in 1893 werd gevoerd in het district Roermond en die ging tussen twee katholieke kandidaten, is een 'bijzonder pittige' genoemd. ${ }^{375}$ Charles Ruijs de Beerenbrouck won zijn eerste verkiezing (district Gulpen, 1905) na een 'zware kamp' met zijn katholieke tegenstrever. ${ }^{376}$

En wat te denken van de verbeten wijze waarop vier jaar later in dit latste district de aanhang van de ene katholieke kandidaat de andere bestreed? Kamerlid Charles Ruijs de Beerenbrouck was er uitgedaagd door de eveneens katholieke Paul Brouwers. Ruijs won, met bijna zestig procent van de stemmen, tegen zo'n veertig voor Brouwers. Aanhangers van deze latste vochten de verkiezing van Ruijs aan bij de Tweede Kamer en zij uitten bijzonder ernstige beschuldigingen. Zo schreven de journalist Jan Thomas en het gemeenteraadslid Emile Caselli, inwoners van Valkenburg, in brieven aan de Kamer dat de lokale autoriteiten in het kiesdistrict Gulpen - volgens de briefschrijvers waren die voorstander van de verkiezing van Ruijs - opzettelijk foutieve stembilietten hadden gebruikt om in het geval dat Brouwers mocht blijken gekozen te zijn, de stemming ongeldig te kunnen verklaren. ${ }^{37}$ Reeds voor de verkiezingsdag, zo verklaarden Thomas en Caselli, waren zij gewaarschuwd dat er 'geknoeid zou worden'; ze hadden vernomen 'dat een wapen (wij wisten toen nog niet welk) gereed 
gehouden werd om de stemming eventueel te kunnen vernietigen.' ${ }^{\prime \prime}$ Er was in hun woorden sprake van 'corruptie' bij en 'pressie' door 'bijkans alle machthebbenden': kiezers zouden zijn bedreigd en voorzitters van stembu. reaus zouden zich hebben begeven in de stemhokjes om daar samen met de kiesgerechtigden de biljetten in te vullen. ${ }^{379}$ Ook de Zuid-Limburgse gees. telijkheid werd een kwalijke rol toegedicht. Bovendien uitten Thomas en Caselli de beschuldiging dat stemmen die op Brouwers waren uitgebracht, bij de telling aan Ruijs de Beerenbrouck waren toegekend. Dit laatste verwijt bleek bij een nader onderzoek van de stembiljetten in Den Haag onjuist, zo berichtte de kamercommissie die de kwestie onderzocht.

Wel kwam vast te staan dat het gehanteerde stembiljet niet overeenkwam met het wettelijk vastgestelde model. De vraag was echter of de verkiezing van Ruijs de Beerenbrouck daardoor ongeldig was en - daarmee samen. hangend - of het gebruik van verkeerde biljetten met opzet was gebeurd. Vooral werd in het parlement de vraag gesteld of diens verkiezing wel geacht mocht worden rechtsgeldig te zijn zonder nader onderzoek naar de ernstige beschuldigingen van corruptie en ongeoorloofde druk op de kiezers.

De Kamer besloot met 39 tegen 36 stemmen om Ruijs de Beerenbrouck niet tot haar midden toe te laten. Daarmee werden nieuwe verkiezingen noodzakelijk. De vier Limburgse kamerleden die bij het debat aanwezig waren - Nolens, Janssen, Bolsius en Beckers - stemden allen voor toelating van hun provinciegenoot. ${ }^{380} \mathrm{Zij}$ werden hierin overigens niet unaniem gevolgd door de andere leden van de katholieke kamerclub.

Op 3 december 1909 vond de nieuwe verkiezing plaats. Brouwers stelde zich niet meer kandidaat en Ruijs de Beerenbrouck won nu overtuigend. Naar de reden waarom Brouwers de strijd opgaf, blijft het gissen. Waarschijnlijk speelde een rol dat het protest van zijn aanhangers slechts gedeeltelijk was gehonoreerd: een onderzoek naar corruptie en pressie was er nooit gekomen en Ruijs was de toegang ontzegd op puur formele gronden. ${ }^{.91}$

Als de (belangrijkste) kandidaten allen katholiek waren, ligt het voor de hand aan te nemen dat de voornaamste items die een rol speelden bij verkiezingen, geen betrekking hadden op het zich al dan niet verbonden weten met het politieke samenwerkingsverband van de Nederlandse katholieken. Dat de kandidaten de katholieke belangen zouden behartigen, werd dan ook slechts een enkele keer in twijfel getrokken. Eerder is gewezen op het vermeende liberalisme van Nijst (Maastricht, 188o).

Een blik in de pers van die dagen en in de literatuur maakt duidelipk dat er in de verkiezingscampagnes veelal kwesties meespeelden die niet of 
nauwelijks hun grond vonden in politiek-inhoudelijke verschillen. ${ }^{382}$ Illustratief is de Maastrichtse verkiezing van mei 1888. Na de programma's van de twee belangrijkste kandidaten - beiden katholiek - te hebben vergeleken, constateerde de Maas- en Roerbode: 'Maastricht heeft derhalve eene keuze te doen tusschen twee candidaten met een bijna eensluidende programma.'383 Uit de cirulaires waarmee de twee kandidaten zich tot de kiezers richtten, blijkt van politieke verschillen inderdaad geen sprake: beiden verklaarden voorstander te zijn van het bijzonder onderwijs en oog te hebben voor de sociale kwestie. ${ }^{384}$

De verkiezingen van 1901 in het district Sittard lijken daarentegen wel te zijn gegaan om een politiek-inhoudelijk thema. M.G.J.G. Arnoldts liet weten zich te kandideren tegen het zittend Tweede-Kamerlid De Bieberstein met als voorname reden dat hij in tegenstelling tot De Bieberstein tegen staatsexploitatie van de Zuid-Limburgse kolenmijnen was. Aanhangers van De Bieberstein beschouwden Arnoldts, zo schreven zij op 12 juni in de Sittardse krant Limburg, als 'de candidaat, de protestcandidaat, van de weinige maar rumoerige tegenstanders van Staatsexploitatie der mijnen'. Waarschijnlijk was de groep echter groter dan het kamp van De Bieberstein dacht, of in ieder geval wenste, want Arnoldts won de verkiezingen.

Meestal speelden politiek-inhoudelijke verschillen geen grote rol. Hieruit volgt de vraag wat er dan werd ingebracht tegen een kandidaat die eveneens van katholieke signatuur was. Soms lag de tegenstelling stad-platteland ten grondslag lag aan een meervoudige katholieke kandidatuur. Zo waren er bij de Maastrichtse verkiezing in 1880 twee katholieke kandidaten: jhr. Gustave Ruijs van Beerenbroek en F. baron de Pelser-Berensberg. De eerste was gekandideerd door de katholieke kiesvereniging, de tweede werd in advertenties aanbevolen door 'vele katholieke kiezers'. Met de katholiciteit van uitdager De Pelser-Berensberg zat het wel goed, zo berichtte zijn aanhang: hij zou de katholieke beginselen 'overal en in alles' handhaven en de katholieke belangen te allen tijde verdedigen. ${ }^{305}$ Ruijs van Beerenbroek werd gezien als stedeling en de andere Maastrichtse Tweede-Kamerzetel werd sinds ongeveer een jaar bezet door Nijst, die ook al uit de stad afkomstig was. 'Het is dus recht, billijk en zelfs noodzakelijk, dat ook de bewoners van het platteland een hunner in Holland voor hunne belangen zien optreden,' hielden de aanhangers van De Pelser-Berensberg de kiezers voor. Zii presenteerden de baron als 'den katholieken Candidaat van het platteland'. Weldra zou het parlement zich moeten buigen over de belasting van landbouwpercelen en, zo werd gesteld in een advertentie ten gunste van 
De Pelser-Berensberg: wat hadden de agrariërs te verwachten indien men die kwestie zou overlaten aan 'de Heeren van de Stad'?

Dat er binnen het district Maastricht een onderscheid gemaakt werd tussen stad en platteland, was eerder al gebleken. Zo'n twaalf jaar eerder, in januari 1868, had een vergadering van kiezers een lijst opgemaakt van twee kandidaten voor de beide Maastrichtse kamerzetels. In het verslag van die bijeenkomst lezen we: 'La ville désire, et elle en a le droit, d'être représentée au parlement.' De stad kreeg haar kandidaat, maar ook het platteland werd niet vergeten: van de tweede persoon die werd gekandideerd, werd vermeld: 'Le candidat qui est né à la campagne et qui habite la campagne [...],'化

De tegenstelling stad-platteland speelde niet alleen een rol in Maastricht. $\mathrm{Bij}$ de algemene verkiezingen van 1913 in het district Roermond stonden 'twee degelijke katholieke en bekwame mannen' tegenover elkaar, schreef de Maas- en Roerbode op 22 april. Tot ergernis van de krant werd echter met name door de aanhangers van een van hen, Th. Verheggen, gepoogd om de bewoners van het platteland op te zetten tegen de stedelingen, dat wil zeggen de inwoners van de stad Roermond.

Ook konden controverses op het persoonlijke vlak aanleiding geven tot het opponeren tegen een kandidaat. Bij de verkiezingen die in 1893 plaatsvonden in het district Roermond voerde F.H.J. Thissen, pastoor te Amstenrade, een heftige strijd tegen de kandidaat van de katholieke kiesvereniging, Willem Everts. Thissen gebruikte hierbij de Limburger koerier als wapen, de krant waarvan hij hoofdredacteur was. Een ander Limburgs blad, De nieuwe koerier, kopte op 24 oktober 'Geen politieke, alleen persoonlijke beweegredenen!', daarmee het verzet tegen Everts veroordelend. Oud zeer speelde in de 'meedogenloze oppositie' van Thissen een duidelijke rol." De priesters Thissen en Everts waren beiden als leraar verbonden geweest aan het seminarie in Rolduc - Everts was tevens directeur geweest - en hun relatie stond bekend als slecht.

Persoonlijke kwesties speelden ook een rol bij de felle verkiezingsstrijd van 1909 in het district Gulpen. De voormannen van de oppositie tegen de kandidatuur van Charles Ruijs de Beerenbrouck hadden in de jaren daarvoor al menig conflict uitgevochten met de Ruijsgezinde burgemeester van Valkenburg, A. Erens. Tegen Erens te zijn hield voor hen in: tegen Ruils te zijn. ${ }^{389}$

Tussen 1879 en 1918 heeft in Limburg 104 maal een verkiezing van een Tweede-Kamerlid plaatsgehad. ${ }^{390} \mathrm{O}$ fschoon er vaak meer dan één katholieke kandidaat was, laten de uitslagen zien dat er meestal sprake was van ein 
prominente katholieke kandidaat, die de katholieke nummer twee ruim achter zich liet. In een klein aantal gevallen vond er een nek-aan-nekrace plats. In tabel 6 zijn de negen verkiezingen opgenomen waarbij het verschil tussen de katholieke nummers één en twee in de eerste ronde minder dan twintig procent bedroeg.

Tabel 6. Politieke verdeeldheid onder katholieken bij Tweede-Kamerverkiezingen in Limburg, 1879-1918: verkiezingen waarbij het verschil in stemmen tussen de twee hoogst geeindigde katholieke kandidaten in de eerste ronde minder dan twintig procent bedroeg

\begin{tabular}{|c|c|c|c|c|}
\hline Jaar & District & Kandidaten & $\begin{array}{l}\text { Stemmen in de } \\
\text { eerste ronde (\%) }\end{array}$ & Verschil (\%) \\
\hline \multirow[t]{2}{*}{1880} & Masstricht & M.V. Nijst & 53,3 & 6,9 \\
\hline & & E. Roberti & 46,4 & \\
\hline \multirow[t]{2}{*}{1888} & Maastricht & J.H.J. Schreinemacher & 55,8 & 14,5 \\
\hline & & E.F.H.J. de Beaumont & 41,3 & \\
\hline \multirow[t]{2}{*}{1888} & Gulpen & L.F.H.C. Ruland & 58,6 & 17,2 \\
\hline & & G. Smeets & 41,4 & \\
\hline \multirow[t]{2}{*}{1892} & Maastricht & M. de Ras & 27,4 & 5,4 \\
\hline & & C. Schreinemacher & 32,8 & \\
\hline \multirow[t]{2}{*}{1897} & Gulpen & I.M.M.H. Merckelbach & 51,2 & 7,8 \\
\hline & & L.H.W. Regout & 43,4 & $\cdots$ \\
\hline \multirow[t]{3}{*}{1901} & Sittard & M.G.J.G. Arnoldts & 51,1 & 2,2 \\
\hline & & Ch.C.M.H. baron de Bieberstein & 48,9 & \\
\hline & & Rogalla Zawadsky & & \\
\hline \multirow[t]{2}{*}{1902} & Maastricht & E.E.F. Sassen & 44,8 & 4,3 \\
\hline & & F.I.J. Janssen & 40,5 & \\
\hline \multirow[t]{2}{*}{1909} & Gulpen & Ch.J.M. Ruijs de Beerenbrouck & 58,7 & 18.8 \\
\hline & & P.M.F.H. Brouwers & 39,9 & \\
\hline \multirow[t]{2}{*}{1916} & Weert & W.F.W. Kolkman & 38,6 & 12,6 \\
\hline & & H.A.G. van Groenendael & 26,0 & \\
\hline
\end{tabular}


Tabel 7. Politieke verdeeldheid onder katholieken bij de kandidaatstelling voor Tweede-Kamerverkiezingen in Limburg, 1897-1918*

\begin{tabular}{|c|c|c|}
\hline District & $\begin{array}{c}\text { Aantal } \\
\text { verkiezingen }\end{array}$ & $\begin{array}{c}\text { Aantal verkiezingen } \\
\text { met een meervoudige } \\
\text { katholieke kandidaatstelling }\end{array}$ \\
\hline Venlo & 5 & 0 \\
\hline Weert & 6 & 2 \\
\hline Roermond & 8 & 1 \\
\hline Sittard & 6 & 5 \\
\hline Gulpen & 6 & 6 \\
\hline Maastricht & 8 & 1 \\
\hline Limburg (totaal) & 39 & 15 \\
\hline \multicolumn{3}{|c|}{ 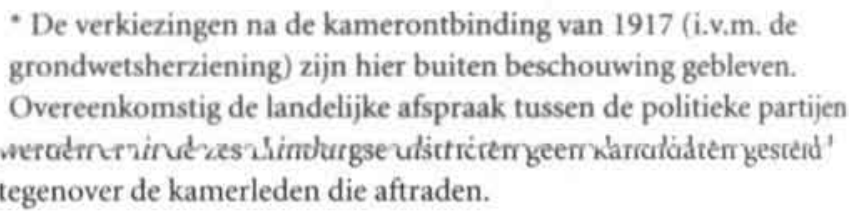 } \\
\hline
\end{tabular}

Tabel 6 bevat buiten Weert alleen Zuid-Limburgse districten. Hoewel het ook in het noorden en midden van de provincie voorkwam dat er meer dan één katholieke kandidaat meedeed, was de verdeeldheid binnen het katholieke electoraat daar kennelijk minder groot dan in het zuiden. Indien we meer gedetailleerd kijken naar de periode vanaf 1897 , het jaar waarin kandidaten zich voor het eerst dienden te laten registreren, blijken met name Gulpen en Sittard zich te onderscheiden, doordat de politieke eensgezindheid onder de katholieken er duidelijk minder groot was dan elders in de provincie (zie tabel 7). In deze twee districten opteerde vaker dan in de rest van Limburg meer dan één katholiek voor een kamerzetel. Als we de provincie in haar totaliteit bezien, blijkt een meervoudige katholieke kandidaatstelling daar in de periode 1897-1918 relatief vaker voor te komen dan in Noord-Brabant, waar bij 17 van de 67 verkiezingen sprake was van meer dan één katholieke kandidaat. ${ }^{391}$

In nog een ander opzicht kunnen we Gulpen en Sittard apart plaatsen. In de overige vier Limburgse districten trad slechts dan meer dan éen katholieke kandidaat op wanneer de verkiezingen plaatsvonden na het overlijden van een zittend kamerlid of nadat het zittende kamerlid aangekondigd had zich niet meer te zullen kandideren. Indien de zittende afgevaardigde zich wel kandidaat stelde, werd hij in Venlo, Weert, Roermond en Maastricht 
nimmer uitgedaagd door een opponent die eveneens behoorde tot de katholieken. In het district Venlo was het zittende kamerlid Nolens bij alle verkiezingen, dat wil zeggen in 1897, 1901, 1905, 1909 en 1913, de enige katholieke kandidaat; in de drie eerstgenoemde jaren werd hij bij enkelvoudige kandidaatstelling gekozen verklaard. In Weert was er meer dan één katholieke kandidaat in 1901 en 1916 na respectievelijk het definitief terugtreden van Truijen en het overlijden van Victor de Stuers; tijdens de overige vier verkiezingen werd het zittende kamerlid (in 1897 Truijen en in 1905, 1909 en 1913 De Stuers) bij enkelvoudige kandidaatstelling gekozen verklaard. In Roermond was er meer dan één katholieke kandidaat na het terugtreden van Bolsius in 1913; bij de overige zeven verkiezingen in Roermond werd de katholieke kandidaat bij enkelvoudige kandidaatstelling gekozen verklard, ook in 1900, na het overlijden van Everts. In Maastricht trad alleen in 1902 meer dan één katholieke kandidaat op; zittend kamerlid De Ras had toen ontslag genomen wegens zijn benoeming tot lid van de Algemene Rekenkamer.

In Gulpen en Sittard lag dit geheel anders. Vanaf 1897 vonden in elk van de beide districten vijf verkiezingen plaats waarbij het zittende kamerlid voor een nieuwe periode opteerde. Voor zowel Gulpen als Sittard geldt dat er in vier gevallen desondanks meer dan éen katholieke kandidaat was. ${ }^{392}$ In Sittard werd de zittende afgevaardigde baron de Bieberstein in 1901 zelfs verslagen door de eveneens katholieke opponent Arnoldts.

Nu was verdeeldheid voor de katholieken nergens in Limburg zo riskant als in Maastricht. In geen ander deel van de provincie was de participatie van niet-katholieke kandidaten zo groot als in dit district, zowel wat betreft het aantal verkiezingen waaraan zij deelnamen als de percentages stemmen die zij haalden. Het ontbreken van een enkelvoudige kandidaatstelling zou een anders welhaast zekere verkiezing van een katholieke afgevaardigde in gevaar kunnen brengen. Overigens werd in katholieke bladen als De Tijd en de Limburger courier op dit risico van katholieke verdeeldheid in Maastricht gewezen. ${ }^{393} \mathrm{Bij}$ de verkiezingen in dit district werkten sociaal-democraten en liberalen vanaf 1901 op incidentele basis samen. ${ }^{394}$ Dit maakte de noodzaak tot eenheid binnen de katholieke gelederen des te urgenter. Uit de tabellen 6 en 7 kunnen we afleiden dat er na 1897 in Maastricht bij zeven van de acht verkiezingen sprake was van katholieke eenheid. Vóór 1897 , toen een kandidaatstelling gemakkelijker was door het ontbreken van wettelijke regels daaromtrent, was de verdeeldheid onder de katholieken in Maastricht beduidend groter. 


\section{Limburgse katholieken en katholieke Limburgers}

Hoewel de Nederlandse katholieken al vanaf de jaren zestig geregeld en vanuit eigen kring werden opgeroepen tot politieke groepsvorming, was van een hechte samenwerking tussen de katholieke volksvertegenwoordigers lange tijd geen sprake. Eind jaren zeventig riep Schaepman de katholieken opnieuw op tot partijvorming. Hij streefde daarbij naar de oprichting van een partij die gericht was tegen het liberalisme en waarin ook voor niet-katholieke christenen plaats was. De facto ging hij echter uit van een (overwegend) katholieke partij. ${ }^{395}$ In 1883 publiceerde hij - inmiddeks kamerlid - zijn ideeèn in Een Katholieke partij. Proeve van een program. Aanvankelijk had Schaepman weinig succes. Van vooroverleg met zijn katholieke medeafgevaardigden was geen sprake geweest en aan de Proeve werd weinig aandacht geschonken.

Een belangrijke stap naar meer eenheid onder katholieke politici werd in 1891 gezet. In een manifest verenigden veertien katholieke Tweede-Kamerleden zich in de Centrumclub. In navolging van het Duitse Zentrum wilden zij in het parlement een onafhankelijke positie innemen, los van de andere politieke groeperingen. De zes Limburgse afgevaardigden waren unaniem in hun steun aan dit initiatief, vier van de elf kamerleden uit Noord-Brabant stonden er niet achter. ${ }^{396}$ Tekenend was dat de Centrumclub zich niet bond aan een programma. Nu waren zijn leden ook voor een belangrijk deel gericht op de regionale belangen. ${ }^{397}$ Dit constateerde, tot zijn grote ergernis, ook Schaepman. Voorafgaand aan de Tweede-Kamerverkiezingen van 1893 schreef hij aan het anti-revolutionaire kamerlid jhr. A.F. de Savornin Lohman:

En dan ... wat het ergste is ... Gij krijgt heel Limburg en Noordbrabant ongeschonden terug. Ik moest het niet zeggen, maar het is zoo: deze troep bederft de Kamer. Het zuiverste provinciale en bourgeoise egoïsme zit hier voor en bederft zelfs de besten. Ik zou zoo gaarne eens het land dooreenschudden en deze katholieken door de overige provinciën zaaien; het zou voor alles en vooral voor henzelven beter zijn. ${ }^{398}$

Geen programma dus voor de Centrumclub, maar overleg en samenwerking tussen de katholieke kamerleden vond de club wel degelijk gewenst. Daarbij werden weldra ook de katholieke afgevaardigden van buiten de Centrumclub betrokken, want eind 1891 werd de Vereeniging van Roomsch. 
Katholieke leden der Tweede Kamer der Staten-Generaal in het leven geroepen. Ook dit samenwerkingsverband - waar de Centrumclub weldra in opging - kende geen programma: wanneer het om louter katholieke belangen ging, wisten de katholieke afgevaardigden heus wel wat hun te doen stond, zo meende zijn voorzitter P.J.F. Vermeulen. ${ }^{399}$

De forse uitbreiding van het aantal kiezers in 1896 - dit aantal verdubbelde ten gevolge van de kieswet-Van Houten - deed de noodzaak tot het opstellen van een programma echter meer dan ooit gelden. ${ }^{400}$ Op 20 oktober van dat jaar ondertekenden de zes Limburgse leden van de Tweede Kamer, Everts, Lambrechts, De Marchant d'Ansembourg, Nolens, De Ras en Truijen, samen met de overige negentien katholieke afgevaardigden in die Kamer een program van beginselen.

Op een eendrachtig optreden van de katholieke kamerleden viel echter lang niet altijd te rekenen. De onderlinge tegenstellingen waren begin jaren negentig zo groot dat er bij Ruijs van Beerenbroek senior, van wie een verzoenende invloed werd verwacht, op werd aangedrongen opnieuw een kamerzetel in te nemen. Ruijs was in augustus 1891 samen met de overige leden van het kabinet-Mackay afgetreden en de Roermondse afgevaardigde Diepen bleek bereid zijn zetel ter beschikking te stellen. Ruijs van Beerenbroek beantwoordde aan de oproep, werd in Roermond gekozen en trad in juli 1892 toe tot de Tweede Kamer. In het kader van het verzoeningsstreven werd Ruijs bij aanvang van het nieuwe parlementaire jaar, enkele maanden later, gekozen tot voorzitter van de Vereeniging van RoomschKatholieke leden der Tweede Kamer der Staten-Generaal. Of hij veel heeft kunnen bereiken in het bevorderen van de katholieke eendracht is twijfelachtig: de tegenstellingen waren daarvoor waarschijnlijk te sterk. ${ }^{401}$ Pas onder de leiding van Nolens - in 1910 werd hij voorzitter van de katholieke kamerclub - groeide de katholieke 'fractie' in de Tweede Kamer uit naar een zekere homogeniteit. Bij verschillende onderwerpen toonden de katholieke afgevaardigden in Den Haag zich duidelijk verdeeld. Of ook de Limburgse kamerleden het daarbij onderling oneens waren, zal nu aan de hand van cen aantal items worden bekeken.

Een van de belangrijkste vraagstukken rond de eeuwwisseling betrof de sociale kwestie. J.H. Wijnen, kapelaan van de Maastrichtse Sint-Matthiasparochie, had de hogere maatschappelijke kringen begin jaren zeventig al in beroering gebracht met zijn beschrijvingen van nachtelijke kinderarbeid, eerst in De Maasbode en later in een brochure. ${ }^{402}$ De artikelen van Wijnen waren in ieder geval niet voorbijgegaan aan Tweede-Kamerlid De 
Bieberstein: hij verwees er uitdrukkelijk naar. ${ }^{403}$ De parlementaire arbeids. enquête van 1887 , met Maastricht als een van haar drie casussen, had de maatschappelijk-politieke elite wederom geconfronteerd met de erbarmelijke leef- en werkomstandigheden van de arbeiders. Een van de Limburgse afgevaardigden, G. Ruijs van Beerenbroek, had zitting in de enquêtecom. missie. Ook kan hier gewezen worden op de sociale encycliek Rerum novarum (Van nieuwe zaken) uit ${ }^{1891 .}$. Paus Leo xIII nodigde katholieke politic daarin dringend uit om zich om de sociale kwestie te gaan bekommeren. In welke mate beantwoordden de Limburgse kamerleden aan deze pauselijke oproep?

Er waren in de jaren tot 1918 verschillende Limburgse kamerleden met (neven) functies die verband hielden met de sociale kwestie, te weten Bolsius, Bongaerts, J. Brouwers, Hermans, L. van der Maesen de Sombreff, Nolens, Pijls, L. Regout, Ch. Ruijs de Beerenbrouck en Ruland. ${ }^{404}$ Het betreft hier grotendeels Zuid-Limburgse afgevaardigden. De nabijheid van industrie, met name in en rondom Maastricht, en van mijnen deed de sociale kwestie waarschijnlijk met name in het zuiden van de provincie op de voorgrond treden.

De Limburgse kamerleden zagen verschillende voorstellen tot sociale wetgeving op de parlementaire agenda verschijnen, te beginnen met het beroemde Kinderwetje van Van Houten in $\mathbf{1 8 7 4}$. De volgende stap op het terrein van de arbeidswetgeving werd zo'n vijftien jaar later gezet door minister van Justitie Gustave Ruijs van Beerenbroek: hij diende in 1889 een ontwerp-arbeidswet in bij het parlement. ${ }^{405}$ Vooral na de eeuwwisseling kwam een aantal belangrijke sociale wetten tot stand.

De Limburgse afgevaardigden in Eerste en Tweede Kamer gaven in verreweg de meeste gevallen hun medewerking aan belangrijke sociale wetten uit de periode 1874-1918. Of zij in hun hoedanigheid van volksvertegenwoordiger belang hechtten aan de sociale kwestie, kunnen we hier niet direct uit afleiden. Dat kan wel duidelijk worden indien we de vraag stellen of zij er tijdens de parlementaire debatten over spraken. Bekend is dat De Stuers in het parlement zweeg wanneer de slechte sociale toestanden in Nederland aan de orde werden gesteld. Zijn aandacht richtte zich wel op het onrecht in Nederlands-Indië, maar niet op de situatie dichter bij huis. ${ }^{406}$

Het parlementair optreden van Nolens staat hiermee in scherp contrast. Nolens voerde juist wel vaak het woord bij beraadslagingen over sociale aangelegenheden. Bij de voorstellen tot sociale wetgeving die tot 1918 in het parlement werden besproken, was hij van de Limburgse kamerleden verreweg het meest aan het woord. Op zijn activiteiten binnen het parlement. 
maar ook daarbuiten, drukte de sociale kwestie een duidelijk stempel. In zijn eerste verkiezingsmanifest verwees hij reeds naar de kwestie. Nolens was buitengewoon actief in het steunen van voorstellen tot oplossing van sociale problemen. ${ }^{407}$ De encycliek Rerum novarum vormde hierbij een bijzonder belangrijke inspiratiebron. In de artikelen die hij - tot 1909 vrijwel wekelijks - schreef voor de Venloosche Courant en later de Nieuwe Venlosche Courant, besteedde hij vooral veel aandacht aan de sociale kwestie en de sociale wetgeving. ${ }^{408}$

De vervanging van Haffmans door Nolens, in 1897 , leidde tot een wezenlijke verschuiving in het aandachtsveld van de Noord-Limburgse afgevaardigde in de Tweede Kamer. Gedurende de laatste tien jaar van zijn mandaat - het betreft hier de periode september 1886 tot september 1896 - heeft Haffmans de sociale kwestie nimmer aan de orde gesteld. Weliswaar vroeg hij in december 1886 aandacht voor 'onze arme landbouwers' en verweet hij minister Pierson van Financièn in juli 1892 niet voldoende te denken aan 'den kleinen man', in deze beide gevallen ging het om een puur fiscale kwestie die Haffmans niet direct in verband bracht met de positie van de arbeiders. ${ }^{409}$ In zijn Venloosch Weekblad verkondigde hij zelfs de sociale kwestie geenszins als probleem te zien. ${ }^{410}$ Nolens stond al in zijn eerste parlementaire rede uitgebreid stil bij de sociale kwestie, die hij bij die gelegenheid 'het maatschappelijk vraagstuk bij uitmuntendheid' noemde. Meermaals refererend aan Rerum novarum riep Nolens de regering op tot 'sociale rechtvaardigheid'.4

$\mathrm{Na}$ de dood van Haffmans was in de Venloosche Courant overigens al gesteld dat diens opvolger in de Kamer zich voortaan in belangrijke mate diende te richten op het sociale vraagstuk. Door de aanstaande uitbreiding van het kiesrecht moest de nieuwe afgevaardigde uit Venlo 'ook de candidaat kunnen zijn der duizenden nieuwe kiezers, dus een waarborg bieden, dat hij ook hunne belangen, $\mathrm{nl}$. [...] de belangen der arbeidende klasse zal willen en kunnen behartigen'. ${ }^{42}$ Om deze reden werd Nolens door de krant aanbevolen.

Naast Nolens waren er andere Limburgse kamerleden voor wie de sociale kwestie een belangrijke rol speelde tijdens hun politieke carrière. Dit geldt in het bijzonder voor vader en zoon Ruijs de Beerenbrouck. Gustave Ruijs van Beerenbroek diende in 1886 - hij was toen afgevaardigd door het district Masstricht - samen met andere kamerleden een verzoek in tot het houden van een parlementair onderzoek naar de arbeidsomstandigheden. Zoals reeds vermeld nam hij ook zelf plaats in de negenkoppige parlementaire enquétecommissie die daarop werd ingesteld. Tijdens zijn werkzaamheden 
voor deze commissie gaf Ruijs overigens wel blijk van zijn inbedding in de maatschappelijke elite van Zuid-Limburg, waarvan ook de daar gevestigde fabrikanten deel uitmaakten. Hij probeerde 'als Limburgs afgevaardigde' nadrukkelijk invloed uit te oefenen op de arbeidsenquête, 'enige partijdig. heid ten opzichte van het behandelde' was hem niet vreemd. ${ }^{413}$ De verslagen van de verhoren nalezend, valt inderdaad op dat Ruijs vaak vragen stelde die uitnodigden tot het geven van een positieve draai aan het negatieve beeld dat was geschetst van de werkomstandigheden in de Maastrichtse fabrieken." ${ }^{\text {th }}$ Tijdens een van de verhoren stelde Ruijs dat hij had onder. vonden dat door arbeiders dikwijls overdreven werd. ${ }^{415}$ Industrieel Petrus Regout, die zich tijdens zijn ondervraging opvallend ongevoelig toonde voor de noden van zijn werklieden, werd door Ruijs welhaast in de mond gelegd dat het bedrijf het zelf ook niet gemakkelijk had door de moordende buitenlandse concurrentie. ${ }^{116}$ Een uiterst kritisch rapport over de omstandigheden in de Maastrichtse aardewerkfabriek Ceramique werd door Ruijs in twijfel getrokken. Zo diskwalificeerde hij de afzender van dit rapport, het Maastrichtse departement van de Maatschappij tot Nut van 't Algemeen, door te stellen dat die organisatie zich 'hoofdzakelijk met de theorie, maar minder met de practijk' bezighield. ${ }^{47}$ Toch had Ruijs wel degelijk oog voor de sociale kwestie. Hij liet zijn zonen, onder wie het latere Tweede-Kamerlid Charles, al op jonge leeftijd kennismaken met de erbarmelijke toestanden in de sloppenwijken van Maastricht. ${ }^{118}$ Daarnaast is en blijft zijn naam verbonden met de eerder genoemde arbeidswet van 1889 .

Ook Charles Ruijs de Beerenbrouck heeft uitdrukkelijk zijn verdiensten gehad op sociaal gebied. ${ }^{419}$ Evenals voor Nolens was Rerum novarum voot Ruijs een richtsnoer. Als lid van de Maastrichtse gemeenteraad was hij de drijvende kracht achter lokale verordeningen op het gebied van pensioenen, minimumloon en een maximum-arbeidsduur voor het gemeentepersoneel. Op zijn initiatief kwamen er in Maastricht een werklozenfonds en voorzieningen op het gebied van de sociale woningbouw tot stand. Ook zijn overige nevenactiviteiten duiden op een sociale betrokkenheid; zo was Ruijs juridisch adviseur van de Maastrichtse vakverenigingen van aardewerkers en van glasblazers en had hij zitting in de raad van adviseurs van de Algemene Bond van Christelijke Mijnwerkers. ${ }^{420}$ Op landelijk niveau heeft Ruijs met betrekking tot de sociale regelgeving vooral van zich doen spreken door het pakket aan maatregelen dat zijn eerste kabinet (1918-1922) doorvoerde. Tijdens de algemene beschouwingen over de begroting van 1919 gaf de toen pas benoemde premier een toelichting op het omvangrijk sociaal plan van zijn minister van Arbeid, P.J.M. Aalberse. ${ }^{21}$ Deze had bij de formatic als 
voorwaarde voor deelname aan het kabinet een achttien punten tellend sociaal werkplan voorgelegd waarmee Ruijs volledig had ingestemd. ${ }^{422}$

Als het gaat om sociale wetgeving, is de houding interessant van de afgevaardigden die behoorden tot de industriële familie Regout. In de Eerste Kamer werd een van de drie Limburgse zetels tussen 1881 en 1915 bezet door een lid van deze Maastrichtse familie: H.G.L. (Louis) Regout was EersteKamerlid tot september 1904; zijn zoon L.H.W. (eveneens Louis) Regout volgde hem op in dat ambt en bleef afgevaardigde tot zijn overlijden in oktober 1915. Hoe stelden zij zich op? Het socialistische Tweede-Kamerlid Ferdinand Domela Nieuwenhuis verwachtte weinig goeds van hen. Tijdens een kamerdebat verzuchtte hij: 'Zoo lang het mogelijk is dat Regout en Stork en dergelijken geduld worden en zelfs lid zijn van de Wetgevende Macht, zoolang weten ook de arbeiders dat het kloppen is aan doovemansoor, wanneer zij voor hunne belangen vragen doen aan de Kamer.'23

Als we de stemmingen bij sociale wetten bekijken, moeten we vaststellen dat de beide Regouts veelal voor het wetsontwerp stemden. Zij trachtten de sociale wetgeving dus niet (voortdurend) tegen te werken. Beiden namen ook deel aan de beraadslagingen die bij deze voorstellen werden gehouden.

Louis Regout senior sprak daarbij naar eigen zeggen 'als industrieel' en hij noemde zich de 'vertegenwoordiger van de Limburgsche industrie'.424 Bij de eerste ontwerp-ongevallenwet, die in juni 1900 door de Eerste Kamer werd verworpen, betreurde hij het dat de regering 'de betrokken industrieelen' niet had geraadpleegd. ${ }^{225}$ Eerder schreef Regout aan de parlementaire enquêtecommissie arbeidsomstandigheden een open brief als 'Industrieel, lid van de Eerste Kamer der Staten-Generaal'. ${ }^{226}$ Bij de behandeling van de tweede ontwerp-ongevallenwet in december 1900 gaf hij aan dat de sociale wetten die voorzagen in uitkeringen bij ziekte, ongelukken, invaliditeit en ouderdom, extra lasten betekenden voor de bedrijven en dus zouden leiden tot lagere lonen voor de arbeiders. Hijzelf zou zich in ieder geval gedwongen voelen de salarissen te korten, tenzij de overheid ter bescherming van de industrie de invoerrechten zou verhogen, maar dat zou wel niet gebeuren, meende het kamerlid. Deze voorkeur voor protectionistische maatregelen had hij overigens gemeen met zijn vader, Petrus Regout, die enkele decennia daarvoor zitting had in de Eerste Kamer. Ook die presenteerde zich in zijn parlementaire werkzaamheden voortdurend als vertegenwoordiger van de industrie. Ten behoeve van zijn herverkiezing in 1850 schreef hij in een brief an Provinciale Staten dat hij 'bij elke gelegenheid, de industrieele en materieele belangen van Limburg verdedigd' had; hij vond het noodzakelijk 'ten minste één Industrieel voor Limburg ter Kamer af te vaardigen'. ${ }^{27}$ In 
het parlement hield hij zich inderdaad uitdrukkelijk bezig met de belangen van de industrie en hij publiceerde daar ook over. ${ }^{228}$

Meer dan bij zijn vader speelde de sociale kwestie een rol bij Loui Regout jr. Deze laatste sprak in de Kamer met name over arbeidszaken. ${ }^{\circ}$ Hij was in 1896 gepromoveerd op een dissertatie getiteld Arbeidsverzekering en had ook gepubliceerd over de ongevallenwet. ${ }^{40}$ Sinds 1902 was hij lid van de Nederlandse Vereniging tot wettelijke bescherming van arbeiders. In de Kamer verklaarde hij 'een beslist voorstander' te zijn van 'een zeer uitgebreide Staatsbemoeiing op sociaal gebied.'31 In vergelijking met zijn vader en grootvader was L.H.W. Regout duidelijk meer terughoudend in zijn (openlijke) vereenzelviging met de industriële sector. Tijdens het debat over de wettelijke regeling van het arbeidscontract in juni 1907 zei hif: 'In verband met mijn maatschappelijke positie buiten deze Kamer, heb ik mij afgevraagd of het niet verstandig zou zijn bij deze gelegenheid te zwijgen, en wel omdat elke critiek op dit wetsontwerp vanwege een Kamerlid, industrieel-werkgever, allicht zal worden bestempeld, ten minste buriten deze Kamer, tot een partijdige daad van eigenbelang.' Hijzelf meende echter 'als lid dezer Kamer, ofschoon dan tevens industrieel' tot een objectief oordeel in staat te zijn. ${ }^{432}$ Toch lijkt hij de wet mede te hebben bezien vanuit de optiek van een industrieel. Evenals zijn vader bij eerdere sociale wetten had gedaan, wees hij op de problematische uitvoering ervan: de regeling wemelde volgens hem van de 'onpractische bepalingen' die vooral ook de werkgevers zouden hinderen. Regout sprak de hoop uit dat het land behoed zou blijven voor 'een verdere reeks van onpractische sociale wetten'. ${ }^{33}$

In de houding ten opzichte van de sociale kwestie deden zich dus duidelijke verschillen voor tussen de katholieke afgevaardigden uit Limburg. Dit geldt ook voor bijvoorbeeld het voorstel van minister J.P.R. Tak van Poortvliet tot uitbreiding van het kiesrecht. Deze kwestie verdeelde niet alleen de katholieke kamerleden, maar ook de Limburgers onder hen. In de strijd die nu plaatsvond tussen de zogeheten takkianen en antitakkianen was er sprake van ernstige verdeeldheid onder de katholieke afgevaardigden. Ook de Limburgers deelden zich op in de twee kampen: Everts, Haffmans en De Ras steunden de beoogde kiesrechtuitbreiding, Lambrechts en graaf de Marchant d'Ansembourg verzetten zich ertegen. ${ }^{a t}$ Aan de zijde van de tegenstanders van de kieswet-Tak kunnen we verder Gustave Ruijs van Beerenbroek scharen. ${ }^{435}$ Tijdens het voortraject van de wet had hij nog zitting gehad in de Tweede Kamer. In juni 1892 had hil zich op een kiezersvergadering in Roermond zelfs nog uitgesproken voor inkrimping van het kiesrecht. ${ }^{436}$ 
In 1896 sprak de Tweede Kamer zich uit over het wetsontwerp van S. van Houten dat beoogde het kiesrecht flink uit te breiden. In de Tweede Kamer stemden veertien katholieken voor en elf tegen het voorstel. Everts, Haffmans, Lambrechts, De Ras en Truijen schaarden zich bij de voorstanders; graaf de Marchant d'Ansembourg was wederom tegen. ${ }^{437}$ In de Eerste Kamer toonden de drie Limburgse leden zich behoudender dan de meeste provinciegenoten in de Tweede Kamer: zij brachten allen hun stem tegen het wetsvoorstel uit. ${ }^{\text {ss }}$

De verdeeldheid binnen de katholieke kamerclub kwam ook op andere momenten tot uiting. Bekend is dat Schaepman een moeizame relatie onderhield met vele geloofsgenoten in de Kamer. Dit gold zeker voor zijn collega-kamerleden uit Limburg. Hij schreef ooit over 'de Limburgers', zoals hij ze noemde: 'Van dezen vertrouw ik geen enkelen meer.' In een andere brief beantwoordde hij een door hemzelf opgeworpen vraag omtrent de betrouwbaarheid van een van de Limburgse afgevaardigden met: 'Amice, denk aan 't Limburger bloed. ${ }^{\text {.499 }}$

De komst van Schaepman naar de Tweede Kamer had overigens nog op de ongedeelde steun van de Limburgse afgevaardigden kunnen rekenen, zo was gebleken bij de discussie over de verenigbaarheid van Schaepmans priesterambt met het kamerlidmaatschap en bij de stemming die daarop volgde. ${ }^{440} \mathrm{Haffmans}$ had ook in zijn krant vurig geplęit voor het toelaten van Schaepman. De 'leeraren der Godsdiensten' waren krachtens de grondwet alleen uitgesloten zolang zij in functie waren, zo schreef hij. 'Wilt Gij het bewijs? Aanschouwt de Kamer. Zij krioelt van dominés of die het geweest zijn.'

In 1890 kwam het tot een breuk tussen Haffmans en Schaepman. Spoedig nadat het voorzitterschap van de katholieke kamerclub toeviel aan Haffmans, in 1893, weigerde Schaepman voortaan de vergaderingen bij te wonen. Twee weken nadat de afgevaardigde uit Venlo gestorven was, was Schaepman weer aanwezig. ${ }^{42}$ De gedachte dat Haffmans na zijn dood zou worden opgevolgd door zijn broer Emile, die zich kandidaat gesteld had, vervulde Schaepman met afgrijzen. Hij bood zijn vriend Nolens aan om diens kandidatuur waar mogelijk te steunen. ${ }^{43}$ Tot vreugde en opluchting van Schaepman won Nolens de verkiezingen.

Het satirisch blad Uilenspiegel vond in de slechte relatie tussen Schaepman en zijn Limburgse collega's in de Kamer een dankbaar onderwerp vor zijn prenten. Naar aanleiding van de komst van Willem Everts naar de Tweede Kamer in 1893 publiceerde Uilenspiegel een prent waarin de nieuwe afgevaardigde uit Roermond, in de rol van Sinterklaas, de leden van 
de katholieke kamerclub vermanend toespreekt; hij roept op tot eenheid." Achter hem zien we Haffmans, die de kandidatuur van Everts had gesteund, afgebeeld als Zwarte Piet (met roe). Schaepman weigert te luisteren naar de Sint en Piet: hij heeft demonstratief zijn hoofd afgewend (zie blz. 370).

Tweede-Kamerlid Brouwers (eerst district Boxmeer, later Roermond) wordt door Witlox een 'vinnig tegenstander' van Schaepman genoemd. Schaepman was zelfs een beetje bang voor Brouwers. ${ }^{45}$ Ruijs van Beeren. broek senior kwam in de Kamer al spoedig in aanvaring met Schaepman en hartelijk is hun verhouding nooit geworden. ${ }^{46}$ Ook De Stuers berichtte in zijn dagboek over een conflict met Schaepman. De laatste was op dat moment voorzitter van de katholieke kamerclub en wilde de leden daarvan een aanhankelijkheidsadres aan de paus laten zenden. De Stuers hechtte echter aan zijn onafhankelijkheid als afgevaardigde en vond het daarom niet gepast dat in het adres gesproken werd van gehoorzaamheid aan de kerkvorst. Schaepman was zeer beledigd en beet De Stuers toe dat hij 'chicaneerde'te

De Stuers liet zich overigens niet alleen door Schaepman moeilijk leiden. Hij stelde zich ook ten opzichte van bijvoorbeeld Nolens en de overige afgevaardigden uit Limburg onafhankelijk op. ${ }^{48}$ In november 1904 werd hij in het openbaar door de gehele katholieke kamerclub terechtgewezen. Bij de behandeling van de Indische begroting had De Stuers in scherpe bewoordingen zijn afkeuring uitgesproken over het militaire beleid in Atjeh en het Nederlandse optreden daar bestempeld als 'een moordgeschiedenis." ${ }^{4}$ Naar aanleiding van deze woorden legde M.J.C.M. Kolkman een verklaring af 'namens de Katholieke Kamerleden' waarin zij zich uitdrukkelijk distantieerden van de wijze waarop De Stuers over de kwestie gesproken had. ${ }^{50}$ De Stuers werd op dit moment kennelijk niet tot de katholieke afgevardigden gerekend. In 1910 stelde hij zich in een ordedebat zelfs uitdrukkelijk tegenover provinciegenoot Nolens op. Het ging toen om het spreekrecht voor kamerleden die behoorden tot een parlementaire minderheid: Nolens en anderen wilden dat volgens De Stuers te zeer beperken. ${ }^{45}$

De verdeeldheid binnen de katholieke 'fractie' in de Tweede Kamer liep soms ook langs provinciale lijnen. Op 29 maart 1881 kregen de Limburgse Tweede-Kamerleden er naar aanleiding van de ontwerp-rentewet in De Tijd ongenadig van langs:

Wij constateren het feit: er zijn elf katholieke afgevaardigden en 6 Limburgers. [...] het feit is er: de homogeniteit houdt op. [...] Voor het oogenblik staat eene zaak vast: de Limburgsche leden hebben zich afgescheiden niet alleen van hunne katholieke mede-afgevaardigden, 
maar van de Katholieken in al de andere provincièn. Zij weten dat hier bij deze wet groote katholieken belangen in het spel zijn. Zij hebben zich des niet willen bekommeren, en hun vermeend of voorgewend provinciaal belang boven het algemeen katholiek belang gesteld: Dat is een feit.

De Maas- en Roerbode beschuldigde De Tijd ervan een 'verwaande en onverantwoordelijke machtspreuk' te bezigen. ${ }^{452}$

De rentewet was de splijtzwam die de Limburgse katholieken had doen veranderen in katholieke Limburgers. In lijn met de voorafgaande decennia kozen de Limburgse afgevaardigden voor de in hun provincie allang gewenste belastinghervorming (zie verder hoofdstuk 5). Alom werd de scheidslijn tussen de Limburgers en hun geloofsgenoten in de Kamer opgemerkt. Het liberale Tweede-Kamerlid W.H. de Beaufort noteerde in zijn dagboek: 'De Limburgers, door hunne houding bij de rentewet, hebben grote achterdocht aan de R.C. partii gegeven'. ${ }^{53}$ In het weekblad Uilenspiegel verscheen een prent onder het opschrift 'De afvalligen'. De kloof tussen 'deze zes brute Limburgers' - het zijn de woorden van Schaepman ${ }^{454}$ - en hun geloofsgenoten in de Kamer was diep. De katholieke afgevaardigde B. Bahlmann schreef: 'De toestand tusschen de elf en de zes wordt met iederen dag meer gespannen.'45s De Limburger courier sprak van 'somtijds onedele verdachtmakingen' jegens de Limburgse afgevaardigden 'zelfs van de zijde hunner partijgenoten'456

De scheiding had echter geen definitief karakter, mede omdat er kennelijk grenzen waren aan de ruimte die de Limburgse kamerleden hadden om zich met een eigen provinciaal standpunt tegenover de overige katholieke afgevaardigden op te stellen. Dit gold in het bijzonder voor de vertegenwoordigers uit het deels Noord-Brabantse kiesdistrict Boxmeer. De rentewet werd in het parlement behandeld in het voorjaar van 1881 en de reguliere Tweede-Kamerverkiezingen naderden: zij zouden in juni van dat jaar plaatsvinden. Haffmans wilde herkozen worden in Boxmeer en de katholieke kandidaat werd in dat district benoemd door de kiesvereniging Noord-Brabant. Indien Haffmans zich te zeer zou vervreemden van het katholieke smaldeel in de Kamer en in het bijzonder van zijn collega-afgevaardigden uit Noord-Brabant, zou zijn kandidaatstelling wel eens gevaar kunnen lopen. Hij hoopte daarom op een spoedig herstel van de banden met de katholieken van buiten zijn provincie. Hij schreef in het Venloosch Weekblad op 21 mei 1881 : 'Men spreke weer als eertijds van onze 17 katholieke afgevaardigden en doe alsof er niets gebeurd ware'. 
Op een vergadering van de kiesvereniging Noord-Brabant in Oeffelt legde Haffmans een verzoenende verklaring af. In De Maasbode werd geschreven dat deze verklaring overtuigend aantoonde dat 'de goede zaak' nog altijd warme harten vond bij 'onze edele Limburgers'. In het blad werd tevens de hoop uitgesproken dat de 'band der onderlinge liefde en eendracht' weer zou worden aangehaald. ${ }^{457}$ De Boxmeerse afdeling van Noord-Brabant nam genoegen met de woorden van Haffmans en kandideerde hem opnieuw voor de Tweede Kamer.

Zijn collega-afgevaardigden Arnoldts, Nijst, Ruijs van Beerenbroek en Brouwers hadden meer moeite met wat zij beschouwden als het gedraai van Haffmans. Zij protesteerden door middel van een ingezonden brief in het Venloosch Weekblad. ${ }^{458}$ Wat opvalt, is dat Lambrechts deze protestbrief niet ondertekende. De Limburger courier bracht dit op 31 mei in verband met de komende verkiezingen. Kennelijk kon ook Lambrechts het zich volgens het blad niet veroorloven om te zeer vervreemd te raken van het katholieke samenwerkingsverband in de Nederlandse politiek.

Overigens hechtte De Tijd van 13 juni weinig waarde aan de excuses van Haffmans: het blad sprak van een goochelact - een 'escamotage' - door de afgevaardigde. Het blad liet voorafgaand aan de verkiezingen daarom na zijn steun te betuigen aan de kandidatuur van Haffmans. Ook Nijst (district Maastricht) werd niet aanbevolen. De kandidatuur van Lambrechts (district Roermond) kreeg wel een positief advies in De Tijd, maar hij had volgens het blad de rentewet dan ook verder niet meer aangeroerd in zijn circulaire aan de kiezers.

Een ander onderwerp waarop diverse Limburgse kamerleden - uit alle delen van de provincie - zeer geregeld hun bijzondere aandacht richtten, was de bevaarbaarheid van de Maas. Op 18 december 2001 kopte Dagblad de Limburger: 'Maas is honderd jaar een splijtzwam'. Volgens de krant is het 'hommeles tussen Limburg en Den Haag' zodra de Maas ter sprake komt. 'Honderd jaar geleden was het niet anders.' De registers op de Handelingen geven aan dat tussen 1890 en 1910 vrijwel jaarlijks door afgevaardigden uit Limburg werd gesproken over wat gerubriceerd staat als 'Verbetering van de rivier de Maas in Limburg' en 'Toestand van de rivier de Maas in Limburg:459

Nolens haalde in december 1900 de woorden aan die acht jaar daarvoor waren gesproken door Tweede-Kamerlid Clercx (district Boxmeer). Deze laatste had zich toen beklaagd over de achterstelling van 'het arme Limburg'. Nolens had in dit opzicht overigens niet alle hoop verloren, want terwil] 
Limburg in vroeger jaren nog 'een terra incognita' was geweest voor ministers en kamerleden, werd de provincie in de loop der jaren meer en meer bezocht: 'Men ziet er nu en dan Kamerleden uit het Noorden, en zelfs eens een Minister. Welnu, Mijnheer de Voorzitter, aanzien doet gedenken.' 400 Toch had de aandacht die jaar in, jaar uit werd gevraagd voor de bevaarbaarheid van de Maas nog steeds niet het gewenste resultaat opgeleverd, zo hield Nolens de regering voor.

De Maaskwestie laat zien dat de Limburgse leden van de katholieke kamerclub de provinciale belangen zeker niet uit het oog verloren. De rentewet geeft aan dat zij er zelfs niet voor schroomden om binnen het (toen startende) katholieke samenwerkingsverband te opereren als een soort provinciale factie, wanneer er naar hun opvatting wezenlijke Limburgse belangen op het spel stonden. De politicoloog Van den Berg schrijft dat veel regionalisme zich wat Limburg betreft, heeft kunnen voortzetten onder de vlag van het politiek georganiseerde katholicisme. ${ }^{461}$ Overigens toont de opstelling van de Limburgse kamerleden bij onderwerpen zoals de sociale kwestie en het kiesrecht, dat zij zeker niet altijd als een (hechte) eenheid optraden.

Hoewel de eenheid in de katholieke gelederen soms ver te zoeken was, is wel duidelijk dat de Limburgse politici binnen het staatsbestel hoge posities konden innemen dankzij hun band met de politiek ( $m$ in of meer) verenigde katholieken. Indien de ministers worden gerangschikt naar geboorteprovincie, had Limburg in de periode 1888-1918 een relatief groot aandeel in de ministersploegen: het was de enige niet-westelijke provincie waarvan het percentage bewindslieden hoger was dan het bevolkingsaandeel. ${ }^{462}$ Toen de anti-revolutionaire voorman Abraham Kuyper in 1901 aan de slag ging met de formatie van een christelijk coalitiekabinet, waaraan dus ook de katholieken zouden deelnemen, had hij op zijn lijstje met kandidaat-ministers in ieder geval twee Limburgers staan. De Stuers, toen net gekozen als afgevaardigde voor het district Weert, wordt vermeld als mogelijk minister van Buitenlandse Zaken en voormalig Tweede-Kamerlid Gustave Ruijs van Beerenbroek als potentieel bewindsman op Binnenlandse Zaken. ${ }^{\text {th }}$

Bij de verkiezingen van juli 1918 behaalden de katholieken dertig van de honderd zetels en vormden daarmee de grootste fractie in de Tweede Kamer. Haar voorzitter, Nolens, trok tijdens de kabinetsformatie mee aan de touwtjes. Zo werd hij ook letterlijk afgebeeld in de Haagsche Post met als onderschrift: 'Dr. Nolens als de groote souffleur en marionettenspeler.'tet Op 29 augustus 1918 werd jhr. Charles Ruijs de Beerenbrouck ontboden op paleis Het Loo. Hij kreeg de opdracht een nieuw kabinet te formeren. Voor 
het eerst zou het ambt van 'minister-president' in Nederland toevallen aan een katholiek en aan een Limburger. Voor de eerste maal trad een premier aan met dit 'dubbel handicap', aldus Stassen in zijn boek over Ruijs. ${ }^{\text {ts }}$ Ook de koningin moest wennen aan het idee. Fasseur schrijft over Wilhelmina's ervaringen met Ruijs: 'Al was hij dan Limburger en katholiek, hij maakte een gunstige indruk.' ${ }^{460}$

Indien we de inbedding van de Limburgse politici in de Nederlandse politiek bezien, is, voor zover het de periode $1840-1918$ betreft, van een eenduidige en voortdurende progressie geen sprake. De relatie die zij in de jaren tot 1863 onderhielden met Thorbecke, een bij uitstek nationaal-politiek kopstuk van buiten de provincie, zou zich later nooit meer zo sterk voordoen. Dat de liberale voorman in Limburg - district Maastricht - werd gekozen (in 1853 en 1856), was uniek voor de acht decennia die in dit boek zijn onderzocht. De Limburgse afgevaardigden bonden zich tot begin jaren zestig zodanig aan Thorbecke en zijn liberalen dat zij in 1849 en in 1862 aan zijn kabinetten een personele bijdrage mochten leveren: eerst Strens, vervolgens Van der Maesen de Sombreff.

Bij de verkiezingen in 1864 openbaarde zich een provinciale beweging, de 'Limburgsche oppositie', die zich afkerig toonde van nationale allianties omdat dergelijke bindingen de belangen van Limburg in de weg zouden staan. De banden die Limburgse afgevaardigden onderhielden met Thorbecke en de liberalen, werden in de jaren die volgden, verbroken. Doot de provinciale invalshoek die deze oppositie koos en door het gegeven dat de politieke samenwerking tussen de Nederlandse katholieken pas na 1890 echt gestalte zou krijgen, waren de Limburgers in de landelijke politiek verder van het nationale machtscentrum verwijderd dan ten tijde van hun bondgenootschap met Thorbecke.

De ideologisering van de Nederlandse politiek waarbij de katholieken zichzelf steeds meer profileerden als parlementaire fractie, ging niet aan de Limburgse volksvertegenwoordigers voorbij. Via het katholieke samenwerkingsverband in het parlement kwamen zij weer dichter bij het politieke machtscentrum. In de periode waarin de katholieken als zodanig gingen deelnamen aan de kabinetsformaties, de jaren vanaf 1888 , namen Limburgers weer regelmatig zitting in kabinetten.

Ofschoon wel is opgemerkt dat het Limburgerschap bij de toebedeling van staatsambten als extra obstakel gold (naast het katholicisme), lijkt deze hindernis bij de verdeling van ministersposten van minder groot belang te zijn geweest. In dit kader schreef De Nedermaas nog in 1925: 
Er schijnt slechts één ambt in Nederland te zijn, waar onze menschen wel voor deugen. Adjunct-inspecteur der Belastingen gaat boven onze capaciteit; voor commies ter gemeente-secretarie blijken eveneens niet-Limburgers beter en betrouwbaarder te zijn. Maar Minister der Kroon, dát kunnen we worden. ${ }^{467}$

Vergeleken bij hun Noord-Brabantse geloofsgenoten 'scoorden' de Limburgers relatief goed. Zowel de eerste katholieke bewindsman op een departement van binnenlands bestuur (Strens in 1852) als de eerste katholieke minister-president (Ruijs de Beerenbrouck in 1918) was in Limburg geboren en getogen. En het aandeel dat deze provincie had in de bemanning van ministersploegen in de jaren 1888-1918, was duidelijk groter dan het part van Noord-Brabant.

Ook binnen het katholieke samenwerkingsverband in de Tweede Kamer namen Limburgers vooraanstaande posities in. Puur getalsmatig bezien hanteerden zij binnen de katholieke kamerclub relatief vaak de voorzittershamer. Hun prominente positie in de Nederlandse politiek was het meest evident in het najaar van 1918 toen voor het eerst twee van hen aan de top stonden van het staatsbestel: Nolens als voorzitter van de grootste fractie in de Tweede Kamer en Ruijs de Beerenbrouck als premier.

De loyaliteiten die Limburgse afgevaardigden hadden in de landelijke politiek - eerst jegens Thorbecke en zijn liberalen en later jegens de katholieke fractie - verhinderden niet dat zij in hun afweging de belangen van hun provincie zwaar lieten meewegen. Zij schroomden er vaak zelfs niet voor om duidelijk te maken dat de belangen van Limburg de doorslag gaven. 



\section{'In een geheel exceptionelen toestand'. Limburgse afgevaardigden en de belastingen}

In de vergadering van 29 december 1840 vroeg Tweede-Kamerlid Frans Corneli het woord. Hij was de eerste onder de Limburgse afgevaardigden die, sinds hun terugkeer in de Staten-Generaal twee maanden eerder, deelnam an de openbare beraadslagingen.' Aan de orde was het Wetsontwerp tot invoering der Rijksbelastingen in het hertogdom Limburg. Corneli begon voorzichtig:

Het was eerst mijn voornemen niet over het ontwerp van wet $[\ldots]$ het woord te voeren. Meer of min onbekend met den Financieelen toestand van Nederland, kan ik de noodzakelijkheid der in te voeren belastingen niet genoeg beoordeelen. ${ }^{2}$

Ondanks de onbekendheid met de situatie in zijn nieuwe vaderland vond hii dat hij toch iets moest zeggen:

Dan de zaak schijnt mij van te groot gewigt en in te nauw verband met alle belangen van het land, 't welk ik te vertegenwoordigen heb, om het stilzwijgen te bewaren. ${ }^{3}$

Voor de Limburgse volksvertegenwoordigers zouden de Nederlandse belastingen ook de volgende decennia een zaak van groot gewicht blijven: geen enkele andere kwestie op de Haagse parlementaire agenda werd tussen 1840 en 1918 door meer Limburgse kamerleden besproken en becommentarieerd. En als we daar de buitenparlementaire handelingen bij optellen, dan liet zelfs de meest zwijgzame onder de Limburgse afgevaardigden van zich horen: jhr. Louis de Villers de Pité, die tijdens zijn ruim dertig jaar lange kamerlidmaatschap nimmer het woord voerde bij plenaire beraadslagingen, schreef in juli 1843 - op dat moment nog lid van Provinciale Staten van Limburg - een ontwerp-verzoekschrift aan de koning over de onrechtvaardigheid van het Nederlandse belastingstelsel.

Bij een aantal Limburgse kamerleden werd de parlementaire carrière zelfs in hoge mate gekenmerkt door belastingonderwerpen. Pieter de Lom 
de Berg (Tweede-Kamerlid van 1848 tot 1868 ) wordt bijvoorbeeld, naar aanleiding van een pleidooi aan het einde van zijn parlementaire loopbaan, 'de oude belasting-opposant' genoemd. ' De Lom de Berg hield zich in zijn parlementaire redevoeringen dan ook sterk bezig met fiscale kwesties. ${ }^{5} \mathrm{Het}$ korte kamerlidmaatschap van Frederik baron de Keverberg de Kessel (n maart tot 19 oktober 1864) stond, zoals we zagen in het vorige hoofdstuk, vooral in het teken van de fiscale lasten. De baron voerde zijn verkiezingscampagne met de leus: 'Weg met het ontwerp, weg met de minister van financièn', waarmee hij zich keerde tegen het wetsontwerp tot verhoging van de grondbelasting in Limburg. ${ }^{6}$

Omdat zovele Limburgse politici in Den Haag zich met de belastingen bezighielden, zal aan de hand van dit onderwerp een beeld worden geschetst van de Limburgse bijdrage aan de Nederlandse politiek. Op een aantal punten zal deze bijdrage worden vergeleken met de parlementaire handelingen van kamerleden uit andere provincies. Vervolgens zal het doen en laten van de Limburgse leden van de Staten-Generaal worden gerelateerd aan de verlangens die in de provincie zelf leefden en die door met name het provinciaal bestuur werden geuit.

\section{Een fiscale status aparte}

Op fiscaal gebied had de terugkeer naar het Koninkrijk der Nederlanden in 1839 Limburg een weinig aanlokkelijk perspectief geboden. De hoge staatsschuld - nota bene voor een belangrijk deel opgebouwd na 1830 - zou ongetwijfeld hoge lasten met zich meebrengen en de hereniging was daarom 'niet zonder bangheid en zwaarmoedigheid te gemoet gezien', aldus TweedeKamerlid Michiels van Verduynen in 1840 . $^{7}$ De opgelegde staatsrechtelijke hereniging maakte de invoering van de Nederlandse belastingwetgeving in Limburg echter onvermijdelijk en onder de gegeven omstandigheden namen de drie Limburgse Tweede-Kamerleden - Corneli, Michiels van Verduynen en Kerens - een coöperatieve houding aan: zij steunden het wetsontwerp dat de invoering van de belastingen in Limburg regelde.

Hierbij was van belang dat de wet, tot tevredenheid van de Limburgse afgevaardigden, niet helemaal voorbijging aan de gevoelens die in de nieuwe provincie leefden. De koninklijke boodschap die het ontwerp vergezelde, gaf aan dat de regering bij het opstellen van de bepalingen rekening had gehouden met 'de plaatselijke gesteldheid van dat Gewest.' ${ }^{\text {Z }}$ o werd bij de accijnzen op het gemaal (granen), het geslacht (slachtvee) en de brandstoffen niet gekozen voor een rechtstreekse heffing, maar voor een indirecte inning 
via een admodiatiestelsel. De accijnzen werden niet op basis van de hoeveelheid van het belaste artikel opgelegd, maar door de gemeenten hoofdelijk omgeslagen; deze regeling gold overigens niet voor de steden Maastricht en Venlo. Op die manier werden de belastingen 'op eene verzachtende wijze' ingevoerd, stelden Corneli en na hem Michiels van Verduynen dankbaar vast."

De fiscale uitzondering die aldus voor Limburg werd gecreěerd, wekte bij een aantal Tweede-Kamerleden bedenkingen. Was hier geen sprake van een privilege, hetgeen toch uitdrukkelijk door de grondwet verboden werd? Dat de regeling geacht werd Limburg voordelen te bieden, mag blijken uit de wens van afgevaardigden uit Noord-Brabant en Gelderland om ook voor hun provincie een admodiatieregeling vast te stellen. ${ }^{10}$

\section{'Met meer verschooning behandeld'}

Naast een separate regeling bij de heffing van de accijnzen gold in Limburg bijzondere wetgeving inzake de grondbelasting, naast de personele belasting en het patentrecht een van de drie directe rijksbelastingen. Deze 'status aparte' dankte de provincie aan haar ontstaansgeschiedenis.

Ten gevolge van de Belgische opstand waren de werkzaamheden van het kadaster, op grond waarvan de belastbare opbrengsten werden geschat, in Limburg nooit voltooid. In oktober 1841 werd daarom, met steun van de Limburgse kamerleden, een voorlopige wettelijke regeling getroffen waardoor Limburg jaarlijks een bedrag van 248906,85 gulden - de zogeheten hoofdsom - zou gaan betalen aan grondbelasting. In vergelijking met de hoofdsommen van de andere provincies was dit een uitermate gunstig bedrag, zo bleek althans uit de kadastrale schattingen die in 1844 gereedkwamen. Op grond van deze schattingen werd namelijk becijferd dat de Limburgse grond- en huiseigenaren in vergelijking met de eigenaren elders tot de helft minder aan grondbelasting betaalden. Er wordt dan wel van uitgegaan dat het kadaster overal in Nederland dezelfde maatstaven hanteerde bij de schattingen, maar hier lag juist een belangrijk punt van kritiek.

De bijzondere behandeling van Limburg bleef, mede als gevolg van deze kadastrale cijfers, niet onopgemerkt. Meermaals werd in het parlement aangedrongen op een fiscale gelijkstelling van Limburg. Toch zou het tot 1869 duren voordat de provincie op het gebied van de grondbelasting volledig was geintegreerd in het Nederlandse fiscale stelsel. Na veel commotie en rumoer kwam er dat jaar een eind aan de status aparte. Bijna dertig jaar lang had de provincie een exceptioneel - en volgens velen uiterst profijtelijk - fiscaal regime gekend. 
Bij de pogingen die tussen 1840 en 1869 werden ondernomen om de separate regeling op het terrein van de grondbelasting te wijzigen en ongedaan te maken, waren de belangen van de Limburgse grondbezitters duidelijk: de bestaande situatie diende zo lang mogelijk te worden gehandhaafd. Zij hadden immers baat bij de vigerende wetgeving en ze beklaagden zich daarover dan ook niet."

Wat was de houding van de Limburgse kamerleden? Spoedig nadat de afscheidingsbeweging in Limburg aan kracht had ingeboet, zagen zij de kwestie van de grondbelasting prominent op de parlementaire agenda verschijnen. In 1850 diende de regering een wetsontwerp in 'betreffende de heffing der grondbelasting in het Hertogdom Limburg'. Omdat het kadaster zijn werkzaamheden al zes jaar daarvoor voltooid had, is het opmerkelijk dat de uitzonderingspositie voor Limburg in het wetsvoorstel niet werd beèindigd; het ontbreken van de kadastrale schattingen was immers de formele grond voor de bestaande situatie. De hoofdsom bleef dus voor Limburg gehandhaafd. Minister P.P. van Bosse erkende overigens wel dat Limburg 'van de vereeniging met ons land af tot op dit oogenblii toe, met het oog op de bijzondere omstandigheid zijner aardrijkskundige ligging, altijd met meer verschooning behandeld is dan andere provincien.". Ofschoon dit zeker niet onbepaald zou kunnen blijven voortduren, meende de bewindsman dat er nog wel enige tijd zou verlopen alvorens aan deze exceptionele toestand een eind zou komen. Voorlopig ging hij daarmee voorbij aan de wet uit 1841 die met betrekking tot de hoogte van de hoofdsom een nadere wettelijke bepaling verlangde. ${ }^{13}$ Een gunstig ontwerp dus voor het hertogdom.

De Limburgse Tweede-Kamerleden waren dan ook tevreden en spraken niet bij de behandeling van het voorstel. Dat hoefde ook niet, want het leek er aanvankelijk op dat het ontwerp soepel door het parlement zou rollen: de algemene beraadslagingen in de Tweede Kamer waren zeer kort - zij beslaan in de Handelingen nog geen halve pagina - en het voorstel werd met algemene stemmen aangenomen. ${ }^{14}$

Hoe anders verliep het in de Eerste Kamer! Hier was de tegenstand tegen een voortzetting van de Limburgse uitzonderingspositie groot: Limburg was een deel van Nederland en moest naast de lusten ook de lasten daarvan dragen, vonden vele leden. Van een privilege op belastinggebied kon dan ook niet langer sprake zijn. In een lange toespraak wees Louis Beerenbroek zijn mede-afgevaardigden op de ongunstige staatsrechtelijke en geografische toestand van zijn gewest, die een uitzondering op belastinggebied volgens hem alleszins rechtvaardigde. De band met Nederland was nog jong en 
fragiel, de Belgische periode lag de Limburgers nog vers in het geheugen en het zou onstaatkundig zijn de bevolking door opdrijving van belastingen enen blik te doen werpen op den gunstigen toestand hunner vroeger landgenoten'. ${ }^{5}$

Door te herinneren aan de voorbije en voor Limburg bijzonder roerige jaren trachtte Beerenbroek zijn collega's te overtuigen van de noodzaak de provincie met de nodige voorzichtigheid te behandelen. Daarbij zou een verhoging van de grondbelasting vanzelfsprekend niet te pas komen. Het lange betoog baatte niet: met 24 tegen 6 stemmen werd het wetsvoorstel verworpen. Beerenbroek en De Villers de Pité - Petrus Regout was afwezig - behoorden tot de kleine schare voorstanders. Door de verwerping van het wetsontwerp werd de bestaande en voor Limburg als gunstig ervaren fiscale situatie weliswaar voortgezet, de vraag was echter wanneer de kwestie opnieuw aan de orde zou komen en vooral of het nieuwe voorstel voor Limburg even gunstig zou zijn als het nu verworpene.

Het antwoord kwam in september 1858. Als onderdeel van een plan tot anpassing van het belastingstelsel diende de regering een nieuw voorstel tot wijziging van de grondbelasting in. Alleen de titel al beloofde weinig goeds voor de Limburgers: wetsontwerp tot evenredigmaking der grondbelasting. Het percentage van de (geschatte) opbrengst werd met ingang van 1859 in alle provincies op een gelijk niveau gesteld: $12,86 \%$. Op dat moment verschilde dat percentage nog per provincie en schommelde tussen de 11 en 13. Limburg schoot daar volgens de berekeningen als enige ver onder met $6,7 \%$.

Vooral het hertogdom zou door een gelijkstelling dus meer moeten gaan bijdragen, hetgeen veel Tweede-Kamerleden 'allezins redelijk' vonden. ${ }^{16}$ Ofschoon voor hun provincie in het wetsvoorstel was voorzien in een overgangstermijn van drie jaar, gold dit niet voor de Limburgers onder hen. Zij kwamen in actie tijdens de besprekingen in de afdelingen. De cijfers klopten niet, betoogden zij: de werkzaamheden van het kadaster, waarmee in Limburg pas later had kunnen worden begonnen, waren toen 'met overdreven spoed en uiterst onregelmatig' uitgevoerd. ${ }^{17}$ Nadat het ontwerp in de afdelingen was besproken, werd het door de regering ingetrokken met als motivering dat de internationale toestand geen ruimte liet voor een omvangrijke wijziging van het belastingstelsel.

In de jaren vijftig en zestig werd vanuit de volksvertegenwoordiging verschillende malen aangedrongen op een geliike behandeling van Limburg, tot grote ergernis van Tweede-Kamerlid Edmond van Wintershoven. Hij merkte al in 1856 op: 'Er mag misschien eenig zeer gering verschil ten 
voordeele van Limburg bestaan, maar dit is zeker, dat dat verschil dan toch zoo aanzienlijk niet is, om daarop telkens hier en in de andere Kamer der Staten-Generaal terug te komen. ${ }^{18}$ Veel gehoor vond hij niet: twee weken later kondigde het Friese Eerste-Kamerlid jhr. T.A.M.A. van Andringa de Kempenaer aan dat hij het vraagstuk van de grondbelasting in Limburg 'steeds zal trachten levendig te houden.' ${ }^{19}$ De provincie verdween als het ging om de grondbelasting nimmer uit de schijnwerper.

Het in beeld houden van de kwestie had succes, want tot vreugde van velen kondigde minister G.H. Betz van Financiën in september 1862 aan een wetsontwerp betreffende de grondbelasting in Limburg gereed te hebben en weldra aan de Kamer te zullen aanbieden. Het ontwerp volgde enkele maanden daarna. De memorie van antwoord liet aan duidelijkheid niets te wensen over: de bestaande en voor Limburg gunstige situatie mocht niet langer voortduren. De regering achtte de tijd gekomen om de zaak met een overgangstermijn van drie jaar te normaliseren: de hoofdsom werd met ruim 100 ooo gulden verhoogd en net zoals elders gesplitst in een deel voor gebouwde en een deel voor ongebouwde eigendommen; mutaties in de hoeveelheid belastbare grond zouden voortaan - eveneens net als elders worden verrekend. Van afwijkingen in de kadastrale schattingen in vergelii. king met de andere landsdelen - altijd een van de belangrijkste Limburgse argumenten tegen wijziging van de bestaande situatie - wilde de minister niet weten. ${ }^{20}$ Aan de Limburgse status aparte inzake de grondbelasting zou, als het aan de regering lag, nu spoedig een einde komen.

De Kamer liet het wetsontwerp vervolgens lange tijd onafgehandeld liggen, wellicht mede onder de indruk van de grote opschudding die erover in Limburg was ontstaan. ${ }^{21}$ Omdat onafgedane wetsontwerpen aan het eind van een parlementair jaar automatisch kwamen te vervallen, stuurde minister Betz hetzelfde ontwerp in september 1863 opnieuw naar de Kamer. Nu werd de behandeling ervan wel ter hand genomen. De drie Limburgse leden die bij de voorbereidende werkzaamheden (in de afdelingen) aanwerif waren - Van Wintershoven was afwezig - maakten hun bezwaren duidelijk kenbaar. 'Wij hebben dus,' zei Charles Antoine baron de Bieberstein, 'onzen eersten pligt vervuld'.22 Hij sprak van hun eerste plicht omdat het wetsvoorstel zich toen nog in het voortraject bevond; de openbare beraadslagingen moesten nog volgen. Een 'grote meerderheid' had overigens al laten weten zich te kunnen vinden in het ministeriële voorstel. ${ }^{23}$ De politieke verwik. kelingen die rondom de indiening en behandeling van het wetsvoorstel plaatsvonden - inclusief de verkiezing van De Keverberg de Kessel - zijp reeds in het vorige hoofdstuk behandeld en blijven hier buiten beschouwing. 
Terwijl de Tweede Kamer in afwachting was van de memorie van antwoord, behandelde zij de begroting van het ministerie van Financiën. De minister die aan het hoofd stond van dit departement, was verantwoordelijk voor het indienen van het wetsontwerp tot verhoging van de grondbelasting in Limburg. De drie Limburgse Tweede-Kamerleden die aan de begrotingsbehandeling deelnamen, gaven zonder uitzondering uiting aan hun weinig warme gevoelens jegens minister Betz. De Lom de Berg sprak van een gebrek aan vertrouwen in de minister van Financiën en Karel Cornelis gaf an dat een stem voor de begroting van Financiën moed vereiste voor een afgevaardigde uit Limburg. ${ }^{24}$

Betz moest aftreden ten gevolge van de Limburgse brievenkwestie (zie hoofdstuk 4). Er werd echter vooralsnog geen nieuwe bewindsman op Financièn benoemd; er kwam een minister ad interim: N. Olivier, de zittende minister van Justitie. De Lom de Berg en ook H.C.F. Kerstens trachtten de kwestie op de lange baan te schuiven door te betogen dat de rak niet door een interimaire minister mocht worden afgehandeld. Ook Olivier zelf gaf aan de behandeling van het voorstel te willen overlaten aan de toekomstige minister van Financiën.

Daar kwam nog bij dat het aantal kamerleden uit Limburg op dat moment beperkt was, omdat de twee Maastrichtse afgevaardigden ontbraken: ithr. Paul van der Maesen de Sombreff had een week daarvoor ontslag genomen vanwege de Limburgse brievenkwestie en De Bieberstein was al weken afwerig wegens ziekte. De Lom de Berg, die wel aanwerig was, voerde ook dit aan als bezwaar tegen de verdere behandeling van het wetsontwerp: daar de Limburgse afgevaardigden in de Kamer niet voltallig waren - 'zij zijn op de helft gereduceerd' -, dienden de parlementaire werkzaamheden inzake de verhoging van de grondbelasting in Limburg gestaakt te worden. ${ }^{25} \mathrm{Hij}$ deed daarom een voorstel tot 'onbepaalde verdaging, na het winterreces'.26 De poging van De Lom de Berg, gesteund door Cornelis en Kerstens, om de kwestie in de ijskast te plaatsen faalde. Een kamermeerderheid wilde overgaan tot behandeling van het wetsontwerp en een week later was het zover.

De angst van De Lom de Berg dat de verdediging van de provinciale belangen nu gevoerd moest gaan worden door een onvoltallige Limburgse vertegenwoordiging in de Kamer, bleek ongegrond: alle kamerleden uit Limburg waren op 15 december 1865 aanwezig. De Bieberstein had zich, na ên maand afwezigheid, één dag voor het finale kamerdebat weer gemeld in Den Haag en ook Van der Maesen de Sombreff was na zijn herverkiezing nog net op tijd present: onmiddellijk nadat hij in de kamerbanken had 
plaatsgenomen, werden de algemene beraadslagingen over het wetsontwerp geopend. Het debat zou twee dagen duren.

Alle Limburgse kamerleden voerden het woord, op beide dagen. Ook Kerstens liet zich niet onbetuigd; hij was immers, zo had hij eerder al laten weten, afgevaardigd door 'een district, gedeeltelijk uit Limburg bestaande'; het kiesdistrict Boxmeer. ${ }^{27}$ Het aandeel van de parlementariërs uit Limburg aan het debat was groot: eenentwintig maal nam een kamerlid het woord, veertien keer betrof het een afgevaardigde uit een van de drie Limburgse kiesdistricten. De Lom de Berg en Kerstens spraken tweemaal, De Bieberstein en Van der Maesen de Sombreff driemaal en Cornelis kwam zelfs vier keer aan het woord. Fel pleitten zij tegen het wetsontwerp. Van de divers argumenten die zij daarbij gebruikten, was de door allen genoemde on. gelijkheid in de door het kadaster vastgestelde belastbare opbrengsten het voornaamste. $2 \%$ Alvorens de grondbelasting in Limburg kon worden vastgesteld, moest daarom eerst een landelijke herziening van de kadastralt schattingen plaatsvinden.

Toen De Lom de Berg zei erop te vertrouwen dat de Kamer haar goed keuring zou onthouden aan het voorstel dat 'voor Limburg eene calamiteit zou zijn', was dit duidelijk tegen beter weten in. ${ }^{29} \mathrm{Bij}$ de behandeling ervan in de afdelingen was immers al komen vast te staan dat een grote meerderheid voor zou stemmen. Dat gebeurde ook: het voorstel werd op 16 december in de Tweede Kamer met 54 tegen 18 stemmen aangenomen.

Op de Eerste Kamer hoefde ook al niet veel hoop gevestigd te worden. In het verslag van de commissie van rapporteurs was daar al gemeld dat het wetsontwerp 'door verreweg de meeste leden der Kamer aannemelijk [wordt] geoordeeld'. ${ }^{30} \mathrm{Nog}$ voordat de wet zelf werd behandeld, gaven de drie Limburgse Eerste-Kamerleden uiting aan hun grote ongenoegen; zii benutten hiervoor de begrotingsbehandeling. De Nederlandsche spectator publiceerde naar aanleiding daarvan een prent waarop Beerenbroek, De Villers de Pité en Michiels van Kessenich zich bij het 'serveren' van de begroting demonstratief hebben afgewend van hun collega-kamerleden. 'Geen enkele schotel bekoort de drie Limburgsche heeren' luidt het onderschrift. Geheel juist is deze tekst niet, want er was wel degelijk een aantal begrotingshoofdstukken dat op de stem van de Limburgers kon rekenen." Maar kennelijk deed dat niets af aan het beeld dat van de Limburgse EersteKamerleden bij de begrotingsbehandeling was ontstaan: een groep die zich duidelijk onderscheidde en afzonderde van de rest van de Kamer.

Bij de beraadslaging over de wet zelf bleek wederom dat de Eerste Kamer in overgrote meerderheid van mening was dat er eindelijk matt 
eens een eind moest komen aan de uitzonderingspositie voor Limburg. Nast Beerenbroek, die een lang betoog hield en Michiels van Kessenich die tweemaal het woord voerde, waren er slechts twee niet-Limburgse kamerleden die over het voorstel spraken. En ondanks alle argumenten die door de beide Limburgers werden aangevoerd, stemden 28 van de 33 anwerige afgevaardigden in met het ontwerp. Naast de drie Limburgers stemde ook J.B.J. Hengst, oud-afgevaardigde uit het district Boxmeer en nu Eerste-Kamerlid uit de provincie Noord-Brabant, tegen. Het lijkt erop dat de Limburgers het parlementaire werk vervolgens demonstratief voor gezien hielden: De Villers de Pité verliet de vergadering al na de stemming, Michiels van Kessenich verscheen niet meer bij de avondzitting en de volgende dag ontbraken alle drie de Limburgse leden.

De onvrede klonk nog door in de Tweede Kamer toen daar enkele maanden later de definitieve begroting aan de orde kwam. Uit protest tegen de verhoging van de grondbelasting stemden de vier Limburgse leden tegen de begroting van het departement van Financiën. De wet waartegen deze protestactie was gericht, was toen inmiddels al van kracht geworden.

En daarmee werd Limburg op 1 januari 1869 - na afloop van een overgangstermijn van drie jaar - geintegreerd in de Nederlandse wetgeving inzake de grondbelasting. Tot dan toe had de bijzondere fiscale status geregeld een stempel gedrukt op de parlementaire handelingen van de Limburgers in Den Haag. Zonder uitzondering was hun streven erop gericht geweest de vigerende regeling te behouden. Dit streven moet ook voor tijdgenoten buiten het parlement duidelijk waarneembaar zijn geweest, met name in de jaren zestig toen de zaak ten gevolge van de brievenkwestie in Nederland met grote interesse werd gevolgd.

Het talrijk publiek, dat in den regel zich niet veel met staatszaken bemoeit en de bereddering van deze maar het liefst aan 'de heeren' overlaat, schijnt dezer dagen eene uitzondering op dien regel gemaakt te hebben.

Dit schreef De Tijd op 30 december 1865 . Vele ogen - 'duizenden en duizenden' - waren volgens het blad gericht op de vergaderzalen van Provinciale Staten in Maastricht en van de Tweede Kamer in Den Haag. Ook in de landelijke pers veroorzaakte de kwestie een ware pennenstrijd. ${ }^{32}$ 


\section{Provinciaal antagonisme}

Dat de Limburgse kamerleden zich op het terrein van de grondbelasting uitdrukkelijk rekenschap gaven van de financiële belangen van hun provincie, lijkt echter niet uitzonderlijk. Bij de behandeling van het eerder gememoreerde wetsontwerp tot evenredigmaking der grondbelasting (1858) was in de Tweede Kamer namelijk de vrees geuit dat de discussie zou leiden tot het 'herleven van een provinciaal antagonisme'. Veel kamerleden zeiden het te betreuren dat 'eene oude, nagenoeg vergeten zaak weder [wordt] opgedelf, die jaren lang een struikelblok tusschen de onderscheidene provincies is geweest en in der tijd maar al te veel bitterheid heeft doen ontstaan."3

De cijfers die het voorstel vergezelden, lieten immers grote verschillen zien in het bedrag dat door de diverse provincies werd betaald aan grondbelasting en ook buiten Limburg heerste er onvrede over het werk van het kadaster. Dat niet alleen de Limburgers zich bezighielden met de provinciale belastingbelangen, laat dit wetsontwerp meer in het bijzonder zien aan de hand van de kamerleden uit Friesland. Alleen deze provincie zou er volgens de berekeningen bij het voorstel financieel op vooruitgaan. Het waren dan ook juist Friese afgevaardigden in zowel Tweede als Eerste Kamer die de grondbelasting al bij de eerstvolgende middelenwet, die voor 1860, aan de orde stelden. Zij rekenden hun collega's precies voor hoeveel Friesland te veel betaalde. ${ }^{34}$ Eerste-Kamerlid jhr. T.A.M.A. van Andringa de Kempenaer klaagde een jaar later, bij de middelenwet voor 1861, wederom dat Friesland te veel moest bijdragen aan de grondbelasting. ${ }^{35}$

Hoewel de Limburgse afgevaardigden kennelijk niet de enigen waren die bij de grondbelasting de belangen van hun provincie in het oog behielden, was Limburg door de separate wetgeving wel de provincie die de vermeende ongelijkheid het duidelijkst voor het voetlicht wierp. Bijna drie decennia lang bestond er een bij wet gecreëerde belangentegenstelling tussen Limburg en de rest van Nederland en deze tegenstelling bevorderde bij discussies over de grondbelasting een afzonderlijke positie van de Limburgse afgevaardigden in de Staten-Generaal. Zij waren immers veelal de enigen die in woord en daad op de bres stonden voor handhaving van de bestaande wetgeving. En dat sprong in het oog, wist ook Eerste-Kamerlid Beerenbroek bij de behandeling van het voorstel van minister Betz tot verhoging van de grondbelasting in Limburg:

Het is eene onaangename taak een voorstel van wet te bestrijden, waarbij bepaald éne provincie is betrokken [...]. Daarbij komt dat 
hij, die optreedt als bestrijder, zoo ligt den schijn aanneemt door een interêt de clocher [kleingeestig belang] te zijn gedreven. ${ }^{36}$

De Limburgse kamerleden moesten mede daardoor, aldus De Lom de Berg, als 'beklaagden' in de vergaderzaal verschijnen. ${ }^{37}$

De Limburgers vormden met hun optreden een eenheid en indien niet alle Limburgse afgevaardigden in de Kamer aanwezig konden zijn, werd dit dan ook aangedragen als een reden voor uitstel. De felheid van de redevoeringen door Limburgse kamerleden over aanpassing van de wetgeving inzake de grondbelasting, met name in de jaren zestig, zal het beeld van eendrachtig verzet van Limburgse zijde in de beide Kamers alleen maar hebben versterkt. De prent uit De Nederlandsche spectator vormt hiervan een fraaie illustratie (zie blz. 369).

Tot slot lijkt ook hun argumentatie te hebben bijgedragen aan een zekere exclusiviteit. Vaak benadrukten de Limburgse parlementariërs de bijzonder ongunstige situatie waarin juist hun provincie zich bevond. En, zo leidden zij vervolgens af: een exceptioneel gewest kon aanspraak maken op een exceptionele regeling. Want, zo vroeg het Tweede-Kamerlid J.J.A. van Wylick (district Roermond) al in 1851 aan zijn collega's, 'wie van u zoude den toestand zijner provincie tegen dien van dat zoo gewaand gelukkige en gepriviligeerde Limburg willen verruilen?'s

Of het hertogdom zich daadwerkelijk in een exceptioneel nadelige situatie bevond, is een andere kwestie. Indien we deze vraag relateren aan de parlementaire activiteiten van de Limburgers in Den Haag, kunnen we ons afvragen of hun handelen getuigde van 'bekrompen provincialisme', of dat ze recht van spreken hadden. ${ }^{39}$ Hoewel het er hier niet om gaat een oordeel te vellen over de rechtmatigheid van hun activiteiten, kan worden gewezen op de vaststelling van Nick Bos dat de klachten over de te hoge schattingen van het kadaster niet zo ongegrond waren als wel wordt gedacht. De vanaf 1865 in Limburg geheven grondbelasting was, voor zover het de belasting op landerijen betrof, zelfs 'onbillijk hoog'. ${ }^{* 0}$ Enkele jaren na de doorgevoerde verhoging van de grondbelasting bleek dat de belastbare opbrengsten in Limburg zowel wat betreft de gebouwde als wat betreft de ongebouwde eigendommen relatief te hoog waren geschat. $\mathrm{Bij}$ de herzieningen in 1870 en 1879 stegen de belastbare opbrengsten van beide soorten eigendommen namelijk minder dan in de rest van Nederland." 


\section{'Effecten koopen kan hij niet'}

In juli 1843 gaf de Limburgse jonkheer de Villers de Pité, toen nog geet kamerlid, in de Provinciale Staten aan waarom het Nederlandse belasting stelsel juist voor zijn provincie nadelig was:

Une très grande partie de la richesse nationale de la Hollande consiste en capitaux placés en affaires de finance et de haut commerce. Ces capitaux échappent aux impôts directs; chez nous, au contraire, tous les capitaux consistent en biens fonds, en industrie agricole et manufacturière, et sont atteints par l'impôt foncier, par les droits de succession, le timbre, l'enrégistrement et les patentes. ${ }^{42}$

Tot begin jaren negentig zou het inkomen uit roerend vermogen, he zogeheten kapitaal in portefeuille, in een geprivilegieerde positie blijver: effectenbezitters konden 'in rustige rust hunne coupons knippen', omdet voornameliik onroerend goed werd belast. ${ }^{43}$ De belastingvriistelling van het kapitaal vormde het zwakste punt van het toenmalige fiscale stelsel. ${ }^{4} \mathrm{Zij}$ was wel verklaarbaar: de overheid was deels afhankelijk van de bezitters van Nederlandse staatspapieren en daarmee van het grootste deel van de effectenbezitters. Bovendien was dit vermogensbezit zeer mobiel en dus niet gebonden aan Nederland. In het zicht van de twintigste eeuw zou et een eind komen aan deze onevenwichtigheid. De weerstand ertegen was in de loop van de negentiende eeuw gegroeid en bovendien was de overheid, dankzij de gezondmaking van de openbare financiên, minder afhankelijk geworden van de effectenbezitters.

In Limburg heerste grote onvrede over de belastingvrijdom van het kapitaal in portefeuille. Die gevoelens hielden verband met de financièle structuren van het gewest: in geen enkele andere provincie werd zoveel in grond en zo weinig in effecten belegd. ${ }^{45}$ Over de reden waarom 'de Limburger' over het algemeen de beurs meed, zei Eerste-Kamerlid Beerenbrock in 1849: 'effecten koopen kan hij niet, daarmede is hij niet bekend [...]." Bovendien, zo voegde hij toe, zijn de beschikbare gelden te gering.

Nu werd deze ongelijkheid enigszins gecompenseerd doordat de Limburgers het niet zo nauw namen met het betalen van de verschuldigde belasting. Bij de parlementaire beraadslagingen over de invoering van de Nederlandse belastingen in Limburg had Tweede-Kamerlid Michiels van Verduynen al voorspeld dat het aantal ontduikers in zijn provincie groot zou zijn. ${ }^{67}$ Belas. tingontduiking zou in Limburg inderdaad een geliefde bezigheid worden." 
Sommige Limburgse kamerleden vormden hierop geen uitzondering. Zo werd Pieter de Lom de Berg midden jaren vijftig vervolgd wegens het doen van een onjuiste aangifte. Bij inspectie van zijn huis in Venlo was gebleken dat er meer haarden (stookplaatsen) aanwezig waren dan het kamerlid had opgegeven; de haarden vormden één van de grondslagen van de personele belasting. Toen De Lom de Berg zich tien jaar later in de Kamer weer eens beklaagde over de belastingwetgeving, schroomde minister Betz van Financiēn niet om hem in alle openbaarheid aan deze affaire te herinneren. Dit tot grote verontwaardiging van De Lom de Berg die nu meende zich uitgebreid te moeten verdedigen. ${ }^{9}$ Een ander voorbeeld treffen we aan in het boek van belastinginspecteur J. Kuyper. Een in Zuid-Limburg woonachtig, niet bij name genoemd, kamerlid gaf een wel zeer lage huurwaarde op voor zijn grote en 'heerlijk gelegen' huis. Kuyper besloot de afgevaardigde hoger aan te slaan, ondanks 'een flesch keurige Hermitage' die hem werd aangeboden. so $^{\circ}$

De neiging belastingen te ontduiken wordt wel gerelateerd aan de verbondenheid met het staatsverband dat ze int. Zo verbindt Weber in zijn boek Peasants into Frenchmen de moeite die het de Franse overheid in bepaalde departementen kostte om belastingen te innen, met een gebrek aan patriottisme. $^{31}$

Nu lijkt het gezien de vele kritiek van niet-Limburgse kamerleden op het belastingstelsel overigens onwaarschijnlijk dat elders in Nederland altijd met genoegen aan de fiscale verplichtingen werd voldaan. Bij een belastingdebat in 1881 zei Tweede-Kamerlid H.A.A. des Amorie van der Hoeven (district Breda):

Laat ons toch geen kinderen zijn, Mijnheer de Voorzitter! De meeste menschen zijn niet buitengewoon slecht, maar ook niet buitengewoon goed [...] de verhouding van de volkomen juiste aangiften tot die, waarbij op de eene of andere wijze is getransigeerd, stel ik, ze ruim nemende, op drie ten honderd $[. ..] .^{52}$

Belastingontduiking was dan ook zeker geen puur Limburgse aangelegenheid. De mate echter waarin de bewoners van deze provincie in de negentiende eeuw trachtten te ontkomen aan de hun opgelegde belastingplicht, verbaasde zelfs de meest ervaren belastinginspecteurs..$^{33}$ 


\section{In het parlement}

Het bewerkstelligen van een meer evenwichtige belastingdruk vormde en slepende kwestie in de negentiende-eeuwse politiek. Tot zeven keer toe wed gepoogd het kapitaal in portefeuille te belasten. Een aantal malen haaldeit desbetreffende wetsontwerp de openbare beraadslagingen in de Kameri).

Gedurende de jaren veertig pleitten kamerleden uit Limburg bij divese gelegenheden voor een gelijke verdeling van de fiscale lasten over roereide en onroerende goederen. Daarom kon De Lom de Berg in februari 152, toen de regering een voorstel tot heffing van een rentebelasting indietse, dan ook opmerken: 'Ik zal wel niet behoeven zeggen dat ik voor de wetzal stemmen.' Ook de twee andere Limburgers die bij de behandeling aanwrig waren, De Limpens en Van Wylick, stemden voor het wetsvoorstel.De Lom de Berg legde nog eens uit waarom de wet steun verdiende: 'Nen, Mijne Heeren, de renteniers zijn reeds al te lang verschoond gebleven an de regtmatige bijdrage welke zij aan den Staat verschuldigd zijn, he is snhilljik die.langer p $^{\prime}$ de schnuders van anderen te laten rusten.'4 Bedeld waren natuurlijk vooral de Limburgse schouders. Van Wylick sloot zich bij hem aan en benadrukte dat een meer evenwichtige spreiding van de belastingdruk hoogst noodzakelijk was.

Bij de kwestie van de verhoging van de grondbelasting in Limburg, die in de jaren zestig speelde, benadrukten de Limburgse kamerleden eveneens de uitzonderlijke verhouding tussen grond- en effectenbezit die hun provinoi parten speelde. Zo zei De Bieberstein: 'Limburg betaalt van al wat het beit. het kan niets aan het oog van de fiscus ontrukken, want de Limburgeche fortuinen bestaan in land en hypotheken; men bezit er geen Staatspapieten en andere bronnen van inkomsten, die onbelast zijn en de groote fortuinen van andere gewesten van het Rijk uitmaken.'55

Een aantal jaren later leek het er even op dat de Limburgse Tweed. Kamerleden de ingezette lijn niet doorzetten: zij stemden in mei 1872 tege het voorstel van minister P. Blussé van Oud-Alblas. Dit voorstel behelsde de heffing van een inkomstenbelasting waardoor ook het roerend goed belas zou gaan worden. Een belangrijke verklaring voor dit paradoxale stemgr drag - een verklaring die overigens is terug te vinden in de pleidooien vat vier Limburgse kamerleden - is dat de wet naast roerende goederen ook nef de onroerende belastte. ${ }^{56}$ Het grondbezit, al onderworpen aan de groo belasting, zou op die manier dubbel worden getroffen: 'de schreeuwent ste onrechtvaardigheid' uit de wet, aldus De Bieberstein, ${ }^{57}$ en daar wilde de Limburgers niet aan meewerken. Het komt daarom in eerste instants 
vreemd voor dat de afgevaardigden uit Limburg tegen het amendement van A. van Delden (district Deventer) stemden. In dit wijzigingsvoorstel werd het grondbezit immers vrijgesteld van de inkomstenbelasting. $\mathrm{Zij}$ zullen zich echter in het geheel niet hebben kunnen verenigen met het motief dat an het amendement ten grondslag lag. Van Delden zei daarover: 'Ik heb geen oogenblik bedoeld [...] de eigenaars van onroerende goederen eene dienst te bewijzen of hen in eene voordeeliger positie te brengen. Integendeel, mijne bedoeling is juist om de eigenaars van onroerend goed later, bij cene speciale regeling, wat meer in de Staatslasten te laten bijdragen.'ss

Het verzet tegen de wet was groot en het aandeel van de afgevaardigden uit Maastricht, Roermond en Boxmeer viel daarin niet op, totdat de Rotterdamse afgevaardigde W.A. Viruly Verbrugge aan het woord kwam. Deze beweerde namelijk dat Limburg, maar ook Gelderland, onder de bestaande belastingwetgeving juist met voorrecht werd behandeld. De afgevaardigden uit de Gelderse districten lieten deze stelling onbesproken. De Bieberstein voelde zich wel uitgedaagd door deze woorden. Er werd altijd gesproken van en gelijke verdeling van de lasten, nimmer van de lusten, aldus de baron, 'en welke zijn de provincien die het meest uit den Staats-hooiberg plukken'? Voor De Bieberstein was het antwoord helder: terwijl 'in de Hollandsche provincien' flinke bedragen werden besteed aan de aanleg van 'groote Rijkswaterwerken', was duizend gulden al te veel als men in Limburg een weg wilde herstellen. ${ }^{59}$ Zoals gezegd, werd het wetsontwerp slecht ontvangen in de Kamer. Het eerste artikel werd dan ook met een ruime meerderheid - 51 tegen 27 - weggestemd en de minister zag zich genoodzaakt het voorstel in te trekken.

Bijna tien jaar later, op 1 maart 1880 , diende minister Vissering van Financięn een wetsontwerp in 'tot heffing eener rentebelasting'. De hierin voorgestelde belasting drukte uitsluitend op roerend goed en dus niet op het grondbezit: de Limburgse wensen leken te worden verhoord.

Parlementair historicus Van Welderen Rengers beschrijft de beraadslagingen over het wetsvoorstel als 'eene verwarrende en afmattende discussie van dertien dagen'. ${ }^{\circ}$ Er was fel verzet van conservatieven, katholieken, anti-revolutionairen en een deel van de liberalen. De Limburgers stonden daarbij, zoals we reeds zagen in hoofdstuk 4 , lijnrecht tegenover de overige katholieke afgevaardigden.

Een van de bezwaren uit confessionele hoek was dat in het wetsontwerp werd bepaald dat de belastingaangifte eventueel door een eed zou moeten worden bevestigd. Gelovige belastingplichtigen werden zo gedwongen te betalen terwijl zij die niet geloofden zich waarschijnlijk weinig van de 
eed zouden aantrekken, vreesde De Maasbode. ${ }^{61}$ Dit punt werd ook dopr de Limburgse kamerleden onderkend en vijf van hen, Leopold Haffmars, Jan Hendrik Arnoldts, Gustave Ruijs van Beerenbroek, Jerome Lambrechts en Victor Nijst dienden gezamenlijk een amendement in dat beoogde de eed te vervangen door een 'verklaring op eer en geweten'. ${ }^{62}$ Dit wijzigings. voorstel werd ook wel aangeduid als 'Het Limburgsche Amendement' of 'amendement van de Limburgers.' ${ }^{33}$ Het bracht hen echter niet nader tot hun geloofsgenoten in de Kamer: 'de Limburgsche leden hebben zich afg;' scheiden', constateerde De Tijd. ${ }^{\text {4 }}$

Met name Lambrechts, Arnoldts en Hubert Brouwers uitten in de Kam 4 nog meer bezwaren. Het principe van de wet - het belasten van het kapital in portefeuille - was alle Limburgse volksvertegenwoordigers echter uit hat hart gegrepen. Dit laatste gold zeer zeker ook voor het enige Limburge kamerlid dat niet het woord voerde bij de beraadslagingen, Leopold Haffmans. Deze maakte zijn mening kenbaar in het Venloosch Weekblad waarvan hij redacteur was.

Rij de stemming over artikel 1, waarin do inkomoten werden opgcsomd waarover belasting verschuldigd zou zijn, bleken de Limburgse kamerleden de enigen ter rechterzijde te zijn die de bepaling steunden. En dat viel op, schreef Le courrier de la Meuse onder het kopje 'Le vote de l'article 1': "le vote émis par les députés du Limbourg en faveur du principe de la loi, a produit partout une pénible impression. ${ }^{65}$ Haffmans noemde 25 maart 1881, de dag waarop de Tweede Kamer had ingestemd met artikel 1, in zijn Venloosch Weekblad een 'Gedenkwaardige dag in de geschiedenis van Nederland'. Hii voorspelde wel dat de Limburgse kamerleden hun stemgedrag zwaar zou worden aangerekend. ${ }^{66}$

Nijst en Ruijs van Beerenbroek stelden in hun bijdragen aan de beraadslagingen Limburg uitdrukkelijk centraal. Volgens het eerstgenoende kamerlid hadden de inwoners van zijn provincie zich op belastinggebied nooit veel illusies gemaakt, want 'de Limburgers [weten] dat hunne klagten in 't algemeen bij hunne Noordsche broeders weinig sympathy zouden ontmoeten'." Zijn woorden en die van Ruijs van Beerenbroek creëerden tevens het beeld van een gemeenschappelijke positie van de Limburge kamerleden: zo sprak de laatste over de motieven van 'ons, Limburgsche afgevaardigden'. ${ }^{\infty}$ Dergelijke aanduidingen zijn ook aan te treffen in de pers. Zo werden zij door de Limburgse correspondent van De Maasbode 'onze mannen in Den Haag' genoemd. ${ }^{\circ}$

Ook kamerlid jhr. A.F. de Savornin Lohman beschouwde de afgevaardigden uit Boxmeer, Roermond en Maastricht als geheel. Hij duidde in 
zijn betoog op een omstandigheid 'die vooral ten bate komt van de heeren uit Limburg, zoodat ik begrijp waarom zij zoo buitengewoon zijn gesteld op deze rentebelasting'. Hun provincie profiteerde volgens het toen nog anti-revolutionaire kamerlid van haar gunstige geografische ligging: 'Dus kunnen de Limburgers, ingesloten door Belgie en Pruissen, zeer gemakkelijk hun geld in buitenlandsche eigendommen beleggen en de noordelijke provincien de belastingen laten betalen. ${ }^{30}$

Maar ook een ander motief werd wel verondersteld mee te spelen in de Limburgse steun voor de ontwerp-wet: het gerucht ging dat de Limburgse kamerleden voor de wet wilden stemmen omdat hun de toezegging was gedaan dat de grondbelasting en de accijnzen op zout en bier zouden worden verminderd. Deze beschuldiging, die volgens De Tijd zeer wel op waarheid kon berusten, bracht het blad ertoe op 30 maart 1881 de Limburgse brievenkwestie in herinnering te roepen en de brief van de toenmalige minister van Financiën aan Tweede-Kamerlid Van der Maesen de Sombreff opnieuw af te drukken. Eens een dief, altijd een dief? De afgevaardigden uit Limburg leken in ieder geval wederom in de beklaagdenbank te belanden. Bewijsstukken kwamen er nu echter niet ter tafel, maar de suggestie was gewekt dat de integriteit van de Limburgse volksvertegenwoordigers mogelijk in twijfel moest worden getrokken. De Limburger courier sprak op 16 april van 'onedele verdachtmakingen'.

De bijzondere positie van de Limburgse afgevaardigden werd ook bij deze kwestie verbeeld in een prent, zoals eerder bij de verhoging van de grondbelasting. Een belangrijk verschil is gelegen in het referentiekader. Bij de grondbelasting positioneerden de 'Limburgsche heeren' zich ten opzichte van alle andere (Eerste-)Kamerleden, bij de rentebelasting vormden zij 'de afvalligen' van (slechts) het katholieke deel van de Kamer. Eerder al is de constatering van $\mathrm{De}$ Tijd aangehaald: 'er zijn elf katholieke afgevaardigden en 6 Limburgers. ${ }^{71}$ Begin jaren tachtig was het de op gang gekomen ideologisering in de Nederlandse politiek die de exceptionaliteit van de Limburgse parlementariërs benadrukte.

De omvangrijke kritiek op het wetsvoorstel deed minister Vissering overigens besluiten te verzoeken om schorsing. Twee weken daarna trok hij het ontwerp in. 'Een slechte tijding' kopte de Limburger courier: de 'klasse der couponknippers' kon tevreden zijn, verzuchtte het blad. ${ }^{72}$ Bij de opening van het nieuwe parlementaire jaar in september 1891, ruim tien jaar later, kwam er echter een hoopvolle mededeling voor de krant, uitgesproken door koningin Emma, regentes van het koninkrijk: 'Verbetering van het Rijks belastingstelsel is een dringende eisch der rechtvaardigheid. Wetsont- 
werpen om hieraan te voldoen, zullen $\mathrm{U}$ spoedig bereiken. ${ }^{73}$ De Kamers kregen vervolgens de ontwerp-inkomstenbelasting van minister N.G. Pierson voorgelegd. Die bestond uit twee elementen: een belasting op vermogen en een bedrijfs- en beroepsbelasting. De vermogensbelasting, die als eerste in behandeling werd genomen, drukte op het kapitaal in portefeuille, maar ook op het grondeigendom.

Johannes Clercx, afgevaardigde uit Weert, diende een amendement in waardoor de beoogde vermogensheffing zou worden verlaagd, echter uitsluitend voor zover die betrekking had op het grondbezit. Zijn motivatie was duidelijk: door het bestaande wetsvoorstel dreigde de grond in vergeliiking met het roerend goed te zwaar belast te worden. En de belasting diende naar evenredigheid van draagkracht te drukken op alle soorten vermogen: 'Een der eerste regels der staathuishoudkunde', aldus het kamerlid. ${ }^{74}$ Hierin konden alle Limburgse afgevaardigden zich vinden en zij stemden eensgezind in met het amendement. Het ging op dit moment om vijf kamerleden, omdat de Maastrichtse zetel door het overlijden van J.H.J. Schreinemacher onbezet was. Deze zetel zou nog gedurende de behandeling van het wetsvoorstel worden ingenomen door Martin de Ras.

Het wijzigingsvoorstel werd verworpen. Dit stelde de Limburgse kamerleden voor een lastige afweging, want wat gaf nu de doorslag: het verlangen de langverwachte belasting op het kapitaal in portefeuille ingesteld te zien of de afkeer om het grondbezit extra te belasten? ${ }^{75}$ Deze afweging werd door de meeste Limburgse leden van de Staten-Generaal in het openbaar gemaakt: Lambrechts, Pijls en Regout in hun betogen in de Tweede en Eerste Kamer, Ruijs van Beerenbroek tijdens een vergadering van de katholieke kiesvereniging in Roermond en Haffmans, zoals vaker, in zijn Venloosch Weekblad. ${ }^{76}$ Hun oordeel was niet eenduidig, zo bleek ook bij de stemming over het (gehele) wetsvoorstel.

De zes Limburgse Tweede-Kamerleden stemden verdeeld. De Ras (district Maastricht), Lambrechts (Sittard), De Marchant d'Ansembourg (Gulpen) en Ruijs van Beerenbroek (Roermond) stemden tegen het wetsvoorstek, Clercx (Weert) en Haffmans (Venlo) steunden de wet. In de Eerste Kamer stemden de Limburgse afgevaardigden eveneens niet unaniem: Magnée en Pijls waren tegen de wet, Regout gaf haar zijn steun.

Indien we de voor- en tegenstanders in de Tweede Kamer splitsen naat district, dan loopt de scheidslijn tussen de afgevaardigden uit NoordLimburg enerzijds en de kamerleden uit het zuiden en midden van de provincie anderzijds. Dat de extra belasting op het grondbezit, ingevoerd door de nieuwe vermogensbelasting, voor de Noord-Limburgse afgevar- 
digden minder bezwaarlijk was, zou zijn oorzaak zeer wel hebben kunnen vinden in de agrarische structuur van deze regio. Het percentage kleinere grondeigenaren was er groter dan in Zuid-Limburg." Het wetsontwerp strekte tot voordeel van deze kleinere grondbezitters, met name doordat vermogens tot 13000 gulden waren vrijgesteld van belasting. 'Deze bepaling is goud waard,' had Haffmans in het Venloosch Weekblad geschreven. ${ }^{78}$ De scheiding tussen Noord en Midden-Zuid had zich dan ook al eerder geopenbaard bij de stemming over artikel 10 van het wetsontwerp, het artikel waarin deze 'belastingvrije voet' alsmede de progressie werd geregeld: Haffmans stemde voor; Lambrechts, De Marchant d'Ansembourg en Ruijs van Beerenbroek stemden tegen (Clercx was afwezig en De Ras had op dat moment nog geen zitting). Bovendien sprak Haffmans zich in de Kamer uitdrukkelijk uit voor een scherpe progressie, terwijl Ruijs van Beerenbroek eerder dat jaar op een kiezersvergadering had laten weten juist tegen een progressieve inkomstenbelasting te zijn. ${ }^{79}$

De verdeeldheid bij de stemming in 1892 laat onverlet dat het streven om roerende goederen te belasten vanaf 1840 als een rode draad loopt door de parlementaire handelingen van de Limburgse afgevaardigden in Den Haag. Bij de diverse wetsvoorstellen waarin het kapitaal werd belast, toonden de Limburgers die bij de beraadslagingen en stemmingen aanwezig waren, zich zonder uitzondering een voorstander van het belasten van kapitaal en effecten. Deze consistentie werd in de jaren tachtig, bij de behandeling van de ontwerp-rentewet, ook door een van hen, kamerlid Nijst opgemerkt: 'In 1881 denken de Limburgers nog even als de Limburgers in het jaar 1852, toen bij de Staten-Generaal een voorstel tot invoering eener effectenbelasting werd gedaan.' ${ }^{\text {'o }}$

De inkomstenbelasting van Pierson zal bij de inwoners van Limburg weliswaar geen algehele jubelstemming teweeg hebben gebracht, maar aan de in hun ogen meest schrijnende fiscale onrechtvaardigheid was na ruim vijf decennia een eind gekomen. En, zo had de Staten-Generaal in 1849 al aan de koning laten weten: 'Sire [...] De natie zal des te gewilliger zijn, naar mate zij meer overtuigd is, dat de offers, die men van haar vergt, te regt worden gevraagd, naar behooren verdeeld, en doeltreffend besteed.'1 Gewilliger of niet, het Limburgse deel van die natie had bij het ingaan van de twintigste eeuw in ieder geval een belangrijke reden minder om te klagen over het in 1839 opgelegde vaderland. En dat gold ook voor zijn afgevaardigden in Den Haag. 


\section{De middelenwet en het Limburgse ongenoegen}

Het belastingstelsel kwam, behalve bij de behandeling van specifieke belastingwetten, op meer regelmatige basis op de parlementaire agenda bij de staatsbegroting, die in de jaren veertig iedere twee jaar en met ingang van 1849 jaarlijks werd vastgesteld. Onlosmakelijk verbonden met de be. grotingswetten was de wet op de middelen, ofwel middelenwet, warin de diverse inkomstenbronnen werden aangewezen tot dekking van de geplande uitgaven. De rijksbelastingen waren de belangrijkste inkomstenbron en vormden daarmee de kern van de middelenwet.

Het verwerpen van de middelenwet betekende niet dat de belastinghef. fing werd geblokkeerd: deze belastingen en hun heffing waren geregeld in afzonderlijke wetten. Toch konden de parlementariërs met een stem tegen de middelenwet hun ongenoegen kenbaar maken met de wijze waarop de Nederlandse staat in zijn inkomsten voorzag, en de Limburgse kamerleden deden dit regelmatig. ${ }^{12}$ De vraag dient zich aan of er sprake was van een gemeenschappelijk Limburgs optreden in de Kamer. Bovendien: weken de Limburgers hierbij af van de overige kamerleden?

Eerst enkele gegevens. Tussen 1840 en 1919 werd vijfenzeventig keer een middelenwet ingediend. ${ }^{83}$ Er werden tegenstemmen uitgebracht in de ja. ren voor 1889; daarna werd de wet in de beide Kamers telkenmale zonder hoofdelijke stemming aangenomen. Ondanks de tegenstand van voor 1889 is de middelenwet nooit verworpen. De Tweede-Kamerleden stemden veel vaker tegen de middelenwet dan Eerste-Kamerleden. Haalde het antal tegenstemmen in de Tweede Kamer meermalen een kwart van het aantal uitgebrachte stemmen, in de Eerste Kamer gebeurde dit nimmer. Hier kwam dit aantal slechts driemaal boven de tien procent uit. De Limburgers in de Eerste Kamer vallen in hun stemgedrag niet op. Hoewel zij regelmatig pleitten tegen het bestaande belastingstelsel, gebruikten zij slechts sparzaam de stemming bij de middelenwet om dit ongenoegen te onderstrepen. Beerenbroek stemde tegen de wetten voor de jaren 1850 en 1851, en De Villers de Pité en Frans Michiels van Kessenich deden dit met de wet voor het jaar 1866.

Bij de Tweede-Kamerleden uit Limburg ligt dit anders. Indien we het tijdvak $1840-1888$ verdelen in perioden van vijf achtereenvolgende middelenwetten en daarbij het stemgedrag van de Limburgse kamerleden apart zetten, krijgen we de gegevens zoals vermeld in tabel 1 . De tabel geeft aan dat de stemming over de middelenwet bij het ingaan van de jaren zeventig duidelijk had afgedaan als uiting van ongenoegen, een tendens die al eet- 
der had ingezet: in 1858 werd de middelenwet voor het eerst met algemene stemmen aangenomen en na 1860 deed zich een duidelijke terugval voor in het aantal tegenstemmers. Een uitzondering is 1868 , toen 23 van de 62 leden zich tegen de wet uitspraken. De Limburgers hielden gelijke tred met deze ontwikkeling. Tijdens het debat over de middelenwet voor 1884 vroeg Tweede-Kamerlid Clercx (district Weert) zich dan ook af of de stemming over die wet wel de geëigende weg vormde om te komen tot wijzigingen van de belastingen. 'Ik geloof het niet,' meende hijzelf. ${ }^{84} \mathrm{Na} 1860$ bracht alleen Haffmans nog één keer, in 1868 , zijn stem uit tegen de middelenwet.

Tabel 1. Aantal tegenstemmers bij de middelenwet, begrotingen $1841 \mathrm{t} / \mathrm{m} \mathrm{1889}$, Tweede Kamer

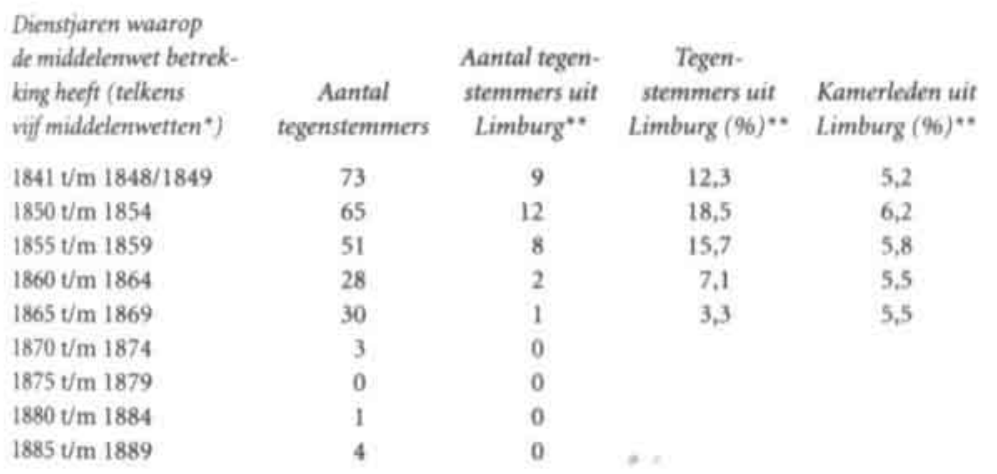

"In de jaren $1841 \mathrm{t} / \mathrm{m} 1849$ werd er eenmal in de twee jaar een middelenwet ingediend bij het parlement, daarna (ten gevolge van de grondwetswijziging van 1848) gebeurde dit jaarlijks.

"Exclusief de Noord-Brabantse leden uit het district Boxmeer (Hengst, Van den Heuvel en Kerstens).

De eerste twintig jaar van hun aanwezigheid in de Tweede Kamer onderscheidden de Limburgers zich echter wel: zij stemden beduidend vaker dan een gemiddeld lid van de Tweede Kamer tegen de middelenwet. Vormden zij door dit afwijkend stemgedrag op individueel niveau ook een te onderscheiden parlementaire groep? De beantwoording van deze vraag noodzaakt tot een nadere vergelijking met de afgevaardigden uit de overige provincies.

Uit de stemmingen die tot en met de middelenwet voor het jaar 1861 plaatsvonden, kan in zeven gevallen een naar provincie te herleiden eensgezinde oppositie worden herleid. Deze stemmingen vonden alle voor 1855 plaats; telkens is er één provincie aan te wijzen waarvan de aanwezige afgevaardigden unaniem tegenstemden. In zes van de zeven gevallen betreft 
het de Tweede-Kamerleden die waren afgevaardigd uit Limburg. ${ }^{.5}$ Tissen 1843 en 1855 stemden zij telken jare eensgezind tegen de middelenweten, met uitzondering van de wetten voor de jaren 1850, 1851 en 1852 . Bi de laatste twee stemmingen stemde de Maastrichtse afgevaardigde Borrt als enig kamerlid uit Limburg voor. Overigens zocht hij in het tweede gevi, de middelenwet voor het jaar 1852 , wel aansluiting bij de overige afgevaadig. den uit Limburg door te verklaren dat wanneer de regering niet snel haar beloften zou nakomen met betrekking tot de afschaffing van de accijzen op granen en slachtvee, hij zich gedwongen zou zien om de volgendekeer tegen de middelenwet te stemmen.

Dat de middelenwet tot midden jaren vijftig door de Limburgers a de Tweede Kamer doelgericht werd ingezet als voorwerp van protest tegn de Nederlandse belastingen, blijkt ook in het jaar dat zij allen juist vó die wet stemden (1855). Ook dit stemgedrag was een politiek signaal: omdt dit jaar de accijns op het geslacht was afgeschaft, gaven zij hun stem aa de middelenwet. $^{\text {.6 }}$

De vergaderingen tijdens welke de begrotingswetten aan de orde wren, behoorden tot de meest belangrijke in de parlementaire cyclus. Het Limburgse stemgedrag zal daarom des te meer zijn opgevallen. De profilering als Limburgs afgevaardigde won nog eens aan kracht door de motivatie die de Limburgers hun stem meegaven. In hun bijdragen aan de beraadslagingen wezen velen van hen met nadruk op de positie van Limburg. De exceptionele situatie van deze provincie diende daarbij als rechtvaardiging van hun wensen.

Het verzet tegen de middelenwet was weliswaar geen exclusief Limburgse aangelegenheid, maar de Limburgse afgevaardigden weken hierbij tot midden jaren vijftig wel duidelijk af van de overige Nederlandse parlementariërs. De mate waarin zij tegen de middelenwet stemden, de regelmaat waarmee zij dat deden en de eenheid die zij daarbij vormden, zorgden voor duidelijke onderscheiding.

Overigens zien we bij de behandeling van een van de middelenwetten, in december 1844, waarom een eensgezind optreden van de Limburgse afgevaardigden door henzelf veelal als dringend gewenst zal zijn beschouwd. Zij beklaagden zich dat jaar alle drie over de belastingen en accijnzen die volgens hen te zwaar op de bevolking drukten. ${ }^{87}$ Over één bepaald aspect bij de uitvoering van de accijnsheffing waren ze het onderling niet eens. Strens stelde dit verschil in opvatting tot zijn leedwezen vast, wellicht omdat hij de reactie van de minister Van Hall van Financiēn voorzag." De bewindsman maakte namelijk dankbaar gebruik van de verdeeldheid 
onder de Limburgse afgevaardigden. In zijn reactie op hetgeen door de Kamer naar voren was gebracht, meldde hij geheel voorbij te zullen gaan aan het onderwerp van de accijnsheffing in Limburg. Daarover was weliswaar door de drie Limburgse kamerleden zonder uitzondering geklaagd, maar angezien zij het niet geheel eens waren, zou het niemand verwonderen, aldus de minister, dat hij zich van een reactie terzake zou onthouden. ${ }^{89}$

\section{Tegenover 'Holland'}

De gesplitste inkomstenbelasting van Pierson (1892) leidde tot een billijker verdeling van de fiscale lasten tussen de verschillende provincies. In vergelijking met de bewoners van westelijk Nederland (Utrecht, Noord- en Zuid-Holland) hadden de inwoners van de plattelandsprovincies tot dan toe over een veel groter deel van hun vermogen belasting moeten betalen.90

In Limburg was men zich van deze ongelijkheid zeer wel bewust. Volgens een uitspraak van het statenlid J. Collaes in oktober 1850 maakte het Nederlandse belastingstelsel 'de vereeniging van het arme Limburg met het Rijke Holland onbestaanbaar.91 Ruim veertig jaar later sprak Gustave Ruijs van Beerenbroek op een kiezersvergadering in Roermond. Hij beloofde zijn toehoorders een belasting op het roerend vermogen te zullen nastreven, 'lees: de effectenportefeuilles van de "Hollanders"', verduidelijkt de historicus Beekelaar. ${ }^{92}$

Nu was (en is) Holland geen eenduidig begrip, zeker niet voor Limburgers: voor velen van hen begon Holland waar hun eigen provincie ophield. Holland stond dan voor de rest van Nederland en fungeerde als 'stemmingsbegrip.93 In de discussies over het belastingstelsel was die stemming in ieder geval negatief. Dat daarbij niet altijd even duidelijk is welk deel van Nederland precies fungeerde als de anti-pool Holland, is minder belangrijk. Evident is hier dat wanneer het ging om de gewenste belasting op effecten, de Limburgse kamerleden zonder uitzondering pal stonden voor de belangen van de provincie waaruit zij waren afgevaardigd. Vormden zij daarmee een uitzondering?

In Limburg zelf meende men van niet, zo wordt onder meer duidelijk uit een ingezonden brief in Le courrier de la Meuse van 25 maart 1881. De briefschrijver waarschuwde de Limburgse kamerleden op hun hoede te zijn: de beoogde rentebelasting heette dan wel gunstig te zijn voor Limburg, maar er moest wel een adder onder het gras schuilen. Waarom hadden anders juist kamerleden verklaard voor de wet te zullen stemmen, die waren afgevaardigd uit provincies waar het effectenbezit zich concentreerde? De 
ingezonden brief kreeg een prominente plaats in de Maastrichtse krant 'vu son importance' - om het schrijven zodoende onder de aandacht te brengen, vooral van de Limburgse kamerleden: 'Nous y appelons toute l'attention de nos honorables députés,' schreef de redactie ter inleiding.

Aan de hand van een stemming uit $\mathbf{1 8 5 2}$ kan inderdaad aannemelijk worden gemaakt dat ook afgevaardigden van buiten Limburg tijdens belastingkwesties de belangen van hun provincie niet uit het oog verloren. De Tweede Kamer boog zich dat jaar over het wetsontwerp tot invoering van 'eene belasting op de renten van kapitalen'. Zoals eerder gemeld, strandde het ontwerp in de Kamer. Nadat artikel 3, waarin de hoogte van de belasting werd bepaald, was verworpen, trok minister Van Bosse het wetsontwerp in. Voorafgaand aan deze stemming had de minister laten weten dat hij de verdere behandeling van het ontwerp afhankelijk zou stellen van het aannemen van dit artikel.

Alle Limburgse afgevaardigden waren voorstander van het wetsvoorstel, hetgeen in verband stond met de situatie in hun provincie. Een dergelijke relatie kan echter ook gelegd worden bij de kamerleden die waren afgevaardigd uit het westelijk deel van Nederland: het deel waar het meest werd belegd in effecten. Van de 64 aanwezige kamerleden waren er 25 afgevaardigd uit kiesdistricten die geheel of hoofdzakelijk gelegen waren in de provincies Utrecht en Noord- en Zuid-Holland. Slechts drie van hen stemden voor artikel 3.94 Met evenveel recht als waarmee de Limburgers regionaal particularisme verweten kan worden, kan dit verwijt daarmee verreweg de meeste kamerleden uit westelijk Nederland en onder hen alle afgevaardigden uit Utrecht en Noord-Holland worden gemaakt. Maar wellicht sprong (en springt) de wijze waarop de Limburgse afgevaardigden de belangen van hun provincie behartigden, meer in het oog.

\section{'... en thans moet ik spreken over het gewest mijner inwoning'}

Op 13 mei 1865 klaagde De Tijd dat veel Nederlandse volksvertegenwoordigers zich lieten leiden door gewestelijke deelbelangen. Dit regionalisme beperkte zich volgens het blad zeker niet tot de kamerleden uit Limburg, maar de afgevaardigden uit deze provincie 'verstaan echter de kunst mindet goed dan andere om de motieven, die hun daden bestieren, te bemantelen'.

Nu speelde dit jaar de verhoging van de grondbelasting in Limburg, een wetsontwerp waar de Limburgse afgevaardigden vrijwel als enigen tegen waren. Dat er sprake was van provinciale belangenbehartiging viel daardoor nauwelijks 'te bemantelen', zeker niet met de naam van de provincie in de 
titel van de wet. Maar hoe zat het bij fiscale kwesties waarbij het verzet van de Limburgse kamerleden niet uitzonderlijk was, maar werd gedeeld door velen in het parlement? Vielen zij ook dan op door bovengemiddeld provincialisme?

Deze vraag kan voor hetzelfde jaar worden beantwoord aan de hand van een andere belangrijke belastingkwestie: de wijziging van de personele belasting. Bij het wetsontwerp dat de regering aanhangig maakte, wisten de Limburgse afgevaardigden zich in hun verzet verenigd met tal van andere kamerleden. Het ontwerp werd dan ook weggestemd en onder het grote aantal tegenstemmers (35) vallen de namen van de Limburgers niet op.

Er doet zich echter een opmerkelijk onderscheid voor in de betogen die werden gehouden tijdens de algemene beraadslagingen. Terwijl van de overige kamerleden er slechts één de naam van 'zijn' provincie in de mond nam - J.F. Zylker (district Appingedam) sprak van 'Groninger landbouwers' werd Limburg door elk van de vier kamerleden uit die provincie meermaals met name genoemd. ${ }^{95}$ Het debat dreigde daardoor, aldus Karel Cornelis (Roermond), 'eene Limburgsche tint' te krijgen. ${ }^{96}$ Naar aanleiding van hun toespraken merkte minister Betz op: 'Zij hebben het doen voorkomen, als of de hand van de Minister van Finantien zwaar op dat gewest [Limburg] drukte en als of dat gewest, boven elk ander, in dit opzigt, ik zou haast zeggen mishandeld wierd. ${ }^{97}$ Naast bezwaren van meer algemene aard, hadden de kamerleden uit Limburg immers zonder uitzondering provincie-specifieke klachten. Na te hebben gesproken over de aigemene beginselen van het Nederlandse belastingstelsel, merkte Van der Maesen de Sombreff dan ook op: '. .. en thans moet ik spreken over het gewest mijner inwoning. ${ }^{96}$

Een voornaam bezwaar van de Limburgers richtte zich op een van de grondslagen van de personele belasting: de haardsteden (stookplaatsen). Hoe meer haardsteden een gebouw had, hoe hoger de belastingaanslag. Nu maakte de onmiddellijke nabijheid van mijnen de steenkool in Limburg goedkoper dan elders en daardoor kon men zich daar per woning meer stookplaatsen veroorloven. Van der Maesen de Sombreff, die gedurende zijn ministerschap in Den Haag had gewoond, had dit naar eigen zeggen persoonlijk kunnen ondervinden. Bij een eerdere poging tot wijziging van de personele belasting, in 1858 , hadden alle Limburgse Tweede-Kamerleden zich al tegen handhaving van de haardsteden als grondslag verzet." Het voorstel liet volgens De Lom de Berg zien dat de regering over 'onvoldoende locale kennis' beschikte. ${ }^{100}$ Met name Limburg dreigde daarvan de dupe te worden: die provincie bevond zich immers 'in een geheel exceptionelen toestand."101 
De Limburgse afgevaardigden klaagden zonder uitzondering ook over het optreden van de belastingambtenaren in hun provincie. De Lom de Berg sprak daarbij, zo zei hij, uit eigen ervaring. Volgens Cornelis was hun optreden vooral te danken aan het feit dat 'op hunne feuille de route van de residentie naar Limburg aangeteekend wordt: gij komt daar in een verwarden boel; er bestaan daar eene menigte misbruiken die uitgeroeid moeten worden'. ${ }^{102}$

De minister schudde ondertussen ontkennend het hoofd, maar Van der Maesen de Sombreff zei hetzelfde: 'Wanneer nu een Nederlandsch ambtenaar, in Holland groot gebragt, daarhenen gaat, steeds verkeerende in de dwaling die hem hier nergens wordt ontnomen, dan ontstaat al van zelf die overdreven ijver waarover ik geklaagd heb.' ${ }^{103}$ En een dag later volgde De Bieberstein: 'Zij komen in ons gewest met een geest van antipathie; zij beschouwen de Limburgers als geene Nederlanders.' 104

Het debat kreeg die tweede dag overigens een persoonlijke wending door de reactie van minister Betz. Kennelijk getergd door de scherpe oppositie van De Lom de Berg besloot hij ter toelichting op zijn verhaal een wel zeer specifiek voorbeeld te nemen: de woning van het Venlose kamerlid. De minister rekende precies voor welk bedrag De Lom de Berg overeenkomstig het nieuwe wetsontwerp zou moeten gaan betalen. De oorzaak van de kleine vermeerdering (à $f 8,83$ ) ten opzichte van de bestaande aanslag moest volgens de minister vooral gezocht worden in het meubilair van $D e$ Lom de Berg. Het verstrekken van deze privé-gegevens werd door verschillende kamerleden als onkies ervaren. Ook De Lom de Berg zelf was niet erg ingenomen met de ongevraagde hulp bij de belastingaangifte: de behandeling van het wetsontwerp op de personele belasting werd op die manier inderdaad persoonlijk, constateerde het kamerlid. ${ }^{105}$

Dat de Limburgse volksvertegenwoordigers zich tijdens het debat 'provincialer' uitlieten dan hun collega's, blijkt ook uit de wijze waarop naar deze kamerleden verwezen werd. Terwijl de minister van Financiën in zijn repliek verschillende afgevaardigden aanduidde met de naam van het district waaruit zij waren afgevaardigd - hetgeen niet ongebruikelijk was bediende hij zich alleen bij de kamerleden uit Roermond en Maastricht tevens van een provinciale terminologie: hij verwees naar 'de beide sprekers uit Limburg' en 'den geachten spreker uit Limburg.' ${ }^{106}$

Eerdere belastingkwesties waartegen breed verzet had bestaan, bevestigen het beeld dat de afgevaardigden uit Limburg zich afzonderlijk opstelden. hoewel zij in hun tegenstand verre van alleen stonden. Zo kan worden gewezen op het belastingplan van minister Van Hall in de jaren veertig. Zijn 
voorstel leidde tot felle discussies in de Staten-Generaal. Om een naderend staatsbankroet te voorkomen wilde de minister in 1844 een staatslening uitschrijven van 127 miljoen gulden. Hoewel het om een vrijwillige lening ging, voorzag de wet in een eenmalige vermogensbelasting voor het geval er onvoldoende op de lening zou worden ingeschreven. Van een dergelijke belasting had men, zo wist de minister, een grote afkeer en zij moest derhalve dienen als stok achter de deur. Het verzet in het parlement richtte zich dan ook vooral tegen het tweede deel van de wet, waarin de eventueel in te voeren vermogensheffing werd geregeld: de lastendruk was in Nederland toch al zo hoog, klaagden veel parlementariërs.

Deze kritiek vinden we ook terug in het betoog van Michiels van Verduynen. Samen met collega-Tweede-Kamerlid Corneli droeg hij echter nog een ander bezwaar aan. De twee afgevaardigden uit Limburg spraken beiden over de unieke verhouding van hun provincie tot Nederland, met name door haar gelijktijdige relatie met de Duitse Bond. Corneli beschreef Limburg als 'eenen afzonderlijken, met bijzondere regten en verplichtingen, en in verscheidenene opzigten zelfstandigen Staat'. ${ }^{107}$ En juist op het terrein van de belastingen kon het gewest aanspraak maken op bijzondere rechten, meende Michiels van Verduynen: 'In dezen toestand kan Limburg wel in de gewone kosten van het landsbestuur, waaronder het is opgenomen en deel heeft in de algemeene landsvoordeelen, gehouden worden bij te dragen; maar de kwijting en afdoening van vroegere lasten en schulden zijn en blijven aan Limburg geheel vreemd. ${ }^{\prime o s}$

Op 29 februari 1844 las Michiels van Verduynen in de Kamer een akte van protest voor tegen het toepassen van de wet op zijn provincie. Hij deed dit, zo vermelden de Handelingen, 'ook uit naam zijner medeleden uit Limburg. ${ }^{109}$ De drie Limburgers presenteerden zich daarmee als een soort provinciale kamerfractie. Geen van de overige provincies manifesteerde zich in de Kamer via een gemeenschappelijke woordvoerder. Bovendien waren de Limburgers de enigen die trachtten om specifiek voor hun provincie een uitzonderingsclausule te bewerkstelligen. Die poging treedt des te meer in het licht doordat van regeringszijde naast de minister van Financièn ook zijn ambtgenoot van Buitenlandse Zaken, luitenant-generaal J.A.H. de Lasarraz, het woord voerde tijdens de beraadslagingen. Zijn reactie richtte zich geheel op de door de Limburgse afgevaardigden naar voren gebrachte bezwaren. Door het lidmaatschap van de Duitse Bond gaf hun provincie een buitenlandse dimensie aan deze overigens puur fiscale kwestie. De Limburgse claim niet te hoeven bijdragen in de lasten die het gevolg zouden zijn van het wetsvoorstel, werd door de minister van tafel geveegd: 'Limburg maakt een 
deel uit van het Rijk der Nederlanden: als zoodanig deelt het in al de voordeelen der vereeniging en draagt het een aandeel in de daarvan onafscheidelijke lasten. ${ }^{\prime 10}$ De Lasarraz kwam er enkele dagen later ook in de Eerste Kamer aan te pas. "' Het enige Limburgse lid van die Kamer, Pieter Willem baron de Liedel de Well, verklaarde uitdrukkelijk tegen de wet te zijn. ${ }^{112}$

Het is onmogelijk precies te achterhalen wie heeft deelgenomen aan de lening en de vrijwillige bijdrage. Dit houdt verband met het voorschrift om de inschrijvingsregisters (omwille van de privacy) te vernietigen en met de mogelijkheid om de bijdragen die werden geregistreerd in het Grootboek van de nationale schuld, via tussenpersonen te voldoen. Van een van de Limburgse kamerleden, Michiels van Verduynen, is bekend dat hij heeft bijgedragen. ${ }^{113}$ Aan de baron was dan ook persoonlijk een uitnodigingsbiljet voor de lening toegezonden door gouverneur Gericke van Herwijnen, 'ten einde daaraan ook door UEdG. [U edelgestrenge] gevolg worde afgegeven'."'

Een andere belasting(soort) waartegen alom in Nederland verzet bestond, werd gevormd door de accijnzen die, met name tot midden jaren vijftig, zwaar drukten op de eerste levensbehoeften. Het in Limburg bestaande admodiatiestelsel betekende niet dat deze weerstand in die provincie niet bestond. Integendeel, zo werd nog eens duidelijk in het parlementaire jaar 1851-1852 toen maar liefst tweeënveertig Limburgse verzoekschriften met als onderwerp de accijnzen in Den Haag arriveerden. ${ }^{115}$ Tweede-Kamerlid Van Wylick (district Roermond) noemde de accijnzen in datzelfde jaar 'den invretenden kanker van ons maatschappelijk bestaan.' ${ }^{116}$

Naast de Limburgers drongen regelmatig vele andere kamerleden aan op verlichting of afschaffing. Opgaand in dit bredere verzet zouden de pleidooien van de Limburgse afgevaardigden tegen de accijnzen niet zijn opgevallen, ware het niet dat zij na 1848 voortdurend benadrukten dat hun provincie in het bijzonder aanspraak meende te kunnen maken op de afschaffing ervan. Tweede-Kamerlid Borret (district Maastricht) zei het eind 1851 zo:

Ja, Mijne Heeren, Limburg houdt niet op de afschaffing van den accijns op het gemaal en het geslagt te vragen; maar er is ook misschien geen gedeelte van het Rijk, dat, om zóó te zeggen meer regt heeft erlangd, die afschaffing te vragen en met volharding te vragen; want de Regering heeft misschien nergens meer dan juist in Limburg uitzigten en verwachtingen opgewekt, dat die belastingen, zoo drukkend overal elders, omdat zij geheven worden op de voornaamste 
voedingsmiddelen, maar dubbel drukkend in Limburg [...] spoedig zouden ophouden gevorderd te worden. ${ }^{117}$

De 'uitzigten en verwachtingen' waarop Borret doelde - De Lom de Berg sprak bij dezelfde gelegenheid van een 'plegtige belofte' - dateerden van mei 1848. Toen had de regering, met het oog op de gespannen toestand in Limburg, in een brief aan Gedeputeerde Staten laten weten een vermindering van de accijnzen te overwegen. De inhoud van dit schrijven was vervolgens door gouverneur Van Meeuwen via een proclamatie openbaar gemaakt.

In 1855 werd de meest gehate accijns, die op het gemaal, afgeschaft. Als we de Handelingen tot en met dat jaar doorlopen, te beginnen in 1848 (het jaar van de proclamatie van de gouverneur), dan zien we dat er jaar na jaar in het parlement door Limburgse kamerleden werd verwezen naar de 'zoo schoone beloften en stellige toezeggingen' die aan specifiek hun provincie waren gedaan. ${ }^{118}$

\section{Gedachten, woorden en werken}

Aan de constatering van De Tijd uit 1865 dat de Limburgse afgevaardigden de provinciale deelbelangen in relatieve openheid behartigden, ging de klacht vooraf dat het regionalisme een wijder verspreid fenomeen was in de Staten-Generaal. Aan de hand van de gehouden betogen lijken de Limburgse afgevaardigden zich echter meer dan hun collega's te hebben beziggehouden met de behartiging van provinciale belangen: voor nationale volksvertegenwoordigers een parlementaire zonde.

Zonden beperken zich echter niet tot hetgeen uitgesproken wordt; een volledig mea culpa bestrijkt immers zonden in 'cogitatióne, verbo et ópere' (gedachten, woorden en werken). Bij het vaststellen van de hier genoemde politieke zonde kunnen daarom, naast de redevoeringen die werden gehouden, ook andere parlementaire handelingen in ogenschouw genomen worden, bijvoorbeeld het stemgedrag.

Indien we de afgevaardigden naar provincie groeperen, blijkt er vaker sprake van eenduidig stemgedrag. Bij het belastingplan van minister Van Hall stemden ook de zeven Tweede-Kamerleden uit Noord-Brabant unaniem tegen; de drie Zeeuwse afgevaardigden waren allen voor dat voorstel. ${ }^{19}$ Een gemeenschappelijke stemverklaring, zoals de drie Limburgers aflegden, lieten echter de Brabanders noch de Zeeuwen horen. Ook in het geval van de personele belasting (1865) was Limburg niet de enige provincie waarvan alle aanwezige kamerleden eenzelfde standpunt innamen: de 
afgevaardigden uit de Friese districten - Dokkum, Leeuwarden en Sneek - stemden eveneens eenparig tegen het wetsontwerp. Dat het werd weg. gestemd, lag hoofdzakelijk aan de overweging dat zijn uitwerking nadelig zou zijn voor de bewoners van het platteland. ${ }^{120}$ Waarom zouden de Friese Tweede-Kamerleden bij de stemming niet de belangen van de hoofdzakelijk agrarische bewoners van hun provincie in het achterhoofd kunnen hebben gehad? Dergelijke gedáchten zijn bij de Friezen echter minder goed te achterhalen dan bij hun Limburgse collega's, die vaak in alle openheid de belangen van hun provincie benoemden.

De uitzonderlijke positie die de Limburgers in 's lands vergaderzaal innamen, zou daarmee wel eens in belangrijke mate een kwestie van presentatie kunnen zijn geweest. Gold dit voor de gehele periode na 1840 ? Ter beantwoording zullen de beraadslagingen over de diverse fiscale wetsontwerpen die hiervoor aan de orde waren nog eens kort de revue passeren. Het betreft de volgende negen wetsvoorstellen: het belastingplan van Van Hall (zittingsjaar 1843-1844), de grondbelasting in Limburg (1850-1851), de rentebelasting (1851-1852), de personele belasting (1857-1858), de grondbelasting in Limburg (1864-1865), de personele belasting (1864-1865), de inkomstenbelasting (1871-1872), de rentebelasting (1880-1881) en de vermogensbelasting (1891-1892). ${ }^{121}$ Bij elk wetsontwerp is bekeken of en hoeveel Limburgse Tweede-Kamerleden bij de parlementaire beraadslagingen de naam van hun provincie in de mond namen.

Tijdens de debatten die werden gevoerd in de jaren veertig, vijftig en zestig, noemden de woordvoerders uit Limburg met één uitzondering de rentewet uit 1851-1852 - altijd de naam van hun provincie. Met andere woorden: als een Limburgs kamerlid het woord nam, betrok hij te allen tijde zijn gewest expliciet in zijn betoog. Vanaf de jaren zeventig nam 'Limburg' een minder prominente plaats in in de bewoordingen waarin de standpunten werden uiteengezet. De kamerleden die toen spraken, noemden de provincienaam vaker niet dan wel. Dit verschil tussen de periode tot 1870 en de jaren daarna blijft overeind indien we de wetsontwerpen buiten beschouwing laten, waarbij het ging om de kwestie van de grondbelasting in Limburg. In het voorgaande is al geconstateerd dat de Limburgse afgevaardigden ook na de jaren zestig vasthielden aan het streven om de lasten op het grondbezit relatief te beperken. Dat zij Limburg daarbij minder uitdrukkelijk gingen noemen, wil dus niet zeggen dat de belangen van die provincie voor hen minder zwaar wogen dan voorheen.

Er valt nog iets op bij de vergelijking van de eerdere met de latere debatten. Wanneer Limburg tijdens de beraadslagingen in de jaren zeventig. 
tachtig en negentig met name werd genoemd, was dat in drie van de vier gevallen pas nadat een kamerlid uit een ander landsdeel zijn Limburgse collegae direct op de situatie in hun provincie had aangesproken of bevragd. De Limburgers werden op die manier als het ware uitgenodigd zich te verdedigen.

Zo sprak, tijdens het debat over de inkomstenbelasting (1872), alleen De Bieberstein over Limburg. Hij ging echter pas deelnemen aan het debat nadat hij zich uitgedaagd had gevoeld door de Rotterdamse afgevaardigde W.A. Viruly Verbrugge, zo blijkt ook uit de woorden waarmee hij zijn betoog begon: hij kon niet nalaten 'wanneer men aan Limburg den handschoen toewerpt', die op te rapen. ${ }^{122}$ Bij de rentewet van minister Vissering (1881) spraken de Tweede-Kamerleden Nijst en Ruijs van Beerenbroek over Limburg. Ook zij noemden hun provincie als reactie op hetgeen eerder in de Kamer naar voren was gebracht. Nijst had zich eerst voorgenomen om niet het woord te voeren. 'Het stilzwijgen dat ik mij had opgelegd, kan ik echter thans niet meer bewaren, en zulks naar aanleiding eener vraag gisteren door een onze medeleden gedaan. ${ }^{123} \mathrm{Hij}$ doelde op een vraag van de afgevaardigde uit Nijmegen, C.J.A. Heydenryck. Ruijs van Beerenbroek werd geprikkeld door beweringen die hij eerder in de Kamer had gehoord over de motieven van de Limburgse afgevaardigden. Hij stoorde zich vooral aan de woorden van jhr. A.F. de Savornin Lohman aan het adres van 'de heeren uit Limburg'; woorden die Ruijs van Beerenbroek in zijn eigen betoog citeerde om ze vervolgens te bestrijden. ${ }^{124}$

Het is alleen Eerste-Kamerlid Pijls die bij de beraadslagingen over de vermogensbelasting (1892) 'onuitgenodigd' begon over de bijzondere omstandigheden waarin zijn provincie zich bevond. Een dergelijk 'spontaan' betoog over Limburg - aan het eind van de negentiende eeuw bijzonder was in de jaren veertig, vijftig en zestig meer regel dan uitzondering.

De constatering dat de provincie in de latere periode verbaal gezien minder op de voorgrond werd geplaatst, komt ook naar voren bij de parlementaire besluitvorming inzake een geheel andere belasting: de accijnzen op alcoholische dranken. In 1864 stelde de regering voor de accijns op het bier meer dan te verdubbelen. Een ramp voor Limburg, zo liet TweedeKamerlid Van Wintershoven de Maastrichtse kiezers weten in een Open brief: "Eene voordragt die dreigt ons Limburg onzen volksdrank te ontnemen [...].' ${ }^{125}$ Ook in Den Haag werd Limburg prominent naar voren geschoven als provincie die in het bijzonder nadeel zou ondervinden van de wet. Evenals in Noord-Brabant was het bier in Limburg immers 'eene eerste levensbehoefte, een voedingsmiddel. Het is daar geen surrogaat voor wijn 
of sterken drank, maar vervangt in menig huisgezin ander voedsel, treedt tot zekere hoogte in de plaats van brood, aardappelen en vleesch', zo lezen we in het voorlopig verslag van de Tweede Kamer. ${ }^{126}$

Bijna een halve eeuw later kwam de regering met een wetsontwerp tot verhoging van de accijns op gedistilleerde dranken. Tot tweemaal toe stelde Nolens voor om de behandeling van het wetsontwerp uit te stellen: in december 1908 tot na het kerstreces en in februari 1909 voor 'nog een paar maanden', waarbij hij uitdrukkelijk de hoop uitsprak dat van uitstel afstel zou komen. ${ }^{127}$ In de toelichting, zowel in december als in februari, nam Nolens de naam van zijn provincie niet in de mond. Ook in het voorlopig verslag werd Limburg niet genoemd. Hoewel de onwenselijkheid van het wetsvoorstel in de kamerstukken niet uitdrukkelijk werd verbonden met Limburg, treffen we deze verbinding wel aan in bijvoorbeeld het dagboek van het liberale Tweede-Kamerlid Willem Hendrik de Beaufort. Hij schreef op 7 maart 1909 naar aanleiding van het voorstel van Nolens: 'Het schijnt dat de Brabantsche en Limburgsche leden wegens de naderende verkiezingen niet voor de wet wilden stemmen en terwille van den katholieken minister van Financieën niet tegen durfden stemmen.' ${ }^{128}$

Ook Nolens vond de dreigende verhoging van de accijns op gedistilleerd kennelijk een goed item om zich naar zijn kiezers toe te profileren: zijn reguliere artikel in de Nieuwe Venlosche Courant van 20 februari 1909 handelde over dit onderwerp. Het besluit van de Kamer op 27 februari om Nolens' voorstel aan te nemen was in Limburg belangrijk nieuws, het bericht werd diezelfde dag nog in Maastricht per bulletin bekendgemaakt door de Limburger koerier.

Zowel in 1864 als in 1908-1909 sneuvelde het voorstel tot accijnsverhoging met hartelijke medewerking van de Limburgse afgevaardigden. Nu was in beide gevallen een grote kamermeerderheid tegen het voorstel. Een verklaring voor het gegeven dat de Limburgse kamerleden in 1864 wél en in 1908-1909 géén behoefte voelden om hun verzet met expliciete voorbeelden uit hun provincie te staven, kan dan ook niet gevonden worden in de moeite die men al dan niet moest doen om de voorstanders van de accijnsverhoging te overtuigen. Nieuw is wel het politieke motief dat Nolens en zijn collega-afgevaardigden uit Limburg ervan weerhield om zich bij de stemming openlijk tegen de wet te verklaren: hun loyaliteit tegenover het zittend kabinet maakte een dergelijke daad ongewenst. ${ }^{129}$

Dat de belangenbehartiging niet zichtbaar was, wil niet zeggen dat zij minder belangrijk werd gevonden. $\mathrm{Al}$ in de jaren zestig had Thorbecke geschreven (naar aanleiding van de verhoging van de grondbelasting): 
Dat men in Limburg aanstonds de hoogste registers heeft uitgehaald, is mij zeer leed; men heeft daardoor tegemoetkomingen niet gemakkelijk gemaakt. ${ }^{130}$ Stille(re) diplomatie had volgens de liberale voorman meer kunnen bewerkstelligen. ${ }^{131}$ Een hieruit voortvloeiend verwijt moet niet in de laatste plaats aan het adres van de Limburgse kamerleden gericht worden. Zij immers hadden het vlammend protest uit Limburg in alle openbaarheid in Den Haag brandende gehouden.

\section{Met last en ruggespraak}

Het verzet van de Limburgse kamerleden tegen het Nederlandse belastingstelsel is niet los te zien van de onvrede die in de provincie zelf heerste. In de jaren veertig vormden de belastingen er een van de voornaamste bezwaren tegen het Nederlandse bewind. ${ }^{132}$ In een opruiend Klaaglied van Limburg, dat in december 1848 in diverse Limburgse gemeenten ten gehore werd gebracht door een rondtrekkende zanger, vormden de belastingen het voornaamste ingrediënt. Diens schoonvader - nota bene veldwachter van beroep - werd ervan verdacht het lied te hebben geschreven. Hij was, hangende het onderzoek, onmiddellijk op non-actief gesteld, rapporteerde gouverneur Gericke van Herwijnen aan minister Schimmelpenninck van der Oye van Binnenlandse Zaken. ${ }^{133}$

De fiscale lasten bleven de gemoederen bezighouden, getuige de commotie die in de jaren zestig ontstond bij de verhoging van de grondbelasting. De verkiezingsoverwinning van De Keverberg de Kessel in 1864 is er zelfs direct aan toe te schrijven. En ook tijdens het carnaval van 1861 was de belastinginning weinig populair gebleken: in Maastricht had Momus, een vereniging die onder meer actief was rondom carnaval, het optreden van de belastingambtenaren op de hak genomen, tot ergernis overigens van bedoelde overheidsdienaren. ${ }^{134}$ Aan het einde van de eeuw heerste er onder de Limburgers nog altijd ontevredenheid. Het was dan ook niet voor niets een kiezersvergadering waarop Ruijs van Beerenbroek zich in 1892 keerde tegen het bestaande fiscale stelsel. De belangen van zijn kiezers waren bovendien door de census - tot 1896 de enige toegang tot het actief kiesrecht - rechtstreeks verbonden met de belastingen.

De belangstelling waarin het Nederlandse belastingstelsel zich in Limburg mocht verheugen, zien we terug in de bemoeienissen van de provinciale politiek met fiscale kwesties. De Limburgse grieven werden door Provinciale en Gedeputeerde Staten regelmatig op papier gezet en naar Den Haag gestuurd. Het recht om klachten door middel van een verzoekschrift- 
ook wel een adres genoemd - kenbaar te maken, ontleende ht provinciaal bestuur aan de grondwet. Hierin was immers bepaald dat $\mathrm{F}$, met in hun verlengde Gs, 'de belangen van hunne provincien en derzelve ingezetenen' bij de koning en bij de Staten-Generaal mochten voorstaan. ${ }^{13}$ De vraag was echter wel waar de provinciale belangen ophielden en wanner het een louter nationale aangelegenheid betrof; provinciale besturen dienden zich dan afzijdig te houden. Gedurende de gehele negentiende eeuw ileef daarover verschil van opvatting bestaan. ${ }^{136} \mathrm{Naar}$ aanleiding van een eeder genoemd adres van Gedeputeerde Staten van Limburg inzake de belastigwet van Van Hall belandde de kwestie van de begrenzing van de bemoeienssen door een provinciaal bestuur in de ministerraad. Gouverneur Gericke un Herwijnen kreeg een stevige reprimande omdat hij zich samen met de gdeputeerden had gekeerd tegen een zaak van algemeen landsbelang; konng Willem n wilde hem zelfs ontslaan! ${ }^{137}$ Het was immers niet aan provnciebesturen om zich bezig te houden met wetsontwerpen, zo had Willen $\mathrm{I}$ al in 1829 laten weten. ${ }^{138}$ Wellicht met deze kwestie in het achterhoofi trachtte een van Gericke van Herwijnens opvolgers, Van Meeuwen, een antal keren te

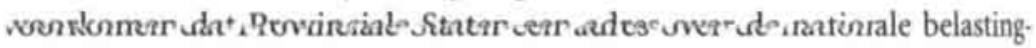
wetgeving naar de koning zouden sturen: in 1850 een verzoekschrift waarin gepleit werd voor een algehele herziening van het fiscale stelsel en zes jaar later een adres met betrekking tot de personele belasting. Over dit laatste onderwerp zei de Commissaris des Konings aan de statenleden dat het niet behoorde 'tot de werkkring dezer vergadering.' ${ }^{139}$

De Staten-Generaal waren echter geneigd om de begrenzing van hetgeen zij rekenden tot de provinciale belangen ruim te trekken. Als het gaat om de belastingen, heeft met name het provinciaal bestuur van Limburg van de geboden ruimte geprofiteerd, zo blijkt aan de hand van de registers op de Handelingen. Uit de overzichten van de bij de Staten-Generaal ingekomenen behandelde verzoekschriften voor de jaren 1840-1918, blijkt dat Provinciale en Gedeputeerde Staten van Limburg van alle provinciebesturen verreweg de meeste petities naar Den Haag hebben gezonden. Elf van de zestien bij het parlement ingekomen adressen zijn afkomstig uit Maastricht. ${ }^{140}$ Meet dan bij andere provincies werden via het petitierecht de bemoeienissen van het Limburgse bestuur met de belastingwetgeving openbaar. Voor TweedeKamerlid Corneli had het provinciebestuur ook een taak als het ging om het fiscaal beleid. Bij een kamerdebat in de jaren veertig gaf hij te kennen een aantal denkbeelden te hebben over de accijnsheffing, maar alvorens die in de openbaarheid te brengen, eerst de opvattingen van Gedeputeerde Staten te willen vernemen. ${ }^{141}$ 
De behoefte bij provinciale politici om zich bezig te houden met fiscale kwesties, blijkt te meer uit de notulen van de vergaderingen van Provinciale Staten. Bij de wetsontwerpen die eerder zijn genoemd, kan een scheiding worden aangebracht tussen de (acht) voorstellen die vóór 1870 op de Haagse agenda verschenen en de (vier) voordrachten die na dat jaar werden voorgelegd aan de Staten-Generaal. Terwijl de wetsontwerpen uit de jaren veertig, vijttig en zestig met slechts één uitzondering aan de orde kwamen tijdens de zittingen van PS, gebeurde dit bij geen van de voorstellen uit de jaren die volgden. Als we hierbij de adressen betrekken die door Provinciale of Gedeputeerde Staten naar Den Haag werden gezonden, dan kan worden vastgesteld dat de openlijke bemoeienissen door het provinciaal bestuur met de landelijke belastingwetgeving hoofdzakelijk te vinden zijn in de jaren tussen 1840 en 1870 .

De klachten die in deze periode vanuit de provincie kenbaar werden gemaakt, hadden duidelijk invloed op haar afgevaardigden in Den Haag. Zoals we in hoofdstuk 4 zagen, voelde Tweede-Kamerlid De Bieberstein zich ten gevolge van de indiening van het wetsontwerp tot verhoging van de grondbelasting (1865) 'lusteloos en zwaar moedend'. De grote commotie die in Limburg was ontstaan, was hieraan debet, schreef de baron. ${ }^{142}$

Soms leken de Limburgse volksvertegenwoordigers hun parlementaire handelingen uitsluitend te verrichten met het oog op het ontevreden thuisfront. Zo verlangden alle Limburgse leden van de Staten-Generaal in 1844 bij de belastingwet van Van Hall aantekening in de notulen dat zij tegen waren. Voor de uitslag van de stemming was deze aantekening van geen enkele betekenis, maar de buitenwereld zou zo wel duidelijk kunnen kennisnemen van hun opvatting. Een tweede voorbeeld treffen we aan in het finale debat over de verhoging van de grondbelasting in Limburg. Al enige tijd was toen duidelijk dat een overgrote meerderheid in het parlement van harte akkoord zou gaan. Desondanks hielden de Limburgse afgevaardigden in zowel Tweede als Eerste Kamer uitgebreide vertogen. Hun toespraken waren bij voorbaat verloren moeite als zij tot doel hadden om collega-kamerleden te overtuigen. De woordenvloed zal daarom veeleer zijn voortgekomen uit de wens - of wellicht beter: uit de politieke noodzaak - om de Limburgse klachten voor de eigen achterban nog eens duidelijk in Den Haag neer te leggen.

Ook de regering en haar hoogste vertegenwoordiger in de provincie konden zich niet altijd onttrekken aan de publieke opinie. Zo was het regeringsvoornemen van mei 1848 om de accijnzen te verlagen een tegemoetkoming aan een van de voornaamste grieven die in de Limburg leefden. Ook 
de belofte van minister Betz inzake de grondbelasting, begin jaren zestig, kwam tegemoet aan een belangrijke wens van de Limburgse bevolking. Gouverneur Gericke van Herwijnen durfde in 1844 een protest van Gedeputeerde Staten tegen de belastingwet van Van Hall, gericht aan de koning en aan de Tweede Kamer, niet tegen te houden uit angst cat zijn toch al geringe populariteit bij de Limburgers verder zou afkalven ${ }^{143}$ Nota bene. de gouverneur was voor de continuering van zijn ambt niet afhankelijk van de kiezersgunst; leden van de Staten-Generaal daarentegen - tot 1849 alleen voor zover het de Tweede Kamer betrof - waren dat wel.

De kamerleden uit Limburg wilden of konden de uit Maastricht binnengekomen verzoekschriften meestal niet onbesproken laten. 'Heel Limburg' was in 1844 tegen de plannen plannen van Van Hall. ${ }^{14}$ Gedeputeerde Staten verwoordden dit verzet door petities te sturen aan de koring en aan de Tweede Kamer. Op voorstel van de commissie voor de verzockschriften van de Kamer werd het laatste rekwest ter inzage gelegd. Kamertd Corneli had daar weliswaar niets tegen, hij meende echter dat het adres - immers afkomstig van 'het wettig orgaan der provincie' - meer aandacht vendiende. En dus beval hij het stuk nog eens van harte aan bij de aanwezige ministers. Gedeputeerde Staten spraken in dit protest over de 'bijzondere omstandigheden' waarin Limburg verkeerde; omstandigheden die de provincie volgens hen vrij pleitten van de voorgestelde belasting. ${ }^{145}$ De drie Limburgse leden van de Tweede Kamer gebruikten vervolgens dezelfde argumentatie in het debat over het wetsontwerp.

Een ander heikel punt vormde de belofte van de regering om iets te doen aan de hoogte van de accijnzen. Bij een bezoek aan Den Haag hadden de Gedeputeerden al laten weten het 'zeer onaangenaam en grievend' te vinden dat deze toezegging die zij nota bene 'op uitnodiging en in naam der Hooge Regering' aan de ingezetenen hadden gedaan, tot dan toe zonder gevolg was gebleven. ${ }^{146}$ In juli 1849 besloten Provinciale Staten de koning te verzoeken de ook namens hem gedane belofte na te komen. Genoemde belastingen veroorzaakten 'algemeene ellende in dit gewest', werd Willem In voorgehouden en 'de onheilen zijn niet te berekenen.' ${ }^{147}$ Het adres zou onbeantwoord blijven, maar Eerste-Kamerlid Beerenbroek zocht datzelfde jaar aansluiting bij het verzoekschrift. Hij benadrukte dat de tekst met eenparigheid van stemmen was aangenomen: de klachten van de Limburgse Staten moesten daarom serieus genomen worden. Beerenbroek toonde zich overigens goed op de hoogte van de beraadslagingen in de provinciale volksvertegenwoor diging. Hij maakte de Kamer erop attent dat het adres eigenlijk door een afvaardiging uit de Staten aan de koning zou zijn aangeboden 'om het 
groot belang der zaak te doen uitkomen', ware het niet dat daarvan uit een oogpunt van kostenbesparing was afgezien. ${ }^{148}$

Louis Beerenbroek nam overigens een bijzondere positie in bij deze kwestie. Hij speelde namelijk een politiek één-tweetje met zijn oudere broer Petrus, lid van Provinciale Staten. Tijdens een parlementair debat in februari 1849 herinnerde kamerlid Beerenbroek de regering eraan dat zij toezeggingen had gedaan aan de Limburgse bevolking over het afschaffen van de accijnzen op granen, slachtvee en brandstoffen; en belofte maakte schuld. ${ }^{149}$ Zijn broer in Maastricht zette deze eis daarna kracht bij door tijdens de eerstvolgende vergadering van Ps, in juli, samen met anderen het initiatief te nemen om een verzoekschrift over de kwestie aan de koning te richten. ${ }^{150}$ Van dit adres werd vervolgens weer dankbaar gebruik gemaakt door het familielid in Den Haag, dat in december wederom aandrong op afschaffing van genoemde accijnzen, dit keer steun zoekend bij het verstuurde verzoekschrift. Het kon de regering nu immers niet langer onbekend zijn hoe Limburg over de materie dacht, aldus Beerenbroek in de Kamer. ${ }^{151}$

Een jaar later, in 1850, speelden Provinciale Staten eveneens een belangrijke rol in de formulering van de Limburgse klachten. Unaniem werd besloten om wederom bij de koning te gaan pleiten voor afschaffing van de accijnzen op graan, slachtvee en brandstoffen. Nu werd wel een commissie naar het paleis gezonden. De kosten van deze reis waren nog steeds bezwaarlijk hoog, maar voor dat probleem was nu een oplossing bedacht: de viff commissieleden moesten de reis zelf financieren, zo vermelden de notulen. ${ }^{152}$ Deze provinciale delegatie kon in Den Haag weer rekenen op ondersteuning in de Staten-Generaal. 'Deze door de afgevaardigden uit Limburg gedane poging ondersteun ik bij de Regering ten sterkste', aldus TweedeKamerlid De Lom de Berg. ${ }^{153}$ Effect had het pleidooi van Provinciale Staten niet en zij droegen Gs een jaar later dan ook op om bij de beide Kamers der Staten-Generaal 'hernieuwde pogingen' te doen om de gehate accijnzen afgeschaft te krijgen. ${ }^{154}$ Bij de begrotingsbehandeling voor 1852 - de beide kamervoorzitters hadden niet lang daarvoor melding gemaakt van de binnenkomst van de adressen - namen vier afgevaardigden uit Limburg het woord om te pleiten tegen de accijnzen. ${ }^{155}$ Een van hen, Tweede-Kamerlid Borret, wees daarbij op de herhaalde malen dat het provinciaal bestuur in Maastricht de kwestie al onder de aandacht van de koning had gebracht. ${ }^{136}$ Bijzonder actief waren de provinciale politici bij de (dreigende) verhoging van de grondbelasting in Limburg, eind jaren vijftig, begin jaren zestig. Vijf verzoekschriften arriveerden bij de Staten-Generaal. De grote opschudding die in Provinciale Staten ontstond over het wetsontwerp, is 
recht evenredig met de energie die de Limburgse kamerleden staken in hun verzet tegen de regeringsplannen.

Uit de notulen van Provinciale Staten wordt ook duidelijk dat de statenleden van de Limburgse politici in Den Haag verwachtten dat zij de belangen van hun provincie zouden voorstaan. Zo gaf Jan Hendrik Arnoldts - later zelf lid van de Tweede Kamer - de Limburgse kamerleden in de najaarsvergadering van 1857 een duidelijk stemadvies: hij sprak de wens uit dat zij het wetsontwerp inzake de personele belasting zouden weten tegen te houden. Dit zou inderdaad gebeuren: alle Limburgse leden stemden tegen en zorgden er daardoor mede voor dat het ontwerp werd verworpen. Viff jaar eerder had een van de statenleden aangegeven het niet eens te zijn met het stemgedrag van sommige Limburgse parlementariërs. ${ }^{157}$

Dat statenleden de Limburgse afgevaardigden in Den Haag een taak toebedeelden in het verkrijgen van een adequate wetgeving voor hun provincie, bleek ook in 1856 . Oud-Eerste-Kamerlid De Rijk deed toen samen met onder anderen toekomstig Tweede-Kamerlid Haffmans het voorstel de regering te verzoeken de personele belasting in een meer bij Limburg passende regeling te gieten. Tuen de vigerende wet op de personele belasting van kracht werd (1833), had Limburg ten gevolge van de Belgische opstand immers 'geene afgevaardigde in de Wetgevende Kamers der Staten-Generaal van Nederland die onze bezwaren en regten konden doen kennen'.158 Provinciale Staten hadden bij de formulering van deze 'bezwaren en regten' een voorname taak, aldus oud-Tweede-Kamerlid Thissen ruim een halfjar later. Hij wees toen op het gevaar dat kleefde aan een adres dat niet op brede ondersteuning vanuit Provinciale Staten zou kunnen rekenen. Het betrof een bij PS ingekomen verzoek van Petrus Regout en anderen om te trachten het wetsontwerp tot herziening van de in- en uitvoerrechten in bepaalde zin te wijzigen. De notulen vermelden: 'Wij zouden, zegt spreker. onze afgevaardigden in de Kamers der Staten-Generaal alligt in eene verkeerde positie brengen.'159 De Limburgse kamerleden waren volgens hun oud-collega dus gebaat bij eenduidige uitspraken uit Maastricht. En vaker dan vanuit andere provinciale hoofdsteden bereikten die uitspraken Den Haag.

Op het terrein waarop de meeste Limburgse kamerleden actief waren, de Nederlandse belastingen, kenmerkten hun handelingen zich door eenheid en consistentie. Het meest fundamentele bezwaar tegen het fiscale stelsel richtte zich op de ongelijke verdeling van de lasten over het grondbezit enerzijds en het kapitaal in portefeuille anderzijds. 
Bij het uiten van hun kritiek namen de kamerleden uit Limburg tot in de jaren tachtig meermaals een bijzondere positie in. Dat hun provincie de enige was die - tot 1869 - aanspraak kon maken op een fiscale status aparte inzake de grondbelasting, heeft sterk bijgedragen aan deze uitzonderingspositie. Door deze bijzondere belastingstatus kwamen zij welhaast als vanzelf tegenover de (meeste) andere afgevaardigden te staan. Mede daardoor voelden zij zich vaak geroepen om de vigerende wetgeving met passie te verdedigen; de financiële belangen die op het spel stonden en die uitsluitend voor hun provincie golden, waren bovendien groot. Ook in gevallen warin er geen sprake was van separate wetgeving trachtten Limburgse kamerleden hun mede-afgevaardigden te overtuigen van het exceptionele van hun provincie, daaruit soms het recht afleidend op een buitengewone regeling voor Limburg.

Als het ging om de rijksbelastingen, stelde de provinciale politiek zich actief op. Met name in de jaren veertig, vijftig en zestig speelden Provinciale en Gedeputeerde Staten van Limburg een voorname rol in het formuleren van klachten over de fiscale lasten. $\mathrm{Zij}$ schroomden niet hun opvattingen ter zake met regelmaat - vaker dan hun collega's in de andere provincies - aan de koning en de Staten-Generaal kenbaar te maken. Van de Limburgers in Den Haag werd verwacht dat zij de belangen van hun gewest in de landelijke politiek probeerden veilig te stellen. De druk die daarmee op de kamerleden werd gelegd, was veelal groot. En zoals werd opgemerkt in de eerste bijdrage door een Limburgse afgevaardigde aan de parlementaire debatten: de zaak werd daardoor van te groot gewicht om het stilzwijgen te bewaren. Deze geluiden vanuit de provinciale politiek zullen niet slechts medebepalend zijn geweest voor de handelingen van de Limburgse kamerleden; zij hadden ook invloed op hun imago. Want door zich - veelal uitdrukkelijk - te conformeren aan de uit Maastricht gehoorde klachten, kon het beeld van provinciale belangenbehartigers alleen maar worden versterkt.

In de periode na 1870 werd Limburg tijdens de parlementaire debatten verbaal minder uitdrukkelijk op de voorgrond geplaatst. Dat de afgevaardigden uit Maastricht, Roermond en Boxmeer in 1881 toch weer te identificeren waren als Limburgers, was dan ook niet zozeer te danken aan hun redevoeringen, maar aan de veranderde politieke verhoudingen. Terwijl deze verhoudingen, met name de katholieke samenwerking, er toen voor zorgden dat zij als groep herkenbaar werden, maakten diezelfde verhoudingen het soms wenselijk om een provinciale opstelling meer te verhullen. De kamerleden uit Limburg verloren de fiscale belangen van hun provincie echter nimmer uit het oog. 



\section{'De naam van "Limburgsch vertegenwoordiger"'}

Indien we ons richten op de koninklijke woorden die bij aanvang van een nieuw parlementair jaar werden gericht tot onder anderen de Limburgse leden van de Staten-Generaal, dan lijkt er in het tijdvak 1839-1918 weinig verandering te hebben plaatsgevonden in de verhouding tussen hun provincie en (overig) Nederland. Koning Willem II sprak in 1840 van 'gemeenschap' en zijn kleindochter, koningin Wilhelmina, bijna tachtig jaar later van 'eenheid'.'

Vit hoofde van zijn functie paste het Willem n de saamhorigheid in zijn koninkrijk te bevorderen. Het is daarom begrijpelijk dat hij in de troonrede voorbijging aan de weinig enthousiaste stemming onder de Limburgse bevolking over de terugkeer onder Nederlands gezag. De woorden van de koning zullen vooral een zalvend doel gediend hebben: de Limburgers het gevoel geven welkom te zijn in hun nieuwe vaderland. Bijna tachtig jaar later sloot de troonrede beter aan bij de publieke opinie in Limburg. De band met Nederland was na 1839 hechter geworden en de in Limburg aanwezige separatistische krachten konden in de twintigste eeuw dan ook op veel minder bijval rekenen dan in de jaren veertig.

Ingeval de aanduiding 'Limburgsch vertegenwoordiger' een hoge mate van representativiteit wil impliceren, dan komt zij op dit punt niet te pas, atthans niet bij voortduring. Bezien we de houding van de Limburgse kamerleden op momenten waarop de staatkundige positie van hun provincie op de politieke agenda verscheen, dan blijken deze afgevaardigden telkens in duidelijke meerderheid voorstander te zijn geweest van een plaats van Limburg binnen het Nederlandse staatsverband. Zelfs toen er in de jaren 1843-1844 en 1848-1849 een krachtige afscheidingsbeweging in de provincie actief was, kwamen separatistische geluiden nauwelijks naar voren via de Limburgse afgevaardigden in Den Haag.

Deels was dit inherent aan de aard en positie van de Nederlandse volksvertegenwoordiging. Het parlement van de staat waarvan men zich wilde afscheiden, nodigde niet uit tot het innemen van standpunten die als 'onvaderlandslievend' konden worden ervaren, te meer daar de kamerleden door een eed van trouw aan die staat waren gebonden. De vijandige houding die de van onvaderlandslievendheid verdachte Limburgse afgevaardigde Henri 
van Groenendael in 1919 in de Tweede Kamer ten deel viel, is in dit verband illustratief. Dat separatistische geluiden vanuit Limburg nauwelijks doordrongen tot de beide Kamers hing ook samen met de plaats die de StatenGeneraal innamen in het politieke krachtenveld: belangrijke beslissingen over de staatkundige toekomst van Limburg werden buiten de Kamers om genomen, vaak zelfs buiten Nederland. De afscheidingsbeweging legde haar prioriteiten dan ook niet in Den Haag.

De geringe mate van representativiteit die de Limburgse bijdrage aan het parlementaire bedrijf in de jaren veertig kenmerkte, vond haar oorzak eveneens - en voor een belangrijk deel - in het kiesstelsel. Enerzijds was de wettelijke toedeling van het kiesrecht nadelig voor de achterban van de afscheidingsbeweging, anderzijds bemoeide de Nederlandse regering zich voortdurend en niet zonder succes met de vraag wie vanuit Limburg zou worden afgevaardigd. De komst van Nederlandsgezinde parlementarièrs naar Den Haag werd daardoor bevorderd.

Dat de Limburgse kamerleden relatief sterk op Nederland waren geori. enteerd, dat wil zeggen in vergelijking met de bevolking die hen afvaardigde, hing daarnaast samen met de mate van ontvankelijkheid voor de krachten die het integratieproces bevorderden. Met name landelijke politici waren gevoelig voor de katalysatoren in deze ontwikkeling. Internationale verhoudingen en Europese conflicten speelden een niet-onbelangrijke rol bij het integratieproces dat de Limburgers doorliepen. Zo werd de band met Nederland versterkt door het falen van het Duitse eenheidsstreven eind jaren veertig, de onzekere toekomst van België (het meest gefavoriseerde alternatieve vaderland) in de jaren zestig, de angst voor de expansiedrift van Pruisen in de jaren zeventig en de neutrale positie van Nederland tijdens de Eerste Wereldoorlog. Bij uitstek kamerleden waren op de hoogte van de internationale situatie, van de (on)mogelijkheden om van nationaliteit te wisselen en van de voor- en nadelen daarvan. Dit gold al helemaal voor prominente Limburgse afgevaardigden zoals jhr. Paul van der Maesen de Sombreff, die voorafgaand aan zijn kamerlidmaatschap minister van Buitenlandse Zaken was geweest, en de invloedrijke Willem Nolens, die zich tijdens zijn lidmaatschap van de Tweede Kamer geregeld in internationale kringen bewoog.

Bij de oriëntatie op Nederland speelde verder een rol dat de Limburgse leden van de Staten-Generaal - gelijk andere provinciegenoten uit de maatschappelijke bovenlaag - hun opleiding steeds vaker aan Nederlandse instellingen voor hoger en academisch onderwijs hadden genoten. Daar komt bij dat diverse Limburgers in de latere jaren leidinggevende posities hadden 
weten te verwerven, met name via een van de grootste 'fracties' in de $\mathrm{Ne}$ derlandse politiek, de katholieke kamerclub. Vanuit carrièreperspectief was het voor hen weinig aanlokkelijk zich te begeven in een onzeker avontuur van een nationaliteitswisseling.

We zien dan ook dat de politiek-bestuurlijke elite waaruit de Limburgse kamerleden veelal werden gerekruteerd, in de loop der jaren een 'zelfcorrigerend vermogen' ontwikkelde: terwijl de Nederlandse gezindheid van de Limburgse kamerleden in de jaren veertig vanuit Den Haag nog een handje moest worden geholpen door bemoeienissen bij verkiezingen, namen de Limburgse politici de kwestie in de twintigste eeuw zelf ter hand door bijvoorbeeld te verhinderen dat een (vermeend) separatist als Van Groenendael zou worden herkozen.

Bovendien verzoenden de inwoners - en daarmee de kiezers - van Limburg zich tussen 1839 en 1918 meer en meer met hun Nederlandse nationaliteit. De regelmatige uitbreiding van het actief kiesrecht vormde daardoor geen grote bedreiging voor het doorgaans anti-separatistische gedachtegoed van het Limburgse smaldeel in de Staten-Generaal.

Wat betreft sociale achtergrond, leeftijd en parlementaire ervaring waren de verschillen tussen de Limburgers in Den Haag en hun collega-parlementariers niet opvallend groot. De Limburgse afgevaardigden waren nagenoeg zonder uitzondering rooms-katholiek, hetgeen gelet op de religieuze samenstelling van de Limburgse bevolking weinig verrassend kan worden genoemd. Het Limburgse part in de Staten-Generaal kenmerkte zich in de latere decennia door een bovengemiddeld aandeel van de adel. Wat betreft de opleiding, was het percentage academisch geschoolde TweedeKamerleden uit Limburg tussen 1888 en 1918 lager dan het landelijk gemiddelde. De Limburgse afgevaardigden sloten daarmee aan bij de volksvertegenwoordigers die evenals zij behoorden tot de emancipatorische 'partijen'.

Als de Limburgse kamerleden ergens naam mee lijken te hebben gemakt, dan is het wel met hun geringe deelname aan de parlementaire werkzaamheden. Dit oordeel - vaak geformuleerd als verwijt - is te generaliserend. Gemiddeld waren zij weliswaar minder frequent aanwezig dan een doorsnee Nederlands kamerlid, de Limburgers laten hierbij grote onderlinge verschillen zien. Een aantal van hen was in alle jaren, waarin zij zijn onderzocht, vaker aanwezig dan de gemiddelde volksvertegenwoordiger. Ook wanneer gekeken wordt naar hun inbreng bij parlementaire beraadslagingen, treden duidelijke onderlinge verschillen aan het licht. Deson- 
danks komen de Limburgse afgevaardigden op het punt van participatie in de parlementair-historische literatuur meermaals als een te onderscheiden groep naar voren.

De naam van 'Limburgsch vertegenwoordiger' kwam in de jaren tussen 1839 en 1918 bij voortduring te pas indien we de verbondenheid van de afgevaardigden met Limburg bezien, geboorteplaats, woonplaats en doorlopen carrière als criteria nemend. Zij onderhielden, met Johan Rudolf Thorbecke (district Maastricht, 1853-1856) als enige uitzondering, allen een band met Limburg, hoewel de mate van binding wel kon verschillen. Indien er zich een kandidaat-kamerlid van buiten Limburg meldde, hetgeen niet vaak voorkwam, dan kon hij erop rekenen dat zijn opposanten zich niet zelden lieten inspireren door zijn vermeende gebrek aan binding met de provincie.

Kijken we naar de geboorteplaats van de afgevaardigden, dan kan worden vastgesteld dat Limburg zich in de tachtig onderzochte jaren steds meer kenmerkte door een gesloten karakter: meer en meer waren de ka. merleden die vanuit Limburg werden afgevaardigd, ook in die provincie geboren. Limburg onderscheidde zich hiermee van het eveneens katholicke Noord-Brabant. Terwijl Noord-Brabant vanaf de laatste decennia van de negentiende eeuw katholieken van buiten de provincie regelmatig in de gelegenheid stelde een parlementszetel in te nemen, vaardigde Limburg slechts personen af die een duidelijke band hadden met de provincie.

Naast een traditionele gerichtheid op de eigen regio - en waarschijp. lijk deels daarmee samenhangend - speelde een rol dat de katholieken in Limburg politiek minder goed georganiseerd waren dan in Noord-Brabant. In deze laatste provincie werd al in 1870 de kiesvereniging Noord-Brabant opgericht, die zich in alle kiesdistricten van de provincie bezighield met het benoemen van een 'officiële' katholieke kandidaat. De katholieke kiesverenigingen kwamen in Limburg later van de grond en kenmerkten zich geregeld door interne strijd. Daardoor was het organisatorisch vaak moeilijk om katholieken van boven de grote rivieren succesvol te kandideren in een van de Limburgse districten.

Bij de selectie van kamerleden betekende de focus op de eigen regio eerder een gerichtheid op de eigen streek dan op de provincie in haar geheel. Hoewel het Limburgerschap belangrijk was in verkiezingscampagnes, kozen de kiesgerechtigden in Limburg primair voor streekgenoten. Bij menis Limburgs kiezer bestond er in de eerste decennia na de vorming van zijn provincie ook nog geen Limburgs zelfbewustzijn. De ontwikkeling van een 
dergelijk gevoel speelde zich in die jaren uitsluitend af in kringen van de matschappelijke elite. Terwijl Limburg voor veel notabalen al een gezicht had, was de provincie voor menig ander kiezer nog van weinig betekenis. Vanaf het einde van de negentiende eeuw verspreidde het Limburgs zelfbewustzijn zich over bredere lagen van de bevolking, waarbij de houding en het beleid van de bisschoppen van Roermond een belangrijke stimulans vormde.

Behorend tot de maatschappelijke elite hielden de Limburgse afgevaardigden in Den Haag zich relatief vroeg bezig met de eigen identiteit van hun provincie. Het latere Tweede-Kamerlid Everts schreef al in 1857 een Limburgs volkslied en veel kamerleden uit de jaren zestig werden lid van het toen opgerichte Oudheidkundig Genootschap in het Hertogdom Limburg, een organisatie waarvan de beginselverklaring mede stoelde op gewestelijk nationalisme.

Bij de ontwikkeling van een Limburgs zelfbewustzijn zagen de afgevaardigden in Den Haag zich bovendien in een bijzondere positie geplaatst: bij uitstek zij kregen te maken met de eigenaardige situatie waarin hun provincie zich bevond. Door hun functie werden zij regelmatig geconfronteerd met de eenheid die Limburg op allerlei gebied vormde, een eenheid waarmee andere Limburgers veel minder expliciet in aanraking kwamen. De proloog werd gevormd door de discussies die in het voorjaar van 1840 in de Tweede Kamer werden gevoerd over de wenselijkheid van de wederopname van Limburg in het Nederlandse staatsverband en over het moment waarop de afgevaardigden uit die provincie (eventueel) weer welkom zouden zijn in de Staten-Generaal. In de jaren veertig en vijftig werd vervolgens tot driemaal toe gedebatteerd in het parlement over de volwaardigheid van het Nederlanderschap van Limburgers.

Daarnaast werden de kamerleden uit Limburg regelmatig en uitdrukkelijk uitgenodigd zich te buigen over de exceptionele positie waarin hun gewest zich bevond, doordat regelgeving die daaraan ten grondslag lag of die daaruit voortvloeide op de parlementaire agenda verscheen. In dit kader kan gewezen worden op het lidmaatschap van de Duitse Bond (tot 1867), het afzonderlijk fiscaal regime met betrekking tot de grondbelasting (tot 1869 ) en de bijzondere verhouding tussen Kerk en staat ten gevolge van een uit 1809 stammend keizerlijk decreet (tot 1876). De staatkundige positie van Limburg hield de parlementaire gemoederen nog in de periode rondom het einde van de Eerste Wereldoorlog bezig.

Deze kwesties, waarbij telkens de status aparte van de provincie in het geding was, zetten de afgevaardigden uit Limburg veelal aan tot een provin- 
cialistische opstelling. Er stonden immers specifiek Limburse belangen op het spel. Deze houding werd hen door collega-parlementriërs vaak kwalijk genomen, met als gevolg dat zij des te meer onder de andacht kwam. Wanneer het ging om de band met Nederland, werd een provinciale profilering paradoxaal genoeg soms juist toegejuicht, want wiorden met etn anti-separatistische strekking wonnen aan betekenis indien zij afkomstig waren van een afgevaardigde uit de betrokken landstreek.

Nu waren de Limburgers niet de enige afgevaardigden lie oog hadden voor de belangen van hun gewest en dienovereenkomstig handelden. Toch kwam het provinciale element in hun presentatie uitdrukkelijker naar vo. ren dan bij andere volksvertegenwoordigers. $\mathrm{Zij}$ voelden diidelijk minder schroom om daarvoor uit te komen. Voortdurend meencen de Limburgers te ervaren dat hun provincie werd achtergesteld. Dit geoel bleef in de gehele periode (1839-1918) bestaan, of het nu ging om eenop staatkundig gebied pro of anti-Nederlands kamerlid.

'De inwoners van Limburg zijn Nederlanders aan Vors en Vaderland gehecht, doch tevreden zijn zij niet,' sprak Eerste-Kamerlii Gerard Johan de Rijk in $1849 .{ }^{2}$ Het openlijk uiting geven aan deze onvred door de Limburgse afgevaardigden werd gestimuleerd door hun (electorale) achterban. Wanneer het bijvoorbeeld ging om belastingen, toonde geen van de provinciebesturen zich zo betrokken als Provinciale en Gedeputeerde Staten in Maastricht. Zij zonden een relatief groot aantal verzoekschriften naar Den Haag. Bij het veiligstellen van de belangen van de provincie werden de Limburgse afgevaardigden in de Staten-Generaal geacht een vooruitgeschoven en uiterst belangrijke post te bezetten.

In de jaren zestig ontstond er bovendien een luid roepende oppositiebeweging in Limburg die de provinciale belangen op de voorgrond platste en die de verkiezingsstrijd beheerste. Charles Antoine baron de Bieberstein Rogalla Zawadsky (district Maastricht) verklaarde in de Tweede Kamer dat hij wel aandacht móést besteden aan de klachten die in Limburg werdengeuit, wilde hij zijn parlementaire zetel niet verliezen; de verkiezingsnederlaag in maart 1864 van Karel Cornelis (district Roermond) was het sprekende voorbeeld. ${ }^{3}$

Het optreden van deze 'Limburgsche oppositie' in de Tweede Kamer betekende een begin van een breuk in de relatie van de Limburgse kamerleden met Thorbecke en zijn liberalen. De kamerleden Edmond van Wintershoven (district Maastricht), Frederik baron de Keverberg de Kessel en later Leopold Haffmans (beiden district Roermond) zetten zich, met name ook 
tijdens de verkiezingscampagnes, af tegen het tweede kabinet-Thorbecke. Dit kabinet voerde een beleid dat, naar zij meenden, in het bijzonder voor Limburg zeer nadelig was.

De toenemende verwijdering tussen de Limburgse afgevaardigden en de liberalen had in eerste instantie een zeker politiek verwezen tot gevolg: terwill de Limburgers zich afwendden van de liberalen, jarenlang hun bondgenoten, sloten zij zich vooralsnog niet aan bij politici uit de overige landsdelen. Dit gebeurde wel weer ten tijde van het conservatieve kabinet-Van Zuylen van Nijevelt-Heemskerk (1866-1868). Toen gingen de (voormalige) Limburgse opposanten, geleid door Haffmans en samen met andere katholieke kamerleden, een bondgenootschap aan met de conservatieven in de Nederlandse politiek. Van lange duur was deze alliantie echter niet en dat kon zij ook niet zijn, omdat de conservatieve beweging spoedig in een neergaande spiraal verzeild raakte. Van een hechte katholieke samenwerking in de Kamer was vooralsnog geen sprake, hetgeen zich duidelijk openbaarde bij de behandeling van de rentewet in 1881 . De zes Limburgse TweedeKamerleden stelden zich toen lijnrecht op tegenover de overige katholieke afgevaardigden.

Indien we de politieke inbedding van de Limburgers in Den Haag bezien, met name van de afgevaardigden in de Tweede Kamer, dan was de aanduiding 'Limburgsch vertegenwoordiger' in de jaren vijftig en begin jaren zestig, ten tijde van het bondgenootschap met Thorbecke, minder van toepassing dan in de periode die volgde. Provinciaal particularisme nam in het politiek programma van de afgevaardigden die in de jaren zestig en zeventig de liberaal-katholieken vervingen, een zeer prominente plaats in. Vanaf de jaren tachtig temperde het samengaan met andere katholieken in een politiek verband - in latere jaren de katholieke kamerclub - bij de Limburgse kamerleden uitingen met een zuiver provincialistische strekking. Aan dit politiek georganiseerde katholicisme werden vanuit Limburg belangrijke bijdragen geleverd. Haffmans nam met zijn Venloosch Weekblad volop deel aan de discussies over de katholieke samenwerking, propageerde daarbij groepsvorming, en binnen het katholieke samenwerkingsverband namen Limburgers relatief vaak vooraanstaande posities in. In 1896 verenigden zij zich op een politiek programma dat uitdrukkelijk niet de provinciale, maar de katholieke belangen als uitgangspunt nam. Voor het kiesdistrict Boxmeer - tot 1888 maakten Limburgse gemeenten hier deel van uit - gold als bijzonderheid dat een Limburgse afgevaardigde, wilde hij kans maken op een herverkiezing, zich niet te zeer kon vervreemden van zijn NoordBrabantse geloofsgenoten in de politiek. Het district telde deels Noord- 
Brabantse kiezers en bovendien stelde de kiesvereniging Noord-Brabant er de katholieke kandidaat. Nadat de zes Limburgse Tweede Kamerleden zich bij de behandeling van de rentewet in 1881 hadden verwiderd van de overige katholieken in de Kamer, zag Haffmans zich dan ook genoodzakt tot een gang naar Canossa. Op een kiezersvergadering van ce vereniging Noord-Brabant legde hij enkele maanden later een verzoenende verklaring af; collega-kamerleden uit Limburg beschuldigden hem van gigoochel met standpunten.

Behalve dat de katholieke samenwerking noodzaakte tot een zekere loyaliteit, had zij nog op een andere wijze een remmende uitweking op het (openlijk) voorstaan van provinciale belangen. Door de plaa's die dit samenwerkingsverband in de Nederlandse politiek ging innemer, ontstonden er mogelijkheden om zaken buiten de openbaarheid te bepleien, zeker indien er politieke bondgenoten in de regering zitting hadden. Dit gold in het bijzonder voor een figuur als Nolens, die in de loop van de tid binnen de Nederlandse politiek een zeer vooraanstaande positie was gaal innemen.

Toch bleef Limburg ook volgens Nolens gediscrimineerd worden. De kwestie van de hevaarhaarheid van de Maas laat rien dat nravinciale belangen nimmer uit het oog werden verloren, ook niet door de Limburgse leden van de katholieke kamerclub. Daarmee sloten zij aan bij hun voorgangers uit Limburg. Gedurende de gehele periode 1839-1918 beklaagden Limburgse afgevaardigden zich immers over de achterstelling van hun provincie. Grondwettelijk gezien overschreden zij daarmee geregeld een grens, zo werd hun wel voorgehouden, onder anderen door Thorbecke die het gebruik van 'de naam van "Limburgsch vertegenwoordiger"' hekelde."Veel indruk lijken deze beschuldigingen niet te hebben gemaakt. Eerste-Kamerlid Louis Beerenbroek zei in 1850 tot zijn collega-afgevaardigden:

Het is waar, Mijne Heeren, de Grondwet houdt in, dat wij het Nederlandsche volk vertegenwoordigen, maar daaruit kan ik niet afleiden, dat wij ons behooren te onthouden de belangen dier ingezetenen voor te staan, welke wij door het dagelijksch verkeer meer bijzonder kunnen beoordeelen.

Zeker zolang de Limburgse volksvertegenwoordigers van oordeel waren dat hun provincie voor menig Haags beleidsmaker 'een terra incognita' was-het zijn woorden van Nolens uit december $1900^{6}$-, voelden zij, bij de behartiging van de Limburgse belangen, een bijzondere verantwoordelijkheid. 


\section{Bijlagen}

BIJLAGE I

\section{Uitslag van de stemming onder zuidelijke notabelen over de grondwet van 1815}

Arrondissementen in absolute aantallen; (latere) provincies in percentages.

De namen van de arrondissementen waarin een meerderheid zich uitsprak voor de grondwet, zijn cursief weergegeven.

\begin{tabular}{|c|c|c|c|c|c|}
\hline \multicolumn{3}{|c|}{$\begin{array}{l}\text { Arrondissementen gevolgd } \\
\text { door de provincie die zij }\end{array}$} & \multicolumn{3}{|c|}{$\begin{array}{l}\text { Arrondissementen gevolgd } \\
\text { door de provincie die zij }\end{array}$} \\
\hline zouden gaan vormen & Voor & Tegen & zouden gaan vormen & Voor & Tegen \\
\hline Lewven & 30 & 24 & Bergen & 32 & 36 \\
\hline Brussel & 40 & 45 & Doornik & 9 & 75 \\
\hline Nijvel & 12 & 25 & Charleroi & 20 & 20 \\
\hline ZUID-BRABANT & $46,6 \%$ & $53,4 \%$ & HENEGOUWEN & $31,8 \%$ & $68,2 \%$ \\
\hline Roermond & 32 & 0 & Antwerpen & 0 & 59 \\
\hline Maastricht & 39 & 12 & Mechelen & 5 & 33 \\
\hline Hasselt & 25 & 7 & Turnhout & 1 & 34 \\
\hline LIMBURG & $83,5 \%$ & $16,5 \%$ & ANTWERPEN & $4,5 \%$ & $95,5 \%$ \\
\hline Luik & 38 & 31 & Namen & 1 & 31 \\
\hline Verviers & 31 & 0 & Dinant & 15 & 0 \\
\hline Hoei & 11 & 14 & Marche et St. Hubert* & 12 & 10 \\
\hline LUIK & $64,0 \%$ & $36,0 \%$ & NAMEN & $40,6 \%$ & $59,4 \%$ \\
\hline Eecloo & 13 & 5 & Luxemburg & 35 & 0 \\
\hline Gent & 10 & 70 & Neufchateau & 27 & 0 \\
\hline Oudenaarde & 20 & 37 & Diekirch & 11 & 0 \\
\hline Dendermonde & 24 & 56 & LUXEMBURG & $100 \%$ & $0 \%$ \\
\hline OOST-VLAANDEREN & $28,5 \%$ & $71,5 \%$ & & & \\
\hline Brugge & 26 & 39 & & & \\
\hline Veurne & 4 & 12 & & & \\
\hline leperen & 0 & 50 & & & \\
\hline Kortrijk & 2 & 71 & totaal (absoluut) & 525 & 796 \\
\hline WEST-VLAANDEREN & $15,7 \%$ & $84,3 \%$ & totaal (percentages) & $39,7 \%$ & $60,3 \%$ \\
\hline
\end{tabular}


N.B. Uit het proces-verbaal van de Vergadering der Notabelen, benoemd ter bijwoning van het opnemen der stemmen te Brussel op 25 augustus 1815, kan worden opgemaakt dat er van de 1322 geldig uitgebrachte stemmen 796 tegen en 526 voor de ontwerpgrondwet werden uitgebracht. ${ }^{1}$ Smeets geeft in zijn artikel over de notabelenvergaderingen in Maastricht, Hasselt en Roermond aan dat er bij de telling van de stemmen uit dat laatste arrondissement een fout is gemaakt: het aantal uitgebrachte stemmen bedroeg daar niet 33, zoals vermeld in het proces-verbaal, maar 32 . Het aantal voorstemmen komt daarmee op 525 en het totaal aantal geldig uitgebrachte stemmen op $1321 .^{2}$

BIJLAGE II

Leden van de Tweede Kamer der Staten-Generaal uit Limburg, 1815-1830

G.A.E. van Aefferden

G.G.F. graaf de Borchgrave d'Altena

jhr. Ch.M.J.G. de Brouckère

J.F. Hennequin

jhr. W.D.A. Kerens de Wolfrath

Ch.F.J. baron de Keverberg d'Aldengoor

jhr. P.G.G.J. Leonaerdts d'Achel

P.W. baron de Liedel de Well

jhr. A.C. Membrède (kamervoorzitter gedurende de zittingen 1816-1817 en 18201821)

jhr. J.A.C. van Panhuys

E.L. baron de Surlet de Chokier 
Tijdsbalk van de vier aan Limburg toebedeelde zetels

\section{Zittingsjaar}

1815

1815-1816

1816-1817

$1817-1818$

1818-1819

$1819-1820$

1820-1821

$1821-1822$

$1822-1823$

1823-1824

1824-1825

$1825-1826$

1826-1827

$1827-1828$

1828-1829

1829-1830

1830
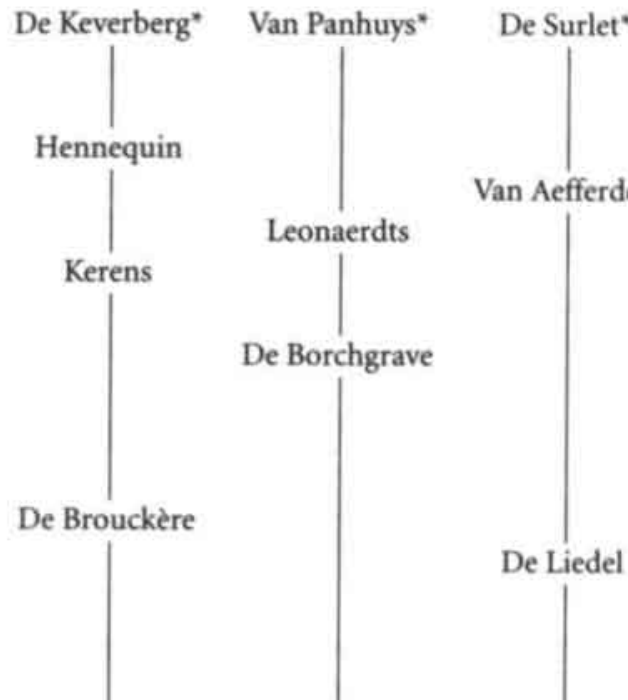

Membrède*

De Borchgrave

Van Aefferden

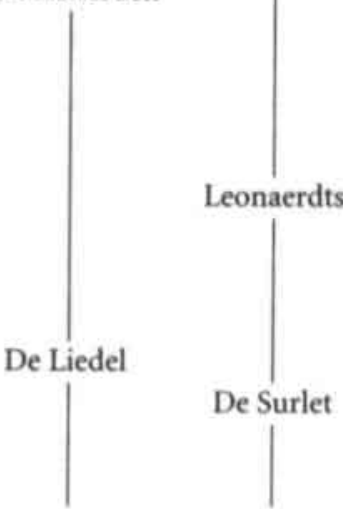

- Benoemd door de koning bij Koninklijk Besluit van 1 januari 1815.

Leesvoorbeeld: Ch.F.J. baron de Keverberg d'Aldengoor had zitting gedurende de parlementaire zittingsjaren 1815, 1815-1816 en 1816-1817. Met ingang van het daaropvolgende zittingsjaar (1817-1818) werd hij opgevolgd door J.F. Hennequin.

\section{BIJLAGE III}

Leden van Belgische nationaal-parlementaire organen uit Limburg, 1830-1839

In de periode $1830-1839$ kende Belgiè drie vertegenwoordigende organen op nationaal niveau: het Nationaal Congres (1830-1831) en daarop volgend de Kamer van Volksvertegenwoordigers en de Senaat (beide vanaf 1831).

\section{Nationaal Congres}

Het Nationaal Congres bestond uit 200 leden. Deze leden werden in iedere provincie aangewezen door middel van directe verkiezingen binnen districten. Iedere Belg van 25 jaar of ouder en woonachtig in Belgiè was verkiesbaar, vrouwen uitgezonderd. Het actieve kiesrecht, wederom slechts voorbehouden aan mannen van ten minste 
25 jaar, was gebonden aan een census en was daarnaast toegekend aan personen met een bepaald beroep of diploma (de capaciteitskiezers).

Limburg koos zeventien afgevaardigden en was ingedeeld in drie kiesdistricten: Roermond (vijf afgevaardigden), Maastricht (zeven) en Hasselt (vijf). De kiesdis. tricten vielen samen met de reeds ten tijde van het Verenigd Koninkrijk bestaande administratieve districten. De districten Roermond en Maastricht besloegen voor het grootste deel de in 1839 te vormen Nederlandse provincie Limburg.

\section{Leden van het Nationaal Congres gekozen in Limburg}

District Naam

Stemgedrag*

12

Roermond H.G.J.M. de Brouckère

N. Gelders

P.W. baron de Liedel de Well

Th. Olislagers de Sipernau

L. de Schiervel

Maastricht J.B.F.J.D. graaf de Marchant d'Ansembourg $T$ T

Ch. Destouvelles

J.F. Hennequin (tot april 1831)

N.J.T. Cruts (vanaf april 1831)

F. graaf de Mérode

C. graaf de Renesse-Breidbach

R.P. de Tiecken de Terhove

Ch. burggraaf Vilain xum

Hasselt

jhr. Ch.M.J.G. de Brouckère

E.L. baron Surlet de Chokier (voorzitter) (tot februari 1831)

P.L.J. Jaminé (vanaf februari 1831)

P.G. Teuwens

B.T. ridder de Theux de Meylandt

A. baron de Woelmont d'Opleeuw
V T

V T

$\mathrm{T}$ a

V V

V T

T T

$\mathrm{V} \quad-$

- $\quad T$

v v

T V

V T

V T

V T

$\mathrm{V}-$

- v

V T

V V

V V

* I Stemming over de uitsluiting van de Oranjes van de Belgische troon

2 Stemming over de Achttien artikelen

V Stemt voor

T Stemt tegen

a Is afwezig

- Heeft op moment van stemming geen zitting in de Kamer 
Kamer van Volksvertegenwoordigers en Senaat

De Kamer van Volksvertegenwoordigers werd gekozen door dezelfde kiezers als die welke de Senaat kozen: de Kamer voor een periode van vier en de Senaat voor een periode van acht jaar. Elke provincie was daartoe ingedeeld in kiesdistricten. Zowel het aantal leden van de Kamer als het aantal senatoren waren afhankelijk van de bevolkingsomvang. Er was sprake van censuskiesrecht. Verkiesbaar waren alle Belgen vanaf 25 jaar (Kamer) of 40 jaar (Senaat), in het bezit van de burgerlijke en politieke rechten en woonachtig in Belgie. Voor de Senaat gold als extra vereiste dat en bepaald bedrag aan belasting moest zijn betaald. Vrouwen waren - wederom uitgesloten van het actief en passief kiesrecht.

Van de 102 leden van de Kamer werden er 9 uit Limburg gekozen. Voor de Senaat golden als overeenkomstige cijfers: 51 en 4 . De districten Roermond en Maastricht kozen elk drie kamerleden; Hasselt koos twee kamerleden. Daarboven werd door Mastricht en Hasselt beurtelings éen extra kamerlid gekozen (te beginnen door Hasselt). De districten Roermond en Hasselt vaardigden elk één senator af; Maastricht koos er twee.

Leden van de Kamer van Volksvertegenwoordigers

gekozen in Limburg, 1831-1839

\begin{tabular}{|c|c|c|c|}
\hline District & & Naam & Periode \\
\hline Roermond & le zetel & H.G.J.M. de Brouckère & $1831-1833$ \\
\hline & & N.J. de Longrée & $1833-1839$ \\
\hline & 2e zetel & Th. Olislagers de Sipernau & $1831-1835$ \\
\hline & & J.G.H. Scheyven* & $1835-1839$ \\
\hline & 3e zetel & N. Gelders & $1831-1832$ \\
\hline & & J.W. Ernst & $1832-1833$ \\
\hline & & J.M. van der Heyden & 1833-1835 \\
\hline & & L.F.H. Beerenbroek & $1835-1839$ \\
\hline Maastricht & le zetel & Ch. Destouvelles & $1831-1833$ \\
\hline & & C. graaf de Renesse-Breidbach* & 1833-1839 \\
\hline & 2e zetel & R.P. de Tiecken de Terhove & $1831-1833$ \\
\hline & & J.H. Schaetzen & $1833-1836$ \\
\hline & & J.J.F.M.H. Corneli & $1836-1839$ \\
\hline & 3e zetel & P.L.J. Jaminé & $1831-1833$ \\
\hline & & H.A. Simons* & $1833-1839$ \\
\hline & 4 e zetel\# & A.E.H.J.F. Pollenus & $1833-1835$ \\
\hline
\end{tabular}


District Naam

Hasselt le zetel

B.T. ridder de Theux de Meylandt*

2e zetel

A. baron de Woelmont d'Opleeuw

1831-1833

E. de Stembier de Wideux

P.L. Raymaeckers*

1833-1835

P.L. Raymaeckers

1835-

3e zetel\#

A.E.H.J.F. Pollenus

1831-1833

1835-1839

- Bleef na 1839 in de Kamer: De Renesse en Simons namen vanaf dat jaar zitting namens het district Tongeren en Scheyven namens Maaseik; De Theux de Meylandt en Raymaeckers hielden zitting voor het district Hasselt.

\# Hasselt en Maastricht kozen beurtelings één kamerlid (extra).

Leden van de Senaat gekozen in Limburg, 1831-1839

District

Naam

Periode

Roermond

L. de Schiervel* (voorzitter vanaf 1838)

$1831-1843$

Maastricht

le zetel I.B.F.J.D. graaf de Marchant d'Ansembourg
ze zetel F. baron de Loë-Imstenraedt de Mheer

1831-1843

$1831-1832$

J.F. Hennequin

1832-1833

A.C.D van Muyssen

1833-1843

Hasselt

C.F. baron de Stockem Méan de Kermpt

$1831-1843$

* Bleef tot 1848 lid van de Senaat: na 1843 nam hij zitting namens het district Hasselt.

\section{BIJLAGE IV}

Leden van de Duitse Nationale Vergadering uit Limburg, 1848-1849

De Nationale Vergadering zetelde in de Paulskirche in Frankfurt am Main en bestond uit 812 afgevaardigden. Ieder gebied dat behoorde tot de Duitse Bond werd verdeeld in kiesdistricten van ongeveer 50000 inwoners. Per district werd een vertegenwoordiger naar Frankfurt am Main gezonden Het hertogdom Limburg - het grondgebied omvattend van de gelijknamige Nederlandse provincie minus de vestingsteden Maastricht en Venlo en hun omgeving - was ingedeeld in twee districten: Roermond en Maastricht.

Alle 'volljährigen und selbstăndigen mầnnlichen Staatsangehörigen' kregen he! actief kiesrecht. De uitwerking van de verkiezingsprocedure, waaronder de keuzz tussen rechtstreekse en indirecte verkiezingen en de precieze invulling van de begrippen meerderjarig en zelfstandig, werd overgelaten aan de autoriteiten in de diverse bondsgebieden. In Limburg vonden getrapte verkiezingen plaats. Alle 
mannelijke inwoners van 23 jaar en ouder - voor zover afkomstig van buiten Mastricht en Venlo en omstreken - die geen steun ontvingen uit de armenkas werden per gemeente bijeengeroepen. Onder voorzitterschap van de burgemeester werd er voor elke 500 inwoners een kiesman aangewezen. In het district Roermond werden 164 kiesmannen gekozen en in het district Maastricht 144. Zij kwamen bijeen in Roermond respectievelijk Valkenburg en kozen daar per district een afgevaardigde voor de Nationale Vergadering. ${ }^{3}$

Vanuit het hertogdom Limburg werden afgevaardigd:

District Roermond: J.L.Th.A.L. baron van Scherpenzeel Heusch uit Baarlo District Maastricht: J.A.L Schoenmaeckers uit Amby

BIJLAGE V

Indeling van Limburgse gemeenten in (hoofd)kiesdistricten ten behoeve van de Tweede Kamerverkiezingen, 1848-1918

Aanduiding van de (hoofd)kiesdistricten

$\begin{array}{llll}\text { B } & \text { Boxmeer } & \text { R } & \text { Roermond } \\ \text { G } & \text { Gulpen } & \text { S } & \text { Sittard } \\ \text { H } & \text { Heerlen } & \text { V } & \text { Venlo } \\ \text { M } & \text { Maastricht } & \text { W } & \text { Weert }\end{array}$

(Grond)wettelijke regelingen met betrekking tot de indeling van Limburg in kiesdistricten waarnaar de jaartallen verwijzen

1848 Besluit van Gedeputeerde Staten van het Hertogdom Limburg d.d. 16 oktober 1848 (Administratief memoriaal voor het Hertogdom Limburg $1848 \mathrm{nr} .127$ ), n.a.v. artikel 6 van het Voorlopig kiesreglement (vervat in additioneel artikel 7 van de grondwet van 1848)

1850 Kieswet van 1850 (Staatsblad 1850 nr. 37), n.a.v. de artikelen 76 en 77 van de grondwet van 1848

1858 Wet tot herziening van de districtsindeling (Staatsblad $1858 \mathrm{nr} .122$ )

1864 Wet tot herziening van de districtsindeling (Staatsblad $1864 \mathrm{nr}$. 34)

1869 Wet tot herziening van de districtsindeling (Staatsblad $1869 \mathrm{nr} .76$ )

1878 Wet tot herziening van de districtsindeling (Staatsblad $1878 \mathrm{nr} .5$ )

1887 Grondwet van 1887 , additioneel artikel vu

1896 Kieswet van 1896 (Staatsblad $1896 \mathrm{nr}$. 154), n.a.v. artikel 81 van de grondwet van 1887 


\section{Limburgse gemeenten}

\begin{tabular}{|c|c|c|c|c|c|c|c|}
\hline Gemeente & 1848 & 1850 & 1858 & 1864 & 1869 & 1878 & 1887 \\
\hline Amby & M & M & M & M & M & M & M \\
\hline Amstenrade & $\mathbf{S}$ & $\mathbf{R}$ & R & $\mathbf{R}$ & $\mathbf{R}$ & $\mathbf{R}$ & $\mathbf{S}$ \\
\hline Arcen en Velden & V & B & B & B & B & B & V \\
\hline Baexem & $\mathrm{R}$ & $\mathbf{R}$ & $\mathbf{R}$ & $\mathrm{R}$ & $\mathbf{R}$ & $\mathrm{R}$ & W \\
\hline Beegden & $\mathrm{R}$ & $\mathbf{R}$ & $\mathbf{R}$ & $\mathbf{R}$ & R & R & $\mathbf{R}$ \\
\hline Beek & S & M & M & M & M & M & $\mathbf{S}$ \\
\hline Beesel & V & $\mathbf{R}$ & $\mathbf{R}$ & $\mathbf{R}$ & B & B & $\mathbf{R}$ \\
\hline Belfeld & V & $\mathbf{R}$ & $\mathbf{R}$ & $\mathbf{R}$ & B & B & V \\
\hline Bemelen & M & M & M & M & M & M & G \\
\hline Berg en Terblijt & M & M & M & M & M & M & G \\
\hline Bergen & V & B & B & B & B & B & V \\
\hline Bingelrade & $\mathbf{S}$ & $\mathbf{R}$ & $\mathbf{R}$ & $\mathrm{R}$ & $\mathbf{R}$ & $\mathbf{R}$ & $\mathbf{S}$ \\
\hline Bocholtz & $\mathrm{H}$ & M & M & M & M & M & G \\
\hline Borgharen & M & M & M & M & M & M & $\mathbf{S}$ \\
\hline Born & $\mathbf{S}$ & $\mathbf{R}$ & $\mathbf{R}$ & $\mathbf{R}$ & $\mathbf{R}$ & $\mathbf{R}$ & $\mathbf{S}$ \\
\hline Broekhuizen & V & B & B & B & B & B & V \\
\hline Broek-Sittard & $\mathbf{S}$ & $\mathbf{R}$ & $\mathbf{R}$ & $\mathbf{R}$ & $\mathbf{R}$ & $\mathbf{R}$ & S \\
\hline Brunssum & $\mathbf{S}$ & M & M & M & $\mathbf{R}$ & $\mathbf{R}$ & $\mathbf{S}$ \\
\hline Buggenum & $\mathbf{R}$ & $\mathbf{R}$ & $\mathbf{R}$ & $\mathbf{R}$ & $\mathbf{R}$ & $\mathbf{R}$ & w \\
\hline Bunde & M & M & M & M & M & M & S \\
\hline Cadier en Keer & H & M & M & M & M & M & G \\
\hline Echt & $\mathbf{S}$ & $\mathbf{R}$ & $\mathbf{R}$ & $\mathbf{R}$ & $\mathbf{R}$ & $\mathbf{R}$ & R \\
\hline Eijgelshoven & $\mathrm{H}$ & M & M & M & M & M & $s$ \\
\hline Eijsden & M & M & M & M & M & M & M \\
\hline Elsloo & $\mathrm{S}$ & M & M & M & $\mathbf{R}$ & $\mathbf{R}$ & S \\
\hline Geleen & S & $\mathrm{R}$ & $\mathbf{R}$ & R & $\mathbf{R}$ & R & S \\
\hline Gennep & V & B & B & B & B & B & v \\
\hline Geulle & M & M & M & M & M & R & S \\
\hline Grathem & $\mathbf{R}$ & $\mathbf{R}$ & $\mathbf{R}$ & $\mathbf{R}$ & $\mathrm{R}$ & $\mathbf{R}$ & W \\
\hline Grevenbicht & S & $\mathbf{R}$ & $\mathbf{R}$ & $\mathbf{R}$ & $\mathbf{R}$ & $\mathbf{R}$ & S \\
\hline Gronsveld & M & M & M & M & M & M & M \\
\hline Grubbenvorst & V & B & B & B & B & B & V \\
\hline Gulpen & $\mathrm{H}$ & M & M & M & M & M & G \\
\hline Haelen & $\mathbf{R}$ & $\mathbf{R}$ & $\mathbf{R}$ & R & $\mathrm{R}$ & $\mathbf{R}$ & w \\
\hline Heel en Panheel** & $\mathbf{R}$ & $\mathrm{R}$ & $\mathbf{R}$ & $\mathbf{R}$ & $\mathbf{R}$ & $\mathbf{R}$ & $\mathrm{R}$ \\
\hline Heer & M & M & M & M & M & M & M \\
\hline Heerlen & $\mathrm{H}$ & M & M & M & M & M & G \\
\hline Heijthuizen & $\mathbf{R}$ & $\mathbf{R}$ & $\mathbf{R}$ & $\mathbf{R}$ & $\mathbf{R}$ & $\mathbf{R}$ & w \\
\hline Helden & V & $\mathbf{R}$ & $\mathbf{R}$ & $\mathbf{R}$ & B & B & w \\
\hline Herten & $\mathbf{R}$ & $\mathbf{R}$ & $\mathbf{R}$ & $\mathbf{R}$ & $\mathbf{R}$ & $\mathbf{R}$ & $\mathbf{R}$ \\
\hline Hoensbroek & $\mathrm{H}$ & M & M & M & $\mathbf{R}$ & $\mathbf{R}$ & $\mathrm{S}$ \\
\hline Horn & $\mathbf{R}$ & $\mathbf{R}$ & $\mathbf{R}$ & $\mathbf{R}$ & $\mathbf{R}$ & $\mathbf{R}$ & R \\
\hline Horst & V & B & B & B & B & B & w \\
\hline Houthem & M & M & M & M & M & M & G \\
\hline Hulsberg & $\mathrm{H}$ & M & M & $\mathrm{M}$ & M & M & S \\
\hline
\end{tabular}


Gemecute

Hunsel

Itteren

Ittervoort

Jabeek

Kerkrade

Kessel

Klimmen

limbricht

Linne

Masbracht

Masbree

Maasniel

Masstricht

Margraten

Meerlo

Meerssen

Meijel

Melick en Herkenbosch

Merkelbeek

Mesch

Mheer

Montfort

Mook

Munstergeleen

Nederweert

Neer

Neerritter

Nieuwenhagen

Nieuwstadt

Noorbeek

Nunhem

Nuth

Obbicht en Papenhoven

Ohé en Laak

Oirsbeek

Ottersum

Oud-Valkenburg

Oud-Vroenhoven

Posterholt

Rijckholt

Rimburg

Roermond

Roggel

Roosteren

Schaesberg

Schimmert

Schin op Geul $\begin{array}{lllllllll}1848 & 1850 & 1858 & 1864 & 1869 & 1878 & 1887 & 1896\end{array}$

$\begin{array}{lllllllll}\mathbf{R} & \mathbf{R} & \mathbf{R} & \mathrm{R} & \mathbf{R} & \mathrm{R} & \mathbf{W} & \mathbf{W}\end{array}$

$\begin{array}{llllllll}M & M & M & M & M & M & S & S\end{array}$

$\begin{array}{llllllll}R & R & R & R & R & R & W & \text { W }\end{array}$

$\begin{array}{llllllll}\mathbf{S} & \mathbf{R} & \mathbf{R} & \mathbf{R} & \mathbf{R} & \mathbf{R} & \mathbf{S} & \mathbf{S}\end{array}$

$\begin{array}{llllllll}\text { H } & \text { M } & \text { M } & \text { M } & \text { M } & \text { M } & \text { G } & \text { G }\end{array}$

$\begin{array}{llllllll}\text { V } & \text { R } & \text { R } & \text { R } & \text { B } & \text { B } & \text { W } & \text { W }\end{array}$

$\begin{array}{lllllllll}\text { H } & \text { M } & \text { M } & \text { M } & \text { M } & \text { M } & \text { G } & \text { G }\end{array}$

$\begin{array}{llllllll}\mathbf{S} & \mathbf{R} & \mathbf{R} & \mathbf{R} & \mathbf{R} & \mathbf{R} & \mathbf{S} & \mathbf{S}\end{array}$

$\begin{array}{llllllll}\mathbf{R} & \mathbf{R} & \mathbf{R} & \mathrm{R} & \mathrm{R} & \mathrm{R} & \mathrm{R} & \mathrm{R}\end{array}$

$\begin{array}{llllllll}\mathbf{S} & \mathbf{R} & \mathbf{R} & \mathbf{R} & \mathbf{R} & \mathbf{R} & \mathbf{R} & \mathbf{R}\end{array}$

$\begin{array}{llllllll}\mathbf{V} & \mathrm{R} & \mathrm{R} & \mathrm{R} & \mathrm{B} & \mathrm{B} & \mathrm{W} & \mathrm{W}\end{array}$

$\begin{array}{llllllll}\text { R } & \text { R } & \text { R } & \text { R } & \text { R } & \text { R } & \text { R } & \text { R }\end{array}$

$\begin{array}{llllllll}M & M & M & M & M & M & M & M\end{array}$

$\begin{array}{llllllll}\text { H } & \text { M } & \text { M } & \text { M } & \text { M } & \text { M } & \text { G } & \text { G }\end{array}$

$\begin{array}{llllllll}\text { V } & \text { B } & \text { B } & \text { B } & \text { B } & \text { B } & \text { V } & \text { V }\end{array}$

$\begin{array}{llllllll}M & M & M & M & M & M & M & M\end{array}$

$\begin{array}{llllllll}\mathbf{R} & \mathbf{R} & \mathbf{R} & \mathrm{R} & \mathrm{R} & \mathrm{B} & \mathbf{W} & \mathbf{W}\end{array}$

$\begin{array}{llllllll}R & R & R & R & R & R & R & R\end{array}$

$\begin{array}{llllllll}\text { S } & \text { M } & \text { M } & \text { M } & \text { R } & \text { R } & \text { S } & \text { S }\end{array}$

$\begin{array}{llllllll}M & M & M & M & M & M & G & G\end{array}$

$\begin{array}{llllllll}H & M & M & M & M & M & G & G\end{array}$

$\begin{array}{llllllll}\mathbf{S} & \mathbf{R} & \mathrm{R} & \mathbf{R} & \mathbf{R} & \mathbf{R} & \mathbf{R} & \mathbf{R}\end{array}$

$\begin{array}{llllllll}\text { V } & \text { B } & \text { B } & \text { B } & \text { B } & \text { B } & \text { V } & \text { V }\end{array}$

$\begin{array}{llllllll}\mathbf{S} & \mathbf{R} & \mathbf{R} & \mathbf{R} & \mathbf{R} & \mathbf{R} & \mathbf{S} & \mathbf{S}\end{array}$

$\begin{array}{llllllll}R & R & R & R & R & R & \text { W } & \text { W }\end{array}$

$\begin{array}{llllllll}R & R & R & R & R & B & \text { W } & \text { W }\end{array}$

$\begin{array}{lllllllll}R & R & R & R & R & R & \text { W } & \text { W }\end{array}$

$\begin{array}{llllllll}H & M & M & M & M & M & S & S\end{array}$

$\begin{array}{llllllll}\mathbf{S} & \mathrm{R} & \mathrm{R} & \mathrm{R} & \mathrm{R} & \mathrm{R} & \mathrm{S} & \mathrm{S}\end{array}$

$\begin{array}{lllllllll}H & M & M & M & M & M & G & G\end{array}$

$\begin{array}{llllllll}\text { R } & \text { R } & \text { R } & \text { R } & \text { R } & \text { R } & \text { W } & \text { W }\end{array}$

$\begin{array}{llllllll}H & M & \text { M } & \text { M } & \text { R } & \text { R } & \text { S } & \text { S }\end{array}$

$\begin{array}{llllllll}\mathbf{S} & \mathbf{R} & \mathbf{R} & \mathbf{R} & \mathbf{R} & \mathbf{R} & \mathbf{S} & \mathbf{S}\end{array}$

$\begin{array}{llllllll}\mathbf{S} & \mathbf{R} & \mathbf{R} & \mathbf{R} & \mathbf{R} & \mathbf{R} & \mathbf{R} & \mathbf{R}\end{array}$

$\begin{array}{llllllll}\mathbf{S} & \mathbf{R} & \mathbf{R} & \mathbf{R} & \mathbf{R} & \mathbf{R} & \mathbf{S} & \mathbf{S}\end{array}$

$\begin{array}{llllllll}\text { V } & \text { B } & \text { B } & \text { B } & \text { B } & \text { B } & \text { V } & \text { V }\end{array}$

$\begin{array}{llllllll}H & M & M & M & M & M & G & G\end{array}$

$\begin{array}{llllllll}M & M & M & M & M & M & M & M\end{array}$

$\begin{array}{llllllll}\mathbf{R} & \mathbf{R} & \mathbf{R} & \mathbf{R} & \mathbf{R} & \mathbf{R} & \mathbf{R} & \mathbf{R}\end{array}$

$\begin{array}{lllllllll}M & M & M & M & M & M & G & G\end{array}$

$\begin{array}{llllllllllllll}H & M & M & M & M & M & * & *\end{array}$

$\begin{array}{llllllll}\mathbf{R} & \mathbf{R} & \mathrm{R} & \mathrm{R} & \mathrm{R} & \mathrm{R} & \mathrm{R} & \mathrm{R}\end{array}$

$\begin{array}{llllllll}R & R & R & R & R & B & W & W\end{array}$

$\begin{array}{llllllll}\mathrm{S} & \mathrm{R} & \mathrm{R} & \mathrm{R} & \mathrm{R} & \mathrm{R} & \mathrm{R} & \mathrm{R}\end{array}$

$\begin{array}{llllllll}H & M & M & \text { M } & \text { M } & \text { M } & \text { G } & \text { G }\end{array}$

$\begin{array}{llllllll}H & M & M & M & M & R & S & S\end{array}$

$\begin{array}{lllllllll} & \mathrm{H} & \mathrm{M} & \mathrm{M} & \mathrm{M} & \mathrm{M} & \mathrm{M} & \mathrm{G} & \mathrm{G}\end{array}$ 


\begin{tabular}{|c|c|c|c|c|c|c|c|}
\hline Gemeente & 1848 & 1850 & 1858 & 1864 & 1869 & 1878 & 1887 \\
\hline Schinnen & $\mathbf{S}$ & $\mathbf{R}$ & $\mathbf{R}$ & $\mathbf{R}$ & $\mathbf{R}$ & $\mathbf{R}$ & S \\
\hline Schinveld & S & $M$ & M & M & $\mathbf{R}$ & $\mathbf{R}$ & $\mathbf{S}$ \\
\hline Sevenum & V & B & B & B & B & B & w \\
\hline Simpelveld & $\mathrm{H}$ & M & M & M & M & M & G \\
\hline Sint-Geertruide & M & M & M & M & M & M & G \\
\hline Sint-Odiliènberg & $\mathbf{R}$ & $\mathbf{R}$ & $\mathbf{R}$ & $\mathrm{R}$ & $\mathbf{R}$ & $\mathbf{R}$ & $\mathbf{R}$ \\
\hline Sint-Pieter & $\mathrm{M}$ & M & M & M & M & M & M \\
\hline Sittard & $\mathrm{S}$ & $\mathbf{R}$ & $\mathbf{R}$ & $\mathbf{R}$ & $\mathbf{R}$ & $\mathbf{R}$ & $\mathbf{S}$ \\
\hline Slenaken & $\mathrm{H}$ & M & M & M & M & M & G \\
\hline Spaubeek & $\mathrm{S}$ & M & $M$ & $\mathrm{M}$ & R & $\mathrm{R}$ & $\mathrm{S}$ \\
\hline Stein & $\mathbf{S}$ & M & M & M & $\mathbf{R}$ & $\mathbf{R}$ & $\mathrm{S}$ \\
\hline Stevensweert & $\mathbf{S}$ & $\mathbf{R}$ & R & $\mathbf{R}$ & $\mathbf{R}$ & $\mathbf{R}$ & $\mathbf{R}$ \\
\hline Stramproy & $\mathbf{R}$ & $\mathrm{R}$ & $\mathbf{R}$ & $\mathbf{R}$ & $\mathbf{R}$ & $\mathbf{R}$ & w \\
\hline Strucht & $\mathrm{H}$ & $M$ & M & M & M & M & $\cdot$ \\
\hline Susteren & $\mathbf{S}$ & $\mathbf{R}$ & $\mathbf{R}$ & $\mathbf{R}$ & $\mathbf{R}$ & $\mathbf{R}$ & $\mathbf{R}$ \\
\hline Swalmen & R & $\mathbf{R}$ & $\mathbf{R}$ & $\mathbf{R}$ & $\mathbf{R}$ & $\mathbf{R}$ & $\mathrm{R}$ \\
\hline Tegelen & V & $\mathbf{R}$ & $\mathbf{R}$ & $\mathbf{R}$ & B & B & v \\
\hline Thorn & $\mathbf{R}$ & R & $\mathbf{R}$ & $\mathbf{R}$ & $\mathbf{R}$ & $\mathbf{R}$ & $\mathbf{R}$ \\
\hline Ubach over Worms & $\mathrm{H}$ & M & M & M & M & M & $\mathrm{S}$ \\
\hline Ulestraeten & M & M & M & M & M & M & $\mathrm{S}$ \\
\hline Urmond & $\mathrm{S}$ & $\mathbf{R}$ & $\mathbf{R}$ & $\mathbf{R}$ & $\mathbf{R}$ & $\mathbf{R}$ & $\mathrm{S}$ \\
\hline Vaals & $\mathrm{H}$ & M & M & M & M & M & G \\
\hline Valkenburg & $\mathrm{H}$ & M & M & M & M & M & G \\
\hline Venlo & V & $\mathbf{R}$ & $\mathrm{R}$ & $\mathbf{R}$ & B & B & V \\
\hline Venray & V & B & B & B & B & B & V \\
\hline Vlodrop & $\mathbf{R}$ & $\mathrm{R}$ & $\mathbf{R}$ & $\mathrm{R}$ & $\mathrm{R}$ & $\mathbf{R}$ & $\mathbf{R}$ \\
\hline Voerendaal & $\mathrm{H}$ & M & M & M & M & M & G \\
\hline Wanssum & V & B & B & B & B & B & V \\
\hline Weert & $\mathbf{R}$ & $\mathrm{R}$ & R & $\mathbf{R}$ & $\mathrm{R}$ & R & W \\
\hline Wessem & $\mathbf{R}$ & $\mathbf{R}$ & $\mathbf{R}$ & $\mathbf{R}$ & R & $\mathrm{R}$ & $\mathbf{R}$ \\
\hline Wijnandsrade & $\mathrm{H}$ & M & M & M & M & $\mathrm{R}$ & $\mathrm{S}$ \\
\hline Wittem & $\mathrm{H}$ & M & M & M & M & $M$ & G \\
\hline Wylre & $\mathrm{H}$ & M & $M$ & M & M & M & G \\
\hline
\end{tabular}

* Strucht werd in 1878 bij Schin op Geul gevoegd en Rimburg in 1886 bij Ubach over Worms.

** De gemeente Heel en Panheel werd in de kieswettabellen van 1850, 1858, 1864 en 1869 ten onrechte Heel, Pol en Panheel genoemd, zo werd pas in dat laatste jaar geconstateerd door Gedeputeerde Staten van Limburg. Het gehucht Pol was namelijk sinds 1818 ingedeeld bij de gemeente Wessem. Desgevraagd deelden de colleges van Burgemeester en Wethouders van Heel en Panheel en Wessem gs mede dat de kiezers uit Pol hun stembriefjes inleverden in Wessem. De minister van Binnenlandse Zaken die hierover werd ingelicht, oordeelde dat deze 'misslag' in de wettekst niet zo ernstig was dat zij 'dringend herstelling vordert'. Bij de eerstvolgende herziening, in 1878 , werd de verbetering in de kieswettabel aangebracht. ${ }^{4}$ 
Noord-Brabantse en Gelderse gemeenten die deel uitmaakten van een district dat tevens Limburgse gemeenten omvatte

$\begin{array}{lccccccc}\text { Gemeente } & \text { I850 } & 1858 & 1864 & 1869 & 1878 & 1887 & 1896 \\ \text { Beens } & \text { B } & \text { B } & \text { B } & \text { B } & \text { B } & - & - \\ \text { Beugen en Rijkevoort } & \text { B } & \text { B } & \text { B } & \text { B } & \text { B } & - & - \\ \text { Boekel } & - & - & - & \text { B } & - & - & - \\ \text { Boumeer } & \text { B } & \text { B } & \text { B } & \text { B } & \text { B } & - & - \\ \text { Cuyk en Sint-Agatha } & \text { B } & \text { B } & \text { B } & \text { B } & \text { B } & - & - \\ \text { Escharen } & \text { B } & \text { B } & \text { B } & \text { B } & \text { B } & - & - \\ \text { Gassel } & \text { B } & \text { B } & \text { B } & \text { B } & \text { B } & - & - \\ \text { Gernert } & - & - & - & \text { B } & - & - & - \\ \text { Grave } & \text { B } & - & - & \text { B } & \text { B } & - & - \\ \text { Groesbeek (G) } & - & - & - & - & \text { B } & - & - \\ \text { Haps } & \text { B } & \text { B } & \text { B } & \text { B } & \text { B } & - & - \\ \text { Heumen (G) } & - & - & - & - & \text { B } & - & - \\ \text { Linden } & \text { B } & \text { B } & \text { B } & \text { B } & \text { B } & - & - \\ \text { Mashees en Overloon } & \text { B } & \text { B } & \text { B } & \text { B } & \text { B } & \text { V } & \text { V } \\ \text { Mill en Sint-Hubert } & \text { B } & \text { B } & \text { B } & \text { B } & \text { B } & - & - \\ \text { Nistelrode } & - & - & - & \text { B } & - & - & - \\ \text { Oeffelt } & \text { B } & \text { B } & \text { B } & \text { B } & \text { B } & - & - \\ \text { Oploo, Sint-Anthonis en Ledeacker } & \text { B } & \text { B } & \text { B } & \text { B } & \text { B } & \text { V } & \text { V } \\ \text { Overasselt (G) } & - & - & - & - & \text { B } & - & - \\ \text { Reek } & - & - & - & \text { B } & \text { B } & - & - \\ \text { Sambeek } & \text { B } & \text { B } & \text { B } & \text { B } & \text { B } & \text { V } & \text { V } \\ \text { Uden } & - & - & - & \text { B } & - & - & - \\ \text { Velp } & - & - & - & \text { B } & \text { B } & - & - \\ \text { Vierlingsbeek } & \text { B } & \text { B } & \text { B } & \text { B } & \text { B } & \text { V } & \text { V } \\ \text { Wanroy } & \text { B } & \text { B } & \text { B } & \text { B } & \text { B } & - & - \\ \text { Zeeland } & - & - & - & \text { B } & - & - & - \\ - \text { gemeente maakte geen deel uit van een district dat tevens Limburgse gemeenten } \\ \text { omvatte } & & & & & & & \\ \text { G Gelderse gemeente } & & & & & & & \end{array}$

\section{BIJLAGE VI}

Leden van de Staten-Generaal geboren in of afgevaardigd uit Limburg, 1839-1918

\section{Tweede Kamer}

Naam

I.H. Arnoldts

M.J.G.J. Arnoldts

J.H.J. Beckers

I.G.S. Bevers

L.F.H. Beerenbroek

6 Ch.A. baron de Bieberstein Rogalla Zawadsky

7 Ch.C.M.H. baron de Bieberstein

\begin{tabular}{|c|c|}
\hline Geboorteplaats & Kiesgebied(en) \\
\hline Sittard & Roermond \\
\hline Sittard & Sittard \\
\hline Sittard & Sittard \\
\hline Roermond & Doetinchem; Zuid-Holland \\
\hline Weert & Limburg; Limburg \\
\hline Tongeren (B) & Maastricht \\
\hline Roermond & Sittard \\
\hline
\end{tabular}


Naam

A.L.G.H. Bloemarts
E.J. Bolsius
M.Ch.E. Bongaerts
E.J.H. Borret
H.J. Brouwers
J.M.L.H. Clercx
J.J.F.M.H. Corneli
K.L.I. Cornelis
G. Diepen
W. Everts
H.H. Geradts
H.A.G. van Groenendael
I.H.L. Haffmans

\section{H.G.M. Hermans}

P. van den Heuvel

F.I.J. Janssen

jhr. P.A.S. Kerens

Thr. G.E.FX.M. Kerens de Wylet

H.C.F. Kerstens

A. Kool

H.F. Lambrechts

J.). Lambrechts

J.L.M. Leclercq

Ch. de Limpens

P.L de Lom de Berg

J.B.C.E.M. graaf de Marchant

d'Ansembourg

J.M.M.H. Merckelbach

jhr. A.H.Th. Michiels van

M.V. Nijst

W.H. Nolens

J.E.H.W, baron d'Olne

jhr. P.M.J.F. Petit

W.H. Piils

M. de Ras

E.R.H. Regout

L.F.H.C. Ruland

G.W. Sannes

Heusch

2 J.H.J. Schreinemacher

W.G. Straetmans

F.H.C.E. baron de Keverberg de Kesse

jhr. P.Th. van der Maesen de Sombreff

Verduynen (vanaf juni 1841 baron)

L.P.M.H. baron Michiels van Verduynen

jhr. Ch.J.M. Ruijs de Beerenbrouck

(voor maart 1895: van Beerenbroek)

jhr. G.L.M.H. Ruijs van Beerenbroek

(na maart 1895; de Beerenbrouck)

J.L.Th.A.L. baron van Scherpenzeel

Geboorteplaats

Weert

Rocrmond

Roermond

's-Hertogenbosch (NBr)

Heer

Kessel

Rimburg

Roermond

Tilburg (NBr)

Sevenum

Roermond

Nunhem

Horst

Boxmeer (NBr)

Blitterswijck

Uden (NBr)

Bingelrade

Mechelen

Maastricht

Boxmeer (NBr)

Stonar (VK)

Maastricht

Roosteren

Grevenbicht

Maaseik (B)

Herenthals (B)

Venlo

Maastricht

Gulpen

Wittem

Roermond

Roermond

Maastricht

Venlo

Baarlo

Roermond

Maastricht

Nijmegen (Gel)

Maastricht

Roermond

\section{Roermond}

Aken (Pr)

Meerssen

Oosterhout (Gel)

Maastricht

Mastricht
Kiesgebied(en)

Limburg

Roermond

Roermond +

Maastricht

Boxmeer; Roermond

Boxmeer; Weert

Limburg

Roermond

Roermond

Roermond

Limburg

Weert +

Roermond; Boxmeer: Venlo

Grave, Boxmeer;

Noord-Brabant

Gulpen +

Eindhoven; Boxmeet

Maastricht +

Limburg

Maastricht

Boxmeer

Roermond

Arnhem

Roermond: Sittard

Sittard

Limburg: Rocrmond

Maastricht

Venlo; Roermond

Maastricht

Gulpen

Gulpen

Limburg

Breda

Maastricht

Venlo +

Roermond

Limburg

Roermond; Limburg

Maastricht

Helmond

Gulpen +

Maastricht; Roermond

Maastricht: Gulpen

Veendam +

Sittard

Maastricht

Maastricht 


\begin{tabular}{|c|c|c|c|}
\hline & Naam & Geboorteplaats: & Kiesgebied (en) \\
\hline 34 & M.P.H. Strens & Roermond & Limburg: Roermond \\
\hline 55 & Thr. V.E.L de Stuers & Masstricht & Weert \\
\hline 56 & 1.M. Swart & Leiden ( $\mathbf{z H})$ & Limburg \\
\hline 57 & A.J.H.H. Thissen & Venilo & Limburg \\
\hline s8 & I.R. Thorbecke & Zwolle (Ov) & $\begin{array}{l}\text { Holland; Zuid-Holland; Leiden; } \\
\text { Maastricht: Deventer; Groningen; } \\
\text { Assen }\end{array}$ \\
\hline 99 & PJ. Truijen & Weert & Weert \\
\hline 60 & Th.G.G. Valette & Tegelen & Gouda \\
\hline 61 & Jhr. LLLW.M.J. de Villers de Pite & Tongeren (B) & Heerlen; Limburg \\
\hline 62 & W.H. Viegen & Gulpen & Amsterdam rx; Noond-Holland + \\
\hline 63 & A.t. Vos de Wael & Venlo & Overijssel; Overijssel \\
\hline 64 & CM.H. baron de Weichs de Wenne & Wanssum & Limburg \\
\hline 65 & P.FE van Wintershoven & Maastricht & Mastricht \\
\hline$\infty 6$ & J.JA, van Wylick & Kessel & Roermond \\
\hline
\end{tabular}

\section{Eerste Kamer}

\section{Naam}

L.F.H. Beerenbroek

I.G.S. Bevers

I.S.H. Brouwers

E.I.P.M. Coenen

\section{O.F.M. Haffmans}

P.W. baron de Liedel de Well

ihr. LH.L., van der Maesen

de Sombreff

8 L.H.A. Magnée

9 ihr. A.H.J.H. Michiels van Kessenich

10 ihr. F.B.H. Michiels van Kessenich

II W.H. Pijls

12 H.G.L. Regout

13 LH.W. Regout

14 P.D. Regout

15 G.j. de Rijk

16 hr. L.L.W.M.J. de Villers de Pité

17 W.H. Vliegen

18 A.J. Vos de Wael
Geboorteplaats

Weert
Roermond
Heer
Weert
Helden
Well
Maastricht
Horn
Maastricht
Roermond
Maastricht
Maastricht
Maastricht
Maastricht
Duisburg (Pr)
Tongeren (B)
Gulpen
Venlo

\section{Kiesgebieden(en)}

Limburg: Limburg

Doetinchem; Zuid-Holland

Limburg

Limburg

Limburg

(Limburg)*

Limburg +

Limburg

Limburg +

Limburg

Roermond; Limburg

Limburg

Limburg; Noord-Brabant

Limburg

Limburg

Heerien, Limburg

Amsterdam Ix; Noord-Holland +

Overijssel; Overijssel

Bijeen geboorteplaats die niet ligt in Nederlands-Limburg (volgens de in het traktaat van 1839 vastgestelde grenzen), is de provincie of het land vermeld: $(B)=$ België; $(\mathrm{Gel})=$ Gelderland; $(\mathrm{NBr})=$ Noord-Brabant; $(\mathrm{Ov})=$ Overijssel; $(\mathrm{Pr})=$ Pruisen; $(\mathrm{vk})=$ Verenigd Koninkrijk van Groot-Brittanniě en lerland; $(\mathrm{zH})=$ Zuid-Holland.

In de kolom 'kiesgebied(en)' zijn de (hoofd)kiesdistricten en de provincies vermeld waar het kamerlid achtereenvolgens werd gekozen. Een achtereenvolgende verkiezing in hetzelfde district of in een gewijzigd district met dezelfde naam is niet angegeven, tenzij het een verkiezing in de andere Kamer van de Staten-Generaal 
betreft. Indien een kamerlid gelijktijdig in meerdere kiesdistricten werd gekozen, is het district vermeld waarvan hij de verkiezing aanvaardde.

Een cursieve weergave van het kiesgebied geeft aan dat het kamerlid voor dat kiesgebied zitting had in de andere Kamer van de Staten-Generaal.

+ Duidt aan dat het kamerlid ook na 1918 zitting heeft gehad in de Staten-Generaal.

- P.W. baron de Liedel de Well werd benoemd na de terugkeer van Limburg onder Nederlands gezag in 1839; de Eerste Kamer werd in die periode niet provinciegewijs samengesteld.

\section{BIJLAGE VII}

Zittingsperiode van de leden van de

Staten-Generaal uit Limburg, 1839-1918

Bij toelating is de datum vermeld waarop de afgevaardigde, na het onderzock van de geloofsbrieven en na het afleggen van de vereiste eden, tot de Kamer werd toegelaten. Bij einde lidmaatschap is naast de datum de reden vermeld waarom het parlementaire mandaat tot een einde kwam.

\section{J.H. Arnoldts}

Lid van de Tweede Kamer, district Roermond

Eerste verkiezing/benoeming $\quad 1871$

Toelating

$18-4-1871$

Herkozen

$1871,1875,1879$

Einde lidmaatschap

19-12-1881: overleden

M.J.G.J. Arnoldts

Lid van de Tweede Kamer, district Sittard

Eerste verkiezing/benoeming 1901

Toelating

18-9-1901

Herkozen

Einde lidmaatschap

28-5-1903: van kamerlidmaatschap vervallen verklaard wegens faillissement

J.H.J. Beckers

Lid van de Tweede Kamer, district Sittard

Eerste verkiezing/benoeming 1903

Toelating

9-10-1903

Herkozen

1905, 1909, 1913, 1917

Einde lidmaatschap

16-9-1918: werd in 1918 niet herkozen (stond te laag op de kandidatenlijst) 
LF.H. Beerenbroek

Lid van de Tweede Kamer, provincie Limburg

Eerste verkiezing/benoeming $\quad 1847$

Toelating

22-3-1847

Herkozen

Einde lidmaatschap

30-6-1848: nam ontslag i.v.m. benoeming tot hertogelijk Limburgs commissaris voor de Duitse Bondszaken (het betrof hier overigens geen wettelijk vastgestelde incompatibiliteit)

Lid van de Eerste Kamer, provincie Limburg

Verkiezing/benoeming

1849

Toelating

15-2-1849

Herkozen

$1850,1856,1865,1874,1883$

Einde lidmaatschap

4-5-1884: overleden

Ch.A. baron de Bieberstein Rogalla Zawadsky

Lid van de Tweede Kamer, district Maastricht

Eerste verkiezing/benoeming $\quad 1858$

Toelating

21-9-1858

Herkozen

$1862,1866,1866,1868,1871,1875,1879$

Einde lidmaatschap

31-10-1880: overleden

Ch.C.M.H. baron de Bieberstein Rogalla Zawadsky

Lid van de Tweede Kamer, district Sittard

Eerste verkiezing/benoeming $\quad 1896$

Toelating

16-2-1897

Herkozen

1897

Einde lidmaatschap

16-9-1901: verslagen bij de verkiezingen

A.L.G.H. Bloemarts

Buitengewoon lid van de Tweede Kamer, provincie Limburg

Eerste verkiezing/benoeming $\quad 1848$

Toelating

Herkozen

Einde lidmaatschap

$18-9-1848$

$-$

7-10-1848: wegens beěindiging buitengewone zitting

E.J. Bolsius

Lid van de Tweede Kamer, district Roermond

Eerste verkiezing/benoeming 1900

Toelating

Herkozen

18-9-1900

Einde lidmaatschap 1901, 1905, 1909, 1911 16-9-1913: geen kandidaat bij de verkiezingen 
M.Ch.E. Bongaerts

Lid van de Tweede Kamer, district Roermond

Eerste verkiezing/benoeming 1913

Toelating

17-9-1913

Herkozen

1914,1917

Einde lidmaatschap bleef na 1918 kamerlid

E.).H. Borret

Lid van de Tweede Kamer, district Maastricht

Eerste verkiezing/benoeming $\quad 1848$

Toelating

15-2-1849

Herkozen

1850

Einde lidmaatschap

19-9-1852: verslagen bij de verkiezingen

H.J. Brouwers

Lid van de Tweede Kamer, district Boxmeer, vanaf 1882 district Roermond

Eerste verkiezing/benoeming $\quad 1877$

Toelating

19-11-1877

Herkozen

$1877,1879,1882,1883,1884,1886,1887,1888$

Einde lidmaatschap

14-5-1889: nam ontslag wegens benoeming tot lid van de Raad van State

J.S.H. Brouwers

Lid van de Eerste Kamer, provincie Limburg

Eerste verkiezing/benoeming 1902

Toelating

2-12-1902

Herkozen

1904,1907

Einde lidmaatschap

19-1-1908: overleden

J.M.L.H. Clercx

Lid van de Tweede Kamer, district Boxmeer, vanaf 1888 district Weert

Eerste verkiezing/benoeming $\quad \mathbf{1 8 8 2}$

Toelating

2-3-1882

Herkozen

$1883,1884,1886,1887,1888,1891$

Einde lidmaatschap 3-4-1894: overleden (de Tweede Kamer was m.i.v. 20-3-1894 ontbonden en formeel eindigde het lidmaatschap van Clercx met deze ontbinding)

F.J.P.M. Coenen

Lid van de Eerste Kamer, provincie Limburg

Eerste verkiezing/benoeming 1902

Toelating

2-6-1902

Herkozen

Einde lidmaatschap

10-10-1902: overleden 
J.F.M.H. Corneli

Lid van de Tweede Kamer, provincie Limburg

Eerste verkiezing/benoeming 1840

Toclating

22-10-1840

Herkozen

1843,1846

Einde lidmaatschap

13-2-1849: verslagen bij de verkiezingen

K.L. Cornelis

Lid van de Tweede Kamer, district Roermond

Eerste verkiezing/benoeming $\quad 1861$

Toelating

20-9-1861

Herkozen

Einde lidmaatschap

17-2-1864: nam ontslag wegens herbenoeming tot kantonrechter, vervolgens verslagen bij de verkiezingen

Verkiezing/benoeming $\quad 1864$

Toclating

Herkozen

Einde lidmaatschap

Verkiezing/benoeming

20-9-1864

-

Toelating

Herkozen

Einde lidmaatschap

18-11-1866: verslagen bij de verkiezingen

1868

29-2-1868

15-3-1871: nam ontslag wegens herbenoeming tot officier van justitie, vervolgens verslagen bij de verkiezingen

G. Diepen

Lid van de Tweede Kamer, district Roermond

Eerste verkiezing/benoeming $\quad 1891$

Toelating

Herkozen

12-5-1891

Einde lidmaatschap

1891

6-6-1892: trok zich terug om zetel ter beschikking te stellen aan jhr. G.L.M.H. Ruijs van Beerenbroek

W. Everts

Lid van de Tweede Kamer, district Roermond

Eerste verkiezing/benoeming 1893

Toelating

Herkozen

14-11-1893

Einde lidmaatschap

1894,1897

8-6-1900: overleden

H.H. Geradts

Lid van de Tweede Kamer, provincie Limburg

Eerste verkiezing/benoeming $\quad 1848$

Toelating

Herkozen

$19-7-1848$

Einde lidmaatschap

13-2-1849: geen kandidaat bij de verkiezingen 


\section{H.A.G. van Groenendael}

Lid van de Tweede Kamer, district Weert

$\begin{array}{ll}\text { Eerste verkiezing/benoeming } & 1916 \\ \text { Toclating } & 12-5-1916 \\ \text { Herkozen } & 1917 \\ \text { Einde lidmaatschap } & \text { bleef na } 1918 \text { kamerlid }\end{array}$

J.H.L. Haffmans

Lid van de Tweede Kamer, district Roermond, vanaf 1869 district Boxmeer, vanaf 1888 district Venlo

Eerste verkiezing/benoeming 1866

Toelating

24-11-1866

Herkozen $1868,1869,1873,1877,1881,1884,1886,1887,1888,1891$, 1894

Einde lidmaatschap 16-9-1896: overleden

O.F.M. Haffmans

Lid van de Eerste Kamer, provincie Limburg

Eerste verkiezing/benoeming 1908

Toelating

27-3-1908

Herkozen

1916, 1917

Einde lidmaatschap

bleef na 1918 kamerlid

\section{J.B.J. Hengst}

Lid van de Tweede Kamer, district Boxmeer

Eerste verkiezing/benoeming 1850

Toelating

9-10-1850

Herkozen

1853,1856

Einde lidmaatschap

14-9-1860: geen kandidaat bij de verkiezingen

N.B. Hengst had in 1849-1850 zitting in de Tweede Kamer voor het Noord-

Brabantse kiesdistrict Grave; hij nam in 1863 zitting in de Eerste Kamer voor de provincie Noord-Brabant.

H.G.M. Hermans

Lid van de Tweede Kamer, district Gulpen

Eerste verkiezing/benoeming 1918

Toelating

9-7-1918

Herkozen

Einde lidmaatschap

bleef na 1918 kamerlid

P. van den Heuvel

Lid van de Tweede Kamer, district Boxmeer

Eerste verkiezing/benoeming 1871

Toelating

19-9-1871

Herkozen

1875-1977

Einde lidmaatschap 1-10-1877: nam ontslag wegens verkiezing tot lid van Gs van Noord-Brabant 


\section{F1.J. Janssen}

Lid van de Tweede Kamer, district Maastricht

Eerste verkiezing/benoeming 1902

Todating

29-4-1902

Herkozen

1905, 1909, 1913, 1917, 1917

Einde lidmaatschap

17-9-1918: geen kandidaat bij de verkiezingen

N.B. Janssen had tussen 1922 en 1946 zitting in de Eerste Kamer.

\section{he. P.A.S. Kerens}

Lid van de Tweede Kamer, provincie Limburg

Ecrste verkiczing/benoeming $\quad 1840$

Toelating

20-10-1840

Herkozen

Einde lidmaatschap

18-10-1841: geen kandidaat bij de verkiezingen

har. G.E.F.X.M. Kerens de Wylré

Lid van de Tweede Kamer, district Maastricht

Eerste verkiezing/benoeming $\quad 1873$

Toelating

16-9-1873

Herkozen

1877

Einde lidmaatschap

5-1-1880: overleden

\section{H.C.F. Kerstens}

Lid van de Tweede Kamer, district Boxmeer

Eerste verkiezing/benoeming 1860

Toelating

18-9-1860

Herkozen

$1864,1866,1868,1869$

Einde lidmaatschap

15-9-1871: verslagen bij de verkiezingen

FH.C.E. baron de Keverberg de Kessel

Lid van de Tweede Kamer, district Roermond

Eerste verkiezing/benoeming $\quad 1864$

Toelating

Herkozen

11-3-1864

Einde lidmaatschap

19-10-1864: verslagen bij de verkiezingen

H.F. Lambrechts

Lid van de Tweede Kamer, district Roermond, vanaf 1888 district Sittard

Eerste verkiezing/benoeming

Toelating

1873

Herkozen

Einde lidmaatschap

16-9-1873

$1877,1881,1884,1886,1887,1888,1891,1894$

25-11-1896: overleden 


\section{J.J. Lambrechts}

Lid van de Tweede Kamer, district Sittard

Eerste verkiezing/benoeming 1849

Toelating

17-7-1849

Herkozen

Einde lidmaatschap

7-10-1850: verslagen bij de verkiezingen

\section{J.L.M. Leclercq}

Lid van de Tweede Kamer, provincie Limburg, vanaf 1849 district Roermond

Eerste verkiezing/benoeming $\quad 1846$

Toelating

niet toegelaten

Verkiezing/benoeming

1848

Toelating

15-2-1849

Herkozen

Einde lidmaatschap

7-10-1850: verslagen bij de verkiezingen

P.W. baron de Liedel de Well

Lid van de Eerste Kamer

Eerste verkiezing/benoeming $\quad 1840$

Toelating

20-10-1840

Herkozen

Einde lidmaatschap

$-$

13-2-1849: geen kandidaat bij de verkiezingen

Ch. de Limpens

Lid van de Tweede Kamer, district Maastricht

Eerste verkiezing/benoeming 1850

Toelating

9-12-1850

Herkozen

Einde lidmaatschap

26-4-1853: geen kandidaat bij de verkiezingen om zodoende zetel ter beschikking te stellen aan J.R. Thorbecke

Verkiezing/benoeming $\quad 1855$

Toelating

30-5-1855

Herkozen

Einde lidmaatschap

20-9-1858: geen kandidaat bij de verkiezingen

P.L. de Lom de Berg

Lid van de Tweede Kamer, district Venlo, vanaf 1850 district Roermond

Eerste verkiezing/benoeming $\quad 1849$

Toelating

15-2-1849

Herkozen $1850,1852,1853,1854,1858,1862,1866,1866$

Einde lidmaatschap 25-2-1868: verslagen bij de verkiezingen 
for. L.H.L.J. van der Maesen de Sombreff

Lid van de Eerste Kamer, provincie Limburg

Eerste verkiezing/benoeming 1909

Toelating

19-3-1909

Herkozen

1910, 1917

Einde lidmaatschap

bleef na 1918 kamerlid

Ar. P.Th. van der Maesen de Sombreff

Lid van de Tweede Kamer, district Maastricht

Eerste verkiezing/benoeming $\quad 1864$

Toclating

20-9-1864

Herkozen

$1864,1866,1868,1869$

Einde lidmaatschap

15-9-1873: verslagen bij de verkiezingen

LH.A. Magnée

Lid van de Eerste Kamer, provincie Limburg

Eerste verkiezing/benoeming $\quad 1884$

Toelating

29-7-1884

Herkozen

$1887,1888,1890,1899$

Einde lidmaatschap

14-4-1902: overieden

J.B.C.E.M. graaf de Marchant d'Ansembourg

Lid van de Tweede Kamer, district Gulpen

Eerste verkiezing/benoeming $\quad 1891$

Toelating

Herkozen

16-9-1891

Einde lidmaatschap

1894

21-9-1897: geen kandidaat bij de verkiezingen

I.M.M.H. Merckelbach

Lid van de Tweede Kamer, district Gulpen

Eerste verkiezing/benoeming 1897

Toelating

Herkozen

22-9-1897

Einde lidmaatschap

1901

19-9-1905: geen kandidaat bij de verkiezingen

Thr. A.H.J.H. Michiels van Kessenich

Lid van de Eerste Kamer, provincie Limburg

Eerste verkiezing/benoeming 1899

Toelating

6-12-1899

Herkozen

$1904,1913,1917$

Einde lidmaatschap

bleef na 1918 kamerlid

Tht, F.B.H. Michiels van Kessenich

Lid van de Eerste Kamer, provincie Limburg

Eerste verkiezing/benoeming 1859

Toelating

Herkozen

20-9-1859

Einde lidmaatschap

1868,1877

1-6-1881: overleden 
(jhr.) A.H.Th. (baron) Michiels van Verduynen

Lid van de Tweede Kamer, provincie Limburg

Eerste verkiezing/benoeming 1840

Toelating

20-10-1840

Herkozen

1842,1845

Einde lidmaatschap

18-10-1846: overleden

M.V. Nijst

Lid van de Tweede Kamer, district Maastricht

Eerste verkiezing/benoeming 1880

Toelating

24-2-188o

Herkozen

1881

Einde lidmaatschap

24-6-1882: overleden

W.H. Nolens

Lid van de Tweede Kamer, district Venlo

Eerste verkiezing/benoeming 1896

Toelating

13-11-1896

Herkozen

1897, 1901, 1905, 1909, 1913, 1917

Einde lidmaatschap

bleef na 1918 kamerlid

J.E.H.W. baron d'Olne

Lid van de Tweede Kamer, district Roermond

Eerste verkiezing/benoeming $\quad \mathbf{1 8 8 9}$

Trolativis

$3>71880$,

Herkozen

Einde lidmaatschap

9-4-1891: overleden

jhr. P.M.J.F. Petit

Lid van de Tweede Kamer, provincie Limburg

Eerste verkiezing/benoeming $\quad 1841$

Toelating

21-10-1841

Herkozen

Einde lidmaatschap

21-10-1844: verslagen bij de verkiezingen 
WH. Pijls

Lid van de Tweede Kamer, district Roermond

Eerste verkiezing/benoeming 1869

Toelating 21-9-1869

Herkozen -

Einde lidmaatschap 15-9-1873: geen kandidaat bij de verkiezingen

Lid van de Eerste Kamer, provincie Limburg

Eerste verkiezing/benoeming $\quad 1880$

Toelating 21-9-1880

Herkozen $\quad 1884,1887,1888,1896$

Einde lidmaatschap 6-12-1899: nam ontslag om gezondheidsredenen

M. de Ras

Lid van de Tweede Kamer, district Maastricht

Eorste verkiezing/benoeming $\quad 1891$

Toelating

16-9-1891

Herkozen

1894, 1897, 1900, 1901

Einde lidmaatschap

16-3-1902: nam ontslag wegens benoeming tot lid van de Algemene Rekenkamer

\section{H.G.L Regout}

Lid van de Eerste Kamer, provincie Limburg

Eerste verkiezing/benoeming $\quad \mathbf{1 8 8 1}$

Toelating

$11-7-1881$

Herkozen

$1884,1887,1888,1893,1902$

Einde lidmaatschap

20-9-1904: geen kandidaat bij de verkiezingen

LH.W. Regout

Lid van de Eerste Kamer, provincie Limburg

Eerste verkiezing/benoeming 1904

Toelating

Herkozen

Einde lidmaatschap

21-9-1904

-

20-1-1909: nam ontslag wegens benoeming tot minister van Waterstaat

N.B. Regout had in 1914-1915 zitting in de Eerste Kamer voor de provincie NoordBrabant

P.D. Regout

Lid van de Eerste Kamer, provincie Limburg

Eerste verkiezing/benoeming $\quad 1849$

Toelating

Herkozen

15-2-1849

Einde lidmaatschap 1850

19-9-1859: verslagen bij de verkiezingen 
G.J. de Rijk

Lid van de Eerste Kamer, provincie Limburg

Eerste verkiezing/benoeming 1849

Toelating

20-12-1849

Herkozen

Einde lidmaatschap

6-10-1850: geen kandidaat bij de verkiezingen

jhr. Ch.J.M. Ruijs de Beerenbrouck

Lid van de Tweede Kamer, district Gulpen

Eerste verkiezing/benoeming 1905

Toelating

20-9-1905

Herkozen

$1909,1913,1917$

Einde lidmaatschap

15-5-1918: nam ontslag wegens benoeming tot

Commissaris der Koningin in Limburg

jhr. G.L.M.H. Ruijs van Beerenbroek

Lid van de Tweede Kamer, district Maastricht, vanaf 1892 district Roermond

Eerste verkiezing/benoeming $\quad 1880$

Toelating

Herkozen

6-12-188o

Einde lidmaatschap

Verkiezing/benoeming $1883,1884,1886,1887,1888$

Toelating

20-4-1888: nam ontslag wegens benoeming tot minister van Justitie

Herkozen

1892

1-7-1892

Einde lidmaatschap

27-9-1893: nam ontslag wegens benoeming tot Commissaris der Koningin in Limburg

L.F.H.C. Ruland

Lid van de Tweede Kamer, district Maastricht

Eerste verkiezing/benoeming $\quad 1886$

Toelating

4-3-1886

Herkozen

$1886,1887,1888$

Einde lidmaatschap

15-9-1891: geen kandidaat bij de verkiezingen

J.L.Th.A.L baron van Scherpenzeel Heusch

Lid van de Tweede Kamer, district Sittard

Eerste verkiezing/benoeming 1849

Toelating

schreef op 22-5-1849 zijn zetel niet in te nemen

Herkozen

Einde lidmaatschap

J.H.J. Schreinemacher

Lid van de Tweede Kamer, district Maastricht

Eerste verkiezing/benoeming $\quad 1888$

Toelating

10-7-1888

Herkozen

1891

Einde lidmaatschap

2-6-1892: overleden 


\section{W.G. Straetmans}

Lid van de Tweede Kamer, district Maastricht

Eerste verkiczing/benoeming $\quad 1882$

Toelating

$19-9-1882$

Herkozen

1884

Einde lidmaatschap

15-1-1886: nam ontslag om gezondheidsredenen

\section{M.P.H. Strens}

Lid van de Tweede Kamer, provincie Limburg, vanaf 1853 district Roermond Ecrste verkiezing/benoeming $\quad 1844$

Toclating

Herkozen

Einde lidmaatschap

Verkiezing/benoeming

22-10-1844

Toelating

$-$

Herkozen

Einde lidmaatschap

23-10-1846: nam ontslag wegens benoeming tot procureur-generaal in Noord-Brabant 1853

16-6-1853

1856,1860

14-3-1861: nam ontslag wegens benoeming tot minister van Zaken der Rooms-Katholieke Eredienst

\section{hr. V.E.L. de Stuers}

Lid van de Tweede Kamer, district Weert

Eerste verkiezing/benoeming 1901

Toelating

18-9-1901

Herkozen

1905, 1909, 1913

Einde lidmaatschap

21-3-1916: overleden

1.M. Swart

Buitengewoon lid van de Tweede Kamer, provincie Limburg

Eerste verkiezing/benoeming $\quad 1848$

Toelating

Herkozen

18-9-1848

Einde lidmaatschap

7-10-1848: wegens beèindiging buitengewone zitting

A.J.J.H. Thissen

Buitengewoon lid van de Tweede Kamer, provincie Limburg

Eerste verkiezing/benoeming $\quad 1848$

Toelating

18-9-1848

Herkozen

Einde lidmaatschap

7-10-1848: wegens beêindiging buitengewone zitting 


\section{J.R. Thorbecke}

Lid van de Tweede Kamer, district Maastricht

Eerste verkiezing/benoeming 1853

Toelating

27-7-1853

Herkozen

1856

Einde lidmaatschap

5-7-1856: nam na herverkiezing geen zitting voor district Maastricht (nam toen zitting voor distric Deventer)

N.B. Thorbecke had voor 1853 en na 1856 van buiten Limburg zitting in de Tweede Kamer.

P.J. Truijen

Lid van de Tweede Kamer, district Weert

Eerste verkiezing/benoeming 1894

Toelating

Herkozen

17-5-1894

Einde lidmaatschap 1897

17-9-1901: geen kandidaat bij de verkiezingen (nam afscheid van de Tweede Kamer om voorzitter te worden van de juist opgerichte Limburgse Landbouw Bond)

jhr. L.L.W.M.J. de Villers de Pité

Lid van de Tweede Kamer, district Heerlen

Eerste verkiezing/benoeming $\quad 1849$

Toelating

15-2-1849

Herkozen

Einde lidmaatschap

7-10-1850: verslagen bij de verkiezingen

Lid van de Eerste Kamer, provincie Limburg

Eerste verkiezing/benoeming 1850

Toelating

9-10-1850

Herkozen

$1853,1862,1871$

Einde lidmaatschap

20-9-1880: verslagen bij de verkiezingen

C.M.H. baron de Weichs de Wenne

Lid van de Tweede Kamer, provincie Limburg

Eerste verkiezing/benoeming $\quad 1846$

Toelating

Herkozen

4-5-1847

Einde lidmaatschap

1847

13-2-1849: geen kandidaat bij de verkiezingen 
PFE. van Wintershoven

Lid van de Tweede Kamer, district Maastricht

Eerste verkiezing/benoeming $\quad 1852$

Toclating

22-9-1852

Herkozen

1853,1854

Einde lidmaatschap

Verkiczing/benoeming

12-3-1855: nam ontslag om gezondheidsredenen

Toclating 1856

Herkozen

$17-9-1856$

Einde lidmaatschap

1860

19-9-1864: verslagen bij de verkiezingen

MA. van Wylick

Lid van de Tweede Kamer, district Roermond

Eerste verkiezing/benoeming $\quad 1850$

Toclating

9-10-1850

Herkozen

Einde lidmaatschap

14-6-1853: verslagen bij de verkiezingen 


\section{BIIL.AGE VIII}

Tijdsbalk met de parlementaire zetels ingenomen door leden uit Limburg, 1839-1918

\section{Eerste Kamer der Staten-Generaal}

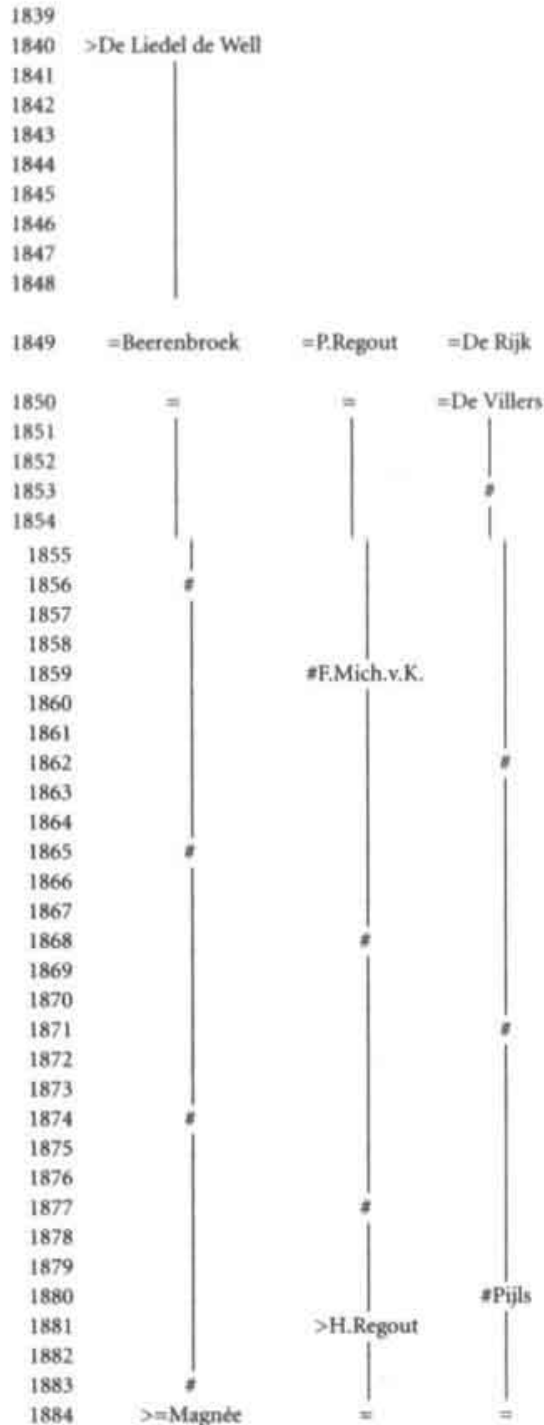




\section{Tweede Kamer der Staten-Generaal}

154

124

IAI

is:

140

144

ins

ith

wit

154

149

150

181

(58)

163

164

155

156

167

iss

159

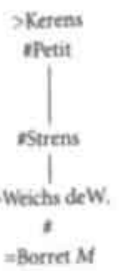

$>$ Mich. Verd.

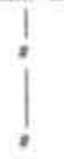

wBorret Mf
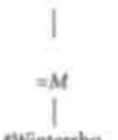

Wintersho.

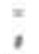

$>$ De Limpens

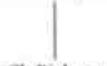

eh.Bicberst.

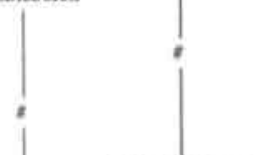

$t=$

1

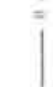

s

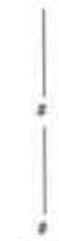

$>$ G.Ruijs

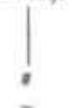

av.d.Maesen

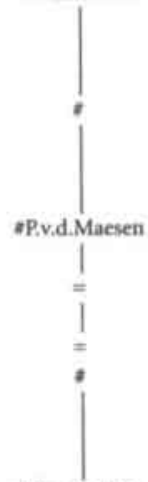

=Villen $H$

simpens $M$

=Thorbecke

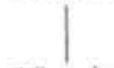

*Wintersho.

okerens deW.

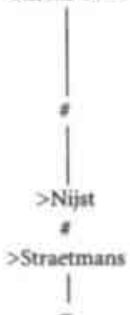

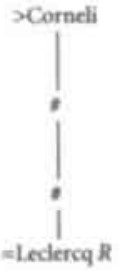

Thisen - Blormarts

$=$ De $\operatorname{Lom} V \quad=($ Scherpenzeel $)+$

J.Lambrechts S

aWyick $R$

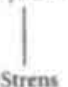

strens<smiles>CC=CCCCC</smiles>

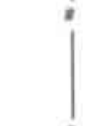

$>$ Cornelis

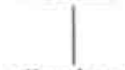

$>$ Keverbergt

pCornetis

$=$. . Haffmans

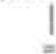

epijls

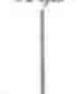

tH.Lambr.
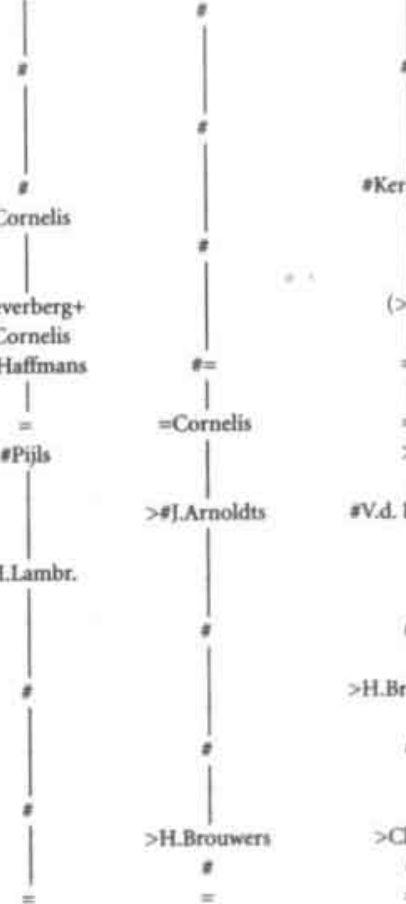

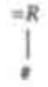

ahengst $B$

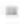

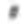

\section{- Kerstens}
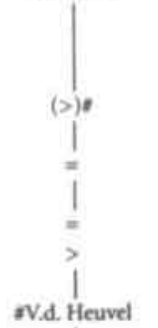

*. Haffmans B

$>$. Arnoldts

ov.d. Heuvel

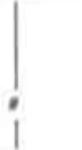

$>$ H. Brouwers
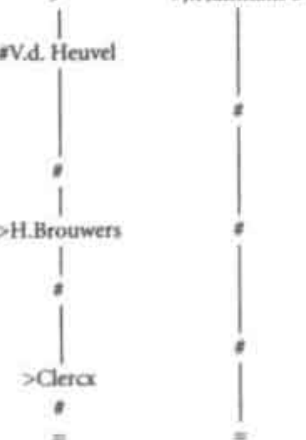


\section{Eerste Kamer der Staten-Generaal}

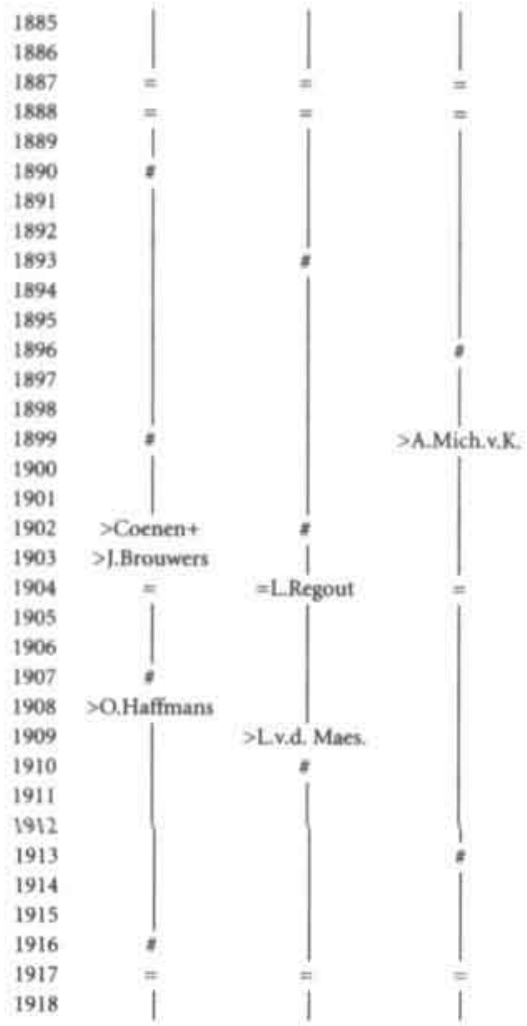

Aanduidingen:

naam cursief

(naam)

\#naam

\#

=naam

$=$

$>$ naam

$>$

$\Rightarrow$

$>=$
Buitengewoon lid van de Tweede Kamer Nam geen zitting

Gekozen bij een periodieke verkiezing Herkozen bij een periodieke verkiezing Gekozen bij een verkiezing na ontbinding van de Kamer(s) Herkozen bij een verkiezing na ontbinding van de Kamer(s) Gekozen/benoemd bij een tussentijdse verkiezing/benoeming

Herkozen bij een tussentijdse verkiezing Achtereenvolgens ge/herkozen bij een verkiezing na een kamerontbinding en bij een tussentijdse verkiezing Achtereenvolgens ge/herkozen bij een tussentijdse verkiezing en bij een verkiezing na een kamerontbinding 


\section{Tweede Kamer der Staten-Generaal}

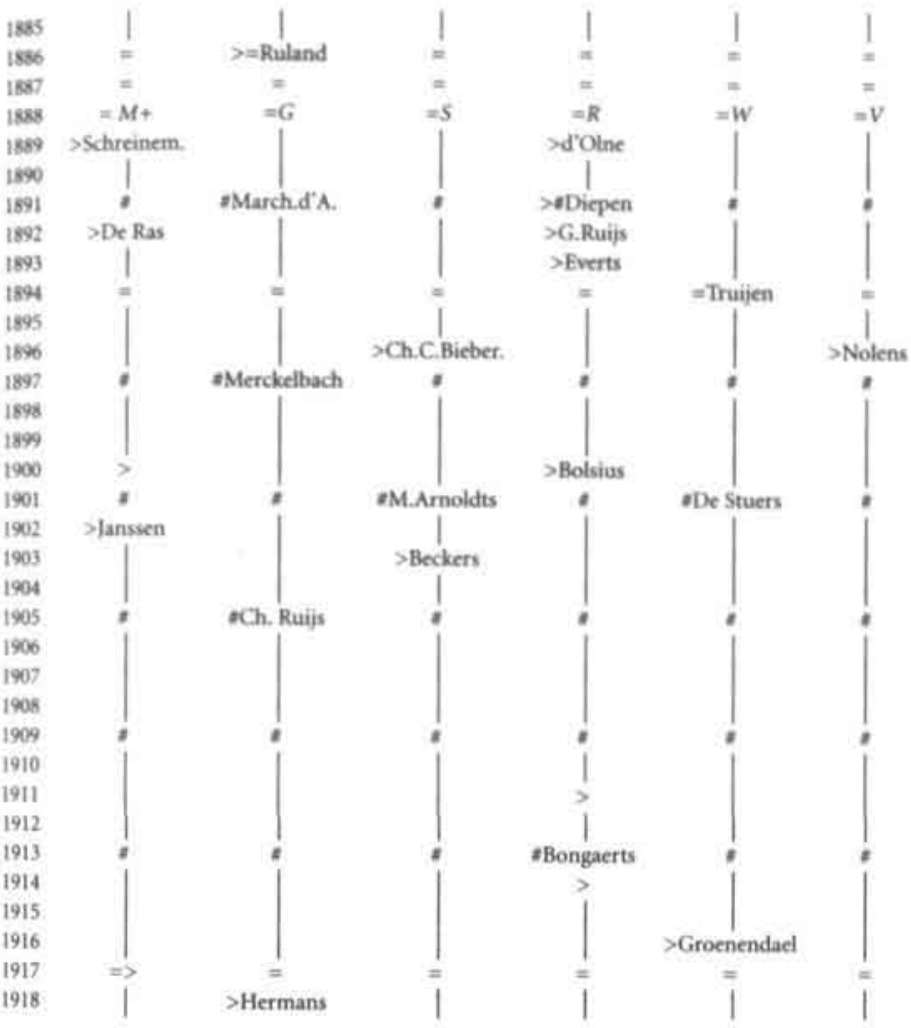

Achtereenvolgens ge/herkozen bij een tussentijdse verkiezing en bij een reguliere verkiezing Achtereenvolgens ge/herkozen bij een reguliere verkiezing en bij een verkiezing na een kamerontbinding Tussentijdse verkiezing viel samen met reguliere verkiezing Binnen één kalenderjaar werden achtereenvolgens de desbetreffende twee kamerleden gekozen Kiesdistrict: resp. Boxmeer, Gulpen, Maastricht, Roermond, Sittard, Venlo en Weert

ledere lijn vormt een tijdsbalk voor een van de Limburgse zetels in de Eerste en Tweede Kamer. Limburg begint in 1840 met één Eerste-Kamerzetel en drie TweedeKamerzetels. Vanaf 1849 telt Limburg drie Eerste-Kamerleden en vijf Tweede-Kamerleden (inclusief de zetel voor het district Boxmeer). Met ingang van 1869 komt er ten 
gevolge van de verdubbeling van het district Boxmeer een zesde Tweede-Kamerzctel bij.

\section{Leesvoorbeeld}

In 1840 traden ten gevolge van een tussentijdse benoeming De Liedel de Well toe tot de Eerste Kamer en Kerens, Michiels van Verduynen en Corneli tot de Tweede Kamer. Kerens werd bij de reguliere verkiezingen van 1841 vervangen door Petit, die op zijn beurt bij de reguliere verkiezingen van 1844 vervangen werd door Strens. Bij een tussentijdse verkiezing in 1846 werd Strens opgevolgd door Weichs de Wenne, die in 1847 werd herkozen bij de reguliere verkiezingen. In $1848 \mathrm{kreeg}$ Nederland een districtenstelsel. Bij de verkiezingen die dat jaar worden gehouden na de kamerontbinding, werd Borret gekozen als afgevaardigde namens het district Maastricht. In 1850 vonden ten gevolge van een kamerontbinding nieuwe verkiezingen plats binnen een nieuw districtenstelsel; Borret werd hierbij herkozen. Bij de reguliere verkiezingen van 1852 werd Borret opgevolgd door Van Wintershoven, die vervolgens werd herkozen bij de verkiezingen in 1853 (na de kamerontbinding) en bii de reguliere verkiezingen van 1854 . Hij werd na een tussentijdse verkiezing in $18550 \mathrm{p}$ gevolgd door De Limpens. De Limpens werd bij de reguliere verkiezingen van 1858 opgevolgd door De Bieberstein Rogalla Zawadsky, die vervolgens werd herkozen bii de reguliere verkiezingen van 1862 en 1866 , bij de verkiezingen na de kamerontbinding van 1866 en 1868 en bij de reguliere verkiezingen van 1871 , 1875 en 1879 . Bij een tussentijdse verkiezing in 1880 werd De Bieberstein opgevolgd door G. Ruijs van Beerenbroek, die vervolgens werd herkozen bij de reguliere verkiezingen van 1883 en bij de verkiezingen na een kamerontbinding in $1884,1886,1887$ en 1888 . Bij deze laatste verkiezing werd het districtenstelsel gewijzigd. In 1888 vond na de verkiezingen ten gevolge van de kamerontbinding ook een tussentijdse verkiezing plaats waarbij Schreinemacher werd gekozen als opvolger van Ruijs van Beerenbroek. Schreinemacher werd herkozen bij de reguliere verkiezingen van 1891 en werd in 1892 bij een tussentijdse verkiezing vervangen door De Ras. De Ras werd herkozen in 1894 bij de verkiezingen na een kamerontbinding, in 1897 bij de reguliere verkiezingen, in 1900 bij een tussentijdse verkiezing en in 1901 bij de reguliere verkiezingen. Bij een tussentijdse verkiezing in 1902 werd hij vervangen door Janssen, die achtereenvolgens werd herkozen bij de reguliere verkiezingen van 1905, 1909 en 1913, bij de verkiezingen na de kamerontbinding van 1917 en bij een tussentijdse verkiezing in datzelfde jaar. 


\section{BIILAGE IX}

Bezettingsgraad van parlementaire zetels, 1839-1918 (elk vijfde zittingsjaar)

\begin{tabular}{|c|c|c|c|c|c|c|c|c|c|c|c|c|c|}
\hline pelentair jaar & $\begin{array}{c}\mathrm{Tr} \\
\mathrm{gem}\end{array}$ & $\begin{array}{c}L b \\
\mathrm{sm} .\end{array}$ & $I$ & 2 & 3 & 4 & 5 & 6 & $\begin{array}{c}\mathrm{ex} \\
\mathrm{gem} .\end{array}$ & $\begin{array}{c}L b \\
\mathrm{gem} .\end{array}$ & I & 2 & 3 \\
\hline $156-181^{*}$ & 79 & 84 & $\begin{array}{l}81 \\
\text { Ker }\end{array}$ & $\begin{array}{c}87 \\
\text { Mic }\end{array}$ & $\begin{array}{c}84 \\
\text { Cor }\end{array}$ & & & & 69 & $8 I$ & $\begin{array}{l}8 ! \\
\text { bie }\end{array}$ & & \\
\hline $146-1546$ & 87 & 85 & $\begin{array}{l}77 \\
\text { Str }\end{array}$ & 92 & 85 & & & & 54 & 62 & 62 & & \\
\hline $12+1850^{\circ}$ & 84 & 76 & $\begin{array}{c}79 \\
\text { Bor }\end{array}$ & $\begin{array}{l}85 \\
\text { Lec }\end{array}$ & $\begin{array}{c}81 \\
\text { Lom }\end{array}$ & $\begin{array}{c}64 \\
\operatorname{Lam}\end{array}$ & $\begin{array}{l}73 \\
\text { Vi }\end{array}$ & & 79 & 76 & $\begin{array}{l}79 \\
\text { Bee }\end{array}$ & $\begin{array}{c}83 \\
\text { Reg }\end{array}$ & $\begin{array}{l}63 \\
R \text { ii }\end{array}$ \\
\hline $153-1854$ & 82 & 63 & $\begin{array}{l}85 \\
\text { Tho }\end{array}$ & $\begin{array}{l}49 \\
\text { Str }\end{array}$ & 61 & $\begin{array}{c}45 \\
\text { Win }\end{array}$ & $\begin{array}{c}73 \\
\text { Hen }\end{array}$ & & 71 & 55 & 29 & 65 & $\begin{array}{l}71 \\
\text { Vi }\end{array}$ \\
\hline 183-1859 & 82 & 80 & $\begin{array}{l}85 \\
\text { Bie }\end{array}$ & 84 & 86 & 71 & 75 & & 74 & 76 & 61 & 82 & 87 \\
\hline $1863-1864$ & 75 & 56 & 76 & $\begin{array}{l}79 \\
\text { C-K }\end{array}$ & 54 & 15 & $\begin{array}{l}63 \\
\text { Ker }\end{array}$ & & 73 & 60 & 70 & $\begin{array}{c}80 \\
\text { Mic }\end{array}$ & 33 \\
\hline 1587 & 84 & 81 & 84 & $\begin{array}{c}69 \\
\text { Haf }\end{array}$ & 69 & $\begin{array}{c}94 \\
\text { Mae }\end{array}$ & 84 & & 70 & 80 & 80 & 100 & 50 \\
\hline $151-1872$ & 82 & 73 & 86 & 71 & $\begin{array}{c}68 \\
\text { Arn }\end{array}$ & 82 & $\begin{array}{l}71 \\
\text { Pijl }\end{array}$ & $\begin{array}{c}64 \\
\text { Heu }\end{array}$ & 81 & 65 & 39 & 87 & 65 \\
\hline $1876-1877$ & 83 & 78 & 90 & 74 & 67 & $\begin{array}{c}88 \\
\text { Ker }\end{array}$ & $\begin{array}{c}85 \\
\mathrm{Lam}\end{array}$ & 64 & 73 & 70 & 100 & 38 & 75 \\
\hline $1891-1882$ & 79 & 61 & $\begin{array}{l}70 \\
\text { Rui }\end{array}$ & 75 & $\begin{array}{c}32 \\
A-B\end{array}$ & $\begin{array}{l}76 \\
\mathrm{Nij}\end{array}$ & 62 & $\frac{53}{B-C}$ & 80 & 52 & 20 & $\begin{array}{c}68 \\
\text { Reg }\end{array}$ & $\begin{array}{l}72 \\
P_{i i}\end{array}$ \\
\hline $1885-1886$ & 82 & 59 & 75 & 55 & 53 & $\begin{array}{c}49 \\
S-R\end{array}$ & 65 & 61 & 79 & 72 & $\begin{array}{c}79 \\
\text { Mag }\end{array}$ & 66 & 72 \\
\hline $164-1889^{\circ}$ & 87 & 80 & $\begin{array}{l}74 \\
\text { Sch }\end{array}$ & 81 & $\begin{array}{c}79 \\
\text { B-O }\end{array}$ & 87 & 81 & 80 & 81 & 75 & 72 & 92 & 89 \\
\hline $1693-1894$ & 81 & 58 & 69 & 90 & $\begin{array}{l}75 \\
\text { R-E }\end{array}$ & $\begin{array}{c}52 \\
\text { Mar }\end{array}$ & 60 & 4 & 83 & 59 & 100 & 83 & 89 \\
\hline $1897-1898^{\circ}$ & 82 & 87 & 76 & $\begin{array}{c}92 \\
\text { Nol }\end{array}$ & 92 & $\begin{array}{c}92 \\
\text { Mer }\end{array}$ & $\begin{array}{l}87 \\
\text { Bie }\end{array}$ & $\begin{array}{c}87 \\
\text { Tru }\end{array}$ & 83 & 66 & 38 & 79 & 76 \\
\hline $1902-1903$ & 79 & 69 & $\begin{array}{l}74 \\
\operatorname{lan}\end{array}$ & 94 & $\frac{82}{\text { Bol }}$ & 63 & $\begin{array}{c}29 \\
\text { Arn }\end{array}$ & $\begin{array}{l}71 \\
5 t u\end{array}$ & 71 & 58 & $\begin{array}{c}61 \\
C-B\end{array}$ & $\begin{array}{c}61 \\
\text { Mic }\end{array}$ & $\begin{array}{c}55 \\
\text { Reg }\end{array}$ \\
\hline $1907-1908$ & 76 & 75 & 71 & 91 & 76 & $\begin{array}{c}92 \\
\text { Rui }\end{array}$ & $\begin{array}{c}66 \\
\text { Bec }\end{array}$ & 52 & 79 & 79 & $\begin{array}{c}66 \\
\text { B-H }\end{array}$ & 69 & 100 \\
\hline $1912-1913$ & 75 & 79 & 75 & 95 & 52 & 97 & 73 & 97 & 73 & 78 & 68 & 78 & $\begin{array}{c}88 \\
\text { Mac }\end{array}$ \\
\hline $197 ?$ & 60 & 66 & 53 & 100 & $\begin{array}{c}73 \\
\text { Bon }\end{array}$ & 80 & 33 & $\begin{array}{c}40 \\
\text { Gro }\end{array}$ & 70 & 50 & 50 & 0 & 100 \\
\hline
\end{tabular}


TK gem. Gemiddelde Tweede-Kamerzetel

EK gem. Gemiddelde Eerste-Kamerzetel

Lb gem. Gemiddelde van de Limburgse zetels in de desbetreffende Kamer

1, 2, enz. Score per individuele Limburgse zetel

- Inclusief de Verenigde Vergadering

De kamerleden zijn bij hun eerste peiljaar weergegeven d.m.v. drie letters van de achternaam. Bij een zetelwisseling die binnen een peiljaar plaatsvindt, is van elk van de beide kamerleden één letter van de achternaam weergegeven. M.b.v. bijlage m kan worden achterhaald welk kamerlid wordt bedoeld.

Omdat de gepubliceerde Handelingen voor de Eerste Kamer in de zittingsjaren $1840-$ 1841 en $1845-1846$ geen presentielijsten of naamlijsten bij stemmingen vermelden, is gebruik gemaakt van de presentielijsten in de geschreven notulen uit het archief van deze Kamer.

De bezettingsgraad geeft aan welk percentage van het totale aantal vergaderingenin een parlementair jaar het kamerlid of de kamerleden die de desbetreffende zetels] $\operatorname{bezette}(\mathrm{n})$, aanwezig was/waren.

De Limburgse percentages die gelijk zijn aan of hoger zijn dan het landelijk gemiddelde, zijn cursief gedrukt.

De Limburgse percentages die meer dan tien procent onder het landeliik gemidddde liggen, zijn vet gedrukt.

\section{BIILAGE X}

Wereldlijke en kerkelijke autoriteiten, Limburg 1815-1918

Gouverneurs en Commissarissen des Konings (der Koningin) in Limburg, 1815-1918

In 1850 werd de benaming gouverneur vervangen door Commissaris des Konings. Tot op heden wordt de Commissaris der Koningin in Limburg ook wel aangeduid als gouverneur, ook in stukken van het provinciaal bestuur. Het provinciehuis in Maastricht draagt de naam gouvernement.

1815-1831, Verenigd Koninkrijk:

jhr. Ch. de Brouckère

M.H.G. baron de Beeckman
Gouverneur, $1815-1828$

Gouverneur, 1828-1831 
\$31-1839, Nederlands gezag (Maastricht en Sint-Pieter)*:

int. J.E.P.E. Gericke van Herwijnen

ith. P.A.S. Kerens
Buitengewoon commissaris, $1831-1839$

Waarnemend gouverneur, $1831-1839$

130-1839, Belgisch gezag (geheel Limburg m.u.v. Maastricht en Sint-Pieter):

F.R.A. de Loé

IF. Hennequin

W. baron de Lamberts Cortenbach
Gouverneur, 1830-1831

Gouverneur, 1831-1834

Gouverneur, vanaf 1834

Vinaf de terugkeer onder Nederlands gezag in 1839:

A.L. Borret en

Itr.J.E.P.E. Gericke van Herwijnen

勃. J.E.P.E. Gericke van Herwijnen PD.E. MacPherson

Ahr. E.J.P. van Meeuwen

Itr. P.J.A.M. van der Does de Willebois fat. E. de Kuyper

Thr. G.L.M.H. Ruijs van Beerenbroek

hr. Ch.J.M. Ruijs de Beerenbrouck
Commissarissen voor de wederinbezitneming ${ }^{*}, 1839-1840$

Gouverneur, 1841-1845

Gouverneur, 1845-1846

Gouverneur/Commissaris des Konings, 1846-1856

Commissaris des Konings, 1856-1874

Commissaris des Konings/der Koningin, 1874-1893

Commissaris der Koningin, 1893-1918 (in 1895 naam gewijzigd in Ruijs de Beerenbrouck)

Commissaris der Koningin, meiaugustus 1918

"Na het ontslag van M.H.G. baron de Beeckman op 8 april 1831 werd de waarneming van het gouverneurschap opgedragen aan jhr. P.A.S. Kerens, lid van Gedeputeerde Staten. Gezien de buitengewone omstandigheden besloot de koning geen nieuwe gouverneur aan te stellen. Jhr. J.E.P.E. Gericke van Herwijnen werd op 27 april benoemd tot 'buitengewoon commissaris des konings, bekleed met het opperste gezag in de provincie Limburg'. Indien Gericke van Herwijnen in Maastricht was, bekleedde hij als buitengewoon commissaris tevens het gouverneurschap. Bij gebrek an werk was hij echter vaak in Den Haag en tijdens zijn afwezigheid wees hij telkens Kerens aan als waarnemer. ${ }^{5}$

" Op 12 juni 1839 benoemde Willem 1 Gericke van Herwijnen en A.J.L. Borret tot commissarisen belast met de wederinbezitneming en het voorlopig bestuur der wederinbezitgenomen landstreken van Limburg. Gericke van Herwijnen bleef buitengewoon commissaris voor Limburg, want Maastricht en Sint-Pieter behoefden niet opnieuw in bezit genomen worden. 
Hertogelijk Limburgs commissaris voor de Duitse Bondszaken, 1848-1849

\section{L.F.H. Beerenbroek}

Hertogelijk commissaris, $1848-1849$

In april 1848 oordeelde de Nederlandse ministerraad dat de regering zich niet lon inlaten met de uitvoering van met name het besluit van de Duitse Bond inzake de verkiezingen voor de Duitse Nationale Vergadering. De koning zou in hoedanighid van hertog van Limburg een commissaris dienen te benoemen die met de uitvoering van onder andere dit besluit werd belast. Op 28 april tekende Willem $\mathrm{u}$ het Koninkink Besluit waarbij Tweede-Kamerlid Louis Beerenbroek werd benoemd tot hertogeliik Limburgs commissaris voor de Duitse Bondszaken. De hertogelijk commissaris maakte geen deel uit van het binnenlands bestuur. Hij ressorteerde onder het departement van Buitenlandse Zaken en de door hem uitgevaardigde verordeningen werden niet gepubliceerd in het officieel orgaan van het provinciaal bestuur max in een speciaal blad: het Memoriaal voor de Duitsche Bondszaken. De gouverneur in Limburg ontving een uitdrukkelijke machtiging om de hertogelijk commissris bij de uitvoering van diens taak behulpzaam te zijn. ${ }^{6}$ De Nationale Vergadering faalde in haar streven naar Duitse eenheid en de hertogelijk commissaris verdween geruisloos van het toneel. Van het ontslag van Beerenbroek uit deze functie is geen spoor terug te vinden.?

Apostolisch vicaris en bisschoppen van Roermond, 1839-1918

Tussen 1815 en 1821 behoorde de provincie Limburg tot het bisdom Luik, met uitzondering van Sittard en de cure Horst die onder het bisdom Aken vielen. In 1821 werd dit Limburgse deel van het bisdom Aken ingedeeld bij Luik, behalve zeven parochies in het noorden, Afferden, Bergen, Heyen, Gennep, Middelaar, Ottersum en Mook, die aan het apostolisch vicariaat Grave werden toegevoegd. ${ }^{8}$ In 1833 , na de Belgische opstand, benoemde de Luikse bisschop C.R.A. van Bommel de apostolisch administrator van 's-Hertogenbosch, $\mathrm{H}$. den Dubbelden, tot vicaris-generaal met een volmacht voor het kerkelijk bestuur van het onder Nederlands gezag staande deel van Limburg, Maastricht en Sint-Pieter. Op 2 juni 1840 ondertekende paus Gregorius xvı een breve waarin het gebied van de nieuwe Nederlandse provincie Limburg tot een apostolisch vicariaat werd verklaard. ${ }^{9} \mathrm{Bij}$ het herstel van de bisschoppelijke hiërarchie in 1853 werd het apostolisch vicariaat verheven tot bisdom.

\section{J.A. Paredis*}

F.A.H. Boermans

I.H. Drehmans

L.J.H. Schrijnen
Apostolisch vicaris, $1840-1853$

Bisschop, 1853-1886

Bisschop, 1886-1900

Bisschop, 1900-1913

Bisschop, vanaf 1914 
- Gelijktijdig met zijn benoeming tot apostolisch vicaris werd Paredis door de paus benoemd tot bisschop van Hirene i.p.i. ('in partibus infidelium': in de gebieden van de ongelovigen; dit was de titulatuur van een bisschop zonder eigen bisdom) ${ }^{10}$

Limburgse ministers, 1839-1918*

M.P.H. Strens

Ahr. P.Th. van der Maesen de Sombreff

1.G. van den Bergh

Jhr. G.L.M.H. Ruijs van Beerenbroek

LH.W. Regout

ER.H. Regout

jhr. Ch.J.M. Ruijs de Beerenbrouck

A.A.H.W. König
Minister van Justitie, 1852-1853

Voorlopig minister voor de Zaken der

Rooms-Katholieke Eredienst, 1852-1853

Kabinet-Thorbecke 1 (1849-1853)

Minister voor de Zaken der Rooms-

Katholieke Eredienst, 1861-1862

Minister van Buitenlandse Zaken ad interim, 1861-1862

Kabinet-Van Zuylen van Nijevelt-Van

Heemstra (1861-1862)

Minister van Buitenlandse Zaken

Kabinet-Thorbecke in (1862-1866)

Minister van Waterstaat, Handel en

Nijverheid, 1883-1887

Kabinet-Heemskerk 11 (1883-1888)

Minister van Justitie, 1888-1891

Kabinet-Mackay (1888-1891)

Minister van Waterstaat, 1909-1913

Kabinet-Heemskerk (1909-1913)

Minister van Justitie, 1910-1913

Kabinet-Heemskerk (1909-1913)

Tijdelijk voorźitter van de ministerraad, vanaf $1918^{* *}$

Minister van Binnenlandse zaken, vanaf 1918

Kabinet-Ruijs de Beerenbrouck I (19181922)

Minister van Waterstaat, vanaf 1918

Kabinet-Ruijs de Beerenbrouck 1 (19181922)

"Als criterium is hier de geboorteplaats genomen.

Thr. P.J.A.M. van der Does de Willebois, van 1874 tot 1877 minister van Buitenlandse Zaken in het kabinet Heemskerk $\mathrm{I}(1874-1877)$, is daarom niet vermeld. Omdat hij voorafgaand aan zijn ministerschap gedurende bijna achttien jaar de functie van 
Commissaris des Konings in Limburg bekleedde, is Van der Does de Wilbois wed opgenomen in 'de rij van Limburgsche Excellenties' in Limburg 1839-1839. an plong tot afbouwhamer."

E.J.H. Borret, tussen juni 1866 en november 1867 minister van Justic in bet kabinet-Van Zuylen van Nijevelt-Heemskerk (1866-1868), staat eveneensiet in de lijst. Borret, geboren en opgegroeid in Noord-Brabant, was in de periode84-1853 werkzaam in Limburg bij de rechterlijke macht en van 1849 tot 1852 muit het district Maastricht afgevaardigd naar de Tweede Kamer.

Jhr. G.A.A. Alting von Geusau, in het eerste kabinet van Ruijs de Beenbrouck minister van Oorlog (1918-1920) en minister van Marine ad interim (ptember 1918), had ook een band met Limburg en wordt daarom zelfs soms als imburgs minister beschouwd. ${ }^{12} \mathrm{Hij}$ werd in 1864 geboren in Arnhem en was zo' vijf jaat, tussen 1885 en 1890 , in Limburg woonachtig. Alting von Geusau was gedrende die jaren als militair gelegerd in Maastricht. Zijn moeder was in Limburg georen - in Sittard - en hij trouwde in 1888 in Maastricht met een hier geboren en wenachtige vrouw. Ook zijn broer Paul Auguste huwde, vier jaar later, een Maastriche vrouw. Hun moeder had zich in 1885 - zij was toen weduwe - met drie van hir andete zoons in Maastricht gevestigd. ${ }^{13}$

** Tijdelijk voorzitter van de ministerraad was de officiēle benamin voor de minister-president. De voorzitter van de ministerraad werd telkens vor een jart benoemd, maar kon vervolgens worden herbenoemd. In de loop van de negentiende eeuw was het gebruik gegroeid naar een vast voorzitterschap gedurende de gehele zittingsperiode van een kabinet. Ook Ruijs de Beerenbrouck was vier jaar lang, van 1918 tot 1922, voorzitter. Hij werd in 1918 al wel minister-president genoemd, bijvoorbeeld door de Limburger Koerier, die hem dezelfde maand tevens bestempelde als eerste-minister en premier. ${ }^{14}$ Sinds 1945 wordt de voorzitter van de ministerraad in het benoemingsbesluit aangeduid als minister-president; in 1983 werd de functie van minister-president opgenomen in de grondwet. ${ }^{15}$ 


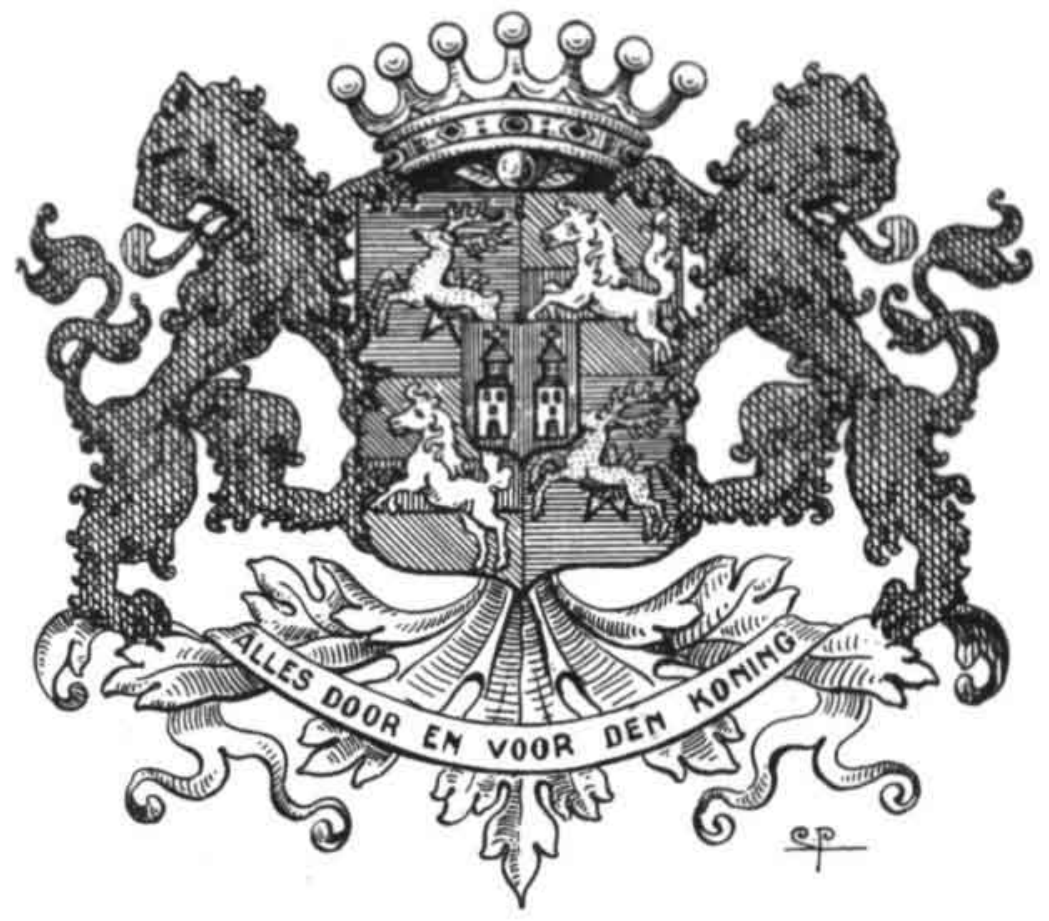

Wapen van Michiels van Kessenich. Overgenomen uit J.M. v.d. Venne (red.), Limburgsche wapens (Maastricht 1925). 


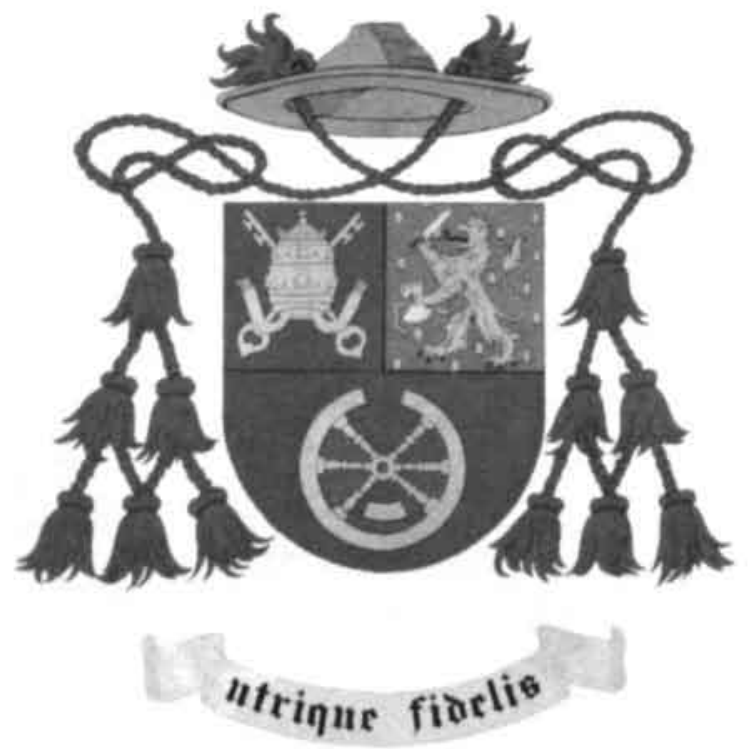

Wapen van W.H. Nolens. Overgenomen uit De Limburgse Leeuw jig. 8 (1959-1960).

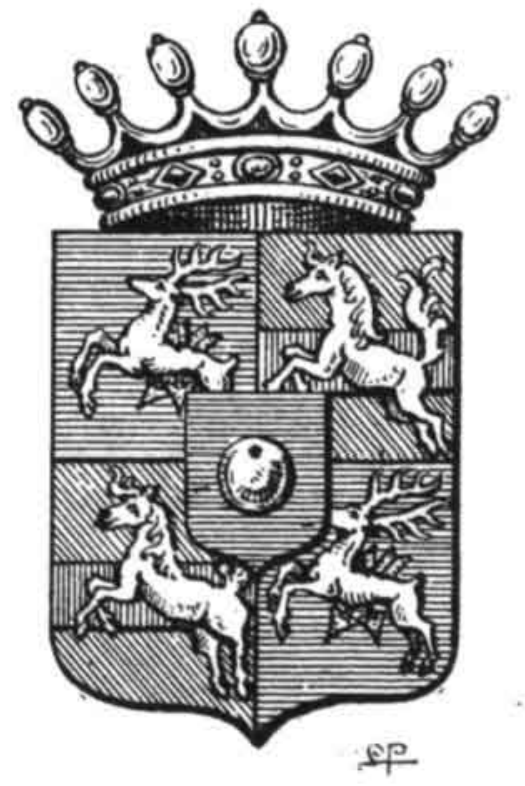

Wapen van Michiels van Verduynen. Overgenomen uit J.M. v.d. Venne (red.), Limburgsche wapens (Maastricht 1925). 


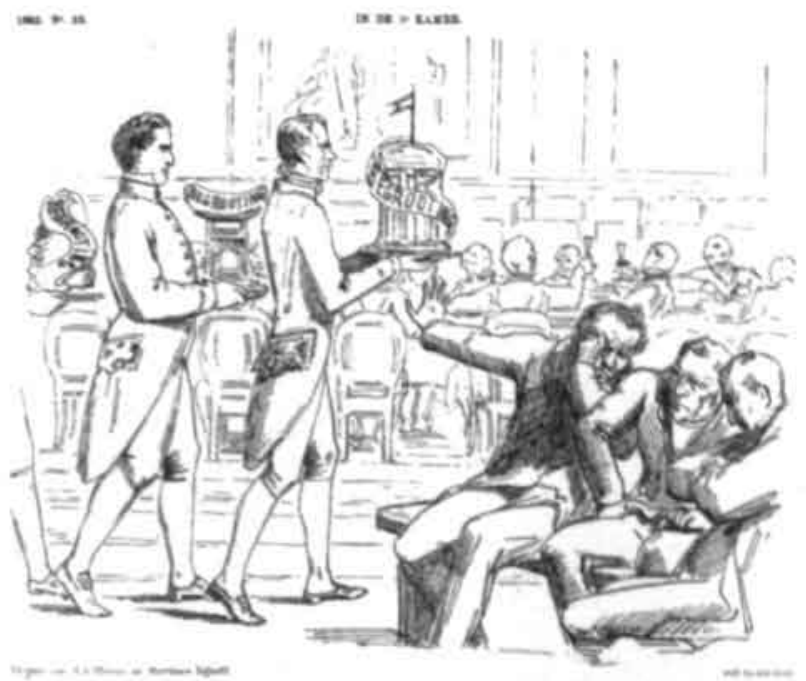

'Geen enkele schotel bekoort de drie Limburgsche heeren.' Overgenomen uit De Nederlandsche spectator 30 december 1865.

\section{DE AFVALLIGEN.}

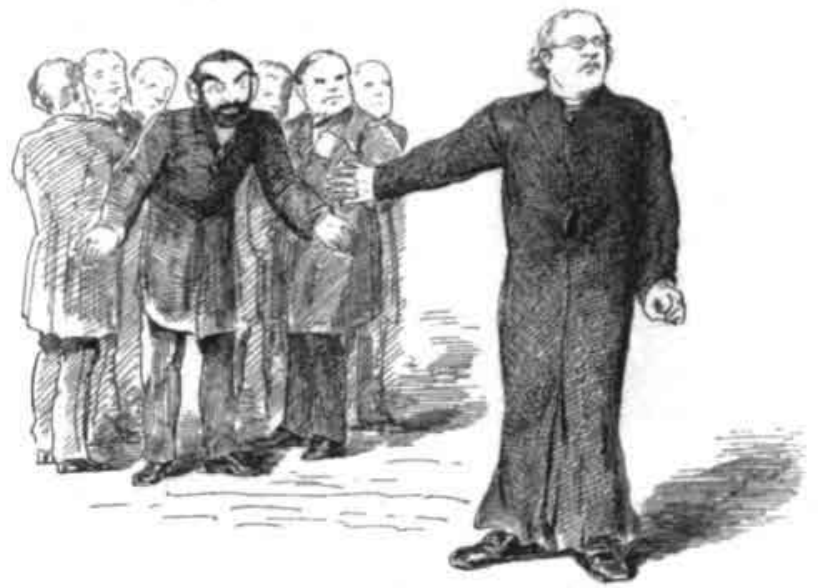

"'Gaat, gij ontrouwe zonen der Kerk, ik wil u niet meer kennen..." - Maar, Eerwaarde vader... wij hebben nog niet gezondigd; de effectenwet is niet in stemming geweest, - misschien zelfs is zij reeds van de baan... "Gaat, zeg ik u... uw ongehoorzaamheid, uw gebrek aan onderwerping is openbaar... Met mijn vloek beladen zult gij uw Paschen vieren."' Overgenomen uit Uilenspiegel 9 april 1881. 


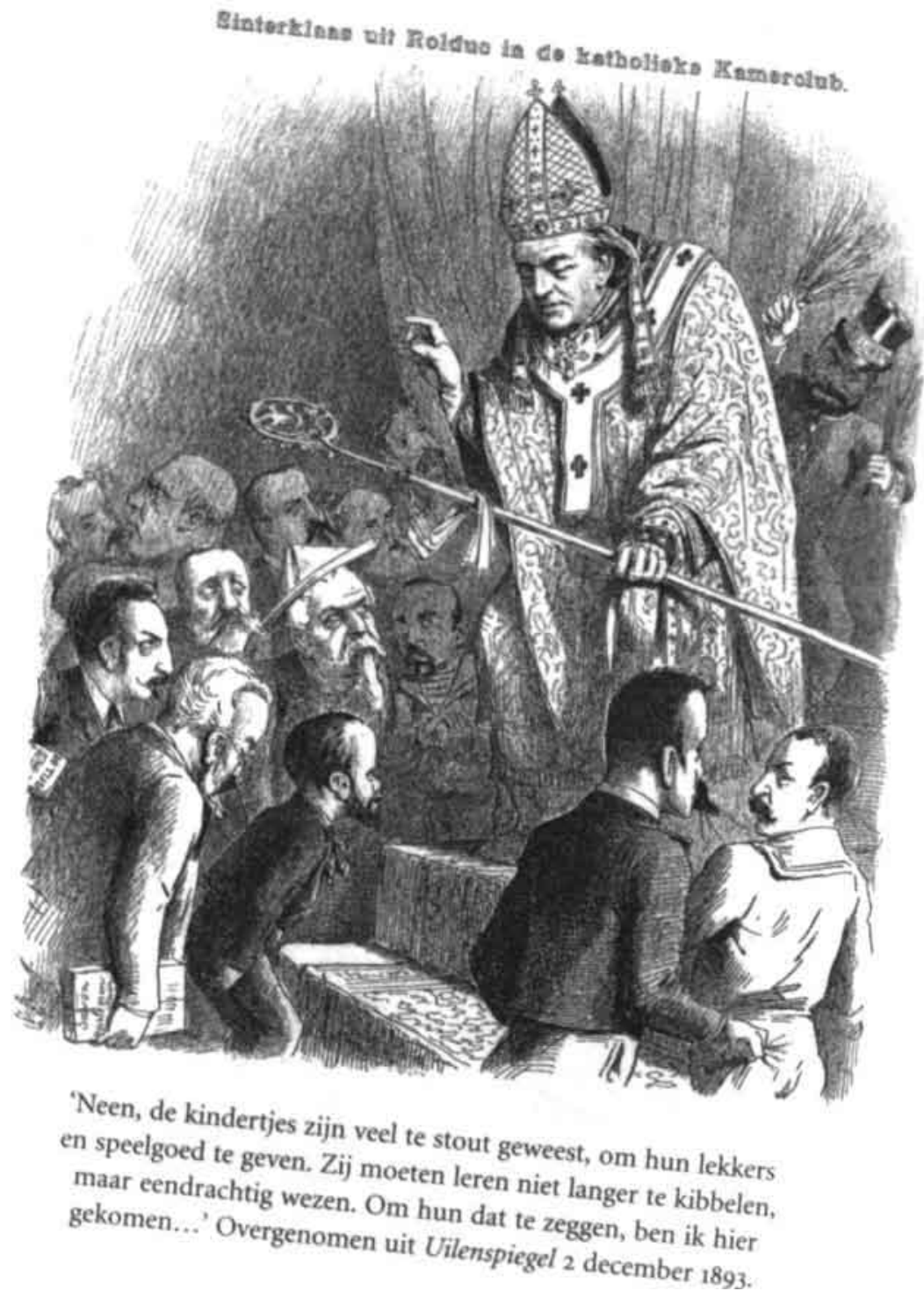




\section{Noten}

\section{Inleiding}

I Openingsitem van het Nos-achtuurjournaal d.d. 28-9-1997.

a mw.stemlimburgs.nl.

I Adres van Gs van Limburg aan de Tweede Kamer, 19 februari 1864, minuut, RAL. Archieven provinciaal bestuur, inv.nr. 5080.

4 HITK 1863-1864, 538.

5 Nuyens, De staatkundige geschiedenis der provincie Limburg, 135.

6 Prins, 'De Limburgsche afgevaardigden' 1, 342.

7 Zie bijv, Orbons en Spronck, 'Limburgers worden Nederlanders'.

I Zie voor de tekst: Limburg: het wapen, de Limburgse vlag, het volkslied. Geregeld wordt de wens geuit om de Nederlandse versie te vervangen door een dialecttekst. Zovroeg de statenfractie van Partij Nieuw Limburg (PNL) in april 1999 aan GS om de dialectversie van P. Zeegers officieel te erkennen. Van Limburgse trouw aan Oranje en van verbondenheid met Nederland is in de tekst van Zeegers overigens niets terug te vinden (Dagblad De Limburger 26-3-1999 en 27-4-1999).

9 De volledige tekst is te vinden bij Geurts, 'Een Limburgs volkslied uit 1857', 61-62.

10 Geurts, 'Een Limburgs volkslied van W. Everts', z.p.

॥ Boogman, Nederland en de Duitse Bond, 222.

12 De aanduiding 'minister-president' bestond formeel nog niet, zie bijlage $\mathrm{x}$.

13 Orbons en Spronck, 'Limburgers worden Nederlariders', 31.

4 Alberts, Geschiedenis van de beide Limburgen $\mathrm{n}, 191$.

15 T.P.M. Huijs, 'Thr. mr. Edouard de Kuyper (1817-1893), commissaris des konings, 1874-1893, in: Wieland e.a. De gouverneurs, 218.

ib Op den Camp, " Noch Fransch, noch Pruissisch maar Nederlandsch!"', 96.

17 Orbons en Spronck, 'Limburgers worden Nederlanders', 35-36.

is Tekst bij Van Banning, 'Honderd jaar "gewone provincie", 135.

19 Prins, 'De Limburgsche afgevaardigden' $11,96$.

20) Alberts, Geschiedenis van de beide Limburgen $\mathrm{n1}, 262$.

II Van den Berg, De toegang tot het Binnenhof, 112.

2 Geciteerd in Van der Hoek e.a., De Venlose krant, 88.

3 Van den Berg, De toegang tot het Binnenhof; Van den Braak, De Eerste Kamer.

\section{Hoofdstuk 1}

t Troonrede van 19 oktober 1840, De Derde Dinsdag.

2 Koninklijke boodschap van 20 oktober 1830 (HTK 1830-1831 в nr. 2, 4). 
3 Geurts, 'Historische aspecten', 54.

4 H. de Schepper, 'De Eerste Kamer in het Verenigd Koninkrijk der Nederlanden', in: Postma e.a., Aan deze zijde van het Binnenhof, 49.

5 Zie voor de citaten: aanhef en het eerste van de Acht artikelen (tekst o.a, in Co. lenbrander, Vestiging van het Koninkrijk, 181). In deze Acht artikelen waren de grondslagen vastgelegd voor de vereniging.

6 Rogier, 'Limburg in de Franse tijd', 668.

7 Grondwet 1815 artikel 2 . Vijf van de dertien waren zuidelijke provincies: zij behielden de grenzen van voormalige Franse departementen.

8 Daarnaast besloeg Limburg enkele kleinere stukken grond die voorheen toebehoorden aan de departementen van de Ourthe en van de Monden van de Rijn. Voor de staatkundige geschiedenis van Limburg in die tijd: Nuyens, De staatkundige geschiedenis. Nuyens constateert overigens dat de omschrijving die de grondwet van 1815 geeft van het Limburgse grondgebied niet geheel juist is (13-15).

9 Zie voor de naamgeving van Limburg: De Wit, 'Waarom draagt de provincie den naam "Limburg".

10 Brouwers, Academisch proefschrift, z.p.

II Boogman geeft aan dat $29 \%$ van de bevolking van het tot de Duitse Bond behorend deel van Limburg, voor 1790 onder Nederlandse soevereiniteit had gestaan. In Maastricht en Venlo, die in de achttiende eeuw (deels) eveneens onder Nederlands gezag hadden gestaan, maar die niet tot de Duitse Bond behoorden, woonde in 1839 nog eens $14,8 \%$ van de Limburgse bevolking (Boogman, Nederland en de Duitse Bond, 199 noot 3; Blok, Stemmen en kiezen, 300).

12 Geciteerd in Nuyens, De staatkundige geschiedenis, 34 noot 2.

13 Zie bijv. Wouters, 'De penetratie van de Republiek in het Limburgse Maasdal', 158. Nuyens merkt uitdrukkelijk op dat zij de hier geciteerde uitlating voorzichtigheidshalve voor rekening van de commissarissen laat (Nuyens, De staatkundige geschiedenis, 34).

14 Naast de generaliteitslanden op de westelijke Maasoever werden aanvankelijk van de generaliteitslanden die (deels) op de oostelijke oever lagen alleen Maastricht, Venlo en Stevensweert ingelijfd bij Brabant. Tegenwerking van Pruisen zorgde ervoor dat de overige gebieden aan die zijde van de Maas pas enkele maanden later in bezit konden worden genomen.

15 Brief van genoemde afgevaardigde, Van Aefferden, aan 'de heren burgemeesters en municipalen Raad der stad Venlo', 20 september 1814, Gemeentearchief Venlo, Stedelijk archief inv.nr. 51-1. Een dag daarvoor had Van Aefferden de vereiste eden afgelegd (RANB, Archieven provinciaal bestuur, inv.nr. 12042).

16 Zie De Wit en Flament, 'De vorming der Heerschappijen', 22.9.

17 HTK $1830-1831,310$.

18 In de Tweede Kamer woonde P.A. Sandelin (provincie West-Vlaanderen) bij aanvang van het parlementaire jaar $1830-1831$ nog één vergadering bij, als enige afgevaardigde uit het Zuiden.

19 Van de mogelijkheid om notabelen te wraken - een recht toegekend aan hoofden 
an huisgezinnen - werd weliswaar gebruik gemaakt, maar de koning negeerde de berwaren en stelde de lijsten vast overeenkomstig de concepten van de secretaris an staat in de Zuidelijke Nederlanden, G.A.G.Ph. baron van der Capellen. Van de arrondissementen die deel zouden gaan uitmaken van Limburg, werden alleen in Hasselt principielle bezwaren ingebracht. Deze bezwaren waren van religieuze aard en richtten zich in hoofdzaak tegen de notabelen die zich gedurende de Franse tijd schuldig hadden gemaakt aan het opkopen van zwart goed: goederen afkomstig van de door de Fransen opgeheven kerkelijke instellingen en kloosters. Zie Smeets, 'De Notabelenvergaderingen'; $33-34$.

w Ibidem, 29. Het gedeelte van het voormalige departement van de Roer dat aan Nederland was toebedeeld, werd bij het arrondissement Roermond gevoegd.

a Voor deze projectie is gebruik gemaakt van het overzicht dat wordt gegeven door Witkamp en Craandijk, Vereeniging en scheiding, 41 onder $\mathbf{B}$.

u Dat een stem voor de grondwet eerder een stem tegen de geestelijkheid dan een stem voor de vereniging was, zoals Colenbrander beweert, wordt door Smeets wor zover het de drie Limburgse arrondissementen betreft, niet onderschreven (Colenbrander, Gedenkstukken der algemene geschiedenis, Lxxxu, en Smeets, 'De Notabelenvergaderingen'; 57 ).

3) Blok, Stemmen en kiezen, 29; zie ook Prins, 'Tien jaren uit onze parlementaire geschiedenis', 46.

4 E.P.M. Ramakers, 'Charles de Brouckère (1757-1850), gouverneur van Limburg, 1815-1828', in: Wieland e.a., De gouverneurs, 18. Prins stelt: 'Van de gouverneur van Limburg, de Brouckère, kan men gerust zeggen, dat hij het weren van onwelgevallige kamerkandidaten als een voornaam deel van zijn taak opvat.' (W.F. Prins, 'De restauratie', in: Fockema Andreae e.a., 500 jaren Staten-Generaal, 175.)

3) Prins, 'Tien jaren uit onze parlementaire geschiedenis', 46.

\ Zie voor de bemoeienissen van de gouverneurs: E.P.M. Ramakers, 'Charles de Brouckère (1757-1850), gouverneur van Limburg, 1815-1828', en idem, 'Maximilien de Beeckman (1781-1834), gouverneur van Limburg, 1828-1830/1', in: Wieland e.a., De gouverneurs, resp. 18-20 en 36-37.

7 Prins, 'Tien jaren uit onze parlementaire geschiedenis', 46 noot 2.

28 W.F. Prins, 'De restauratie', in: Fockema Andreae e.a., 500 jaren Staten-Generaal, 175. 29 Geciteerd in Prins, 'Tien jaren uit onze parlementaire geschiedenis', 46. De Brouckère schreef dit in 1819 toen het hem voor de tweede keer lukte om De Surlet de Chokier niet te laten kiezen.

10 Vgl. Prins, 'Vijf jaren uit onze parlementaire geschiedenis', 134-135; notulen van Provinciale Staten van Limburg, 7 juli 1830, RAl, Archieven provinciaal bestuur, inv.nr. 2796).

\$1 Prins, 'Tien jaren uit onze parlementaire geschiedenis', 87 en 46.

\&) Ibidem, 57.

j) Ibidem, 78.

34. Wingens, 'Een Maastrichts voorspel', 85.

35 Geciteerd in: ibidem, 88. 
36 Ibidem. Zie ook: Van Banning, 'Belgium and Dutch Limburg', 24.

37 Prins, 'Tien jaren uit onze parlementaire geschiedenis' voor de periode $1815-1825$ en 'Vijf jaren uit onze parlementaire geschiedenis' voor de erop volgende jaren tot 1830.

38 Prins, 'Tien jaren uit onze parlementaire geschiedenis', 59. Andere kwesties waarbii de Handelingen geen volledig beeld verschaffen, zijn het voorstel om de uitvoer van granen te verbieden (stemming op 12 december 1816) en de ontwerp-successiewet (stemming op 23 januari 1817).

39 Prins, 'Tien jaren uit onze parlementaire geschiedenis', 54 en 55.

40 HTK 1815-1816, 302-304.

41 Van Hogendorp, Bijdragen tot de huishouding van staat v1, 115 en HTK 1820-1821, 496.

42 Van Hogendorp, Bijdragen tot de huishouding van staat v1, 123.

43 Prins, 'Tien jaren uit onze parlementaire geschiedenis', 100-101.

44 Nederlandsche staatscourant 6 september $1830 \mathrm{nr}$. 209. Oorspronkelijk hadden zes Tweede-Kamerleden de verklaring ondertekend, onder wie De Brouckère. Negen kamerleden waren later tot de verklaring toegetreden.

45 HTK $1830,6$.

46 Voor de verdeling van de Eerste-Kamerleden in noordelijke en zuidelijke leden: zie Witkamp en Craandijk, Vereeniging en scheiding, 145-146.

47 De Brouckère: HTK 1830, 82; De Surlet de Chokier: ibidem, 42-43.

48 Ibidem, 67.

49 Ibidem B nr. 11, 9.

50 HTK $1830,78$.

51 Niets pleit tegen dit vermoeden, aldus het Nationaal Biografisch Woordenboek van de Koninklijke Vlaamse Academiën van België (deel 3, 108-109).

52. Brief van De Borchgrave aan de koning, 30 september 1833, NA, Archieven Staatssecretarie, inv.nr.6164.

53 Ibidem.

54 Brief van secretaris van staat De Mey van Streefkerk, 21 oktober 1830, voorgelezen in de Eerste Kamer (HTK 1830-1831, 310, cursivering in origineel).

55 Zie voor de tekst van dit rapport: Gedenkstukken der algemene geschiedenis, xIv.

56 Zie voor de tekst van deze nota: ibidem, xIv-xv.

57 Zie voor de bemerkingen van Willem r: ibidem, xxII.

58 Protocol van 21 mei 1831, tekst o.a. in HTK 1830-1831 B, 395.

59 Boogman, Nederland en de Duitse Bond, 23-24.

60 Ibidem, 24.

61 Voor de tekst van de Vierentwintig artikelen, zie o.a. HTК 1830-1831 B, 433-436.

62 Boogman, Nederland en de Duitse Bond, 27.

63 Ibidem, 28-29.

64 Van Banning stelt dan ook dat 'The credit of saving Maastricht and East Limburg for the Netherlands goes especially to Dibbets'. (Van Banning, 'Belgium and Dutch Limburg', 31.) 
65 Toespraak tot de Senaat, 25 maart 1839, Histoire parlementaire du traité II, 530.

\& Boogman, Nederland en de Duitse Bond, 25 noot 1.

6\% lbidem, 53.

a Voor de invloed van de aanwezigheid van de militairen zie ibidem, 15, en De Vroede Voor of tegen Belgiê', 4-5. Voor de stemming onder de Limburgse bevolking in 1830 vic ibidem, 4.

6s Verbeet, Limburg op de tweesprong, 134.

₹v De Vroede, 'Voor of tegen Belgiè', 9, 34 en 35 noot 1.

7 lbidem, 9-11.

7 Zie voor een bundeling van deze petities: Comité de Politique Nationale, La protestation du Limbourg.

7 Ament, Van Belg tot Hollander, 100, Van der Heijden, 'De terugkeer van het Nederlands gezag', 67.

7 Ibidem, 106.

\$ Van der Heijden, 'Separatisme in Limburg', 24. Verder wordt er in de literatuur gewezen op de afwezigheid van leiders en van een oppositionele krant en op de repressieve gerechtelijke uitspraken. Van der Heijden stelt daarnaast dat het feit dat een belangrijk deel van het aan Nederland toekomende gebied vroeger tot de generaliteitslanden had behoord, mede een verklaring kan vormen voor de berustende houding van de bevolking (Van der Heijden, 'De terugkeer van het Nederlands gezag', 68).

कo Geciteerd in Wingens, 'Het Journal du Limbourg', 184.

$\pi$ Brief van de regering der stad Venlo aan de koning, RAL, Archieven provinciaal bestuur, inv.nr. 10745 .

\$ Verdrag van 19 april 1839 (Staatsblad $1839 \mathrm{nr} .26$ ), artikel xx.

\) Besiuit van het Voorlopig Bewind d.d. 12 oktober 1830 (Recueil des décrets 1, 59-62), artikel 19.

bo Wingens, Generaal Dibbets, 39.

bi Het citaat is afkomstig uit het Belgisch koninklijk besluit van 18 augustus $1831 \mathrm{nr} .207$ (Recueil des lois $\mathrm{n}, 336-337$ ).

62 Proclamatie d.d. 5 oktober 1830 ; tekst in: Nederlandsche staatscourant 8 oktober 1830 , nr. 239.

by Proclamatie d.d. 16 oktober 1830. Tekst o.a. in: Gemeentearchief Maastricht, Gemeentebestuur Maastricht 1814-20e eeuw, deel 1, inv.nr. 835 (Gepubliceerde verordeningen) nr.72, 'Belges' en 'mème mode' in origineel in kapitalen.

4 Tekst in: ibidem.

is Juste, Histoire du Congrès National 1, 135.

16 thidem, 138-140.

b) lbidem, 298.

18 Comité de Politique Nationale, La protestation du Limbourg, 19.

by tbidem, 27.

to Verbeet, Limburg op de tweesprong, 347.

91 Histoire parlementaire du traité 1, 315 (6 maart 1839). 
92 Veertien senatoren stemden tegen en twee onthielden zich van stemming.

93 Histoire parlementaire du traité n, 619-620 (26 maart 1839).

94 Nederlandsche staatscourant 23 maart 1839 , $\mathrm{nr} .71$.

95 Zie Van Eenoo, 'De evolutie van de kieswetgeving', 351. Strijdig hiermee selt Van Banning dat de Limburgse scheiding vijf leden uit de Kamer deed vertwijnen (Van Banning, 'Belgium and Dutch Limburg', 29). De wet van 3 juni 1834 nr. 260 (Recueil des lois X, 165) bepaalde dat de nieuw gevormde (Belgisch-)Linburge districten Hasselt en Tongeren elk twee kamerleden zouden kiezen en Maaseik één. Volledigheidshalve zij vermeld dat Hasselt één senator kreeg en Tonperen en Maaseik er gezamenlijk één kregen, waardoor het aantal Limburgse senateren met twee afnam.

96 Nederlandsche staatscourant 15 november 1839 , $\mathrm{nr} .271$.

97 Omdat verkiezingen voor de Kamer om de twee en die voor de Senaat on de vier jaar werden gehouden, verloor Luxemburg al eerder, namelijk in 1841 , een deel van zijn kamerzetels.

98 Geheim rapport van gouverneur Gericke van Herwijnen aan de koning, 15 december 1841, NA, Archief Kabinet des Konings, inv.nr. 4479.

99 De Schiervel werd bij de verkiezingen van 1843 herkozen, nu in het (nieuwe distria Hasselt.

100 HTK 1839-1840, 210.

ror E.W. van Dam van lsseic, Tweede-Kamerlid uit Geiderland, was van oordeel dat het traktaat wel ter goedkeuring aan het parlement had moeten worden voorgelegd (ibidem, 205). Zie ook het verslag van de derde afdeling (ibidem B, 406).

102 Verslag van de eerste afdeling, ibidem B, 392, cursivering in origineel.

103 Ibidem resp. 216 (J. Corver Hooft, provincie Holland), 205 (E.W. van Dam van Isselt, provincie Gelderland) en 221 (jhr. J.C.R. van Hoorn van Burgh, provincie Holland). 104 HTK 1840,41 , cursivering in origineel.

105 Ibidem, 48. Daarnaast kan, wat betreft de tweede lezing, gewezen worden op de redevoering van J.M. de Kempenaer (provincie Gelderland) die zei het belang van de aanwinst van Limburg niet te kunnen ontdekken (HTK 1840, 65).

106 HTK 1839-1840, 219 resp. HTK 1840, 116-117. Gouverneur weidde hierbij minder uit dan De la Court: hij beperkte zich tot de opmerking geen bezwaar te hebben tegen de vereniging van Limburg met Nederland.

107 Biografie P. Gouverneur, databestand PDC.

108 HTK 1839-1840, p. 230.

109 Deze drie uitspraken werden gedaan tijdens de beraadslagingen gedurende de tweede lezing: HTK 1840 , resp. 76,101 en 30.

110 Zie bijv. Van der Heijden, 'De terugkeer van het Nederlands gezag', 71, en Bannier Grondwetten van Nederland, 361.

nI Rapport van de ministerraad aan de koning, 28 oktober 1839, in: Gedenkstukken der algemene geschiedenis, 703 .

112 HTK 1839-1840 8, 392 (eerste afdeling), 401-402 (tweede), 406 (derde), 413 (vierde), 420 (vijfde). Er is hier gekeken naar de afdelingsverslagen tijdens de eerste lezing. 
(3) 8 IrK $1839-1840,165$.

4 Aldus de vijfde afdeling (ibidem B, 420). De eerste afdeling was van oordeel 'dat het niet roepen dier afgevaardigden in vervolg van tijd tot groote moeilijkheden anleiding kan geven' (ibidem, 392). De vierde afdeling verwoordde het aldus: 'de ervaring gedachtig oordeelde men dit nodig en raadzaam, ten einde niet uit de nalating daarvan te eenigen tijd redenen of voorwenschen ontleend zouden kunnen worden, nadeelig van gevolgen' (ibidem, 413).

If lbidem, 420.

at lbidem, 427.

If HIX 1839-1840, 234.

at tbidem, 209-210.

D9 $417 \times 1840,55$.

as lbidem, 75 resp. 112.

at Bbidem, 60.

a journal du Limbourg 31 augustus-1 september 1840.

as Brief van Thorbecke aan L.C. Luzac, 3 juni 1840, en brief van Thorbecke aan H. Box (redacteur van het Journal de la Haye), 5 juni 1840, in: Thorbecke, Briefwisseling ur, resp. 415 en 416.

a $\operatorname{arx} 1840,127$, cursivering in origineel.

s lbidem, 80 (L.C. Luzac) en 76 (J. Rau).

16 lbidem, 126.

In Journal du Limbourg 6, 7, 8-9-10 juni en 31 augustus-1 september 1840 .

is lbidem 8-9-10 juni 1840.

19. Uitdrukkelijk vermeldde het desbetreffende Koninklijk Besluit dat de grondwet niet in Maastricht van kracht hoefde te worden verklaard, omdat de grondwet daar nimmer had opgehouden van kracht te zijn (Кв 24 september 1840 , Staatsblad 1840 ar. 61).

\section{Hoofdstuk 2}

1. NA, Archief Tweede Kamer, inv.nr. 290, HTK 1840-1841, 5.

2 Grondwet 1848 artikel 74; grondwet 1887 artikel 78 . Het artikel maakt - in gewijzigde spelling - tot op de dag van vandaag deel uit van de Nederlandse grondwet.

3 Beekelaar, 'Tussen twee revolutiejaren. De Eerste Kamer van 1830 tot 1848 ', in: Postma c.a, Aan deze zijde van het Binnenhof, 91.

4 Algemeen Handelsblad 27 oktober 1840, artikel in: Thorbecke, Briefwisseling Iv, 343.

5 Geheim rapport van gouverneur Gericke van Herwijnen aan de koning, 15 juli 1843 , in: Rapporten van de gouverneurs, 111-112.

6 Brief van L.F.H. Beerenbroek, Hertogelijk Limburgs commissaris voor de Duitse Bondszaken (zie voor deze functie: bijlage $\mathbf{x}$ ), aan de minister van Buitenlandse Zaken, A.A. baron Bentinck van Nijenhuis, 19 oktober 1848, in: Bescheiden betreffende, 523.

7 Bijdeze tweede ronde was tot de kieswet van 1897 sprake van een lacune in de kieswet: 
het was formeel niet uitgesloten dat bij de herstemming buiten de twee kandidaten die in de eerste ronde de meeste stemmen hadden behaald, andere kandidaten naar voren werden geschoven (Talsma, Kiezen en delen, 4). Voor zover bekend is dit in Limburg nimmer gebeurd.

8 De Volksvriend 23 juni 1860.

9 Ibidem 21 juli 1860.

10 Zie o.a. ibidem 14 juli 1860 (bijvoegsel).

11 Brief van Thorbecke aan W.H. Pijls, 14 juni 1860 (ontwerp) in: Thorbecke, Eriefwisseling $\mathrm{v}, 423$.

12 In 1917 was er in elk van de zes Limburgse districten sprake van een enkelvoudige kandidaatstelling. Het betrof de verkiezingen na de kamerontbinding ir.m. de grondwetsherziening; de politieke partijen hadden (landelijk) onder het motto 'laat zitten, wat zit' een akkoord gesloten om geen kandidaten te stellen tegenover de kamerleden die aftraden (Oud en Bosmans, Staatkundige vormgeving 1, 222.).

13 Kieswet 1896 (Staatsblad $1896 \mathrm{nr}$. 154) artikel 52. Zie voor de bepalingen van de kieswet inzake de kandidaatstelling: ibidem artikelen $51 \mathrm{t} / \mathrm{m} 55$.

14 Aldus een ingezonden stuk in de Limburger koerier (d.d. 6 juni 1901).

15 In lijn hiermee is er in de bekendmaking van de burgemeester van Venrav inzake de kandidaatstelling voor de Tweede-Kamerverkiezingen van juni 1909 niets terug te vinden over een bewilliging door een kandidaat (Peel en Maas 29 mei 1909). Het Venloosch Nieuwsblad berichtte op 15 juni 1901 over de Gulpense kandidaatstelling 'tegen wil en dank'.

16 Zie voor een overzicht van de parlementaire discussies over de indeling in kiesdistricten: Huizinga, 'Zeventig jaar districtenstelsel'.

17 Alleen de grote steden - Groningen, Utrecht, Amsterdam, Rotterdam, Den Haag bleven tot de kieswet van 1896 meervoudige districten vormen.

18 Buijs, De Grondwet, 442.

19 Dagblad de Limburger 3 maart 2000.

20 Vóor 1848 moest een kamerlid ingezetene zijn van de provincie waaruit hij werd afgevaardigd en waren zee- of landofficieren met een rang lager dan hoofdofficier uitgesloten; er golden verder beperkingen t.a.v. de bloedverwantschap of zwagerschap. Volgens de grondwet van 1848 dienden Tweede-Kamerleden behalve aan de leeftijdsvereiste en de eis dat men Nederlands ingezetene was, te voldoen aan de bepaling dat zij in het volle genot waren van de burgerlijke en burgerschapsrechten. De grondwet van 1887 sloot personen uit die bij rechterlijke uitspraak de beschikking of het beheer over hun goederen waren verloren of uit de verkiesbaarheid waren ontzet.

21 Tot de directe rijksbelastingen werden in de periode 1850-1893 gerekend: de grondbelasting, de patentheffing - in 1893 afgeschaft; hiervoor kwam de inkomsten- en bedrijfsbelasting in de plaats - en de personele belasting. In 1894 werd hieraan de nieuwe vermogensbelasting toegevoegd.

22 Grondwet 1887, artikel 90.

23 Bos, Notabele ingezetenen, 134. 
2) $\operatorname{sTx} 1846-1847,90$, cursivering in origineel.

5 HTx $1850-1851,7$.

a) Rapport van de commissie tot onderzoek van de geloofsbrieven, HTK 1854-1855, 668 . 2 Verslag van de tweede afdeling,

y Eerder hadden Provinciale Staten van Limburg zich gebogen over de kwestie, omdat De Limpens ongeveer gelijktijdig met zijn verkiezing tot lid van de Tweede Kamer was gekozen tot statenlid. Ps hadden besloten hem in hun midden toe te laten.

y HT 1846-1847, 102. Zie verder bijv. de redevoering van het Tweede-Kamerlid Faber an Riemsdijk (ibidem, 91).

10 Brief van Van Meeuwen aan minister L.N. graaf van Randwijck van Binnenlandse Zaken, 28 mei 1847 , NA, Archief Min. Binnenlandse Zaken Kabinet, inv.nr. 57, dossiernr. 1605 .

y Rapport van gouverneur Gericke van Herwijnen aan de minister van Binnenlandse Zaken, 14 oktober 1841, minuut, RAL, Archieven provinciaal bestuur, inv.nr. 474.

y. HTK $1850-1851,80$.

is HTK 1846-1847, 103 .

14 lbidem, 94, 'ingezetenen' in origineel.

3. Voor een omschrijving van het subjectieve en het objectieve natiebegrip, zie: Labrie, 'La religion civile'.

* Notulen Provinciale Staten van Limburg, 25 september 1850, RAL, Archieven provinciaal bestuur, inv.n. 2805 .

37 Geheim rapport van gouverneur Van Meeuwen aan de koning, 17 juli 1847, NA, Archief Kabinet des Konings, inv.nr. 4481.

38 Thorbecke vroeg na zijn herverkiezing in Maastricht aan de kiezers aldaar om hem, hoewel hij voor een ander district (Deventer) in de Kamer zou zitting nemen, als vijfde afgevaardigde op te tellen 'bij de vier vertegenwoordigers, die Limburg naar de Kamer afvaardigt' ('Manifest aan de kiezers van het hoofdkiesdistrict Maastricht', 2 juli 1856, in Thorbecke, Briefwisseling v1, 517). De Lom de Berg constateerde dat 'de Limburgsche afgevaardigden' na het ontslag van Van der Maesen de Sombreff en door de ziekte van De Bieberstein 'op de helft gereduceerd' waren (HTK 1865-1866, 310).

39 Van der Hoek e.a., 'Het Venloosch Weekblad', 64.

40 Adres Gs van Limburg aan de Tweede Kamer, 14 december 1877 , en brief gs van Limburg aan de minister van Binnenlandse Zaken, 13 november 1868 , minuten, rAL, Archieven provinciaal bestuur, inv.nr. 5080.

44 Notulen gemeenteraad van Venray, vergadering 18 maart 1869 , Gemeentearchief Venray, Gemeentebestuur 1815-1941, inv.nr.3.

42 Venloosch Weekblad 10 juni 1871.

4 Ibidem, 20 oktober 1877.

4 lbidem, 4 februari 1882 (abusievelijk gedateerd 4 maart 1882). Ruim een jaar later ( 9 juni 1883) schreef dezelfde krant iets soortgelijks: 'Noord-Brabant is zoo goed van twee afgevaardigden uit Limburg te nemen, terwijl er toch evenveel NoordBrabantsche als Limburgsche kiezers in het district Boxmeer zijn.' 
45 Ibidem, 20 oktober 1877 .

46 Boxmeersch Weekblad Maasbode 20 oktober 1877,7 juni 1879, 4 februari 1882, $4 \mathrm{em}$ n juni 1882, 2 en 9 juni 1883, 25 oktober 1884, 12 juni 1886, 27 augustus 1887, h het eerstgenoemd nummer werd weliswaar kritiek geleverd op de kandidatuur van Hubert Brouwers, echter niet omdat hij Limburger was, maar omdat hij buiten het district woonde.

47 HTK 1862-1863, 1065.

48 Prins noemt Borret in zijn artikel over Limburgse kamerleden 'een Brabande' (Prins, 'Limburgsche afgevaardigden' 1, 351).

49 Ibidem, 354; NNBW 1, 'Borret (Mr. Eduard Joseph Hubert)', 423.

5o Aangehaald in De Tijd 13 augustus 1850.

51 Brief van Van Wintershoven aan Thorbecke, 1 juni 1853, in: C.H.E. de Wit, 'Limburg - Maastricht - Thorbecke, 1848-1853, in: Van Hellenberg Hubar e.a., Maasland Melange, 288.

52 Biografieèn E.J.H. Borret, F.H.H. Borret en Th.L.M.H. Borret, databestand PDC.

53 Gemeentearchief Roermond, Bevolkingsregister Roermond, George Diepen 30 april 1986; biografie G. Diepen, databestand PDC; Gemeentearchief Heel, bevolkingsregister Heel en Panheel, inv.nr. 1609, 1870 fiche 12 en inv.nr. 1610, 1880 fiche 19; Gemeetearchief Heel, Burgerlijke stand Heel en Panheel, akten van huwelijk 1853-jan-24i1) - 1859-tafel(z); Van den Dam, Arnold Leon Armand Diepen, 141.

54 Dit wordt duidelijk aan de hand van de kamerleden die werden gekozen in de eerste jaren na 1848 , het jaar waarin de regels op dit punt werden versoepeld. De geboorteplaatsen die buiten Limburg gelegen zijn, blijken vaak ook buiten Nederland te liggen: in de eerste tien jaar na 1848 werden er zeven Tweede-Kamerleden afgevaardigd die buiten Limburg geboren waren. Vier van hen waren, volgens de grenzen van 1839, buiten Nederland geboren; zij zouden voor 1848 daarom niet verkiesbaar zijn geweest.

55 Brief van gouverneur Van Meeuwen aan minister Thorbecke van Binnenlandse Zaken, 7 december 1849, minuut, RAL, Archieven provinciaal bestuur, inv.nr. 503.

56 Gemeentearchief Roermond, Bevolkingsregister Roermond 1850-1860, nr. 62, 1850. In Den Haag had Strens op het Voorhout een huis gehuurd (Witlox, 'Mr. M. Strens', 279).

57 Jurriaanse, De Nederlandse Ministers, 187 en 194.

58 Het Kanton Weert 2 mei 1916, extra uitgave.

59 Stadsarchief Sittard-Geleen, Bevolkingsregister Sittard, 1910-1939, deel D Iv, 293: Biografie H.A.G. van Groenendael, databestand PDC.

60 Limburger koerier 16 juli 1892.

61 De nieuwe koerier 6 juni 1889.

62 Gemeentearchief Maastricht, Bevolkingsregister Maastricht, 1890-1920, 399; Gemeentearchief Meerssen, Bevolkingsregister Meerssen, 1890-1900, 55 (nr.3570) en 1900-1910, 42 (nr. 5210).

63 Brief van Thorbecke aan waarschijnlijk Ch. de Limpens, ongedateerd, in: Thorbecke. Briefwisseling v1, 43. 
g krief van De Stuers aan P.J.H. Geurts, 5 juni 1901, KDC, Archief P.A.M. Geurts, invar. 253.

8 Van den Berg, De toegang tot het Binnenhof, 84-87.

Gidem, 87 .

De Jong, Van standspolitiek naar partijloyaliteit, 141-142.

is Vin den Braak De Eerste Kamer, 123.

s. llidem, 183.

\Golstein, 'Het ontstaan van het Limburgs chauvinisme', 25-26.

a De nieuwe koerier 6 juni 1889.

3 Mass-en Roerbode 15 juni 1889.

5 Limburger koerier 30 juni 1892, brief van 'Een oprecht Maastrichtenaar'.

4 lbidem 25 en 27 juni 1892.

5 llidem 24 februari 1900.

5 sagw IX, 'Hengst (Mr. Johannes Baptista Josephus)', 354.

7 De Volksvriend 6 en 13 april 1861 , cursivering in origineel.

x) Mass-en Roerbode 30 maart 1861.

y Geurts en Janssen, 'Ruim een eeuw geschiedbeoefening', 64-65.

B Brief van Nolens aan P.J.H. Geurts, 5 mei 1901, in Geurts, 'Kamerzetel voor De Stuers', 74 noot 23.

in Maas-en Roerbodes juni 1901.

12 Brief van Bolsius aan P.J.H. Geurts, 15 mei 1901, KDC, Archief P.A.M. Geurts, inv.nr. 253.

B Geurts, 'Kamerzetel voor De Stuers', 64.

4 De Roermondse burgemeester Diepen, geboren en getogen in Noord-Brabant, is daarom hier niet meegenomen: hij woonde voorafgaand aan zijn burgemeestersbenoeming zeventien jaar in het Limburgse Heel.

5 Limburger koerier 12 juni 1913, cursivering in origineel; Het Kanton Weert 2 mei 1916, extra uitgave.

16 sHCL, Pamfletten, doos nr.1.

h) Zie ledenlijst in Publications jrg. 2, 1865, 269 e.v. De Noord-Brabantse leden uit Boxmeer (Kerstens en Van den Heuvel) zijn hier buiten beschouwing gelaten.

4 'Assemblée Générale', 3, cursivering in origineel.

5 Geurts en Janssen, 'Ruim een eeuw geschiedbeoefening', 50.

De Volksvriend 29 mei 1869.

R I Bbidem 5 juni 1869.

8. Maas- en Roerbode 23 en 25 juni 1892.

58 Bidem 18 juni 1892 .

4 lbidem 8 en 12 juni 1901, Het Kanton Weert 1 en 8 juni 1901.

5 Tillema, Victor de Stuers, 5 . In een brief aan de pastoor van de Sint-Martinusparochie schreef De Stuers dat hij de gift deed ter herinnering aan het feit dat zijn grootvader in 1789 tijdens de Brabantse revolutie door een aantal Weertenaren gevangen was genomen en vanuit Roermond naar hun stad was gevoerd (ibidem). Dorren, De Tweede Kamerverkiezing, 16. 
97 Klijn, Onze man uit Maastricht, 104.

98 P.J.A. Nissen, 'De ontplooiing van het regionaal zelfbewustzijn in de beide provincies Limburg na 1839', in: Schöffer e.a., Eenheid en scheiding, 185-186 en 192. Kuiper constateert in zijn dissertatie uit de jaren negentig van de twintigste eeuw dat het lokalisme zich in Limburg tot in onze tijd lijkt te doen gelden (Kuiper, Lokad en landelijk, 26).

99 P.J.A. Nissen, 'De ontplooiing van het regionaal zelfbewustzijn in de beide provincies Limburg na 1839', in: Schöffer e.a., Eenheid en scheiding, 193-195.

100 Ibidem, 189-190.

101 Rogier, Katholieke herleving, 209.

102 Gijsen, Joannes Augustimus Paredis, 297.

103 Verhage, 'Realiteit of retoriek?', 39; Rogier, Katholieke herleving, 209.

104 Bornewasser, 'De Nederlandse katholieken', 585.

105 Nissen geparafraseerd in: Sniekers, 'De voorgangers van Gijsen', 67.

106 Alberts, Geschiedenis van de beide Limburgen 11, 155.

107 Goltstein, 'Het ontstaan van het Limburgs chauvinisme', 11.

108 Brief van Commissaris des Konings Van Meeuwen aan minister Van Reenen van Binnenlandse Zaken, 14 april 1855, minuut, RAL, Archieven provinciaal bestuut. inv.nr. 4168. In het district Maastricht was inderdaad een groter deel van de bevolking kiesgerechtigd. Volgens een overzicht gevoegd bij het wetsvoorstel tot herziening van de districtsgrenzen uit 1855 mochten 1829 van de 88861 inwoners van het district Maastricht deelnemen aan de Tweede-Kamerverkiezingen (2,06\%), in het district Roermond waren dit er 1416 van de 90450 (1,57\%) (HTK 1855-1856 B, 433-434).

109 Boessen, “"Geest der Provincie"', 7.

110 Brief van gouverneur Gericke van Herwijnen aan de minister van Binnenlandse Zaken, 14 oktober 1841, minuut, RAL, Archieven provinciaal bestuur, inv.nr.474. Overigens bepaalde de grondwet tot 1848 dat Provinciale Staten ernaar dienden te streven dat de door hen aangewezen Tweede-Kamerleden 'zoo veel doenlijk uit alle oorden van hunne provincie' afkomstig waren (grondwet 1840 artikel 142).

111 J. Perry, De voorman, 129 e.v.

112 Regout was o.a. lid van het hoofdbestuur van de Katholieke Sociale Actic en voorzitter van de juridische afdeling van de Vereniging tot bevordering van de beoefening der wetenschap onder Katholieken in Nederland.

113 Limburger koerier 19 mei 1909.

114 Brief van Hertogelijk Commissaris Beerenbroek aan de minister van Buitenlandse Zaken, 16 juli 1848, NA, Archieven Min. Buitenlandse Zaken, inv.nr. 1772.

115 S.J. Fockema Andreae, 'De grootburgers (1848-1879)' in: Fockema Andreae e.a.,500 jaren Staten-Generaal, 210. Ook kamerleden die afkomstig waren uit andere perifere landsdelen moesten in die tijd lang reizen. Zie bijvoorbeeld de reis naar Den Haag die het Groningse Tweede-Kamerlid J.F. Zijlker maakte (beschreven in Knippenberg en De Pater, De eenwording, 56).

116 HTK 1842-1843, 210.

117 De informatie over treinreizen en -tijden die in deze alinea is verwerkt, is verkregen 
bij het Nederlands Spoorwegmuseum te Utrecht. De reistijd tussen Maastricht en Den Haag bedroeg volgens de dienstregeling 8 uur en 47 minuten (1868), 7 uur en yo minuten (1880), 5 uur en 33 minuten (1900) en 4 uur en 23 minuten (1917).

1 Bdman, 'Spoor en mijn', 15 .

क) IIT 1842-1843, 210 (memorie van toelichting).

$\Rightarrow$ lbidem (voorlopig verslag).

\pm De Limburger 4 april 1850.

at Bodman, 'Spoor en mijn', 15.

a) Den Braak, De Eerste Kamer, 129.

*1.1. Vis, "Van "ménagerie du roi" tot politiek college. De Eerste Kamer van 1849 tot 1887, in: Postma e.a., Aan deze zijde van het Binnenhof, 178.

5) Van Welderen Rengers, Schets eener parlementaire geschiedenis 1, 130.

is Prins, 'De Limburgsche afgevaardigden' i, 342 .

$z$ Orbons en Spronck, 'Limburgers worden Nederlanders', 43.

5 Venloosche Courant 3 oktober 1896, geciteerd in Gribling, Willem Hubert Nolens, 41. * Schreuder, 'Een Kamerverkiezing in 1855', 18. De Limpens sprak 'vrijwel nooit' in de Tweede Kamer (biografie Ch. de Limpens, databestand PDC).

Blok, Veertig jaar, 34-35.

3 Tiliema, Victor de Stuers, 51.

IN De Tijd 5 juli 1850.

35 Geciteerd in Schreuder, 'Een Kamerverkiezing in 1855 ', 17.

* Venloosch Weekblad 10 juni 1871.

ถึ DeNoord-Brabanter 16 januari 1868.

के HTK 1864-1865, 632 (zie ook hoofdstuk 4). Voorafgaand aan de plenaire behandeling werden voorstellen besproken in de afdelingen waarin de Kamer was verdeeld. Elk lid had zitting in een van deze afdelingen.

(1) Lavater, Politieke photografien, 5.

3 De katholieke illustratie 15 (1882) nr. 43, 339.

3) HEK 1907-1908, 129.

4. De Nedermaas 6 (1919) nr. 8, 86.

4.P. Gribling, 'Regout, Louis Hubert Willem (1861-1915)', in: Biografisch Woordenboek van Nederland deel 2.

C HEK 1915-1916, 11.

48 'Nécrologie', 375 .

4 HTK 1869-1870, 651. Haffmans citeerde hier een dichter.

5. HTK 1871-1872, 1150 (Haffmans); нTK 1862-1863, 795, en HTK 1868, 335 (De BieberStein).

6 Blok, Veertig jaar, 21.

5 De Amsterdammer 5 februari 1882.

A HTK 1878-1879, 230.

4 Tillema, Victor de Stuers, 86.

Verloosch Weekblad 20 maart 1886.

8. G.A.M. Beekelaar, 'Gustave Ruijs de Beerenbrouck (1842-1926), commissaris der 
koningin, 1893-1918, en Charles Ruijs de Beerenbrouck (1873-1936), commissaris der koningin, mei-augustus 1918', in: Wieland e.a., De gouverneurs, 275-276.

152 HEK 1869-1870, 51.

153 HTK 1902-1903, 773.

154 J.J. Vis, "Van "ménagerie du roi" tot politiek college. De Eerste Kamer van 1849 tot 1887', in: Postma e.a. Aan deze zijde van het Binnenhof, 180-181.

155 Geheim rapport van gouverneur Gericke van Herwijnen aan de koning, 15 augustus 1843, in: Rapporten van de gouverneurs $11,163$.

156 P. Orbons, 'Limburg in isolement, 1848-1914' in: Venner, Geschiedenis van Limbury II, 39.

157 De Tijd 20 mei 1864; zie ook hoofdstuk 4.

158 Van der Hoek, 'Een Limburgs dialectstuk', 1 en 6.

159 Limburger courier 20 november 1880 (advertentie ten gunste van jhr. G. Ruijs van Beerenbroek).

160 Geciteerd in Op den Camp, '“Wandelend in den vreemde"', 168.

161 P. Orbons, 'Limburg in isolement, 1848-1914' in: Venner, Geschiedenis van Limburg II, 39. Zie ook Goltstein, 'Het ontstaan van het Limburgs chauvinisme', 11.

162 Lavater, Politieke photografien, 7.

163 De Gids 51 (1887) 11, 182.

164 De Tempeleers, expositie over carnaval in Maastricht, 2000, vetdruk in origineel.

165 Zie voor de indeling in zittingsjaren: Bannier, Grondwetten van Nederland bijlage IIIA (602-606).

166 Limburg 12 juni 1901, vetdruk en cursivering in origineel.

167 Limburger koerier 12 juni 1913.

168 Op 4 september 1880 meldde De Bieberstein verhinderd te zijn wegens ongesteldheid (HTK 1879-1880, 1283), enkele weken later, na de opening van het nieuwe parlementaire jaar was hij weer drie dagen aanwezig, om het tijdelijk voorzitterschap op zich te nemen; vervolgens bleef hij afwezig tot zijn dood op 1 november 1880 .

169 Zie bijlage III.

170 Van den Braak, De Eerste Kamer, 125.

171 Ibidem, 185.

172 De minimumleeftijd was in de periode $1840-1918$ voor de Tweede Kamer dertig jaat. Voor de Eerste Kamer gold tussen 1840 en 1848 een minimumleeftijd van veertig, vanaf 1848 was de leeftijdsgrens gelijk aan die voor de Tweede Kamer.

173 Voor wat betreft de onderzoeksperiode van Van den Berg (1849-1977) was De Bieberstein recordhouder, samen met P.G.J. van der Schrieck die ten tijde van zijn kamerlidmaatschap eveneens de leeftijd van vierentachtig jaar bereikte (Van den Berg, De toegang tot het Binnenhof, 281 noot 3). De Tijd 3 november 1880.

174 Brief van De Bieberstein aan Thorbecke, 31 januari 1862, NA, Archief Thorbecke, inv.nr.73.

175 De Tijd 3 november 1880.

176 Respectievelijk: HTK 1875-1876, 1638, HTK 1871-1872, 1120, en HTK 1870-1871, 821.

177 HTK 1878-1879, 292. 
is urx 1880-1881, 9 .

s. SJ. Fockema Andreae, 'De grootburgers (1848-1879)', in: Fockema Andreae e.a., 500 ieren Staten-Generaal, 224.

s Voor de tekst van dit gedicht en nadere informatic, zie: Geurts, 'De entree van Mgr. W. Everts'.

\# Van den Berg, De toegang tot het Binnenhof, 121.

bi lbidem, 122 en 124-125.

is bidem, 133-134.

is Biografie J.H.J. Beckers, databestand PDC,

\$) De herverkiezing in 1917 telt hier minder, omdat toen ook in Limburg het principe 'aat zitten wie zit' werd gehanteerd.

is Geurts, 'Kamerzetel voor De Stuers', 61.

e Bolsius, 'De Stuers als kamerlid', 99.

is Geurts, 'Kamerzetel voor De Stuers', 64.

in Geciteerd in ibidem, 67-68.

90 Geurts, 'Kamerzetel voor De Stuers', 63.

1. Onze afgevaardigden $1897,49$.

a Perry, Roomsche kinine, 155.

क De Nedermaas 2 (1925) nr. 10, 1.

4 Exclusief de Noord-Brabantse leden uit het district Boxmeer (Hengst, Van den Heuvel en Kerstens).

195 Van den Braak, De Eerste Kamer, 120 en 179.

196 . De opmerking van J.J. Vis dat het opvallend is dat 'het aan landadel zo rijke Limburg' tussen 1849 en 1887 slechts tweemaal een jonkheer naar Den Haag zond, dient daarom van een kanttekening te worden voorzien. (J.J. Vis, 'Van "ménagerie du roi" tot politiek college. De Eerste Kamer van 1849 tot 1887', in: Postma e.a., Aan deze zijde van het Binnenhof, 181.)

\$7 Van den Braak, De Eerste Kamer, 179-180.

\$s Zie Van den Berg, De toegang tot het Binnenhof, 67-71, en Van den Braak, De Eerste Kamer, 487-498.

$\rightarrow$ Van den Berg, De toegang tot het Binnenhof, 42-43.

>0 Onze afgevaardigden $1897,277$.

in Van der Hoek e.a., De Venlose krant, 77-78.

is Venloosch Weekblad 10 oktober 1896.

in Venloosche Courant 10 oktober 1896.

\section{Hoofdstuk 3}

I HTK 1864-1865, 410.

2 Rogier, 'Nederlands-Limburg 1813-1863', 83 .

3 De Gids 51 (1887) n, 182.

4 Voor de tekst van de grondwet van 1840 (en van latere grondwetten) zie o.a.: Bannier, Grondwetten van Nederland, 362 e.v. 
5 Over de geografische reikwijdte van deze 'omgeving' - de in de grondwet genoemde 'kringen' - zie Dingemans, 'De invoering en afkondiging', 491.

6 Brief van de rijksminister van Binnenlandse Zaken, A. Ritter von Schmeling, aan de Nederlandse gezant te Frankfurt, jhr. F.H.W. von Scherff, 11 oktobe 1848, in: Bescheiden betreffende, 525-527. Bij de grondwetsherziening van 1848 werd ce redactie van het artikel gewijzigd. De nieuwe tekst sprak van '[...] Groningen, Drenthe en het Hertogdom Limburg, behoudens [...]': Von Schmerling vond deze wijziging. waarin het verbindingswoord 'vorangerückt ist', minder wenselijk (ibiden).

7 Gezien de neutrale status die aan Belgiè werd toegekend, was de opaame van Belgisch-Luxemburg in de Duitse Bond geen optie.

8 Mededeling van de Nederlandse gezant bij de Duitse Bond, HTK 1839-1840 \& vIII, 302.

9 Zie o.a. de inhoud van een rapport van de minister van Buitenlandse Zaken, I.G. baron Verstolk van Soelen, aan de koning, weergegeven in Dingemans, 'Deinvoering en afkondiging', 480 .

10 In artikel 1 van de grondwet (zie hiervoor) werd aangegeven dat Limburg dee uitmaakte van Nederland 'behoudens' zijn betrekkingen met de Duitse fond.

11 Grochtmann, Die Niederländische Provinz Limburg, 42 noot 16.

12 Voor de tekst van dit besluit zie Administratief memoriaal $1841 \mathrm{nr} .154,24-31$. Een toelichting op dit besluit is te vinden bij Huber, Deutsche Verfassungigeschichte II, 155-158. Gezien de publicatie van dit besluit in Limburg (in 1841) waren zijn bepalingen volgens de gouverneur ook daar van kracht.

13 Zie ook: Grochtmann, Die Niederländische Provinz Limburg, 42.

14 Zie voor een overzicht m.n. Van der Heijden, 'Separatisme in Limburg.'

15 Ibidem, 25.

16 Boogman, Nederland en de Duitse Bond, 350-351.

17 Stenographischer Bericht 1, 218.

18 Ibidem ni, 1012.

19 Wollstein, Das 'Großdeutschland' der Paulskirche, 249-250.

20 Stenographischer Bericht $\mathrm{Ix}, 6543$.

21 Ibidem, 6544.

22 Het afscheid van de Nationale Vergadering was allesbehalve hartelijk. Nadat de tekst van de verklaring van Van Scherpenzeel Heusch was voorgelezen, klonken er weinig vriendelijke uitroepen in de vergaderzaal, zo lezen we in het stenografisch verslag: 'Stimmen von der hinten: Hinaus! er kann nicht mehr hier sitzen, wenn er ausgetreten ist!' (ibidem).

23 Boogman, Nederland en de Duitse Bond, 199-200.

24 Zie 0.a. ibidem, 204-205 en 356-357; Geurts, 'Historische aspecten', 62.

25 Kraume, Außenpolitik 1848, 192.

26 J.C. Boogman, 'The Netherlands in the European Scene 1813-1913', in: G.A.M. Beekelaar e.a. (red.), Vaderlands Verleden, 65.

27 Kladnotulen ministerraad 21 oktober 1848 , in: Bescheiden betreffende, 527 noot 2

28 Boogman, 'Achtergronden en algemene tendenties', 52. 
8 MrK $1840,41$.

* Boissevain, De Limburgsche kwestie, citaat op 39.

11 Alberts, Geschiedenis van de beide Limburgen 11, 191; Kraume, Außenpolitik 1848, 18-190; Geurts, 'Historische aspecten', 68-69.

9 Notulen ministerraad 5 september 1848 , in: Bescheiden betreffende, 469-470.

3) Boogman, Nederland en de Duitse Bond, 71 .

y Beumers, Limburgs separatisme, 14.

इ5 J.H.M. Wieland, "s Konings verschijning in het hertogdom Limburg', in: Van Bree e... 'Van der Nuyersen upwaert', 309.

क Orbons en Spronck, 'Limburgers worden Nederlanders', 52; Ubachs, Handboek, 370. 3 Maenen, Petrus Regout, 114.

I Munier, 'De reorganisatie van het kerkelijk bestuur', 165 noot 134.

3 Alberts, Geschiedenis van de beide Limburgen 11, 191. De aankoop van Vaeshartelt lijkt inderdaad vooral symbolisch bedoeld te zijn geweest: vaak kwam de koning niet op het kasteel. Op 8 oktober 1846 meldde het Weekblad van Heerlen dat de koninklijke knk, die ter voorbereiding op een gepland bezoek op Vaeshartelt was aangekomen, an de gouverneur had bericht dat het bezoek niet doorging.

a) Brief van de minister van Binnenlandse Zaken aan gouverneur Gericke van Herwijnen, 17 juni 1843 , in: Rapporten van de gouverneurs $\mathrm{n}, 84$.

4. Brief van de tijdelijk minister van Binnenlandse Zaken, De Kempenaer, aan de koning, 28 juli 1848, NA, Archief Kabinet des Konings, inv.nr. 4203.

2. Miesen, A misserable appendix, 18; Boogman, Nederland en de Duitse Bond, 709-710. 43 Op den Camp, 'Towards one nation', 85 .

4 Spiertz, 'Limburg uit de Duitse Bond', 14; Verbeet, 'Limburg 100 jaar onverkort Nederlands', 66; Op den Camp, 'Towards one nation', 84; Rogier 'Nederlands Limburg $1813-1963,83$.

45 HEK $1866-1867,278$ en 264.

46 Op den Camp, "“Noch Fransch, noch Pruissisch", 96-97; Everts, 'Liever Turks dan Pruisisch', 138.

47 Boessen, "'Geest der Provincie"', 25-26.

4 Op den Camp, 'Vreemd Vaderland', 389.

99 Abeling, Teloorgang en wederopstanding, 81-82

30 Boogman, 'Achtergronden en algemene tendenties', 44-45.

51 Het ene кв had betrekking op Maastricht en Sint-Pieter, het andere op overig Limburg (Staatsblad 1867 nrs. 98 en 99).

\$) HEK 1866-1967, 264.

5. Nederlandsche gedachten 30 januari 1864 . Het bewuste artikel draagt de titel 'De Limburgsche quaestie'.

4. Van Karnebeek, Ter toelichting van de Limburgsche kwestie, 1 (voorwoord).

75 HTK $1863-1864,644$.

36 Boogman, 'Achtergronden en algemene tendenties', 48. Het streven richtte zich overigens met name op Luxemburg.

57 Witlox, 'Wilde geruchten', 250-251. 
58 De Limburger koerier schreef op 31 januari 1919: 'De Belgische annexionisten spreken steeds van een "Limbourg cédé", een afgestaan Limburg - zij bedoelen er Neder. landsch Limburg mee - dat zij terug willen hebben.'

59 De Waele, 'De Belgische annexionistische campagne', 353.

60 La protestation du Limbourg, titelblad.

61 Wagemans, 'Limburg en het Belgische annexionisme', no-111 en 115; Van der Heijden, 'Tijden veranderen', 154.

62 Aantekening in zijn dagboek, 14 november 1917, De Beaufort, Dagboeken en aantekeningen $11,961$.

63 Van der Heijden, 'Tijden veranderen', 103.

64 Orbons en Spronck, 'Limburgers worden Nederlanders', 51.

65 Van der Heijden, 'Tijden veranderen', 149; Wagemans, 'Limburg en het Belgische annexionisme', 115 .

66 Van der Heijden, 'Tijden veranderen', 151.

67 Bank en Van Buuren, 1900, 23. Zie ook Wagemans, 'Limburg en het Belgische annexionisme', 132.

68 Gemeenteblad van Venlo $1919 \mathrm{nr} .584,8$; notulen gemeenteraad van Venray, ver. gadering 14 december 1918, Gemeentearchief Venray, Gemeentebestuur 1815-1941, inv.nr.7.

69 Dit manifest had de titel 'Aan de Limburgsche Bevolking'; tekst o.a. in: Niewwe Venlosche Courant, 10 december 1918.

70 Zie Van der Heijden, 'Tijden veranderen', 129-131.

71 Wilhelmina, Eenzaam maar niet alleen, 182-183. Elk van deze liederen had (en heeft) een uitgesproken pro-Nederlandse strekking, bij het Limburgse volkslied vervat in het vierde couplet. De officiële titel van het Limburgs volkslied is overigens Limburg mijn vaderland.

72 Troonrede van 16 september 1919, De Derde Dinsdag.

73 Wilhelmina, Eenzaam maar niet alleen, 182-183.

74 Wagemans, 'Limburg en het Belgische annexionisme', 132.

75 Ibidem, 108.

76 Prins, 'De Limburgsche afgevaardigden' $1,342$.

77 Ook Beumers wijst hierop in zijn onderzoek naar het gedrag van Limburgse afgevaardigden in de Tweede Kamer in de periode $1840-1848$ (Beumers, Limburgs separatisme, 27).

78 HTK $1847-1848,653$.

79 Brief van hertogelijk commissaris Beerenbroek aan gouverneur Van Meeuwen, 3 november 1848, afschrift aan de minister van Binnenlandse Zaken, NA, Archief Min. Binnenlandse Zaken Kabinet, inv.nr. 60, dossiernr. 1702. De typering 'hinkende seperatist' gold Tweede-Kamerlid Corneli, daar hij bij de grondwetsherziening van 1848 voor hoofdstuk 1 had gestemd.

8o Zie de brief van Van Scherpenzeel Heusch aan de voorzitter van de Tweede Kamer waarvan in de zitting van 15 februari 1849 melding werd gemaakt: $н T К 1849,2$.

81 KDC, Archief Nolens, inv.nr. 186. De Nieuwe Venlosche Courant liet zich gelijkluidend 
uit (Nieuwe Venlosche Courant, 10 december 1918). De term 'onvaderlandslievende gevoelens' is afkomstig van Nolens (Notulen katholieke kamerclub, vergadering 1oktober 1919, KDC, Archief RK Staatspartij, inv.nr. 104).

s Prins, 'De Limburgsche afgevaardigden' 1, 349 noot 2; Boogman, Nederland en de Duitse Bond, 339 noot 1. Beumers sluit zich in deze kwestic aan bij Prins (Beumers, Limburgs separatisme, 25).

\$) Van der Heijden, 'Bedreigd Maastricht', 106.

is 'Hij heeft zijn banden met de separatisten goed verborgen weten te houden.' Aldus Van der Heijden (ibidem).

is Van der Heijden, 'Tijden veranderen', 149; De Waele, 'De Belgische annexionistische ampagne'; 377-378 (abusievelijk genummerd 378-377).

16 Geheim rapport van gouverneur Van Meeuwen aan de koning, 15 april 1848, NA, Archief Kabinet des Konings, inv.nr. 4481.

b. Vgl. Boogman, Nederland en de Duitse Bond, 339 noot 1.

Is lbidem, 690 noot 2.

in Brief van gouverneur Van Meeuwen aan de minister van Binnenlandse Zaken, 26 oktober 1848, NA, Archief Min. Binnenlandse Zaken Kabinet, inv.nr. 60.

yo HTK 1918-1919, 686.

51 KDC, Archief RK Staatspartij, inv.nr. 104, notulen van de vergadering van 1 oktober 1919.

92 Journal du Limbourg aangehaald in Witlox, De staatkundige emancipatie, 47, cursivering in origineel.

93 A.J. Geurts, 'Stemming en stemming maken. Noordoost Limburg in het voorjaar van 1848', in: Van Hellenberg Hubar e.a., Maaslands Melange, 272.

i4 Zie voor deze gevoelens van Gericke van Herwijnen: A.F.J. van Kempen, 'J.E.P.E. Gericke (1785-1845), gouverneur van Limburg, 1841-1845', in: Wieland e.a., De gouverneurs, $97-98$.

\%) Geheime rapporten van gouverneur Gericke van Herwijnen aan de koning, 15 april en 15 juni 1843, in: Rapporten van de gouverneurs in, resp. 54 en 80.

\$6 Geheim rapport van gouverneur Gericke van Herwijnen aan de koning, 30 september 1842, NA, Archief Kabinet des Konings, inv.nr. 4480.

97 Wagemans, 'Limburg en het Belgische annexionisme', 121 en 127.

of Alberts, Geschiedenis van de beide Limburgen $\mathrm{I1}, 196$.

99 Citaat uit: Kemp, Limburg 1839-1939, 10.

ino Verbeet, Limburg op de tweesprong, 29.

in Alberts, Geschiedenis van de beide Limburgen $\mathrm{n}, 195$.

ton lbidem.

wog Ibidem.

14 Brief van Von Scherff aan de minister van Buitenlandse Zaken, 19 juli 1848, in: Bescheiden betreffende, 336-337.

105 Zie voor het wapen van Michiels van Verduynen:V.d. Venne, Limburgsche wapens, 70.

166 HTK 1840-1841, 189. 
107 Geheim rapport van gouverneur Gericke van Herwijnen aan de koning, 15ni 18843. in: Rapporten van de gouverneurs $11,80-81$.

108 Brief van de directeur van het Kabinet des Konings aan de minister van Binenlandse Zaken, 20 juni 1843 , in: ibidem, 82.

109 Zie Cramer, Parlement en pers, 110.

110 Geheim rapport van gouverneur Gericke van Herwijnen aan de koning, juli 1843 , in: Rapporten van de gouverneurs $11,109-111$.

I11 Boogman, Nederland en de Duitse Bond, 339 noot 1.

112 Ubachs, Handboek, 370.

13 Brief van de minister van Binnenlandse Zaken aan de koning, 15 decener 1848 , minuut, NA, Archief Min. Binnenlandse Zaken Kabinet, inv.nr.60. In ze brief droeg de minister, op aangeven van gouverneur Van Meeuwen, Beerenbek voor. Dezelfde dag liet de koning weten de onderscheiding te zullen verlenen.

114 Geheim rapport van gouverneur Gericke van Herwijnen aan de koning, juli 1843 , in: Rapporten van de gouverneurs 11, 109-111.

115 Mededeling van gouverneur Gericke van Herwijnen (zie Boogman, Nerland en de Duitse Bond, 204 noot 2).

116 Brief van hertogelijk commissaris Beerenbroek aan de minister van Bünlandse Zaken, 16 juli 1848, NA, Archieven Min. Buitenlandse Zaken, inv.nr. 1772.

нү НTK $104 /-1040,8 y \%$

118 Van Banning, 'Honderd jaar "gewone provincie", 130.

119 Brief van gouverneur Van Meeuwen aan de minister van Binnenlandse Zaken, II september 1848, minuut, RAL, Archieven provinciaal bestuur, inv.nr. 497.

120 HTK $1847-1848,899$.

121 Nies, Weert, 159.

122 Geheim rapport van gouverneur Gericke van Herwijnen aan de koning, 15 juli 1843. in: Rapporten van de gouverneurs $\mathrm{n}, 109-111$.

123 A.J.H.J. Bloemarts had zich tijdens en na de Belgische opstand aan de zijde van het Noorden geschaard; 'zijne steeds betoonde gehechtheid aan de Nederlandsche regering' had voor hem een zware financiële aderlating betekend. Dat er een goede band bestond tussen de twee familieleden werd duidelijk toen het latere TweedeKamerlid zijn neef steunde bij een (vergeefse) poging benoemd te worden tot griffier van Provinciale Staten van Limburg. (Geheim rapport van gouverneur Gericke van Herwijnen aan de koning, 15 oktober 1841 , minuut, RAL, Archieven provinciaal bestuur, inv.nr. 578; brief van gouverneur Gericke van Herwijnen aan de minister van Binnenlandse Zaken, 28 oktober 1841, NA, Archief Min. Binnenlandse Zaken Geheim, inv.nr. 54: Verbeet, Limburg op de tweesprong, 133.)

124 Brief van waarnemend gouverneur Kerens aan buitengewoon commissaris Gericke van Herwijnen, 10 juni 1839, RAL, Archieven provinciaal bestuur, inv.nr.10680. Gericke van Herwijnen had Kerens om advies gevraagd n.a.v. Swarts verzoek aan de koning om te worden benoemd tot auditeur-militair in de Limburg.

125 HTK $1847-1848,898-899$ (Thissen), 930 (Bloemarts) en 935-937 (Swart).

126 In de districten Sittard en Venlo was een herstemming noodzakelijk omdat geen van 
de kandidaten bij de eerste stemmingsronde in november een absolute meerderheid had behaald.

It Prins, 'De Limburgsche afgevaardigden' 1, 349 noot 2.

di HTK 1849, 179.

ay Volgens cen mededeling van gouverneur Gericke van Herwijnen (Boogman, Nederland en de Duitse Bond, 204 noot 2).

w Brief van de minister van Binnenlandse Zaken aan gouverneur Gericke van Herwijnen, 17 juni 1843; brief van gouverneur Gericke van Herwijnen aan de minister van Binnenlandse Zaken, 14 juli 1843; in: Rapporten van de gouverneurs 11 , resp. 84 en 112. * Brief van gouverneur Gericke van Herwijnen aan de minister van Binnenlandse Zaken en bijlage, 14 juli 1843 , in: ibidem, 113 en 114.

s. Geheim rapport van gouverneur Gericke van Herwijnen aan de koning, 30 november 1843 , in: ibidem, 216.

3 Brief van gouverneur Van Meeuwen aan de minister van Binnenlandse Zaken, 20 november 1848 , NA, Archief Min. Binnenlandse Zaken Kabinet, inv.nr.60, dossiernt. 1702 .

4 Nationaal Biografisch Woordenboek van de Koninklijke Vlaamse Academièn van België 111, 108-109. Zie ook: Boogman, Nederland en de Duitse Bond, 216 noot 3 en 516-517 noot 2.

13 Brief van De Liedel de Well aan gouverneur Van Meeuwen, 23 mei 1848, rAL, Archieven provinciaal bestuur, inv.nr. 495. De Liedel de Well voldeed met deze brief an het uitdrukkelijk verlangen van de koning om de zaak voor te leggen aan de gouverneur.

56 A.J. Geurts, 'Stemming en stemming maken. Noordoost Limburg in het voorjaar van 1848', in: Van Hellenberg Hubar e.a., Maaslands Melange, 272. Overigens kan nogmaals gewezen worden op de neiging van De Liedel de Well om tegenstanders bijzonder snel te voorzien van het predikaat separatist. Het opplakken van een dergelijk etiket zegt hier meer over degene die typeerde dan over de personen die getypeerd werden. Het is in ieder geval duidelijk dat de baron zichzelf rekende tot de tegenstanders van een afscheiding.

137 Geheim rapport van gouverneur Gericke van Herwijnen aan de koning, 31 juli 1843, in: Rapporten van de gouverneurs II, 124.

138 Beekelaar, 'Tussen twee revolutiejaren. De Eerste Kamer van 1830 tot 1848', in: Postma c.a., Aan deze zijde van het Binnenhof, 134.

19. Boogman, Nederland en de Duitse Bond, 691 noot 1.

40 Brief van gouverneur Van Meeuwen aan de minister van Binnenlandse Zaken, 28 januari 1849, NA, Archief Min. Binnenlandse Zaken Kabinet, inv.nr.6o.

41 Maenen, Petrus Regout, 88-89.

42 Verbeet, De beide Limburgen, 20.

43 HEK $1849-1850,56^{17}$.

4. L'Aviso de la Meuse 9 december 1848, geciteerd in Op den Camp, "Noch is Limburg niet gescheiden!', 37. Het betrof de uitslag van de eerste ronde. Weliswaar had die stemming in het district Venlo geen winnaar opgeleverd, er waren daar wel twee 
anti-separatisten op de plaatsen één en twee geëindigd; de tweede ronde zu tussen deze twee tegenstanders van afscheiding plaatsvinden.

145 Blok, Stemmen en kiezen, 31.

146 Brief van Gericke van Herwijnen, commissaris voor de wederinbezitnening, aan de secretaris van staat, baron van Doorn van Westcapelle, 23 september1840, in: Munier, 'De reorganisatie van het kerkelijk bestuur', 222.

147 Rapport van de raad van ministers aan de koning, 28 oktober 1839 , in: Coletbrander, Gedenkstukken, 703.

148 A.F.J. van Kempen, 'Mr. A.J.L. Borret $(1782-1858)$ en J.E.P.E. Gericke (1735-1845), commissarissen voor de inbezitneming, 1839-1840', in: Wieland, De gouverieurs, 89 .

149 Deze benoeming geschiedde bij Koninklijk Besluit van 30 september $184 \mathrm{inr} .65$ en betrof 33 van de 39 statenleden. Alleen de zes leden die namens de stad Naastricht zouden plaatsnemen, werden op reguliere wijze gekozen (d.w.z. door de tedelijke raad van Maastricht).

150 Kraume, Außenpolitik, 192.

151 Geheim rapport van gouverneur Van Meeuwen aan de koning, 15 juli 846, NA, Archief Kabinet des Konings, inv.nr. 4481.

152 Van der Heijden, 'Separatisme in Limburg', 25; Boogman, Nederland en le Duitse Bond, 204-205 en 356-357.

153 Voor de bevolkingscijfers en het aantal stemgerechtigden in Limburg in 1839, zie: Blok, Stemmen en kiezen, 300.

154 Ibidem.

155 Verbeet, De beide Limburgen, 8.

156 Geheim rapport van gouverneur Gericke van Herwijnen aan de koning, 30 september 1841, minuut, RAL, Archieven provinciaal bestuur, inv.nr. 578 .

157 Circulaire van de minister van Binnenlandse Zaken aan de Commissarissen des Konings in de verschillende provincies, 24 januari 1854, ibidem, inv.nr. 508 (onder nr. 4331).

158 Brief van gouverneur Van Meeuwen aan de minister van Binnenlandse Zaken, 28 januari 1854, minuut, ibidem.

159 In juli moest er een vervanger gekozen worden voor Beerenbroek en diende de reguliere vacature te worden opgevuld; in september werden drie buitengewone leden gekozen en in november vonden de eerste rechtstreekse verkiezingen plaats.

160 Brief van hertogelijk commissaris Beerenbroek aan de minister van Buitenlandse Zaken, 17 mei 1848, in: Wels, Bescheiden betreffende, 208; brief van Eerste-Kamerlid De Liedel de Well aan gouverneur Van Meeuwen, 23 mei 1848, RAL, Archieven provinciaal bestuur, inv.nr. 495. De baron schreef de gouverneur dat hij de koning had medegedeeld dat de verkiezingsuitslag moest worden beschouwd 'als gevolg der directe verkiezingen zonder kiescens'. Van een relatie tussen census en uitslag is volgens Derks geen sprake, daar Van Scherpenzeel Heusch ook bij de kamerverkiezingen in november - toen de lagere sociale klassen waren uitgesloten - 'door de Limburgers als afgevaardigde [werd] gekozen' (Derks, De gewenning, 51). Hierbii] dient te worden opgemerkt dat Van Scherpenzeel Heusch toen, anders dan bij de 
verkezingen van mei, niet gekozen werd in geheel Limburg, maar slechts in twee van de viff districten. Bovendien was de steun voor de baron ook in die twee districten, sittard en Heerlen, minder groot dan in de vergaderingen van kiesmannen die in mei hadden plaatsgevonden.

\# Geurts, 'De Limburgse meiverkiezingen'; 52.

a De geringe opkomst bij de mei-verkiezingen relativeert ook volgens Boogman de overwinning van Van Scherpenzeel: onder de thuisblijvers bevonden zich waarschijnlijk heel wat onverschilligen, sceptici en (een beperkt aantal) overtuigde antiseparatisten (Boogman, Nederland en de Duitse Bond, 355-356).

is Geurts, 'De Limburgse meiverkiezingen'; 54 . Geurts vraagt daarom ook aandacht voor de lokale omstandigheden als verklaringsfactor (ibidem, 53-54; zie ook A.J. Geurts, 'Stemming en stemming maken. Noordoost Limburg in het voorjaar van 148', in: Van Hellenberg Hubar e.a., Maaslands Melange, 262).

\$4 Geurts, 'De Limburgse meiverkiezingen'; 54.

s: Niet alle 308 kiesmannen namen deel aan de verkiezingen, maar het aantal dat niet opkwam was bijzonder klein (zes) en hier te verwaarlozen.

is De namen en beroepen van de kiesmannen werden (per gemeente) gepubliceerd in het Memoriaal voor de Duitsche Bondszaken en zijn opgenomen in: Dorren, 'Het Hertogdom Limburg', 120-125. Boogman heeft deze kiesmannen naar beroep gegroepeerd: Boogman, Nederland en de Duitse Bond, 356 noot 1.

ib; Dorren, 'Het Hertogdom Limburg', 163.

is Brief van de minister van Binnenlandse Zaken aan gouverneur Van Meeuwen, 21 oktober 1848, minuut, NA, Archief Min. Binnenlandse Zaken Kabinet, inv.nr. 50.

hy Blok, Stemmen en kiezen, 28-29.

to Brief van de minister van Binnenlandse Zaken aan gouverneur Gericke van Herwijnen, 9 oktober 1841, RAL, Archieven provinciaal bestuur, inv.nr. 474 .

7) Brief van gouverneur Gericke van Herwijnen aan de minister van Binnenlandse Zaken, 14 oktober 1841 , minuut, ibidem.

th Ibidem.

to Geheim rapport van gouverneur Gericke van Herwijnen aan de koning, 15 oktober 1841, minuut, ibidem, inv.nr. 578.

74 Brief van gouverneur Gericke van Herwijnen aan de minister van Binnenlandse Zaken, 14 oktober 1841 , minuut, ibidem.

75 Cramer, Parlement en pers, 110.

V6 HTK 1844-1845, 55. Bij een vacature voor de Hoge Raad nomineerde de Tweede Kamer volgens grondwettelijk voorschrift drie kandidaten. De koning benoemde vervolgens een van deze genomineerden. Voorafgaand aan de hier voorliggende nominatie zond de Hoge Raad op 19 oktober 1844 een lijst naar de Tweede Kamer met mogelijke kandidaten; Strens werd daarbij als eerste vermeld (HTK 1844-1845, 10).

77 Geciteerd in Witlox, 'Mr. M. Strens', 271.

78 Geheim rapport van gouverneur Gericke van Herwijnen aan de koning, 30 juni 1842, minuut, RAL, Archieven provinciaal bestuur, inv.nr. 578 . 
179 Brief van de minister van Binnenlandse Zaken aan gouverneur Gericke van Herwijnen, 31 oktober 1846 , ibidem; 'goede' onderstreept in origineel.

180 Ibidem.

181 Geheim rapport van gouverneur Van Meeuwen aan de koning, 17 juli $184 \%$, $\mathrm{x}$, Archief Kabinet des Konings, inv.nr. 4481.

182 Geheim rapport van gouverneur Van Meeuwen aan de koning, 16 juli 1848, ibidem.

$183 \mathrm{Vgl}$. Blok, Stemmen en kiezen, 29.

184 De Jong, Van standspolitiek naar partijloyaliteit, 57.

185 Boogman, Rondom 1848, 72.

186 Blok, Stemmen en kiezen, 28.

187 Brief van de hertogelijk commissaris Beerenbroek aan de minister van Buitenlandse Zaken, 19 oktober 1848 , in: Bescheiden betreffende, 523.

188 Notulen van de ministerraad, 21 oktober 1848 , in: ibidem, 527-528.

189 NA, Archief Min. Binnenlandse Zaken Kabinet, inv.nr. 62, dossiernr. 1702; 'Tegenwerking ten goede' onderstreept in origineel.

190 Brief van de minister van Binnenlandse Zaken aan gouverneur Van Meeuwen, a oktober 1848 , minuut, ibidem, inv.nr. 50.

191 Ibidem, inv.nr. 62, dossiernr.1702; de namen Leclercq en Bontamps onderstreept in origineel.

192 Brief van de minister van Binnenlandse Zaken aan gouverneur Van Meeuwen, 22 oktober 1848 , minuut, ibidem, inv.nr. 60 .

193 Brief van de minister van Binnenlandse Zaken aan gouverneur Van Meeuwen, 21 oktober 1848 , minuut, ibidem, inv.nr. 50. Brief van gouverneur Van Meeuwen aan de minister van Binnenlandse Zaken, 28 januari 1849, ibidem, inv.nr. 60.

194 Geciteerd in Boogman, Nederland en de Duitse Bond, 691.

195 Stadsarchief Sittard-Geleen, Archief Sittard 1794-1930, inv.nr. 3435.

196 Brief van de minister van Binnenlandse Zaken aan gouverneur Van Meeuwen, 21 oktober 1848, minuut, NA, Archief Min. Binnenlandse Zaken Kabinet, inv.nr. 50.

197 Nederlandsche staatscourant 1848 nrs. 297 en 307,15 en 28 december 1848 .

198 Brief van districtscommissaris van Roermond Beerenbroek aan gouverneur Van Meeuwen, 9 november 1848; afschrift door de gouverneur gezonden aan de minister van Binnenlandse Zaken: brief gouverneur Van Meeuwen aan de minister van Binnenlandse Zaken, 10 november 1848, NA, Archief Min. Binnenlandse Zaken Kabinet, inv.nr.60, dossiernr. 1702.

199 Geciteerd in Boogman, Nederland en de Duitse Bond, 691.

200 Brief van gouverneur Van Meeuwen aan de minister van Binnenlandse Zaken, 28 januari 1849, NA, Archief Min. Binnenlandse Zaken Kabinet, inv.nr.60.

201 Geheim rapport van gouverneur Van Meeuwen aan de koning, 15 april 1848, NA, Archief Kabinet des Konings, inv.nr. 4481.

202 Brief van de directeur van het Kabinet des Konings, A.G.A. ridder van Rappard, aan gouverneur Van Meeuwen, 25 juli 1847, ibidem, inv.nr. 4195.

203 Alberts, Geschiedenis van de beide Limburgen $11,191$.

204 Notulen van de ministerraad, 21 oktober 1848 , in: Bescheiden betreffende, 527. 
s. Boogman, Nederland en de Duitse Bond, 365.

6 月ाK $1847-1848,697$.

Ibidem, 653 .

4 Ibidem, 280.

s) arr $1843-1844,284$.

\# Beumers, Limburgs separatisme, 26-27; J.L.M. Leclercq is ten onrechte niet meegenomen in dit onderzoek. De drie buitengewone leden van de Tweede Kamer, Thissen, Bloemarts en Swart, worden door Beumers terzijde behandeld (ibidem, 21).

르 Geradts: HTK 1847-1848, 690 e.v.; Swart: HTK 1847-1848, 936-937; Thissen: HTK 18471848, 899; Bloemarts: HTK 1847-1848, 930; Borret: HTK 1849, 162; De Lom de Berg; HTK 1849, 179; Beerenbroek: HEK 1849, 18-19; Regout: HEK 1849, 19. De Liedel de Well is hier buiten beschouwing gebleven vanwege de summiere verslaglegging van de Eerste-Kamervergaderingen.

\# HEK $1849-1850,56^{17}$.

as Bescheiden betreffende, 511 noot 6 .

3 Brief van de Nederlandse gezant in Frankfurt, Von Scherff, aan de minister van Buitenlandse Zaken, 12 oktober 1848, in: Bescheiden betreffende, 511.

as De Tijd is januari 1849 .

af $\operatorname{HTK} 1849,2$.

a) Ook volgens Wollstein was het zo dat Van Scherpenzeel Heusch er met zijn brief uit mei 1848 aan de Nationale Vergadering voor zorgde dat de Limburgse kwestie op de politieke agenda in Frankfurt verscheen (Wollstein, Das 'Großdeutschland', 245).

ul HTK $1849,157$.

39 Boogman, Nederland en de Duitse Bond, 662 noot 3.

220 Notulen ministerraad 12 augustus 1848 in: Bescheiden betreffende, 400.

24 Boogman, Nederland en de Duitse Bond, 607.

122 HTK $1847-1848,697$.

23 нтк 1840-1841, 119.

24 Histoire parlementaire du traité 1, 468 (8 maart 1839).

25 Ernest Renan schrijft: 'L'oubli et je dirai même l'erreur historique, sont un facteur essentiel de la formation d'une nation [...]' (Renan, Qu'est-que c'est une nation?, 8). Hobsbawn omarmt deze stelling (Hobsbawn, Nations and nationalism, 12).

26 Tekst in het verslag van de commissie aan PS: notulen van Provinciale Staten van Limburg, zomervergadering 1867, Provinciaal blad van Limburg $1867 \mathrm{nr} .140,125-131$. Het besluit tot het zenden was genomen op 2 juli 1867: ibidem, 23-24.

24 Zie 0.a. Cornelis: HTK 1863-1864, 23; De Bieberstein Rogalla Zawadsky: HTK 18631864, 172 en 423, HTK 1864-1865, 214; Van der Maesen de Sombreff: o.a. HTK 1865-1866, 140; De Keverberg de Kessel: HTK 1863-1864, 644 en 653; Van Wintershoven: HTK 1863-1864, 423 en 654; Haffmans: HTK 1867, 142-143.

28 HTK $1864-1865,220^{5}$. Het verzoek om deze wens niet al te nadrukkelijk tot uiting te brengen, was overigens niet alleen gericht tot de Limburgse kamerleden.

29) HTK 1865-1866, 140.

30 HTK $1863-1864,23$. De commissie die was belast met het opstellen van een ontwerp- 
adres, had deze zin geformuleerd. Een kleine meerderheid in de Tweede Kamer wilde de kwestie echter onvermeld laten.

231 HTK 1863-1864 B, 766.

232 Van Banning, "Honderd jaar "gewone" provincie', 135.

233 HTK 1867, 111-114 (Van der Maesen de Sombreff) en 142-143 (Haffmans); HTK 1867 147 (Van Zuylen van Nijevelt).

234 Ibidem, 164-165.

235 Overigens geeft ook Van Banning aan dat de onderlinge verdeeldheid verband zou kunnen houden met de verschillende politieke achtergrond van de Limburgse kamerleden. Een betrouwbare verklaring kan hij dit onmogelijk hebben gevonden. omdat hij vermeldt dat de klerikale en daarmee verre van liberaal-gezinde I.H. Arnoldts zich aan de zijde schaarde van de liberaal-katholieken Van der Maesen de Sombreff en De Bieberstein Rogalla Zawadsky. Arnoldts zou echter pas in 1871 zitting nemen in de Kamer en wordt dus ten onrechte door Van Banning bij de Limburge afgevaardigden van dat moment betrokken. (Van Banning, 'Honderd jaar "gewone" provincie', 135-136.)

236 HTK $1867,143$.

237 Grochtmann, Die Niederländsche Provinz Limburg, 137.

238 Van alle Limburgse afgevaardigden uit de periode $1863-1868$ was Van der Maesen de Sombreff het meest aan het woord in de Kamer. Samen met Thorbecke verlangde hij dat de regeringsstukken betreffende de Limburgse (en Luxemburgse) kwestie openbaar zouden worden gemaakt, hetgeen gebeurde in het Oranjeboek van 1868. De kamercommissie die werd belast met het onderzoek van deze stukken bestond uit onder anderen Thorbecke en Van der Maesen de Sombreff.

239 De Jong, Van standspolitiek naar partijloyaliteit, 58.

240 Oud en Bosmans, Staatkundige vormgeving $1,83$.

241 Tekst van de proclamatie in ibidem, $77-78$.

242 Ook De Jong plaatst de uitspraken van Van der Does de Willebois in deze nationaalpolitieke strijd (De Jong, Van standspolitiek naar partijloyaliteit, 58).

243 De Tijd 27 mei 1869 . Haffmans zelf kwam in 1885 nog op de kwestie terug (Huizinga, 'Een gebroken spiegel', 434).

244 Hermans, 'Limburg in de parlementaire geschiedenis', 118.

245 Wagemans, 'Limburg en het Belgische annexionisme', m.n. 118 e.v.; Van der Heijden, 'Tijden veranderen', 131-135.

246 HTK 1918-1919, 833.

247 Zie voor het wapen van Nolens: De Limburgse Leeuw 8 (1959-1960), 137.

248 Gribling, Willem Hubert Nolens, 135.

249 Ibidem, 61 (noot 79) en 65.

250 Verbeet, De beide Limburgen, 43.

251 HTK 1918-1919, 695.

252 Perry, 'Jubeljaren', 20.

253 Alberts, Geschiedenis van de beide Limburgen n, 270.

254 NNBW 1X, 910. 
I5 G.A.M. Beekelaar, 'Gustave Ruijs de Beerenbrouck (1842-1926), commissaris der koningin, 1893-1918, en Charles Ruijs de Beerenbrouck (1873-1936), commissaris der koningin, mei-augustus 1918', in: Wieland e.a., De gouverneurs, 283.

is sTK 1918-1919, 705.

ig Spreuk in: Limburg, 'Gedenkboek', 4.

\& Briefie van Ch. Ruijs de Beerenbrouck, afgedrukt in De Nedermaas 2 nr. 1 (1924), 3.

* La protestation du Limbourg hollandais, 148 (toespraak Fock).

so Statenvergadering van 10 december 1918 en van 1 juli 1919 (Provinciaal blad van Limburg 1919 nr. 5, 33-36 en nr. 74, 23-28); gemeenteraadsvergadering van 25 februari 1919 en van 11 augustus 1919 (Gemeenteblad van Maastricht afdeling B ['Handelingen van den Gemeenteraad van Maastricht'] 1919 nr. 4, 2-5 en nr. 13, 43-47).

.i Gemeenteblad van Maastricht 1919 в nr.13, 45. De naam Janssen is in de notulen met èn $s$ geschreven.

*2 De katholieke illustratie 53 (1919) nr. 48, 568. Zijn artikel draagt de titel 'Limburg bij Nederland'.

43 HEX 1918-1919, 65.

\$ Zie voor het wapen van Michiels van Kessenich: V.d. Venne, Limburgsche wapens, 46.

is Geciteerd in: Wagemans, 'Limburg en het Belgische annexionisme', 127.

* HTX 1918-1919, 696.

267 lbidem.

258 Janssen in De katholieke illustratie 53 (1919) nr. 48, 568.

ab HTK 1918-1919, 696.

70 Wagemans, 'Limburg en het Belgische annexionisme', 128.

д) Notulen katholieke kamerclub, vergadering 1 oktober 1919 (KDC, Archief RK Staatspartij, inv.nr. 104).

72 Notulen katholieke kamerclub, vergaderingen 1 oktober en 4 november 1919 (ibidem).

273 Zie de redes van Van Groenendael op 11 en 19 december 1918 en 14 oktober en 11 november 1919 (resp. HTK 1918-1919, 685-686 en 832, en HTK 1919-1920, 65-67, 68, 254 en 255).

74 HTK 1919-1920, 67.

n5 Gribling, Willem Hubert Nolens, 212.

176 Notulen katholieke kamerclub, vergadering 1 oktober 1919 (KDC, Archief RK Staatspartij, inv.nr. 104).

I7 HTK 1918-1919, 695.

278 HEK 1918-1919, 695 resp. 65.

17y HTK 1918-1919, 686 resp. HEK 1918-1919, 65.

30 La protestation du Limbourg hollandais, 22 resp. 25.

is HTK 1918-1919, 695 .

23: lbidem, 695 en 705 .

诂 HEK 1918-1919, 65 .

24 lbidem.

2t5 KDC, Archief Nolens, inv.nr. 186. 
286 Limburgsch Dagblad 14 augustus 1919.

287 Brief van minister Van Karnebeek aan de Eerste Gedelegeerde ter conferentie te Parijs inzake de herziening van de verdragen van 1839, De Marees van Swinderen, 14 augustus 1919, in: Documenten betreffende, 122.

288 KDC, Archief RK Staatspartij, inv.nr.104, notulen van de vergadering van 1 oktober 1919.

289 lbidem, inlegvel.

290 Ibidem, notulen van de vergaderingen van 9 september en 1 oktober 1919.

291 Ibidem, vergadering van 1 oktober 1919. De notulen vermelden overigens niet of Van Groenendael zelf meestemde.

292 HTK 1919-1920, 66.

293 Van der Heijden, 'Tijden veranderen', 135. Het aantal benodigde stemmen voor een zetel bedroeg $75 \%$ van de kiesdeler.

294 De term 'onvaderlandslievende gevoelens' gebruikte Nolens tijdens een vergadering van de katholieke kamerclub. (Notulen katholieke kamerclub, vergadering 1 oktober 1919, KDC, Archief RK Staatspartij, inv.nr. 104).

295 HTK 1919-1920 Aanhangsel, 397.

$296 \mathrm{KDC}$, Archief Nolens, inv.nr. 186.

297 Notulen katholieke kamerclub, vergadering 1 oktober 1919 (KDC, Archief RK Staats. partij, inv.nr. 104).

298 Geciteerd in Van der Heijden, 'Tijden veranderen', 135.

299 Geciteerd in Van der Hoek e.a., De Venlose krant, 85.

300 Van der Heijden 'Tijden veranderen', 103.

301 Ibidem, 143 resp. Verbeet, De beide Limburgen, 42.

302 De Waele, 'De Belgische annexionistische campagne', 372 resp. 377 (abusievelijk genummerd 378 ).

303 Wagemans, 'Limburg en het Belgische annexionisme', 132 en 133.

\section{Hoofdstuk 4}

1 Venloosch Weekblad 27 februari 1864.

2 De Godsdienstvriend 45 (1840), 167. Het desbetreffende artikel, getiteld 'Miskenning der Nederlandsche Catholijken', werd overgenomen door De Noord-Brabanter (23 oktober 1840).

3 HTK 1840-1841, 189.

4 Ibidem B, 342.

5 Alberts, Geschiedenis van de beide Limburgen n, 200.

6 Beekelaar, Rondom grondwetsherziening, 23.

7 Alberts, Geschiedenis van de beide Limburgen $\mathrm{II}, 192$

8 Witlox, De staatkundige emancipatie, 195.

9 lbidem, 47. Het Journal du Limbourg keerde zich desondanks tegen de verkiezing van Beerenbroek, omdat zijn Nederlandse gezindheid in twijfel werd getrokken (zie hoofdstuk 3). 
w De Jong, Van standspolitiek naar partijloyaliteit, 27.

a Dit was tijdens de beraadslagingen en de stemming over het adres van antwoord op de troonrede (HTK 1844-1845, 43-44).

II Alberts, Geschiedenis van de beide Limburgen II, 195.

18 н7к 1847-1848, 937. Zie verder ibidem, 653 (De Weichs de Wenne), 701 (Corneli) en 899 (Thissen).

4 Beekelaar, 'Tussen twee revolutiejaren. De Eerste Kamer van 1830 tot 1848 ', in: Postma ca., Aan deze zijde van het Binnenhof, 134.

5 C.H.E. de Wit, 'Limburg - Maastricht - Thorbecke, 1848-1853', in: Van Hellenberg Hubar e.a., Maaslands Melange, 281.

is HTK $1847-1848,280$.

$\checkmark$ Brief van Van Scherpenzeel Heusch voorgelezen in de Nationalversammlung te Frankfurt op 14 mei 1849: Stenographischer Bericht 1x, 6644.

3 Brief van Van Wintershoven e.a. aan Thorbecke, 20 maart 1848, in: C.H.E. de Wit, 'Limburg - Maastricht - Thorbecke, 1848-1853', in: Van Hellenberg Hubar e.a., Maaslands Melange, 286.

19 Brief van Strens aan Thorbecke, 7 november 1849, in: Thorbecke, Briefwisseling v, 201 noot 2 , cursivering in origineel.

so Bij de formatie van het kabinet was Thorbecke er overigens nog geen voorstander van geweest dat Strens minister van Justitie zou worden. Hij had zich daarbij laten leiden door een advies van zijn vriend L.D. Storm (dagboekaantekeningen 18 maart -14 april 1848 , in: Thorbecke, Briefwisseling v, 503-504; Witlox, 'Mr. M. Strens', 272). In oktober 1852 werd Strens tevens minister voor de Zaken van de Rooms-Katholieke Eredienst.

a Witlox, 'Mr. M. Strens', 277.

2 M.K.J. Smeets, 'Van der Does de Willebois (1816-1892), commissaris des konings, 1856-1874', in: Wieland e.a., De gouverneurs, 146.

3 Geciteerd in: Witlox, De staatkundige emancipatie, 63.

4 De Jong, Van standspolitiek naar partijloyaliteit, 22.

25. De Jong, 'Katholieken en verkiezingen', 439.

26 In het databestand van het PDC worden de volgende kamerleden uit Limburg voorzien van (o.a.) het predikaat 'liberaal': Ch. baron de Bieberstein Rogalla Zawadsky, Cornelis, Hengst, Kerstens, De Limpens, Strens, Thorbecke, Van Wintershoven en Van Wylick. De Lom de Berg wordt bijv. in een lijst uit het archief van Thorbecke aangeduid als 'liberaal' (Thorbecke, Briefwisseling vi, 523 noot 4).

27 Biografie E.J.H. Borret, databestand PDC; Prins, 'De Limburgsche afgevaardigden' t, 349 noot 2 en 353; De Jong Van standspolitiek naar partijloyaliteit, 137.

28 Zie bijv. Witlox, De staatkundige emancipatie, 139-150.

29 De Tijd 7 juni 1852 . Dat Borret niet werd herkozen, werd dan ook door het blad betreurd (ibidem 12 juni 1852).

30 Witlox, De staatkundige emancipatie, 183.

31. Prins, 'De Limburgsche afgevaardigden' 1, 355.

32 NNBW 1, 'Borret (Mr. Eduard Joseph Hubert)', 423-424. Borret erkende de positieve 
daden van het kabinet-Thorbecke op godsdienstig gebied, zonder daarot, als het op de beginselen aankwam, de leiding van Thorbecke te aanvaarden (Vemeulen, 'Staatkundige mannen', in Loeff e.a., Het Katholiek Nederland 1, 297).

33 Witlox, De staatkundige emancipatie, 191-193.

34 De Tijd 9, 11 en 25 juni 1860 .

35 In de tweede ronde waren de cijfers: 723 voor Strens en 570 voor Corneli (uitslag in De Tijd 15 juni en 28 juni 1860). Zie voor deze verkiezing ook hoofdstuh

36 Ook van voormalig kamerlid baron de Weichs de Wenne is bekend dat hij eze wens krachtig steunde (Beekelaar, Rondom grondwetsherziening, 157-158 en 167)

37 Prins, 'De Limburgsche afgevaardigden' 1, 354-355.

38 Witlox, De staatkundige emancipatie, 190.

39 Thorbecke, Briefwisseling vi, vil.

40 Prins, 'De Limburgsche afgevaardigden' $11,74$.

41 Zie voor de Limburgse bijdragen aan het debat: HTK 1853, 203-205, 78 (Van Wintershoven), 250-252 (De Lom de Berg) en 259-262 (Strens).

42 Beerenbroek en Regout namen deel aan het debat: HEK 1853, 69-71 resp. 8.

43 Thorbecke e.a., Redevoeringen uitgesproken door de Afgevaardigden van ht hertog. dom Limburg. Deze bundel bevat de redevoeringen van de Tweede-Kanerleden Thorbecke, Van Wintershoven, Strens, De Lom de Berg, Hengst (afgevaarigd van-

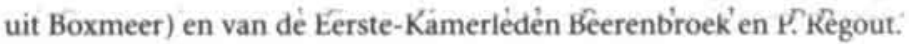

44 Brief van Thorbecke aan Van Wintershoven, 11 maart 1853, in: Thorbecke, Briefwisseling $\mathrm{vi}, 164$.

45 Thorbecke, Briefwisseling vi, 523 noot 4. Jespers en Meeuwsen worden in deze lijst aangeduid als 'liberaal-rooms'; Luyben als 'rooms'; Bots, Kerstens en De Poorter als 'rooms-liberaal'.

46 Geciteerd in Jurriaanse, De Nederlandse Ministers, 426 noot 19.

47 Witlox, De staatkundige emancipatie, 195. Het blad hoopte dat Thorbecke in alle Limburgse en ook in alle Noord-Brabantse districten zou worden gekozen.

48 Thorbecke behaalde in Roermond 122 van de 1109 uitgebrachte stemmen (cijfers uit De Tijd 21 mei 1853).

49 Brief van Thorbecke aan Van Wintershoven, 11 mei 1853, in: Thorbecke, Briefwisseling vi, 18.

5o Brief van Van Wintershoven aan Thorbecke, 1 juni 1853 , in: C.H.E. de Wit, 'Limburg - Maastricht - Thorbecke, 1848-1853', in: Van Hellenberg Hubar e.a., Maaslands Melange, 288.

51 Matthey, "'Een diepe hulde, een warme toon"', 139-141. Roermond bezette na het Gelderse Haaften een tweede plaats.

52 De Tijd 13 juni 1856.

53 'Manifest aan de kiezers van het hoofdkiesdistrict Maastricht', 2 juli 1856, in: Thorbecke, Briefwisseling vi, 517.

54 HTK 1863-1864, 538.

55 Brief van Thorbecke aan waarschijnlijk De Limpens, ongedateerd, in: Thorbecke, Briefwisseling vi, 43. 
\$ Brief van P.D. Regout aan Thorbecke, 17 september 1853 , in: C.H.E. de Wit, 'Limburg - Maastricht - Thorbecke, 1848 -1853', in: Van Hellenberg Hubar e.a., Maaslands Melange, 289.

q Brief van Thorbecke aan P.D. Regout, 21 oktober 1853, in: Thorbecke, Briefwisseling vi, 64 .

$\$$ Brieven van Thorbecke aan A. Thorbecke-Solger, april-mei 1851, juli 1855 en juni-juli 1856, in: Thorbecke, Briefwisseling v, 329-331, vi, 187-194 en 247-253.

99 Brieven van Thorbecke aan A. Thorbecke-Solger, 7 juli 1855, in: Thorbecke, Briefwisseling v1, 188.

to lbidem, 470 noot 1 . Hooykaas en Santegoeds schrijven over de zilveren bruiloft van Thorbecke: 'Het is interessant te zien welke politieke vrienden werden uitgenodigd, al zal er met de aanwezigheid in 's Gravenhage rekening zijn gehouden.' (Ibidem, ix.)

6. Brief van Thorbecke aan I.J.P. van Zuylen van Nijvelt, 13 september 1855, in: ibidem. 201.

6s lbidem, register. Limburg wordt hierin veertien keer genoemd, gevolgd door Friesland (zeven vermeldingen), Noord-Brabant (vijf), Noord-Holland (drie), Groningen (twee) en Utrecht (eén).

69 Zie de ledenlijst in Publications de la Société Historique et Archéologique dans le Limbourg 2 (1865), 269-280.

64 HTK 1863-1864, 538 .

65 HTK $1855-1856,636-638$.

66 HTK $1858-1859,821$.

67 Smeets, 'Van der Does de Willebois (1816-1892), commissaris des konings, 1856-1874', in: Wieland e.a., De gouverneurs, 166.

68 In de registers op de Handelingen van de Staten-Generaal over de jaren 1857-1862 wordt melding gemaakt van eenenveertig verzoekschriften die uit Limburg aan de Tweede Kamer werden gericht; uit de rest van Nederland arriveerden veertien verzoekschriften. Gedeputeerde Staten van Limburg en de drie Kamers van Koophandel en Fabrieken uit de provincie stuurden elk verschillende adressen.

69 HTK 1859-1860, 869 (Strens); 872-873, 877 (Van Wintershoven); 875-876 (De Lom de Berg); 876 (De Bieberstein). Verder spraken Hengst (district Boxmeer) en Thorbecke, resp. 876 en $879-880$.

70 J.J. Vis, "Van "ménagerie du roi" tot politiek college. De Eerste Kamer van 1849 tot 1887', in: Postma e.a., Aan deze zijde van het Binnenhof, 185.

71 HTK $1854-1855,653$.

72 Th. van Tijn, 'The party structure of Holland and the outer provinces in the nineteenth century', in: Beekelaar e.a., Vaderlands Verleden, $570-571$ en 583.

73 Zie bijv. Prins, 'De Limburgsche afgevaardigden' $\mathrm{n}, 80$.

74 Brief van De Bieberstein aan Thorbecke, 31 januari 1862 en brief van Paul de Bieberstein aan Thorbecke, 6 februari 1862, Archief Thorbecke inv.nr. 73.

75 Blok, Veertig jaar, 21. In het origineel is abusievelijk 'zuideiijke' gedrukt.

76 HTK 1862-1863, 1065. 
77 Ibidem.

78 Van Wintershoven, Open brief, 4.

79 Ibidem, 1.

8o Van Wintershoven, De Heer Hubert Pyls, 5.

81 Van Wintershoven, Open brief, 4.

82 Smeets, 'Van der Does de Willebois (1816-1892), commissaris des konings, 1856-1874'. in: Wieland e.a., De gouverneurs, 166.

83 Van der Hoek e.a., 'Het Venloosch Weekblad en de verkiezingen', 61.

84 Bos, Notabele ingezetenen, 161.

85 L'ami des intérêts Limbourgeois van o.a. 13 juni 1864; Venloosch Weekblad van 0.2 .14 mei 1864.

86 Venloosch Weekblad 14 mei 1864; L'ami des intérêts Limbourgeois 13 juni 1864.

87 Venloosch Weekblad 20 oktober 1866.

88 HTK 1863-1864, 631.

89 Venloosch Weekblad 27 februari 1864.

90 HTK $1862-1863,1074^{4}$ (m.b.t. Van Wintershoven) en HTK 1863-1864, 538 (m.b.t. De Keverberg de Kessel).

91 Boessen, "'Geest der Provincie"', 16.

92 Van Wintershoven, Tweede open brief, 2, 3 en 4; De Heer Hubert Pyls, 3 en 4.

93 Van Wintershoven, De Heer Hubert Pyls, 5 noot 1.

94 Van Wintershoven, Open brief, 2.

95 De Tijd u juni 1864.

96 Van Wintershoven, Open brief, 6.

97 NNBW X, 'Wintershoven (Mr. Pieter Frederik Eduard van)', 1227.

98 Maas- en Roerbode 28 mei 1864.

99 Venloosch Weekblad 5 maart 1864 , cursivering in origineel.

100 Ibidem 28 februari 1863 .

101 Ibidem 7 mei 1864 .

102 Vgl. Van der Hoek e.a., 'Het Venloosch Weekblad en de verkiezingen', 59.

103 Venloosch Weekblad u juni 1864.

104 Van Wintershoven, Tweede open brief, 2.

105 Lami des intérêts Limbourgeois 13 juni 1864 . Het Venloosch Weekblad sprak van 'staatkundige verblinding' (Venloosch Weekblad 27 februari 1864).

$106 \mathrm{De}$ Volksvriend 4 juni 1864 , cursivering in origineel.

107 Geciteerd in: Hans Verhage, 'Rijks of Rooms? Strijd om de HBs in het bisdom Roermond', in: Te Velde en Verhage, De eenheid en de delen, 48.

108 Tot leedwezen van hemzelf, maar ook van Thorbecke, had hij ontslag moeten nemen toen zijn beleid inzake de situatie in Polen door de Eerste Kamer was afgekeurd. Zie voor deze kwestie m.n. Jurriaanse, De Nederlandse ministers, 190-193.

109 Brief van Betz aan Van der Maesen de Sombreff, 4 mei 1864, tekst in: Frunsch, 'Hoe cen Limburgse belastingkwestie', $93-94$, cursivering in origineel.

110 HTK 1865-1866, 192.

i1 Cramer, Wandelingen door de handelingen, 25. 
at H. Dorren, 'Maesen de Sombreff, Jhr. Paul Theresia van der. Kamerlid. Minister van Buitenlandse Zaken', in: Rutten e.a., 'Limburgs Biografisch Repertorium', 178, Zie ook Sagittarius, Parlementaire portretten, $\mathrm{u}_{4}$.

it H. Dorren, 'Bieberstein Rogalla Zawadsky, Charles Antoine baron de. Kolonel, Kamerlid', in: Rutten e.a., 'Limburgs Biografisch Repertorium', 155.

a Zie bijv. Venloosch Weekblad 26 maart 1864.

as HTK 1863-1864, 297; HTK 1865-1866, 3764.

ab HTK 1863-1864, 296 (De Bieberstein en Cornelis) en 296-297 (De Lom de Berg).

in Maenen, Petrus Regout, 105-106.

is Prins, 'De Limburgsche afgevaardigden' II, 78-79.

ag Maenen, Petrus Regout, 108.

an Ibidem, 123.

a NNBW X, 'Wintershoven (Mr. Pieter Frederik Eduard van)', 1227.

12 Maas- en Roerbode 4 juni 1864 , circulaire van Cornelis aan de kiezers d.d. 2 juni 1864 (eerste alinea).

as Maas- en Roerbode 28 mei 1864 (circulaire Van der Maesen) en 4 juni 1864 (circulaire Cornelis).

14 arK $1863-1864,296$ en 632.

125 lbidem, 296.

126 Brief van De Bieberstein aan Thorbecke, 3 november 1865, NA, Archief Thorbecke inv.nr. 80 .

177. Adres van Gs van Limburg aan de Tweede Kamer, 19 februari 1864, minuut, RAL, Archieven provinciaal bestuur, inv.nr. 5080 .

128 нтк 1863-1864, 536-537 (Dullert) en 538 (Thorbecke).

129. De Bieberstein noemde zichzelf graag 'oud-soldaat' of 'oud-strijder' en hij sprak geregeld in militaire termen (zie bijvoorbeeld HTK 1862-1863, 1067 en 1867; HTK 1880-1881, 9).

130 HTK 1863-1864, 535 (De Keverberg) en 537 (De Bieberstein).

131 Venloosch Weekblad 26 maart 1864.

132 HTR 1863-1864, 537.

133 Venloosch Weekblad 26 maart 1864.

134 Van Wintershoven, De heer Hubert Pyls, 9 en 10.

135 De Tijd, 12 juni 1866.

136 L'ami du Limbourg 12 mei 1866.

13) lbidem.

138 Venloosch Weekblad 3 september 1864 , cursivering in origineel.

139 lbidem 10 september 1864.

40 lanssen, Kleine Rheinische Geschichte, 337-340.

44 Van der Hoek e.a., 'Het Venloosch Weekblad en de verkiezingen', 65.

42 Venloosch Weekblad 9 juni 1866.

43 L'ami du Limbourg 12 mei 1866.

14 H. Dorren, 'Pijls, Willem Hubert. Burgemeester van Maastricht', in: Rutten e.a., 'Limburgs Biografisch Repertorium',191. L'ami du Limbourg stelde vast dat Pijls zich 
'toujours' zeker wist van de steun van de geestelijkheid (L'ami du Limbour 12 mei 1866).

145 Venloosch Weekblad 19 mei 1866.

146 Van der Hoek e.a., 'Het Venloosch Weekblad en de verkiezingen', 64-65.

147 HTK 1863-1864, 297; Venloosch Weekblad 5 maart 1864.

148 HTK $1865-1866,376^{4}$.

149 Venloosch Weekblad 6 januari 1866.

150 Ibidem 28 april 1866.

151 Zie bijvoorbeeld Oud en Bosmans, Staatkundige vormgeving 1, 73-85, en Var Raalte, Het Nederlandse parlement, 5-6.

152 De Jong, Van standspolitiek naar partijloyaliteit, 128-129, en De Jong, 'Conseratieven en katholieken', 9.

153 De Jong, Van standspolitiek naar partijloyaliteit, 129.

154 Zijn tegenstanders moesten dat toegeven, aldus het Venloosch Weekblad (2 jui 1866).

155 Zie bijv. Van den Berg, De toegang tot het Binnenhof, 109, en De Jong, 'Conseratieven en katholieken', 7.

156 De Jong, 'Conservatieven en katholieken', 17.

157 Van een aantal kamerleden gaf $\mathrm{De}$ Tijd aan het te betreuren dat zij nietzouden

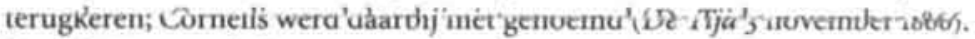

158 Russel, Hoe men de kiezers, 5.

159 Maas- en Roerbode 11 en 18 januari 1868.

160 De Tijd 18 januari 1868.

161 Venloosch Weekblad 4 januari 1868.

162 Der Limburger Courier 17 januari 1868.

163 Venloosch Weekblad n januari 1868.

164 De Tijd 28 januari 1868.

165 Ibidem 18 januari 1868.

166 Geciteerd in Witlox, De staatkundige emancipatie, 398.

167 Zie hoofdstuk 2 voor de verdeling van de beide Boxmeerse zetels tussen Limburgers en Noord-Brabanders.

168 De Tijd 28 januari 1868.

169 De Maasbode 22 juni 1871.

170 De Tijd 8 juni 1871.

171 Circulaire in: Limburger courier 10 juni 1871.

172 De Maasbode 11 juni 1871.

173 Ibidem.

174 Wanneer er bij het innemen van zitplaatsen in de vergaderzaal van de Tweede Kamer precies een scheiding is gekomen tussen links en rechts, is niet bekend. Von Santen concludeert in een onderzoek naar deze kwestie dat de definitieve vorming van een linker- en een rechterzijde tussen 1864 en 1869 tot stand moet zijn gekomen (Von Santen, 'Sinds wanneer zit men links en rechts', 137).

175 HTK $1870-1871,596$, cursivering in origineel.

176 De Tijd 14 juni 1873. 
I7 De Maasbode 1 juni 1875 .

is Venloosch Weekblad 29 mei 1875.

9y Brief van M.S.E.W. Marx aan De Bieberstein, als bijlage gevoegd bij brief van De Bieberstein aan Thorbecke, 10 mei 1871, NA, Archief Thorbecke, inv.nr. 86.

is Zie bijwoorbeeld de brieven van De Bieberstein aan Thorbecke, 7 januari 1863 (nietdoorgaan van de benoeming van Beekman tot militiecommissaris) en 22 juli 1865 (invulling vacature van procureur-generaal in Limburg), NA, Archief Thorbecke, inv.nrs. 75 en 80.

A Russel, Hoe men de kiezers, 7.

is Ramakers, 'De invoering van achterlaadgeweren', no-m.

is Smeets, 'Van der Does de Willebois (1816-1892), commissaris des konings, 18561874, in: Wieland e.a., De gouverneurs, 151 en 160-161. Zie bijvoorbeeld jaarverslagen 1872 en 1873: minuten, RAL, Archieven provinciaal bestuur, inv.nrs. 574 en 575.

4 laarverslag 1874: minuut, RAL, Archieven provinciaal bestuur, inv.nr. 575.

की HTK 1875-1876, 1651.

A6 *TK 1875-1876, 1586-1587, 1638-1639, 1649-1650, 1654, 1655 (De Bieberstein); 1587-1590 (Lambrechts); 1601-1604, 1621, 1637-1638 (Haffmans); 1605, 1651, 1653 (Arnoldts); HEK 1875-1876, 303-306, 309 (Beerenbroek); 307-308 (Michiels van Kessenich).

167 De Tijd 9 en 10 juni 1879; De Maasbode s juni 1879.

is Lavater, Politieke photografien, 23.

159. De Jong, Van standspolitiek naar partijloyaliteit, 84 .

190 Op den Camp, "'Nog Fransch, noch Pruissisch"', 88.

191 HTK 1871-1872, 1264.

192 Russel, Hoe men de kiezers, 7.

193 Verhage, 'Realiteit of retoriek?', 39-40.

194 Lemmens, 'Provincialisme en kieswetgeografie', 31-33.

195 HTK $1866-1867,13-14$.

196 HTK $1866-1867,36$.

197 HTK 1868 8, 107. Eerder, in juni 1866, had Haffmans juist geklaagd dat bij de toen gehouden verkiezingen biljetten met daarop 'L. Haffmans' ongeldig waren verklaard, 'als geen persoon genoegzaam aanduidende' (Venloosch Weekblad 16 juni 1866).

198 Der Limburger Courier 17 januari 1868.

199 HTK $1869-1870,7$.

200 Ibidem. Het betrof hier de verkiezing van Haffmans in het district Boxmeer.

201 Zie Van der Hoek, 'Een Limburgs dialectstuk'.

202 Prins, 'De Limburgsche afgevaardigden'

${ }^{203}$ Van der Hoek, 'Waarom kantonrechter Leopold Haffmans', 160 en 164-165.

204 Zie voor deze kwestie m.n.: ibidem.

205 Venloosch Weekblad io februari 1872.

206 HTK $1871-1872,752$.

207 Ibidem, 764 .

sos Van der Hoek, 'Waarom kantonrechter Leopold Haffmans', 166-169. 
209 Brief van mr. De Bieberstein aan Thorbecke, 8 september 1865, NA, Archief Thor. becke, inv.nr. 80 .

210 Brief van De Bieberstein aan Thorbecke, 31 januari 1862, NA, Archief Thorbecke, inv.nr.73.

211 Michael Wintle, 'Natievorming, onderwijs en godsdienst in Nederland, 1850-1900', in: Te Velde en Verhage, De eenheid en de delen, 19.

212 Geciteerd in Witlox, De staatkundige emancipatie, 355.

213 Zie voor de tekst van deze beide amendementen: HTK 1868-1869, 28 en 31.

214 Oud en Bosmans, Staatkundige vormgeving 1, 57.

215 HTK 1856-1857, 1002.

216 Prins, 'De Limburgsche afgevaardigden' $\mathrm{n}, 76$.

217 Oud en Bosmans, Staatkundige vormgeving 1, 53 en 57.

218 Alberts, Geschiedenis van de beide Limburgen $\mathrm{n}, 205$.

219 L.M. Tagage, 'Onderwijscongregaties en vrijheid van vereniging: een aspect van de schoolstrijd in Limburg, 1857-1859', in: Van Hellenberg Hubar e.a., Maaslands Melange, 302.

220 Ibidem, 297-298.

221 HTK 1856-1857, register, 12-16.

222 Van Vugt, 'De verzuiling van het lager onderwijs in Limburg', 20.

223 Ubachs, Handboek, 359.

224 HTK 1868-1869, 59. Hij zei o.a.: 'Ik voor mij zou gaarne zien dat men verder kon gaan, en sommige bepalingen der wet gewijzigd konden worden, opdat aan de voorstanders van het privaat onderwijs zoo mogelijk voldoening kon worden gegeven.'

225 HTK $1869-1870,665-666$.

226 Ibidem, 626.

227 HTK 1870-1871, 821 en 823 .

228 Ibidem, 820.

229 Zie o.a.: HTK 1868-1869, 535 (Cornelis); HTK 1869-1870, 626 (Pijls) en 665 (Van der Maesen); HTK 1871-1872, 433 (Arnoldts); нTK 1877-1878, 1022e.v. (Lambrechts); Weekblad voor de stad en het kanton Grave 5 juni 1869, abusievelijk gedateerd 1868 (Clerex).

230 HTK $1870-1871,823$

231 Ibidem, 533.

232 Limburger courier to juni 1872.

233 HTK $1870-1871,803$.

234 HTK $1869-1870,652$.

235 HTK 1870-1871, 811, cursivering in origineel.

236 Der Limburger Courier 17 januari en 24 januari 1868. Onder de kop 'Kiezers samenspraak' werd in het eerstgenoemde nummer ter promotie van Brouwers en Wenmaekers een aantal vragen gesteld en beantwoord. Een van deze vragen luidde: 'Hoe denken die heeren over het onderwijs?'

237 De Jong, Van standspolitiek naar partijloyaliteit, 138. 
i De Jong en Verhage, 'Episcopaat en politiek', 59-60; Sniekers, 'De voorgangers van Gijsen; 67.

z De Jong en Verhage, 'Episcopaat en politiek', 66. Dat bisschop Paredis zich eerder, in juli 1865, door middel van een eigen herderlijk schrijven had uitgesproken tegen openbaar onderwijs, lijkt in strijd met zijn (latere) streven de kwestie niet op de worgrond te plaatsen. Die bisschoppelijke brief had echter geen betrekking op het lager onderwijs en ging bovendien over een specifiek geval: de vestiging van een rijk-hbs in Roermond. (Zie: Hans Verhage, 'Rijks of Rooms? Strijd om de Hвs in bet bisdom Roermond', in: Te Velde en Verhage, De eenheid en de delen, 45-55.) Het Venloosch Weekblad beperkte zich in 1865 dan ook tot de korte mededeling dat het mandement van Paredis in de kerken van het bisdom was voorgelezen; verder besteedde het blad geen aandacht aan de bisschoppelijke woorden (Venloosch Weckblad 19 augustus 1865).

40 Zie voor deze kwestie m.n.: Th.J. van Rensch, 'De afbraak van de Wijker Kruittoren', in: Van Bree e.a., 'Van der Nuyersen upwaert', 313-326.

4 laspar, Kint geer, 210.

44 Ubachs, Handboek, 436-437. Zie ook: Alberts, Geschiedenis van de beide Limburgen I1, 263, Van Vugt, 'De verzuiling van het lager onderwijs in Limburg', 20, De Jong en Verhage, 'Episcopaat en politiek', 68, en E. Lamberts e.a., 'De invloed van het katholicisme op het maatschappelijk leven in de beide Limburgen (1839-1989)', in: Schöffer e.a., Eenheid en scheiding, 128.

4) HTK 1868-1869, 536.

24 Venloosch Weekblad 31 mei 1873 . Bedoelde kandidaat was jhr. L. Michiels van Kessenich.

45 Gijsen, Joannes Augustinus Paredis, 267 en 456; Sniekers, 'De voorgangers van Gijsen', 67.

46 Geheim rapport van gouverneur Gericke van Herwijnen aan de koning, 28 februari 1842, in: Rapporten van de gouverneurs $1,346$.

47. T.P.M. Huijs, 'Thr. mr. Edouard de Kuyper (1817-1893), commissaris des konings, 1874-1893,' in: Wieland e.a., De gouverneurs, 219.

48 Zie hiervoor m.n.: De Valk, Roomser dan de paus?

49. Ibidem, 144.

250 Boessen, "'Geest der Provincie", 26-27.

in Habets, 'Cronijkje van het Hertogdom', De Maasgouw 97 (1978), 27-28.

5.2 Ibidem, De Maasgouw 96 (1977), 29.

53 De Valk, Roomser dan de paus?, 135. Verhage, 'Realiteit of retoriek?', 39 en 41 noot

12. De Valk meldt dat de adresbeweging een groot succes was in de bisdommen Roermond en Haarlem.

5t4 Van Essen, Voor Paus en Koning, 33; Bosman, 'Ter eere Gods', 18.

55 Witlox, De staatkundige emancipatie, 389.

266 HEK 1861-1862, 11.

57) De desbetreffende zin in het ontwerp-adres luidde: 'De erkenning van den Koning van Italie zal, hopen wij, blijken in Nederlandsch belang te zijn geschied.' (HTK 
1861-1862, 21.) Thorbecke meende dat deze zin betekende dat het nog geenszins vaststond dat de erkenning in het belang van Nederland zou zijn (ibidem).

258 Ibidem, 24-25, citaat op 24.

259 Voor de uitspraken van Groen van Prinsterer zie: HTK 1862-1863, 147 en voor de reactie daarop van Van der Maesen de Sombreff: ibidem, 148. Als kamerlid zou Van der Maesen in november 1871 - bij de beraadslagingen naar aanleiding van het amendement-Dumbar - zijn vroegere antwoord als minister aan Groen van Prinsterer in herinnering brengen (HTK 1871-1872, 219).

260 HTK 1864-1865, 215.

261 Ibidem, 223 (aankondiging amendement) en 225 (intrekking).

262 Ibidem, resp. 222 en 223.

263 Witlox, De staatkundige emancipatie, 392-393.

264 Zie voor de tekst van de motie: HTK 1870-1871, 216.

265 Zie voor de tekst van de moties van Fransen van de Putte en Cremers: HTK 1870-1871, 227 en 228.

266 Van der Hoek e.a., 'Het Venloosch Weekblad', 75.

267 HTK 1870-1871, 226. "Met den meesten eerbied voor de zienswijze der petitionarissen [...]' kon hij toch niet tegen de motie-Cremers stemmen, aldus Van der Maesen de Sombreff.

$268 \mathrm{Zie}$ de algemene beraadslagingen bij de definitieve vaststelling van de begroting voor 1871 (departement van Buitenlandse Zaken), HTK 1870-1871, 613-666.

269 нтк 1871-1872, 215 (De Bieberstein), 218-219 (Van der Maesen), 234 (Pijls), 248249 (Haffmans; citaat op 248) en 433 (Arnoldts); HEK 1871-1872, 124 (Michiels van Kessenich).

270 Ibidem, 220 (Storm van 's-Gravesande), 224 ('s Jacob), 226 (Van der Does de Willebois), 227 (Van Zinnicq Bergmann); het citaat is van laatstgenoemde. Voor de rede van De Bieberstein: ibidem, 215-216.

271 Ibidem, 253. Katholieken zoals Van den Heuvel en Heydenrijck stemden bijvoorbeeld voor de begroting.

272 HEK 1871-1872, 124 en 130-131. Michiels van Kessenich beriep zich op artikel 168 van de grondwet (uit 1848): 'De traktementen, pensioenen en andere inkomsten van welken aard ook, thans door onderscheidene godsdienstige gezindheden of derzelver leeraars genoten wordende, blijven aan dezelve gezindheden verzekerd. [...]' (Tekst artikel o.a. in: Bannier, Grondwetten van Nederland).

273 Nederlandsche staatscourant 4 en 5 februari 1872 (nr. 30).

274 Maenen, Petrus Regout, 94.

275 нTК 1876-1877, 1167.

276 Ibidem, 1168.

277 Ibidem, resp. 1169 en 1175.

278 Ibidem, 1174.

279 Geciteerd in Wely, Schaepman, 196.

280 Alberts, Geschiedenis van de beide Limburgen I1, 263.

281 Zaal, De vuist van de paus, $70-71$. 
st $8751877-1878,571$.

s) Nederlands Zouavenmuseum, Namenlijst Nederlandse zouaven. Als criterium geldt hier de geboorteplaats.

4 Lecourrier de la Meuse 7 en 8 april 1878.

कf Zaal, De vuist van de paus, 123.

\&5 De Valk, Roomser dan de paus?, 145.

t) $17 \pi \times 1871-1872,215$.

so Witlox, De staatkundige emancipatie, 393.

so lbidem, 397 .

*o In het parlementaire jaar $1870-1871$ zou Kerstens naast zijn interpellatic in de plenaire vergadering slechts éénmaal kort het woord nemen (en wel op 15 mei, HTK 1870-1871. B04).

; 'Aan de Heeren Kiezers in het Hoofd-Kiesdistrict Maastricht', in: Limburger courier 10 juni 1871 .

in $17 \pi$ 1870-1871, 563 .

第 lbidem, 596.

4 L'ami du Limbourg 18 januari 1868 (bijvoegsel).

क $17 x$ 1863-1864, 653. Over de relatie tussen Limburg en de Duitse Bond en over het verbreken van die relatie, zie hoofdstuk 3.

* De Tijd 20 mei 1864 en De Noord-Brabanter geciteerd in De Tijd 25 mei 1864.

*) Maas- en Roerbode 11 juni 1864. De Keverberg excuseerde zich voor zijn uitspraken ook in De Tijd (De Tijd 3 juni 1864).

\$3 Venloosch Weekblad 4 juni 1864.

* Limburger courier 4 juni 1873, cursivering in origineel. Zie ook Limburger courier 7 juni 1873 , onder de kop 'Geen Verkeerdheden'.

30. Prins, 'De Limburgsche afgevaardigden' II, 90.

猜 HTK 1871-1872, 228.

yo Witlox, De staatkundige emancipatie, 413.

犸 Geciteerd in ibidem.

14 Verhage, 'Realiteit of retoriek?', 39; Oud en Bosmans, Staatkundige vormgeving 1, 57. 35 Brief van Thorbecke aan C.T. Stork, 9 november 1860 , in: Thorbecke, Briefwisseling VI, 439.

कo Venloosch Weekblad 2 december 1871.

in HIK 1871-1872, 234.

30 Verhage, 'Realiteit of retoriek?', 39; De Jong en Verhage, 'Episcopaat en politiek', 59 noot 11 ; Gijsen, Joannes Augustimus Paredis, 413.

as Van Raak, In naam van het volmaakte, 165.

30 Ibidem, 166. Na het aantreden van het tweede kabinet-Thorbecke in $1862 \mathrm{ging}$ Heemskerk oppositie voeren, met name tegen de koloniale politiek van de liberalen (ibidem, 170).

\$7 Venloosch Weekblad 13 oktober (tekst proclamatie) en 20 oktober 1866 (openingsartikel met positief commentaar n.a.v. de proclamatie); L'ami du Limbourg 13 oktober 1866. 
312 Van Raak, In naam van het volmaakte, 174.

313 Venloosch Weekblad 20 oktober 1866.

314 HTK $1866-1867$, 186. Haffmans behoorde, zo meldde hij enkele weken later, uitdruk: kelijk niet tot 'de oppositie' (ibidem, 461).

315 Van der Hoek e.a., De Venlose krant, 49.

316 HTK 1866-1867, 537 .

317 Weitzel e.a., Maar majesteit!, 90

318 HTK 1868, 332.

319 Ibidem, 335.

320 Dagblad van Zuidholland en 's Gravenhage 4 en (o.a.) 21 januari 1868.

321 Venloosch Weekblad u januari 1868.

322 De Jong, 'De Algemeene Kiesvereeniging', 245.

323 Dagblad van Zuidholland en 's Gravenhage 6-7 juni 1869.

324 De Jong, 'De Algemeene Kiesvereeniging', 244.

325 Van Raak, In naam van het volmaakte, 182 en 183.

326 Geciteerd in: Van der Hoek, 'Waarom kantonrechter Leopold Haffmans', 167.

327 Venloosch Weekblad 27 oktober 1866.

328 L'ami du Limbourg 18 januari 1868.

329 Venloosch Weekblad 31 maart 1866, cursivering in origineel.

330 Ibidem 22 juli 1871.

331 Janssen, Kleine Rheinische Geschichte, 340; Kellenbenz, 'Wirtschaft- und Sozialentwicklung', 84 .

332 De Wachter 2 (1872), tweede deel, 8-25.

333 Venloosch Weekblad 22 juli 1871. Zie ook: ibidem 27 juli 1871.

334 Ibidem $n$ januari 1868 en 23 september 1871.

335 HTK 1870-1871, 811.

336 Limburger courier 31 mei 1873.

337 HTK 1870-1871, 821.

338 Venloosch Weekblad 30 maart 1872.

339 Ibidem 18 november 1871 , cursivering in origineel. Drie conservatieven stemden voor het amendement.

340 Ibidem 7 januari 1871.

341 De Jong, Van standspolitiek tot partijloyaliteit, 131.

342 G.A.M. Beekelaar, 'Mulken, Joannes Jesephus van (1796-1879)', in: Biografisch Woordenboek van Nederland deel 4, 346-347.

343 Prins, 'De Limburgsche afgevaardigden' $\mathrm{n}, 95$.

344 Le courrier de la Meuse 25 februari 1885.

345 De Tijd 15 juni 1886.

346 L. Geradts behaalde in Roermond 580 van de 1668 stemmen; G. Tripels behaalde in Maastricht 474 van de 1938 stemmen. Waarschijnlijk heeft Tripels geprofiteerd van de verdeeldheid binnen de katholieke kiesvereniging die dat jaar met twee kandidaten kwam (zie verderop). 
I1 Bii de uitslag van de verkiezingen in 1884 vermeldt De Tijd bij de 128 blanco temmen in het district Maastricht: 'waarschijnlijk Lib.' (De Tijd i november 1884). De historicus Geurts schrijft dat bij de verkiezingen in 1893 in het district Roermond 'nist minder dan 92 blanco stemmen [werden] uitgebracht'. Hierbij dient men vigens Geurts te bedenken dat 'de Roermondse liberalen [...] niet zo vlot bereid zullen zijn geweest iemand uit de clerus hun stem te geven, ook al hadden zij geen igen kandidaat naar voren willen brengen'. (De katholieke kandidaat in Roermond was dat jaar de priester W. Everts.) (Geurts, 'Moeilijkheden rond de Kamerzetel wor W. Everts', zp.)

*a Parlement en kiczer.

Limburger courier 2 juni 1875.

Bet databestand van het PDC vermeldt in de biografie van Clercx: 'liberaal tot 1875'. 2 Venloosch Weekblad (terugkijkend) 28 april 1877.

3 De afdeling Boxmeer van kiesvereniging Noord-Brabant had Clercx in haar vergadering van 28 februari 1882 tot kandidaat gekozen.

4 Venloosch Weekblad 4 februari 1882 (abusievelijk gedateerd 4 maart 1882).

5. Zie advertentie in de Limburger courier van 16 juli 1881.

\$ ln een artikel over de verkiezing gaf het Venloosch Weekblad op to juli 1880 uitdrukkelijk aan zich te onthouden 'daaromtrent een advies te geven'.

15. Limburger koerier 27 juni 1892.

19. Limburger courier 24 januari 1880 , cursivering in origineel.

30 Ibidem 31 januari 1880 .

30 Naast de SDAP was in Limburg ook de Sociaal-Democratische Bond (SDB) actief met afdelingen in Maastricht en Roermond. De SDB had echter in 1893 besloten niet meer deel te nemen aan verkiezingen (mede ten gevolge hiervan was de SDAP opgericht). Verder heeft aan de verkiezingen in Maastricht éénmaal, in 1913, een kandidaat van de Sociaal-Democratische Partij (SDP) deelgenomen; hij behaalde $0,8 \%$ van de stemmen.

164 De sociaal-democraten in Maastricht namen alleen aan reguliere verkiezingen deel met kandidaten. Bij de tussentijdse stemmingen van 1900 en 1902 meldde zich geen sociaal-democratische kandidaat. Perry schrijft dat het voor de SDAP in Maastricht te kostbaar was om bij elke verkiezing mee te doen (Perry, Roomsche kinine, 222).

为 De sociaal-democraten behaalden in Limburg in de periode 1897-1917 de volgende percentages van het aantal uitgebrachte stemmen (cijfers uit Parlement en kiezer): district Maastricht: 11,6 (1897), 23,9 (1901), 25,0 (1905), 18,7 (1909), 23,7 (1913); district Gulpen: 3,4 (1905), 1,4 (1909), 10,9 (1909), 2,9 (1913); district Venlo: 4,8 (1909), 6,6 (1913).

* 3 Bij de Tweede-Kamerverkiezingen van 3 juli 1918 waren de Limburgse stemmen voor de SDAP goed voor ongeveer een halve zetel (cijfers uit Parlement en kiezer).

4 Venloosch Weekblad 28 april en 20 oktober 1877.

* Limburger courier 24,27 en 31 januari 1880.

360 Maas-en Roerbode 12 mei 1888.

6\% Brief van J.H. Drehmans, bisschop van Roermond, aan 'de Heeren Leden der beide 
Kiesvereenigingen te Ubachs-over-Worms', 6 juni 1913, in: Limburger koerier n jun 1913.

368 De Limburger. Orgaan ter bevordering van de candidatuur Jean Beckers, nr. 2, sHct. Pamfletten, doos nr. 1 .

369 Maas- en Roerbode 18 oktober 1884.

370 Ibidem 25 oktober 1884 . Van der Heijden kandideerde zich twee jaar later (1886) wederom tegenover de kandidaat van de katholieke kiesvereniging, ditmaal in het district Weert (de districtsindeling was gewijzigd en daarbij was het kiesdistrict Weert ontstaan).

371 Ibidem 15 juni 1889.

372 Ibidem 7 juni 1913.

373 Nieuwe Venlosche Courant 31 juli 1909.

374 Limburgsch Nieuwsblad geciteerd in De Tijd 5 juli 1892. Er deden in de eerste ronde ook nog twee liberale kandidaten mee.

375 Geurts, 'Moeilijkheden rond de Kamerzetel voor W. Everts', z.p.

376 Stassen, Charles Ruys de Beerenbrouck, 33; zie ook: Dorren, De Tweede Kamerverkizing, 16-17.

377 Verslag commissie tot onderzoek van de geloofsbrieven van Ruijs de Beerenbroud (HTK 1909-1910 в 154.1, 1).

378 Adres van Jan Thomas en Emile Caselli d.d. 6 november 1909, drie dagen later voorgelezen in de Tweede Kamer (HTK 1909-1910, 129).

379 Adres van Jan Thomas en Emile Caselli; de inhoud werd in samenvatting bericht aan de Tweede Kamer (ibidem, 16).

380 Zie voor de stemming: HTK 1909-1910, 139. De Stuers was afwezig.

381 Dorren, De Tweede Kamerverkiezing van juni 1909, 34-35.

382 Zo stelt Jos Goltstein bijvoorbeeld dat bij de Tweede-Kamerverkiezingen in Sittard 'niet-principielle factoren' belangrijk waren (Goltstein, 'Het ontstaan van het Limburgs chauvinisme', 4).

383 Maas- en Roerbode 12 mei 1888 (bijvoegsel).

384 Zie de circulaires in bijv. de Maas- en Roerbode van 12 mei 1888.

385 Limburger courier 20 november 1880.

386 Ibidem.

387 L'ami du Limbourg 16 januari 1868.

388 Geurts, 'Een kamerzetel voor W. Everts' en 'Moeilijkheden rond de Kamerzetel voor W. Everts:

389 Dorren, De Tweede Kamerverkiezing, 28.

390 Ook de verkiezingen waarbij een persoon wegens een enkelvoudige kandidaatstelling zonder stemming gekozen werd verklaard zijn meegeteld. De ongeldig verklaarde stemming in Gulpen in 1909 en de daarop gevolgde nieuwe stemming zijn als tèn geteld.

391 Parlement en kiezer.

392 Het betreft de verkiezingen in Gulpen in 1897, 1901, 1909 en 1913 en in Sittard in $1897,1901,1905$ en 1913. Bij de verkiezingen van 1909 werd het zittende katholicke 
kamerlid in zowel Gulpen als Sittard zonder (katholieke) tegenkandidaten herkozen (verklaard).

F) De Trid 5 juli 1892; Limburger courier 20 november 1880 (advertentie ten gunste van de kandidatuur van G. Ruijs van Beerenbroek).

w Perry, Roomsche kinine, 222.

Bs Bornewasser, Katholieke Volkspartij i, 15-16.

कo Bbidem, 23.

7 lbidem, 23 en 27. Dit beeld wordt bevestigd door de politicoloog Van den Berg (Van den Berg. De toegang tot het Binnenhof, 112).

w Geciteerd in Kasteel, Abraham Kuyper, 213.

W Bornewasser, Katholieke Volkspartij 1, 24.

w Bbidem.

a G.A.M. Beekelaar, 'Gustave Ruijs de Beerenbrouck (1842-1926), commissaris der koningin, 1893-1918, en Charles Ruijs de Beerenbrouck (1873-1936), commissaris det koningin, mei-augustus 1918', in: Wieland e.a., De gouverneurs, 277-278.

a T.P.M. Huijs, 'Thr. mr. Edouard de Kuyper (1817-1893), commissaris des konings, in74-1893' in: Wieland e.a., De gouverneurs 225; Maenen, Petrus Regout, 3u e.v.

की $17 \mathrm{TrK} 1873-1874,1341$.

4 Hierbij is vooral gebruik gemaakt van gegevens uit de biografieèn van het databestand van het PDC.

is Zie voor de totstandkoming van deze wet en de rol van Ruijs daarbij m.n.: E.J.J.M. Kimman, 'De arbeidswet van minister Ruys van Beerenbroek', in Brinkel e.a., Het kabinet Mackay, 169-190.

so Tillema, Victor de Stuers, 50-51.

47 Gribling, Willem Hubert Nolens, 42-43.

a Van der Hoek e.a., De Venlose krant, 81.

क) нтк 1886-1887, 616, en нTК 1891-1892, 1243.

$\varpi$ Van der Hoek e.a., De Venlose krant, 49.

AI HTK 1897-1998, 258-261.

a) Venloosche Courant 10 oktober 1896.

is Een kwaad leven, xxvu.

4 Zie bijv. ibidem, 151, 156, 178, 181, 192-193.

5 lbidem, 272.

af tbidem, 207.

E lbidem, 276.

a Stassen, Charles Ruys de Beerenbrouck, 30.

9) lbidem, 195. De gegevens in deze alinea zijn vooral gebaseerd op deze biografie, 30-32.

ॠ Biografisch woordenboek van het socialisme en de arbeidersbeweging in Nederland II, 'Ch.J.M. Ruijs van Beerenbroek', 132.

a Stassen, Charles Ruys de Beerenbrouck, 51-52.

a Ibidem, 37.

के मTK 1888-1889, 842. 
424 HEK 1896-1897, 364 .

425 HEK 1899-1900, 322.

426 Zie voor de inhoud van deze open brief: Een kwaad leven, 292-300.

427 Brief van Petrus Regout aan Provinciale Staten, 19 september 1850, RAL, Archieven provinciaal bestuur, inv.nr. 2805 .

428 Handel en nijverheid: het tarief (1858) en De bezwaren van de Nederlandse industrie tegen het wetsontwerp tot herziening van het tarief van in-, uit-en doorvoer/verzamed door P. Regout (1859).

429 Biografie L.H.W. Regout, databestand PDC.

430 Laatstgenoemde publicatie droeg de titel: Over het wetsontwerp tot wettelijke verz. kering van werklieden tegen de gevolgen van ongevallen in bepaalde bedrijven (1897).

431 HEK 1906-1907, 461.

432 Ibidem.

433 Ibidem, 471.

434 HTK 1893-1894, 799 (stemming over artikel 3) en 990 (stemming over het amendement Meijer)

435 Van Welderen Rengers Schets eener parlementaire geschiedenis 11, 61.

436 G.A.M. Beekelaar, 'Gustave Ruijs de Beerenbrouck (1842-1926), commissaris der koningin, 1893-1918, en Charles Ruijs de Beerenbrouck (1873-1936), commissaris der koningin, mei-augustus 1918', in: Wieland e.a., De gouverneurs, 278.

437 HTK 1895-1896, 1501; zie ook de stemming over artikel 1: 1253.

438 HEK 1895-1896, 508. In de Eerste Kamer stemde één katholieke afgevaardigde voor; zeven stemden tegen.

439 Witlox, Schaepman 1, 53, en $11,159$.

440 Het voorstel om Schaepman toe te laten kon rekenen op de stem van de vijf aanwerige Limburgse kamerleden (Brouwers was afwezig), HTK 1879-1880, 1250-1251.

441 Venloosch Weekblad 18 oktober 1879 . Zie ook: ibidem 31 oktober 1879 en Witlox, Schaepman 1, 155.

442 Gribling, Willem Hubert Nolens, 39.

443 Ibidem, 40.

444 Dat Everts werd afgebeeld als Sinterklaas houdt mede verband met zijn bisschoppelijke waardigheid (zie hoofdstuk 2).

445 Witlox, Schaepman I, 157.

446 G.A.M. Beekelaar, 'Gustave Ruijs de Beerenbrouck (1842-1926), commissaris der koningin, 1893-1918, en Charles Ruijs de Beerenbrouck (1873-1936), commissaris der koningin, mei-augustus 1918', in: Wieland e.a., De gouverneurs, 273.

447 Tillema, Victor de Stuers, 50-51.

448 Ibidem, 50.

449 HTK 1904-1905, 223.

450 Ibidem, 241.

451 HTK 1909-1910, 1568. Zie ook Tillema, Victor de Stuers, 211-212.

452 Maas- en Roerbode 4 juni 1881.

453 De Beaufort, Dagboeken en aantekeningen I, 18. 
44 Geciteerd in: Witlox, Schaepman II, 132.

\$5 Geciteerd in: ibidem, 186.

6 Limburger courier 16 april 1881.

G De Maasbode 9 juni 1881.

\& Vemloosch Weekblad 28 mei 1881 .

a Registers over de jaren 1890-1891 t/m 1899-1900 en over 1900-1901 t/m 1909-1910.

6) IIT 1900-1901, 801.

a Vin den Berg. De toegang tot het Binnenhof, 112 .

a Secker, Ministers in beeld, 136. Tot de westelijke provincies worden hier Utrecht, Noord- en Zuid-Holland gerekend. In 1888 kwam met katholieke deelname het erste christelijke coalitiekabinet tot stand onder leiding van Ae. Mackay.

is 'Lijtie met kandidaat-ministers uit het formatie-dossier van Kuyper', in: De Bruijn, Abuham Kuyper, 236.

A4 Afeelding in: Oud en Bosmans, Staatkundige vormgeving 1, 226.

Bs Sassen, Charles Ruys de Beerenbrouck, 195.

\& Fassur, Wilhelmina 1, 541.

* De Nedermaas januari 1925, jrg.3 nr. 6, 62 .

\section{Hoofdstuk 5}

I Diezelfde dag leverde ook jhr. A.H.Th. Michiels van Verduynen een bijdrage aan het debat. Overigens had het derde Limburgse Tweede-Kamerlid, jhr. P.A.S. Kerens, de dag ervoor al wel gesproken als lid van de commissie voor de verzoekschriften. In die hoedanigheid had hij verslag uitgebracht over twee aan de Kamer gerichte adressen.

1. HTK 1840-1841, 118.

3 lbidem.

4 Prins, 'De Limburgsche afgevaardigden' 11,83 .

3 Biografie P.L. de Lom de Berg, databestand PDC. Prins spreekt van een voortdurende oppositie door De Lom de Berg tegen het belastingstelsel (Prins, 'De Limburgsche afgevaardigden' 1,351 ).

6 Bos, Notabele ingezetenen, 161.

7 HTK 1840-1841, 120.

Ibidem, 252.

9 lbidem, 118 en 120 . Het citaat is afkomstig van Corneli (118).

10 Resp. J.L.A. Luyben (ibidem, 119) en E.W. van Dam van Isselt (ibidem 120).

In Bos, Notabele ingezetenen, 159-160.

12 HEK 1850-1851, 52.

3 Wel werd de hoofdsom, 248906,85 gulden, evenals elders onderhevig gemaakt an een vermeerdering of vermindering al naar gelang de toe- of afname van de (totale) hoeveelheid geschatte belastbare opbrengst. Daarnaast splitste het ontwerp de hoofdsom in een deel voor bebouwde en een deel voor onbebouwde grond, zoals terder al (1843) voor de overige provincies was gebeurd. 
14 HTK 1850-1851, $105-106$.

15 HEK 1850-1851, 51.

16 Voorlopig verslag, HTK 1858-1859 B, 508.

17 HTK 1858-1859 в, 509.

18 HTK 1856-1857, 500.

19 HEX 1856-1857, 107.

20 Memorie van toelichting, HTK 1862-1863 B, 449-452.

21 Bos, Notabele ingezetenen, 160.

22 HTK 1864-1865, 296.

23 Voorlopig verslag, HTK 1863-1864 B, 506-510.

24 HTK 1863-1864, resp. 296 (De Bieberstein), 297 (De Lom de Berg) en 296 (Cornelis),

25 HTK 1865-1866, 310.

26 Ibidem, 314.

27 Ibidem, 311.

28 Voor een overzicht van de aangevoerde argumenten, zie Bos, Notabele ingezetenen, $165-166$.

29 HTK $1865-1866,390^{3}$.

30 HEK 1865-1866, 98.

31 De drie Limburgse leden stemden voor de eerste twee hoofdstukken van de begroting ('Huis van de Koning' en 'Hoge Colleges van Staat') en voor de hoofdstukken voor de Rooms-Katholieke en de Hervormde Eredienst; Beerenbroek en Michiels van Kessenich stemden daarnaast nog voor de hoofdstukken 'Nationale schuld' en 'Onvoorzien'.

32 Bos, Notabele ingezetenen, 157.

33 Voorlopig verslag, HTK 1858-1859 B, 506.

34 W.H. Idzerda (district Leeuwarden) in de Tweede Kamer (HTK 1859-1860, 588') en jhr. T.A.M.A. van Andringa de Kempenaer in de Eerste Kamer (HEK 1859-1860, 101).

35 HEK 1860-1861, 118.

36 HEX 1865-1866, 135, cursivering in origineel.

37 HTK 1865-1866, 310.

38 HTK 1851-1852, 525 .

39 Bos, Notabele ingezetenen, 165.

40 Ibidem, 167.

41 Ibidem, 166-16\%.

42 Ontwerp-adres van Provinciale Staten van Limburg aan de koning, in: Rapporten van de gouverneurs $\mathrm{n}, \mathbf{1 1 4}_{4}$. De geciteerde tekst maakt deel uit van een toelichting op het adres, ontworpen door De Villers de Pité. Hij probeerde tevergeefs zijn collega-leden over te halen zich met dit adres tot de koning te wenden.

43 Bok, De belastingen, 36. Regelmatig werden bezitters van effecten 'couponknippers' genoemd - soms is dit minachtend bedoeld. Een obligatie bevatte o.a. coupons: bewijsjes die recht gaven op betaling van een periodieke - meestal halfjaarlijkserente. Deze rente werd uitbetaald na inlevering van een (afgeknipte) coupon.

44 Ibidem. 
5 Bos, Notabele ingezetenen, 123. Zie ook Bos, 'Vermogensbezitters', m.n. 560 en 570. is $45 \times 1849-1850,56^{14}$.

g. HTK $1840-1841,120$.

Bos, Notabele ingezetenen, 125.

B itK 1864-1865, $1210^{8}$ resp. 12101.

\$ Kuyper, Mijne carrière, 14 - Kuyper werd daarna overigens overgeplaatst: 'Avis au lecteur, voor jonge ambtenaren die Kamerleden lastig vallen,' zo schrijft hij (ibidem). \$. Weber, Peasants into Frenchmen, 104 en 106.

1) :TTK 1880-1881, 1020, cursivering in origineel.

is Bos, Notabele ingezetenen, 125.

4) iTrK 1851-1852, 878 .

छ

को irx 1871-1872: Arnoldts, 1156; De Bieberstein, 1121; Van der Maesen de Sombreff. 1088-1089; Pijls, 1089. Haffmans noemde deze reden niet; hij wilde, als de zoveelste spreker tijdens het debat, niet in herhaling vallen, zo meldde hij de Kamer (1149). Van den Heuvel (district Boxmeer) sprak niet.

g lbidem, 1121.

$\$$ lbidem, 1200.

\$ flbidem, 1120 .

io Van Welderen Rengers, Schets eener parlementaire geschiedenis I, 606.

it De Maasbode 31 maart 1881, naschrift van de redactie bij een brief van een Limburgse correspondent.

62 HTK 1880-1881 в 11, 23.

is 'Het Limburgsche Amendement' is de kop van een artikel in De Tijd van 29 maart 1881 ; 'amend. v.d. Limburgers' komt voor in een prent in De Nederlandsche spectator van 26 maart 1881.

4 De Tijd 29 maart 1881.

is Le courrier de la Meuse 27-28 maart 1881.

to Venloosch Weekblad 26 maart 1881.

67 HTK 1880-1881, 985 .

s Ibidem, 1059.

6 De Maasbode 31 maart 1881.

70 HTK 1880-1881, 1008.

i De Tijd 29 maart 1881.

72 Limburger courier 16 april 1881.

73 Troonrede van 15 september 1891, De Derde Dinsdag.

74 HTK 1891-1892, 1217.

§ Overigens had de minister toegezegd spoedig een voorstel tot verlaging van de grondbelasting te zullen indienen. De vraag was echter of een kamermeerderheid zo'n voorstel zou steunen, stelde onder anderen Ruijs van Beerenbroek (HTK 1891$1892,1362)$.

\% HTK 1891-1892, 1120-1122; HEK 1892-1893, 34 resp. 42; De Tijd 21 juni 1892 en Venloosch Weekblad 25 juni en 2 juli 1892. 
77 Philips e.a., Geschiedenis van de landbouw in Limburg, 158-159 en 246-249, m.n. tabellen xxII, xxxIv en xxxv.

78 Venloosch Weekblad 25 juni 1892.

79 HTK 1891-1892, 1243; G.A.M. Beekelaar, 'Gustave Ruijs de Beerenbrouck (1842-1926), commissaris der koningin, 1893-1918, en Charles Ruijs de Beerenbrouck (1873-1936), commissaris der koningin, mei-augustus 1918', in: Wieland e.a., De gouverneurs, 277.

80 HTK 1880-1881, 986, cursivering in origineel.

81 Adres van antwoord van de Tweede Kamer op de Troonrede, HTK 1849, 159.

82 Prins, 'De Limburgsche afgevaardigden' I en It.

83 Niet meegeteld zijn aanvullende wetten op de middelen.

84 HTK $1883-1884,817$.

85 Alle aanwezige kamerleden uit Limburg stemden tegen de middelenwetten voor $1844 / 1845,1846 / 1847,1848 / 1849,1853,1854$ en 1855 . Bij de stemmingen na 1848 is gekeken naar de afgevaardigden uit de districten Maastricht, Roermond en Boxmeer. Bij de middelenwet voor 1842/1843 stemden de leden uit Groningen - vier in getal unaniem tegen. Drenthe kan, wat betreft de jaren veertig, niet worden betrokken in deze vergelijking, omdat deze provincie toen slechts éen afgevaardigde had.

86 Prins, 'De Limburgsche afgevaardigden' $n, 74$. Het betreft hier de middelenwet voor 1856.

87 HTK 1844-1845, 145 (Strens), 148-149 (Corneli) en 149 (Michiels van Verduynen).

88 Ibidem, 149.

89 Ibidem, 152.

90 Bos, Notabele ingezetenen, 124.

91 Memorie van toelichting op een ontwerp-adres aan de koning en aan de StatenGeneraal, notulen van Provinciale Staten van Limburg, najaarsvergadering 1850, RAL, Archieven provinciaal bestuur, inv.nr. 2806.

92 G.A.M. Beekelaar, 'Gustave Ruijs de Beerenbrouck (1842-1926), commissaris der koningin, 1893-1918, en Charles Ruijs de Beerenbrouck (1873-1936), commissaris der koningin, mei-augustus 1918', in: Wieland e.a., De gouverneurs, 278.

93 Aerts en Te Velde, 'De taal van het nationaal besef', 402.

94 De beide afgevaardigden uit het district Gouda en een afgevaardigde uit het district Dordrecht. Smit spreekt in haar proefschrift van 'een opvallende verdeling in stemgedrag', waarbij die verdeling geografisch wordt geduid: kamerleden uit Holland (Noord- en Zuid-), Utrecht en Zeeland stemden overwegend tegen het wetsontwerp; het Noorden en het Zuiden spraken zich nagenoeg unaniem voor een renteheffing uit (Smit, Omwille der billijkheid, 83).

95 HTK 1864-1865, 1177. P.J.J. Hollingerus Pijpers (district Breda) noemde weliswaar de naam van zijn provincie, maar hij had het daarbij over 's-Hertogenbosch (hii) gebruikte de aanduiding 'de hoofdstad van Noord-Brabant') (HTK 1864-1865, 1181).

96 Ibidem, 1213.

97 Ibidem, $1210^{7}$.

98 lbidem, 1180.

99 Zie de stemming over het amendement van J. Bieruma Oosting, HTK 1857-1858, 354 
so HTK 1864-1865, 1182'.

a Zo had De Lom de Berg het al herhaaldelijk doen voorkomen, aldus minister Betz (ibidem, 12108).

is lbidem, 1214, cursivering en 'bestaan' in origineel.

Ibidem, 1206.

44 lbidem, 1217 .

5 lbidem, $1210^{\prime}$.

of lbidem, resp. $1210^{7}$ en $1210^{\circ}$.

if HTX $1843-1844,284$.

is lbidem, 255.

ng Ibidem, 366.

so Ibidem, 367.

an Devergaderingen van de Eerste Kamer waren (tot 1848) niet openbaar en de verslagen van de vergaderingen die later werden opgenomen in de Handelingen, zijn uiterst summier. In dit geval is slechts aangegeven hoeveel kamerleden en welke ministers hebben deelgenomen aan de beraadslagingen; de inhoud van de toespraken is niet vermeld. Mede gelet op het debat in de Tweede Kamer ligt het voor de hand aan te nemen dat de positie van Limburg ook hier de reden was voor de minister van Buitenlandse Zaken om de Kamer toe te spreken.

III De Liedel de Well en drie andere tegenstanders 'deden hunne afkeuring van het gevallen besluit aanteekenen', zo vermeldt het beperkte verslag van de vergadering (HEK, opgenomen bij HTK 1843-1844, 472). Het voorstel werd aangenomen met twaalf tegen zes stemmen.

u3 Van Beusekom-Chuddy, Limburg en de lening, 33.

14 Geciteerd in ibidem, 28. Michiels van Verduynen ontving dit biljet in zijn hoedanigheid van districtscommissaris van Roermond.

us In totaal kwamen er dat jaar 184 adressen binnen bij Eerste en Tweede Kamer met de belastingen en/of accijnzen als onderwerp. Ruim een vijfde was dus afkomstig uit Limburg.

16 HTK $1851-1852,144$.

117) Beraadslaging over de middelenwet voor 1852 , ibidem, 520 .

118 Zie voor 1848: HTK 1847-1848, 930; voor 1849: HEK 1849, 19 en HEK 1849-1850, $56^{14}$; voor 1850: HTK 1850-1851, 202; voor 1851: HTK 1851-1852, 520 en 522; voor 1852: HTK 1851-1852, 878; voor 1853: HTK 1853-1854, 428 en 476; voor 1854: HTK 1854-1855, 57 ; voor 1855: HTK $1854-1855,846^{1}$. Het citaat is van Tweede-Kamerlid De Lom de Berg (HTK 1851-1852, 522).

Dig Drenthe, dat slechts één kamerlid had, is hier buiten beschouwing gelaten.

1:0 Van Welderen Rengers, Schets eener parlementaire geschiedenis I, 311.

ial Het gaat om de wetsvoorstellen die ná de invoering van de Nederlandse belastingwetgeving aan de orde waren; het wetsontwerp tot invoering der rijksbelastingen in het hertogdom Limburg blijft daarom buiten beschouwing. De vele wetsontwerpen op de middelen zijn eerder al aan de orde geweest.

[2] HTK 1871-1872, 1120 . 
123 HTK 1880-1881, 985. Nijst deed deze uitspraak voorafgaand aan de beraadslagingen over de wet, tijdens het debat over het voorstel de behandeling van de wet uit te stellen.

124 Ibidem, 1008 en $1058-1059$.

125 Van Wintershoven, Open brief, 5.

126 HTK 1863-1864 B, 1865.

127 HTK 1908-1909, 1379.

128 De Beaufort, Dagboeken en aantekeningen 1, 459.

129 Behalve De Beaufort maakte ook de sociaal-democratische afgevaardigde J.H.A. Schaper gewag van deze politieke overwegingen (HTK 1908-1909, 1638).

130 Brief van Thorbecke aan W.H. Pijls, 2 februari 1864, in: Bos, Notabele ingezetenen, 167.

131 Bos sluit hierbij aan door te concluderen dat de zaak van de Limburgse belastingbetalers in de jaren zestig waarschijnlijk juist werd geschaad doordat van het onderwerp een politiek item werd gemaakt (ibidem, 167).

132 Boogman, Nederland en de Duitse Bond, 200-202.

133 Rapport van gouverneur Gericke van Herwijnen aan de minister van Binnenlandse Zaken, 15 januari 1842, NA, Min. Binnenlandse Zaken Kabinet, inv.nt.46, dossiernr. 1355 .

134 Zo herinnerde het Maastrichtse Tweede-Kamerlid De Bieberstein zich een aantal jaren later ( $H$ TK 1863-1864, 296).

135 Grondwet 1840 artikel 149; grondwet 1848 artikel 134; grondwet 1887 artikel 138; grondwet 1917 artikel 138 . Het citaat is genomen uit de grondwet van 1840.

136 Talsma, Het recht van petitie, 44.

137 Van Beusekom-Chudy, Limburg en de lening, 15-17, en A.F.J. van Kempen, 'J.E.P.E. Gericke (1785-1845), gouverneur van Limburg, 1841-1845', in: Wieland e.a., De gouverneurs, 100-101.

138 Talsma, Het recht van petitie, 44.

139 Notulen van Provinciale Staten van Limburg, najaarsvergadering 1850, RAL, Archieven provinciaal bestuur, inv.nr. 2806. Notulen van Provinciale Staten van Limburg, zomervergadering 1856, in: Provinciaal blad voor het Hertogdom Limburg $1856 \mathrm{nr} .81$, 82.

140 In de overzichten van ingekomen en behandelde verzoekschriften is behalve nar trefwoorden als Accijnzen, Belastingen, Belastingstelsel en de namen van de divers afzonderlijke belastingwetten ook gekeken naar In-, Uit- en Doorvoerrechten, die soms afzonderlijk, soms onder Belastingen zijn gerubriceerd. Het betreft de volgende elf Limburgse verzoekschriften (de jaartallen verwijzen naar de parlementaire jaren). In 1843-1844: Gs aan de Tweede Kamer inzake het belastingplan van Van Hall. In 18511852: Gs aan de Eerste Kamer inzake de accijnzen op het gemaal, het geslacht en de brandstoffen; datzelfde jaar: Ps aan de Tweede Kamer inzake hetzelfde onderwerp. In 1862-1863: GS aan de Tweede Kamer inzake de grondbelasting in Limburg In 1863-1864: Gs aan de Tweede Kamer inzake de bieraccijns; datzelfde jaar: ps twee maal aan de Tweede Kamer inzake de grondbelasting in Limburg. In 1865-1866: G5 
an zowel de Tweede als de Eerste Kamer inzake de grondbelasting in Limburg. In 1879-1880; Gs aan de Tweede Kamer inzake de zoutaccijns. In 1893-1894: os aan de Tweede Kamer inzake de invoerrechten op graan. Voor de duidelijkheid zij hier opgemerkt dat petities aan de koning niet zijn meegerekend.

4f HTK 1844-1845, 148-149.

if Brief van De Bieberstein aan Thorbecke, 3 november 1865; NA, Archief Thorbecke, inv.nu. 80.

40 A.F.J. van Kempen, 'J.E.P.E. Gericke (1785-1845), gouverneur van Limburg, 18411845, in: Wieland e.a., De gouverneurs, 101.

w Ibidem.

45 aTK 1843-1844, 134-135 (verslag van de commissie voor de verzoekschriften).

if Notulen van Provinciale Staten van Limburg, zomervergadering 1849, RAL, Archieven provinciaal bestuur, inv.nr. 2804 .

we lbidem.

4 HEx 1849-1850,56 ${ }^{14}$. Beerenbroek sprak bij de beraadslagingen over de middelenwet voor 1850 .

49 HEK 1849, 19.

30 Notulen van Provinciale Staten van Limburg, zomervergadering 1849, RAL, Archieven provinciaal bestuur, inv.nr. 2804 .

151 HEK $1849-1850,56^{14}$.

52 Notulen Provinciale Staten van Limburg, 5 oktober 1850, RAL, Archieven provinciaal bestuur, inv.nr. 2806 .

153 HTK 1850-1851, 202.

154 Notulen Provinciale Staten van Limburg, najaarsvergadering 1851, in: Provinciaal blad voor het Hertogdom Limburg 1851 nr. 179, 82-83.

155 In de Tweede Kamer (HTK 1851-1852): Van Wylick, 144; Borret, 520-521; De Lom de Berg, 521-522 en in de Eerste Kamer (HEK 1851-1852): Beerenbroek, 77.

156 HTK 1851-1852, 521.

157 Het betrof het wetsontwerp tot goedkeuring van de overeenkomst tussen Nederland en Pruisen. In de Tweede Kamer had alleen De Limpens tegen gestemd; Van Wylick en Borret steunden het ontwerp (De Lom de Berg was afwezig). Ook in de Eerste Kamer stemden de Limburgers verdeeld: Beerenbroek was tegen, P. Regout en Villers de Pité stemden voor.

158 Notulen Provinciale Staten van Limburg, najaarsvergadering 1856, in: Provinciaal blad voor het Hertogdom Limburg $1856 \mathrm{nr} .142,29-30$.

159 Notulen Provinciale Staten van Limburg, zomervergadering 1857, in: Provinciaal blad van het Hertogdom Limburg $1857 \mathrm{nr} .85,85$.

\section{Slot}

1 Troonredes van 19 oktober 1840 en 16 september 1919, De Derde Dinsdag.

2 HEK 1849-1850, 5617.

3 HTK $1863-1864,537$. 
4 lbidem, 538.

5 HEK 1849-1850, 5614.

6 HTK 1900-1901, 801. Er was volgens Nolens overigens op dit punt wel sprake van eer verbetering.

\section{Bijlagen}

1 Nederlandsche staatscourant 28 augustus $1815, \mathrm{nr} .203,2-3$.

2 Smeets, 'De Notabelenvergaderingen', 48 en 53.

3 Boogman, Nederland en de Duitse Bond, 349-356; Dorren, 'Het Hertogdom Lim. burg', 151-163; Grochtmann, Die Niederländische Provinz Limburg, 52-58.

4 Voor de correspondentie terzake tussen Gs, gemeenten en de minister zie: RAL, Archieven provinciaal bestuur, inv.nr. 5080 .

5 E.P.M. Ramakers, 'Maximilien de Beeckman (1781-1834), gouverneur van Limburg, 1828-1830/1', en A.F.J. van Kempen, 'J.E.P.E. Gericke (1785-1845), buitengewoon commissaris, 1831-1839 en P.A.S. Kerens (1781-1862), waarnemend gouverneur, 18311839', in: Wieland e.a., De gouverneurs, 43-44, 51 en 54-55; Nuyens, Inventaris der archieven, 10.

6 Dingemans, 'De invoering en afkondiging', 483-484; Boogman, Nederland en de Duitse Bond, 349-350.

7 Dingemans, 'De invoering en afkondiging', 487.

8 Alberts, Geschiedenis van de beide Limburgen, 163-164; Ubachs, Handboek, 291.

9 Munier, 'De reorganisatie van het kerkelijk bestuur', 135-136 en 150.

10 Vanaf 1882 wordt gesproken van een titulair bisschop.

11 Kemp, Limburg 1839-1839, 14.

12 Zie bijv. Carel Bloemen, 'Nolens, de eenzame', De Limburgse leeuw 8 (1960), 141.

13 Gemeentearchief Maastricht, Bevolkingsregister Maastricht 1880-189o nr.972, 156; ibidem 1890-1920 nr.1306, 82-84; ibidem Burgerlijke Stand Maastricht nr. 627, 125 (1888) en 148 (1992); Biografie jhr. G.A.A. Alting von Geusau, databestand PDC.

14 Limburger Koerier resp. 21, 10 en 25 september 1918.

15 Internetsite van het Ministerie van Algemene Zaken. 


\title{
Geraadpleegde bronnen
}

\author{
Archieven
}

Nationaal archief (NA), 's-Gravenhage

Afdelingsarchieven van het Ministerie van Buitenlandse Zaken 1813-1870 (nummer toegang: 2.05.01)

Archief mr. Johan Rudolph Thorbecke en enige van zijn verwanten (nummer toegang: 2.21.161)

Anchief van de Tweede Kamer der Staten-Generaal 1815-1945 (nummer toegang: 202.22)

Archief van het Kabinet des Konings 1841-1897 (nummer toegang: 2.02.04)

Archieven van de Algemene Staatssecretarie en van het Kabinet des Konings met de daarbij gedeponeerde archieven over 1813-1840 (nummer toegang: 2.02.01)

Archieven van de Staten-Generaal 1814-1815 en van de Eerste Kamer der StatenGeneraal 1815-1945 (nummer toegang: 2.02.13)

Geheim archief van het Ministerie van Binnenlandse Zaken 1814-1850 (nummer toegang: $2.04 \cdot 26.01$ )

Kabinetsarchief van het Ministerie van Binnenlandse Zaken 1817-1949 (nummer toegang: 2.04.26.02)

\section{Gemeentearchief Heel, Heel}

Bevolkingsregister Heel en Panheel

Burgerlijke stand Heel en Panheel

Gemeentearchief Maastricht, Maastricht

Bevolkingsregister Maastricht

Burgerlijke stand Maastricht

Gemeentebestuur Maastricht 1814-20e eeuw, deel 1

\section{Gemeentearchief Meerssen, Meerssen}

Bevolkingsregister Meerssen

Gemeentearchief Roermond, Roermond

Bevolkingsregister Roermond

Gemeentearchief Venlo, Venlo

Collectie Kaarten \& Prenten

Stedelijk archief van Venlo 1814-1850 (nummer archief: 22) 
Gemeentearchief Venray, Venray

Archief gemeentebestuur 1815-1941

Katholiek Documentatiecentrum (KDC), Nijmegen

Archief P.A.M. Geurts

Archief van de RK Staatspartij

Archief W.H. Nolens

Nederlands Spoorwegmuseum, Utrecht

Informatie over aankomst- en vertrektijden van treinen

Nederlands Zouavenmuseum, Oudenbosch

Namenlijst Nederlandse zouaven

Parlementair Documentatiecentrum (PDC), Universiteit Leiden

Biografisch Archief 1813-heden

Rijksarchief in Limburg (RAL), Maastricht

Archieven van het provinciaal bestuur van Limburg 1814-1913 (nummer toegang: 04.01)

Rijksarchief in Noord-Brabant (RANB), 's-Hertogenbosch

Archieven van het provinciaal bestuur van Noord-Brabant 1814-1920 (nummer toegang: 17)

Sociaal Historisch Centrum voor Limburg (sHCL), Maastricht

Krantenknipsels betreffende het politieke, sociale, economische en culturele leven in Limburg (DOC 0041 en Doc 0059)

Pamfletten (Doc 0018)

Stadsarchief Sittard-Geleen, Born

Archief Sittard 1794-1930

Bevolkingsregister Sittard

Streekarchief Brabant-Noordoost, rayon Land van Cuijk, Grave

Gemeentebestuur Boxmeer, 1811-1936 


\section{Periodieken}

Administratief memoriaal voor het Hertogdom Limburg (in 1851 voortgezet als Provinciaal blad voor het Hertogdom Limburg)

lami des intérets Limbourgeots (in 1866 voortgezet als L'ami du Limbourg)

l'ami du Limbourg (in 1866 voortzetting van L'ami des intéréts Limbourgeois)

DeAmsterdammer

Baxmeersch Weekblad Maasbode (in 1869 voortzetting van De Maasbode. Boxmeersch week- en advertentie-blad)

Le courrier de la Meuse (nam in 1854 het Journal du Limbourg over)

Dagblad de Limburger

Gemeenteblad van Maastricht

Gemeenteblad van Venlo

De Gids

De Godsdienstvriend

Journal du Limbourg (in 1854 overgenomen door Le courrier de la Meuse)

Het Kanton Weert

De katholieke illustratie

Limburg

Der Limburger Courier (in 1868 voortgezet als Limburger courier)

Limburger courier (voortzetting in 1868 van Der Limburger Courier, in 1886 voortgezet als de Limburger Koerier)

Limburger Koerier (voortzetting in $\mathbf{1 8 8 6}$ van de Limburger courier)

De Limburgse leeuw

De Maasbode

De Maasbode. Boxmeersch week- en advertentie-blad (in 1869 voortgezet als Boxmeersch Weekblad Maasbode)

Maas- en Roerbode (in 1904 opgegaan in De nieuwe koerier)

Nederlandsch adelsboek (vanaf 1904 o.d.t. Nederland's adelsboek)

Nederlandsche gedachten

De Nederlandsche spectator

Nederlandsche staatscourant

Nederland's patriciaat

De Nedermaas

De nieuwe koerier (in 1904 is hierin de Maas- en Roerbode opgegaan)

Nieuwe Venlosche Courant (samenvoeging in 1908 van het Venloosch Nieuwsblad en de Venloosche Courant)

De Noord-Brabanter

Parlement en kiezer: jaarboekje

Peelen Maas

Provinciaal blad voor het Hertogdom Limburg (ook o.d.t. Provinciaal blad van het Hertogdom Limburg, in 1851 voortzetting van Administratief memoriaal voor het Hertogdom Limburg, in 1863 voortgezet als Provinciaal blad van Limburg) 
Provinciaal blad van Limburg (in 1863 voortzetting van Provinciaal blad voor het Hertogdom Limburg)

Staatsblad van het Koningrijk der Nederlanden (later o.d.t. Staatsblad van het ko. ninkrijk der Nederlanden)

De Tijd

Uilenspiegel

Venloosch Weekblad (in 1898 voortgezet als Venloosch Nieuwsblad)

Venloosche Courant (in 1908 met het Venloosch Nieuwsblad samengevoegd tot de Nieuwe Venlosche Courant)

Venloosch Nieuwsblad (voortzetting in 1898 van het Venloosch Weekblad)

De Volksvriend

De Wachter

Weekblad van Heerlen

Weekblad voor de stad en het kanton Grave

\section{Literatuur en uitgegeven bronnen}

Abeling, J., Teloorgang en wederopstanding van de Nederlandse monarchie (1848-1898) (Amsterdam 1996)

Aerts, Remieg, e.a., Land van kleine gebaren: een politieke geschiedenis van Nederland 1780-1990 (Nijmegen 1999)

Aerts, R., en H. te Velde, 'De taal van het nationaal besef', in: N.C.F. van Sas (red.), Vaderland: een geschiedenis van de vijftiende eeuw tot 1940 (Amsterdam 1999), 391-454

Akkermans, P.W.C., en A.K. Koekoek (red.), De Grondwet: een artikelgewijs commentaar (Zwolle 1992 (2e druk))

Albers, P., 'Victor de Stuers (1843-1916) Kamerlid', Studiën. Tijdschrift voor godsdienst. wetenschap en letteren 52 II (1920), 337-358

Alberts, W.J., Geschiedenis van de beide Limburgen, In (Maaslandse monografieên 17) (Assen 1974)

Ament, H.G.M., Van Belg tot Hollander (onuitgegeven doctoraalscriptie Katholieke Universiteit Nijmegen, Nijmegen 1983)

Arnold, Paul, Jac van den Boogaard en Willibrord Rutten, Limburg 1900-2000. Historisch vademecum (Maastricht 1999)

'Assemblée Générale de la Société. Séance du 3 janvier 1864. Extrait du procès-verbal', Publications de la Société Historique et Archéologique dans le Duché de Limbourg 1 (1864), 3-20

Bank, J., en M. van Buuren, 1900: hoogtij van burgerlijke cultuur (Den Haag 2000)

Bannier, G.W., Grondwetten van Nederland; teksten der achtereenvolgende staatsregelingen en grondwetten sedert 1795 , met verschillende andere staatsstulkkn. historische toelichtingen en eenige tabellen (Zwolle 1936)

Banning, J.P.D. van, 'Belgium and Dutch Limburg, 1830-1839', in: F.M. van Asbeck e.a. (red.), Symbolae Verzijl. Présentétes au professeur J.H.W. Verzijl a I'occasion de 
son LXX-ième anniversaire (Den Haag 1958)

Banning, J.P.D. van, 'Honderd jaar "gewone" provincie', De Maasgouw 86 (1967), 129-136

Bcaufort, W.H. de, Dagboeken en aantekeningen van Willem Hendrik de Beaufort $1874-1918$, uitgegeven door J.P. Valk en M. van Faasen ( 2 delen) ('s-Gravenhage 1993)

Beckelaar, G.A.M., Rondom grondwetsherziening en herstel der hierarchie. De Hollandse katholieke jongeren 1847-1852 (Hilversum-Antwerpen 1964)

Beekelaar, G.A.M. e.a. (red.), Vaderlands Verleden in Veelvoud. Opstellen over de Nederlandse geschiedenis na 1500, deel 2: '19e - 20e eeuw' (Den Haag 1980 [2e druk])

Bekman, Bern. J.M., 'Spoor en mijn. Een halve eeuw voortreffelijke samenwerking', Niesw Spoor 3 nr. 5 (1949), 14-15 en 27

Berg. J.Th.J. van den, De toegang tot het Binnenhof. De maatschappelijke herkomst van de Tweede Kamerleden tussen 1849 en 1970 (Weesp 1983)

Bescheiden betreffende de buitenlandse politiek van Nederland 1848-1919, eerste periode 1848-1870, eerste deel 1848, uitgegeven door C.B. Wels (Rijks Geschiedkundige Publicatièn Grote Serie 139) ('s-Gravenhage 1972)

Best, Heinrich en Wilhelm Weege, Biographisches Handbuch der Abgeordneten der Frankfurter Nationalversammlung 1848/49 (Düsseldorf 1996)

Beumers, R., Limburgs separatisme in de jaren 1840-1848 en het gedrag van Limburgse afgevaardigden in de ze Kamer in deze voor Limburg woelige periode (onuitgegeven werkstuk, Oirsbeek 1982)

Beus, J.W. de, e.a., De ideologische driehoek. Nederlandse politiek in historisch perspectief (Meppel 1989)

Beusekom-Chudy, M.C.W. van, Limburg en de lening van 127 miljoen (onuitgegeven doctoraalscriptie, Kerkrade 1982)

Biografisch woordenboek van het socialisme en de arbeidersbeweging in Nederland Biografisch Woordenboek van Nederland

Blok, B., Veertig jaar op de tribune. Parlementaire indrukken en herinneringen ('sGravenhage 1901)

Blok, L., 'Van eene wettelijke fictie tot eene waarheid. Beschouwingen over kiesstelsel en kiesrecht in Nederland in de eerste helft van de negentiende eeuw', Tijdschrift voor Geschiedenis 92 (1979), 391-412

Blok, Lo, Stemmen en kiezen. Het kiesstelsel in Nederland in de periode 1814-1850 (Groningen 1987)

Boessen, Manuël, "“ Geest der Provincie”. Commissaris des Konings Van der Does de Willebois over de ontwikkeling van een Nederlands-nationaal gevoel in Limburg, 1856-1874', De Maasgouw 119 (2000), 1-38

Boissevain, J.H.G., De Limburgsche kwestie (Tiel 1848)

Bok, W.P., De belastingen in het Nederlandsche parlement van 1848-1888, twee delen (Haarlem 1888-1895)

Bolsius, E.J., 'De Stuers als kamerlid', in: Het levenswerk van Jhr.Mr. Victor de Stuers. 
Herdacht door zijne vrienden (Utrecht 1913), 99-106.

Boogman, J.C., Nederland en de Duitse Bond 1815-1851 (Groningen/Djakarta 1955) Boogman, J.C., 'The Dutch Crisis in the Eighteen-Forties', in: J.S. Bromley en

E.H. Kossmann (red.), Britain and the Netherlands I (Londen 1960)

Boogman, J.C., 'Achtergronden en algemene tendenties van het buitenlands beleid van Nederland en België in het midden van de 19e eeuw', Bijdragen en mededelingen van het Historisch Genootschap, deel 76, 1962, 43-73

Boogman, J.C., Die Suche nach der nationalen Identität: die Niederlande 1813-1848

(Institut für europäische Geschichte Mainz, Vortrăge, Nr. 49) (Wiesbaden 1968) Boogman, J.C., Rondom 1848: de politieke ontwikkeling van Nederland 1840-1858 (Bussum 1978)

Bornewasser, J.A., 'De Nederlandse katholieken en hun negentiende-ceuwse vaderland', Tijdschrift voor Geschiedenis 95 (1982), 577-604

Bornewasser, J.A., Katholieke Volkspartij 1945-1980, 1: 'Herkomst en groei (tot 1963)' (Nijmegen 1995)

Bos, Nick, Notabele ingezetenen. Historische studies over Nederlandse elites in de negentiende eeuw (Brunssum 1995)

Bos, Nick, 'Agitatie in Limburg, de verhoging van de grondbelasting in het hertog. dom in 1865', De Maasgouw 108 (1989), 79-95

Bos, N.J.P.M., 'Vermogensbezitters en bevoorrechte belastingbetalers in de negentiende eeuw', Bijdragen en Mededelingen betreffende de Geschiedenis der Nederlanden 105 (1990), 553-577

Bosman, Th.E.A., 'Ter eere Gods, tot heil van Paus en Kerk'. Enige aspecten van de Nederlandse zouavenbeweging nader beschouwd (onuitgegeven doctoraalscriptie, Utrecht 1979)

Bossevain, J.H.G., De Limburgsche kwestie (Tiel 1848)

Braak, Bert van den, De Eerste Kamer. Geschiedenis, samenstelling en betekenis 18151995 (Den Haag 1998)

Bree, G.W.G. van, e.a. (red.), 'Van der Nuyersen upwaert'. Een bundel opstellen over Limburgse geschiedenis aangeboden aan drs. M.K.J. Smeets bij zijn afscheid als Rijksarchivaris in Limburg (Werken uitgegeven door Limburgs Geschied- en Oudheidkundig Genootschap nr. 7) (Maastricht 1981)

Brinkel, Th.B.F.M., e.a. (red.), Het kabinet Mackay. Opstellen over de eerste christelijke coalitie (1888-1891) (Baarn 1990)

Brouwers, H.J., Academisch proefschrift over den staatsregtelijken toestand van Limburg in betrekking tot den Duitschen Bond (Leiden 1857)

Bruijn, J. de, Abraham Kuyper: leven en werk in beeld. Een beeldbiografie (Amsterdam 1987)

Buys, J.Th., De Grondwet. Toelichting en kritiek, I (Arnhem 1883)

Camp, R. op den, "'Noch is Limburg niet gescheiden!" De afscheidingsbeweging in Nederlands-Limburg in 1848 en de reacties daarop van de Aviso de la Meuse', $D e$ Maasgouw 16 (1997), 15-44

Camp, Rico op den, "Noch Fransch, noch Pruissisch maar Nederlandsch!" Publieke 
opinie en Nederlands-nationaal gevoel in de Nederlandse provincie Limburg rond 1870, De Maasgouw m (1992) 81-102

Camp, Rico op den, 'Towards one nation: the province of Limburg and the Dutch nation during the eighteen-seventies', in: Annemieke Galema e.a. (red.), Images of the Nation: different meanings of Dutchness, 1870-1940 (Amsterdam-Atlanta 1993) 81-104

Camp, Rico op den, 'Vreemd vaderland. Limburg en de Nederlandse natie in de 19e eeuw', Spiegel Historiael 28 (1993), 387-392

Camp, Rico op den, "Wandelend in den vreemde". Limburg en de Nederlandse natie in de reisverslagen van J. Craandijk', De Maasgouw 113 (1994), 161-176

Camp, Rico op den, "'Niet gansch van vreemde smetten vrij". Limburg en het Nederlandse vaderland in de 19e eeuw', Beleid en Maatschappij 22 (1995), 92-99 Colenbrander, H.T., Vestiging van het koninkrijk (1813-1815) (Amsterdam 1927) Colenbrander, H.T., De afscheiding van Belgiē (Amsterdam 1936)

Comité de Polítique Nationale, La protestation du Limbourg: quelques documents 1831-1839 (Brussel-Parijs 1919)

Comité de Politique Nationale, La question du Limbourg (Brussel 1919)

Cornips, I., 'De "Sociale Ruijs"', De nieuwe mens. Maandblad voor beleving van het Christendom 4 nr. 12 (1953), 366-374

Cramer, N., Parlement en pers in verhouding tot de overheid (Leiden 1958)

Cramer, N., Wandelingen door de handelingen ('s-Gravenhage 1975)

Dam, Frans van, Wat hebben de kiezers te doen? (Sittard 1866)

Dam, J.P.A. van den, Arnold Leon Armand Diepen 1846-1895. Industrieel en publicist over economische en sociale vraagstukken (Bijdragen tot de geschiedenis van het Zuiden van Nederland v) (Tilburg 1966)

De Derde Dinsdag: troonredes in de Nederlanden na 1814. De troonrede als parlementaire dia, redactie, compilatie en samenstelling door Pieter C. Lages, Delft: Eburon (cd-rom)

De semi-officiële en particuliere briefwisseling tussen J.C. Baud en J.J. Rochussen 18451851, uitgegeven door W.A. Baud, ur: Brieven van J.C. Baud aan J.J. Rochussen (Den Haag 1983)

Derks, M.G.H., De gewenning aan het koninkrijk; de integratie van het Hertogdom Limburg in het koninkrijk der Nederlanden, 1815-1867 (onuitgegeven doctoraalscriptie, Ubach over Worms, 1986)

Dingemans, P.A.W., 'De invoering en afkondiging van de Duitse Bondswetgeving. Een aspect in de verhouding Limburg-Duitse Bond', Publications de la Société Historique et Archéologique dans le Limbourg 115 (1979), 475-494

Documenten betreffende de buitenlandse politiek van Nederland 1919-1945, periode A, t: ' 1 juli 1919 - 1 juli 1920', bew. door J. Woltring (RGP Grote Serie 156) ('sGravenhage 1976)

Dorren, J.G.M., De Tweede Kamerverkiezing van juni 1909 in het district Gulpen (onuitgegeven scriptie Katholieke Leergangen Sittard, Maastricht 1986)

Dorren, Th., 'Het Hertogdom Limburg in zijne verhouding tot den Duitschen Bond', 


\section{Limburg's Jaarboek 19 (1913), 92-130 en 146-197}

Eenoo, R. van, 'De evolutie van de kieswetgeving in België van 1830 tot 1919',

Tijdschrift voor Geschiedenis 92 (1979), 333-352

Essen, Petra van, Voor Paus en Koning: een korte geschiedenis van de Nederlandse zouaven, 1860-1870 (Oudenbosch 1988)

Evers, I.M.H., 'Liever Turks dan Pruisisch. De publieke opinie in de provincie Limburg 1866-1867', De Maasgouw 100 (1981), 129-149

Evers, I.M.H., De Momus (Maastricht 1982)

Fasseur, Cees, Wilhelmina. De jonge koningin (Amsterdam 1998)

Fishman, J.S., Diplomacy and Revolution: the London Conference of 1830 and the Belgian Revolt (Amsterdam 1988)

Fockema Andreae, S.J., en H. Hardenberg (red.), soo jaren Staten-Generaal in de Nederlanden: van statenvergadering tot volksvertegenwoordiging (Assen 1964)

Fruin, R., 'De Souvereine vorst en de Limburgsche Generaliteitslanden', De Maas. gouw 42 (1922), 1-2

Frunsch, H.J.M., 'Hoe een Limburgse belastingkwestie een einde maakte aan een ministeriële loopbaan', Het Land van Herle 13 (1963), 73-76 en 93-96

Gedenkstukken der algemene geschiedenis van Nederland van 1795 tot 1840 , tiende deel: regering van Willem I 1830-1840, vijfde stuk, uitgegeven door H.T. Colenbrander (RGP Grote Serie 5o) ('s-Gravenhage 1922)

Geurts, A.J., 'De Limburgse meiverkiezingen in 1848: kanttekeningen bij de interpretatie van de uitslag', in: A.J. Geurts (red.), Verwoord verleden. Opstellen over het Noordlimburgse Maasdal en aangrenzend Duits gebied aangeboden aan J.G.M. Stoel ter gelegenheid van haar zestigste verjaardag (Cahiers van de historische werkgroep Arcen-Lomm-Velden nr. 5) (Lomm 1982), 52-57

Geurts, A.J., 'Historische aspecten van de provincie(s) Limburg 1815-1848', De Maasgouw 105 (1986), 49-78

Geurts, P.A.M., 'Een vermaard boeket van W. Everts', Sèrums krentje 2 (1983), nr. 7, z.p.

Geurts, P.A.M., 'Een Limburgs volkslied van W. Everts', Sèrums krentje 2 (1983), nr. 8, z.p.

Geurts, P.A.M., 'Een kamerzetel voor W. Everts in 1893 (vredige versie)', Sèrums krentje 2 (1983), nr. 9, z.p.

Geurts, P.A.M., 'Moeilijkheden rond de Kamerzetel voor W. Everts in 1893', Sèrumis krentje 2 (1983), nr. 10, z.p.

Geurts, P.A.M., 'De entree van Mgr. W. Everts in de Tweede Kamer', Sèrums krentje 2 (1983), nr. 11, z.p.

Geurts, P.A.M., 'Kamerzetel voor De Stuers', De Maasgouw 103 (1984), 60-72 Geurts, P.A.M., 'Een Limburgs volkslied uit 1857', De Maasgouw 110 (1991), 59-66 Geurts, P.A.M., en A.E.M. Janssen, 'Ruim een eeuw geschiedbeoefening met betrekking tot de Nederlandse provincie Limburg. Enige historiografische aspecten', Publications de la Société Historique et Archéologique dans le Limbourg 125 (1989), 
Giele, Jacques, Een kwaad leven. De arbeidsenquête van 1887, I1: Maastricht (Nijmegen 1981)

Gijsen, 1.M., Joannes Augustimus Paredis (1795-1886): bisschop van Roermond en het Limburg van zijn tijd (Maaslandse monografieèn 8) (Assen 1968)

Goltstein, Jos, 'Het ontstaan van het Limburgs chauvinisme in Sittard', Studies over de sociaal-economische geschiedenis van Limburg/laarboek van het Sociaal Historisch Centrum voor Limburg 31 (1986), 1-77

Gribling, J.P., Willem Hubert Nolens 1860-1931. Uit het leven van een priester-staatsman (Maaslandse monografieèn 26) (Assen 1978)

Grochtmann, Hermann, Die Niederländische Provinz Limburg im Deutschen Bund (Keulen 1937)

Habets, I.J., 'Cronijkje van het Hertogdom Limburg sedert MDcccxxx', in- en uitgeleid door M. Smeets, De Maasgouw 94 (1975), 57-63, 123-128, 198-206; 95 (1976), 70-74, 139-146; 96 (1977), 27-31, 11-122, 181-188, 97 (1978), 24-32, 91-93, $125-128,191-198,98$ (1979), 21-29, 127-134, 195-198; 99 (1980), 51-52.

Hans, D., Het Nederlandsche Parlement. Korte Schets onzer Volksvertegemwoordiging (Amsterdam 19u)

Heijden, Rob P.W.J.M. van der, 'Separatisme in Limburg, 1840-1851', in: Fr.J. Hermans e.a. (red.), Tussen twee Tricolores, Een Limburgse vestingstad onder Nederlands en Belgisch bestuur, Venlo 1815-1850 (Venlo 1990)

Heijden, Rob P.W.J.M. van der, 'Tijden veranderen: Limburg tussen Nederland en België. De reactie in Nederlands-Limburg op het Belgisch annexionisme van 1918-1919', De Maasgouw 111 (1992), 101-167

Heijden, R.P.W.J.M. van der, 'De terugkeer van het Nederlands gezag in Limburg, 1839-1840', De Maasgouw 108 (1989), 65-78

Heijden, R.P.W.J.M. van der, 'Bedreigd Maastricht. De dreiging van het Limburgs separatisme en de reactie van de Maastrichtse bevolking', Studies over de sociaaleconomische geschiedenis van Limburg 36 (1991), 87-108

Hellenberg Hubar, Bernadette C.M. van, e.a. (red.), Maaslands Melange: opstellen over Limburgs verleden Dr. P.J.H. Ubachs aangeboden bij gelegenheid van zijn vijfenzestigste verjaardag (Werken uitgegeven door Limburgs Geschied- en Oudheidkundig Genootschap nr. 14) (Maastricht 1990)

Hermans, Henri G.M., 'Limburg in de parlementaire geschiedenis', in: Beda Verbeek (red.), Limburg onder de gouden Oranjezon 1898-1948, 115-121

Histoire parlementaire du traité de paix du 19 avril 1839 entre la Belgique et la Hollande, contenant, sans exception, tous les discours qui ont été prononcés dans les chambres législatives belges, précédée d'une introduction [etc.], 2 delen (Brussel 1839)

Hobsbawn, E.J., Nations and nationalism since 1780: programme, myth, reality (Cambridge [etc.] 1990)

Hoek, Ragdy van der, en Adri Gorissen, De Venlose krant: 125 jaar in Noord-Limburg (Venlo 1987)

Hoek, S.H.H. van der, 'Waarom kantonrechter Leopold Haffmans in 1872 werd ontslagen', Horster historiën 1 (1986), 154-171 
Hoek, S.H.H. van der, 'Een Limburgs dialectstuk als politiek propagandamiddel, De Maasgouw 105 (1986), 1-10

Hoek, S.H.H. van der, en J.M.W.C. Schatorjé, 'Het Venloosch Weekblad en de verkiezingen voor de Tweede Kamer, met name in 1869 en 1871', De Maasgouw 104 (1985), 57-81

Hoffschmidt, A. d', La représentation nationale en Belgique, 1830-1880 (Aarlen 1880) Hogendorp, G.K. van, Bijdragen tot de huishouding van staat in het Koningrijk der Nederlanden, verzameld ten dienste der Staten-Generaal, 10 delen ('s-Gravenhage 1818-1825)

Huber, Ernst Rudolf, Deutsche Verfassungsgeschichte seit 1789, II: 'Der Kampf um Einheit und Freiheit 1830-1850' (Stuttgart 1975 [2e druk])

Huizinga, J.J., 'Een gebroken spiegel. Zeventig jaar districtenstelsel (1848-1917)', Tijdschrift voor Geschiedenis 92 (1979), 426-332

Hymans, L., Histoire parlementaire de la Belgique de 1830 à 1880 (Brussel 1879)

Janssen, Wilhelm, Kleine Rheinische Geschichte (Veröffentlichung des Instituts für Geschichtliche Landeskunde der Rheinlande der Universităt Bonn) (Düsseldorf 1997)

Janssen de Limpens, K.J.Th., 'Genealogische en biografische geschiedenis van het geslacht De Limpens', Publications de la Societé Historique et Archéologique dans le Limbourg 118 (1982), 9-58

Jaspar, Edmond, Kint geer eur eige stad? De historie vaan Mestreech aan de Mestreechteneers verteld, mèt illustraties en 'n alfabetische lies vaan naome (Maastricht 1968 [3e druk])

Jong, R. de, 'De Algemeene Kiesvereeniging, 1868-1875. De eerste politieke partij van Nederland; Jaarboek 1999. Documentatiecentrum Nederlandse Politieke Partijen (2000), 240-248

Jong, Ron de, 'Conservatieven en katholieken tijdens het kabinet-Van ZuylenHeemskerk, 1866-1868', Jaarboek van het Katholiek Documentatie Centrum 25 (1995), 7-26

Jong, Ron de, 'Katholieken en verkiezingen, 1850-1900. Oude en nieuwe vormen van politiek', Groniek 30 (1997), 433-442

Jong, Ron de, Van standspolitiek naar partijloyaliteit. Verkiezingen voor de Tweede Kamer 1848-1887 (Hilversum 1999)

Jong, Ron de, en Hans Verhage, 'Episcopaat en politiek. Ontwikkelingen rondom het bisschoppelijk onderwijsmandement van 1868 in Nederland in het algemeen en in Limburg in het bijzonder', Trajecta 5 (1996), 56-70

Jurriaanse, M.W., De Nederlandse Ministers van Buitenlandse Zaken 1813-1900 (Den Haag 1974)

Juste, Th., Histoire du Congrès National de Belgique ou de la fondation de la monarchie Belge, 2 delen (Brussel 1850)

Karnebeek, A.P.C. van, Ter toelichting van de Limburgsche kwestie ('s-Gravenhage 1864)

Kasteel, P., Abraham Kuyper (Kampen 1938) 
Kellenbenz, Hermann, 'Wirtschaft- und Sozialentwicklung der nördlichen Rheinlande seit 1815', in: Rheinische Geschichte, 3: 'Wirtschaft und Kultur im 19. und 20. Jahrhundert', uitgegeven door Franz Petri en Georg Droge (Düsseldorf 1979) Kemp, M. (red.), Limburg 1839-1839. Van ploeg tot afbouwhamer (Maastricht 1941) Klijn, Annemieke, Onze man uit Maastricht: Sjeng Tans 1912-1993. Een biografie (Nijmegen 2001)

Klotzer, Wolfgang, Die Paulskirche. Symbol demokratischer Freiheit und nationaler Einheit (Kleine Schriften aus dem Institut für Stadtgeschichte) (Frankfurt am Main 1985)

Knippenberg, Hans, en Ben de Pater, De eenwording van Nederland. Schaalvergroting en integratie sinds 1800 (Nijmegen 1988)

Kortmann, C.A.J.M., Constitutioneel recht (Deventer 1990)

Kraume, H.G., Außenpolitik 1848. Die hollandische Provinz Limburg in der deutschen Revolution (Düsseldorf 1979)

Kuiper, Wim, Lokaal en landelijk in Limburg. Veranderingen in de Limburgse lokale politiek (Maastricht 1994)

Kuyper, J., Mijne carrière en Mijne kijkjes in de wereld ('s-Gravenhage 1893)

Labrie, A., "La religion civile": nationalisme, nationale staat en modernisering in Europa', in: L.H.M. Wessels en A. Bosch (red.), Veranderende grenzen. Nationalisme in Europa, 1815-1919 (Nijmegen 1992), 59-103

La protestation du Limbourg hollandais 1918-1919 (Roermond 1920)

Lavater jr., Politieke photografien van de aftredende leden der Tweede Kamer (Sneek 1879)

Leeuwen-Cannemans, M.C. van, Inventaris van archieven van de familie Michiels van Kessenich (Publicaties Rijksarchief Limburg nr. 2) (Maastricht-'s-Gravenhage 1995)

Lemmens, Eric, 'Provincialisme en kieswetgeografie: de Limburgse kiesdistricten, 1860-1870', Openbaar bestuur 11 (2001), 30-33

Limburg: het wapen, de Limburgse vlag, het volkslied, uitgegeven door het Bureau Voorlichting en Public Relations van de provincie Limburg (z.j.)

Limburg, Provinciaal genootschap voor geschiedkundige wetenschappen, taal en kunst, 'Gedenkboek bij gelegenheid van het vijfentwintigjarig Regeeringsjubileum van Hare Majesteit Koningin Wilhelmina 1898-1923', Limburg's Jaarboek 29 (1923)

Loeff, J.A., e.a., Het Katholiek Nederland 1813-1913. Ter blijde herinnering aan het eerste eeuwfeest onzer nationale onafhankelijkheid, 2 delen (Nijmegen 1913)

Luykx, T., Politieke geschiedenis van Belgiê, I: 'Van 1789 tot 1944' (Amsterdam 1977 [4e druk])

Maenen, A.J.Fr., Petrus Regout 1801-1878. Een bijdrage tot de sociaal-economische geschiedenis van Maastricht (Bijdragen tot de sociale en economische geschiedenis van het Zuiden van Nederland vir) (Nijmegen 1959)

Matthey, Ignaz, "Een diepe hulde, een warme toon". De oprichtingsgeschiedenis van het Thorbeckebeeld', Jaarboek van het Genootschap Amstelodamum 85 (1993), $133-166$ 
Miesen, A misserable appendix which wastes our best juices. Limburg separatists in the Frankfurt Parliament (onuitgegeven scriptie, Amsterdam 1992)

Müller, P.L.J.M.A., 'Het Hertogdom Limburg en zijn verhouding tot den Duitschen Bond', De Nedermaas 14 (1937), 112-116, 128-132, 155-159

Munier, W.A.J., 'De reorganisatie van het kerkelijk bestuur in het zuidelijk gedeclte van het koninkrijk der Nederlanden na de definitieve afscheiding van Belgie. Een documentatie betreffende de Nederlandse provincie Limburg en de NoordBrabantse vicariaten', in Publications de la Société Historique et Archéologique dans le Limbourg 112 (1976), 135-250

Nationaal Biografisch Woordenboek van de Koninklijke Vlaamse Academièn van Belgiz 'Nécrologie. Notice sur Charles Antoine baron de Bieberstein Rogalla Zawadsky', Publications de la Société Historique et Archéologique dans le Limbourg 17 (1880), 373-375

Nies, Frits, Weert. Het verleden van een stad (Weert 1999)

Nieuw Nederlandsch Biografisch Woordenboek (NNBw)

Nijkamp, G.P., en O. Schutte (samenstelling), Y. Taverne (red.), De Nederlandse Adel: besluiten en wapenbeschrijvingen ('s-Gravenhage 1989)

Nuyens, E.M.Th.W., De staatkundige geschiedenis der provincie Limburg vanaf haar ontstaan tot aan haar uiteenvallen in 1839 (Maastricht 1956)

Nuyens, E.M.Th. W., Inventaris der archieven van het Provinciaal Bestuur van Limburg 1814-1913 (Rijksarchief in Limburg nr. 25) (Maastricht 1982)

Ommeren, H.R. van, 'Over de aanduiding "Hertogdom Limburg", De Maasgouw 96 (1977), 11-27

Onze afgevaardigden bevattende portretten en biographieën van de leden van de Eerste en Tweede Kamer der Staten-generaal (Rotterdam 1897)

Onze afgevaardigden: portretten en biographieën der leden van de Eerste en Tweede kamer der Staten-generaal (Rotterdam 1901)

Orbons, Piet, en Lou Spronk, 'Limburgers worden Nederlanders. Een moeizaam integratieproces', Publications de la Société Historique et Archéologique dans le Limbourg 102 (1966), 31-53

Oud, P.J., en J. Bosmans (bewerking), Staatkundige vormgeving in Nederland, I: 1840-1940 (Assen/Amsterdam 1990)

Panhuysen, G., "'Honderdvijftig jaar Provincie Limburg" in 1865?', De Maasgoww 84 (1965), 129-140

Perry, Jos, Roomsche kinine tegen roode koorts. Arbeidsbeweging en katholieke kerk in Maastricht 1880-1920 (Amsterdam 1983)

Perry, J., De voorman. Een biografie van Willem Hubert Vliegen, 1862-1947 (Amsterdam 1994)

Perry, Jos, 'Jubeljaren. Staatsmijnen weerspiegeld in vier jubilea', Publications de la Société Historique et Archéologique dans le Limbourg 134-135 (1998-1999), 784

Philips, J.F.R., J.C.G.M. Janssen en Th.J.A.H. Claessens, Geschiedenis van de landbouw in Limburg 1750-1914 (Maaslandse monografieĕn 4) (Assen 1965) 
Postma, A., e.a. (red.) Aan deze zijde van het Binnenhof. Gedenkboek ter gelegenheid van het 175-jarig bestaan van de Eerste Kamer der Staten-Generaal ('s-Gravenhage 1990)

Prins, W.F., 'De Limburgsche afgevaardigden in de Nederlandsche Staten-Generaal, 1840-1880', I en 11, De Gids 100 (1936), resp. 341-356 en 74-96

Prins, W.F., 'Tien jaren uit onze parlementaire geschiedenis 1815-1825', De Gids 101 (1937), 41-102

Prins, W.F., 'Vijf jaren uit onze parlementaire geschiedenis 1825-1830', De Gids u1 (1948), 126-144

Raak, Ronald van, In naam van het volmaakte. Conservatisme in Nederland in de negentiende ceuw (Amsterdam 2001)

Raalte, E. van, P.T.T. Bovend'Eert en H.R.B.M. Kummeling (bewerking), Het Nederlandse parlement ('s-Gravenhage 1991 [7e druk])

Ramakers, E.P.M., 'De invoering van achterlaadgeweren bij de Nederlandse infanterie', Mededelingen van de Sectie Krijgsgeschiedenis Koninklijke Landmacht, 2 (1979), 76-138

Ramakers, E.P.M., 'De Limburgse Jagers 1813-1940', in: Stichting Vrienden van de Limburgse Jagers, De Limburgse Jagers 1813-1850-1995. Limburg en zijn regiment. De geschiedenis van het Regiment Limburgse Jagers en zijn Stamregimenten in de periode 1813-1995 (Maastricht 1995), 7-17

Rapporten van de gouverneurs in de provinciën, 1840-1849, uitgegeven door A.J.C. Rüter, drie delen (Utrecht [etc.] 1941-1972)

Recueil des décrets du Congrès Nationale de la Belgique, et des arrêtés du pouvoir exécutif/Recueil des lois et arrêtés royaux de la Belgique, 1 (1830) t/m x (1839) (Brussel 1833-1839)

Regout, L.H.W., Arbeidsverzekering (Amsterdam 1896)

Regout, L.H.W., Over het wetsontwerp tot wettelijke verzekering van werklieden tegen de gevolgen van ongevallen in bepaalde bedrijven (Amsterdam 1897)

Regout, P., Handel en nijverheid: het tarief ('s-Gravenhage 1858)

Regout, P., De bezwaren van de Nederlandse industrie tegen het wetsontwerp tot herziening van het tarief van in-, uit- en doorvoer. Verzameld door P. Regout ('s-Gravenhage 1859)

Regout, P., Een woord over eenige Maastrichtse belangen ('s-Gravenhage 1862)

Regout, P., Wat heeft Limburg voor den heer Thorbecke, en de heer Thorbecke voor Limburg gedaan? Beantwoord door P. Regout (Maastricht 1864)

Renan, Ernest, en Joep Th. Leerssen (inleiding), Qu'est-quec'est une nation? (Leiden 1994)

Rheenen, H. van, 'De deelname aan het lager onderwijs in de beide Limburgen (1846-1914)', Studies over de sociaal-economische geschiedenis van Limburg XI (1995) (Jaarboek van het Sociaal Historisch Centrum voor Limburg), 161-186

Rogier, L.J, Katholieke herleving. Geschiedenis van katholiek Nederland sinds 1853 ('s-Gravenhage 1956 [2e druk])

Rogier, L.J., 'Limburg in de Franse tijd', in: E.C.M.A. Batta e.a. (red.), Limburg's 
verleden. Geschiedenis van Nederlands Limburg tot 1815, 2 (Maastricht 1967), 668703

Rogier, L.J., 'Nederlands-Limburg 1813-1863', De Maasgouw 83 (1964), 71-86

Russel, Jos., Hoe men de kiezers wil verschalken (Maastricht 1867)

Russel, Jos., La visite de M. Thorbecke au duché de Limbourg en Octobre 1865: à nos compatriotes limbourgeois (Maastricht 1865)

Rutten, W.J.M.J., L. Smets en S. Vandevelde (red.), 'Limburgs Biografisch Repertorium', Studies over de sociaal-economische geschiedenis van Limburg 33 (1988) (Jaarboek van het Sociaal Historisch Centrum voor Limburg), 150-200

Sagittarius, Parlementaire portretten: de aftredende helft van de Tweede Kamer der Staten-Generaal (Amsterdam 1869)

Santen, J.H. von, 'Sinds wanneer zit men links en rechts in de Tweede Kamer? Een raadselachtig probleem', De Negentiende Eeuw 26 (2002), 123-142

Schöffer, I., e.a., Eenheid en scheiding van de beide Limburgen. Verslagbundel van het op 26 mei 1989 te Alden Biesen gehouden congres bij gelegenheid van de herdenking 150 jaar beide Limburgen (Maaslandse monografieèn 47) (Leeuwarden 1989)

Schreuder, P., 'ie Limburgse minister stierf 100 jaar geleden. Mr. R.M.P.H. Strens uit Roermond', Limburg vandaag 6 (1974-1975) nr. 16, 9-11

Schreuder, P., 'De "vrij zonderlinge rede" van een Limburgs Kamerlid in 1854', Limburg vandaag 6 (1974-1975) nr. 18, 27-29

Schreuder, P., 'Een Kamerverkiezing in 1855 in Limburg', Limburg vandaag 8 (19761977) nr. 15, 15-18

Secker, W.P., Ministers in beeld: de sociale en functionele herkomst van de Nederlandse ministers (1848-1990) (Leiden 1991)

Smeets, M.K.J., 'De Notabelenvergaderingen in de arrondissementen Hasselt, Maastricht en Roermond - de latere provincie Limburg - in 1815', Bijdragen voor de Geschiedenis der Nederlanden 20 (1965), 24-61

Smit, Christianne, Omwille der billijkheid. De strijd over de invoering van de inkom stenbelasting in Nederland (Amsterdam 2002)

Sniekers, Theo, 'De voorgangers van Gijsen', in 'God in Limburg', bijlage van het Limburgs Dagblad, 25 maart 1989, 67

Spiertz, 'Limburg uit de Duitse Bond', Publications de la Société Historique et Archéologique dans le Limbourg 102 (1966), n-29

Stassen, M.J.L.A., Charles Ruys de Beerenbrouck: edelman-staatsman, 1873-1936 (Munstergeleen 2000)

Stenographischer Bericht über die Verhandlungen der Deutschen Constituirenden Nationalversammlung zu Frankfurt am Main, 10 banden (Frankfurt am Main 1848-1850)

Talsma, J., Kiezen en delen: de 'verkiezingsculturr' in Amsterdam in de tweede helft van de negentiende eeuw; accommodatie en/of polarisatie (onuitgegeven paper, Amsterdam 1988)

Talsma, J., 'Geeft met verschuldigde eerbied te kennen. Petities over kiesstelsel en kiesrecht uit de periode 1848-1850', Tijdschrift voor Geschiedenis 92 (1977), 438-451 
Talsma, J., Vijf historische en rechtshistorische studies over het recht van petitie. verzoekschriften aan de Tweede Kamer en het ombudsvnaagstuk: Nederland, 17951983 (Arnhem 1989)

Thorbecke, J.R., e.a., Redevoeringen uitgesproken door de Afgevaardigden van het hertogdom Limburg in de beide Kamers der Staten Generaal bij de beraadslagingen over het wets-ontwerp tot regeling van het toezicht op de onderscheidene kerkgenootschappen (Roermond 1853)

Thorbecke, J.R., De briefwisseling van J.R. Thorbecke, deel m: 1836-1840; deel IV: 1840-1845, uitgegeven door G.J. Hooykaas, RGP Kleine Serie 64 ('s-Gravenhage 1988), resp. RGP Kleine Serie 72 ('s-Gravenhage 1993); deel v: 1845-1853; deel vr: 1853-1862, uitgegeven door G.J. Hooykaas en F.J.P. Santegoeds, RGP Kleine Seric 78 ('s-Gravenhage 1996), resp. RGP Kleine Serie 92 ('s-Gravenhage 1998)

Tillema, J.A.C., Victor de Stuers. Ideeèn van een individualist (Ons xxste-eeuwse verleden in mémoires en biografieên 10) (Assen 1982)

Ubachs, P.J.H., Handboek voor de geschiedenis van Limburg (Maaslandse monografieên 63) (Hilversum 2000)

Valk, J.P. de, Roomser dan de paus? Studies over de betrekkingen tussen de Heilige Stoel $e n$ het Nederlands katholicisme, 1815-1940 (Nijmegen 1998)

Velde, Henk te, Gemeenschapszin en plichtsbesef: liberalisme en nationalisme in Nederland, 1870-1918, (z.p. 1992)

Velde, Henk te, Stijlen van leiderschap. Persoon en politiek van Thorbecke tot Den Uyl (Amsterdam 2002)

Velde, Henk te, en Hans Verhage (red.), Deeenheid \& de delen. Zuilvorming, onderwijs en natievorming in Nederland, 1850-1900 (Amsterdam 1996)

Venne, J.M. v.d., (red.), Limburgsche wapens (Maastricht 1925)

Venner, Jos, (red.), Geschiedenis van Limburg, n (Maastricht 2001)

Verbeet, G.J.B., 'Limburg 100 jaar onverkort Nederlands, 11 mei 1867- 11 mei 1967', Kleio 9 (1968), 66-81

Verbeet, G.J.B., Limburg op de tweesprong: welvaart en politiek dilemma, 1814-1839 (Maastricht 1978)

Verbeet, G.J.B., De beide Limburgen inzet van staatkundige verwikkelingen tussen de Duitse Bond, Nederland en België na 1839. De periode tussen de 24 artikelen van 1831 en de vredesconferentie van 1919 (Maastricht-Lanaken 1992)

Verhage, Hans, 'Realiteit of retoriek? Het katholieke onbehagen ten aanzien van de Nederlandse natie in Limburg in de 19e eeuw', in: Transparant 5 (1994), 38-41 Verslag van de Handelingen der Staten-Generaal:

Handelingen van de Eerste Kamer (HEK)

Handelingen van de Tweede Kamer (HTK)

Handelingen van de Verenigde Vergadering ( $\mathrm{HVV}$ )

Vroede, M. de, 'Voor of tegen Belgiē. De openbare mening in het huidige NederlandsLimburg in de jaren 1830', Bijdragen voor de geschiedenis der Nederlanden 15 (1960), 1-40

Vugt, Joos van, 'De verzuiling van het lager onderwijs in Limburg 1860-1940', 
Jaarboek van Katholiek Documentatie Centrum 10 (1980), 17-6o

Waele, M. de, 'De Belgische annexionistische campagne in Nederlands-Limburg (1914-1920)', in: Colloquium over de geschiedenis van de Belgisch-Nederlandse betrekkingen tussen 1815 en 1945 (Gent 1982), 353-395

Wagemans, Kasper, 'Limburg en het Belgische annexionisme 1918-1920', Studies over de sociaal-economische geschiedenis van Limburg 43 (1998), 89-133

Wap, J.J.F., 's Konings Verschijning in het Hertogdom Limburg', in: J.J.F. Wap, Gedenkboek der Inhuldiging en Feesttogten van Zijne Majesteit Willem 11 , 18401842 ('s-Hertogenbosch 1842) 206-244

Weber, E., Peasants into Frenchmen: the modernization of rural France, 1870-1914 (Stanford 1976)

Weitzel, A.W.P., en Paul van 't Veer (bewerking en inleiding), Maar majesteit! Koning Willem $m$ en zijn tijd. De geheime dagboeken van minister A.W.P. Weizzel (Amsterdam 1980 [se druk])

Welderen Rengers, W.J. van, Schets eener parlementaire geschiedenis van Nederland van 1849 tot 1901, I en II ('s-Gravenhage 1948 [4e druk])

Wely, Jos. van, Schaepman: levensverhaal (Bussum 1954 [2e druk])

Wieland, J.H.M., e.a. (red.), De gouverneurs in de beide Limburgen 1815-1989 (Maastricht 1989)

Wilhelmina, Eenzaam maar niet alleen (Amsterdam 1959)

Wingens, Th., 'Het Journal du Limbourg in het eerste jaar na de traktaten van Londen van 1839', De Maasgouw 83 (1964), 181-192.

Wingens, Th., 'Een Maastrichts voorspel van de Belgische opstand. Het proces Hennequin (1821)', De Maasgouw 83 (1964), 85-96

Wingens, Th., Generaal Dibbets. Zijn historische rol en zijn voortleven in de Maastrichtse legende (Maastricht 1972)

Wintershoven, Edm. van, Open brief aan de Heeren kiezers van het district Maastricht van Mr. Edm. van Wintershoven, lid van de Tweede Kamer der Staten-Generaal, gedagteekend 31 Maart 1864 (Gulpen 1864)

Wintershoven, Edm. van, Tweede open brief aan de Heeren kiezers van het district Maastricht (Gulpen 1864)

Wintershoven, Edm. van, De Heer Hubert Pyls, burgemeester van Maastricht en de candidatuur van Jhr. Mr. P. van der Maesen de Sombreff [etc.] (Gulpen 1864)

Wit, J.J. de, 'Waarom draagt de provincie den naam "Limburg"?', Publications de la Société Historique et Archéologique dans le Limbourg 46 (1910), 141-148

Wit, J.J. de, en A.J.A. Flament, 'De Vorming der Heerschappijen op het grondgebied in Limburg of die zich daarvoor hebben uitgestrekt, van de Romeinse overheersching tot 1814-1817 (ontstaan der provincie Limburg)', Publications de la Societé Historique et Archéologique dans le Limbourg 47 (1911), 1-259

Witkamp, P.H., en P.H. Craandijk, Vereeniging en scheiding. Geschiedenis van NoordNederland en België van 1813-1880 (Utrecht 1881)

Witlox, J.H.J.M., De Katholieke Staatspartij in haar oorsprong en ontwikkeling gfschetst, 1 en II ('s-Hertogenbosch 1919 en 1927) 
Witlox, J., 'Een merkwaardige benoeming in 1853', Historisch tijdschrift 7 (1928), 263-269

Witlox, J., 'Mr. M. Strens', Historisch tijdschrift 7 (1928), 270-304

Witlox, J., 'Wilde geruchten in 1853', Historisch tijdschrift 7 (1928), 249-262

Witlox, J., Schaepman als staatsman, 3 delen (Amsterdam 1960)

Witlox, J.H.J.M., De staatkundige emancipatie van Nederlands katholieken 1848-1870 (Bussum 1969)

Wollstein, G., Das 'Großdeutschland' der Paulskirche: nationale Ziele in der bürgerlichen Revolution, 1848/49 (Düsseldorf 1977)

Wouters, H., 'De penetratie van de Republiek in het Limburgse Maasdal in de 17e eeuw', De Maasgouw 79 (1960), 151-158

Zaal, Wim, De vuist van de paus: de Nederlandse zouaven in Italie, 1860-1870 (Nieuwegein 1996) 



\section{Register}

Aalberse, P.J.M., 270

Aefferden, G.A.E. van, 23, 28, 32, 330, 331

Alberts, W.J., 14, 15

Albert 1, koning, 169

Alting von Geusau, jhr. G.A.A., 366

Alting von Geusau, jhr. P.A., 366

Amorie van der Hoeven, H.A.A. des,

293

Andringa de Kempenaer, jhr. T.A.M.A. van, 286,290

Anemaet, S.H., 54, 125

Archot Schoonhoven, Ph.J.M. graaf d', 46

Arnoldts, J.H., 89, 90, 99, 101, 106, 115, $165,210,214,215,218,221,222,226$, $228,230,234,237,240,241,247,248$, $254,263,276,296,318,339,342,357$, 361

Arnoldts, M.J.G.J., 70, 115, 261, 265, $339,359,361$

Asch van Wijck, familie van, 114 Asch van Wijck, jhr. H.M.A.J. van, 52, 56

Baart, S.P., 88

Bahlmann, B.M., 275

Banning, J.P.D. van, 163

Beaufort, W.H. de, 129, 275, 312

Beaumont, E.F.H.J. de, 257, 263

Beckers, J.H.J., 85, 103, 109, 167, 171, $258,260,339,342,359,361$

Beeckman, M.H.G. baron de, 27,362 , 363

Beekelaar, G.A.M., 303

Beelaerts van Blokland, jhr. G., 54

Beerenbroek, L.F.H., 50, 64, 94, 95,
$100,104,122,131,133,135,138,139$, $142-144,149,154,155,162,182,198$, $226,234,284,285,288-290,292$, $300,316,317,328,333,339,341,343$. $356,357,361,364$

Beerenbroek, P.J.Th., 317

Bentinck van Nijenhuis, A.A. baron, $64,95,154,159$

Berg, J.Th.J. van den, 16, 17, 84, 105 . $108,112,277$

Bergh, J.G. van den, 365

Betz, G.H., 195, 198, 199, 201, 286, 287 , 290, 293, 305, 306, 316

Beumers, R., 158

Bevers, J.G.S., 94, 339, 341

Bieberstein Rogalla Zawadsky, Ch.A. baron de, 74, 78, 79, 98-100, 103 , $104,106,107,111,113,115,128$, 162-164, 188, 191, 193, 195, 199, 200, 202-205, 209, 210, 212-220, 223, $226,227,229,230,234,236-241,243$. $245,247-249,252,268,286-288$, 294, 295, 306, 311, 315, 326, 339, 343, 360,361

Bieberstein Rogalla Zawadsky, Ch.C.M.H. baron de, 102, 111, 115, $261,263,265,339,343,357,359,361$ Bieberstein Rogalla Zawadsky, F.H.J. baron de, 113, 253 Bieberstein Rogalla Zawadsky, F.W.H.C. barones de, 113 Bieberstein Rogalla Zawadsky, P.G.E.H. baron de, 113, 193, 224 Bloemarts, A.J.H.J., 139 Bloemarts, A.L.G.H., 43, 64, 135, $139,143,144,183,340,343$. 357 
Bloemarts, familie, 139

Blok, B., 98, 100, 193

Blussé van Oud-Alblas, P., 208, 209, 219, 294

Boermans, F.A.H., 364

Boissevain, J.H.G., 125

Bolsius, F.J., 87, 99, 106, 109, $260,265,268,340,343,359$, 361

Bommel, C.R.A. van, 364

Bongaerts, M.Ch.E., 109, 167, 171, 176, $268,340,344,359,361$

Bontamps, Ch., 154

Boogman, J.C., 42, 124, 132

Borchgrave d'Altena, G.G.F. graaf de, 28, 33, 35-37

Borchgrave d'Altena, W.G.F. graaf de, 330,331

Borret, A.J.L., 38, 80, 140, 363

Borret, E.J.H., 72, 73, 78-80, 106, 135 , $140,143-145,185,186,188,191,223$. $302,308,309,317,340,344,357,360$, 361,366

Borret, F.H.H., 80

Borret, Th.L.M.H., 80

Bos, N., 291

Bosse, P.P. van, 125, 166, 227, 231, 247, 284, 304

Braak, B. van den, 17, 85, 97, 104

Brouckère, H.G.J.M. de, 49, 332, 333

Brouckère, jhr. Ch. de (senior), 26, 27, $35,60,362$

Brouckère, jhr. Ch.M.J.G. de (junior), $27,28,32,33,35,37,46,330-332$

Brouwers, H.J., 23, 69, 77, 89, 107, 115 , $210-214,220,221,226,230,246$, $248,263,274,276,296,340,344$. 357,361

Brouwers, J.S.H., 94, 99, 268, 341, 344, 358,361

Brouwers, P.M.F.H., 259, 260

Bruijn, J.G. de, 85

Buys, J.Th., 68
Camp, R. op den, 15

Carlos, don, 239

Caselli, E., 259, 260

Cavour, C.B. graaf di, 163, 241, 242

Chastel de la Howarderie, L.G.I.F. graaf du, 238

Clercx, J.M.L.H., 77, 211, 214, 228, 245 . $254,276,298,299,301,340,344,357$. 361

Clifford, G.G., 38

Coenen, F.J.P.M., 94, 105, 341, 344, 358, 361

Collaes, I., 303

Copes van Cattenburch, L.C.R., 54

Corneli, J.J.F.M.H., 58, 61, 63, 64 . $73,132,135,136,138,140,143,144$. $146,151,155,156,158,161,183,184$. $281-283,307,314,316,333,340,345$, $357,360,361$

Cornelis, K.L.J., 65, 86, 105, 162, 163 , $187,195,198-201,203,206,207,209$, $210,212-215,219,221-223,226-231$, $234,235,237,241-244,254,287$, $288,305,306,326,340,345,357$, 361

Court, jhr. P.E.A. de la, 54

Craandijk, J., 101

Cramer, N., 152

Cremers, E.J.J.B., 162, 234, 237, 243

Cruts, N.J.T., 332

Delahaye, W., 155

Delden, A. van, 295

Destouvelles, Ch., 46-48, 332, 333

Dibbets, (baron) B.J.C., 41, 46, 47

Diepen, A.F., 80

Diepen, G., 80, 267, 340, 345, 359

Does de Willebois, jhr. J.M.B.J. van der, 211,248

Does de Willebois, jhr. P.J.A.M. van der, 13, 93, 127, 165, 166, 192, 196, $217,227,233,238,239,249,363,365$, 366 
Domela Nieuwenhuis, F., 271

Donker Curtius van Tienhoven, W.B., 38

Donker Curtius, D., 125, 154, 160

Dotrenge, Th., 28

Drehmans, J.H., 257, 364

Dubbelden, H. den, 364

Dullert, W.H., 203

Dumbar, G., 234, 235, 237, 238, 240,

$243,244,252$

Eck, D. van, 234, 235, 242

Elders, K., 133

Emma, koningin-regentes, 297

Erens, A., 262

Ernst, J.W., 333

Everts, W., 12, 13, 108, 262, 265, 267,

$272-274,325,340,345,359,361$

Fock, C., 166, 227, 231

Fock, D, 170

Fokker, A.J.F., 174

Forstner van Dambenoy, H.F.Ch.

baron, 192

Fransen van de Putte, I.D., 234

Fransen van de Putte, J., 235, 237

Frederik, prins, 37,38

Gefken, J.W., 225-228

Gelders, N., 332, 333

Geradts, H.H., 95, 135, 138, 139,

$143-145,147,158-161,183,340,345$, 357

Geradts, L., 253

Gericke van Herwijnen, jhr. J.E.P.E., $52,63,72,93,101,126,134-138,140$, $141,146,148,151,152,227,232,308$, $313,314,316,363$

Geurts, A.J., 149

Geurts, P.A.M., 87

Geurts, P.J.H., 84,87

Gijzels, A.H., 87, 88, 258

Godefroi, M.H., 236
Goltstein, W. baron van, 225-228

Gouverneur, P., 54

Gregorius Xv1, paus, 364

Groen van Prinsterer, G. 54, 235

Groenendael, H.A.G. van, 82, 83, 131, $133,134,167-169,171-178,263,322$, $323,340,346,359,361$

Groot, Hugo de, 57

Guljé, N.R.H., 214

Habets, J.J., 233

Haex, J., 86, 254

Haffmans, E, 116, 273

Haffmans, J.H.L., 75-77, 89, 98-100, 103, 106, 116, 162-165, 195, 197, 199. 200, 204-207, 209-216, 218, 219 , $221-223,226-230,234,237-239,242$, $246-252,254,255,269,272-276$, 296, 298, 299, 301, 318, 326-328, 340, $346,357,361$

Haffmans, O.F.M., 94, 105, 168, 341, 346,358

Haffmans, familie, 116

Hall, F.A. van, 121, 122, 186-188, 302, $309,310,314-316$

Heemskerk Azn., J., 126, 127, 163, 165 , $166,185,208,209,211,231,245-247$. $249,327,365,366$

Heemskerk, Th., 365

Heemstra, S. baron van, 154, 235, 236, 365

Heijden, C.M. van der, 258

Hengst, J.B.J., 75, 77, 79, 81, 83, 86, 87, $115,218,289,301,340,346,357,361$

Hennequin, J.F., 28, 29, 330-332, 334, 363

Hermans, H.G.M., 110, 111, 167, 168 , $171,268,340,346,359$

Heu, A.J.H. le, 31

Heuvel, P. van den, 75-77, 79, 81, 83, $211,214,301,340,346,357,361$

Heyden, J.M. van der, 333

Heydenryck, C.J.A., 215, 243, 251, 311 
Hogendorp, (jhr.) G.K. (graaf) van, 24,31

Houten, S, van, 215, 267, 268, 273

Huijs, T.P.M., 15

Hulshof, B.J., 87, 91, no

Jaminé, P.L.J., 48, 332, 333

Janssen, F.I.J., 130, 167, 170-172, 177 , $260,263,340,347,359-361$

Jaspar, E., 231

Jolles, J.A., 223, 249

Jong, R. de, 85

Jonge, jhr. W.C. de, 88

Jonge van Campensnieuwland, jhr.

M.W. de, 61, 72, 73

Juste, Th., 47

Kappeyne van de Coppello, J., 224, 226

Karnebeek, jhr. A.P.C. van, 127

Karnebeek, jhr. H.A. van, 175,176

Kempenaer, J.M. de, 125, 126, 151, 154, 155

Kerens, jhr. P.A.S., 58, 61, 111, 135, 139, $143-145,151,282,340,347,357,360$, 361,363

Kerens de Wolfrath, jhr. W.D.A., 28, 31 , $32,330,331$

Kerens de Wylré, jhr. G.E.F.X.M., 98, $106,111,210,215,216,218,226,239$, $340,347,357,361$

Kerstens, H.C.F., 75-77, 79, 81, 83, 98, $211,212,214,236,237,240,246,248$, $254,287,288,301,340,347,357,361$

Keuchenius, L.W.C., 208, 209, 246 Keverberg d'Aldengoor, Ch.F.J. baron de, 330,331

Keverberg de Kessel, F.H.C.E. baron de, $79,101,11,113,114,162,163$, $195-198,200,203,204,207,241$, $242,245,282,286,313,326,340,347$ 357,361

Kleuters, ]., 257

Klijn, A, 91
Kolkman, M.J.C.M., 274

Kolkman, W.F.W., 88, 263

Kool, A., 94, 340

Kuyper, A., 277

Kuyper, J., 293

Kuyper, jhr. E. de, 217,363

König, A.A.H.W., 168, 365

Laer, P.D. van, 231

Lamberts Cortenbach, W. baron de, 363

Lambrechts, H.F., 106, 115, 210, 215. $218,226,228,251,267,272,273,276$, $296,298,299,340,347,357,361$

Lambrechts, J.J., 98, 115, 135, 141, 143 , $144,151,158,340,348,357,361$

Lasarraz, J.A.H. de, 307,308

Lavater jr., 99, 101, 218

Leclercq, J.L.M., 70-74, 79, 135, 138, $140,143,144,154,156,157,340,348$, 357,361

Leeuwen, G. van, 57

Leo $\mathrm{xm}$, paus, 268

Leonaerdts d'Achel, jhr. P.G.G.J., 330 , 331

Leopold I, koning, 39, 46, 48 Liedel de Well, P.W. baron de, 27, 28 , $33,35-37,48,58,61,62,94,111,133$, $141-144,149,157,183,308,330-332$, $341,342,348,356,360,361$

Liedel de Well, W.L.J.B. baron de, 144 Lightenveld, L.A., 125

Limpens, Ch. de, 70-74, 79, 98, 155 . $189-191,226,294,340,348,357,360$ Lion, Iz.J., 245

Lom de Berg, P.L. de, 75, 119, 135, 140, $143-145,162-164,182,188,191,195$, $199,200,206,207,209,210,212$, $226,234,246,248,282,287,288$, $291,293,294,305,306,309,317,340$, $348,357,361$

Longrée, N.J. de, 333

Louis, L.H.W., 104 
Louis-Philippe, koning, 33, 50

Loè, F.K.A. de, 363

Loé-Imstenraedt de Mheer, F. baron

$$
\text { de, 49, } 334
$$

Luyben, J.L.A., 35

Luzac, L.C., 57

Lynden, W. baron van, 235

Lynden tot Sandenburg, F.A.A.C.

baron van, 54, 57

MacPherson, P.D.E., 363

Mackay, Ae. baron, 26\%, 365

Maesen de Sombreff, jhr. L.E. van der,

113

Maesen de Sombreff, jhr. L.H.L.J. van der, 66, 105, 111, 113, 115, 168, 268, $341,349,358,361$

Maesen de Sombreff, jhr. P.Th. van der, 82, 105, 111, 113, 115, 162-165, 189, 198-201, 204, 207, 209, 210, 212, $213,215,216,219-221,226-231,234$. $235,237,241,243,244,247,248,254$, $278,287,288,297,305,306,322,340$, $349,357,361,365$

Magnée, L.H.A., 94, 104, 110, 298, 341, $349,356,361$

Marchant, H.P., 172

Marchant d'Ansembourg, J.B.C.E.M. graaf de, 111, 114, 267, 272, 273, 298, 299, 340, 349, 359, 361

Marchant d'Ansembourg, J.B.F.J.D. graaf de, 48, 50-52, 332, 334

Matthey, L., 190

Meeuwen, jhr. E.J.P. van, 72, 82, 93, 132, $133,141,143,147-149,151,154,156$, $157,160,184,309,314,363$

Membrède, jhr. A.C., 24, 28, 31, 32, 35,

$37,44,330,331$

Menten, J.H., 253

Merckelbach, J.M.M.H., 66, 263, 340, $349,359,361$

Mey van Streefkerk, J.G. baron de, 37 Michiels van Kessenich, familie, 136
Michiels van Kessenich, jhr. A.H.J.H., 105, 111, 115, 168, 171, 174, 341, 349, 358,361

Michiels van Kessenich, jhr. F.B.H., 100, 104, 11-113, 115, 162, 226, 234, 237 . $238,288,289,300,341,349,356,361$ Michiels van Kessenich, F.B.H.M., n3. us

Michiels van Kessenich, H.J. baron, 172

Michiels van Kessenich, jkvr.

H.M.C.H., 113

Michiels van Kessenich, jhr. L., 88, 253

Michiels van Kessenich, $j \mathrm{kvr}$.

R.M.S.H., 113

Michiels van Verduynen, familie, 136,

172

Michiels van Verduynen, (jhr.)

A.H.Th. (baron), 27, 43, 58, 61, 111, $113,115,134-136,137,143,144,152$, $153,157,179,182,183,282,283,292$, $307,308,340,350,357,360,361$

Michiels van Verduynen, jkvr. J.F.P., 113

Michiels van Verduynen, L.P.M.H. baron, 94, 115, 340

Mijer, P., 208

Mulken, J.J. van, 236

Muyssen, A.C.D. van, 334

Mérode, F. graaf de, 46, 48, 332

Napoleon 1, keizer, 22, 153, 217

Napoleon III, keizer, 208

Nijst, M.V., 106, 184, 255, 257, 260, 261, $263,276,296,299,311,340,350,357$, 361

Nispen, familie van, 114

Nispen van Sevenaer, jhr. C.J.C.H. van, 239

Nolens, W.H., 16, 87, 100, 103, 108, 116, $132,167-170,173-177,259,260,265$. $267-270,273,274,276,277,279,312$, $322,328,340,350,358,359,361$ 
Nothomb, J.B. baron, 41

Nuyens, E.M.Th.W., 12

Olislagers de Sipernau, Th., 332, 333

Olivier, N., 186, 287

Olne, J.E.H.W. baron d', 86, 111, 113 , $258,340,350,359,361$

Oppen, L.B.J., 171

Orbons, $\mathrm{P}, 14,15,98$

Panhuys, jhr. J.A.C, van, 25, 330, 331

Paredis, J.A., 72, 92, 126, 230-232, 245 . 364, 365

Pelser-Berensberg, F. baron de, 101, 261,262

Petit, jhr. P.M.J.F., 93, 111, 135, 137, 143. $151,152,158,340,350,357,360$

Pierson, N.G., 269, 298, 299, 303

Pijls, W.H., 89, 90, 104, 132, 198-202, 204-206, 210, 214, 215, 219, 220, $226,228-231,234,237,244,247,251$, $252,254,255,268,298,311,340,341$, $351,356,357,361$

Pius IX, paus, 232, 233, 245

Pollenus, A.E.H.J.F., 333, 334

Princkers, J.H., 91

Prins, W.F., 12, 15, 28, 29, 31, 78, 98, 132

Raalte, van, 99

Randwijck, L.N. graaf van, 72, 153 Rappard, W.L.F.Ch. ridder van, 57 Ras, M. de, 69, 80-83, 85, 86, 96, 116 , $254,257-259,263,265,267,272,273$, $298,299,340,351,359,360$

Rau, J., 57

Raymaeckers, P.L., 334

Reenen, jhr. G.C.J. van, 93, 148, 193

Regout, familie, 114, 271

Regout, E.B.H., 114

Regout, E.R.H., 70, 94, 95, 114, 115, 340, 365

Regout, H.G.L., 104, 114, 115, 271, 298, $341,351,356,361$
Regout, L.H.W., 70, 94, 95, 99, 105, 114, 115, 263, 268, 271, 272, 341, 351, 358, 361,365

Regout, P.D., 42, 94, 114, 115, 126 , $142-145,190-192,194,200,201$, 205-207, 219-221, 226, 233, 238, 241, $270,271,285,318,341,351,356,361$

Reh, J.L.T., 123

Renesse-Breidbach, C. graaf de, 48, 50 , 332,333

Reyphins, L.A., 31

Rijk, G.J. de, 79, 94, 142-145, 159, 191 .

$318,326,341,352,356,361$

Roberti, E., 255, 257, 263

Rogier, L.J., 22, 92, 119

Rosen, Ch.J.A. baron de, 136

Ruijs de Beerenbrouck, jhr. Ch.J.M.

$14,69,90,91,95,103,106,110,111$, $115,167-170,174,259,260,262,263$, 268-271, 277-279, 340, 352, 359, 361, $363,365,366$

Ruijs van Beerenbroek, jhr. Ch.E.M. 169

Ruijs van Beerenbroek, jhr. G.L.M.H., $69,89-91,100,111,113,115,169,170$, $252-254,261,267-270,272,274,276$, $277,296,298,299,303,311,313,340$, $345,352,357,359-361,363,365$ Ruland, L.F.H.C., 79, 85, 257, 263, 268, $340,352,359,361$

Russel, J., 194, 212, 220, 221

Rutgers van Rozenburg, jhr. J.W.H., 240

Rutten, F.X., 255

Sannes, G.W., 94, 340

Sasse van Ysselt, jhr. L.J.B, van, 192 Sassen, E.E.F., 263

Savornin Lohman, jhr. A.F. de, 266, 296, 311

Schaepkens, A., 88

Schaepman, H.J.A.M., 84, 266, 273-275

Schaetzen, J.H., 333 
Scherff, jhr. F.H.W. von, 136, 159 Scherpenzeel Heusch, J.L.Th.A.L. baron van, 79, 111, 113, 122-124. $131-133,135,136,140,141,143,144$. 149-151, 155, 156, 159, 160, 184, 335, $340,352,357$

Scherpenzeel Heusch, M.Th.V. barones van, 113

Scheyven, J.G.H., 333

Schiervel, L. de, 46, 51, 52, 332, 334

Schimmelpenninck, familie, 114

Schimmelpenninck van der Oye, J.E.N. baron, 99

Schimmelpenninck van der Oye, W.A. baron, 137, 141, 151, 313

Schmerling, A. Ritter von, 120

Schoenmaeckers, J.A.L., 123, 124, 136, 335

Schreinemacher, C., 86, 115, 257, 259, 263

Schreinemacher, J.H.J., 109, 115, 257 $263,298,340,352,359-361$

Schreuder, P., 98

Schrijnen, L.J.H., 364

Scott, W., 191

Secus, F.M.J.H. baron de, 34

Seipkens, E., 222

Simons, H.A., 333

Sloet tot Oldhuis, B.W.A.E. baron, 54 Smeets, G., 263

Smeets, M.K.J., 330

Son, J.B. van, 187

Sophie, koningin, 127

Spronck, L., 14, 15, 98

Stassen, M.J.L.A., 270, 278

Stembier de Wideux, E. de, 334

Stevens, P., 217

Stockem Méan de Kermpt, C.F. baron de, 51,334

Stork, Ch.Th., 271

Storm, L.D., 57

Straetmans, W.G., 254, 340, 353, 357, 361
Strens, M.P.H., 65, 69, 82, 108, 135, 137. 143-145, 152, 183-188, 191, 192, 226, $233,278,279,302,341,353,357,360$. 361,365

Stuers, H.J.J.L. ridder de, 153

Stuers, jhr. V.E.L. de, 83, 84, 87, 89-91, $98,100,110,111,265,268,274,277$. $341,353,359,361$

Stuers, jkvr. A.J.H.J.A. de, 171

Surlet de Chokier, E.L., baron de, 27. $28,33,35,37,45,46,48,330-332$

Swart, J.M., 64, 79, 108, 135, 139 . $143-145,159,183,341,353,357$

Tak van Poortvliet, J.P.R., 272

Tans, J.G.H., 91

Teuwens, P.G., 332

Theux de Meylandt, B.T. ridder de, 46, $49,50,332,334$

Thissen, A.J.J.H., 64, 135, 139, 143, 144, $159,161,183,318,341,353,357$

Thissen, F.H.J., 262

Thomas, J., 259, 260

Thorbecke, J.R., 11, 57-59, 63, 65, 67, $75,78-84,106,107,117,164,165,181$, 183-200, 202, 203, 205, 209, 216, $223,224,229,244,245,248-250$, $252,278,279,312,324,326-328,341$, $348,354,357,361,365$

Tiecken de Terhove, R.P. de, 49, 332, 333

Tillema, J.A.C., 98

Tripels, G., 253

Truijen, P.J., 87, 109, 110, 115, 265, 267, $273,341,354,359,361$

Ubachs, P.J.H., 227

Valette, Th.G.G., 94, 341

Velsen, jhr. G.J.M. van, 36

Verhage, H., 220

Verheggen, Th., 262

Vermeulen, P.J.F., 267 
Verstolk van Soelen, J.G. baron, 56

Victor Emanuel 11, koning, 233, 235

Vilain XIII, Ch. burggraaf, 332

Villers de Pité, jhr. L.L.W.M.J. de, 74 ,

79, 98, 100-102, 104, 111, 112, 114,

$135,139-141,143,144,151,158,162$,

$218,226,234,281,285,288,289,292$,

$300,341,354,356,357,361$

Villers de Pité, jkvr. J.M.L. de, 113

Viruly Verbrugge, W.A., 295, 311

Vissering, S., 295, 297, 311

Vliegen, W.H., 88, 94, 95, 110, 255, 341

Voorst tot Voorst, J.J.G. baron van, 99

Voort van Zijp, C. van der, 172, 173

Vos de Wael, A.J., 94, 341

Waele, $M$. de, 177

Wagemans, K., 131, 177

Wassenaer van Catwijck, O. baron van, 225-228

Weber, E., 293

Weekers, F.H.H., n

Weichs de Wenne, C.M.H. baron de, 111, 113, 131-133, 135, 138, 143, 144 .

$151,156,158,178,183,341,354,357$,

360

Weichs de Wenne, F.M.H. baron de, 113

Weichs de Wenne, M.J.Th.J.H. barones de, 13

Weitzel, A.W.P., 247

Welderen baron Rengers, W.J. van, 97 , 98, 295

Wenmaekers, L., 210, 212, 213, 230, 248
Weyer, S. van de, 40

Wijnans, A.P.E.A., 253

Wijnen, J.H., 267

Wilhelmina, koningin, 130, 131, 168-170, 278, 321

Wilhelm n, keizer, 129

Willem 1, koning, 21, 23-26, 33, 36-43, $47,49,52,53,58,59,62,63,94,120$, $136,142,144,146,314,363$

Willem 11 , koning (prins), 21, 46, 52, $58,61,74,94,125,126,134,137,141$, $142,144,145,147,152,153,155,156$, 183, 314, 321, 364

Willem II, koning, 127, 161, 186, 208, $211,223,225,234,236,239,247,316$ Wilmer, G.P., 92, 231

Wintershoven, P.F.E. van, $73,78,79$ $98,103,106,162,163,184,186,188$, 189, 191, 193-202, 204-207, 225, 226, $234,235,245,285,286,311,326,341$, $355,357,360,361$

Witlox, J., 152, 274

Woelmont d'Opleeuw, A. baron de, 332,334

Wylick, J.J.A. van, 291, 294, 308, 341, 355, 357

Zuylen van Nijevelt, J.J.P. baron van, 191

Zuylen van Nijevelt, J.P.J.A. graaf van, 163-166, 185, 208, 209, 211, 231, 246, $247,327,365,366$

Zwijsen, J., 187

Zylker, J.F., 305 


\title{
Summary
}

\section{Attached to Sovereign and Fatherland, yet they are not satisfied}

\author{
Limburg politicians in The Hague 1839-1918
}

After the return of their province to the Kingdom of the Netherlands in 1839 . many inhabitants of Limburg felt themselves more or less like strangers within the Dutch state, religiously, culturally and economically. As Limburg at that time largely became part of the German Confederation - and remained so until 1867 - the development of Dutch national feelings was hampered. This ambiguous position, balancing between the Dutch state and the German Confederation, was illustrated by Jan Lodewijk baron van Scherpenzeel Heusch who in 1848 was elected as member of the Second Chamber of the States-General in The Hague and at the same time was a representative in the German National Assembly in Frankfurt am Main.

In 1864, Johan Rudolf Thorbecke - liberal foreman and at that time Leader of the Cabinet - condemned the way certain Limburg Members of Parliament behaved during the debate. In his opinion they had a purely provincial approach. Instead of promoting the interests of their own province, they, being members of the national parliament, were supposed to represent the entire Dutch population, as stated in the constitution. Therefore, the label Limburg representative wouldn't do, as Thorbecke said. The main question of this book is whether the Limburg members of the States-General dissociated themselves from their colleges in parliament, as Thorbecke seems to have suggested. Did they indeed form a separate group and did they operate as such, looking at their background and political behaviour? This dissertation focuses on the position the Limburg Members of Parliament (the two chambers of the States-General) took in Dutch politics: their political loyalties as well as their attitude towards the Dutch nation state. The period under investigation covers the years between 1839, when Limburg again became part of the Dutch kingdom, and 1918, when the first Limburger, Charles Ruijs de Beerenbrouck, was appointed Prime Minister: an event that may be considered as an indication that the integration of the province within the national political system in the meantime had made major progress.

According to the historiography regarding Dutch parliamentary history, absence and reticence seem to have been two prominent characteristics of the behaviour of 
Limburg deputies in the States-General. Indeed, on average, their rate of attendance appears to have been lower than that of their colleagues, as chapter 2 demonstrates. And minutes of the parliamentary sessions show that some of the Limburgers in The Hague did not hold public speeches at all during their membership of parliament. For instance, Louis Libert de Villers de Pité, who was a member of the StatesGeneral for more than thirty years, never said a word in the plenary assembly. Not all Limburg representatives conform to this: the presence of some of them exceeded the national average. Moreover, there were Limburg Members of Parliament who were renowned for their verbal quality. So we may conclude that it was at least not participation that clearly distinguished Limburg representatives as a group from their colleagues in parliament, although this has been suggested by the press of that time as well as by later historical literature.

Neither can they be identified as a separate group when we look at their socialeconomical background, their age and education. Although for the last thirty years (1888-1918) their level of education was below average. This was part of a pattern that was characteristic for emancipation parties in general, in Limburg the Catholic 'party'. Whereas the influence of the nobility in the Dutch Parliament, generally speaking, diminished over the years - at least in the later years of the period under investigation - the share Limburg aristocrats, mostly descending from the southern part of the province, took in the Limburg deputation in The Hague, remained almost constant. Only between April 1888 and July 1889 were none of the representatives of noble birth.

The election campaigns and their results amply illustrate that the label Limburg representative applied as far as the bond between representatives and province is concerned (see chapter 2). Candidates from outside the province were rare and had to reckon with resistance as they were considered to be strangers. With one exception, they all had ties with Limburg through birth or residence. The big exception was Johan Rudolf Thorbecke, who was chosen in the constituency of Maastricht in 1853 and 1856 . In this respect, Limburg differed markedly from the other mainly Catholic province in the Netherlands: Noord-Brabant. On more than one occasion this province elected Catholic politicians who were born in the northern parts of the country and still resided there.

One could even go a step further. Limburg voters seem to have had a strong preference for representatives from their own region within the province. Evidently, the inhabitants and voters of Limburg made a sharp distinction between the separate parts of their province. Following the same pattern, the Provincial States of Limburg took great care for a proportional geographic distribution of representatives when electing the members of the First Chamber of parliament. Although feelings of attachment to the province gradually became stronger during the nineteenth and twentieth centuries, localism - a deepattachment to the local community-remained an important characteristic of political and cultural life in Limburg until the end of the period 1839-1918. 
According to many, in the rest of the country as well as in the province itself, the integration of Limburg in the Dutch nation state was problematic. At least three times the so-called Limburg question, by which the (unequivocal) Dutch status of the province was disputed, became urgent and was therefore put high on the political agenda (see chapter 3). During the 405 , many inhabitants of Limburg still hoped their province would return to the Kingdom of Belgium or would be incorporated into a new German empire. In $1843-1844$ and in $1848-1849$ a separation movement played an active role in Limburg. With the failure of the German unification, the question faded away, but in 1863 it re-appeared when the German Confederation became involved in a war with Denmark over Schleswig, a duchy which belonged to the Confederation and found itself more or less in the same position as Limburg. Many Dutch feared that through the ties Limburg had with the German Confederation, their country could become involved in a European conflict. The crisis lasted until 1867 when the German Confederation was dissolved as a result of the war between its two main members, Prussia and Austria. Finally, the third time the Dutch status of Limburg became a political topic was at the end of World War I, due to Belgian territorial claims.

From the start, a clear majority among the Limburg parliamentarians was in favour of the integration of their province into the Dutch kingdom. This is all the more remarkable for the period $1840-1850$ when many inhabitants of Limburg, in contrast with the later period, advocated a separation. So Limburg Members of Parliament hardly represented popular sentiment, at least not in the first decade after Limburg returned to the Netherlands. This was partly due to the electoral system, which was to the advantage of those groups within the Limburg society that wanted to remain Dutch, especially the higher classes in the cities. Moreover, the Dutch authorities, in particular the Governor in Maastricht, did not hesitate to intervene in elections in order to promote pro-Dutch candidates. As already became clear during the period of the united kingdom (1815-1830, see chapter 1), when the Netherlands and Belgium were united in one state, certain parts of the Limburg elite were willing to accept the ties with the northern parts of the Netherlands. It was especially from among this group that Governor and government after 1839, many times successfully, tried to recruit candidates for membership of the States-General.

Apart from the effects of the electoral system and the interventions on the part of the Dutch authorities, national parliament itself was hardly a suitable place to express separatist sentiments. Since representatives were obliged to take an oath of allegiance to the constitution of the kingdom, they were supposed to behave as patriots. It is therefore not surprising that we can find only one occasion (in August 1848) on which a Limburg member of the States-General, Clemens baron de Weichs de Wenne, asked the government in clear - but still diplomatic - terms to consider a separate administration for Limburg.

During the discussions about the national status of Limburg, deputies from this province were regularly labelled Limburg representative, by themselves as well as by others. Even Limburg parliamentarians who strongly resisted secession, referred to 
themselves as such. However, since they opposed separation, these representatives were not condemned for adopting a parochial approach. The reason is simple: arguments against secession clearly made the deepest impression if expressed by deputies who came from the disputed territory itself.

To resist separation of Limburg did not automatically imply devotion to the Netherlands. For instance Arnold Hendrik Michiels van Verduynen (Baron since 1841 , member of the Second Chamber between 1840 and 1846 ) was first and above all a loyal servant to his King and to the dynasty of Orange-Nassau. He was not alone on this. According to some, separation from the Netherlands didn't have to mean a separation from this dynasty - as the example of Luxemburg already demonstrated. That's why Michiels van Verduynen could combine his separatist ideas with his attachment to the King, at least at the beginning. This combination proved to be problematic, when King William $\mathrm{u}$ asked him to restrain his support to activities of the separation movement.

Even Limburg Members of Parliament who were loyal to the monarchy or fatherland, or to both, were not always content with the way they felt their province was treated by the Dutch authorities. As Gerard Johan de Rijk, member of the First Chamber, put it during a debate in 1849: 'The people of Limburg are Dutchmen attached to Sovereign and Fatherland, yet they are not satisfied.' Even in the twentieth century many Limburg politicians still felt their province was discriminated against. A pointed case was the policy of taxation, which was one of the main targets of their criticism.

Taxation was indeed a major issue for the Limburg Members of Parliament, as chapter 5 concludes. No other subject was discussed by as many Limburg deputies in The Hague. Generally speaking, their complaint was that Dutch taxes were disproportionately divided and weighted to heavy upon their province. This was particularly so because until the end of the nineteenth century there was no tax on capital (e.g. shares) whereas the property of real estate was taxed. Since the possession of shares was relatively rare among the inhabitants of Limburg, who preferred to invest in real estate, they felt at a serious disadvantage compared to people in other parts of the country.

In many debates on the system of taxation, Limburg representatives could be distinguished from their colleagues in parliament by their parochial attitude, openly advocating the interests of their province. Certainly in these cases the label Limburg representative was justified. Matters were further complicated by the constant attacks on the exceptional system for taxation on real estate especially designed for Limburg. This system existed for almost thirty years (until 1869) and outside Limburg many thought it was a relatively mild and therefore profitable regime. Its abolition was therefore an ever occurring subject on the parliamentarian agenda. This compelled the Limburg delegates to defend the interests of their province, setting them apart from their colleagues.

The pressure to advocate provincial interests was intensified by public opinion in Limburg, which expressed a strong desire for a fundamental change in the tax 
system - which meant charging capital too. Until the 70 , the Provincial States also took an active part in these protests against the current state of affairs, being much more involved in discussions on national taxation than the legislative assemblies of other provinces. These signals couldn't be ignored by the Limburg Members of Parliament: if they wanted to be re-elected they would have to manifest themselves clearly as Limburg representatives in The Hague.

Although Limburg Members of Parliament were usually close to the Liberals, and their foreman Thorbecke in particular, until 1863, the taxation issue put this bond under great pressure (see chapter 4 ). At the elections of 1864 , a provincial opposition movement, the so-called Limburg opposition, emerged which turned away from this national alliance as it was considered to be in the way of Limburg interests. The Roman question formed another factor in the removal between the Liberals and the Limburg politicians: whereas the Liberals applauded the unification of Italy into one nation state, Limburg representatives felt disturbed by the restriction this new state placed upon papal sovereignty.

In their resistance against the Liberals, the Limburg opposition sided with the Conservatives in parliament. However, they did not constitute a firm alliance. Apart from the fact that the Conservatives failed to build up a real party or well-organised movement, ideological differences remained important and could only be overcome in matters where Limburg representatives and Conservatives were confronted with their common opponent, the Liberals. With the activities of the Limburg opposition, a period began in which the Limburg Members of Parliament were less strongly allied with politicians from other parts of the country than before.

In the 8 os the Catholic co-operation in Dutch politics became apparent and the Limburgers participated in this new collaboration. Although the Catholics worked together, they still differed on important issues. On items like suffrage and the social question they disagreed and so did the Limburg representatives among them. At the same time this incorporation into the Catholic parliamentary group did not mean that Limburg representatives did not feel the urge anymore to look after the specific interests of their province. Whenever these interests were threatened, they did not hesitate to dissociate themselves from their Catholic colleagues in parliament. On such occasions the Limburg Catholics became Catholic Limburgers.

Nevertheless it was through this Catholic co-operation at national level that the Limburg politicians gained access to the centre of political power in the Netherlands. The process in which Dutch politics became national and ideological of character and which took place during the second half of the nineteenth century, did not only include the Limburg politicians, they even took an active part in it. And at the end of the period under investigation, it was politicians from Limburg who held two of the most important political offices: Charles Ruijs de Beerenbrouck was Prime Minister and Willem Nolens was Chairman of the most numerous group in the Second Chamber of the States-General, the Catholic group. Although the Queen still had to get used to the idea of having a Catholic and a Limburger as her Prime 
Minister, Nolens had no doubts about the position of a Limburg politician: he himself felt Dutch and, as he told his colleagues in 1919, he would not like to see his parliamentary seat transferred to Brussels. He felt at home in the Dutch Parliament. 


\section{Curriculum vitae}

Eric Lemmens (Venray 1970) volgde van 1982 tot 1988 het vwo aan het Boschveldcollege te Venray. Van 1988 tot 1994 studeerde hij politicologie aan de Katholieke Universiteit Nijmegen. Tussen 1996 en 2002 verrichtte hij promotieonderzoek aan de Universiteit Maastricht. Momenteel is hij in Brussel werkzaam als beleidsmedewerker van Ria Oomen-Ruijten, lid van het Europees Parlement. 
Nadat Limburg in 1839 tegen de zin van veel van zijn inwoners was ingelijfd bij Nederland, moest het ook afgevaardigden leveren voor het parlement in Den Haag. Deze kamerleden opereerden in een ongemakkelijk spanningsveld, want hun provincie was en bleef lange tijd een buitenbeentje in de Nederlandse natiestaat. Enerzijds voelden zij zich pure belangenbehartigers van hun provincie, anderzijds moesten zij zich volgens de heersende opvattingen opstellen als nationale volksvertegenwoordigers. In Aan Vorst en Vaderland gehecht, doch tevreden zijn zij niet vertelt Eric Lemmens hoe de Limburgse kamerleden van 1839 tot $1918 \mathrm{om}$ gingen met deze spagaat. Hij kijkt daarbij naar hun positie in de nationalisering en ideologisering van de Nederlandse politick in de negentiende eeuw die uiteindelijk leidden tot de vorming van landelijke politieke partijen. Hoe stonden zij tegenover deze ontwikkelingen, en zochten en kregen zij er ook aansluiting bij? Voor het antwoord onderzoekt Lemmens de netwerken waarin de Limburgse kamerleden opereerden, de band met hun kiezers, hun parlementaire activiteiten en hun politieke standpunten binnen en buiten de Eerste en Tweede Kamer.

Aan Vorst en Vaderland gehecht, doch tevreden zijn zij niet is een uitgave in de reeks De natiestaat. Politick in Nederlands sinds 1815 .

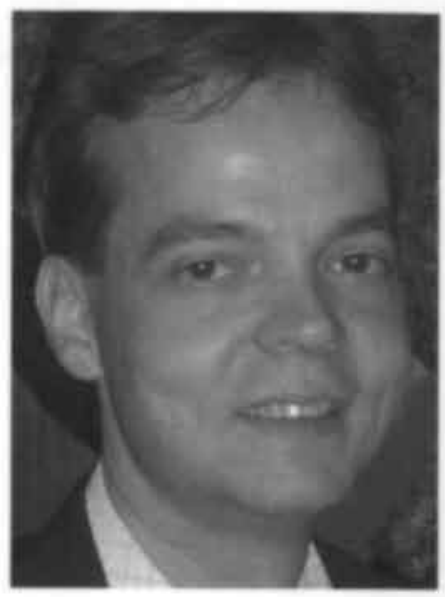

Eric Lemmens (Venray 1970) studeerde politicologie aan de Katholieke Universiteit Nijmegen. Van 1996 tot 2002 was hij als onderzoeker verbonden aan de Universiteit Maastricht, waar hij in januari 2004 promoveert op de proefschrifteditie van dit boek. Momenteel is hij werkzaam als beleidsmedewerker in het Europese Pariement.

Illustraties voorplat: linksboven 'In de Eerste Kamer' uit De Nederlandsche spectator, 30 december 1865 ; midden 'Sinterklaas uit Rolduc in de katholieke Kamerclub' uit Uilenspiegel, 9 april 1881 en onderaon 'Afvalligen' uit Uilenspiegel, 2 december 1893 -
POLITIEK

IN NEDERLAND

SINDS 1815 